UNITED STATES DEPARTMENT OF THE INTERIOR

Harold L. Ickes, Secretary

GEOLOGICAL SURVEY

W. E. Wráther, Director

Professional Paper 201

\title{
GEOLOGY AND ORE DEPOSITS OF THE \\ COTTONWOOD-AMERICAN FORK AREA, UTAH
}

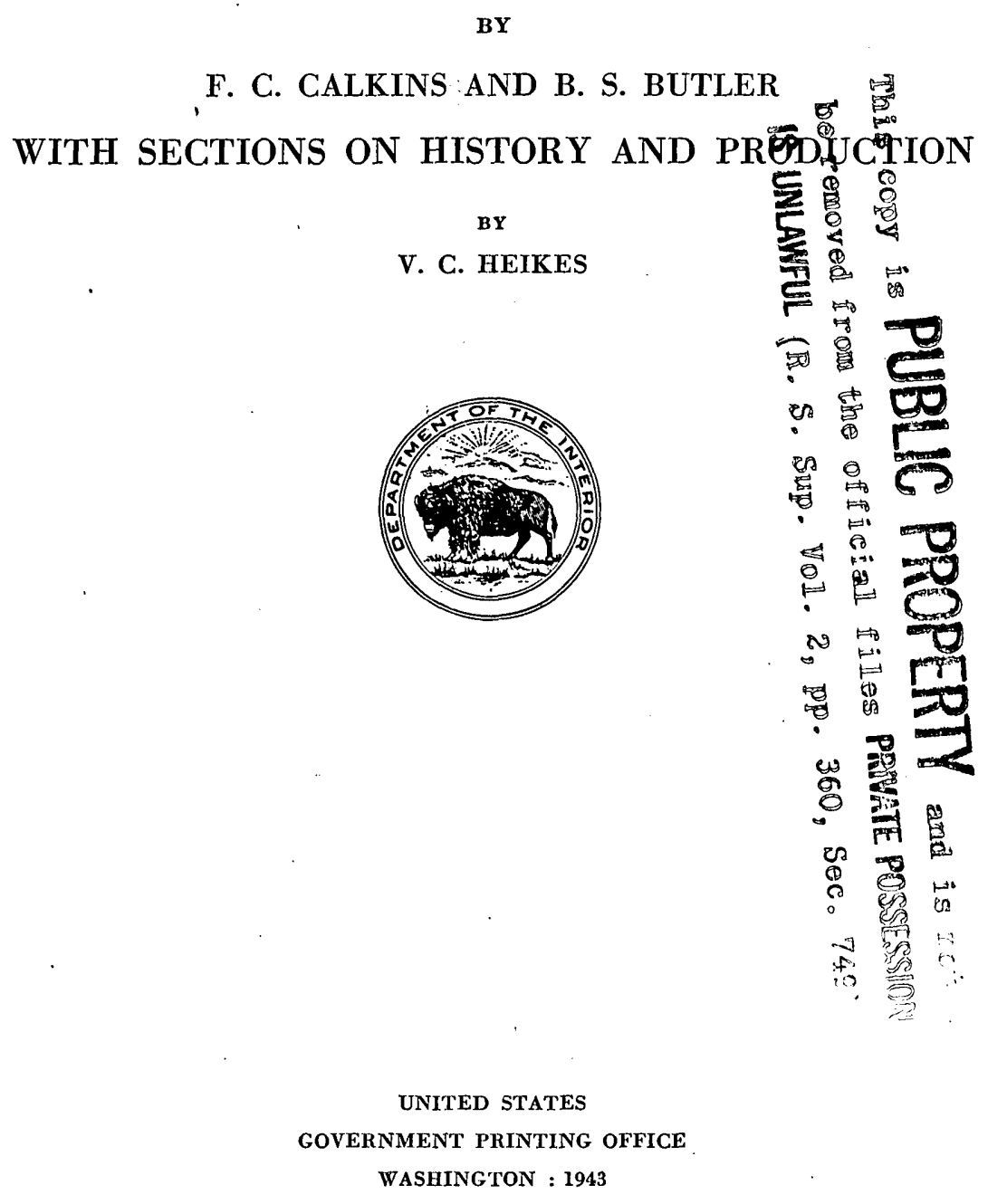

For sale by the Superintendent of Documents, U. S. Government Printing Office, Washington, D. C.

Price $\$ 1.75$ cents 



\section{CONTENTS}

Outline of the report.

Ore deposits

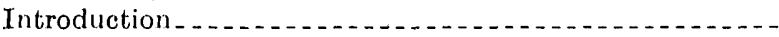

Work of other geologists....................

Field work by the authors . . . . .

Authorship.....................................

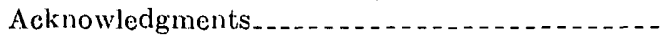

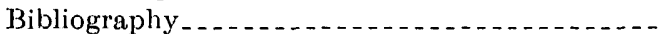

Location and setting of area. Topography

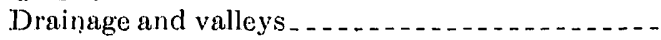

Ridges and peaks............................

Climate and vegetation.........................

Settlements and roads . . . . . . . . . . . . . . .

General geology, by F. C. Calkins........

Sedimentary rocks. . . .

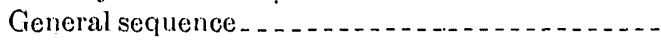

Pre-Cambrian rocks ....................

Distribution and mapping . . . . . . . . . .

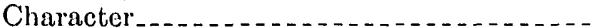

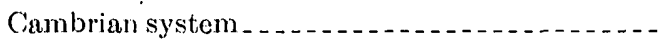

General sequence . . . . . . . . . . . . . . .

Tillite (Cambrian?)

Character................................

Relation to underlying rocks...........

Tintic quartzite Correlation and charactet. . . . . . . . . Relation to underlying rocks.......... Conditions of deposition . . . . . . . .

Ophir shale............................... General features. Lower shale member................. Limestone member.................. Upper shale member............... Age. . . . . . . . . . . .

Maxfield limestone..................... Name . . . . . . . . . . . . . . General character and distribution ..... Lower member . . . . . . . . . . . . . . . . Middle member..................... Upper member. . . . . . . . . . . . . . Age.............................. Unconformity at base of Devonian (?) ..... Devonian (?) system ....................... Jefferson (?) dolomite................. General features.................... Detailed sections.........................

Carboniferous system .......................

Sequence of formations . . . . . . . . . . . . .

Madison limestone................... Relation to Jefferson (?) dolomite ..... . . Occurrence.......................... Lithologic character................. Age...............................

Deseret limestone. . . . . . . . . . . . . . . . Occurrence............................ I. Correlation ......................

Humbug formation ........... Occurrence and thickness.............. Iithologic character Correlation and age.

\begin{tabular}{|c|c|}
\hline Ige & General geology-Continued. \\
\hline $\mathrm{IX}$ & Sedimentary rocks-Continued. \\
\hline IX & Carboniferous system-Continued. \\
\hline$x$ & Morgan (?) formation \\
\hline 1 & Occurrence and character \\
\hline 1 & Correlation and age \\
\hline 2 & Weber quartzite \\
\hline 2 & Correlation \\
\hline 2 & Occurrence and thickness \\
\hline 3 & Character \\
\hline 3 & Park City formation \\
\hline 4 & Occurrence \\
\hline 4 & Character \\
\hline 5 & Age and relations \\
\hline 5 & Triassic system \\
\hline 6 & Woodside shale \\
\hline 6 & Occurrence-1-n \\
\hline 6 & Character \\
\hline 6 & Age $_{-}$ \\
\hline 7 & Thaynes formation \\
\hline 7 & Occurrence \\
\hline 7 & Gharacter \\
\hline 9 & Age \\
\hline 9 & Ankareh shale \\
\hline 9 & Occurrence-_. \\
\hline 9 & Character \\
\hline 10 & Age \\
\hline 10 & Jurassic system \\
\hline 10 & Nugget sandstone \\
\hline 11 & Igneous rocks \\
\hline 12 & Plutonic rocks \\
\hline 12 & Diorite (Clayton Peak stock) \\
\hline 12 & General character and occurrence..... \\
\hline 12 & Petrographic details \\
\hline 13 & Granodiorite (Alta stock) \\
\hline 14 & General character and occurrence..... \\
\hline 14 & Relations \\
\hline 14 & Structure $\ldots \ldots$ \\
\hline 14 & Petrographic details \\
\hline 15 & Quartz monzonite (Little Cottonwood \\
\hline 16 & stock) \\
\hline 17 & General character and occurrence..... \\
\hline 18 & Relations $\ldots$ \\
\hline 18 & Petrographic character \\
\hline 18 & Chemical composition of plutonic rocks.... \\
\hline 20 & Contact metamorphism \\
\hline 20 & Minor intrusive bodies \\
\hline 20 & General features. \\
\hline 20 & Diorite porphyry, granodiorite porphyry, \\
\hline 22 & onite porphyry \\
\hline 22 & Endomorphic alteration with addition of \\
\hline 23 & lime \\
\hline 23 & Diorite of Big Cottonwood Creek \\
\hline 23 & Lamprophyric dikes \\
\hline 23 & General features. \\
\hline 24. & Lamprophyres with phenocrysts of bio- \\
\hline 24 & tite \\
\hline 24 & Lamprophyres without biotite pheno- \\
\hline 25 & (n- \\
\hline 26 & Alaskite porphyry dikes \\
\hline 26 & General character and relations....... \\
\hline 26 & Petrography \\
\hline 27 & ry deposits-1- \\
\hline 27 & deposits \\
\hline
\end{tabular}


General geology - Continued.

Quaternary deposits-Continued.

Landslides. . . . . . . . . . . . . .

Graveyard Flat landslide. . . . . . . . . . .

Albion Basin landslide..................

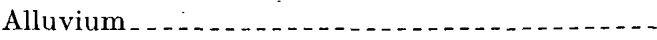

Talus and alluvial fans................

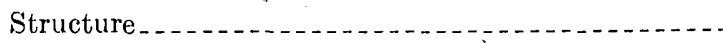

General outline...............................

Folds_...

Uinta arch...............................

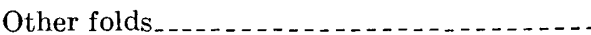

Overthrust faults . . . .

General features............................

Alta thrust zone......................... Columbus overthrust.....................

Reed \& Benson thrust zone . . . . . . . . . Grizzly overthrusts . . . . . . . . . . . . . .

Some other overthrusts................. Overthrusts bringing younger over older rocks.

Normal faults and steep reverse faults........ General features. ......................... Silver Fork fault.

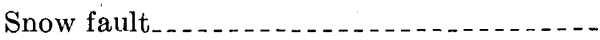
Superior fault zone................

General character................. East Superior fault.................. West Superior fault ................

Faults between the Superior and Silver

Fork fault zones.....................

Howland fault.....................

Flagstaff fault...........

Tom Moore fault ..................

Vallejo (South Star or Burgess?) fault . . . . . . . .

Illinois (Tiger Trail?) fault..........

Montezuma fault..................

Hiawatha fault . .

Other faults near Alta..............

Minor faults in Grizzly Gulch and Honey-

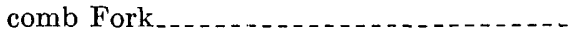

Some faults near Mill D South Fork .....

Carbonate faúltt.....................

Evarena fault. .....................

Sampson and related faults.........

Faults in Albion Basin . ...............

Faults in and near Peruvian Gulch........-

Faults near upper part of American Fork -

West of Silver Fork fault...........

Near Pittsburg mine. ..............

In Dry Fork Canyon

Faults in Miller Hill. ...............

Mountain Dell (Pacific) fault..........

Miller Hill fault. ....................

Texan fault .......................

Dutchman (Silver Fork?) fault......

Whirlwind fault. . . .

Other faults......................

Faults west of Mary Ellen Gulch Yankee fault....................... Belorophan and associated faults..... Globe fault . . . . . . . .

Minor faults . . . . . . .

Faults in. Major Evans Gulch.......... Mnieralized fissures. . . . . .

\section{CONIENTS}

Page

50

50

50

50

51

51

51

53

53

53

54

54

55

57

58

58

59

59

60

60

61

63

64

64

64

64

65

65

65

65

66
66
66
66
66

66
66

67

67

67

67

67
History of mining, by V. C. Heikes The first prospectors............ Early conditions in the Cottonwood area. . . . . . . Regulations governing mining locations........... Early shipments and experiments in smelting.......

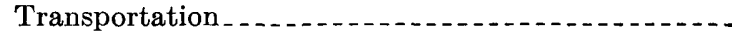
Electric power Mining

Milling - . Big Cottonwood district...................... Little Cottonwood district. . . American Fork district.

Production, by V. C. Heikes. Little and Big Cottonwood districts..............

Total production Production by ores. Dry or siliceous ores.............. Copper ore and concentrates. ........ Lead ore and concentrates. ............ Zinc ore Copper-lead ore and concentrates....... Lead-zinc ore

Dividends ...

American Fork district . . Ore deposits, by B. S. Butler.

Mineralogy . . . . B...

Native metals. . . .

Sulfides. - . -

Sulfo salts. . . . -

Haloids ... . . . . .

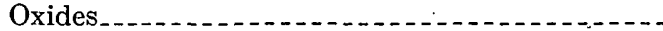

Carbonates. . . . .

Silicates. - . -

Titanosilicates

Phosphates and antimonates..........

Borates.

Sulfates. . . . . . -

Tungstates and molybdates.

General geologic relations of the ore deposits.......

Relation of faults to ore deposits...........

Relation of intrusive rocks to ore deposits......

Classification of ore deposits......

Veins in intrusive rocks

Deposits in sedimentary rocks..............

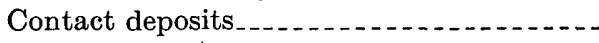
Deposits containing sulfides........ Deposits containing scheelite......... Deposits associated with fissures.......... Bed deposits . . . Deposits associated with thrust faults..... Composition of bed replacement and thrust-

fault replacement deposits . . . . . . - -

Paragenesis. . . . . . .

Alteration

Water level and relief . . . . .

Copper............

Lead.

Silver. - . . .

Zinc

Antimony

Molybdenum .................................

Tungsten ............

Genesis of ore deposits

Position relative to intrusive rocks........

Chemical relations of vein materials to igneous rocks .
Page 
Ore deposits-Continued.

Classification of ore deposits-Continued.

Genesis of ore deposits-Continued.

Conditions favorable to the deposition of Page

the ores................ 99

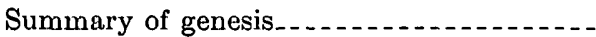

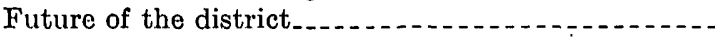

The mines, by B. S. Butler and F. C. Calkins.....

Big Cottonwood district...........

Maxfield.

History and production

Geology ................................

Big Cottonwood Monarch...............

Baker.....................................

Logger. . . . .

Dolly Varden...............................

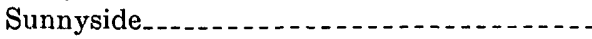

Confidence....................

Prospects on Days Fork . . . . . . . . .

Cottonwood Metals..................

Silver Moon

Gipsy Blair . .

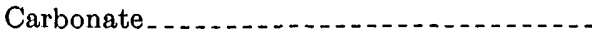

History and próduction..........

Geology . . . . . . . . . . . . . . . . . .

American Metạl Mining Co ............

Tar Baby ................

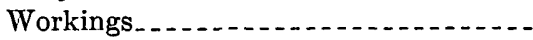

Geology . . . .

Mineralization

Kennebec..............................

Howell . . . . . . . . . . . .

Last Chance. . . . . . . . . . . . . .

Price...

Cardiff _-

History and production Geology

Reeds Peak

Cottonwood Consolidated...............

Kentucky-Utah....................

Queen Bess....................................

Evergreen...............................

Scottish Chief .........................

Silver King Coalition Mines Co...........

American ...........................

Iowa Copper.......................

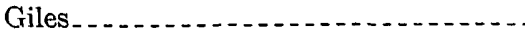

Mountain Lake.........................

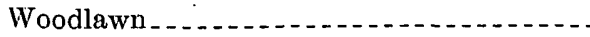

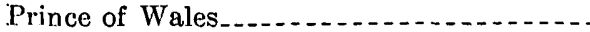

History and production

Geology . . . . . . . . .

Alta Tunnel \& Transportation Co........ History and development........... Geology . . . . . . .

Little Cottonwood district . ................

Frederick tunnel_...........

West Toledo . . . . . .

Superior..............

Rettich....................

Columbus-Rexall . . . . . . . . . Production Geology ...........................

Columbus Consolidated and Wasatch drain tunnel................................... History and production Geology
Ore deposits-Continued.

The mines-Continued.

Little Cottonwood district-Continued. Page

Flagstaff . . . . . . . . . . . . . 120

History and production . . . . . . . . 120

Geology .................. 121

Cabin

Tom Moore tunnel...

Emma

History and production

Geology ........................ 123

South Hecla

History and production

Geology ........................ 125

Ore deposits.................... 126

South Columbus.................... 127

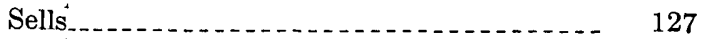

Native Copper . . . . . . . . . 128

Peruvian Consolidated Mining Co _. . . . . 128

Prospects in and near Peruvian Gulch.... 128

Cottonwood-Atlantis Mining Co....... 129

Albion

History and production........... 129

Geology .................. 129

Davenport........ 130

Alta Consolidated.................. 130

History and production . . . . . . . . 130

Geology _........ 130

Michigan-Utah......... 131

History and production

Geology ................... 131

Ore deposits

American- Fork district.

Silver Dipper....... 133

Pittsburg ...

History and production. . . . . . 134

Geology ........................ 134

South Park _._.

Water Fall ...

Pacific

History and production.......... 135

Geology ........... 135

Borüssia...

Bog _. .

Miller Hill Mining Co.............. 136

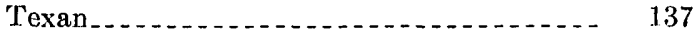

Treasure Consolidated..._.

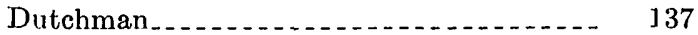

History and production........... 137

Geology . . . .

Whirlwind tunnel. . .

Bay State

Miller Mining \& Smelting Co _.......... 139

History and production........... 139

Geology . . . .

Workings in Major Evans Gulch._......- 141

Hines prospects............. 143

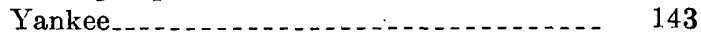

History and production............ 143

Geology . . . .

Ore deposits .

Globe. 145

Index . . . 


\section{ILLUSTRATIONS}

Page

PlATE 1. Topographic map showing principal tunnels of Cottonwood-American Fork area, Utah

2. $A$, View down Little Cottonwood Canyon from spur above Wasatch drain tunnel; $B$, Albion Basin from the north .- 6

3. Geologic map of Cottonwood-American Fork area

4. Geologic sections of Cottonwood-American Fork area

5. Generalized stratigraphic section of sedimentary rocks of Cottonwood-American Fork area ............... 6

6. A, Western part of ridge north of Little Cottonwood Creek, from Collins Gulch; B, Southern part of Reed \& Benson Ridge, from bench near Monte Cristo mine

7. $A$, North side of Little Cottonwood Canyon near Superior Gulch; $B$, Tillite blocks in talus at head of Mill D South Fork - _

8. A, Tintic quartzite in cliff west of Pittsburg Lake; $B$, Siliceous banding at top of limestone member of Ophir Shale,

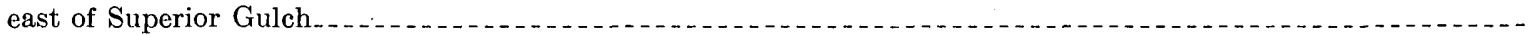

9. Wormlike bodies in Ophir shale

10. $A$, Oolitic texture in Maxfield limestone; $B$. Twiglike bodies in Maxfield limestone

11. A, "Guinea-hen" dolomite in Maxfield limestone; $B$, Shale with limestone nodules, middle member of Maxfield limestone.

12. $A$, Shale and limestone in middle member of Maxfield limestone; $B$, "Guinea-hen" dolomite in Maxfield limestone

13. $A$, White dolomite in Maxfield limestone; $B$, Intraformational limestone conglomerate in Maxfield limestone...-.

14. A, Fine-grained whitish dolomite forming top of Jefferson (?) dolomite; $B$, Jefferson (?) dolomite east of Twin Peaks_........

15. A, Metamorphosed nodule of chert from Deseret limestone; $B$, Quartz diorite from Clayton Peak stock at head of Big Cottonwood Creek.

16. A, Contact of quartz diorite (Clayton Peak stock) and granodiorite (Alta stock); $B$, Highly metamorphosed

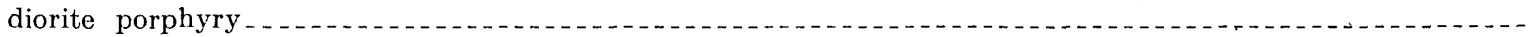

17. A, Quartz monzonite from Little Cottonwood stock; $B$, Granodiorite from Alta stock; $C$, Partly altered diorite porphyry from offshoot of Clayton Peak stock . . .

18. A, Alaskite porphyry of Grizzly dike; $B$, View across Big Cottonwood Canyon from head of Solitude Fork

19. Generalized geologic map of Cottonwood-American Fork area

20. A, Alta overthrust northwest of Montreal Hill; $B$, Silver Fork fault on Davenport Hill

21. $A$, Metamorphosed Maxfield limestone with garnet; $B$, Weathered brucite-bearing limestone; $C$, Metamorphosed dolomite with forsterite

22. $A$, Replacement breccia of pyrite and other sulfides; $B$, Smithsonite deposited on cerusite crystals; $C$, Ludwigite and sulfides

23. $A$, Ore from Cardiff mine; $B$, Ore from Columbus-Rexall mine

24. Photomicrographs showing relations of sulfides: $A$, Pyrite partly replaced by bornite and chalcopyrite; $B$, Chalcocite replacing galena; $C$, Blebs of chalcopyrite in sphalerite; $D$, Covellite replacing tetrahedrite

25. Photcmicrographs showing relations of sulfides: $A$, Tungstenite intergrown with galena and pyrite; $B$, Tungstenite

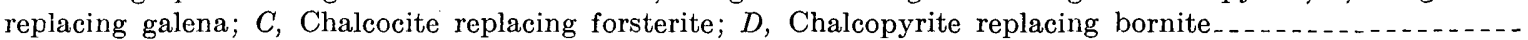

26. Photomicrographs showing relations of sulfides: $A$, Central area, covellite replacing galena; $B$, Central area, intergrowth of galena and tetrahedrite; $C$, Chalcocite with grating structure; $D$, Anglesite and covellite replacing

27. Photomicrographs showing relations of sulfides: $A$, Sphalerite replacing pyrite, Cardiff mine; $B$, Chalcopyrite

(veins) replacing pyrite, Columbus-Rexall mine

29. A, Mineralized limestone from Carbonate mine; $B$, Chalcocite in limestone with forsterite, Steamboat tunnel ....

30. Claim map of Cottonwood-American Fork area

31. Workings of Maxfield mine .... In pocket

32. Plan and sections of Carbonate mine

33. Geologic map of Tar Baby mine

34. Howell mine, upper and lower tunnels

35. Geologic map of Cardiff mine and part of Columbus-Rexall tunnel

36. Workings of Woodlawn mine .

37. Geologic plan of Alta Tunnel \& Transportation Co. workings, with projection parallel to Prince of Wales fissure, showing relation to Annie tunnel and Prince of Wales workings ...

38. Geologic map of Frederick tunnel and part of Columbus-Rexall tunnel

39. Wasatch drain tunnel

40. Geologic map of Columbus Consolidated mine

41. Geologic map of workings in Flagstaff-Emma ore zone

42. $A$, Limestone breccia, Old Emma mine; $B$, Replacement banding in limestone ore, Old Emma mine . ........ 126

43. A, Mineralized limestone breccia, Old Emma mine; $B$; Mineralized limestone breccia, No. 1 shoot, South Hecla mine . . . .

44. Geologic map of South Hecla, Sells, Rustler, and South Columbus workings _...

45. Upper workings of Albion mine

46. Geologic plan of main tunnels of Michigan-Utah and Alta Consolidated mines, and longitudinal projection of workings on City Rocks fissure. .

47. Workings of Pacific mine 
PLATE 48. Workings of Miller Hill Mining Co

49. Workings of Dutchman mine

50. Workings of Miller Mining \& Smelting Co

51. Geologic map of workings of Yankee mine

Figure 1. Index map showing location of Cottonwood-American Fork area

2. Structure in Alta stock

3. Kennebec Consolidațed Mining Co., Reed \& Benson,; and Craig tunnels and workings .

4. Plan and section of Steamboat tunnel and workings on Legget and Relief claims

5. Section through Emima ore body

6. Map of Pittsburg mine

7. Workings of Bay State mine-139

8. Plan of Earl-Eagle tunnel 



\section{OUTLINE OF THE REPORT}

\section{GEOLOGY}

The segment of the Wasatch Mountains that lies opposite the Uinta Range is exceptional, as compared with other adjacent parts of the Wasatch, for the complexity of its structure and the fullness of its stratigraphic record; it contains, also, the only large intrusive bodies and the only ore deposits credited with any considerable production that occur in the Wasatch Mountains. This segment embraces, on the east slope of the local main divide, the Park City district, still highly productive, which was described by J. M. Boutwell in Professional Paper 77. On the west slope of the divide it includes three districts, formerly thriving but now comparatively inactive, that coincide respectively with the upper parts of the drainage basins of Big Cottonwood and Little Cottonwood Creeks and American Fork and are accordingly named, in north-south order, the Big Cottonwood, Little Cottonwood, and American Fork districts. These three adjoining districts form the subject of this report. The area mapped includes most of the mines and important prospects in each district. Near its geographic center is Alta, an old mining camp, which lies about 20 miles southeast of Salt Lake City.

The rocks of the area are in greater part sedimentary strata ranging in age from pre-Cambrian to Jurassic. All these strata are cut by intrusive stocks and dikes, whose age is probably late Cretaceous or Tertiary. The only later rocks are the Quaternary deposits, of small areal extent, laid down by extinct glaciers nnd by mountain streams.

Pre-Cambrian time is represented in the region by several thousand feet of quartzitic and shaly rocks, which are largely if not wholly of shoal-water or continental origin. Although they are somewhat more highly metamorphosed, on the whole, than the younger strata, it is chiefly because of their greater exposure to the effects of igneous intrusions, for where these effects have not been operative the pre-Cambrian rocks do not show much grenter metamorphism than the later rocks. A rather small but distinct angular unconformity between the pre-Cambrian rocks and Cambrian (Tintic) quartzite is visible in certain exposures.

The lowest folmation above the known pre-Cambrian rocks is a body of tillite and banded argillite, which is lenticular and does not persist throughout the district. It is here tentatively assigned to the Cambrian, although in previous reports it has been included in the pre-Cambrian. The Cambrian rocks above the tillite are divisible into three formations, the lowest consisting essentially of quartzite, the middle chiefly of shale, and the highest chiefly of limestone and dolomite. All these are fairly uniform in thickness and persist throughout the district except for the effect of an unconformity, which cuts out varying portions of the limestone and even reaches, locally, into the shale. rower Cambrian fossils have been found in shale just above the top of the quartzite, and Middle Cambrian fossils in shale a little below the highest limestone assigned to the Cambrian.

The Cambrian is overlain unconformably by a large thick body of dolomite and limestone. The lower 150 feet of these calcareous beds yielded no determinable fossils in this area, but they are provisionally assigned to the Jefferson limestone, of Middle Devonian age, because they lithologically resemble the Jefferson as it appears in the Oquirrh Range. Above this unit is a limestone that carries a rich lower Mississippian Madison fauna and clearly belongs to the widespread Madison limestone. Upon the Madisnn, and not separated from it on the map, is some hundreds of feet of cherty limestone and dolomite less rich in fossils, which are correlated on lithologic grounds with the Deseret limestone of the Stockton and Fairfield quadrangles. Above the Deseret formation lies several hundred feet of limestone interbedded with sandstone and shale and carrying, in the upper part, fossils of Brazer (upper Mississippian) age. These beds lithologically resemble the Humbug formation of the Stockton and Fairfield quadrangles and are called by that name. They are limited at the top by an erosion surface upon which there rests, with local basal conglomerates, about 200 feet of limestone rich in Pennsylvanian fossils, which is correlated provisionally with the Morgan formation. The Morgan is conformably overlain by the Weber quartzite. The Weber is conformably overlain by the Permian and Pennsylvanian Park City formation, a heterogeneous assemblage of limestone, chert, shale, and sandstone, which contains a little low-grade phosphate rock.

The Park City formation is overlain, without observed unconformity, by about 3,500 feet of strata, divided into three formations, the Woodside shale, Thaynes formation, and Ankareh shale, the first two of which are certainly and the last probably of Triassic age. The lowest and highest of these formations consist mainly of red shale, the middle one mainly of limestone and calcareous sandstone. The upper red shale (Ankareh) is conformably overlain, in the northeast corner of the mapped area, by several hundred feet of pale-red to nearly white sandstone (Nugget sandstone) of Jurassic age.

A large part of the area is occuied by intrusive igneous rocks. These belong chiefly to three stocks, which crop out along the course of the Uinta axis and which are named, in order of position from west to east, the Little Cottonwood stock of quartz monzonite, the Alta stock of granodiorite, and the Clayton Peak stock of diorite. The Alta stock is younger than the Clayton Peak, and the Little Cottonwood stock is probably the youngest of the three; but all were presumably intruded within a relatively brief period, for they are so closely related in composition as to indicate that they were differentiated from a single body of magma. Dikes, though subordinate to the stocks in total volume, are fairly abundant. Most of them strike northeastward. The greater number are more or less evidently offshoots from the stocks; others consist of alaskite porphyry or of lamprophyres. The most conspicuous of all is a dike of alaskite porphyry which has been traced northeastward across the greater part of the district.

The large intrusive bodies have produced extensive metamorphism, which is especially conspicuous in the limestones and other calcareous rocks. Among the more remarkable of these effects are the formation of large quantities of brucite, probably through alteration of periclase, in some of the limestones, and the local formation of the boron minerals ludwigite and magnesioludwigite. Many of the dikes and parts of the margins of the stocks have themselves been metamorphosed by the action, apparently, of late magmatic solutions that were heavily charged with calcium derived from the limestones; the most characteristic product of this alteration is a fine-grained aggregate of anorthite and diopside, commonly accompanied by some garnet.

The pre-Cambrian, Paleozoic, and Mesozoic strata have been 
subjected to thrust faulting, to folding, and to complex faulting, generally in the order named. The igneous rooks were intruded later than the major thrusting and folding but are displaced by some of the faults. The thrust faults are mainly parallel to the bedding planes and, like them, dip for the most part eastward; but it is faily certain that here, as in adjoining parts of the Rocky Mountains, the overridling blocks moved relatively eastward on surfaces that originally dipped to the west. The thrust faults, together with the sedimentary strata, have been. arched up into an anticline of northeasterly pitch, in line with the Uinta anticline. The intrusive stocks are ranged along this axis of uplift, and their emplacement is presumably connected with the arching. The many faults other than the overthrusts are mostly on fissures of steep dip, but some of them are reverse. The greatest of them is the Silver Fork fault, a normal fault of low westerly dip, which probably extends entirely across the mapped area from north to south.

The rocks whose character has been outlined are carved into a rugged mountainous topography. The highest summits on the divides between the main streams are in the western part of the area, the main divide of the range being relatively low. This fact may be due in part to an eastward tilting of the range which occurred when it was rejuvenated by faulting, but it is certainly due in part to the fact that the rocks near the western face of the range are harder than those near the divide. Evidence of rejurenation is afforded by the fact that the lower parts of the main canyons have steep gradients, in striking contrast to the gentle gradients of their middle parts. The topography is strongly marked by the effects of former alpine glaciation. Each of the three main canyons contained a long glacier; that in Little Cottonwood Canyon was the longest in the Wasatch Range and extended a short distance out trom the mouth of the canyon. All the northward-facing gulches contained tributary g]aciers.

\section{ORE DEPOSTTS}

The earliest recorded mineral discoveries in this area were made in 1865 . The discovery of the famous Emma ore body in 1869 initiated a period of production that has continued, with fluctuations, to the present time.

The district has yielded metals amounting in value to about $\$ 37,000,000$, of which silver malkes up about 50 percent, lead 40 percent, and copper, gold, and a little zinc the rest.

The ore deposits are closely grouped around the intrusive stocks that form the belt extending from the front of the range northeastward to the Park City district, though no large deposits have been developed within the stocks. The economic importance of the deposits associated with the different stocks differs greatly. Deposits associated with the Little Cottonwood stock, to the west, have yielded little in metals; those associated with the stocks near Alta have been moderately productive; and those around the stock in the Park City district have produced abundantly. This general relation is thought to have resulted from the deeper erosion of the western stocks and the consequent removal of deposits that probably existed at one time in the rocks abive these stocks.

Faulting has strongly influenced both the formation and the preservation of the ore bodies. The thrust faults were early, and brecciation accompanying the thrust faulting prepared the ground for the deposition of some of the large ore bodies, so that mineralization spread along them where the intrusive and mineralized zone crossed the thrust zone. The northward bulge of the mineralized zone that extends in general along the line of intrusive stocks into the Big Cottonwood district and the southward burge into the American Fork district lie along this thrust zone. Fissures and faults, parallel in general to the trend of the intrusive zone, were formed at the time of intrusion and closely thereafter, and they serred as channelways for dikes and for the ore-depositing solutions, which replaced favorable limestone beds and breccia zones adjacent to the fissures. The mineralization was followed by faulting along general northsouth lines, with some renewal of movement along earlier faults. These later faults have added to the difficulties of prospecting and mining, but by lowering the block between the Silver Fork fault and the Superior fault zone they have preserved the deposits within it from erosion.

The commercially important deposits were formed in a few favorable beds-one in the Ophir shale, one in the Maxfield limestone above the Ophir, and one at the top of the Jefferson (?) dolomite. These beds and the breccia zones associated with the thrust faults have yielded most of the ore of the district. The ore deposits may be divided into two general classes-contact deposits and deposits associated with fissures-and the latter may be subdivided into fissure deposits and replacement deposits along bedding planes, of which the breccia zones formed by thrust faulting may be regarded as a variety. The replacement deposits along bedding planes have been far more productive on the whole than the fissure deposits.

The original sulfides have been oxidized to varying distances below the surface. During this process there was some concentration of the metals, and the ores were thus rendered more amenable to the metallurgical treatments known in the seventies and eighties.

The ores are closely related, both geographically and geologically, to the intrusive rocks, and the two are believed to bave had a common origin. 


\section{GEOLOGY AND ORE DEPOSITS OF THE COTTONWOOD-AMERICAN FORK AREA, U'TAH}

By F. C. Calkins and B. S. Butler

\section{INTRODUCTION \\ WORK OF OTHER GEOLOGISTS}

The first systematic geological study of the Wasatch Range was done by the Fortieth Parallel Survey, mainly by Clarence King and S. F. Emmons. These pioneers broadly outlined the stratigraphy and distribution of the rocks and prepared regional geologic maps that for parts of the region have not yet been superseded by more detailed work.

In 1902 Boutwell ${ }^{2}$ examined part of the Cottonwood district in connection with his study of the Park City district. He measured a detailed section, in the Cottonwood quadrangle, of the rocks above the Weber quartzite, established the intrusive nature of the granitic rocks, and recognized overthrust faults in the Park City. district.

Emmons, ${ }^{3}$ on being shown by Boutwell the evidence that the Little Cottonwood stock was intrusive, published an acknowledgment that the Fortieth Parallel Survey had erred in this regard.

In 1909 Blackwelder recognized ${ }^{4}$ the great extent of overthrust faulting in the Wasatch Range, and his work resulted in radical revision of the stratigraphic section of the Fortieth Parallel Survey in the Ogden region. In 1912 Hintze, ${ }^{5}$ Butler, ${ }^{6}$ and Loughlin ${ }^{7}$ made studies in the Cottonwood-American Fork region and found extensive overthrust faults, which necessitated a revision of the stratigraphy much like that made by Blackwelder for the Ogden region. The work of Hintze was independent of that of Butler and Loughlin, and all later workers in the region owe much to his report.

Atwood $^{8}$ in 1909 described the glaciation of the

\footnotetext{
1. U. S. Geol, Wxpl. 40th Par. Rept., vol. 1, 1.S78.

a Boutwell, 'T. M. Geology and ore deposits of the Park City district, Utah : U. S. Genl. Survey Prof. Paper 77, p. 4.1, 191.2.

${ }^{3}$ Emmons, S. F., The Little Cottonwood granite body of the Wasatcl Mountains: Am. Jour. Sci., 4th ser., vol. 16, pp. 139-147, 1903.

4 Blackwelder. Eliot. New light on the geology of the Wasatch Mountains, Utah: Geol. Soc. America Bul1., vol. 21, pp. 517-542, 1910.

"Hintze, F. F., A contribution to the geology of the Wasatch Mountains, Utah: New York Acad. Sci. Annals, vol. 23, pp. 85-143, 1913.

"Butler, B. S., and Loughlin, G. F., A reconnaissance of the Cottonwood-American Fork mining district, Utah : U. S. Geol. Survey Bull. 620 , pp. $1.65-266,1.15$.

7 Toughlin, G. F., Reconnaissance in the Wasatch Mountains, Utah Jour. Geology, vol. 21, pp. 436-452, 1.91.3.

s Atwood, W. W., Glaciation of the Uinta and Wasatch Mountains : U. S. Geol. Survey Prof. Paper 61, 1909.
}

Wasatch Mountains. In 1928 a posthumous report by Gilbert ${ }^{9}$ summarized his studies, extending over many years, on Basin Range structure, with special reference to that of the Wasatch Mountains.

In addition to these more general studies and reports, many studies of mines have been made by engineers and geologists for private interests. Some reports have been published in the mining journals; others have not been published. The careful structural study of the area around the Old Emma mine made by J. J. Beeson in 1916-18 has not been published in full, but some of its results were available to the writers; and the same is true of the work done by R. T. Walker for several companies. The American Fork district has been studied by W. R. Landwehr and F. D. Hansen, geologists for the American Smelting \& Refining Co., whose geologic maps were made available to the writers.

Eardley ${ }^{10}$ has in recent years made structural studies of wide scope in the Wasatch Mountains and adjacent areas. One of these has dealt with a part of the Wasatch Mountains south of the area here described, embracing Santaquin and Nephi. One of its most interesting structural results has been the discovery of two overthrusts, which moved eastward and are associated with a great fold overturned toward the east. A later study by the same author ${ }^{11}$ covers a larger area, including the area described in the present report. One of its conclusions is that the Cottonwood uplift-regarded as a dome-crowded the strata into folds and small thrusts against the west end of the Uinta uplift.

The work of Gilluly ${ }^{12}$ in the Ophir district has thrown much light on the stratigraphy of the area here described.

Arthur Baker, of the Geological Survey, has been studying the geology of the Strawberry Valley quadrangle for several seasons, and his work has extended. somewhat into the surrounding region. His results are in! the main unpublished.

\footnotetext{
"Gilbert, G. K., Studies of Basin Range structure: U. S. Geol. Survey Prof. Paper 153, pp. 10-69, 1.928 .

${ }^{10}$ Eardley, A. J., Structure and physiography of the southern Wasatch Mountains, Utah: Mich. Acad. Sci. Jour., vol. 19, pp. 377-399, 1934

11. Eardley, A. I., Structure of the Wasatch-Great Basin region: Geol. Soc. America Bull., vol. 50, pp. 1277-1310, 1939.

${ }^{12}$ Gilluly. Tames. Geology of the Stockton and Fairfield quadrangle,
} Utah: U. S. Geol. Surrey Prof. Paper 173, 1932. 
FIELD WORK BY THE AUTHORS

B. S. Butler first visited the area in 1912. In 1916 detailed mapping of the area (fig. 1) was taken up by Butler and F. F. Hintze, Jr. In 1917 Butler and F. C. Calkins continued the work, which was interrupted by the World War. The mapping was considerably extended in 1919, and a preliminary report on the area was published in the report on the ore deposits of Utah. ${ }^{13}$

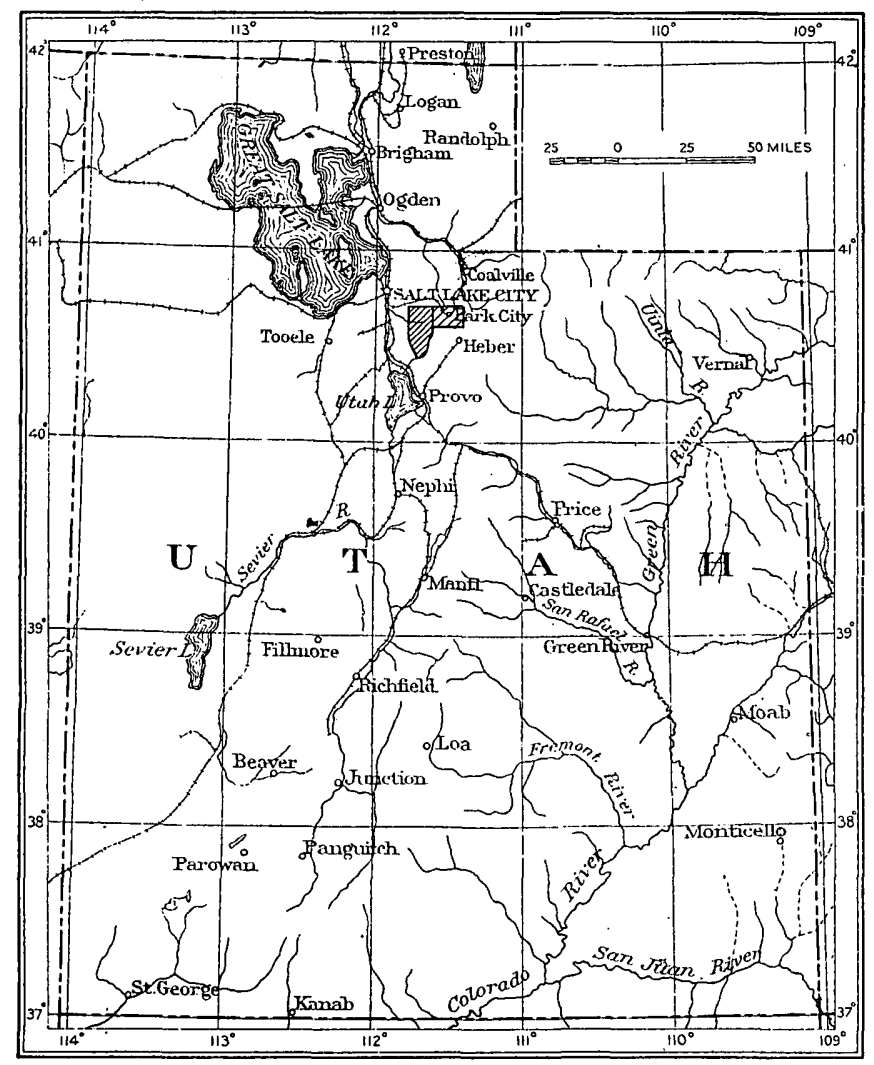

Figure 1.-Index map showing location of Cottonwood-American Fork area.

Further visits to the area have been made in 1920,1921 , 1934, 1936, 1939, and 1941.

W. H. Bradley served efficiently as field assistant in 1920; and Francis Cameron, in the same year, did a little geologic work in addition to various other duties.

\section{AUTHORSHIP}

The introduction to this report and the part that relates to the general geology have been written mainly by Calkins, the part relating to ore deposits, excepting some descriptions of the geology of the mines, were written mainly by Butler. V. C. Heikes contributed the sections on history and production. For the geologic mapping shown in the final maps both of the surface and of most of the mine workings, Calkins is mainly responsible, and most of the descriptions of the geologic features of several of the mines were written,

${ }^{13}$ Butler, B. S., and others, Ore deposits of Utah : U. S. Geol. Survey Prof. Paper 111, pp. 227-283, 1920. and the others revised, by him. But he feels obliged to say-being the writer of these lines-that Butler's contributions, direct and indirect, to the understanding of the stratigraphy, petrology, and structure of the region were at least coordinate in value with his own, and not repaid by any corresponding help toward an understanding of the ore deposits.

\section{ACKNOWLEDGMENTS}

So many persons concerned with mining in the area have laid the authors under obligation, during the course of their field work, that it is impossible to name them all. Among those that come readily to mind is Mr. George H. Watson, manager of the South Hecla Mine for many years and since then engaged in other mining enterprises, the Thompson family, owners of the Cardiff mine, and the Jacobsen family, active in working the Columbus-Rexall and Flagstaff mines, now controlled by the Mineral Veins Coalition Mines Co. All these men facilitated the work in many ways.

Guidance and stimulating discussion were given at the beginning of the work by J. J. Beeson; who placed his detailed maps of the Emma and neighboring properties, showing the geology both on the surface and underground, at the disposal of the authors, to whom R. T. Walker also gave copies of some of his geologic mine maps. Through Mr. Walter Landwehr, the American Smelting \& Refining Co. generously supplied geologic maps and sections of the Yankee, Pacific, and Dutchman mines. The company also gave permission to use an excellent contour map, based on an airplane survey, of an area lying mainly south of the Cottonwood quadrangle, and from this map was taken a part of the south margin of the map published as plate 2.

The authors are indebted to $\mathrm{H}$. V. Bodfish, projector of the Alta tunnel, for maps, information, and hospitality; and C. T. Van Winkle and others also have contributed maps.

The companionship of Robert Marvin, who was helpful in giving the right names of several topographic features, is pleasantly remembered; and the cordial hospitality of Mr. and Mrs. Fred Powell at the Frederick tunnel, and the many items of information that Mr. Powell was able to give, because he had so long lived and worked in the Cottonwood districts, are held in especially warm remembrance.

To V. C. Heikes, statistician at Salt Lake City for many years under the Geological Survey, and to C. N. Gerry, who has continued his work under the Bureau of Mines, the authors are indebted for countless favors and never-failing kindness. The present writer profited, in 1939, by pleasant and enlightening excursions with A. A. Baker, of the Geological Survey, in the region adjoining the area here described on the south. Sub- 
sequent discussions with $\mathrm{Mr}$. Baker have also been profitable.

Constant and helpful interest in the work was manifested by G. F. Loughlin, who was one of the first to gain a true insight into the remarkable structure of the area and whose descriptions of several of its mines that are now inaccessible are included in this report. James Gilluly gave highly constructive criticism to the stratigraphic descriptions in the light of his own work in the Oquirrh Range and of a visit to the Cottonwood quadrangle. W. T. Schaller revised the section on mineralogy; M. N. Short and Jewell J. Glass determined certain minerals; W. F. Hillebrand, Charles Milton, and R. C. Wells made chemical analyses of several rocks, and G. H. Girty determined many Carboniferous fossils.

This report is indebted, like all others but in greater degree than most, to office workers whose services are usually taken for granted, and of whom it would be impracticable, as well as unconventional, to give all the names; but the authors are grateful for the patience and skill of the many who had a hand in coping with the special problems involved in preparing the text and illustrations.

\section{BIBLIOGRAPHY}

The following list includes the more important general papers on the Cottonwood-American Fork region:

Atwood, W. W., Glaciation of the Uinta and Wasatch Mountains, Utah: U. S. Geol. Survey Prof. Paper 61, 1909.

Beeson, J. J., Emma Consolidated: G. G. Rice's Industrial and Mining Age, p. 4, Aug. 6, 1917.

Beeson, J. J., Mining districts and their relation to structural geology : Am. Inst. Min. \& Met. Eng. Traus. [reprint] No. 1500, Sept. 1925.

Blackwelder, Eliot, New light on the geology of the Wasatch Mountains, Utah: Geol. Soc. America Bull., vol. 21, pp. 517-542, 1910.

Blackwelder, Eliot, An ancient glacial formation in Utah: Jour. Geology, vol. 40, pp. 865-922, 1932.

Boutwell, J. M., Geology and ore deposits of the Park City district, Utah: U. S. Geol. Survey Prof. Paper 77, 1912

Boutwell, J. M., The Salt Lake region: 16th Internat. Geol. Cong. Guidebook 17, 1933.

Butler, B. S., Loughlin, G. F., and Heikes, V. C., A reconnaissance of the Cottonwood-American Fork mining region, Utah: U. S. Geol. Survey Bull. 620, pp. 165-226, 1916.

Butler, B. S., Ore deposits of Cottonwood-American Fork area, in Butler, B. S., Loughlin, G. F., Heikes, V. C., and others, The - ore deposits of Utah: U. S. Geol. Survey Prof. Paper 111, pp. 265-278, 1920.

Calkins, F. C., Cottonwood-American Fork area, in Butler, B. S., Loughlin, G. F., Heikes, V. C., and others. The ore deposits of Utah: U. S. Geol. Survey Prof. Paper 111, pp. 229-254, 1920.

Eardley, A. J., Structure and physiography of the southern Wasatch Mountains, Utah: Mich. Acad. Sci. Jour., vol. 19, pp. 377-399, 1934.

Eardley, A. J., Structure of the Wasatch-Great Basin region: Geol. Soc. America Bull. vol. 50, no. 8, pp. 1277-1310, Aug. 1939.

Emmons, S. F., The Little Cottonwood granite body of the Wasatch Mountains: Am. Jour. Sci., 4th ser., vol. 16, pp. 139147, 1903.

Geikie, Archibald, On the Archean rocks of the. Wasatch Mountains: Am. Jour. S‘i., 3d ser., vol. 19, pp. 363-367, 1880.
Gilbert, G. K., Studies of Basin Range structure: U. S. Geol. Survey Prof. Paper 153, 1928.

Hintze, F. F., Jr., A contribution to the geology of the Wasatch Mountains, Utah: New York Acad. Sci. Annals, vol. 23, pp. 85-143, 1913.

King, Clarence: U. S. Geol. Expl. 40th Par. Rept., vol. 1, 1878. Leith, C. K., Pre-Cambrian geology of North America: U. S. Geol. Survey Bull. 360, pp. 788-789, 1909.

Loughlin, G. F., Reconnaissance in the Wasatch Mountains, Utah: Jour. Geology, vol. 21, pp. 439-443, 1913.

Loughlin, G. F., [Ore deposits of] American Fork district, in Butler, B. S., Loughlin, G. F., Heikes, V. C., and others, The ore deposits of Utah: U. S. Geol. Survey Prof. Paper 111, pp. 279-284, 1920.

Mathews, A. A. L., Lower Triassic cephalopod fauna of the Fort Douglas area, Utah: Walker Mus. Mem., vol. 1, no. 1, 1929. Mathews, A. A. L., Stratigraphy of the central Wasatch Mountains: Oberlin College Bull., new ser., no. 1, 1931.

Van Hise, C. R., Correlation papers-Archean and Algonkian: U. S. Geol. Survey Bull. 86, pp. 294, 297-298, 1892.

Walcott, C. D., Second contribution to the studies on the Cambrian faunas of North America: U. S. Geol. Survey Bull. 30, p. $38,1886$.

Walcott, C. D., Correlation papers-Cambrian: U. S. Geol. Survey Bull. 81, pp. 159-160, 319-320, 1891.

Zirkel, Ferdinand: U. S. Geol. Expl. 40th Par. Rept., vol. 6, 1876.

\section{LOCATION AND SETTING OF AREA}

The largest features in the relief of Utah are the Wasatch and Uinta Ranges. The Wasatch Range extends from Nephi, near the center of the State, northward into Idaho. Its western face, which is well-defined throughout its length, forms part of the eastern limit of the Basin and Range province; its eastern side, the boundary of which is more or less indefinite, merges with an upland region of which the northern part is the Wyoming Basin and the southern part the Colorado Plateaus. These two regions are separated by the Uinta Range, a broad linear uplift that trends nearly eastward, almost perpendicular to the Wasatch Range, from which it is separated by a relatively narrow depression.

The segment of the Wasatch Range included between the westward prolongations of the north and south margins of the. Uinta Range has an especially interesting and complex geology. Its structure is fundamentally a composite of the north-south folds and thrust faults which characterize the Wasatch Range with the east-west anticline which dominates in the structure of the Uinta Range, but it seems to have even greater complexity than would result from superposing the known persistent structural features of the two ranges. In line with the Uinta crest, moreover, are exposed some fairly large intrusive bodies, which are alined with several others exposed in desert ranges farther west and which are the only intrusive rocks, other than dikes or sills, that are known to occur in the Wasatch Mountains. This segment also contains the only ore deposits in the Wasatch Range from which any considerable production has been won, the presence of these deposits having 
doubtless resulted from the combination of intricate structure with large intrusive bodies that are not too deeply eroded.

These distinctive geologic features are expressed in an equally distinctive topography. ${ }^{14}$ The old sedimentary rocks, partly metamorphosed, that were made accessible to erosion by uplift along the Uinta axis, and the granitoid rocks intruded along the axis, are harder than the rocks of the Wasatch Mountains in general. Mainly because of the high resistance of the axial rocks to erosion, but perhaps in part as a direct result of differential uplift, this segment of the range, though not containing its highest peaks, probably has a greater average height than any other segment of similar area. It was at the west that the greatest uplift occurred, along a relatively recent fault, and it is here also that the hardest rocks are exposed; and, as a natural consequence of these facts, some of the highest peaks of the range look directly down upon the Salt Lake Valley and crown that lofty section of the Wasatch front which is the dominant feature in the panorama. visible from Salt Lake City.

The area (see fig. 1) that forms the subject of this report lies behind this section of the range front, at the heart of this segment in which the geologic interest of the range is so remarkably concentrated. At the center of the area is Alta, one of the two chief mining camps of the range, the other, which is much larger, being Park City, about 8 miles to the northeast. A detailed account of the geology of the Park City district nas already been published. ${ }^{15}$ Although the economic importance of Alta is now far less than that of Park City, the geologic interest of the tract adjacent to it is even greater than that of the Park City district, its stratigraphic section being more comprehensive, its intrusive igneous rocks more varied, and its structure more complex.

The situation and limits of the area are, more definitely, as follows: Alta, which is near its center, lies about 20 miles southeast of Salt Lake City. The greater part of the area is a quadrangle 6 minutes on a side, bounded by parallels $40^{\circ} 33^{\prime}$ and $40^{\circ} 39^{\prime} \mathrm{N}$. and meridians $111^{\circ} 34^{\prime}$ and $111^{\circ} 40^{\prime} \mathrm{W}$. This tract is shown on the original Cottonwood special map, which includes most of the mines and noteworthy prospects in the drainage basins of Big Cottonwood and Little Cottonwood Creeks, though it does not extend quite far enough west to include all of them. An irregular southward extension of the map was made by the Geological Survey in 1919, and a map made by airplane survey for the American Smelting and Refining Co. has been used, with the kind permission of the

\footnotetext{
${ }^{14}$ A description of the physiographic development of the Wasatch Range as a whole by G. K. Gilbert is presented in U. S. Geol. Survey Range as a whole
F'rof. Paper 153.

${ }^{16}$ Boutwell, J. M., Geology and ore deposits of the Park City district, Utah, with contributions by L. H. Woolsey: U. S. Geol. Survey Prof. Fuper 77, 1912 .
}

company, to extend the map a little farther. This extension shows the mines and most of the prospects in the basin of American Fork. The whole area covered (see pl. 1) includes the active parts of the Big Cottonwood, Little Cottonwood, and American Fork mining districts, and it will be called in this report the Cottonwood-American Fork area. It is adjoined on the east by a rectangular area, mapped on the same scale of 1:25,000, which includes the Park City district. The most productive part of the Cottonwood-American Fork area has it center about a mile south of Alta, and it extends about 6 miles from north to south and 4 miles from east to west. A few of the ore producers lie cutside this area, but their total output has been small.

\section{TOPOGRAPHY}

\section{DRAINAGE AND VALLEYS}

The Wasatch Mountains have no persistent main divide. The entire range drains into the Great Basin, partly by way of short streams that flow more or less directly westward, partly by way of much longer streams that rise east of the range and turn westward to flow through it in deep and rugged canyons. The best-known of these transverse gorges, because it is followed by the Union -Pacific Railroad, is that of the Weber River, which at its nearest point is about 30 miles north of Alta. The next one south, about 15 miles south of Alta, is that of the Provo River. The segment of the range lying between these two canyons is the only one that may be said to have a main divide, the term being applicable to the parting between the streams that flow eastward into certain main tributaries of the Weber and Provo Rivers and those that flow westward into Gieat Salt Lake, the Jordan River, and Utah Lake. But in respect of drainage as well as of gecilogic structure this segment opposite the Uinta Range is peculiar. It is intermediate in character between the subdued part of the range just north of it, in which the higher hilltops lie on or near a main divide, and the more rugged southern part, whose culminating peaks, though alined along a gentle curre, are isolated or separated into groups by several deep transverse canyons.

The Cottonwood-American Fork area (see pl. 1) is drained almost wholly by the three streams, of general westerly course, for which it is named. The two Cottonwood Creeks enter the Jordan River near Murray, and American Fork flows into Utah Lake. The water parting between these streams and the Weber and Provo Rivers weaves in and out across the eastern boundary of the area, so that its northeast corner drains by way of East Canyon Creek into the Weber River and some of its southeastern part is drained by Snake Creek, a tributary of the Provo.

The middle part of the area is drained by Little Cottonwood Creek, which flows very directly (pl. $2 A$ ) to the mountain front after passing the sharp bend near 
Alta, where the main headwater branch flows from the broad north-facing Albion Basin into the eastward prolongation of the main valley (pl. $2, B$.). 'This headwater basin is the largest of a series of glaciated hollows. which extend far back into the south wall of the main canyon, whose north wall is merely scarred by relatively shallow gullies. The main valley has a broad floor and a gentle gradient down to a point a mile or two west of the area mapped; from there to the base of the range its average gradient, well represented by that of the road, is considerably steeper, though in detail the valley bottom presents a stair-like alternation of flats and gorges.

The valley of Big Cottonwood Creek is similar in many of its features to that of Little Cottonwood but is on a larger scale. It heads in a broad north-facing compound amphitheater containing. several lakes. A series of smaller basins farther west gives rise to a series of northward-flowing tributaries, the longest of which within the mapped area is Mill D South Fork. The gulches on the northeast side of the valley are shorter than those on the southwest side, but they are much larger than the southward-facing gullies of Little Cottonwood Canyon. The upper part of the valley of Big Cottonwood Creek is even more open and gentle in gradient than that of Little Cottonwood Creek, but it, also, passes downstream into a narrow-bottomed gorge of uneven but generally steep gradient, the transition occurring near the northwest corner of the Cottonwood quadrangle.

American Fork, whose broad irregular basin includes the souther'n part of the area mapped on plate 1 , flows eastward in its upper part, but near the mouth of Dry Fork it turns into a prevailing southwesterly course. Its main tributary in the area is the stream in Mary Ellen Gulch, which flows southeastward from the 'Twin Pealks.

RIDGES AND PEAKS

Although the higher points of the area lie on or near the divides between the principal streams, the highest summits are at the wester'n edge of the area, on divides of the second order, rather than on the main divide farther east. The highest point on this main divide within the area is Sunset Peak, at which the boundaries of Salt Lake, Wasatch, and Utah counties join. Westward from Sunset Peak the Salt Lake-Utah County boundary follows the crest that divides the basins of Little Cottonwood Creek and American Fork. This crest is the most rugged in the area, and it bears half a dozen peaks whose altitude approaches or exceeds 11,000 feet. The highest of these, and also the highest in the area, are the Twin Peaks, 11,491 and 11,434 feet, respectively. (See pl. 8, A.) The Twin Peaks lie close to the southwest corner of the Cottonwood quadrangle, and the other peaks on the same divide are in general sircerssively lower from west to east.
On the divide between Big and Little Cottonwood Creeks, again, the highest summit shown on the map is Superior Peak, which lies just within the western border of the area. (See pl. 7, A.) The south slope of this mountain is almost uniformly steep and rises more than 3,000 feet in a little less than a mile, its base being less than 7,900 feet and its top more than 11,000 feet above sea level. Eastward from this peak the height of the divide varies irregularly, and some of its higher points are on the north-south part near the main divide of the range; this, however, is because of the special hardness of the rocks in that vicinity.

Some of the spurs between the branches of the main streams are almost as prominent as the crests of higher rank already described. This is true in particular of the ridge west of Mill D South Fork, the crest of which lies just off the west margin of the area, and of the jagged Reed \& Benson Ridge, on the east side of the sáme stream (pl. $6, B)$. In the southern part of the area the landscape is dominated by Miller Hill, whose conical peak surmounts a sloping plateau almost surrounded by the deep canyons of American Fork and Mary Ellén Gulch.

The character of the mountain sculpture in the Cottonwood-American Fork area is rugged, as its great range of altitude, nearly 4,500 feet, implies. This ruggedness is accentuated by features that attest the former presence of a branching system of alpine glaciers, which occupied the three largest canyons and all their tributary gulches and canyons except the smaller southwardfacing ones. It is due to the work of these longvanished glaciers that these valleys generally have $U$-shaped cross sections and head in broad, steep-sided amphitheaters.

The ridge, with its branching spurs, on the north side of Big Cottonwood Creek within the Cottonwood quadrangle is much less rugged than most of those at the south. (See pl. 18, B.) Its character expresses the relative softness of its constituent rocks, which are chiefly unmetamorphosed strata of Carboniferous and Mesozoic age, and their simple structure, which presents a striking contrast to the complexity of the structure to the south. Two exceptionally prominent summits on this ridge are Scott Hill, just within the eastern boundary of the quadrangle, and an unnamed peak about 3 miles outside the western boundary. Both are products of differential erosion; Scott Hill consists of calcareous rocks hardened by contact metamorphism, and the other peak of the hardest beds of the Weber quartzite. This ridge north of Big Cottonwood Creek, even though relatively subdued, bore many glaciers on its northern slope and several, in cirques facing nearly east or west, on its south side.

\section{CLIMATE AND VEGETATION}

The climate of the region surrounding Alta is generally cool in summer and severely cold in winter. The annual precipitation is large and is chiefly in the form 
GEOLOGY AND ORE DEPOSITS OF COTTONWOOD-AMERICAN FORK AREA, UTAH

of snow. The summer days are for the most part fair, though afternoon showers are common in the latter part of summer. Long-continued rainstorms are few; they occur chiefly in early autumn and are likely to turn, at least momentarily, to snow. The first considerable snowstorms usually arrive in late September, but the early snows, as a rule, melt away for the most part, and the month of October may contain some of the most genial weather of the year. At some indefinite time in the late fall or winter the snow begins to accumulate, and it soon covers the region so deeply that the roads are kept open only by snow plows until late in spring. The winter snows then rapidly melt and are reduced to isolated patches in high northward-facing cirques. Most of these patches disappear before the succeeding fall.

The heavy snows frequently give rise to slides that cause destruction of property or of human life; it is said that more than 300 persons have been killed by snowslides in the Little Cottonwood district alone. These slides are probably more frequent and impetuous on the high, steep, and barren southeast slope of Superior Peak than at any other place in the area.

The snowslides are largely a result of the almost complete removal of the original forest growth of the region. Hardly a tree of this primeval coniferous forest is now standing except in the basin at the head of Cottonwood Creek, where there is a fairly thick stand of conifers. The north slope of Little Cottonwood Canyon near Alta is barren of timber, though thrifty young saplings are growing thickly on the south slope. Aspen is very abundant in places where the conifers are largely destroyed, especially in the broad part of Cottonwood Canyon below Silver Lake. It supplies a moderate amount of timber that is usable for mining and some other purposes, though its wood is greatly inferior to that of conifers.

\section{SETTLEMENTS AND ROADS}

The Cottonwood-American Fork area now contains but one settlement having a post office, which is named Silver Lake although the village that it serves is called Brighton. Brighton, beautifully situated in the wooded basin at the head of Cottonwood Creek, consisting mainly of cottages owned by citizens of Salt Lake City, is chiefly a summer resort, but winter sports are now practiced there to some extent.

Alta, in recent years, has become widely known as a skiing resort visited weekly during the winter by thousands, mainly from Salt Lake City and other neighboring valley towns but partly from more distant places. It has a ski-lift about three-quarters of a mile long, and some shorter ones, besides a hotel, and two other buildings where shelter and refreshments can be obtained. The Civilian Conservation Corps had a permanent camp in Albion Basin. All these recent developments have made the remnants of the old mining town of Alta, which in the seventies and eighties had a population of many hundreds, seem all the more forlorn. The valley now contains hardly a dozen buildings that are, or ever were, used by miners, and only three or four at most that were built in the days of Alta's prosperity.

Automobile roads extend from the Salt Lake Valley up the canyons of Big Cottonwood Creek, Little Cottonwood Creek, and American Fork. Those in Big Cottonwood and Little Cottonwood Canyons are kept open throughout the winter; both are much traveled, the road to Brighton mainly during the summer and the one to Alta mainly in the winter. The Big Cottonwood road is connected with Park City by a secondary road extending northeastward from the vicinity of Brighton, and branch roads extend up several tributary canyons. The one that is most used, in the canyon of Mill D South Fork, is in part so steep that it often proves impassable to cars that are overloaded or in poor mechanical condition. A road of easier gradient leads to the KentuckyUtah and Alta tunnels. The old road up Little Cottonwood Creek was steep and rough, but an excellent new road up the canyon was completed in 1936, and it has since been extended to the camp of the Civilian Conservation Corps.

The map, which was last revised in 1936, does not show the hotel, the Forest Service Shelter, the Conservation Camp, nor the road from that camp to Alta. The main canyon road uses the grade of the narrowgage railway which formerly connected Alta with Salt Lake Valley but which was torn up some years ago. This new road is well maintained and makes travel by automobile to Alta fairly easy, though second gear must be used for much of the distance.

\section{GENERAL GEOLOGY}

By F. C. Calkins

\section{SEDIMENTARY ROCKS}

GENERAI SEQUENCE

The sedimentary rocks of the Cottonwood-American Fork area, whose distribution and structure are depicted in the geologic map and sections forming plates 3 and 4, have an aggregate thickness of about 12,000 feet. (See pl. 5.) The lowest strata that occur in the area mapped are pre-Cambrian shales and quartzites, of which about 1,500 feet is exposed within the area but whose total thickness is very much greater. As the top of the preCambrian was provisionally drawn in Professional Paper 111, its highest division, which is not present in all sections, is a tillite, or glacial deposit; but this, for reasons indicated on page 10, is now regarded as more probably the lowest Cambrian formation, separated from the underlying rocks by an unconformity.

The lowest formation that is certainly Cambrian is the Tintic quartzite, about 800 feet thick, which may be seen in places to rest unconformably on the preCambrian quartzite and which is also believed to be unconformable with the tillite. The quartzite is overlain by the Ophir shale, which is divisible into a lower 


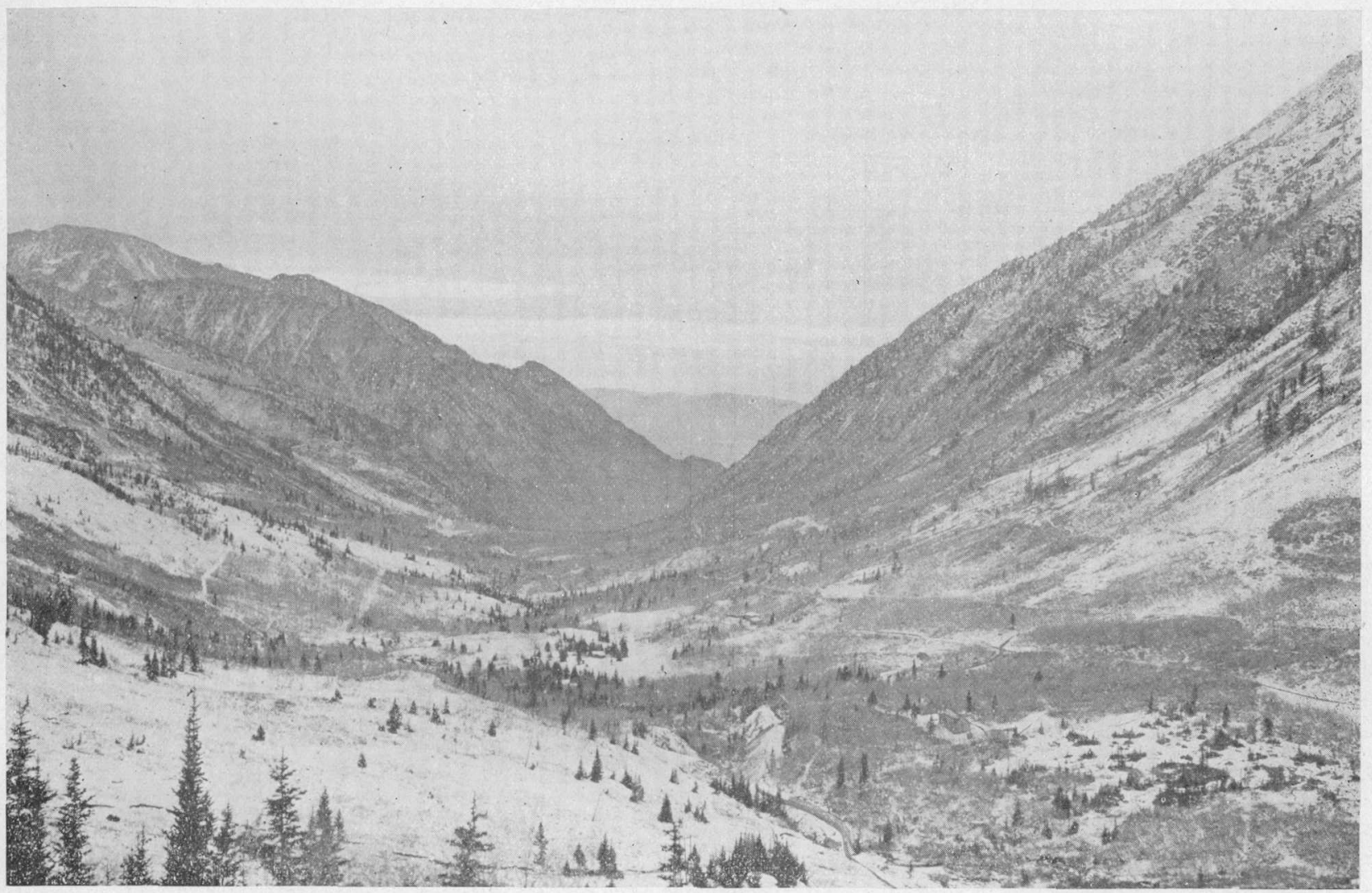

A. VIEW DOWN LITTLE COTTONWOOD CANYON FROM SPUR ABOVE WASATCH DRAIN TUNNEL, Shows $U$-shaped section and abrupt steepening of grade.

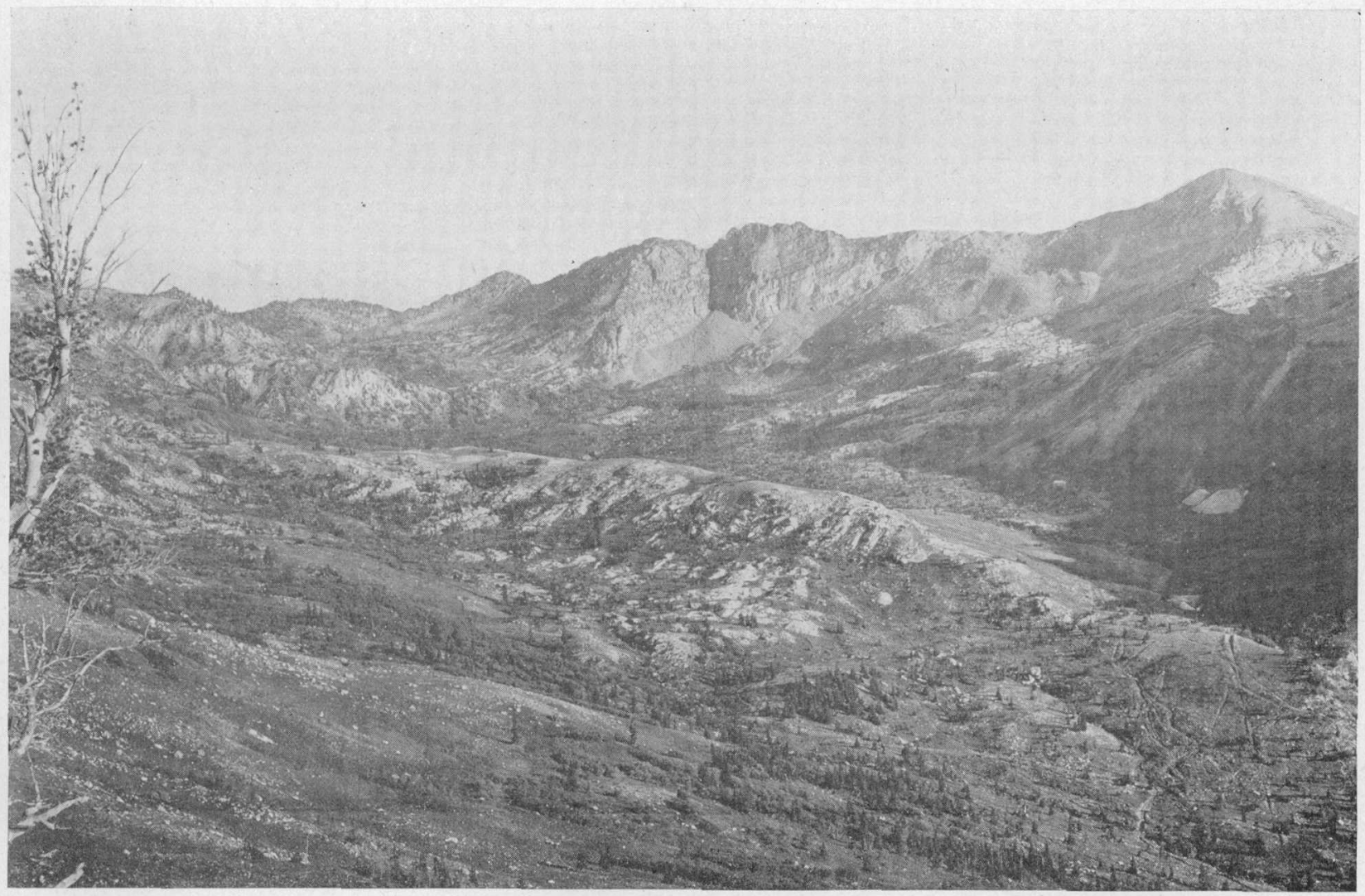

B. ALBION BASIN FROM THE NORTH.

Devils Castle in middle of skyline, above cliff of Deseret and Madison limestones and Jefferson (?) dolomite. Sugarloaf Mountain, at right, is Tintic quartzite. Silver Fork fault passes to the left of dumps near right-hand edge. 


\begin{tabular}{|c|c|c|c|c|c|c|}
\hline $\begin{array}{l}\text { Sys- } \\
\text { tem }\end{array}$ & Series & & Formation & Section & $\underset{\text { (feet) }}{\text { Thickness }}$ & Kind of rock \\
\hline 鸳 & & $\mathbf{J n}$ & Nugget, sandstone. & +1, & & Light-colored sandstone with interbedded red shale. \\
\hline 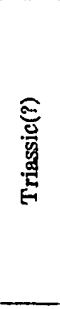 & & Fa & Ankareh shalo. & 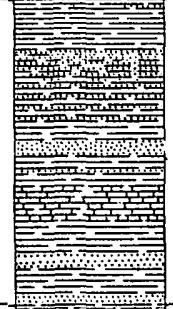 & 1,225 & $\begin{array}{l}\text { Red shale, locally sandy, with interbedded coarse gray sandstones. Prominent bed of } \\
\text { light-colored hard sandstone near the middle. }\end{array}$ \\
\hline \multirow{2}{*}{ 莺 } & & kt & Thaynes formation. & 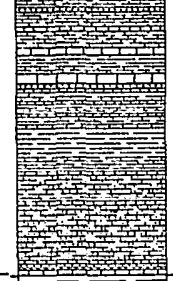 & 1,180 & $\begin{array}{l}\text { Limestone with sandstone and shale, the calcareous rocks weathering brown in part. A A } \\
\text { stratum of red shale separates a more calcareous upper portion from a more sandy lower } \\
\text { portion. }\end{array}$ \\
\hline & & Fw & Woodside shale. & 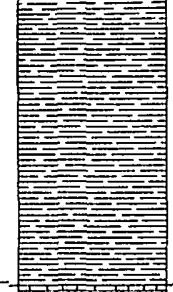 & 1,175 & $\begin{array}{l}\text { Shale, nainly red, partly altered to green; fne-grained, thin-bedded. Ripple marks, mud } \\
\text { cracks, and rain-drop imprints. }\end{array}$ \\
\hline \multirow{6}{*}{ 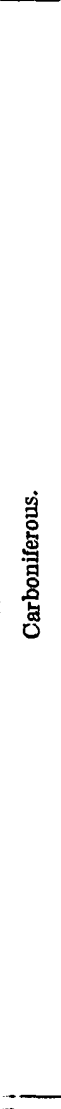 } & \multirow{3}{*}{ 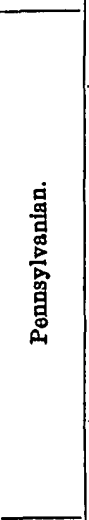 } & Cpc & Park City formation. & 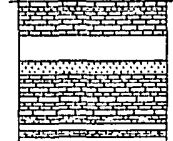 & 575 & Limestone with interbedded quartzite, sandstone, and shale and a little phosphate rock. \\
\hline & & $\mathrm{Cw}$ & Weber quartzite. & का & $1,350+$ & $\begin{array}{l}\text { Fine-grained, homogeneous quartzite, white to pale gray, weathering pale buff, inter- } \\
\text { bedded with calcareous sandstone and with gray limestone which is cherty in part. }\end{array}$ \\
\hline & & Cmo & Morgan(?) formation. & 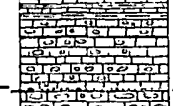 & $350 \pm$ & $\begin{array}{l}\text { Limestone, gray, cherty. Creen nodular shale and red limestone near top. Conglomerate } \\
\text { at base, pebbles of chert and limestone. } \\
- \text { Unconformity }\end{array}$ \\
\hline & \multirow{3}{*}{ 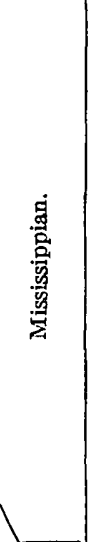 } & $\mathrm{Ch}$ & Humbug formation. & 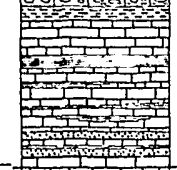 & $750 \pm$ & $\begin{array}{l}\text { Limestone, black, cherty; large corals and other fossils near top. } \\
\text { Limestone, black, weathering to bulf, more or less argillaceous. } \\
\text { Blacks shale, apparenty yabsent in southern part of area. } \\
\text { Limestone, gray to buff, interbedded with calcareous shale and sandstone. }\end{array}$ \\
\hline & & Cdm & Deseret limestone. & 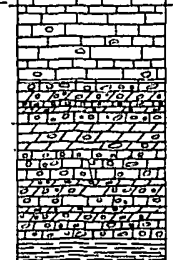 & 900 & 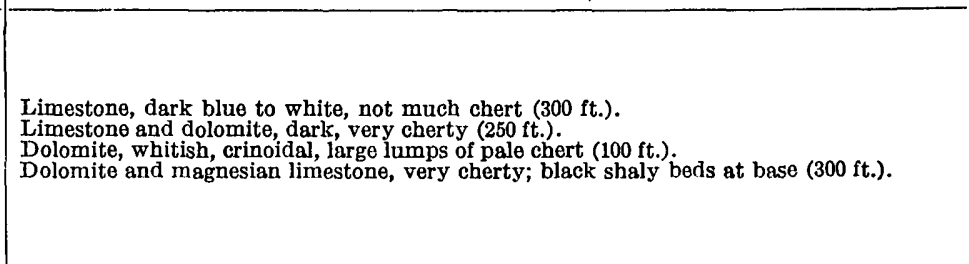 \\
\hline & & & Madison limestone. & 1 & 450 & $\begin{array}{l}\text { Limestone, partly magnesian, free from chert; blue, altering to blue and white; highly } \\
\text { fossiliferous, especially near base. }\end{array}$ \\
\hline $\begin{array}{l}\text { nlan } \\
(?)\end{array}$ & & $\mathrm{Dj}$ & Jeffierson(?) dolomite. & 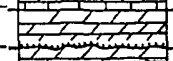 & 150 & $\begin{array}{l}\text { Dolomite, mostly thick-bedded; bluish-white bed at top; flaggy and vuggy layers; sand- } \\
\text { stone at base. }\end{array}$ \\
\hline \multirow{3}{*}{ 袁 } & 䔽 & $\epsilon \mathrm{m}$ & Maxfield limestone. & $\begin{array}{r}1 \\
y \\
y \\
y\end{array}$ & 570 & $\begin{array}{l}\text { Dolomite, gray, mottled, oolitic (70 ft.). } \\
\text { Limostone, gray to buff-mottled, interbedded with shale (150 ft.). } \\
\text { Dolomite and limestone, mottled with buff and gray (150 ft.). } \\
\text { White dolomite sandy in utper part (20 ft.). } \\
\text { Dolomite, mostly gray, lower part largely oolitic (180 ft.). }\end{array}$ \\
\hline & $\begin{array}{c}\text { Midle } \\
\text { Cam- } \\
\text { brian. }\end{array} \mid$ & Eo & Ophir shale. & 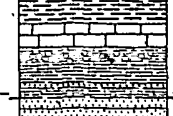 & 420 & $\begin{array}{l}\text { Shale, partly calcareous, greenish gray, yellowish brown on weathered surface. } \\
\text { Limestone, nodular and mottled. } \\
\text { Dark micaceous shale. }\end{array}$ \\
\hline & 离 & etq & Tintic quartzite. & 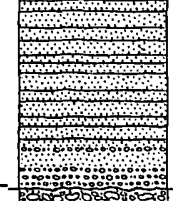 & . & Quartzite, light-colored, conglomeratic layers near base. \\
\hline 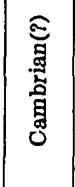 & & et & Tillite. & 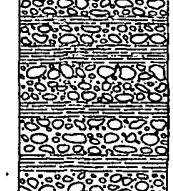 & 0 to 1,000 & Tillite interbedded with varved shale; dark-colored, weathering rusty. \\
\hline \multirow{4}{*}{ 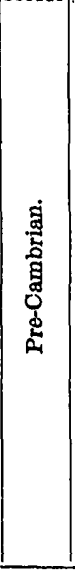 } & & \multirow{4}{*}{ pre-€ } & & & 400 & $\begin{array}{l}\text { - Unconformity(?) } \\
\text { White quartzite. } \\
\text { Light-colored quartzite interbedded with purple shale. }\end{array}$ \\
\hline & & & & ? & 200 & $\begin{array}{l}\text { Argillite, dark purple with green areas. } \\
\text { Rusty purple quartzite. }\end{array}$ \\
\hline & & & & & 500 & Argillite with slaty cleavage; dark gray, stained with ocher on weathered surface. \\
\hline & & & & $\begin{array}{ll}1 \\
11 \\
11\end{array}$ & $1,000+$ & Mainly quartzite, whitish to red or dull purple; upper beds fine-grained and white. \\
\hline
\end{tabular}




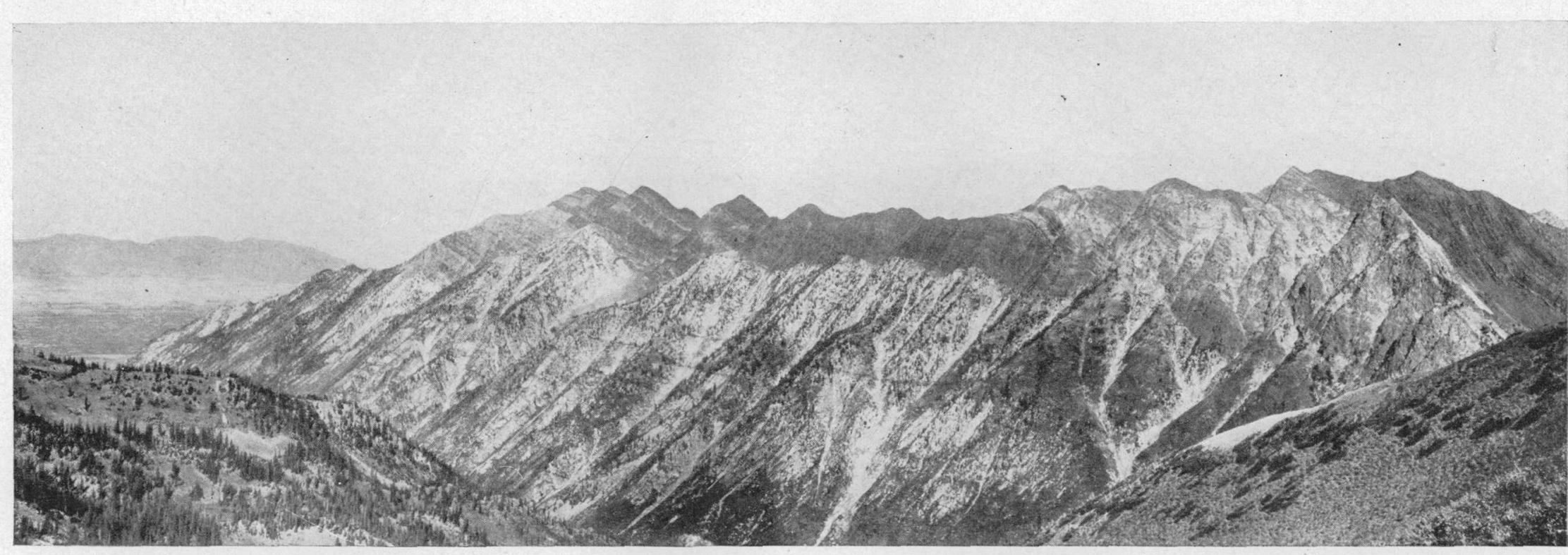

A. WESTERN PART OF RIDGE NORTH OF LITTLE COTTONWOOD CREEK, FROM COLLINS GULCH.

Shows Cambrian (?) tillite (dark) at right, pre-Cambrian strata along most of erest. and guartz monzomite of Little Cottonwood

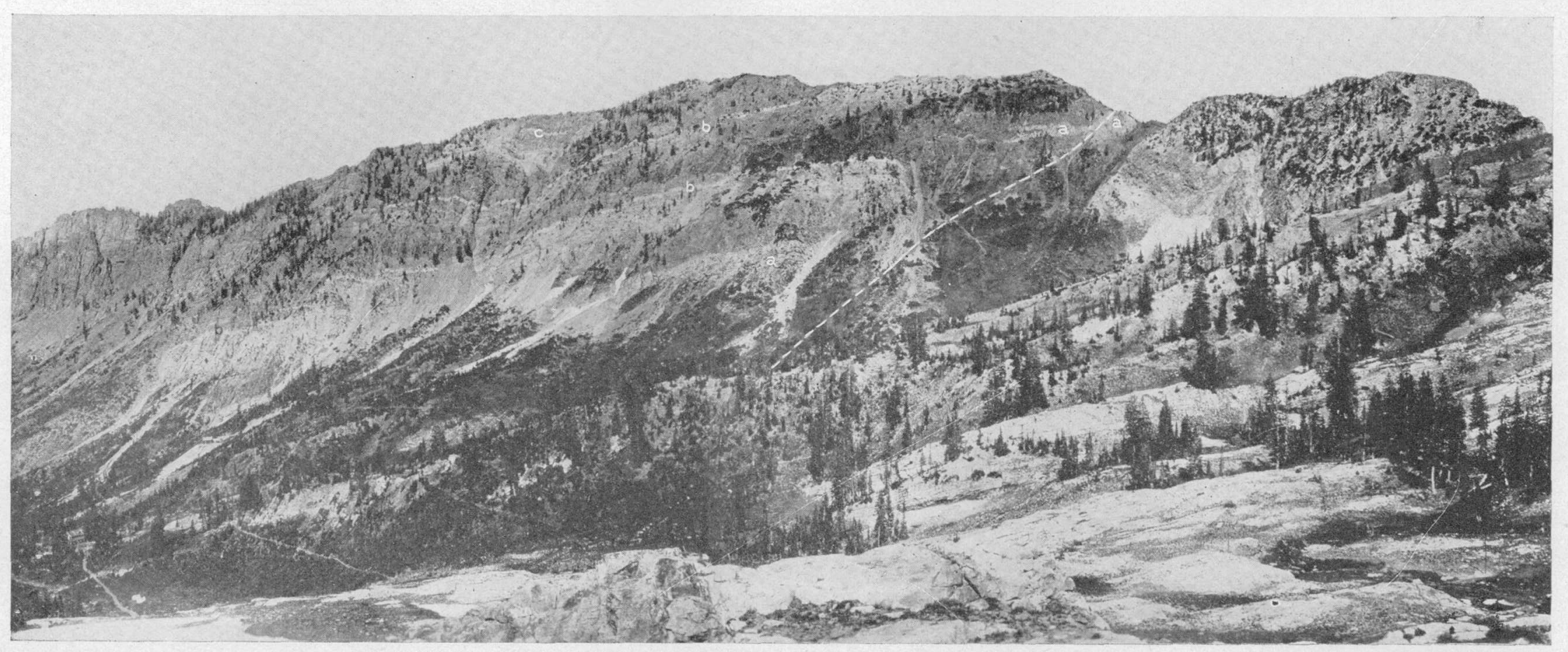

B. SOUTHERN PART OF REED \& BENSON RIDGE, FROM BENCH NEAR MONTE CRISTO MINE.

Light.colored bands are (a) limestone in Ophir shale, (b) dolomite at top of Maxfield limestone, and (c) dolomite at top of Jefferson (?). Block between Superior faults forms ridge in middle distance. Dashed line, 


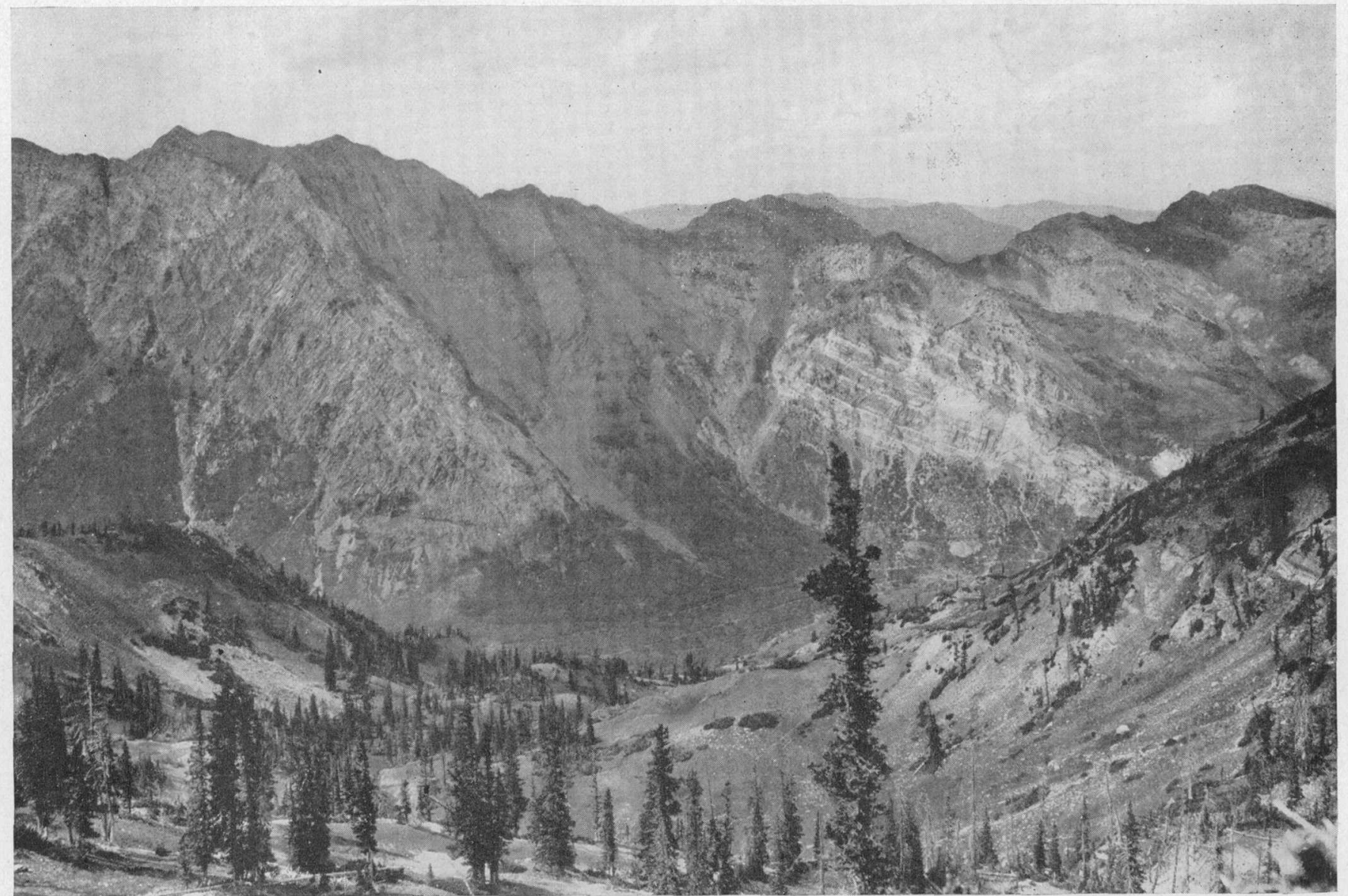

A. NORTH SIDE OF LITTLE COTTONWOOD CANYON NEAR SUPERIOR GULCH

Superior fault zone near middle. Tillite and pre-Cambrian quartzite at left. Light-banded cliff at right chiefly Mississippian limestone, overlain by Tintic quartzite above Alta overthrust. Columbus overthrust just below small dark knob on crest.

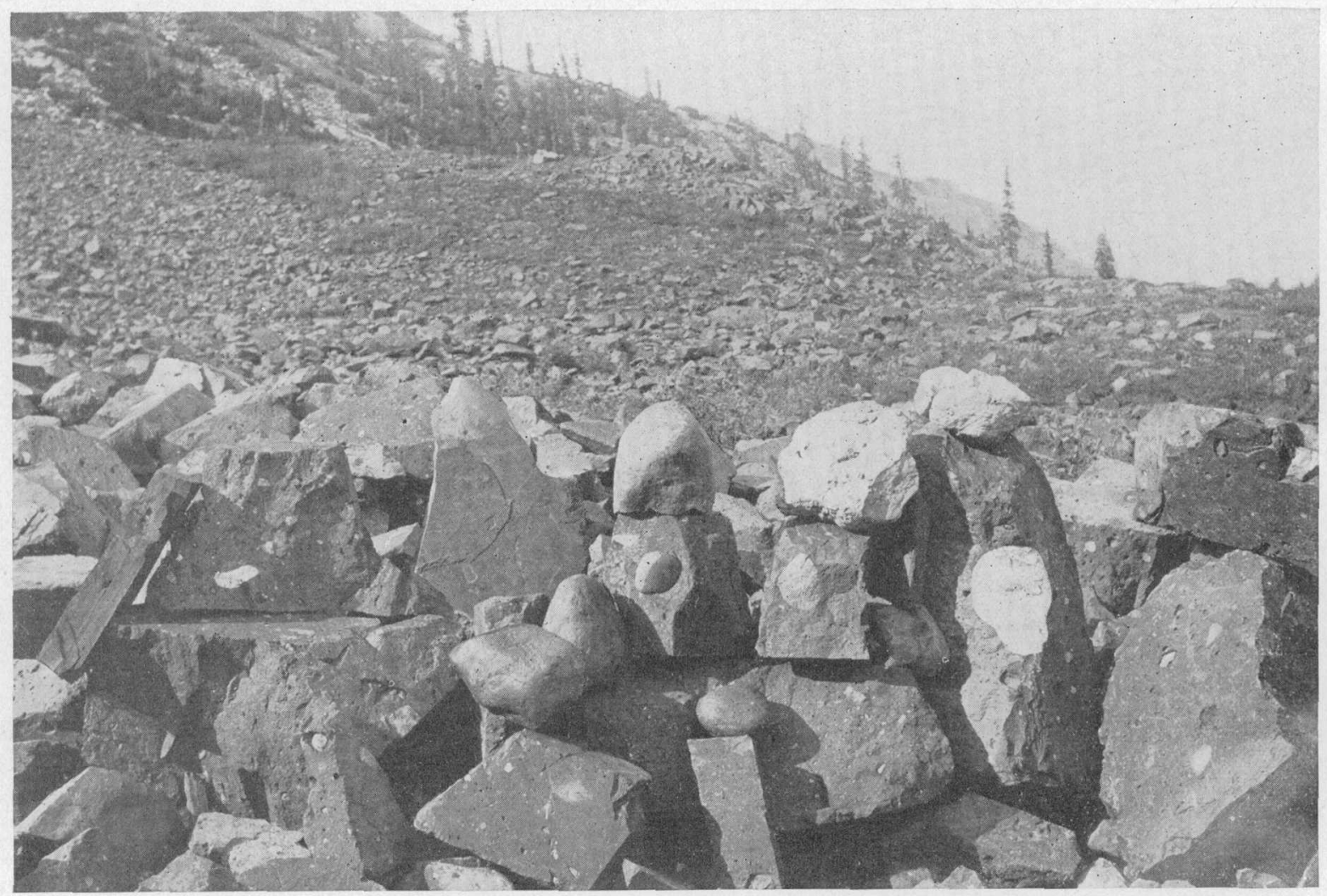

B. TILLITE BLOCKS IN TALUS AT HEAD OF MILL D SOUTH FORK.

Slab of varved shale at left. Boulders mainly quartzite: some are granite and a few, partly dissolved out, are limestone. 
shale member, a middle limestone member, and an upper shale member. The total thickness of this formation is about 400 feet. The remainder of the Cambrian section in this area consists mainly of dolomite and limestone but includes shaly strata near the top. The maximum observed thickness of this youngest Cambrian formation, to which Hintze applied the name "Maxfield limestone," is about 600 feet, but it varies widely, the formation being very thin at some places and wholly absent from others, because of erosion that preceded the deposition of the Devonian (?) dolomite. In at least one place a slight angular unconformity between these two formations can readily be seen. Cambrian fossils have been found at a small distance, stratigraphically, below the unconformity, and Carboniferous fossils about 150 feet above it. It is fairly certain that Ordovician and Silurian rocks are lacking in the area, and-it is believed by the authors of this report that the next younger, probably Devonian strata represent the Jefferson limestone, which they resemble lithologically.

The Carboniferous rocks are noteworthy from several points of view- they occupy about as great an area as all the other rocks combined; their thick-bedded limestones form striking topographic features; and they contain or at least form one wall of some of the most productive ore bodies. The lowest and thickest formation of unquestioned Carboniferous age is a body of limestone about 560 feet thick, which contains abundant fossils indicating that it belongs to the lower Mississippian Madison limestone. Above this lies 200 feet of cherty magnesian limestone and dolomite, which represents the Deseret limestone. The Deseret is overlain by about 750 feet of limestones interbedded with sandstone and containing in the upper part fossils of late Mississippian (Brazer) age. This formation appears to have been originally an extension of the Humbug formation of the Stockton and Fairfield quadrangles, to the west.

The Mississippian rocks are overlain, apparently with a slight unconformity, by 200 feet of limestone, rich in Pennsylvanian fossils and with a conglomerate at the base. This limestone is believed to correspond to the Morgan formation, and is herein tentatively so called. Above it lies the Weber quartzite, which contains some beds of sandstone and limestone and is about 1,200 feet thick. The Weber is overlain by the Park City formation, of Permian and Pennsylvanian age, which is 600 feet or more in thickness. This formation is heterogeneous in composition, containing limestone, chert, sandstone, shale, and a little phosphate rock.

The Mesozoic series is represented by four formations, which crop out mainly in the northeast corner of the area. The oldest is the dark-red Woodside shale, about 700 feet thick. Above that lies the Thaynes formation, about 1,100 feet thick, consisting of limestone, sand- stone, and shale. The Woodside and Thaynes are of Lower Triassic age. Next comes the red Ankareh shale, also about 1,100 feet thick and probably also 'Triassic. This in turn is overlain by the latest sedimentary formation in the area except the surficial Quaternary deposits-the Nugget sandstone-only a few hundred feet of which is exposed in the area and whose total thickness is not known. No fossils have been found in the Nugget sandstone of this area, but it is regarded as certainly Jurassic and probably Middle Jurassic.

The rocks from the Park City formation to the Nugget sandstone crop out mainly in the northeastern part of the area, adjacent to the Park City area. Boutwell ${ }^{10}$ measured and studied his type section in this neighboring area of Cottonwood Canyon. This section is reproduced as part of plate 5 , and the descriptions of the Park City and later formations are partly taken from Boutwell's paper.

\section{PRE-CAMBRIAN ROCKS DISTRIBUTION AND MAPPING}

The pre-Cambrian rocks of the mapped area occupy a relatively small fraction of its surface and occur almost wholly in its southwestern part. Their largest outcrop within the area extends from the head of Mill D South Fork to the head of Mary Ellen Gulch and includes the Twin Peaks and Superior Mountain; another large outcrop, bounded on the west by the Silver Fork fault, extends along Mary Ellen Gulch and the upper part of American Fork. Outside the mapped area, Big Cottonwood and Little Cottonwood Canyons reveal splendid sections of the pre-Cambrian strata. Part of the section on the north side of Little Cottonwood Creek is shown in plate $6, \mathrm{~A}$.

The part of the pre-Cambrian that crops out within the area mapped consists mainly of quartzite, and, although locally at least it includes layers of shale that are thick enough to have been mapped, it is here mapped as a unit.

In Professional Paper 111 the pre-Cambrian was regarded as including a large lenticular body of tillite overlying the quartzite, but this tillite is now thought to be probably Cambrian. (See p. 10.)

\section{CHARACTER}

The pre-Cambrian rocks that occur in the mapped area are in large part close to intrusive stocks, by which they have been considerably metamorphosed. Because of this fact and of the limited extent to which these rocks have been studied, they cannot be satisfactorily correlated until the study has been carried out over a wider area and away from the intrusive rocks; the correlations suggested between the sections described must be rcgarded as tentative.

Pre-Cambrian rocks in a relatively unaltered condition are best exposed on the walls of the upper part of

${ }^{16}$ Boutwell, J. M., Geology and ore deposits of the Park City district, Utah : U. S. Geol. Survey Prof. Paper 77, pl. 5, 1912. 
the American Fork Canyon, especially on the north wall near the Bog and Silver Dipper mines. The strata that occur here are, in ascending order, (1) about 1,000 feet of mainly quartzitic rocks, whitish to red or dull purple, the uppermost beds very fine in texture and white or only faintly tinged with red and purple; (2) about 500 feet of very homogeneous argillite, some showing slaty cleavage, dark gray on fresh fracture, but greenish and partly coated with ocher on weather surface; (3) about 200 feet of rusty quartzitic rocks, mostly purplish on fresh fracture; (3) about 100 feet of argillite, mostly dull; very dark purple but showing several green bands and local mottling with green, which appear to:be due to some secondary reducing process; and (5) about 400 feet of quartzitic rocks interbedded with several layers of dark-purple shale; quartzitic beds are mainly: tinged with purple but in the upper 40 or 50 feet they are whitish and so hard that they form a steep bluff. Some of the higher beds are, indeed, whiter, finer-grained, and purcr than any of the overlying Cambrian quartzite. Much of the purple sandstone is pebbly, the pebbles being mainly of red argillite and less than a quarter of an inch in diameter.

On the south side of American Fork, opposite the cliff just described, white quartzites dipping northward under the shaly beds are widely exposed. The shaly beds have no large exposure here. They may in part be cut out by the unconformity at the base of the Cambrian, which is distinctly visible about opposite the lower Bog tunnel.

In Mary Ellen Gulch the character and thickness of the exposed pre-Cambrian rocks is essentially the same as on the cliff northwest of the Bog mine.

The north face of the Twin Peaks affords very striking exposures of the pre-Cambrian rocks, but a detailed comparison between these exposures and those in the American Fork Basin, so near at hand, is rendered difficult by the fact that the rocks of the Twin Peaks have been strongly metamorphosed by the quartz monzonite - of the Little Cottonwood stock; whose boundary rises southwestward from the north base of the mountain over the crest of its northwest spur. This metamorphism has tended to obliterate any distinctive coloration the sedimentary rocks into which the monzonite was intruded may once have had. Nevertheless, the highest layer of shale in the mountain, which is about as thick as the layer of purple shale in the cliff near the Bog mine, resembles it also in character. 'Though nearly black in general tone, it is still obscurely tinged with purple and is blotched and irregularly laminated with green by the local action of reducing agencies. These features tend to justify a correlation of this stratum with the similar bed above described; the overlying beds, moreover, which form the top of the eastern Twin Peak, are tinged in part with purple like the supposedly corresponding beds farther east, though their tints are dull and pale and shade into greenish gray. No pebbles were found here below the basal conglomerate of the Cambrian.

If, however, this upper shale is correctly correlated, the sequence of strata here differs considerably from that only 2 miles to the east. The purplish argillite is underlain by about 400 feet of quartzite, which forms the top of the western peak. The lower part of the north slope of the peaks, below the thick layer of quartzite that caps the west peak, consists mainly of dark shaly rocks, having a total thickness of fully 1,000 feet, though divided near the middle by a layer of white quartzite somewhat less than 100 feet thick. It was thought possible that a thrust fault at the base of this quartzite had repeated the shale, but close examination of the contact.revealed no evidence of faulting. The lower shales, which are more strongly metamorphosed than the upper, are in part finely laminated in dark gray and white, in part more homogeneous. Some beds are siliceous enough to approach quartzite. Their general color in outcrops is very dark and is tinged with reddish-brown iron oxide, which coats much of the weathered surface. Nothing was found in the mountain mass that resembles tillite, no pebbles nor even the characteristic angular grains of quartz being embedded in the argillite.

Toward the base of the mountain, which is near the incrusive contact of the Little Cottonwood stock of monzonite, the laminae are intricately contorted in places, and the rock contains much biotite and a prismatic mineral, probably cordierite, that forms small lumps on cleavage faces.

'The quartzite in Twin Peaks, below the upper shale, is for the most part white or faintly striped in gray; it is of fine, compact texture and is free from pebbles.

Between the Twin Peaks and Little Cottonwood Creek, the pre-Cambrian rocks are not extensively exposed and their sequence is not clear. On the steep slope northeast of the lower end of Gad Valley a dark rusty rock, resembling and possibly.equivalent to the highest band of shale in the Twin Peaks, underlies the tillite and overlies the highest pre-Cambrian quartzite, about 500 feet of which overlies the intrusive monzonite. No body of shale approaching in thickness the main body of argillite on the lower slopes of Twin Peaks was noted here.

The north wall of Little Cottonwood Canyon affords a truly spectacular exposure of pre-Cambrian rocks in contact with the Little Cottonwood stock of quartz monzonite (pl. 6, A). The portion of the pre-Cambrian' that is exposed within the mapped area is roughly 1,500 feet thick and consists mainly of quartzite. The main quartzite north of Little Cottonwood Canyon is interleaved with beds of shale, and in its lower part is a stratum of gray quartz-mica rock, presumably reppresenting a shaly sandstone, about 100 feet thick. Between the lowest quartzite and the intrusive quartz 
monzonite is about 200 or 300 feet of dark-gray hornfels representing a strongly metamorphosed shale. No detailed correspondence with the sequence on Twin Peaks was recognized.

The best exposures of the pre-Cambrian in this region are displayed along Big Cottonwood Creek west of the mapped area. This section was measured by Walcott, ${ }^{17}$ but it has not been studied as a whole by the writers of the present report. The north wall of the canyon was ascended, however, near the 19-mile post, some distance west of the mapped area, and there the Cambrian quartzite was found to lie directly upon reddish-purple, in part pebbly sandstones, interbedded with dark-maroon shales that are similar in general to the highest preCambrian beds near American Fork and unaffected by the metamorphism that has occurred near the Little Cottonwood stock. "Most of the pebbles consist of red shale and are nut more than a quarter of an inch in diameter, but the rock also contains angular flakes of red shale and some pebbles of white quartzite, which are larger than the shale pebbles.

The lack of detailed correspondence between the sections exposed in different ${ }^{\circ}$ places may mean that the thick strata of shale and quartzite are lenticular and do not persist throughout the district; but it may be due in part to an unconformity at the base of the tillite by which these strata are overlain.

The character of the pre-Cambrian rocks, especially the presence of red shales and of anguiar red-shale fragments in the sandstone, indicates that they are of continental origin.

Little microscopic study of the pre-Cambrian rocks has been made, but a few highly metamorphosed specimens appear worthy of brief description. A dark-gray obscurely dappled rock from the north base of the Twin Peaks is found to contain both andalusite and cordierite in abundance. The cordierite is in large poikilitic grains, the andalusite in smaller prisms. In some interstitial areas, the original texture of the rock is still visible; subangular grains of quartz are there embedded in an abundant micaceous cement. There is much redbrown biotite in ragged flakes, a good deal of magnetite, and sporadic tourmaline and zircon.

A somewhat similar rock from the slope west of Superior Gulch contains much andalusite and a limpid poikilitic mineral, which proves to be not cordierite but orthoclase. This encloses very numerous grains of quartz, as smoothly rounded as if they were in process of dissolving. The rock contains much biotite and muscovite and a good deal of magnetite and tourmaline.

A metamorphosed sandstone from the south slope of Superior Peak has rounded grains of quartz, between which are rather large areas filled in mainly with pale green amphibole and pyroxene and calcic feldspar.

\footnotetext{
${ }^{17}$ Walcott, C. D., Second contribution to the studies on the Cambrian faunas of North America : U. S. Geol. Survey Bull. 30, pp. 38-39, 1886 ; Correlation papers-Cambrian: U. S. Geol. Survey Bull. 81, pp. 159, 810 .
}

\section{CAMBRIAN SYSTEM}

GENERAL SEQUENCE

The lowest rocks here tentatively assigned to the Cambrian system consist of tillite, a glacial deposit, which is lenticular and is absent from the southern part of the area. The overlying Cambrian rocks consist of strata that originally must have extended throughout the area with nearly uniform thickness, although an unconformity cuts more or less deeply into the upper part of the sequence. The rocks above the tillite are divisible into three formations, of which the lowest consists chiefly of quartzite, the middle chiefly of shale, and the highest chiefly of limestone and dolomite.

\section{TILIITE (CAMBRIAN?)}

CHARACTER

The tillite is lithologically the most unusual of all the formations in the area. Its dark, rusty rocks have a very conspicuous and impressive exposure in Superior Peak (pl. 7, A), where the formation is about 1,000 feet thick and where its bedding shows a bold sigmoid flexure. This exposure extends around the main head of Mill D South Fork, in a line of cliffs and steep barren slopes plunging downward into a vast body of talus. The formation was not found, however, about 4 miles to the northwest, where the base of the Tintic (Cambrian) quartzite crosses Cottonwood Creek and is immediately underlain by pre-Cambrian quartzite. Toward the south the tillite in this belt is less well exposed, and in this direction it diminishes greatly in thickness, pinching out altogether about lialf a mile south of the Cottonwood quadrangle: A much narrower belt, broken into small areas because of complex faulting, extends along the east side of the Silver Fork fault from Little Cottonwood Creek to the cliff above the Bog mine, where it, too; pinches out.

The most abundant rock of this formation is a tillite, a rather coarse facies of which is illustrated in plate $7, B$. The most significant feature of the tillite is that it contains large cobbles or small boulders in an abundant relatively fine matrix, which would be relatively much less abundant if the deposit had been laid down by water. The pebbles, cobbles, and boulders are in part subangular, though on the whole fairly well rounded. Few of them are over 1 foot in diameter; the largest observed are perhaps 3 feet. Their composition is varied. Perhaps the greater part of them consist of gray, red or purplish, and white quartzite, much of it resembling quartzite in the underlying strata. A small proportion of the boulders consist of light-grey limestone; many more consist of calcareous rocks containing much silica and argillaceous matter; and a few consist of a granitic rock. The source of the granite and calcareous rocks is not known.

The matrix of these worn rock fragments is all very dark, and is vaguely tinged with blue, green, or 
purple. It contains a large proportion of black pigment; which is at least in part magnetite, and the decomposition of this mineral may have supplied the ferric oxide that coats the weathered surfaces of the rock. The matrix contains abundant readily visible grains of quartz, which are embedded in dull, nearly black material of microscopic fineness. These grains may be seen under the microscope to have, almost invariably, a sharply angular outline, which shows that they do not belong to a well-washed aqueous deposit; and the abrupt transition from fragment to matirix holds true of the quartz grains as it does of the boulders.

Rock like the matrix of the boulders but free from anything larger than a few small pebbles forms a good many beds several feet in thickness. A large proportion of the formation, though much lëss than half, consists of shale, which is in general dark blue gray, with the same rusty coating as the tillite, but shows a fine lamination marked by stripes of lighter gray color. Ripple marks, or markings taken to be such, appear on the bedding planes in places. This material resembles the varved clays of the last glacial stage, which have been studied by Antevs. ${ }^{18}$

\section{RELATION TO UNDERLYIÑ ROCK}

The contact of the tillite with the underlying quartzite is best exposed on Superior Peak and is there sharply defined. At one point on the southeast spur of the mountain the bedding of the quartzite, as seen from a short distance, appears to dip more steeply than the contact. The presence of boulders of white and reddish quartzite in the tillite suggests, though it does not prove, an unconformity. The lenticular form of the tillite body and the fact that the highest beds of the underlying quartzite formation, including the purple shale and pebbly beds, occur where the tillite is absent and are lacking where it is thick point in the same direction. Indeed, an unconformable relation of the tillite, whose deposition must have signalized a marked change of climate, to the underlying rocks would appear to be inherently probable.

\section{TINTIC QUARTZZITE}

CORRETATION AND OHARACTER

A quartzitic formation resembling in character and relations the lowest formation that in most of the Rocky Mountain province is pretty certainly Cambrian is welldeveloped in the Cottonwood-American Fork area. It occurs mainly in the southwest quarter of the Cottonwood quadrangle and the western part of the southward extension. It borders the pre-Cambrian rocks and the tillite on the east wherever they occur, and though much thinner than these rocks it occupies a somewhat larger portion of the mapped area. It underlies the Ophir shale and overlies the Cambrian(?) tillite and the pre-

\footnotetext{
18 Antevs, Ernest, Varved sediments : Nat. Research Council Reprint and Circ. ser., No. 98, pp. 51-53, 1931; Nat. Research Council Bull. 89, pp. $89-90,1932$.
}

Cambrian rocks. It occupies the same stratigraphic position as the Tintic quartzite of the Tintic district and the: Stockton and Fairfield quadrangles, to the west, where the Tintic is overlain by the Ophir shale, and it is therefore designated the Tintic quartzite. It is considered to be equivalent to the lower part of the Brigham quartzite of northeastern Utah, but the Brigham formation includes Middle Cambrian beds that probably correspond to part of the Ophir shale.

Being highly resistant to weathering (see pl. 8, $A$ ), this quartzite is. well exposed in all its occurrences. The most accessible complete exposure, which is also the most compact and best suited to measurement, is on the divide between Big Cottonwood and Little Cottonwood Creeks, about half a mile due east of the Monte Cristo shaft. (See pl. 6, B.) The thickness exposed in this section is about 800 feet. Other sections near the head of American Fork give somewhat greater figures, but these are not so reliable.

The formation is more homogeneous than most others, consisting almost wholly of quartzite, though it includes a little conglomerate near the base and some thin beds and partings of *shale, chiefly in the upper part. The dominant material in mose exposures is a white or faintly flesh-tinted quartzite of medium to rather coarse texture. Some layers are faintly striped in gray; some of those in the lower part, at places where little alteration has occurred, are more or less deeply tinged with purple. Bedding planes and joint faces are as a rule thinly coated with iron oxide, so that large outcrops viewed from a distance appear to have an orange hue, but the general tones of the outcrốps are light and present a striking contrast to the dark colors of the tillite below-where that is the underlying rock-and of the shale above. In most places where the Tintic quartzite rests on pre-Cambrian quartzite the contact is not marked by any sharp distinction of color, and in such places it is not always easy to find.

Features present in certain beds of the quartzite are pebbles, cross-bedding, and crystals of siderite and pyrite. The pebbly beds, which in part are well-washed conglomerates, occur mainly in the lower part of the formation, though small pebbles, chiefly of quartz, are found in the upper part. The lower pebbly beds are described below, in the section on the unconformity at the base of the quartzite.

Cross-bedding is rather common in the Tintic quartzite. At two localities west and northwest of Alta, and also in the Wasatch drain tunnel, it was observed that if the dip of the bedding proper were made horizontal the cross-bedding would dip westward. The crossbedded layers are commonly porous, and the lamination is brought out by a fluting on weathered surfaces.

Weathered surfaces of the quartzite show in places rather evenly distributed rusty pits about $1 / 4$ inch in diameter. Fresh material from a dump (marked " 9457 " on the map) near the head of American Fork 
is faintly marked with brownish-yellow spots of similar size and spacing; and it is seen in thin section that these spots are caused by incipient weathering of irregular grains of a ferruginous carbonate, which has grown in the rock since its consolidation. A similar development of iron-bearing carbonate is common in quartzitic rocks of the Coeur d'Alene district, Idaho. ${ }^{19}$

\section{RELATION TO UNDERLYING ROCKS}

At several places in the American Fork Basin the Tintic quartzite may be seen to rest upon pre-Cambrian quartzite with distinct angular unconformity: At these places and many others it contains well-rounded pebbles of quartzite closely resembling and presumably derived from the immediately underlying pre-Cambrian beds. If they were so derived, the pre-Cambrian sands must have been thoroughly consolidated, as well as tilted, before the Cambrian was deposited. The relation to the tillite on the other hand is not certain. Neither angular unconformity nor the presence of pebbles or boulders of tillite in the overlying quartzite has been observed by the writer, but near the face of the lower tunnel of the Howell mine, which is on Mill D South Fork and just west of the Cardiff mine, an arkosic conglomerate that appears to lie in the basal part of the Cambrian quartzite contains many pebbles of shale like that interbedded with the tillite: The Cambrian quartzite is believed; nevertheless, to be only a little younger than the tillite, for clay may be suffciently hardened to form pebbles in a relatively short time.

The clearest evidence of an unconformity at the base of the Cambrien quartzite is to be seen on the west side of Mary Ellen Gulch about a mile below the Yankee mine. The contact is here at the top of a bluff which affords a good exposure of about 100 feet of the preCambrian rocks. These consist mainly of quartzite and quartzitic sandstone, more or less deeply colored with reddish purple, but they include some thin beds of greenish-gray quartzite and some beds and partings of dark reddish-purple shale. 'The bedding is sufficiently marked by color banding to be readily visible at a distance, and when the outcrop is viewed from the opposite side of the gulch it is readily seen that, although both the Cambrian and the pre-Cambrian dip gently downstream, the dip of the pre-Cambrian rocks is several degrees steeper than that of the light-colored Cambrian quartzite. Good observations, taken close together, for dip and strike give N. $80^{\circ} \mathrm{E}$., $23^{\circ} \mathrm{S}$., for the Cambrian and N. $50^{\circ} \mathrm{E}$., $33^{\circ} \mathrm{S}$., for the pre-Cambrian, and if the Cambrian were made horizontal, the dip of the pre-Cambrian would be a little more than $10^{\circ} \mathrm{SE}$.

At the base of the Cambrian here is a layer of conglomerate about 1 foot thick, made up of fairly well

\footnotetext{
${ }^{10}$ Ransome, F. I., and Calkins, F. C., Geology and ore deposits of the Coeur d'Alene district, Idaho: U. S. Geol: Survey Prof. Paper 62, p. 97, 1908 .
}

rounded pebbles of quartz and of quartzite and sandstone like the immediately underlying rocks. The most usual diameter of the pebbles is about 2 inches and the largest about 5 inches; there is a good deal of sandy matrix. This basal conglomerate is overlain by about 30 feet of coarse sandstone with pebbly bands. This rock is mostly tinged with purple, but its color is less reddish and lighter than that of the pre-Cambrian rocks. About 50 feet above the base is a layer of conglomerate 1 foot thick, which contains pebbles of hard dark-purplish argillite and of quartz and quartzite. A bench marks the place of a softer unexposed stratum, above which is a bluff of the flesh-tinted quartzite that constitutes the main body of the formation.

The cliff above the Bog mine exhibits relations very similar to those on Mary Ellen Gulch, though the angular unconformity is not so readily visible; it may best be seen from certain points near the contact, by looking along the cliff. The amount of discordance..is about $10^{\circ}$, but the older beds dip in a more northerly:direction than the younger, indicating the presence of a broad arch between this locality and the one already described.

On the slope east of the cliffs, near the lower Bog tunnel, a band of white quartzite in the pre-Cambrian may be seen to taper out eastward beneath the Cambrian, which overlaps its beveled edge. The character of both the Cambrian and the pre-Cambrian beds is here much the same as on Mary Ellen Gulch, but the Cambrian has no well-defined basal conglomerate, though it is more or less pebbly for some 40 or 50 feet above the base. On the south side of American Fork, opposite the Bog lower tunnel, a distinct angular unconformity between Cambrian pebbly quartzite and white pre-Cambrian quartzite is visible and is shown by dip symbols on the geologic map.

At one place near the west end of Miller Hill a conglomerate believed to mark the base of the Cambrian may be seen to wedge out and, the quartzite above and below it being much alike, the contact becomes inconspicuous.

At various places in the western part of the Cottonwood quadrangle a basal Cambrian conglomerate, usually' not far from 5 feet in thickness, was observed. Its pebbles, about 6 inches in maximum diameter, consist almost exclusively of quartz and white and purple quartzite. No pebbles of the tillite, which is now a very tough rock and which at many places immediately underlies the conglomerate, have been found in this rock by the writer. This fact would seem to indicate that the tillite had not become consolidated when the basal Cambrian beds were laid down. An apparent contradiction of this evidence, however, is afforded by a peculiar arkosic conglomerate which was entered by the lower tunnel of the Howell mine.

This rock, which formed the face of the tunnel when the mine was visited in 1921 and then covered most of 
the surface of the dump, is a tough, dark, fine-grained conglomerate, containing pebbles mostly less than an inch in diameter. It appeared underground to grade into a coarser, lighter conglomerate like that usually found near the base of the Cambrian, and it was therefore itself presumed to be Cambrian; its base was not then exposed in the mine. It contains a few pebbles of some granitic rock and of quartz, and rather more numerous grains and small pebbles of bright-lustered, generally pink feldspar, which give the rock somewhat the appearance of a porphyry. Well-rounded pebbles of white or dull reddish-purple quartzite are fairly abundant, but the rock is chiefly characterized by fragments of a black argillite similar to that which is interbedded with the tillite. The maximum size of these fragments is about the same as that of the quartzite pebbles. Some of them are rounded or partly so, but more of them are angular, and the outlines of many are in part concave, some but not all of the concavities having been formed by the pressure of hard pebbles either before or after the rock was consolidated.

Although it may appear at first thought that this rock must have been formed after the black argillite was lithified, this is not necessarily true. If such lithification had occurred, pebbles of the tillite would hardly be lacking, for this rock is now much tougher than the argillite. In a state of merely incipient consolidation, however, clay is more coherent than a sandy material like tillite. Moreover, a mechanism can readily be imagined for the formation of pebbles of clay that would not operate in the case of tillite-namely, through the breaking up of the plates formed by sun cracking of a layer of mud. It seems probable that this peculiar conglomerate, apparently very local in its distribution, was formed on and adjacent to a mud flat where upwarped plates of cracked and partly dried black mud were roughly molded into pebbles, but not transported far, by waves or currents, and that these pebbles became mingled with long-traveled and well-rounded pebbles of quartz: ite, of igneous rocks, and of quartz and feldspar derived from such rocks. The same explanation is believed to account for the abundance in some of the pre-Cambrian sandstone of little pebbles and fragments of red argillite similar to that interbedded with the quartzite.

An unconformity between Cambrian and pre-Cambrian quartzites, representing an interval during which the earlier formation became well consolidated, then tilted so as to have dips in places exceeding $10^{\circ}$, and considerably eroded, has been demonstrated by the observation of angular discordance at several places along the contact and of pebbles of the older quartzite in the younger. No such proof that the Cambrian is unconformable on the tillite has been found by the writer. On the contrary, the absence of tillite pebbles from the Cambrian conglomerate resting on tillite seems - inconsistent with the lapse of a geologically long inter- val of time between the deposition of the two formations, and the presence of abundant fragments of argillite in the arkosic conglomerate of the Howell mine is explainable without postulating a long interval.

Evidence, though it is hardly conclusive, has been given that a long interval elapsed between the deposition of the pre-Cambrian quartzite and that of the tillite. It is believed, therefore, that the tillite was deposited in a valley which had been eroded, partly by glacial action, in the pre-Cambrian quartzite, and that the tillite was overlapped without angular unconformity by the Cambrian sands not long after the withdrawal of the ice.

CONDITIONS OF DEPOSITION

Although no fossils have been found in the Cambrian quartzite of the Cottowood-American Fork area, marine fossils occur at other places in the similar quartzite which generally forms the lowest part of the Cambrian in the Rocky Mountain region; and on Big Cottonwood Creek the overlying Ophir shale, into which the quartzite gradually passes, contains marine fossils. Doubtless, therefore, this quartzite is a salt-water beach deposit of Cambrian age. It is unconformable on the underlying rocks and is believed to have originally been an eastward extension of the Tintic quartzite.

OPHIR ShaLE

\section{GENERAL FEATURES}

The Tintic quartzite is overlain by a formation, about 420 feet in total thickness, which consists mainly of shale but contains a well-defined medial stratum of limestone. This formation is correlated with the Ophir formation of the Ophir district.

The occurrences of the Ophir formation are distributed similarly to those of the underlying quartzite and are mainly confined to the southwest half of the area. Being soft, the formation is not generally well exposed, and the only continuous and complete unfaulted exposure of it in unaltered condition is on the east spur of Twin Peaks. A nearly complete natural section is displayed just enst of Superior Gulch, but there the rocks are considerably metamorphosed. A good section of the lower shale member adjoins that of the quartzite at the head of Mill D South Fork, and there are good exposures of the upper shale west of the lower part of that stream and on the ridge west of Devils Castle. The limestone, being more resistant than the shales, is conspicuously exposed in many places.

\section{LOWER SHALE MEMBER}

The lower shale member is about 240 feet thick. Its general color, where it is least altered, is dark olivegreen to dull bluish-green, more or less veiled on weathered surfaces with a reddish-brown coating of iron oxide. Where it has been affected by contact metamorphism the shale is darker than elsewhere and mostly 
has a dark brownish-gray color. In places, notably in the Columbus workings (pl. 40), great masses of this shale have taken on a green color as the result of hydrothermal action in fault zones.

The basal beds of the formation are transitional to the underlying quartzite, being interleaved with thin beds of quartzite just as the highest part of the quartzite is interleaved with shale; the boundary is so drawn as to delimit the predominantly shaly beds from the predominantly quartzitic beds. Once clear of the quartzite, the formation shows beds of distinctly fissile shale, which are olive green where they are least altered. The main, middle part of the shale is less fissile and a little sandy, and its bedding partings are characteristically spangled with mica. For about 20 to $60^{\circ}$ feet from the top, at least near Alta, the rock is slightly calcareous, and some of it contains nodules of limestone; the uppermost 15 or 20 feet is fine-grained and fissile like the beds neai the base but darker in color.

The bedding surfaces of the shale, other than the fissile beds, are characteristically wavy and lumpy, and some of those in the lower part of the formation have ripple marks associated with raindrop impressions and irregular groovelike markings that may be worm trails or imprints of fucoids. Fossils, including trilobites and linguloids, appear to be numerous, but they are rarely so well preserved that even their genus can be determined. The identified fossils found in the formation are discussed on page 18. Wormlike bodies, possibly fucoids, occur in certain beds. (See pl. 9.)

The lower member of the Ophir shale is not very conspicuously affected by contact metamorphism; even where it is most altered its characteristic dark coloring and reddish rusty staining are retained and even accentuated. The most evident effect of moderate metamorphism in the main body of the shale is an increase in the amount of visible mica; in a ferv places an obscure knotty structure suggests the presence of andalusite or cordierite: The finer-grained rocks become less fissile, the uppermost fine-grained beds, in particular, taking on the character of tough, dark, chocolate-brown hornfels, which brealss into regular joint blocks. The slightly calcareous beds next below are shaiply banded in chocolate and green. The chocolate color is due to biotite, and the green to amphibole and pyroxene. The gray color, imparted locally by hydrothermal alteration, is due to chloritization of the biotite.

In thin sections from the less altered specimens representing the lower member of the Ophir shale, it is seen that the coarser layers consist mainly of subangular to rounded grains of quartz, with only a small proportion of orthoclase and sodic plagioclase and some biotite and muscovite. In the finer-grained parts there is more mica. Calcite, lime-bearing silicates, and titanite are lacking in the main body of this member. Contact metamorphism has had some effect on all of the material collected. A sjecimen taken just west of the Tom Moore portal contains tourmaline and altered cordierite, though the original texture of the rock is largely preserved. In a more strongly altered specimen from east of the South Hecla mine, there is much orthoclase in large poikilitic grains and much andalusite in small ragged grains, together with much quartz, some biotitle, muscovite, and magnetite, and a little tourmaline and zircon.

The only specimens from the calcareous layer near the top of the formation that have been studied microscopically are highly metamorphosed. Two of these are hornfels banded in brown, greenish white, and dark green, but present a striking contrast in the character of their feldspars. In one, from the east side of Albion Basin, there is much diopside, hornblende, and calcic feldspar with minor quantities of quartz, epidote, magnetite, titanite, and apatite. This rock contains no orthoclase, though both orthoclase and calcic feldspar occur in a specimen taken from this layer on Pat:y Marley Hill. In the rock from the Alta tunnel there is no plagioclase; the matrix consists of granular orthoclase, enclosing ragged grains of hornblende and diopside, small grains of quartz, and minute flakes of brown biotite. The difference between these rocks is probably due in large part to chemical changes involved in metamorphism.

\section{IIMESTONE MEMBER}

The middle member of the Ophir formation is a welldefined stratum of more or less siliceous limestone about 80 feet thick. It is sometimes called by mining men the "little lime", in contradistinction to the great body of Cambrian and Carboniferous limestone above the Ophir. It is of economic interest in that it contains several ore bodies, most of which occur at places where this rock is crushed and overlain by quartzite because of the Alta overthrust.

The dominant rock of this part of the Ophir is a light blue-gray nonmagnesian limestone, the bedding of which is characteristically marked by thin wavy siliceous laminae (pl. 8, B). Similar limestone occurs in the Cambrian at many places in the Rocky Mountain region. The main body of the limestone member, except about 10 feet at the base and a like thickness at the top, consists of rock in which the siliceous is subordinate to the limy ingredient, but the limestone becomes more and more dominant upward until the siliceous layers are commonly but a small fraction of an inch in thickness, partly discontinuous, and about 2 inches apart. This fairly pure limestone is succeeded rather abruptly by a strongly laminated rock at least half of which consists of siliceous material. Here it is the limestóne layers that tend to be discontinuous and to pinch out into nodules, pods, and biscuitlike forms. A similar structure shown in later Cambrian limestone is illustrated in plate $11, B$. These siliceous nodular beds are transitioned between the limestone and the upper shale mem- 
ber, although their boundary against either is fairly well defined. The basal part, also, of the limestone member consists of siliceous and nodular limestone, less distinctly laminated than that at the top.

UPPER SHALE MEMBER

The shale above the limestone differs rather consistently in character from that below. Its color in weathered outcrops where it is not metamorphosed is a yellowish brown, distinct from the reddish hue of the weathered lower shale and less superficial; it penetrates so deeply that the color of the unweathered rock, which is generally a pale brownish or greenish gray, is rarely seen except in mine workings. The brown color of the weathered rock is doubtless due to the decomposition of an iron-bearing carbonate, for carbonate is visible in the thin sections. The shale breaks down into thin slabs, but none of it is flaky like certain parts of the lower shale. Like the lower shale, it contains fossils and organic markings.

Because of its carbonate content, the rock of this unit is very susceptible to contact metamorphism. Where it is moderately altered by intrusive bodies, as it is at many localities, it has become hard and lost its fissility, so that the partings along bedding planes are widely spaced and less conspicuous than the transverse joints, which are unusually regular and clean-cut. This blocky jointing is highly characteristic of the upper shale member of the Ophir, which is sometimes referred to by local geologists as the "blocky shale." The bedding of this metamorphosed rock is marked by narrow banding in shades of green and brown, the green usually predominating, especially where metamorphism is advanced.

The least altered specimens from the upper member of the Ophir that have been studied in thin section were taken in the Wasatch drain tunnel. One is mostly pale greenish gray, the other mostly reddish brown. Both are seen under the microscope to consist mainly of angular to subangular grains, at least half of which are quartz, and the rest mainly orthoclase, plagioclase being very scarce. In both rocks calcite is fairly abundant. The color of the greenish specimen is due to green biotite and a little chlorite, that of the brown specimen to brown biotite. Both contain tourmaline-an evidence of incipient metamorphism-and numerous finegrained aggregates of titanite.

'The calcareous shales of this member of the Ophir are highly susceptible to contact metamorphism, and there are abundant exposures of the rocks produced by this alteration in the South Hecla and South Columbus workings and on the surface east of them. The differences between the upper and lower shale members of the Ophir are somewhat exaggerated by contact metamorphism. When metamorphosed the lower shale keeps its dark color, and in some degree its fissility; the upper shale becomes much tougner and is even less readily divided along bedding planes than before, and its general color is lighter. Especially typical of the metamorphosed upper shale is a pale greenish-gray hornfels; in any large exposure this material shows bands and patches of darker green and of chocolate brown, or, where metamorphism is especially intense, of the lighterred or greenish-brown tints characteristic of garnet. In thin sections from almost all of these rocks the background is a mosaic of quartz and orthoclase, the latter on the whole slightly the more abundant. The other chief minerals are diopside, hornblende, and biotite, which respectively characterize the pale gray-green, the darker-green, and the chocolate-brown parts of the rock. Titanite is the most characteristic of the minor constituents. The diopside was formed, at least in part, later than the biotite; in some exposures one may see illdefined brown patches, surrounded by pale green, representing residual masses of biotite-bearing rock enclosed in the diopside-bearing rock. Pale streaks following joints that cross the darker bands, which mark the bedding in some specimens, are found to consist essentially of diopside and orthoclase, the alteration that caused them having evidently enriched the rock in potash. The pale diopside-bearing rock, where its boundaries transgress the bedding, thus represents more advanced alteration than the biotitic or the amphibolebearing facies. Alteration still more advanced is indicated by the formation of garnet, which is always surrounded by the pale-green rock, which the garnet is replacing.

Paleontologic evidence regarding the Ophir shale has been on record for many years. Walcott ${ }^{20}$ long ago reported Lower Cambrian fossils including Olenellus Gitberti from a narrow zone near the base of the lower member of the Ophir shale, and many species of Middle Cambrian fossils from what appears to have been the upper member of this formation. Burling regards the Ophir shale as equivalent to the Pioche.

\section{MAXFIELD LIMESTONE}

NAME

The Cambrian rocks above the Ophir shale are named the Maxfield limestone. The name Maxfield is adopted from Hintze, ${ }^{21}$ who applied it to the Cambrian calcareous beds above the Ophir that occur in the vicinity of the Maxfield mine, although the formation is represented only in small part at that locality. The term "limestone" "as here applied is to be understood in a broad sense. Most of the formation consists of dolomite and of magnesian limestone. Only in what will be described as the middle member does it contain any nonmagnesian limestone, and this occurs only in thin beds

20 Walcott, C. D., Correlation papers-Cambrian : U. S. Geol. Survey Bull. 81 , p. 319,1891 ; Cambrian Brachionoda, U. S. Geol. Survey Mon. 51 , p. 189 , locality $30 \mathrm{a}$, p. 195 , locality $33 \mathrm{~b}$, and p. 206 , locality $55 \mathrm{u}$, 1912 .

21 Hintze, F. F., Jr., A contribution to the geology of the Wasatch Mountains, Utah: New. York Acad. Sci. Annals, vol. 23, p. 107, 1913. 


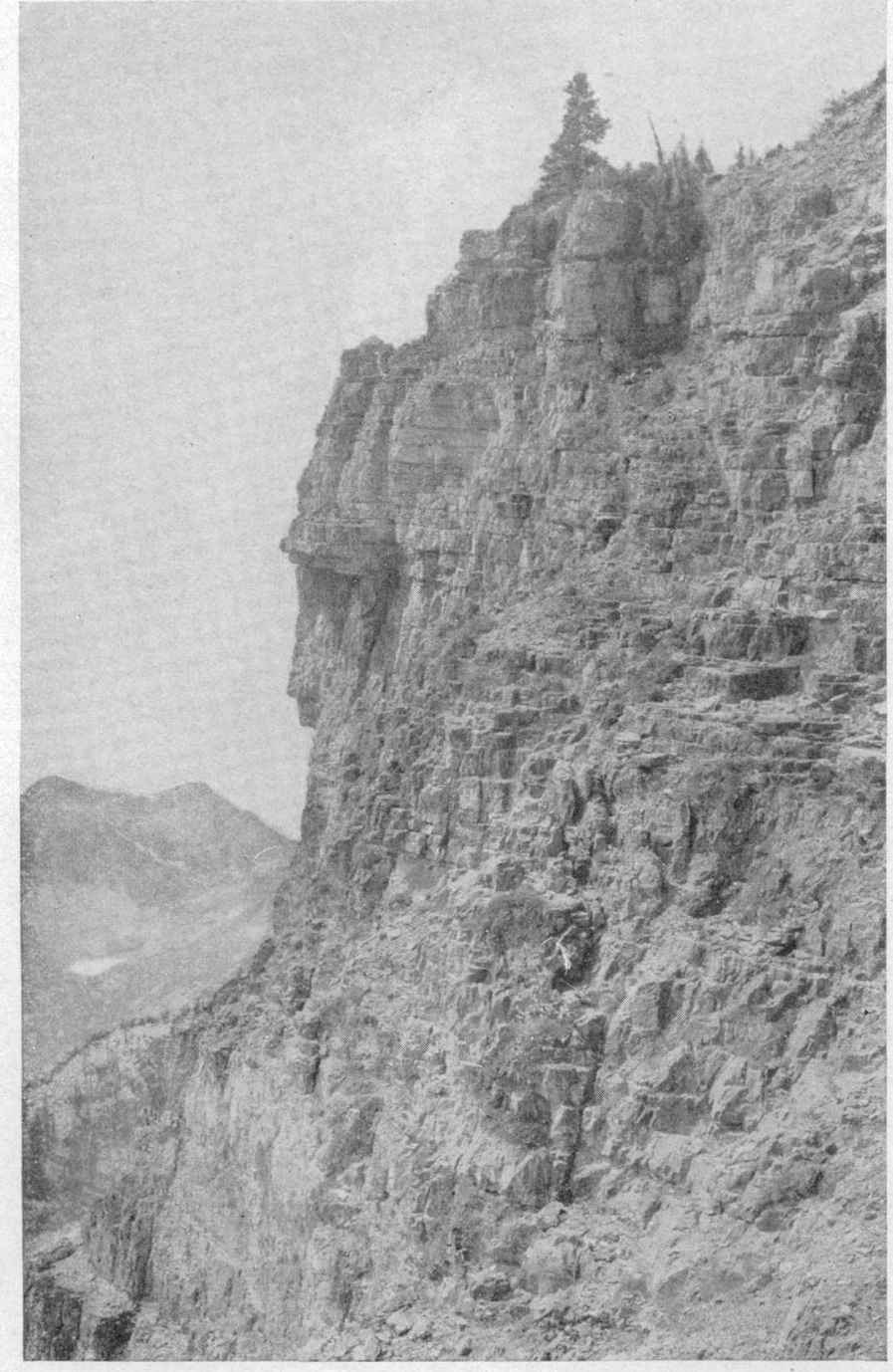

A. TINTIC QUARTZITE IN CLIFF WEST OF PITTSBURG LAKE Twin Peaks in distance.

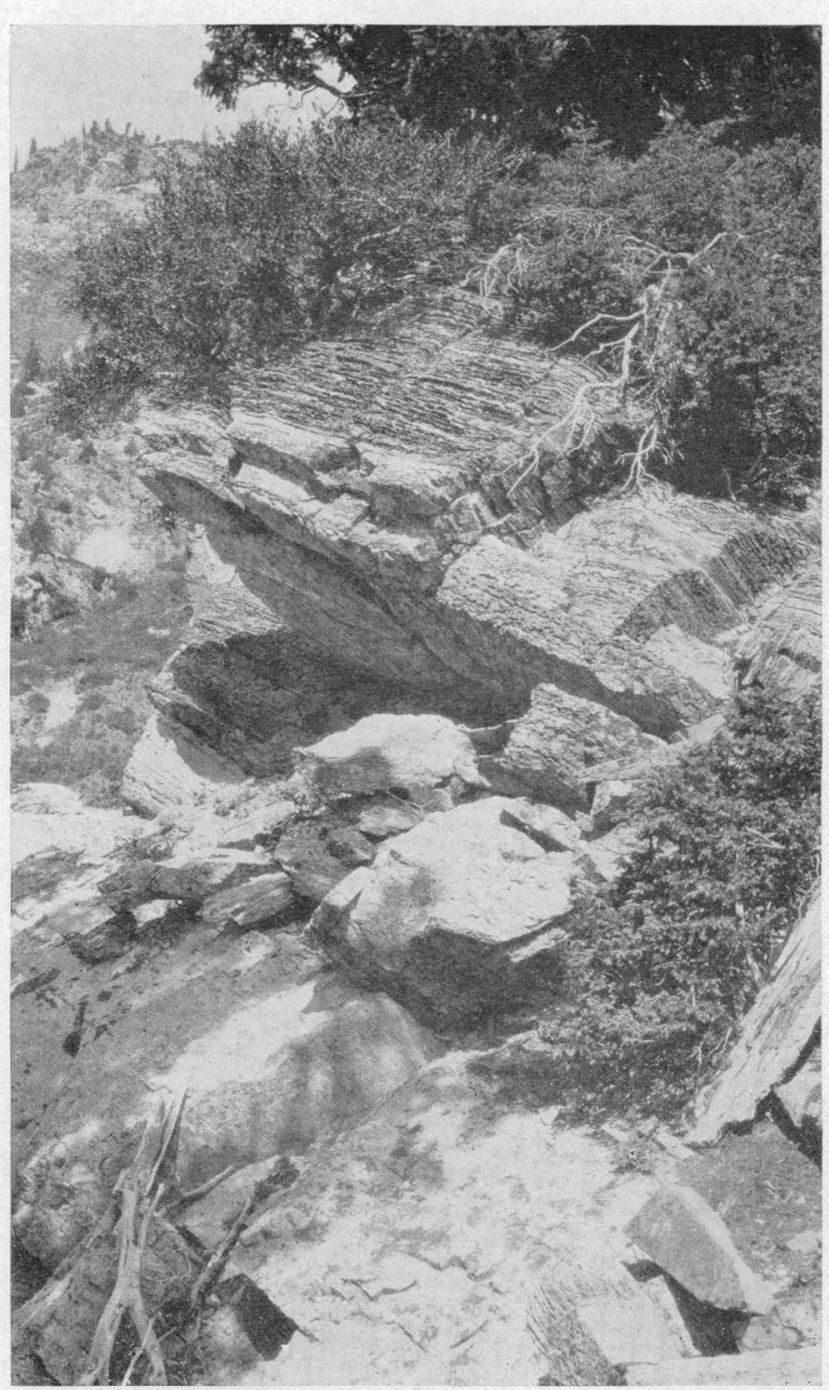

B. LIMESTONE MEMBER OF OPHIR SHALE, EAST OF SUPERIOR GULCH.

visible belowe, at top of member, and faint 


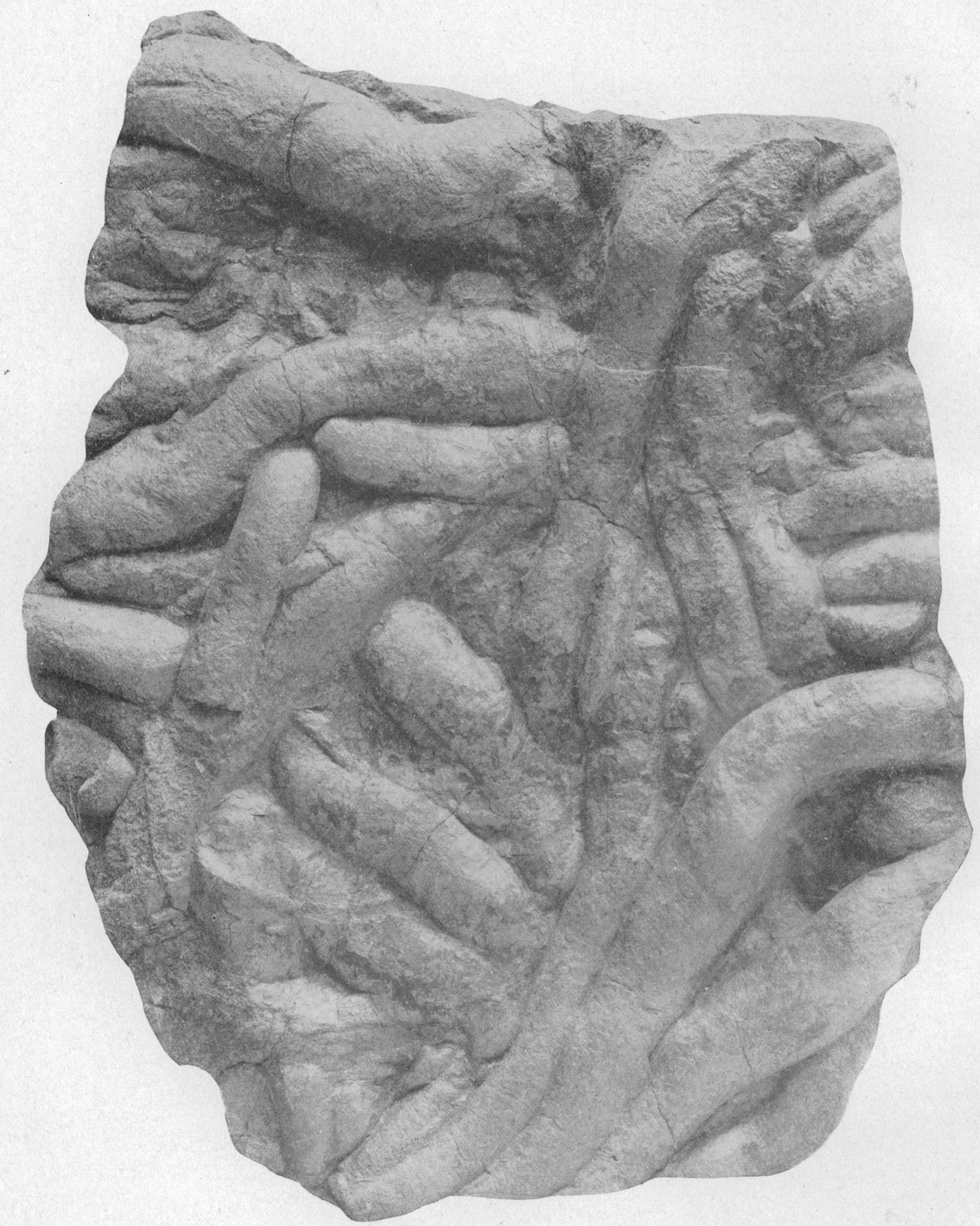

WORM-LIKE BODIES IN OPHIR SHALE.

Specimen from lower shale member. Natural size. 


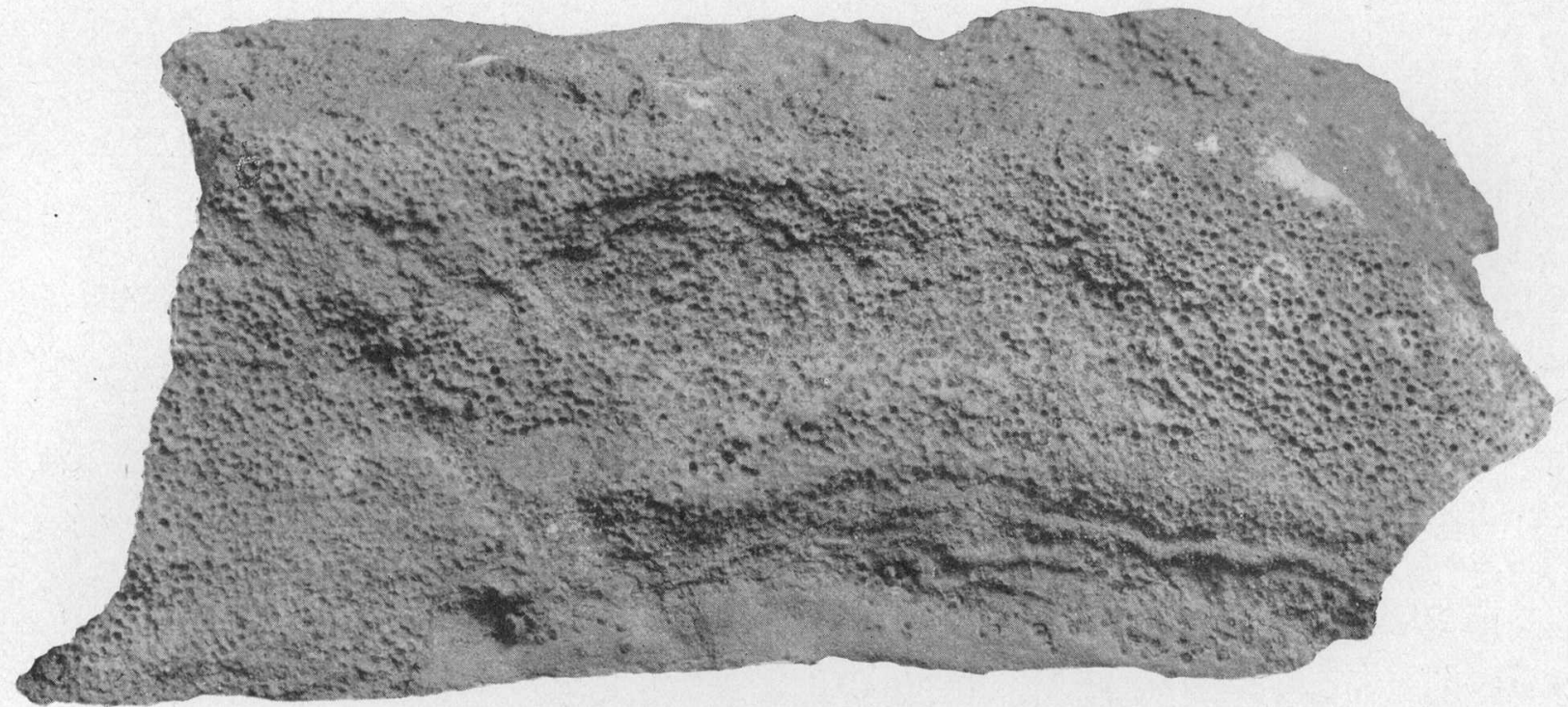

A. OOLITIC TEXTURE IN MAXFIELD LIMESTONE.

Specimen from near base. $\times 1 \frac{112 .}{2}$

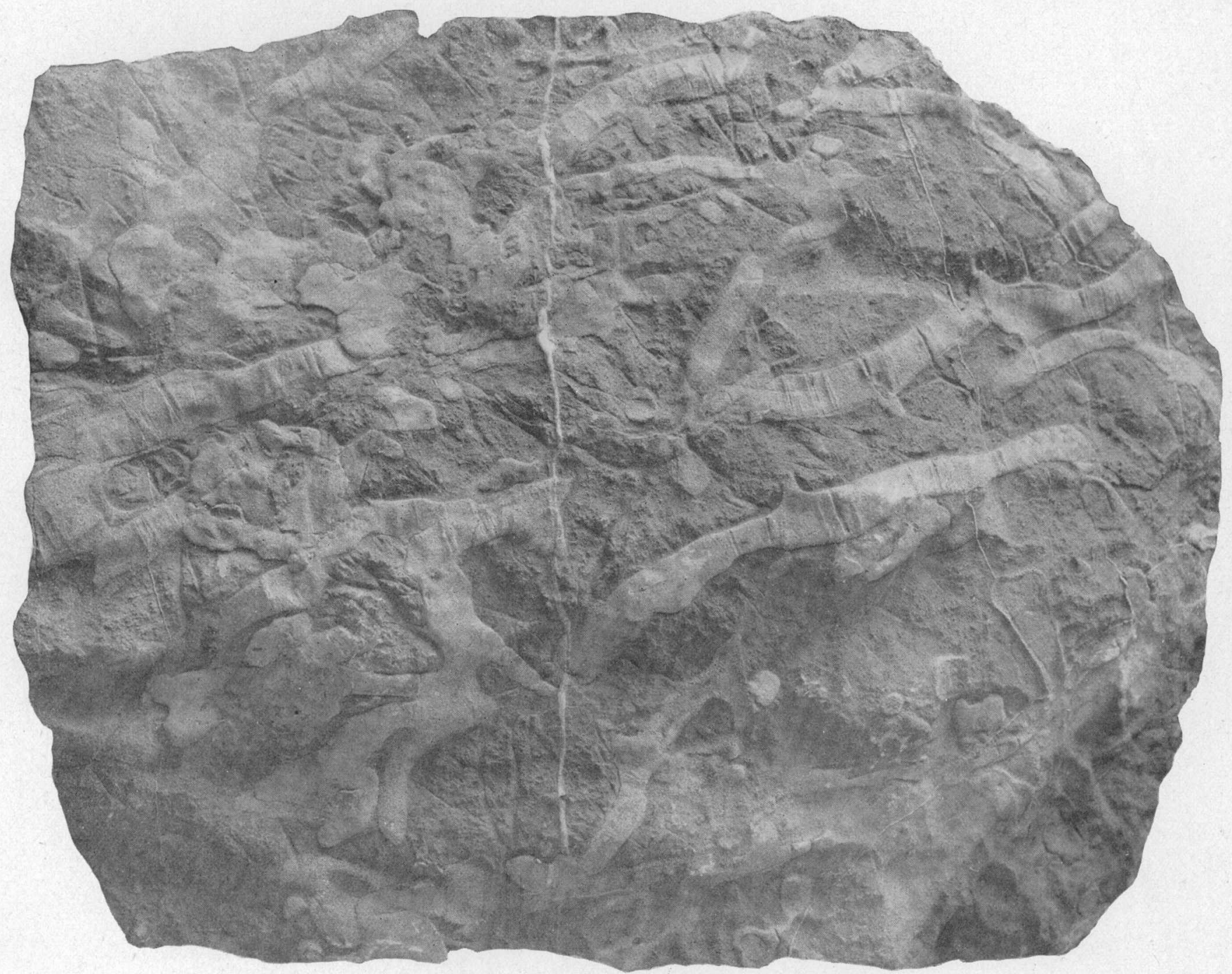

B. TWIGLIKE BODIES IN MAXFIELD LIMESTONE.

Specimen from lower part of middle member. Slightly reduced. 


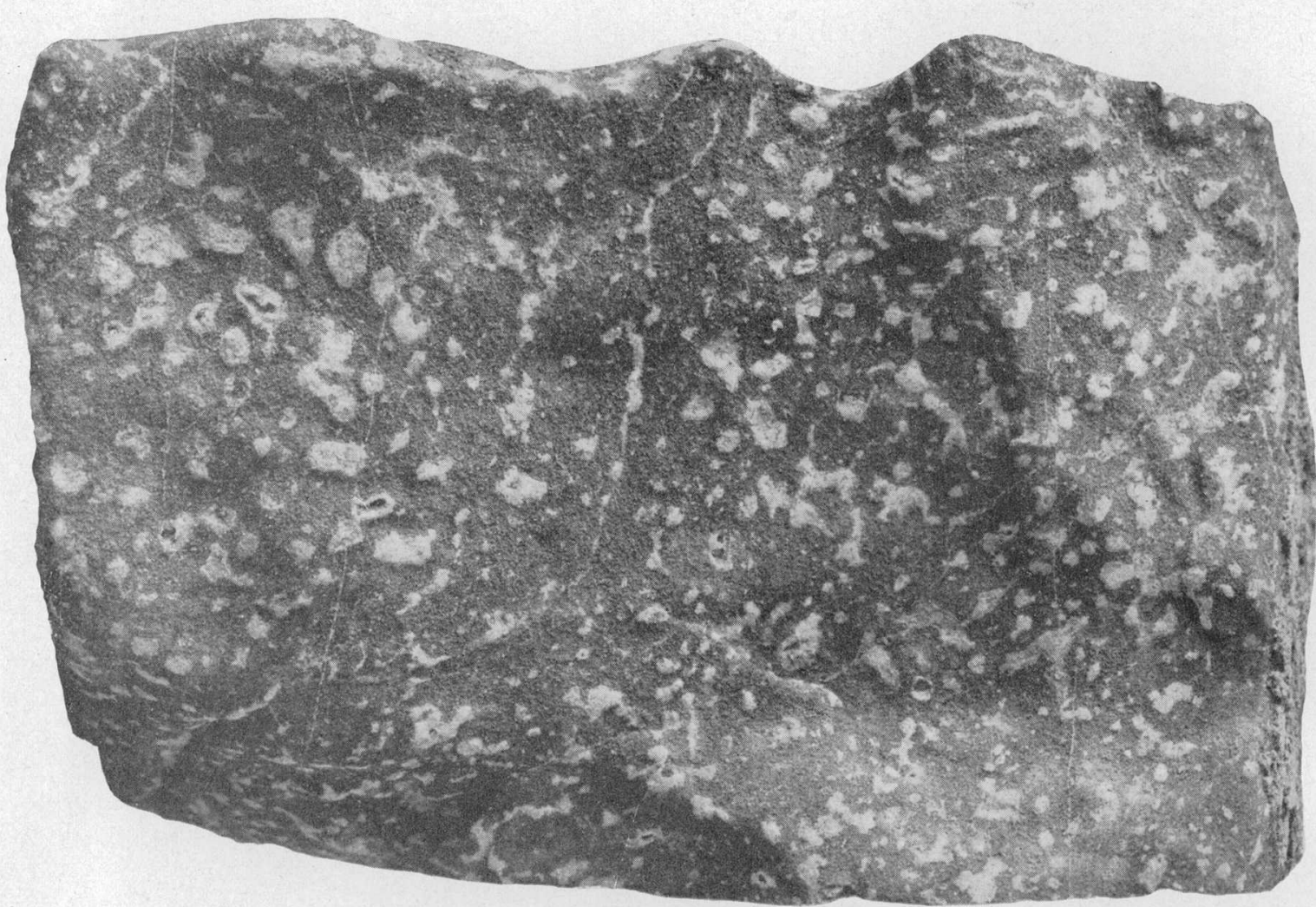

A. "GUINEA-HEN" DOLOMITE IN MAXFIELD LIMESTONE.

Specimen from upper part of lower member. $\times 13$.

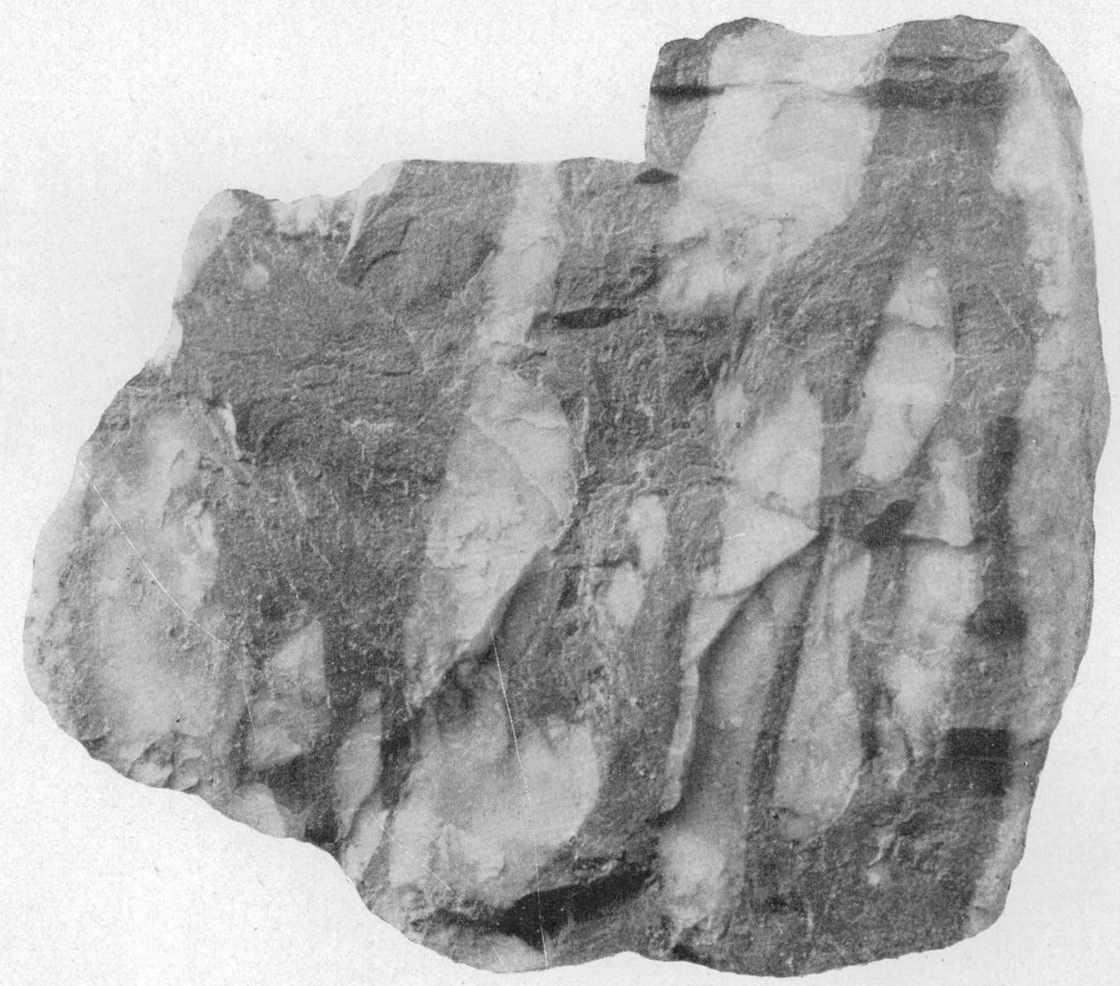

B. SHALE WITH LIMESTONE NODULES, MIDDLE MEMBER OF MAXFIELD LIMESTONE.

From Tom Moore tunnel. $\times 1 \frac{114}{4}$ 


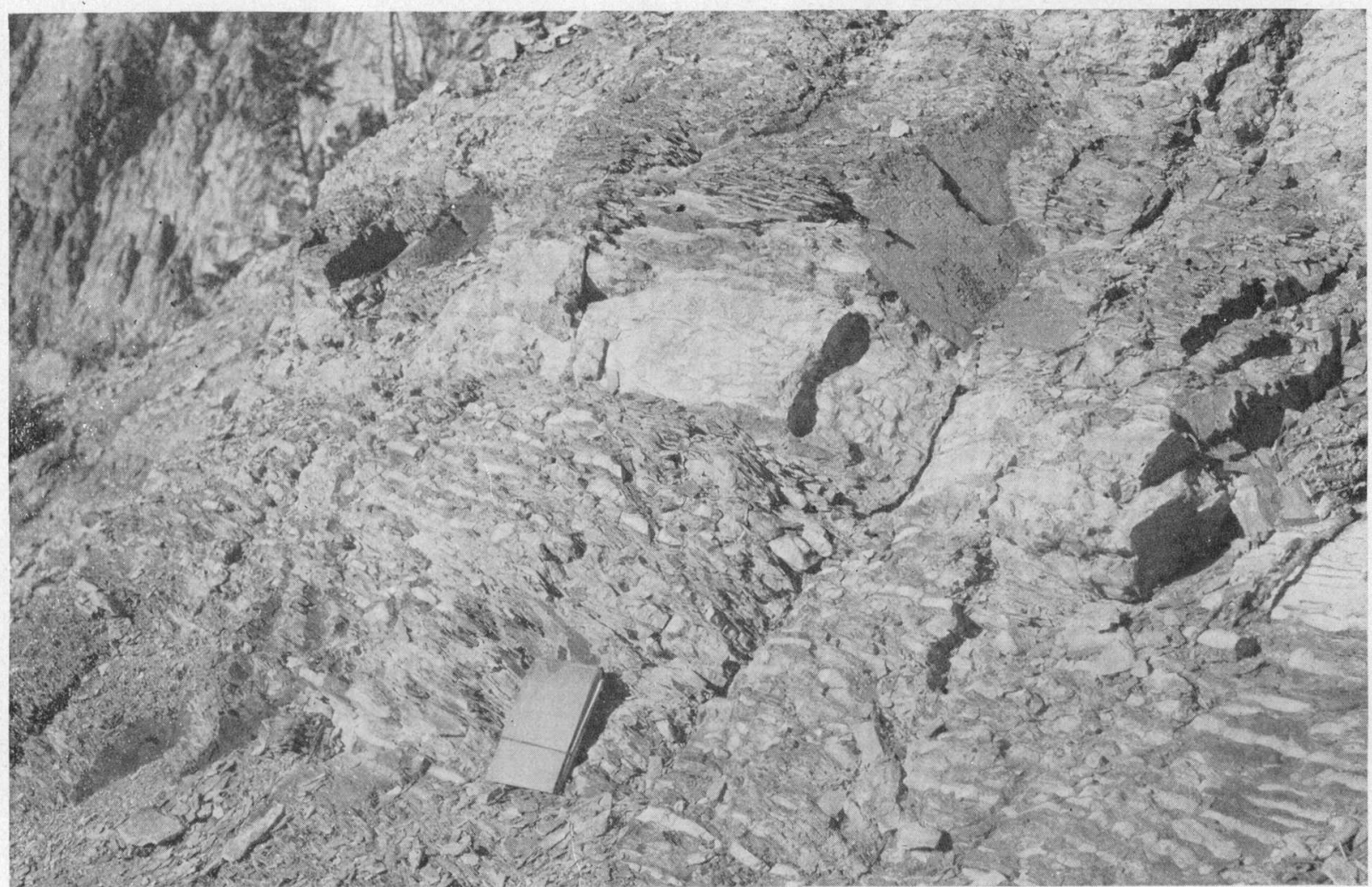

A. SHALE AND LIMESTONE IN MIDDLE MEMBER OF MAXFIELD LIMESTONE.

Outcrop on west slope of Reed \& Benson Ridge.

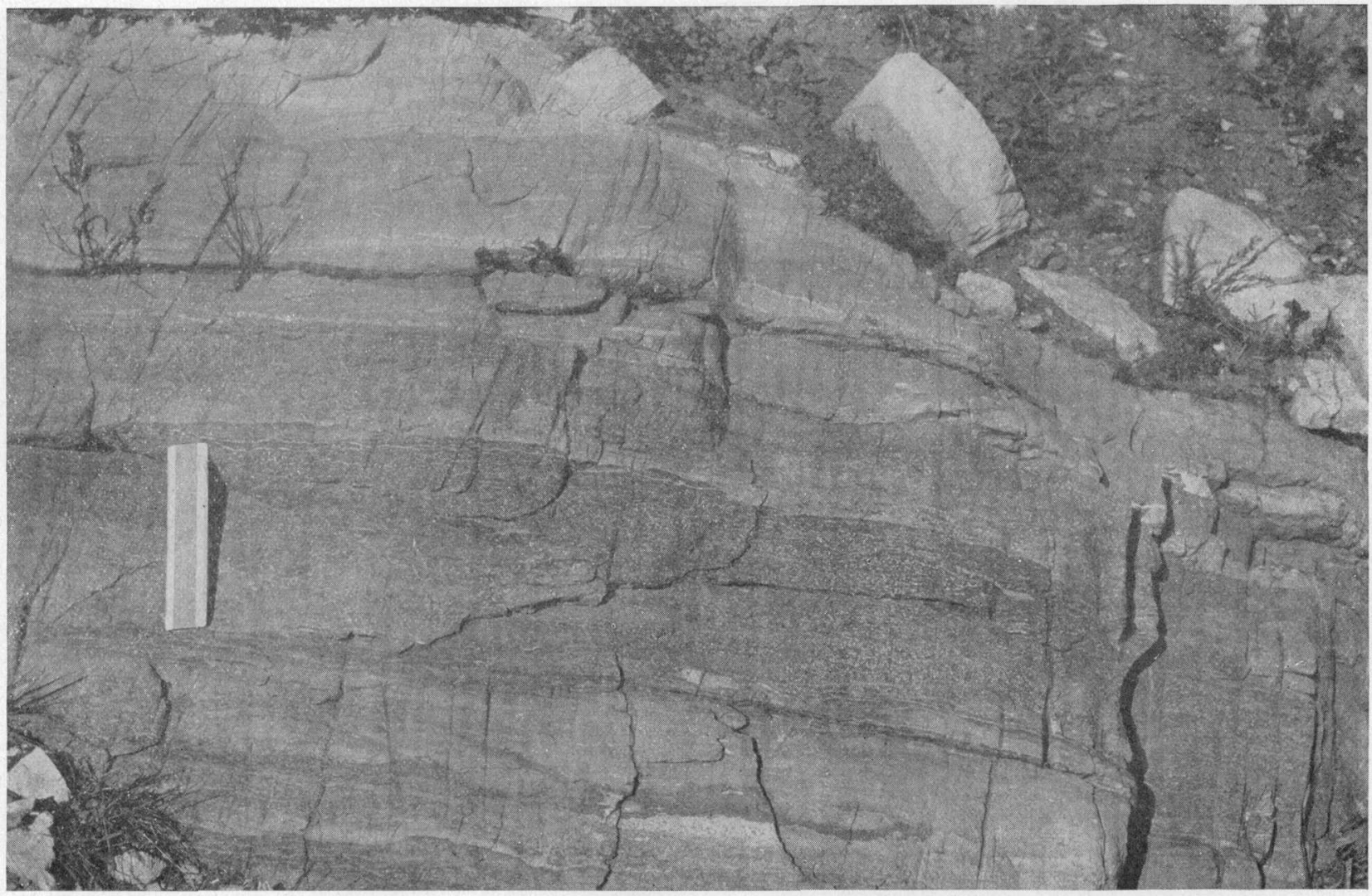

B. "GUINEA-HEN" DOLOMITE IN MAXFIELD LIMESTONE, OVERLAIN BY WHITE DOLOMITE AT TOP OF MIDDLE MEMBER, Outcrop on slope west of Flagstaff mine. 


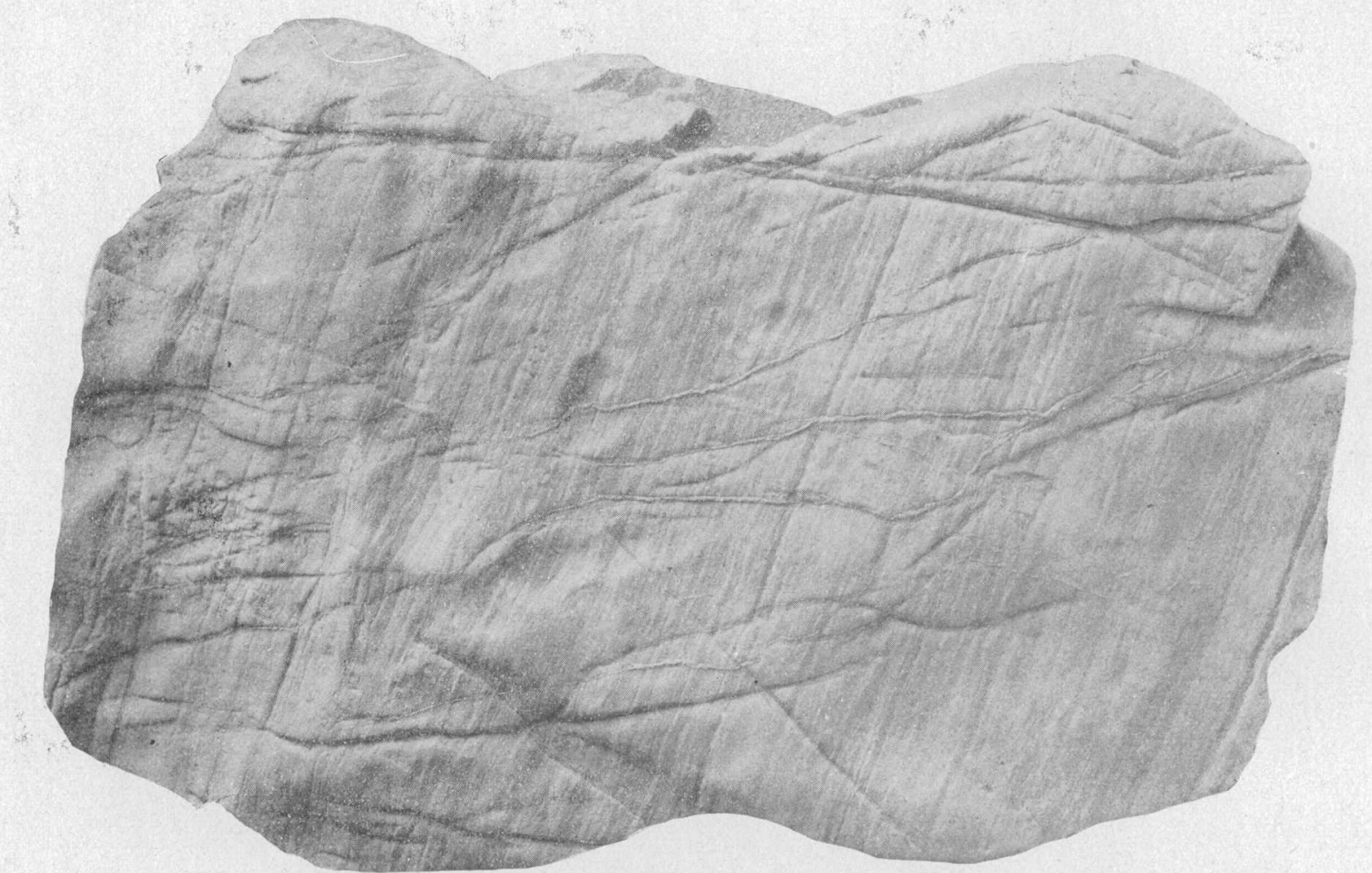

A. WHITE DOLOMITE IN MAXFIELD LIMESTONE

Forms top of middle member. Slightly enlarged.

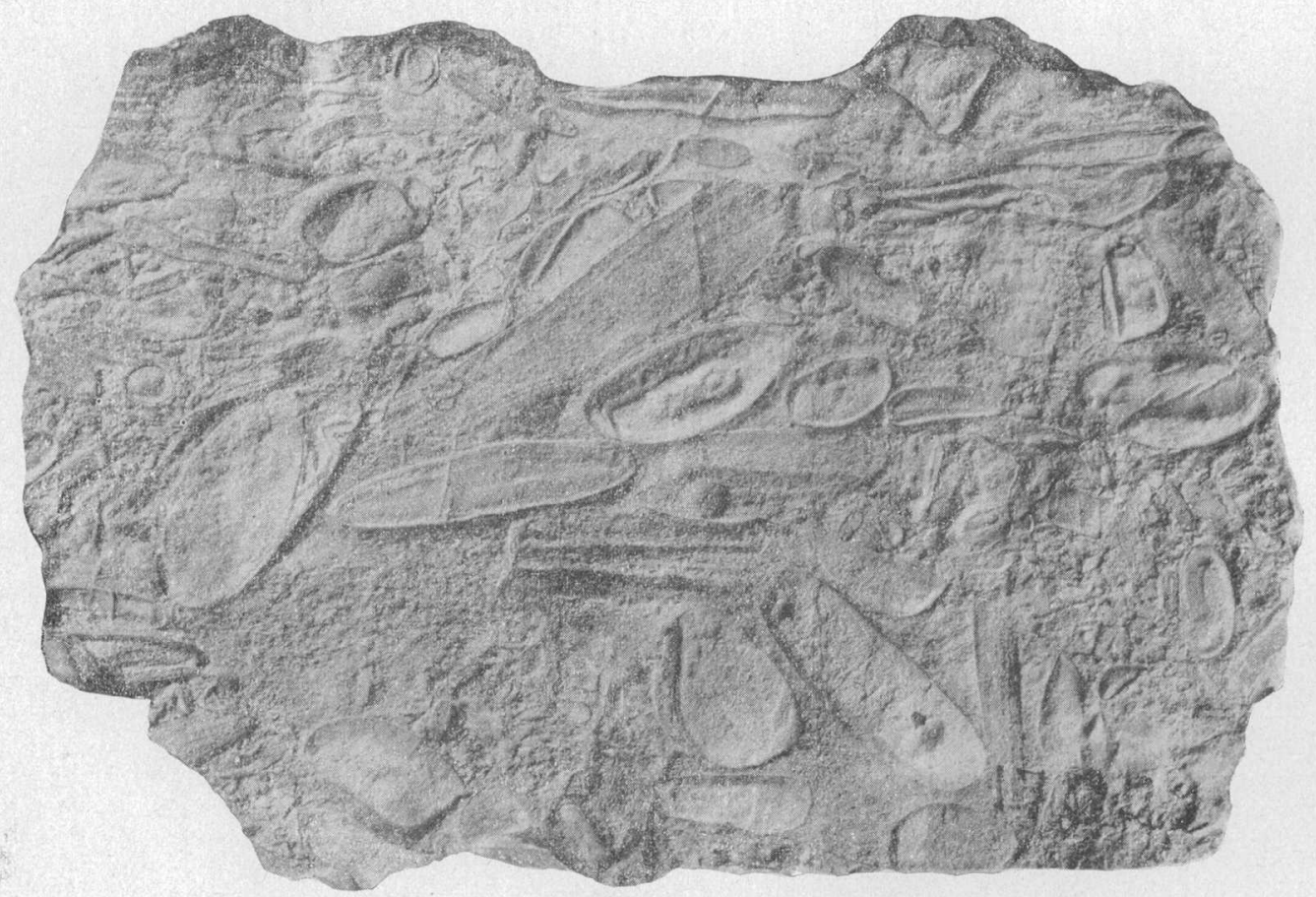

B. INTRAFORMATIONAL LIMESTONE CONGLOMERATE IN MAXFIELD LIMESTONE. Specimen from middle member. Natural size. 
and nodules associated with shale. However, the term "limestone," is more general than "dolomite", which it may be regarded as including, and therefore seems more appropriate as a lithologic term for this formation.

\section{GENERAT CHARACTER AND DISTİIBUTYON}

Almost all the rocks of this formation are marked with highly characteristic textural features, which make it possible in most outcrops to distinguish the Maxfield from the later limestones and, where there has not been much metamorphism, to assign an outcrop of Maxfield limestone to its approximate stratigraphic position within the formation. The formation is mapped as a unit on the geologic map of the district (pl. 3), for to

-bdivide it there would tend to.confuse rather than uify the structure; but for purposes of description th formation may be divided somewhat arbitrarily into thite members. The lowest member includes the dolowite and limestone below the top of a conspicuous layer of hard white dolomite; the middle member includes all

.o buff-mottled limestone, with some interbedded shale, 'ove this white layer; and the upper member, consisting of dolomite, is limited at the top by the unconformity at the base of the Jefferson (?) dolomite.

The outcrops of the Maxfield limestone in the Cottonwood quadrangle occur in three irregular belts. The westernmost of these lies west of-that is, below-the Alta overthrust; it extends from the head of Mill D .. .uth Fork to the head of American Fork, where it is cist off by the Silver Fork fault. The next belt eastward lies above the Alta overthrust and is itself cut by minor thrusts nearly parallel to the bedding; it extends southeastward from the vinicity of the Carbonate mine to that of the Albion shaft, where it ends at the Silver Fork fault. The remaining outcrops lie east of the Silver Fork fault, and most of them are on the upper, - stern side of a great overthrust fault. The northernmost outcrop above this fault is just east of the portal of the Alta tunnel; the southernmost is half a mile east of the Devils Castle. A narrow strip of the limestone below the overthrust extends from a point half a mile northeast of Secret Lake to a point about a mile east of

- Bog mine; it is much broken by fiulting toward the soi!th.

These three belts, except the westernmost, are hardly traceable into the southern part of the mapped area, where many strong faults of varied course and character cause these limestones to appear at the surface in a large number of irregularly distributed areas.

The Maxfield limestones are moderately resistant to er sion, and there are many good exposures of a considerable part of the formation, but no complete section of it is exposed. The formation is more fully represented at some places than at others, because of the unequal degree to which it was eroded before the deposition of the Carboniferous rocks began. Because of this erosion, it is thin and in places altogether lacking below the great overthrusts both east and west of the Silver Fork fault, and it approaches its greatest thickness above the highest thrust. The highest beds that remain in the area are exposed near the south end and on both sides of Reed \& Benson Ridge, and it is in this vicinity also that some of the best exposures of the lower part of the formation are found. Other good sections of the lower half or two-thirds of the formation are to be seen on the slope east of the Pittsburg mine and on the eastern spur of Twin Peaks.

Most of the peculiar textural features of the Maxfield limestones recur in different beds; space may therefore be economized by describing these features in general terms before describing in detail the sequence of beds within the formation.

Some of the lowest and some of the highest beds in the formation have an oolitic texture, characterized by dark-gray spherical pellets, mostly less than 1 millimeter in diameter, embedded in a lighter-gray matrix. (See pl. 10, A.) Closely associated with this texture in places is a pisolitic texture, in which there are ellipsoidal concentrically layered bodies about 0.5 centimeter in average diameter. There does not seem to be a gradation in size between the small and the large pellets, although their association suggests a similar origin.

Some beds of dolomite or magnesium limestone show a clouding or mottling in shades of gray, which is due to irregular interpenetration of lighter and darker material. This texture is most readily apparent on the weathered surface, where the darker patches are grittier than the lighter and stand slightly.in relief. A similar clouding occurs less commonly in beds that are not gritty on the weathered surface.

A mottling with buff or brown, essentially similar to that in the limestone member of the Ophir formation, is about as common as the gray clouding, being found in much of the dark-gray nonmagnesian limestone. The material that causes the mottling, like most of the shale in the upper member of the Ophir, is brown where it has been at all affected by weathering; where. unweathered it is either gray or brown and darker than the body of the limestone; it evidently contains both iron-bearing carbonate and siliceous material. It varies widely in abundance from one bed to another, and as its abundance increases the limestone grades into a limy claystone, containing limestone nodules, which in turn grades into shale. (See pls. 12, $A$ and $11, B$.)

Certain beds contain bodies that appear to be organic, though they have not been specifically identified. (See pl. 10, B.) These organic-looking bodies are mostly like little twigs, some of them branched and some not. Some are buff and some white; the white ones are generally not branched and simulate worms, so that the limestones containing them were generally described in field notes as "wormy" or, because of their spotted appearance, as "guinea-hen" limestone (pls. 11, $A$ and 12, $B$ ). This variety of limestone much resembles the Bluebird dolo- 
mite of Tintic, ${ }^{22}$ and similar material is widespread in the Cambrian of western Utah. ${ }^{23}$

\section{LOWER MEMBER}

The lowest member of the Maxfield limestone is well represented by the following section, all but the highest part of which was measured in a virtually continuous outcrop northwest of the Flagstaff dump. The measurements of the highest beds, constituting a conspicuous light-colored stratum whose top forms a convenient upper limit for the unit, are taken from their best exposure, which is about 1,000 feet west of the 10,551-foot peak on Reed \& Benson Ridge. The section is given in descending order. It has been necessary to describe some of the lowest beds as "dolomite or limestone," because these beds were not individually tested with acid at the time the measurement was made, and it was later found that some were dolomitic and some calcitic.

Section of lower member of Maxfield limestone, chiefly from exposures northwest of Flagstaff tunnel

Dolomite, very fine-grained, buff on weathered surface, f'eet from which thin wavy and cross bedded layers of sand project in relief; on fresh fracture the rock is light bluish gray

Dolomite, very fine-grained; not sandy; weathered surface of middle part is bluish white, that of upper and lower parts pale yellow; all gray on fresh fracture

Dolomite, very fine-grained, weathered surface white and finely fluted, fresh fracture light gray (see pl. 13, $A_{-}$

Dolomite, gritty-surfaced, rather broadly banded, in greater part almost black and containing conspicuous white wormlike bodiès, some of which are hollow and lined with crystals of calcite; this rock was called "guinea-hen limestone" in the field. It alternates with bands, about half as thick on the arerage; of lightergray, gritty-surfaced, unmottled dolomite (see pl. 12, $B_{-}$

Limestone, somewhat magnesian, medium gray, faintly clouded, grading into rock below

Dolomite, very gritty on weathered surface, strongly clouded in a pattern suggesting a partridge wing

Limestone, magnesian, very pale gray, nearly homogeneous

"Guinea-hen" dolomite

Iimestone, magnesian, massive, unclouded, light gray, upper half pitted

Limestone, magnesian, upper half of "guinea-hen" type, lower half same with light gray bands

Limestone, magnesian, rather light gray, gritty, unclouded ; contains a few oolites and worm-like bodies.-

Limestone, magnesian, blue gray, darker than above; weathered surface is gritty and a little brownish and shows nodules about half an inch in diameter

Dark, clouded magnesian limestone

Dolomite, medium blue gras, gritty-surfaced, containing abundant small oolites.

Dolomite, rather massive, medium blue gray, coarsely clouded_-_-

${ }^{22}$ Loughlin, G. F., Geology and ore deposits of the Tintic district, Utah : U. S. Geol. Survey Prof. Paper 107, pl. 12, p. 28, 1919.

${ }^{23}$ Gilluly, James, Geology and ore deposits of the Stockton and Fair field quadrangles, Utah: U. S. Geol. Survey Prof. Paper 173, pl. 6, pp. 12-17, 1932. Nolan. T. B., Geology and ore deposits of the Gold Hill quadrangle, Utab: U. S. Geol. Survey Prof. Paper 177, pl, 5, C, p. 14, 1935.
Section of lower meniber of Maxfield limestone, chiefly from exposures northwest of Flagstaff tunnè-Continued

Dolomite or limestone, rather dark blue gray, oolitic, "wormy" in layers, partly mottled with buff, somewhat flaggy

Feet

Dolomite or limestone, medium-dark blue gray to very dark at base; dirty and gritty on weathered surface; faintly clouded; contains some ill-defined "wormy"looking bodies.

Dolomite or limestone, very dark blue "gray, somewhat flaggy ; in part oolitic; partly mottled with pale grayish buff

Dolomite or limestone, dark blue gray, obscurely oolitic.Dolomite or limestone, dark blue gray, oolitic

Dolomite or limestone, oolitic, dark blue gray, with thin irregular sandy laminae; rusty on weathered surface; base concealed but not far below. $-$

Another section of this member, even better exposed, is to be seen on the south side of Devils Castle, east of the Pittsburg mine, where the conditions permit somewhat more accurate measurement at this locality than at the other. The total thickness and the thickness of the light-colored dolomite at the top are somewhat less here than in the section near the Flagstaff tunnel.

Section of lower member of Maxfield:limestone east of Pittsburo mine

Dolomite, fine-grained, whitish on weathered surface, upper part containing cross-bedded sandy layers, middle part. faintly mottled

Limestone, magnesian, broadly banded in light to medium gray, the darker layers mottled; contains small vugs. This rock does not show the "guinea-hen" marking on the line of the main section, but this texture is seen a little farther east at the same stratigraphic level, the nearly black white-spotted beds fading out westward to a gray color

Dolomite, rather dark gray, gritty-surfaced, somewhat mottled and "wormy"a groove...

Limestone, magnesian, very dark gray in general tone, but rather coarsely and distinctly mottled in shades of gray; thick-bedded

Dolomite, medium-dark gray, oolitic, gritty-surfaced, lower part mottled and irregularly striped with darker gray ("partridge-wing" type)

Dolomite, very dark gray, coarsely pisolitic, oolitic, and "wormy"

Dolomite like bed above the one last described_............ 11 Dolomite or limestone, very dark gray móttled with lighter gray, "wormy" and somewhat flaggy

Dolomite or limestone, gray, pisolitic; thin-bedded........-.

Dolomite or magnesian limestone, gritty, very dark gray, fainitly banded, pisolitic, oolitic, and "wormy"-_-_-_-_- 25 Dolomite or limestone, thin-bedded, bleached, oolitic_....-. 12

When the cliff exposure is viewed at a moderate distance, the rocks below the white band appear to be readily divisible into two parts-the upper of a relatively light gray tone and the lower darker and more 
bluish. The boundary between them is not sharp, but it may be placed at the top of the thin soft bed 92-94 feet above the base of the section. The upper division, apart from the white band, thus comprises about 55 feet, and the lower division about twice as much. The ooiites range through the lower 80 feet, as compared with about 95 feet in the Flagstaff section. The "partridgewing" mottling was noted in both sections, but it lies only about half as far above the base in this section as in the other, so that it may not belong to the same geologic horizon in both.

.This lower member of the Maxfield limestone as a whole cannot be fully characterized in a few words. The only feature that is virtually persistent throughout is its magnesian composition, which is common also to the lower part of the middle member. The placing of its upper limit at the top of the white band is determined essentially by convenience, for this bed, which occurs throughout the area and is everywhere conspicuous, is one of the most useful horizon-markers in the stratigraphic section.

Metamorphism affects the characteristics of the three portions of this member somewhat unequally.' The lowest, dark portion retains its blue color tenaciouslymore so in general than the oolitic texture. The middle, lighter portion is readily bleached and loses its characteristic markings under moderate metamorphism; its bedding becomes obscure, and the result is a featureless mass of white sugary limestone in which complicated structure is very hard to decipher. The light-colored layer at the top becomes pure white throughout and may retain its fine lamination even when it has taken on a sugary, friable consistency.

\section{MIDIDLE MEMBER}

The middle member of the Maxfield limestone is more distinctly heterogeneous than the lower, but it is pretty generally characterized by mottling, and the limestone in it is largely nonmagnesian. It contains many beds of shalè, but these alternate with beds of limestone, into which they grade. Its lower part consists mainly of gray-mottled dolomite and magnesian limestone, in some of which the parts that weather in relief are dolomitic and the rest calcitic or only slightly magnesian. Its. middle part consists mainly of buff-mottled partly magnesian limestone, and its upper part consists of strongly buff-mottled nonmagnesian limestone interbedded with shale.

Identifiable fossils, regarded as Upper Cambrian, have been found in some beds of the shale.

The best exposures of the middle member are on the west slope of Reed \& Benson Ridge, above the highest overthrust. Lower down on the slope-in a lower thrust plate-and at most other localities in the district; these rocks were wholly or partly eroded away before the overlying Devonian (?) limestone was deposited. A section measured west of the Sampson shaft is as follows:
Section of midale member of Maxfield limestone west of Sampson shaft.

Limestone with oolitic and conglomeratic textures (upper member) (-_-_._-

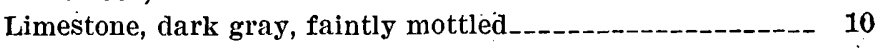

Limestone, bluish gray, all more or less flaggy and strongly mottledi.

Shale, crowded with nodules of limestone

Shale, olive green, flaky, in part nodular, interbedded with and grading into layers of yellow-mottled limestone; 6 -inch bed of limestone conglomerate about 10 feet from base

Limestone, blue, mottled with ocher yellow, the yellow part commonly enclosing nodules and irregular flat pieces of blue limestone; interleaved with thin beds of shale.

Buff-weathering limestone without blue nodules.

Shale, olive green, fissile

Limestone, partly magnesian, dark gray, mottled with light gray, flaggy, the layers mostly 1 inch to 2 inches thick--

Limestone, magnesian, rather thick-bedded, mostly dark gray, mottled with lighter gray and some buff; lighter

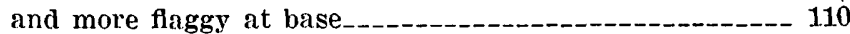

Limestone, sandy, buff-weathering-_-_-_-_-_-_-_-_-_ 3

Limestone, magnesian, or. dolomite, very dark gray, clouded

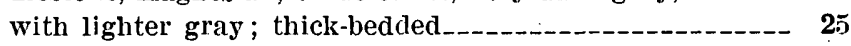

Total thickness of middle member Light-colored limestone at top of lower member.

A partial section of the lower part of the middle member as exposed on the spur penetrated by the Reed \& Benson tunnels gives some details not noted in the more general section.

Section of part of Maxfield limestone near Reed \& Benson tunnels

Limestone conglomerate Ft. In

Limestone blue gray, buff-mottled

Limestone conglomerate_-_- 3

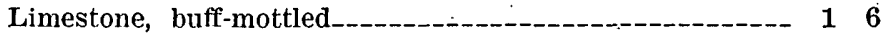

Limestone conglomerate._-_._- 6

Limestone, buff-mottled_-_-_-_________-_ 40

Limestone, magnesian, gritty-surfaced, dark gray, clouded with finer grained, lighter glay patches and containing white "worms"; slightly stained with buff

Limestone like that just above but not stained; a 2 -inch bed of limestone conglomerate 13 feet from base_____-_- 300

Limestone, flaggy, dark blue gray, somewhat mottled____-_ 50

Limestone, pisolitic_________ 10

Dolomite, almost sooty black, mottled with light gray; "wormy" - _._- 30

Limestone, dark gray, stained with - huff. showing thin

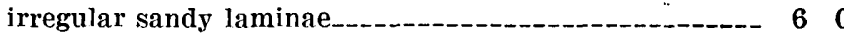

Limestone, magnesian, dull grayish black, mottled with finer-grained, lighter-gray patches and containing white "worms." Uppermost 3 feet slightly stained with yellow ocher-_-_-_-_- 250

\section{$\overline{87} \div$}

These beds are underlain, with abrupt transition, by pale-buff sandy limestone, which forms the top of the lower mèmber. (See sections, p. 16.)

The limestone conglomerates (pl. 13, B), beds of which are found also higher in the buff-mottled part of this member, are of a sort that is common in the Cam- 
brian elsewhere. The pebbles in each bed are strikingly uniform in character and consist wholly of limestone. In form they are generally flattish, with well-rounded edges. Probably they are intraformational and were formed by the breaking up and gentle rolling of layers of limy ooze that had been partly consolidated but not exposed to the atmosphere.

-This member might be divided into two parts. The upper part, extending down to the base of the lowest shale and about 125 feet thick, is characterized by buff mottling in the limestone and by the presence of shale. (See pls. 12, $A, 11, B$.) This mottling in its most marked development, whether in surface outcrops or in exposures underground, makes these beds easily recognizable, and their distinctive character is not obliterated by metamorphism. The argillitic parts of the mottled limestones readily become altered to hard brown and green hornfels or, where the alteration is more advanced, to coarsely crystalline aggregates of garnet, vesuvianite, and other lime-bearing silicates. (See pl. 21, A.) The shales are commonly altered to dark chocolate brown hornfels.

The lower division, a little thicker than the upper, consists almost wholly of limestone that is very dark gray in general tone-some of it being, indeed, almost black-but all of it clouded or mottled, for the most part with lighter shades of gray but in smaller part with buff. The dark-gray clouded beds commonly contain white wormlike bodies, like those in the beds near the top of the lower division, but the strongly mottled beds above the white stratum are readily distinguished from the broadly striped beds below it. Some of the buff-mottled beds in this division contain conspicuous twiglike bodies. (See pl. 10, B.)

The effects of metamorphism on this lower part of the middle member are not especially characteristic. The dark mottled limestones are fairly tenacious of their color, and they may still show a suggestion of their peculiar texture even where they are completely bleached.

\section{UPPER MEMBER}

The upper member of the Maxfield limestone, overlying the buff-mottled limestone and shale member already described, is present only in some of the areas between the Alta overthrust and the Silver Fork fault and in the hill south of the Prince of Wales shaft, having been removed elsewhere by the pre-Jefferson (?) erosion. Its greatest observed thickness is about 100 feet.

No detailed section of this member has been made. It somewhat resembles the lower member and is sharply distinct from the middle member: the contact of the middle and upper members can be located to an inch in the perfect exposure on the crest northwest of the Flagstaff tunnel, but it is not marked there by any observed evidence of erosion. Near the Sampson shaft limestone conglomerate was notéd at or near the base of the upper member, but it seems to be of the same intraformational type as that in the middle member.

The upper member of the Maxfield consists of dolomite, the gritty surface of which is mottled in shades of gray. Some of the rock is almost black, some very light; some of the light beds display a very faint tinge of lavender that is not found in the lower member. Oolitic texture, not conspicuous elsewhere except in the lowest part of the Maxfield limestone, is rather common here, and the white wormlike bodies already described are found in the dark dolomite.

Metamorphosed rocks of this member are exposed on the slope above the Michigan-Utah workings and at the base of the Honeycomb Cliffs. Metamorphism at these places has obliterated more or less wholly the characteristic markings, so that the beds are identified merely by their relation to the more strongly characterized rocks immediately above and below.

Burling ${ }^{24}$ states that he and F. B. Weeks found Middle Cambrian fossils (whose names he does not give) in the Maxfield limestone on Reed \& Benson Ridge.

Butler and Loughlin ${ }^{25}$ found fossils in shale "a little south and east of the Flagstaff mine," which would seem to be most probably in the middle member of the Maxfield limestone. They write: "On this collection $\mathrm{L}$. D. Burling made the following report: 'Contains Zacanthoides cf. Z. spinosus and Obolus (Westonia) ella and is almost certainly to be correlated with the Spence shale of the lower portion of the Middle Cambrian.' Another collection was made at a horizon about 100 feet higher, of which Mr. Burling says, 'Contains Micromitra (Iphidella) pannula and is probably to be referred to the lower part of the Middle Cambrian.' A collection was also made from the shale on the divide between Little Cottonwood and American Fork canyons. Of this Mr. Burling says, 'Contains Obolus (Westonia) ella and is probably to be referred to the lower part of the Middle Cambrian, though this species is not very. diagnostic." "

It thus appears fairly safe to regard all the Maxfield limestone as Cambrian, and probably as. Middle Cambrian.

\section{UNCONFORMITY AT BASE OF DEVONIAN (?)}

The erosion surface which limits the Cambrian at the top has been referred to several times incidentally; it may here appropriately be described in some detail.

The only place at which this erosion surface has clearly been seen to bevel the underlying beds is on the west side of Reed \& Benson Ridge, about 1.600 feet"

2A Burling, L. D., Early Cambrian stratigraphy in the North American Cordillera, with a discussion of Albertella and related faunas: Geol. Survey Canada, Museum Bull. No. 2, pp. 100-101, 1914.

${ }_{25}$ Butler, B. S., and Lougblin, G. F., A reconnaissance of the Cottonwood-American Fork mining region, Utah: U. S. Geol. Survey Bull. 620, p. $170,1916$. 
northeast of the portal of the Kennebec tunnel. Here the overlying bed is a sandstone, which is exposed continuously for several rods. The amount of angular discordance was not accurately measured but is of the order of $5^{\circ}$, and the beds below the erosion surface, which is very neirly plane, converge with it in a northerly direction. The lowest beds with which it is in contact in this outcrop are the buff-mottled limestone between the two shaly strata in the upper part of the middle member of the Maxfield limestone. Toward the south end of the outcrop the upper shale of this member appears and is overlain by ocherous limestone. The divergence continues toward the south, so that the upper member of the Maxfield limestone appears and attains almost its maximum thickness within about a quarter of a mile.

In an outcrop that lies only a few hundred feet west of that just described but is separated from it by one of the lesser overthrusts, the base of the Jefferson (?) dolomite rests upon dark limestone that is stratigraphically only a few feet above the light-colored band at the top of the lower member of the Maxfield limestone. It lies at about the same horizon in the northernmost outcrops within the mapped area, which are near the Carbonate mine. Near the Maxfield mine, which is on Big Cottonwood Creek west of the mapped area but probably in the same thrust block as the two localities last mentioned, the unconformity lies still lower, only a few feet of Maxfield limestone intervening between the Ophir formation and the base of the Jefferson (?) dolomite.

In the westernmost zone, below the Alta overthrust, the base of the Jefferson (?) dolomite lies very low stratigraphically at the north and rises steadily toward the south. On Vena Flat, north of Montreal Hill, it is only a few feet above the limestone member of the Ophir. At the summit of Montreal Hill it ${ }^{-}$rests on the muddy oolitic beds at the very base of the Maxfield limestone. On the east side of Superior Gulch it lies a few feet higher. The white-weathering dolomite at the top of the lower division first appears a little south of Mount Baldy; and at the heads of American Fork and Mary Ellen Gulch (pl. 14, B) the greater part of the middle member of the Maxfield limestone, including some of the nodular limestone interbedded with shale, is present. The unconformity approaches its highest level in the lower thrust block near the southern limit of the mapped area, where it lies about 15 feet above the base of the dolomite that constitutes the highest member of the Maxfield.

In the belt, also, that lies east of the Silver Fork fault and below the eastern zone of thrust faults-this belt being probably the same as the westernmost in the mapped area but repeated by the Silver Fork faultthe unconformity lies lower at the north than at the south. Near Grizzly Gulch, indeed, it is lower than at any other place in the quadrangle, being about at the top of the lower shale member of the Ophir formation. The limestone member of the Ophir and part of the upper shale member are present at the south boundary of the Alta stock of granodiorite, and a featheredge of the overlying Maxfield limestone appears about half a mile farther south. The conspicuous white bed first appears on the ridge top west of the Devils Castle, and the highest beds found in this belt are not much higher stratigraphically.

In the thrust plates between and above the overthrusts of the eastern zone - probably equivalent to those exposed along the east side of Mill D South Fork-the position of the erosion surface is higher. In the lower thrust plate, along the east side of Silver Fork, the Jefferson (?) dolomite lies on gray-clouded magnesian limestone or dolomite apparently belonging to the lower part of the middle member of the Maxfield limestone. In the plate above the highest overthrust-as on the top of Reed \& Benson Ridge-the unconformity is near its highest level; at the center of sec. 33, T. 2 S., R. 3 E., it lies on shale near the top of the middle member, and southward along the slope of the hill the upper member gradually comes in; but farther south, near Sunset Peak, the highest Cambrian beds present are not so high stratigraphically, being near the top of the middle member of the Maxfield limestone.

The general similarity of relation between the unconformity and the thrust faults in the eastern and the western zones of thrusting is one of the evidences that the two thrust zones are equivalent. (See p. 58.)

In brief, the occurrence of an erosion interval is demonstrated by the angular unconformity between the Jefferson (?) and the Maxfield, which is visible in one outcrop, and by the differing levels at which the base of the Jefferson (?) dolomite lies in different places. The presence of pebbles in the overlying bed is further proof of an erosion interval, though these pebbles are almost exclusively of quartz and include none of the underlying limestone. The widely different age of the nearest fossils above and below the contact indicate that the erosion interval was long.

The stratigraphic level of the unconformity, as may be gathered from the preceding discussion, rises toward the south. In east-west sections across the middle part of the quadrangle, where the unconformity is repeated many times by thrust faulting, the unconformity is at higher stratigraphic levels in the higher plates than in the lower. As the movement on the thrusts was eastward, so that each was originally farther west than the one beneath it (see p. 51), this means that the stratigraphic level of the unconformity originally rose toward the west. In general, then, it rose toward the southwest; the land therefore was tilted southwestward before the period of erosion that preceded the deposition of the Jefferson (?) dolomite. 


\section{DEVONIAN (?) SYSTEM}

JEFFERSON (?) DOLOMITE

GENERAL FEATURES

The formation that, throughout the area, rests unconformably on the Ophir shale or the Maxfield limestone is provisionally regarded as of Jefferson (Middle Devonian) age. This correlation is based primarily upon resemblance in stratigraphic relations and lithologic character to the formation so designated-also provisionally_-by Gilluly ${ }^{26}$ in the Ophir district. Gilluly's correlation, in turn, was based on a few poorly preserved fossils and on lithologic resemblance to strata of well established Jefferson age that occur in other parts of northern Utah. The lithologic resemblance between the Jefferson (?) of the Ophir district and that of the Cottonwood-American Fork area has been observed both by Gilluly, in a visit to the Wasatch Range, and by the present writer, in a visit to the Oquirrh Range. No fossils were collected from the Jefferson (?) in the Cottonwood-American Fork area except a few corals that were too poorly preserved to have any diagnostic value.

The formation is, in this area, about 150 feet thick. It differs from all parts of the Maxfield in its comparative lack of the peculiar mottlings and other characteristic markings which characterize even those dolomitic parts of the Maxfield that most resemble the Jefferson (?) dolomite in composition. Where it is least metamorphosed, the thick-bedded dolomite that constitutes most of the formation is light- to medium-dark gray and in places very faintly: mottled. At two horizons, one near the base and one near the middle of the formation, there are layers of thin-bedded impure dolomite interbedded with a little shale and thin laminae of chert. This flaggy dolomite commonly has a greenish hue, especially where it has been slightly metamorphosed. Its most remarkable characteristic is that it contains eye-shaped vugs, commonly an inch or two in diameter, elongated parallel to the bedding and lined with crystals of calcite and quartz. Similar vugs occur; though more sparsely, at some places in the massive dolomite. These vugs, most of which in this area are hollow, evidently correspond to the solidly filled "eyes" of white calcite described by Gilluly ${ }^{27}$ as occurring in the Ophir district. The vugs are so well recognized as characteristic by mining geologists familiar with the CottonwoodAmerican Fork area that the Jefferson (?) dolomite is cornmonly referred to as the "vug lime."

The basal beds of the formation commonly consist of yellow-weathering sandstone and calcareous shale. Much of the sandstone contains pebbles of quartz, less than an inch in diameter; which are not, as a rule, very well rounded. The upper limit of the formation is

${ }^{26}$ Gilluly, James, Geology and ore deposits of the Stockton and Fairfield quadrangles, Utah: U. S. Geol. Survey Prof. Paper 173, p. 20, 1932.

27 Idem, p. 20, pl. 6, $A$. placed, somewhat arbitrarily, at.the top of a bed of very fine-grained light-gray dolomite, which is commonly about 10 feet thick but is thinner and perhaps locally absent in the extreme southern part of the area. This bed is very conspicuous in weathered outcrops because of its whitish color and because it commonly forms a ledge, From a distance it strikingly resembles the bed that forms the top of the lower division of the Maxfield limestone, but on closer inspection it shows a less marked lamination and a bluish rather than a creamy-tint. It is characterized, because of its extreme brittleness, by a multitude of fractures, by reason of which its weathered s.urface is commonly seamed like a long-used piece of beeswax. (See pl. 14, A.) This bed, like the lower one that it resembles, is a most.useful horizon marker; the two, indeed, are sometimes said to have been confused; though they can readily be distinguished at close range not only by their own minor lithologic differences but by the greater differences in the character of the beds adjacent to them.

'The chief effect of metamorphism on the more massive beds of the Jefferson (?) dolomite is a bleaching and obliteration of the bedding, which causes the greater part of it to become a featüreless white sugary mass. The top of the formation cannot always be delimited accurately in areas where the limestones are bleached. The thin-bedded vuggy layers, however, retain much of their distinctive bluish color, as well as their vuggy character, even where metamorphism is moderately advanced, and they are therefore among the beds most helpful in deciphering structure.

The general distribution of the Jefferson (?) dolomite may be traced on the map as a narrow band between the larger areas of Cambrian and Mississippian rocks. Some of the exposures that show it in its altered condition are on the ridge east of the Twin Peaks and on the slope east of the Pittsburg mine, which are described in detail below. Others are on Montreal Hill and at some places on the west side of Mary Ellen Gulch. This formation is the principal country rock of the Flagstaff and Emma ore bodies. Its aspect in a metamorphosed condition is fairly well shown in the cliff above the Frederick tunnel, and still better in the vicinity of the Prince of Wales mine.

One of the best exposures of the Jefferson (?) dolomite is on the ridge east of Twin Peaks, between the south headwater branch of American Fork and Mary Ellen Gulch. (See pl. 14, B.)

$$
\text { Section on ridge east of Twin Peaks }
$$

Madison limestone :

12: Limestone, dark blue-gray, beds averaging less than 6 inches in thickness; some layers shaly, some a little stained with buff

Fect mestone like that above but with beds about twice as thick; a little chert about 5 feet from base; fossiliferous. 
Section on ridge easi of Twin Peaks-Continued Jefferson (?) dolomite:

10. Dolomite, light gray on fresh fracture, bluish white on weathered surface, very finegrained ; contains neither vugs nor fossils_.--

9. Dolomite,' very dark gray, magnesian, gritty on weathered surface. Near the base are large whitish nodules of calcite which may represent vug fillings_

8. Dolomite, dark gray, rather distinctly and broadly banded; thick-bedded. Some large vugs irregulârly distributed.

7. Dolomite, dark gray, somewhat stained with brown on surface, faintly banded but massive; contains a gọod many vugs

6. Dolomite, dark gray ; beds mostly 1 foot to 2 feet thick; a few, vugs at base

5. Dolomite, dark gray, somewhat stained with browu on weathered surface; beds mostly less than 1 foot; thick and in part shaly; vugs common, some of them large

4. Dolomite, medium gray, lower part darker and somewhat stained with buff; contains small vugs

3. Shale, stained yellowish

2. Dolomite, dark gray, slightly stained with buff; contains a few small vugs.

1. Shale, as above

Thickness of Jefferson (?) dolomite (beds 1-10)

Near the Pittsburg mine, about 11/2 miles northeast of the locality of the section just described but separated from it by the great Silver Fork fault, there are other excellent exposures of the Jefferson (?) dolomite which display essentially the same features. The differences that appear between the foregoing section and the one below doubtless do not all represent real differences in the rocks but are due to the fact that a given feature does not always impress even the same observer in the same way. The thickness as measured here is a little less than in the section already described, but the measurement is a little less accurate.

Section of Jefferson $(?)$ dolomite near Pittsburg mine

8. Dolomite, light gray, very fine-grained, brittle, nearly white on weathered surface. About 4 feet from the base is adark-gray layer 6 inches thick, overlain by a 2 -inch layer of chert. Same as bed 10 in preceding section. 10

7. Dolomite, very dark gray, massive; upper part broadly and faintly banded; lower part slightly rusty; vugs are more or less common for about 25 feet from the base

6. Dolomite, gray, buff-stained, vuggy, with some shale near the base, and with discontinuous layers of chert, about half an inch thick, which are very characteristic...-..-

5. Dolomite, medium to light gray, thick-bedded in all but lower 5 feet, which is rather thin-bedded; contains conspicuous vugs filled with white calcite, most abundant in lower part; lower boundary indefinite; thickness measured only roughly

4. Dolomite, light gray, massive, containing a few vugs near top and bottom.
Section of Jefferson (?) dolomite near Pittsburg mine-Con.

3. Dolomite, gray on fresh fracture but rusty on weathered Feet surface, containing many vugs, thin-bedded to shaly, and interbedded with shale

2. Sandstone, calcareous, brownish gray, rough-weathering

1. Dolomite like bed 3_-_-_._- 5

The corresponding beds in the two sections are not numbered alike. If the southwestern section is called $\mathrm{A}$ and the other B, then beds 1,2, and 3 in B correspond roughly to beds $1,2,3$, and basal part of 4 in $A ; 4$ and 5 of $\mathrm{B}$ correspond to most of 4 in $\mathrm{A} ; 6$ in $\mathrm{B}$ is 5 in $\mathrm{A} ; 7$ in $B$ represents $6,7,8$, and 9 in $A$; and 8 in $B$ is the same as 10 in $\mathrm{A}$.

The sequence may be generalized as follows:

\section{Generalized section of. Jefferson (?) dolomite}

Dolomite, pale blue-gray, very fine-grained.

Feet

Dolomite, thick-bedded, dark gray, faintly and broadly banded in the upper part, containing large vugs mostly filled with white calcite and rather sparsely distributed

Dolomite, dark blue-gray, rusty on weathered surface, thinbedded to shaly; contains abundant vugs lined with crystals of calcite, and thin lenses of chert. (Called in the field

"upper flaggy vug.") -

Dolomite, thick-bedded, rather light gray ; certain layers contain vugs mostly filled with white calcite

Dolomite, rusty, flaggy, and containing many vugs, interbedded with rusty shale and locally with calcareous sandstone

One of the most complete exposures of the Jefferson (?) dolomite is that on Montreal Hill, where its char-acter is not affected by contact metamorphism. This section has not been measured in detail, but it shows the following general sequence:

\section{Section of Jefferson (?) dolomite on Montreal Hill, with approximate thicknesses}

Light-gray brittle fine-grained dolomite. Feet

Very dark blue-gray dolomite

Flaggy dolomite with vugs.

Thicker-bedded, darker blue-gray dolomite_..............- 20

Dark-gray, brown-weathering flaggy dolomite with vugs; sandy bed near base

At a prospect on Vena Flat, a little to the north, the lowest flaggy portion is only about 7 feet thick and consists of flaky shale interbedded with a little limestone. The Jefferson (?) dolomite has peculiar characteristics that set it apart from the overlying rocks. It is in large part dolomitic, which very little of the overlying Madison formation appears to be, and is characterized by vugs and by the absence of the irregular lumps of chert that are common in the Mississippian limestones. It is 
almost devoid of fossils, only a few ill-preserved corals having been found in it, and these are of little diagnostic value, whereas typical Madison fossils are abundant in the beds just above it.

\section{CARBONIFEROUS SYSTEM}

\section{SEQUENCE OF FORMATIONS}

Carboniferous strata occupy about half the surface of the Cottonwood-American Fork area, where they have a greater total thickness than all the older systems put together. The aggregate thickness of the formations from Mississippian to Permian inclusive is about 8,000 feet; yet this is but a small fraction of the thickness of the beds deposited during Carboniferous time in the Oquirrh Range, to the west, and in the part of the Wasatch Range that lies just south and east of the area here described.

The Carboniferous rocks of this area have been divided for mapping purposes into five units.

The lowest unit comprises the Madison limestone (lower Mississippian) and the Deseret limestone (upper Mississippian). The Madison, which contains many fossils and little chert, is about 450 feet thick. The Deseret, which is in part very cherty and is comparatively poor in ofossils, is about 950 feet thick. The two formations together, constitute the thickest mass of limestone in the area, and the one from which most of the high cliffs and other picturesque topographic features have been carved.

The Deseret is conformably overlain by strata assigned to the Humbug formation, also upper Mississippian. These strata, which are about 750 feet thick, consist mainly of limestone but include some dolomite, sandstone, and shale.

The Carboniferous section up to about the stratigraphic level taken as the top of the Humbug is very like that of the adjacent regions to the west and south. But from here upward thère are great differences between the section exposed in the drainage basin of Big Cottonwood Creek and that which is so magnificently displayed in the drainage basin of Provo River and in Rock Canyon south of it, which is very similar to that found in the Oquirrh Range.

The most obvious difference between the Big Cottonwood and the Provo section is that the former contains no beds that can on the basis of present knowledge be positively correlated with either the Great Blue limestone (upper Mississippian), which is about 2,500 feet thick in Provo Canyon, or the Manning Canyon shale (upper Mississippian and Pennsylvania), which is there about 1,600 feet thick..$^{28}$ It is indeed possible that some beds in the Big Cottonwood section are of the same age as the Great Blue limestone, but if so their thickness can be only a very small fraction of that which the formation has in Provo Canyon-so small that to map it separately would hardly be justifiable even if the correlation were well established. The Manning canyon shale has not been shown to be represented in the Cottonwood-American Fork area. A layer of dark shale probably not over 100 feet thick is exposed at a few places in the basin of Big Cottonwood Creek, but it cannot represent the Manning Canyon shale, for it is separated from the lowest beds that have been shown to be Pennsylvanian by limestone that contains upper Mississippian fossils. This shale, in the opinion of Mr. Baker, ${ }^{29}$ might be roughly equivalent to the Long Trail shale member of the Great Blue limestone but may not represent any particular member of the other sections. It is possible, then, that the beds here mapped as Humbug may in small part be equivalent to the lower part of the Great Blue limestone; it seemed useless, how:ver, in view of the uncertainties indicated, to try to separate these beds. Even were they known to be present their thickness must be relatively small and the position of their base could not be determined without careful paleontologic study.

The highest beds assigned to the Humbug formation are overlain, at the unconformable contact already mentioned, by a few hundred feet of limestone containing Pennsylvanian fossils and of other rocks, all of which are tentatively correlated with the Morgan formation.

Above the Morgan (?) formation comes the Weber quartzite, which does not by any means consist wholly of quartzite, but contains many beds of limestone and of rocks composed of sand and carbonate in various proportions. The Weber quartzite, again, has only a fraction of the thickness that it has in the basin of the Provo River. In the Big Cottonwood basin the formation is not over 1,500 feet thick; in the Provo basin it is probably at least ten times as thick. In the Stockton and Fairfield quadrangles, ${ }^{30}$ likewise, the Oquirrh formation, equivalent to the Weber, is thought to be at least 15,000 feet thick.

Such enormous variations in the thicknesses of the upper Mississippian and Pennsylvanian formations constitute one of the outstanding and unsolved stratigraphic problems of the region. It may be partly accounted for as being due to an unconformity at the base of the Park City, as suggested by Blackwelder: ${ }^{31}$ It seems probable, however, that the differences are in greater part original rather than the result of erosion in Carboniferous time, and that an area embracing the basin of Big Cottonwood tended for much of this time to stand higher than adjacent areas.

Mr. Baker ${ }^{32}$ points out that the enormous increase in the thickness of the Weber, Great Blue, and Manning Canyon between Big Cottonwood Creek and Provo

\footnotetext{
${ }^{20}$ Oral communication.
}

${ }^{30}$ Gilluly, James, Geology and ore deposits of" the Stockton and Fairfield quadrangles, Utah : U. S. Geol. Survey Prof. Paper 173, p. 35, 1932.

${ }^{31}$ Blackwelder, Nliot; New light on the geology of the Wasatch Mountains, Utah : Geol. Soc. America Bull., vol. 21, p. 531, 1910.

${ }^{32}$ Oral communication. 


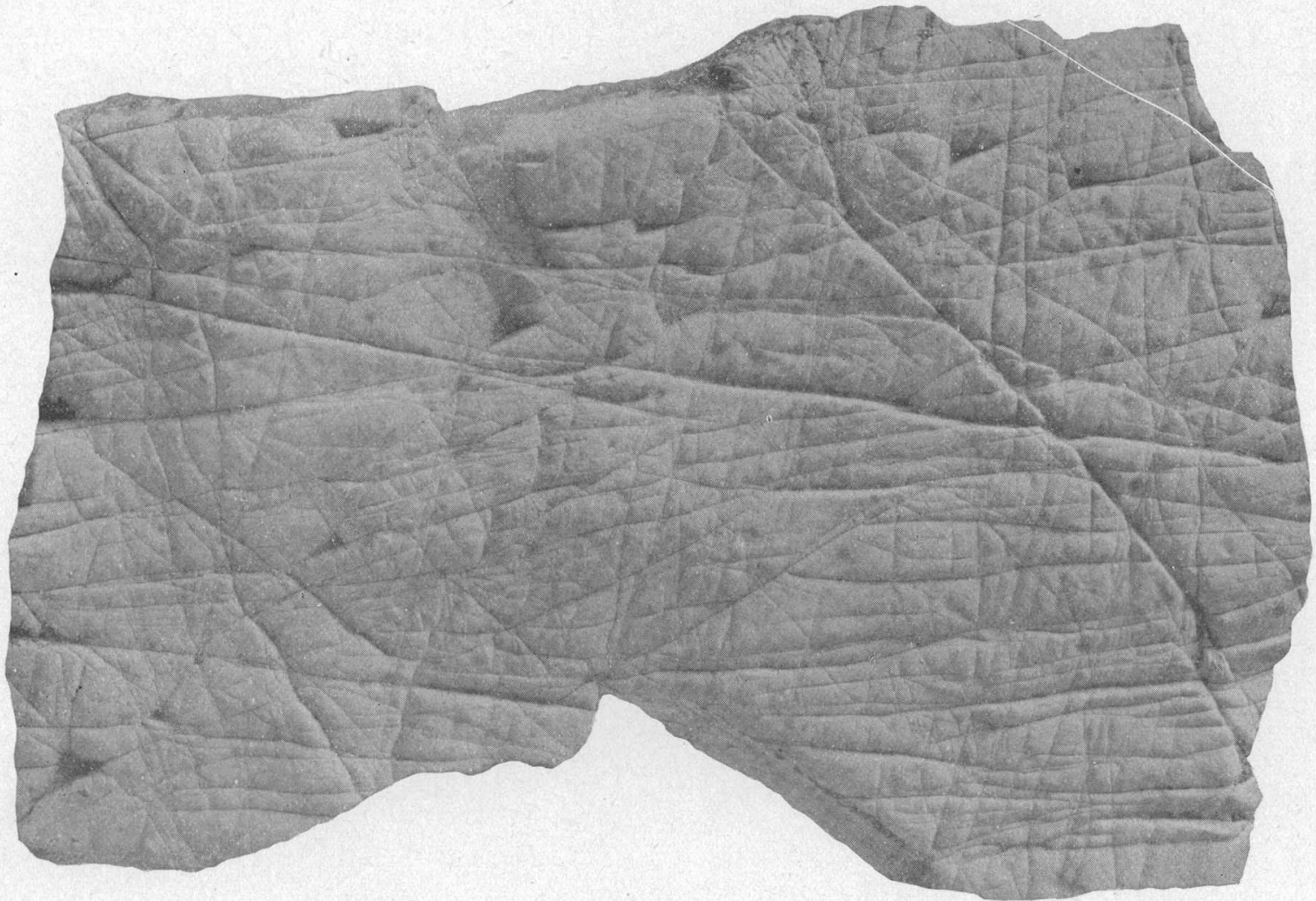

A. FINF-GRAINED WHITISH DOLOMITE FORMING TOP OF JEFFERSON (?) DOLOMITE. Specimen shows characteristic minute jointing. $\times 1 \frac{11 / 4}{}$

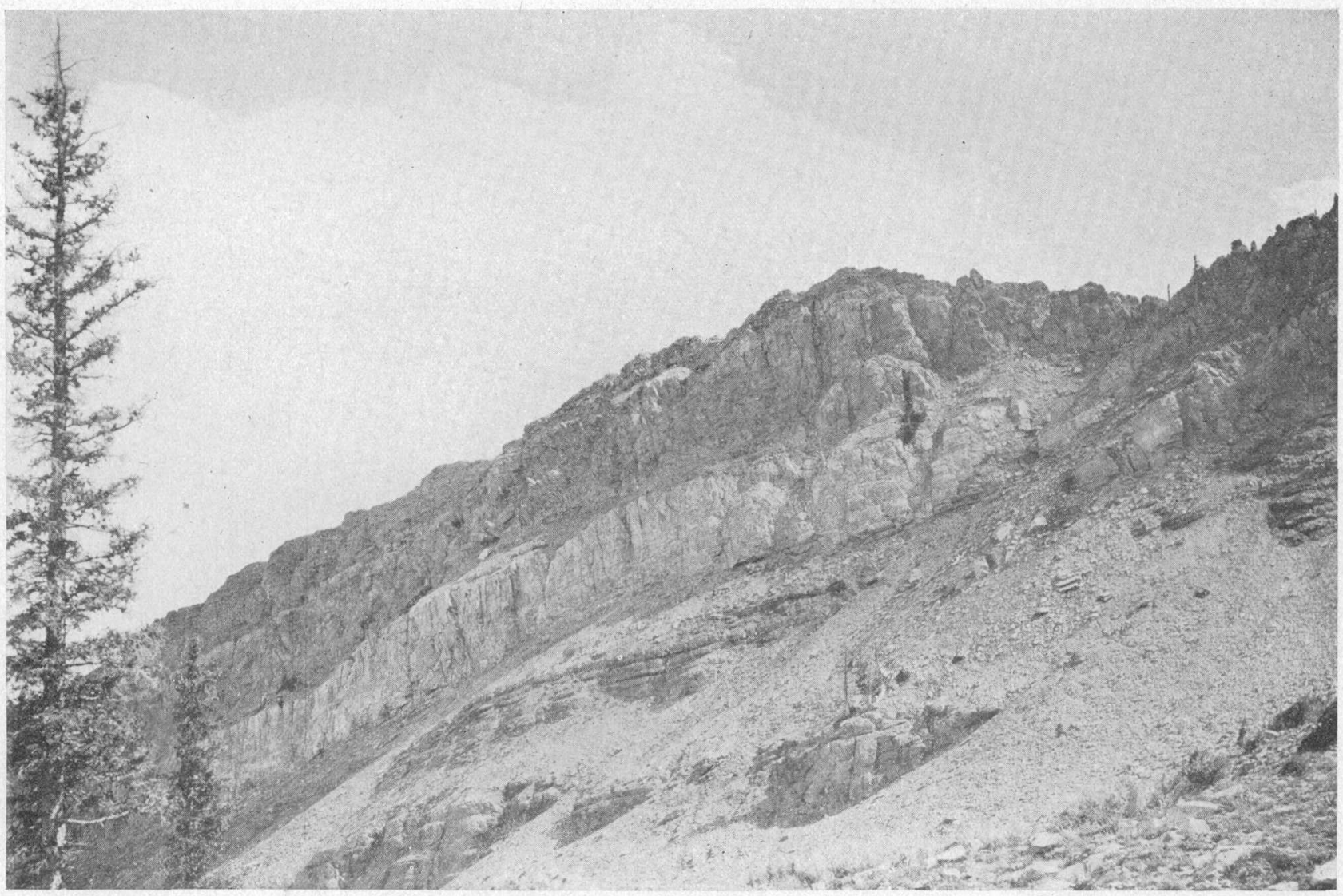

B. JEFFERSON (?) DOLOMITE EAST OF TWIN PEAKS.

Maxfield limestone in foreground. Base of Madison limestone just below top of knob. 
Canyon may not have been originally so abrupt as it now seems, for this reason: these localities are apparently separated by a thrust fault of enormous throw, which has brought them many miles nearer together than they were in late Carboniferous time. This consideration seems valid, but it only diminishes the magnitude of the problem without solving it.

The Weber quartzite is overlain without visible unconformity by the Pennsylvanian and Permian Park City formation, about 600 feet thick, which is the most heterogeneous in the entire section, for it contains quartzite, shale, and phosphate rock besides the limestone which is its most abundant rock.

\section{MADISON LIMESTONE}

RELA'TION TO JEFFERSON (?) DOLOMITE

No unconformity has been observed by the writer in the Cottonwood-American Fork area between the Madison limestone and the Jefferson (?) dolomite, and it is safe to say that there cannot have been a marked angular unconformity between the two formations. Not only has no such discordance been observed, but the lightcolored fine-grained dolomite which has arbitrarily been taken as the top of the Jefferson (?) is present throughout the district, with the possible exception of a small area along the west side of Mary Ellen Gulch, and Madison fossils are found in many sections only a few feet above this bed.

The statement ${ }^{33}$ that the Mississippian rested unconformably on various older formations was based on the belief that the Jefferson itself was absent from this area, whereas the lowest beds above the Cambrian are provisionally assumed, in the present report, to be of Jefferson (Middle Devonian) age.

But if this lowest dolomite above the Cambrian is indeed the Jefferson, and the fossils in the dark beds above have been rightly identified as lower Mississippian, there must have been an erosion interval between them. Gilluly ${ }^{34}$ finds evidence of such erosion in the Oquirrh Range in the form of a karst topography, irregular holes as much as two or three feet deep in the Jefferson being filled with Madison limestone. Similar relations might be found in the Cottonwood-American Fork area by special search, even though they have not been observed hitherto.

\section{OCCURRENOE}

The outcrops of the Madison limestone in the Cottonwood-American Fork area are very extensive, and their general location may be found by following on the geologic map (pl. 3) its contacts with the Jefferson (?) dolomite. No boundaries are shown on the map between the Madison and the Deseret, but some rough estimate of the extent of each can be made by remembering that

\footnotetext{
Butler, B. S., and others, Ore deposits of Utah : U. S. Geol. Survey Prof. Paper 111, pp. 237-238, 1920.

${ }^{34}$ Gilluly, James, op. cit., p. 22, fig. 4.

$462858-43-3$
}

the Madison has about half the thickness of the Deseret.

Especially good exposures of the formation in a littlealtered state are to be found on the slope north of the Carbonate mine and on the top of Montreal Hill, in the slopes of Devils Castle, on the ridge east of the Twin Peaks, and on the south side of American Fork opposite the mouth of Major Evans Gulch.

In many good exposures, such as those in the cliff above the Frederick tunnel and elsewhere in the vicinity of Alta, the Madison linestone is more or less bleached and otherwise affected by contact metamorphism, which is very pronounced for some distance north and south of the Alta stock of granodiorite.

\section{LITHOLOGIC CHARACTER}

The Madison limestone is one of the most homogeneous formation in the area. Where it is least altered, its prevailing color is blue-gray and its bedding well marked, the beds being mostly less than a foot thick. Its general aspect is well shown in the readily accessible exposure opposite the mouth of Major Evans Gulch, though this exposure shows only about a quarter of the entire thickness of the formation. The lowest part of the Madison where its contact with the whitish bed taken as the top of the. Jefferson (?) can be seen, is very dark gray or nearly black. Fossils are most abundant in the lowest 50 feet or so of the formation, and the richness in fossils of these lowest beds, together with their dark color and thin bedding, presents a striking contrast to the prevailingly massive and light-gray Jefferson (?) dolomite, which is nearly devoid of fossils. The fossils in the Madison, at least where it is not metamorphosed, inevitably catch the eye even of an observer who does not know their names, and help to identify the formation. The commonest of them are cylindrical sections of crinoid stems, the ribbed shells of brachiopods, and corals, some of which are branching and some cone-shaped. A detailed report on the fossils and their significance will be found on page 24 .

Chert similar in color to the limestone, forming lenses and ovoid or more irregular lumps unlike any that are found in the lower limestones, occurs here and there in the Madison, mostly in the upper part, but it is nowhere so abundant as in the Deseret.

The term "limestone" is applied to the Madison in somewhat the same broad sense that it was applied to. the Maxfield. The formation contains both true limestone and dolomite, and perhaps magnesian limestone also. In the slope north of Alta it is mostly calcitic. In the exposure at the mouth of Major Evans Gulch, where the rocks are not conspicuously altered, application of 10 percent $\mathrm{HC} 1$ to the ledges at several places failed to cause effervescence, though some of the float effervesced on application of the same acid. There is no convincing evidence here that limestone has been altered to dolomite. Such alteration has doubtless 
occurred, however, in places. At another locality cherty limestone-perhaps in the Deseret-that had locally been bleached was tested with this weak acid; the unbleached parts effervesced, though rather weakly, as if slightly magnesian, while the bleached parts did not effervesce at all.

The prevalence of partial bleaching in the Madison limestone near Alta caused it to be called, first apparently by Beeson and then by others, the "Blue and White" limestone. This term aptly describes these beds as they appear in the area that contains most of the mines-say from the Frederick tunnel to Honeycomb Fork. Good exposures in this area show an alternation of blue and white layers not differing very widely in thickness and giving an effect of considerable regularity. The banding is conspicuous also in the Honycomb Cliffs. The term is not descriptive of the division as a whole, however. The general color of the Madison in the Devils Castle, for example, where it is little affected by metamorphism, is dark blue gray, some beds being nearly black and none of them distinctly light. On the other hand, beds at the same horizon in areas of moderately strong contact metamorphism are more white than blue, and close to contacts they are altogether white. At many places-as may be seen in the cliff by the Frederick tunnel - the boundary between blue and white cuts across the bedding.

AGE

The Madison age of the lower part of the formation that has here been described was well established, in the opinion of the late Dr. George H. Girty, by fairly numerous fossils. The fullest collections made- were from the top of Montreal Hill and from the knob about half a mile northwest of the Yankee mine. In both these places, the fossils were all collected within 100 feet of the top of the fine-grained bed considered to be the top of the Jefferson (?). A large number of Madison fossils were collected also from angular blocks of limestone forming part of a moraine or an old landslide, lying on the knobs southwest of Reynolds Flat near the northwest corrier of the quadrangle. The value of these is limited inasmuch as they are not from rock in place, but so many of the fossils in them occur also on Montreal Hill as to leave no doubt that they represent the same general horizon, and the blocks yielded a few species not found on Montreal Hill.

The collections identified as Madison are:

8983. Knob half a mile northwest of Yankee mine :

Fenestella sp.

Productus laevicosta

Camarotoechia Herrickana?

Dielasma Utah

Spirifer centronatus

Composita humilis

Cliothyridina crassicardinalis

- Euomphalis sp.
Of this lot Dr. Girty wrote that it "contains a characteristic Madison fauna."

3979. Top of Montreal Hill :

Michelinia sp.

Syringopora surcularia?

Lithostrotion $\mathrm{n}$. sp.

Triplophyllum excavatum

Campophyllum sp.

Plàtycrinus

Spirorbis n. sp.

Fenestella sp.

Cystodictya n. sp.

Schuchertella Chemungensis?

Productella aff. concentrica?

Productus aff. Fernglenensis

Camarotoechia metallica?

Girtyella? sp.

Spirifer centronatus

Brachythyris? sp.

Spiriferina solidirostris

Composita immatura?

Cliothyridina crassicardinalis

Pleurotomaria sp.

Paraparchites n. sp.

3980. Boulder from knob west of Reynolds Flat:

Michelinia n. sp.

Syringopora sp.

Triplophyllum excavatum

Amplexus? sp.

Cy.stodictya n. sp.

Schuchertella Chemungensis

Chonetes Loganensis

Productus sp.

Dielasma Burlingtonense?

Spirifer centronatus

Cliothyridina crassicardinalis

Composita? sp.

Pernipecten Shumardianus

Cypricardina scitula?

Euomphalus sp.

Loxonema sp.

Regarding lots 3979 and 3980, Dr. Girty wrote that they "contain an early Mississippian (Madison) fauna. They cannot by any possibility be Devonian."

\section{DESERET LIMEST,ONE}

OCCURRENCE

The distribution of the Deseret limestone is of course very similar to that of the Madison, from which it is not separated on the map (pl. 3), but its outcrops are much more extensive, both because of its greater thickness and because of the resistant character of its cherty, lower part. The upper beds, which contain comparatively little chert, have no very extensive outcrops in the area mapped except those in the northern part of Reed \& Benson Ridge and along the sides of Big Cottonwood Canyon nearby. The cherty beds are especially well exposed north of the Carbonate mine and along. the middle part of Reed \& Benson Ridge. Parts of them are well-exposed, also, in more or less altered condition, along the east side of Silver Fork and in the canyons of Honeycomb and Solitude Forks. The 
Devils Castle ridge and the head and west side of the canyon of Dry Fork afford some of the best exposures of the cherty beds, which are not extensively exposed at any place farther south within the mapped area.

Cherty beds in the lower part of the Deseret form the footwall of the lowest thrust fault in the Alta thrust zone for' some distance.

\section{IITHOLOGIC CHARACTER}

The base of what has been mapped as the Deseret limestone is marked in most places by a nearly black shale or shaly limestone, which is nowhere well enough exposed to be measured but whose thickness is probably nowhere more than 25 feet. The largest fragments of this material that can ordinarily be found in the float are little sharp-cornered joint-blocks not more than an inch in diameter. Probably the bed consists, in places, largely of much more fragile shaly material. This bed is thought to be the source of the black muck which is so abundant in the Dutchman mine and the Whirlwind tunnel (p. 138). In the Ophir district, what appears to be the same bed includes a layer of phosphatic oolite, but such material was not definitely recognized in the Cottonwood-American Fork area. Even in some places where the adjacent limestone is largely bleached, this black bed remains dark enough to be readily traceable.

These shaly basal beds, where they are present, are overlain by limestone or dolomite that differs in general from the Madison in being darker, more cherty, and poorer in fossils. It is also more prevailingly dolomitic than the Madison. The most striking of these characteristics is the abundance of chert.

The chert ${ }^{35}$ that is so abundant in the Deseret limestone differs altogether in character from the siliceous layers in the Cambrian (Maxfield) limestone. It is of a sort that is common in many post-Cambrian limestone formations. It occurs partly in nodules (see pl. 15, $A$ ), which may be nearly spherical and several inches in diameter, but there are all gradations from these thick rounded masses to more lenticular ones, flattened along the bedding planes; and these, where the chert is abundant, may coalesce to form podlike or more irregular bodies. Nodules of limestone in cherty material, such as are common in the Cambrian, do not occur in the Madison.

The chert substance, where least altered, has a characteristic very fine, compact texture and conchoidal fracture. Its color in a given bed is generally almost the same as that of the enclosing limestone but may be darker. In places a mottling or a fine color-banding is present, and the bands may have an appearance of close folding. The surface of the chert nodules and other masses is dull and commonly brownish. Fossils partly or wholly embedded in the chert occur but are somewhat rare.

${ }^{35}$ The term "chert" is applied here to all the cryptocrystalline siliceous matter enclosed in limestone, without regard to color.
The chert has been more readily altered by metamorphism than the enclosing limestone. The earliest alteration seemis to have been a partial replacement of the chert by white calcite; the most characteristic change in areas of strong metamorphism was the formation of abundant tremolite.

The abundantly cherty part of the Deseret limestone in the Cottonwood region is divided medially by a stratum of pale crinoidal dolomite (none of the specimens taken effervesce with weak $\mathrm{HCl}$ ) that on the whole is relatively free from chert. This stratum seems to extend continuously throughout the area mapped. It is conspicuous and well defined on the slope above the Maxfield mine, where its thickness is about 80 feet; it forms the ruggedest part of the crest of Reed \& Benson Ridge, and it is recognizable on Dry Fork, 10 miles to the southeast, though its limits there are not very definite. In most places it has enough individuality and thickness to be a useful horizon marker; its thickness, however, is far from uniform. The best exposure of this limestone occurs in the cliffs at the head of Days Fork, nearly due southeast of the Eclipse shaft. Although there are some small normal faults at this locality, the measurement of an apparently unfaulted section gives a thickness for the crinoidal bed of about 110 feet. This is the greatest thickness that has been measured at any place in the region, yet the south slope of Flagstaff Mountain, near the Tiger tunnel, where the crinoidal stratum should crop out according to the apparent structure, shows hardly 10 feet of limestone that could reasonably be correlated with this crinoidal bed on lithologic grounds. It is not clear whether the original thickness of the stratum rapidly dwindled in the short distance through the mountain, whether the stratum has been beveled by an undetected fault, or whether a thrust fault has brought near together a thick and a thin portion of the crinoidal stratum, once separated by so great a distance that their difference in thickness implies only a gradual, instead of an abrupt thinning.

The rock of the crinoidal stratum. is thick-bedded. Its color where it is-least altered is very pale smoky gray, locally tinged with lavender. It consists in greater part of fragments of crinoids, among which perforated discoidal sections of the stems are most abundant. Under the influence of metamorphism, this rock readily bleaches to snowy white, the bedding becomes still more obscure, and the outlines of the crinoid fragments are blurred by recrystallization. Although most of the crinoidal bed is free from chert, large nodules of white or flesh-colored chert are everywhere present in the basal part of the crinoidal stratum. These generally remain recognizable even underground; where, also, the crinoid fragments often reflect the gleam of the carbide lamp. These features frequently serve to distinguish this bed from certain other massive beds in the Maxfield limestone and the Jefferson (?) dolomite. 
The cherty limestone above the crinoidal stratum is similar in general to that below, but some of the beds are perhaps more abundantly cherty than any in the lower portion. A characteristic feature near Alta is the presence of corals, of both cone-shaped and tubular forms, in a bed of this chert.

The thickness of the cherty limestone above the crinoidal stratum is estimated at 90 feet on the slope above the Maxfield mine, but in other places it appears to be greater.

The very cherty part of the Deseret limestone is overlain by about 200 feet of carbonate beds that contain very little chert, because of which fact they are not especially well exposed. Some of the best exposures of these are near the Big Cottonwood Ranger Station. They are at least in part dolomitic, some beds being noticeably gritty on the weathered surface. The color of these upper beds is prevailingly rather light blue gray but ranges from nearly black to nearly white. A few beds near the top are oolitic, and a few are mottled somewhat like certain beds in the Cambrian; but these features are not so marked or so prevalent as to be a possible source of confusion.

\section{CORRELATION}

The assignment of the upper two thirds of the great limestone mass above the Jefferson to the Deseret depends on its resemblance in stratigraphic position-between a formation rich in Madison fossils and one in which limestone and sandstone alternate-to the Deseret limestone of the Ophir district. ${ }^{36}$ The black shaly beds in the two sections are assumed to lie at the same horizon. This correlation makes the thickness of the Madison virtually the same in both areas. It makes the Deseret, on the other hand, about 50 percent thicker in the Cottonwood-American Fork area than it is in the Ophir district, but this difference is trifling compared to that shown by some of the later Carboniferous formations. The lithologic correspondence between the two sections, again, is not especially close, the Madison of the Ophir district being described as very cherty and the Deseret as not especially so. The correlation must then be regarded as tentative, and it may be as well that no boundary between the Madison and the Deseret is drawn on the map. In this part of the section as in others there is need of more paleontologic field work.

The top of the Deseret, which is the base of the Humbug, is arbitrarily placed at the horizon where sandstone beds become noticeable.

\section{HUMBUG FORMATION}

OCOURRENCE AND THIOKNESS

The outcrops of the rocks correlated with the Humbug formation of the Ophir district lie mostly in an area

${ }^{36}$ Gilluly, James, Geology and ore deposits of the Stockton and Fairfield quadrangles, Utah: U. S. Geol. Survey Prof. Paper 173, p. 25, 1932. that extends almost continuously, though interrupted by moraines in the canyon of Mill D South Fork, from the northwestern corner of the Cottonwood quadrangle to the vicinity of Davenport Hill, where it is cut off by the Silver Fork fault. A minor area lies nearby, on the north side of Big Cottonwood Canyon. A second large area lies far to the southeast, in the drainage basins of Dry Fork and Snake Creek, and another small one, bounded by a fault (p. 60), lies west of Major Evans Gulch.

The Humbug formation is perhaps the least satisfactorily exposed in the region, being nowhere exposed in one continuous section. The best section across it; on the whole, is the one east of Mill D South Fork, near Doughnut Falls. At this locality the beds dip almost uniformly northeastward and apparently are not faulted. The exposures of the upper beds are especially good, and it is only here that their contact with the overlying Pennsylvania limestone is clearly displayed. In the basin of Days Fork there are extensive exposures of parts of the formation, and a vivid impression of certain of its features may be gained by looking into the canyon from commanding viewpoints. The structure; however, is here so complex that the thickness of the formation is not measurable at this locality.

Some of the best exposures of the formation occur in the southeastern area. The lowest beds are best exposed in a bluff about three-quarters of a mile northwest of the Ant Knolls, and the middle part in a gully a little more than a mile northwest of the Ant Knolls; and some of the higher beds form a conspicuous bluff on the west slope of the Ant Knolls. Nearly all the beds in the formation are probably exposed at one or more of the three localities, but it was not practicable to make up a complete section from them. The lower part of the west slope of the Ant Knolls is covered with talus and moraines; the bluff to the north is separated by faults from the other exposures; and the section in the gully still farther north is beheaded by a thrust fault.

The most reliable basis for estimating the thickness of the Humbug formation is afforded by the section on the east slope of Mill D South Fork. If this section is not faulted, the thickness from the lowest bed of sandstone to the basal conglomerate of the Pennsylvanian is about 800 feet. Measurements made by Butler and Hintze on the north side of Cottonwood Creek above the Maxfield mine indicate a thickness of a little over 1,000 feet, whereas the thickness of the Humbug north of Big Cottonwood Creek is apparently a good deal less than 800 feet. Such discrepancies are not surprising in view of the possibility of undetected faulting, of the fact that the upper limit of the Humbug, here mapped, is an erosion surface, and of the fact that the lower limit of the formation has been arbitrarily fixed at the lowest considerable bed of sandstone. A sandstone bed that is conspicuous in one section might be either absent or 
unexposed in another section a mile away. Variations in the stratigraphic range of the lowest sandstone of the interbedded sandstone and limestone series of upper Mississippian age which is so widely distributed in western Utah have been recognized at Tintic, ${ }^{37}$ and in the Oquirrh Range; ${ }^{38}$ and sandy beds probably at about this horizon are found in the Woodman formation of the Deep Creek Range. ${ }^{39}$

\section{LITHOLOGIC CHARACTER}

Somewhat more than half of the Humbug formation as mapped in the Cottonwood-American Fork area consists of dark- to light-gray limestone with subordinate sandstone and a little shale. The limestone is mostly blue-gray and calcitic, though very dark and very light beds occur also. Chert is present in moderate quantity, and fossils are not abundant. Some magnesian beds, and a bed of vuggy limestone about 20 feet thick, were noted in Dry Fork; and the same section contains buffweathering sandy limstone, in which the sand shows cross-bedding.

The sandstone that is interbedded with this limestone is perhaps a quarter as abundant as the limestone. Few beds of it are more than 5 feet thick. The rock is remarkably similar to much of that in the Weber quartzite above; it is fine-grained, and is light grayish brown on weathered surfaces but grayish when it is not weathered. Much of it is cross-bedded. A few beds of shale that weather yellow or brown are found in this part of the formation.

'The upper part of the Humbug formation as mapped in this area consists mainly of very fine-grained limestune that is almost black on fresh fractures but bears a thin film of buff on weathered surfaces. 'This Characteristic is illustrated in a conspicuous ledge on the west slope of the Ant Knolls. Some of this dark limestone is very cherty; a hundred-foot layer of cherty black limestone was noted between Mill D South Fork and Days Fork, below the shaly beds that are now to be noted.

At several places in the basin of Big Cottonwood Creek a layer of black shale and shaly limestone occurs near or somewhat above the middle of these dark limestones. On the east side of Days Fork, about half a mile south of the 9,694-foot hill, there is exposed a welldefined bed of black shale about 40 feet thick, apparently repeated by a small thrust fault. In Silver Fork Canyon, a few hundred feet west of the portal of the Alta tumnel, the shale is exposed, and the dump of a caved tunnel here is mainly black shale. The shaly

${ }^{37}$ I.indyren, Waldemar, and Loughlin, G. F., Geology and ore deposits of the 'Tintic district, Utah: U. S. Geol. Survey Prof. Paper 107, p. 42 191.9.

${ }^{38}$ Gilluly, James, op. cit., pp. 25-28. Spure, T. E. Economic geology of the Mercur mining district, Utah : U. S. Geol. Survey 16th Ann. Rept., pt. 2, pp. 372-374, 1895.

${ }^{30}$ Nolan, I. B., Geology and ore deposits of the Gold Fill quadrangle, Utah: U. S. Geol. Survey l'rof. Paper 177, pp. 27, 41, 1935. beds cross the ridge between Days Fork and Mill D South Fork in a saddle due east of Doughnut Falls, and the course of its outcrop both eastward and northwestward from the saddle is well expressed by the contours of the topographic map. The shale is well exposed near the mouth of Willow Creek, and its position is marked by the shoulder below the 8,500-foot contour north of the Big Cottonwood Ranger Station. These shaly beds find their strongest topographic expression in the ravine northeast of Doughnut Falls, though they are not very well exposed here and seem to consist mainly of flaggy limestone rather than true shale.

No exposures of these black shaly beds were found in the Ant Knolls area, but there they may be covered with moraine.

These ill-defined shaly beds are overlain, on the north side of the ravine, by about 50 feet of dark limestone, some of it shaly and some of it cherty, near the top of which are remarkably large cone corals and brachiopods. Similar fossils are found near the top of a cliff of dark, buff-weathering limestone on the western slope of the Ant Knolls.

The characteristics of the Humbug formation as thus far described are those which it presents where it is not much altered. In much of the area between Days Fork and Silver Fork, the formation has undergone minor thrust faulting and crumpling and is extensively brecciated. This brecciation has probably been facilitated, and has certainly been made the more conspicuous, by the alternation of sandstone and shale with the limestone beds.

CORRETATION AND AGE

- The lower part of the Humbug formation as mapped in the Cottonwood-America Fork area is very similar lithologically to the Humbug of the Ophir district as described by Gilluly, ${ }^{40}$ and it is upon this fact that the correlation from one district to the other is based: As for the upper, dark-colored strata mapped as. Humbug in this report, they are strikingly different from the lower strata so mapped, yet they do not closely resemble any part of the Great Blue so far as the writer can judge from Gilluly's description or from his own observations in the Ophir district and in Provo Canyon. The only clear evidence regarding the age of these upper beds is given by the fossils.

Small lots of fossils have been collected from the upper part of the Humbug formation at two localities, one in the northwestern and one in the southeastern.part of the Cottonwood quadrangle. These were determined by Dr. Girty as follows:

3982, 3982a, and 3982b. Cliff northeast of Doughnut Falls, Mill D South Fork:

Stenopora aff. rudis

Fenestella aff. tenax

${ }^{40}$ Gilluly, James, Geology and ore deposits of the Stockton and Fairfield quadrangles, Utah: U. S. Geol. Survey Frof. Paper 173, pp. 26-29, 1392. 
Campophyllum Nevadense?

Productus semireticulatus

Spirifer aff. striatus

Dr. Girty wrote concerning these: "I regard [them] as of Upper Mississippian age (Brazer). I entertain very little doubt of these, although larger collections would have been desirable."

8986. Western slope of Ant Knolls :

Chonetes aff. Loganensis

Dielasma sp.

Spirifer aff. striatus

Cliothyridina crassicardinalis .

Platyceras sp.

Griffithides sp.

This collection was apparently even less satisfactory than that taken northeast of Doughnut Falls. Dr. Girty gave the opinion that lot 8986 might be either Brazer or Madison. The stratigraphic position of these faunules, however, indicates that they are of about the same age as those in lot 3982 .

Confirmatory evidence is afforded by a small lot of fossils from the knob northwest of the Ant Knolls, collected by Butler and Loughlin. ${ }^{41}$ These were assigned by Dr. Girty to the Upper Mississippian, and determined by him as follows:

\section{Fenestella sp. \\ Chonetes sp. \\ Diaphragmus elegans. \\ Martinia? sp. \\ Composita sp. \\ Cliothyridina hirsuta.}

\section{MORGAN (?) FORMATION}

OCCURRENCE AND CHARACTER

Between the highest beds mapped as Humbug and the lowest quartzitic or sandy bed in the Weber quartzite there intervenes a formation, consisting mainly of limestone, that is tentatively correlated with the Morgan formation.

The relation of this formation to the supposed Humbug is shown in the cliffs northeast of Doughnut Falls far better than at any other place in the CottonwoodAmerican Fork area. The more prominent of the two ledges, so well expressed by the contours, on the northeast side of the ravine that marks the outcrop of the shaly beds consists of blue-gray limestone, much lighter on the average than the upper beds of the Humbug, though about as dark near the base as the underlying beds. This limestone contains a moderate proportion of chert, much of which, on the weathered surface, is flesh-tinted or of an orange hue. Near the bottom both the limestone and the chert are nearly black. A little above the base of this ledge is a conglomerate, about 3 feet thick, containing unusually well rounded pebbles, up to about 2 inches or more in diameter, of dark chert

\footnotetext{
"1 Butler, B.'S., and Loughlin, G. F., A reconnaissance of the Cottonwood-American Fork mining region, Utah : U, S, Geol. Survey Bull. 620, p. $173,1916$.
}

and limestone similar to those in the strata beneath. From a distance there appears to be a slight angular unconformity between the limestone above the conglomerate and that below, the lower dips dipping a little more steeply northward than the upper, but the discordance, if there be any, is very slight.

The Brazer fossils already mentioned were collected only about 8 feet below the conglomerate. Pennsylvanian fossils, on the other hand, have been collected from limestone similar in character and position to that which here overlies the conglomerate on the west slope of the Ant Knolls and on the slope above the Maxfield mine. It is thus evident that the Humbug, or possibly younger, upper Mississippian beds are here separated by an erosional unconformity, and probably a small angular unconformity, from the overlying Pennsylvanian beds.

The relations at this place were first perceived by Hintze. ${ }^{42}$

The prominent ledge of Pennsylvanian limestone at this locality is overlain by softer beds, including some thin-bedded maroon limestone and calcareous shale, some gray limestone enclosing irregular red argillaceous masses, and, immediately beneath the Weber quartzite, some olive-green shale with irregular nodules of limestone. The total thickness of the formation here is roughly 350 feet, of which about 250 is in the lower, cliff-forming gray limestone.

This occurrence may be taken as typical; no other in the mapped area affords nearly so complete a section, or so good an exposure of the basal conglomerate. This contact apparently is not everywhere marked by a conglomerate. A poor exposure of conglomerate with pebbles of chert and limestone has been found, however, at this horizon on the ridge west of Mill D South Fork, and a limestone conglomerate crops out on the west slope of the Ant Knolls.

The thick ledge of limestone is prominent on the steep slope east of the lower part of Days Fork, though the basal conglomerate and the upper beds are not well exposed there; and fairly good exposures of the upper part of the formation may. be seen north of the Ant Knolls. On the whole, however, the exposures in the mapped area, apart from the best one, are not very satisfactory. Perhaps the best nearby hunting-ground for fossils in this formation is at the top of the slope above the Maxfield mine.

CORRELATION AND AGE

The name Morgan formation was first used, though not published, by F. B. Weeks, and was adopted by Blackwelder ${ }^{43}$ as a designation for 500 to 2,000 feet of red sandstone and shale, with some interbedded limestone, which in Weber Canyon conformably underlie a

${ }^{42}$ Hintze, F. F., Jr., a contribution to the geology of the Wasatch Mountains, Utah : New York Acad. Sci. Annals, vol. 23, p. 114, 1913.

43 Blackwelder, Eliot, New light on the geology of the Wasatch Mounttains, Utah: Geol. Soc. America Bull., vol. $21_{2}$ pp. 519, 529-542, 1910. 
great thickness of quartzite and unconformably overlie Mississippian limestones. The Morgan was part of the Weber as defined by King, ${ }^{44}$ who described the Weber as resting on the tWasatch ${ }^{45}$ limestone, the upper part of which was erroneously regarded as Pennsylvanian.

The beds assigned to the Morgan in the CottonwoodAmerican Fork area have the same stratigraphic relations as the typical Morgan but do not strongly resemble it in character, the most definite similarity consisting in the presence of a little red material in the Cottonwood section. This formation may be equivalent to the lowest part of the Oquirrh formation.

A few fossils taken on the upper part of the western slope of the Ant Knolls above an inconspicuous bed of conglomerate seem to indicate, or at least to be consistent with, a Pennsylvanian age. A small lot taken a short distance northeast of the Ant Knolls, apparently at about the same horizon, gives very inconclusive testimony.

8984. Slope west of Ant Knolls :

Rhombopora? sp.

Spirifer Rockymontanus

Composita subtilita

Griffithides sp.

8987. Same locality :

Stenopora sp. .

Spirifer Rockymontanus

Composita subtilita

Deltopecten sp.

8988. Ridge northeast of Ant Knolls :

Triplophyllum sp.

Syringopora sp.

Fistulipora sp.

Dr. Girty said that lots 8984 and 8987 "appear to belong together." He wrote: "I should refer them to the Pennsylvanian, although not with entire confidence. In their lithologic and faunal characters they resemble a limestone that occurs in Weber Canyon at the base of the Pennsylvanian in the lower part of the Morgan formation." Of lot 8988 Dr. Girty wrote that "it might occur at almost any horizon."

\section{WEBER QUARTZITE}

CORRELATION

The Weber quartzite as originally defined included what is now called the Morgan formation (p. 28), but the term as used here includes only the strata, consisting mainly of quartzite and hard sandstone, that overlie the Morgan, the base being that of the lowest bed that can be called quartzite. Were it not that the name has been established in local usage, the name Oquirrh,

\footnotetext{
4 King, Clarence, Paleozoic subdivisions on the fortieth parallel : Am. Jour. Sci., 3d. ser., vol. 11, pp. $477-479,1876$.

${ }^{45} A$ dagger $(t)$ preceding a geologic name indicates that the name has been abandoned or rejected for use in classiflcation in publications of the U. S. Geological Survey. Quotation marks, formerly used to indicate abandoned or rejected names, are now used only in the ordinary sense.
}

used by Gilluly ${ }^{46}$ in the Ophir district for the general equivalent of the Weber, might seem more appropriate, since the formation here, as well as there, contains a large proportion of limestone.

\section{OCCURRENCE AND THICKNESS}

The Weber quartzite in this area occurs in three tracts. The smallest lies in the southeast corner of the Cottonwood quadrangle. The most northerly, a virtually continuous strip, extends northwestward along the north side of the valley of Big Cottonwood Creek and is cut off at the southeast by the Alta stock of granodiorite. It comes to the surface along the southwest side of the Silver Fork fault, but because of its higher position its area of exposure is divided into two parts by the canyon of Days Fork, northwest of which it would extend to the boundary of the quadrangle were it not interrupted by the great moraine of Mill D South Fork.

The exposures of the Weber quartzite in this region are only fairly good, because the quartzite and sandstone of the formation are so closely jointed that they rarely stand up in thick ledges. The best exposures are not within the map area but a little farther northwest. One of the most striking features in the view westward from the middle valley of Cottonwood Creek is a peak on the north side of the lower canyon of the stream, not high compared with those across the canyon from it, but dominating the rounded crests nearby. The summit of this peak consists of Weber quartzite. The peak is readily reached by ascending the slope from a point near the 19-mile post on the road in the canyon, and the route to the top leads across the strike of one of the most compact and comprehensive sections in the region. Strata that range from pre-Cambrian to a horizon well up in the Weber are exposed here, although the Cambrian limestones are not well represented, being reduced in thickness to a few feet by the erosion that produced the unconformity at the base of the Jefferson (?) dolomite. The Weber quartzite is well exposed in this section, which displays a large part of the formation, free from the quartzitic talus that mantles it in most other places.

Within the mapped area the section that shows the greatest part of the formation in fairly continuous outcrops is to be found on the steep south end of the spur west of Mule Hollow. Here talus covers the base of the formation but probably overlaps it only a little.

The thickness of the Weber is given by Boutwell as 1,350 feet, and that figure cannot be far from correct. Not more than 1,200 feet could actually be measured in the section west of Mule Hollow, which is about the best in the area, but a rough estimate as to how much is concealed under the talus brings the greatest possible thickness up to a round figure of 1,500 feet. (See section $B-B^{\prime}$, pl. 4.)

\footnotetext{
${ }^{6}$ Gilluly, James, op. cit., p. 34
} 
CHARAGTER

The Weber quartzite is far from being so dominantly composed of quartzite as the Tintic. It contains, near the top and middle, some beds of nearly white, very hard quartzite, with rusty pits on the weathered surface, such as forms the top of the 9,243-foot hill west of Beartrap Creek. The most abundant rock in the formation, however, is a uniformly fine-grained quartzite or quartzitic sandstone, which has on the weathered surface a very characteristic pale grayish brown color. Unweathered fragments from underground are pale gray without any tinge of brown. This rock breaks down into small sharp-cornered joint blocks, which readily creep downhill for long distances, covering up the less resistant rocks in the formation. The quartzitic beds, moreover, naturally form the highest summits. Casual observation therefore gives an exaggerated idea of the proportion of quartzite in the formation, hardly more than half of which, in this area consists of quartzite, even if the term be construed somewhat liberally.

The formation contains much limestone that is bluegray, calcitic, and fairly pure except that it contains irregular lumps of black chert. Between such limestone and the purest quartzite there is every gradation. Some of the limestone is both cherty and sandy, with the weathered surface showing wavy or cross-bedded lamination. Chert is abundant even in rock that might be called either sandy limestone or calcareous sandstone. The sandstone beds may be calcareous in any degree, and a large part of the formation might be classed as very slightly calcareous quartzitic sandstone.

A rough section of the part of the Weber, measured downward from the brow of the steep slope northwest of the mouth of Mule Hollow, follows:

Partial section of Weber quartzite near Mule Hollow

Quartzite, fairly pure

Quartzite mixed with sandy and cherty limestone; poorly preserved fossils

Limestone, blue-gray, about half chert, which is black where fresh but weathers gray.--_-

Quartzite, light brownish-gray, almost continuously exposed; one thin calcareous bed

Quartzite, gray, platy

Limestone, drab, buff-weathering, containing some fine sand and a good deal of brownish-gray chert._.....................

Limestone, blue, with abundant black chert

Quartzite, fine-grained, light. gray, weathering to light brown

Unexposed; float quartzite and bluish limestone with black chert _-_- 140

Limestone, laminated, siliceous, with chert

Quartzite, hard, white

Sandstone, gray to white, weathering pale brownish, with calcareous and cherty streaks; about 100 feet from base is a 6-foot bed of limestone with sandy laminae and long pods of chert

\section{PARK ,CITY FORMATION}

OCCURRENCE

The Park City formation was so named by Boutwell for the Park City district, where it is the host rock for: many of the largest ore deposits. In the CottonwoodAmerican Fork area the formation crops out mainly in a belt that extends northwestward from the south base of Scott Hill. There is a single small V-shaped area on the ridge west of Silver Fork, south of Big: Cottonwood Creek; and, just outside the area, the slope northwest of Reynolds Flat affords good exposures of the greater part of the formation, which is there brought by the Silver Fork fault into contact with the Madison or Deseret limestone.

The thickness given by Boutwell is 575 feet, that indicated by structure section $B-B^{\prime}$ is somewhat greater.

\section{CHARACHER}

The most obvious characteristic of the Park City formation is its lack of topographic prominence as compared with the more resistant Weber quartzite. Another characteristic, which becomes evident only when the formation is studied in detail, is its heterogeneity. Limestone is the most abundant rock in it, but it contains much sandstone and shale and a little phosphate rock. In walking northeastward across the formation on the spur west of Mule Hollow from the ledge of hard quartzite presumably near the top of the Weber, one finds few exposures for about 300 feet; the float here is mostly light to dark gray limestone, containing much chert, and calcareous sandstone. Vugs are common in both the sandstone and the limestone. A soft gray fossiliferous limestone crops out about 100 feet, stratigraphically, above the base. About 300 to 400 feet above the base is a stratum of sandstone, coarse and fossiliferous in the bottom part and grading upward into quartzite, which forms a bulge in the profile of this spur and those to the northwest. Above this quartzitic bed is the most distinctive layer in the formation-a very dark apparently clastic rock, a large proportion of whose grains are quartz, but which contains many grains of dark brown phosphatic material, having the characteristic pale blue-gray bloom on the weathered surface. The rock has the look of an intraformational conglomerate.

Above this rock, the float indicates a bed of black shale associated with some black chert and a very little red shale. Beyond this the rocks appear to be mainly shale that weathers yellow, and is not exposed, but a ledge of sandstone and limestone and another of limestone project from the slope below the point where the homogeneous red Woodside shale supplies most of the float.

The section northwest of Reynolds Flat, which was not measured in detail, shows similar rocks with the addition of some pink to purplish limestone and shale near the top. Brown sandstone that may be phosphatic was noted near the middle. 
Below is a detailed section of the Park City formation as measured by Boutwell in Big Cottonwood Canyon, the locality not being indicated more specifically. The phosphate may be the 8 -foot bed described as fine calcareous sandstone.

Type section of Park City formation in Big Cottonwood Canyon

Grayish-white limestone, with fine gray and white cherts increasing toward bottom

Shale and fine buff sandstone.

Dark-gray limestone; thin chert, red shale, and porous loose member at base.

Sandy shale.

Yellowish-gray quartzitic sandstone changing into cherty white limestone below

Gruy and white banded chert with a few white-sandstone intercalations

Fine calcareous sandstone, with lentils of chert and brecciated fragments of sandstone.

Float of buff sandstone and shale, becoming more shaly and calcareous at base

Siliceous arkose comprising mainly rounded quartz grains and feldspars cemented with ferruginous material

Coinpact grayish quartzite

White compact sugary sandstone, fossiliferous at base

Fine gray and pink massive quartzite with brown sandstones and gray-white chert bands near base

Light-gray limestone weathering whitish gray with an imbricated pattern; fine gray limestone near base carries good faunas at two horizons in particular, 20 and 55 feet above the base.

Gray calcareous sandstone-_.-_-_-_-_-_-_-_-_-_-_-_

Fine gray limestone

Float showing bits of grayish and brown calcareous sandstone

Sandy limestone, more calcareous at base, with cavernous weathered surface.

Float; upper sandy beds at top of Weber quartzite

AGE AND RELATTONS

At the time of the publication of the Park City report (1912) the formation was assigned to the Permian. Since that time it has received especially intensive study, because it is the phosphate-bearing formation of Utah, Idaho, Wyoming, and Montana. Mansfield ${ }^{47}$ makes the following statement regarding its age:

The Phosphoria formation, as previonsly stated, is the equivalent of the upper two members of the Park City formation, as described in earlier reports on parts of the district. 'The Park City formation was at first referred by Boutwell to the Pennsylvanian, but in his later work he referred it as a whole donbtfully to the Permian. The lower part, which at Park City contains the well-known ore deposits, is now referred by G. H. Girty on faunal evidence to the Pennsylvanian, whereas the upper part, which corresponds to the Phosphoria formation, is regarded as Permian.

The United States Geological Survey now classifies the Park City formation as Pennsylvanian and Permian.

47 Mansfeld, G. R., Geography, geology, ind mineral resources of parts of southern Idaho: U. S. Geol. Survey Prof. Paper 152, p. 78, 1927.
Although, as pointed out on page 22, Blackwelder found evidence farther north that the Park City rests on an eroded surface of Weber and older rocks, no unconformity at its base has been recognized in the area here described.

\section{TRIASSIC SYSTEM \\ WOODSIDE SHALE}

OCCURRENCE

The Woodside shale, named by Boutwell after Woodside Gulch, in the Park City district, is the country rock of the hills immediately adjacent to Park City. In the Cottonwood quadrangle it forms a belt, of nearly uniform width, extending northwestward from the south slope of Scott Hill, and a single small triangular area, bounded on one side by a fault, west of Silver Fork. In both areas it is rather poorly exposed. Its thickness is given by Boutwell as 1,090 feet, which agrees closely with that shown in section $B-B^{\prime}$, plate 4 .

\section{CHARACTTIR}

To judge from the rather poor exposures of the Woodside shale found in the Cottonwood quadrangle, the formation is the most homogeneous in the entire stratigraphic column. It consists predominantly of finegrained dark purplish red shale. The rock is very fissile, and for that reason abundant lustrous flaky fragments of it have been washed down the gulch that flows northward from the area west of Silver Fault; in Beartrap Gulch, also, much of it has slidden down over older rocks.

Some of the Woodside shale in and near Bear Gulch, mostly near the base of the formation, is olive-green, probably as a result of alteration. Little of the shale is distinctly sandy, and only a few thin layers approach saindstone in character. Boutwell notes color variations to buff, brown, and gray. East of the head of Willow Creek the Woodside shale is metamorphosed, being duller and more purplish than usual, and in places dark green; and some joint faces are encrusted with epidote and specularite.

No fossils have been found in the Woodside shale. On the basis of lithology Boutwell regarded it as Lower Triassic, which is the age of the overlying Thaynes formation, and this age designation has been accepted for the present by the United States Geological Survey. The Woodside is apparently conformable with both the Park City and the Thaynes formations.

\section{THAYNES FORMATION \\ OCCURRENCE}

The Thaynes formation, was named by Boutwell for Thaynes Canyon, west of Park City. Like the lower Mesozoic formations, it occupies a broad belt across the northeast corner of the Cottonwood-American Fork area. Scott Hill is in the midd̀le of this belt. The formation occurs nowhere else in the area mapped, but a 
cliff of it is conspicuous just outside the area, north of Reynolds Flat, where it is brought down against Mississippian limestones by the Silver Fork fault.

The thickness given by Boutwell is 1,180 feet; that indicated by section $B-B^{\prime}$ is about 1,000 feet, but a little steepening of the dip would lessen the discrepancy.

\section{CHARACTER}

The Thaynes formation presents a strong contrast to the prevailingly red and shaly formations immediately below and above it. Its outstanding characteristic in most outcrops is a broad banding in light gray and brown. The most abundant rocks of the formation are fine-grained highly calcareous sandstones or sandy limestones, deeply stairied with a brown pigment whose hue indicates that it is largely manganese oxide. Olive green and other shale also is abundant and is stained, though less deeply, with this same brown color. The contrasting light-colored layers are of relatively pure, unstained, blue-gray limestone, which is commonly fossiliferous. The cliff mentioned above consists of some of the lower beds of the formation, the outcrops of which in general are on rather gentle slopes.

The formation contains beds of red shale, the lowest and thickest layer that contains much red shale, about 500 feet from the base, being called by Boutwell the "mid-red." Boutwell characterizes the part above this bed as more calcareous than that below; another difference lies in the more markedly heterogeneous character of the upper part; the shales there are more fissile than in the lower part, so that the beds of sandstone and limestone stand out as reefs.

A detailed section made by Boutwell in Big Cottonwood Canyon follows.

\section{Section of Thaynes formation north of Cottonwood Creek}

Sandstone, massive, even, fine-grained, basal member of Ankareh shale

Limestone, blue, locally sandy, fossiliferous______-_-_-_ 10

Shale, fine, gray green

Limestone, blue-gray, cavernous, fossiliferous

Limestone, transition from shale through sandstone, fossiliferous

Sandstone, gray-brown, with calcareous shale intercalated, fossiliferous

Shale, maroon, fine-banded

Limestone, gray, impure, semicrystalline, fossiliferous

Limestone, light gray-blue, massive, sandy, fossiliferous_- 240

Shale, gray-brown-_-_-_._-_- 160

Linestone, impure, gray, massive, fossiliferous____...-.- 50

Shale, gray to buff-_-_-__-_-_- 40

Sandstone, massive, gray-brown; vertical sheeting; fossiliferous.

Shale and sandstone, green to brown; calcareous intercalations

Sandstone, gray, finely laminated; chert lenses

Shale

Limestone, fine, blue, with intercalated ripple-marked sandstones, lenticular gray cherts, and biotitic fossilbearing bed.

Shale, olive-green
Section of Thaynes formation north of Cottonwood Creek-Con.

Sandstone, olive-gray, massive; weathers rusty; trails, fucoids, and imprints__-_._._._._. 40

Limestone, bluish ; matrix enclosing "tangle" stringers of

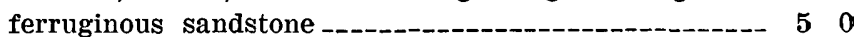

Limestone, impure, blue, very fossiliferous__-_-_-_-_-_._ $4 \quad 0$

Shale, olive-green, fine-grained______-______._-_-_-_ 190

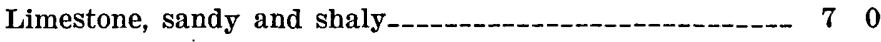

Limestone, blue to gray; spheroidal weathering; fossil-

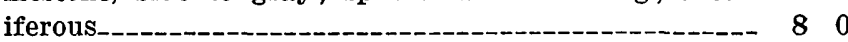

Debris, limestone with intercalated shale

Limestone, dark blue, locally shaly; weathers rough;

several highly fossiliferous layers_-_-_-_-_-_-_-_-- 140

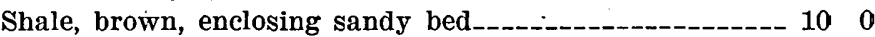

Limestone, gray-blue; gray chert lenses; fossiliferous_--- 59

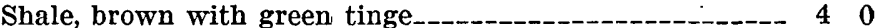

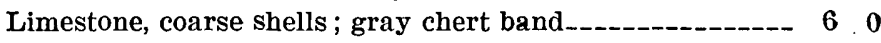

Limestone, dark blue, sandy, massive._-___-__-__-_-_ 140

Limestone, dark blue; weathers rusty ; fossiliferous_...-. 350

Sandstone, calcareous, rusty; breaks in slabs_-_-_-_-_--- 110

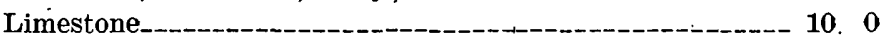

Sandstone, gray-black, shaly, with bands of black slaty shale; fossiliferous_-_-_-_-_-_-_-_ 660

Sandstone, calcareous; finely laminated, highly fossiliferous -

Shale, maroon

Float, varicolored shale_________-_ $30 \quad 0$

Shale, green, buff, olive-green, maroon, yellow (Last three beds together called the "mid-red" by Boutwell.)

Sandstone, gray, calcareous; intercalated shales_--_----- 340

Limestone, gray ; intercalated gray calcareous sandstone_- 50

Sandstone, greenish brown; intercalated shales__._-_._- 140

Limestone, gray-blue, fossiliferous____-____-_-_-_-_-_ 40

Shale, olive-green, with three fossiliferous argillaceous limestones

$\begin{array}{ll}17 & 0\end{array}$

Limestone________._- 50

Limestone, blue; shale, olive-brown; sandstone, calcareous; alternating series, varying much in color and texture; fossiliferous _..-- $370 \quad 0$

Talus, containing shale regarded as top of Woodside shale.

On and near Scott Hill the formation is metamorphosed and for the most part light in color, without the usual brown coloring.

\section{AGE}

On the basis of fossil evidence in this and neighboring areas Boutwell ${ }^{48}$ assigned the Thaynes formation to the Lower Triassic, which is the present age designation accepted by the United States Geological Survey.

\section{ANKAREH SHALE}

\section{OCCURRENCE}

The Ankareh shale is named for Ankareh Ridge, which extends northeastward into the Park City district from the knob north of Scott Hill. The ridge itself was so named by Boutwell with the ulterior motive of supplying an appropriate formation name: "Ankareh" is the Ute word for red, and a red color is the most conspicuous feature of this formation. In the Cottonwood quad-

48 Boutwell, J. M., Geology and ore deposits of the Park City district Utah: U. S. Geol. Survey Prof. Paper 77, p. 57, 1912. 
rangle the Ankareh shale occupies a small area on the eastern boundary and a rather large one farther to the northwest.

The thickness of the formation as given by Boutwell is 1,150 feet: but a considerably greater thickness in indicated in Section $B-B^{\prime}$. A small part of the difference may be due to a different placing of the boundaries. A part of the beds may here be duplicated by a small unmapped thrust fault; but it seems equally possible that the thickness was diminished by faulting in the section measured by Boutwell, and that the formation is at least 1,500 feet thick.

\section{CHARAOTIER}

The formation consists mainly of red shale, with colors that, on the whole, are much brighter than those in the Woodside, ranging from dark purple to the most brilliant semblance of a vermillion hue that iron oxide can give. Much of the shale is sandy, and it grades at many places into purple, terra-cotta, or white sandstone. Near the middle of the formation is a bed of hard quartzite, about 75 feet thick, which forms a prominent ledge traceable throughout the area. The quartzite is mostly white but is mottled and streaked with purple. Most of it is coarse-grained, and some of it is pebbly, with well rounded pebbles of quartz up to $11 / 2$ inches in diameter. The shale is also interbedded in places with gray limestone, some of it tinged or mottled with red or purple. There are also a few beds of intraformational limestone conglomerate.

Some of the sandstone is cross-bedded; many beds of shale and sandstone show ripple marks, mud-cracks, rain-drop imprints, or mud-flake breccias; and in places a few moulds of salt crystals appeared to be present.

A partial section roughly measured in the basin at the head of Willow Creek will help to illustrate the character of the formation.

Partial section of Ankareh shale, head of Willow Creek

Sandstone, purple Feet

Shale, red to purple, sandy in part

Limestone, gray, tinged with purple

Red shale, more or less sandy

Limestone conglomerate, brick-red mottled impure limestone, and purplish-gray limestone with red seams; grades into bed below

Shale, nearly all bright red to purplish red, but with some gray layers and patches; some sandy layers, most abundant in upper part. Mud-cracks and ripple marks. A few inches of limestone conglomerate near top.

Sandstone, pale terra-cotta, cross-bedded, fine-grained, moderately hard, very homogeneous.

The upper and lower limits of the formation are determined by lithologic changes that are fairly marked, although there appears to be some gradation into both the adjoining formations. As mapped in plate 3 , the lower part of the Ankareh contains some red shale that is interbedded with rocks like those characteristic of the Thaynes, the base might therefore be placed a little higher and may have been so placed by Boutwell. Toward the top, on the other hand, gradation to the Nugget is suggested by an increase in the proportion of sandstone.

From rather meager fossil evidence Boutwell assigned the Ankareh shale to the Lower Triassic, but he recognized that the upper part might not be of that age. Since Boutwell's report was published, doubt has arisen regarding the Triassic age of the Ankareh, and it is at present classified by the United States Geological Survey as Triassic (?).

\section{JURASSIC SYSTEM}

NUGGET SANDSTONE

Nugget as a formation name was first used by A. C. Veatch, who took it from Nugget Station,Wyoming. As originally defined, the formation included a white sandstone and underlying red shales. Boutwell in the Park City report restricted the term to a sequence dominantly composed of light-colored sandstone, though interbedded with some shale which he named Ankareh, making a separate formation of the great underlying body of red shale. This usage has been followed by other authors.

The Nugget formation as mapped in this area consists of a few hundred feet of very homogenous pale terracotta sandstone, which is strongly cross-bedded, with little or no interbedded shale. This thick body of sandstone is underlain by about 20 feet of red shale, and that by a bed of sandstone some 50 feet thick, mostly of a maroon color but in part similar to the Nugget, which forms the crest of the ridge where it crosses the northern boundary of the mapped area. It is possible that this 50 -foot bed of sandstone was included in the Nugget by Boutwell, but in default of evidence as to the location of the Triassic-Jurassic boundary-which should logically be the base of the Nugget-the boundary was drawn at the horizon where the sharpest lithologic change takes place.

The Nugget beds are not fossiliferous in this area, but not far to the north they are overlain by limestone containing Jurassic fossils; they have therefore been assigned to the Jurassic.

\section{IGNEOUS ROCKS}

The igneous rocks of the Cottonwood-American Fork area are all intrusive, the nearest exposures of volcanic rocks being several miles away, in the Park City district. The great bulk of the intrusives are plutonic rocks, occurring in large irregular bodies of unknown but presumably great depth and having a granular texture. The area also contains many dikes, which range in composition from alaskite to lamprophyre but are mostly porphyries related to the stocks.

\section{PLUTONIC ROCKS}

The plutonic rocks of the area occur in three large masses, each consisting in the main of a rock that is 
definitely though not greatly different from that in the other two. These masses are alined in a nearly east-west direction, roughly with the Uinta crest and with the intrusive masses in the Oquirrh Mountains. They decrease in size, in coarseness of grain, and in percentage of silica from west to east. The westernmost body is the Little Cottonwood stock, consisting of siliceous granodiorite and quartz monzonite. Only the eastern margin of this stock overlaps the mapped area, but it extends westward with generally broadening outcrop to the west base of the range, where it is about 4 miles wide from north to south. At the surface this body is separated by an interval of about 2 miles from the Alta stock, consisting of typical granodiorite. The easternmost large intrusive body, called the Clayton Peak stock, is diorite. This stock is in contact with the Alta stock for a long distance. When Professional Paper 111 was written it had not been proved that the two are of different age and they were provisionally designated as parts of a single mass, which was called the Alta-Clayton Peak stock, but it has now been shown that the Alta stock is later than the Clayton Peak stock.

The relation of the Little Cottonwood stock to the others is not shown by any direct evidence that has been observed. Ordinarily, however, where several intrusive masses so closely related as these occur in contact with one another the least silicic mass was intrucled first and was followed by the others in order of increasing silicity. Presumably, therefore, the Little Cottonwood stock is the youngest of the three.

\section{DIORITE (CLAYTON PEAK STOCK)}

GENERAL CHARACTER AND OCCURRENCE

The diorite of the Clayton Peak stock was first described by Boutwell and Woosley in the Park City report. The peak for which it is named is the highest summit in the Park City district. It is on the boundary between Salt Lake and Wasatch Counties and is a short distance east of the area mapped, but it overlooks the basin at the head of Big Cottonwood Creek. This diorite is a dark-gray, rather fine-textured granular rock (pl. 15, B), which contains little quartz but so large a proportion of orthoclase as to verge on monzonite; its dark silicate minerals are biotite, hornblende, and augite, accompanied at least in places by hypersthene. The rock mapped as diorite on the Park City map includes a small area of the porphyroid granodiorite described on page 37 of the present report and mapped on plate 3 as part of the Alta stock.

The principal area of the diorite is the one that includes Clayton Peak. Most of it lies in the Park City district; the portion in the Cottonwood quadrangle occupies the southeastern part of the basin at the head of Big Cottonwood Creek and extends southward into the basin of Snake Creek. A smaller area lies on Snake Creek near the Steamboat mine, and another, separated from the main mass by granodiorite, is crossed by the canyon that drains Lake Solitude, west of Silver Lake.

The diorite is not so well exposed as the granodiorite of the Alta stock, but extensive outcrops and fresh talus are accessible in the head of the Silver Lake basin and on the spur east of Solitude Fork.

The diorite in its largest area is in contact with the granodiorite of the Alta stock for about 2 miles, but the contact is almost wholly concealed by soil and glacial deposits. Only at one locality, near the Big Cottonwood mine, and for a distance of only a few yards, has the relation between the two rocks been clearly perceived (pl. 16, A). The contact at this place is described on page 35 , in connection with the granodiorite.

\section{PETROGRAPHIC DETAILS}

The appearance of the diorite almost throughout its larger areas is remarkably uniform. It has a dark bluegray color and a rather fine granitic texture, the grains, for the most part, being not over 1 millimeter in diameter. The plagioclase feldspar, which is the chief constituent, is gray and fresh-looking. Orthoclase is variable in quantity; where most abundant it forms rather large ragged individuals enclosing all the other constituents. Quartz, though everywhere present, is inconspicuous. Of the dark minerals, biotite is the most conspicuous because of its bright cleavage faces, the diameters of which are generally about 1 millimeter or less. The other dark mineral grains have a prismatic cleavage that suggests hornblende but are rather dull in luster; most of them, when seen under the microscope, prove to be intergrowths of hornblende with pyroxene.

The microscope reveals considerable minor variation among specimens that all show the characteristic traits of the diorite. The average mineral constitution of the mass, as indicated by the available material, may be stated in general terms as follows: The most abundant mineral is andesine, of average composition about $\mathrm{An}_{40},{ }^{49}$ which is more or less distinctly zoned, the anorthite percentage of the main, inner part being commonly 45 or more and that of the rim about 25 . The constituent second in average abundance is orthoclase, which encloses.crystals of all the other minerals except quartz or fills the spaces between them. A little less abundant than orthoclase and nearly equal to each other in quantity are quartz and biotite; hornblende and pyroxene together are present in about the same quantity as biotite. The chief pyroxene is a pale-greenish augite, but hypersthene also was identified in one specimen and probably is represented by secondary minerals in others. As

40 The composition of the plagioclase feldspars is expressed in this report by terms analogous to " $A n_{20}$ ", which means $A b_{80} A n_{20}$. The specific names, when used, have the following significations: Albite, $A n_{0 \_} 10$; oligoclase, $\mathrm{An}_{10 \_30}$; andesine, $\mathrm{An}_{30_{-} 50}$; labradorite, $\mathrm{An}_{50 \_} \mathrm{i0}$; bytownite, $\mathrm{An}$ 70_80; anorthite, $\mathrm{An}_{90 \_100}$. 
accessory minerals, magnetite and apatite are fairly abundant; titanite is less so but is present in every slide; allanite and zircon occur sporadically.

The principal variations are shown by the plagioclase, orthoclase, hornblende, and pyroxene. The plagioclase in some specimens is more calcic than that described; the cores of some crystals contain calcic labradorite $\left(A n_{05}\right)$ and consist largely of sodic labradorite $\left(A n_{50-05}\right)$. Orthoclase in some specimens is almost as abundant as plagioclase and forms crystal individuals as much as 4 millimeters in diameter.

The relative quantity of hornblende and pyroxene varies widely. Hornblende and augite bear a complementary relation to each other, the one being abundant where the other is scarce; either may be distinctly predominant, but augite is perhaps the more abundant on the whole. The two minerals mostly occur in parallel intergrowths, with the hornblende enclosing the augite. Hypersthene, with characteristic pleochroism in pale red and green, occurs in one remarkably fresh specimen taken on the crest between Cottonwood and Snake Creeks. It has begun to alter, along fine cracks and on the margins, to a green, finely fibrous mineral, apparently an amphibole. As the augite of this and other specimens does not seem to have been replaced in the same way, the aggregates of fibrous amphibole occurring in most of the other slides may be alteration products of hypersthene. The alteration process was probably a deep-seated one effected by magmatic fluids. In other specimens similar agencies may have been the cause of partial chloritization of the biotite, which is associated with sericite and pyrite and encloses much titanite that also is probably secondary.

A textural variation is shown in a specimen obtained from near the Steamboat mine; which is finer-grained than the typical rock and is obscurely porphyritic, though the phenocrysts are not much larger than the crystals in the groundmass.

\section{GRANODIORITE (ALTA STOCK)}

GENERAL OHARACTER AND OCCURRENCE

The main area of the Clayton Peak stock of diorite is adjoined on the northwest by a smaller stock of granodiorite, close to the west end of which is the town of Alta. The rock consists essentially of plagioclase, quartz, orthoclase, biotite, and hornblende. It is lightercolored, coarser, and more siliceous than the diorite of the Clayton Peak stock, from which it differs mainly in containing more quartz and no pyroxene.

The area of outcrop of the granodiorite is about 3 miles long and about $11 / 4$ miles wide in its widest part. It lies almost wholly within the Cottonwood quadrangle, although the northeastern part of its area as mapped extends for half a mile into the Park City district, where it was not distinguished on the map, though it was recognized as distinct in character from the diorite of the Clayton Peak stock. ${ }^{50}$ The rock is more resistant to erosion than most of the others in the district, and it forms a rugged group of peaks at the head of Big Cattonwood Creek, the highest of which is Mount Wolverine. The most accessible good exposures of the rock are on the glaciated spur northeast of the Albion tunnel, and the dump of a prospect there contains comparatively fresh rock. Good exposures at the head of Big Cottonwood Creek are easily reached from Silver Lake. Typical granodiorite of the Alta stock forms part of the dump of one of the caved adits of the Steamboat mine, though its nearest outcrop on the surface is across the ridge to the north, about three-quarters of a mile away.

\section{RELATIONS}

The granodiorite is intrusive into all the pre-Quaternary rocks with which it is in contact. In its extension from southwest to northeast it cuts across all the strata from the upper part of the pre-Cambrian to the lower part of the Triassic, and all these strata are strongly metamorphosed in a zone roughly parallel to the contact by the action of the granodiorite magma and its emanations. The bold outcrops of the Cambrian quartzite and the overlying indurated shale east and southeast of Alta contain many small dikes of granodiorite or granodiorite porphyry, a few of which can be traced to a connection with the main body. A larger dike than any of these can be traced from the main body eastward across the southern part of the Honeycomb Cliffs. It is virtually certain that many other dikes of granodiorite porphyry, the most striking group of which occurs south of Alta, likewise branch out from the main mass, though the junction of most of them with the stock is invisible.

The relation of the granodiorite to the Clayton Peak stock of diorite has been observed in only one place, a few rods northeast of the Big Cottonwood mine, at the head of Big Cottonwood Creek. A glaciated outcrop here shows several angular masses of the diorite (pl. 16, A), normal and fairly uniform in character, surrounded by streaky rock that is largely pegmatitic, especially for a few inches from the immediate contact. The streaky rock, which is obviously younger than the diorite, grades into typical granodiorite.

\section{STRUCTURE}

Figure 2, prepared by F. F. Grout, ${ }^{51}$ shows foliation structure and linear and dike structure in the Alta stock. Dr. Grout considers the structures to indicate an up-tothe-east movement of the magma at a moderate to low angle.

\section{PETROGRAPHIC DETAILS}

The granodiorite as mapped has, apart from local variations mostly related to contacts, two principal

${ }^{50}$ Boutwell, J. M., and Woolsey, L. H., Geology and ore deposits of the Park City district, Utah: U. S. Geol. Survey, Prof. Paper 77, p. 79, 1912.

${ }^{51}$ Personal communication. 
facies-a dominant one of granitic texture, which forms most of the mass, and minor facies of obscurely porphyritic texture, which occurs chiefly in the northeastern
Peak stock, and a medium-grained granitic texture, the grains being for the most part about 2 or 3 millimeters in average diameter (pl. 17, $B$ ). The light minerals,
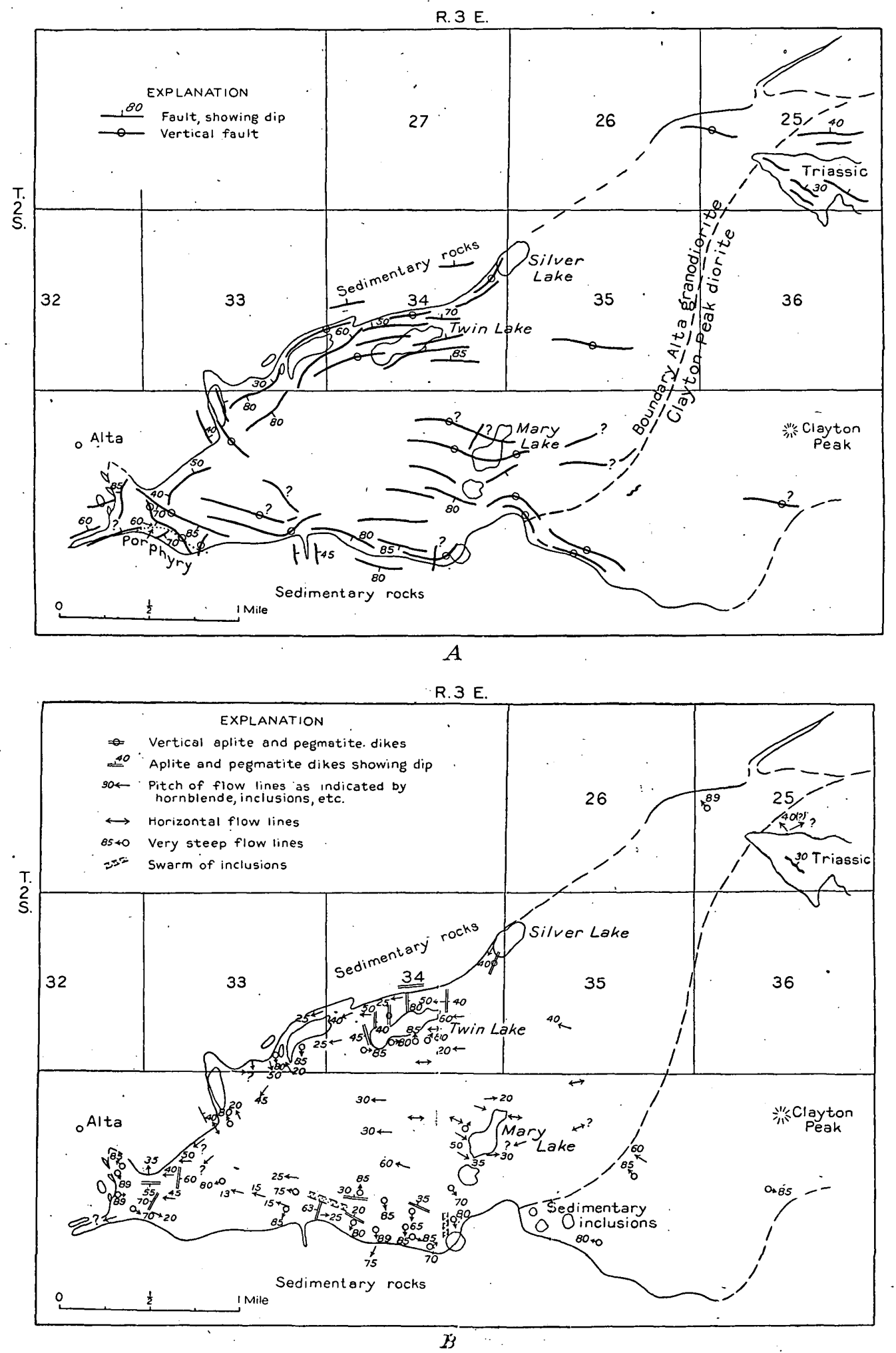

Figure 2.- Structure in Alta stock: $A$, Foliation structure; $B$, Linear and dike structure. After F. F. Grout.

part of the area. The two facies may be of slightly different age, but their contact is not exposed.

The dominant facies has a pale- to medium-gray color, distinctly lighter than that of the diorite of the Clayton taken together, seem about four times as abundant as the dark; they consist mainly of feldspars, with which is mingled a moderate amount of limpid and inconspicuous quartz. Plagioclase predominates over orthoclase, 
though to a widely varying degree; for the orthoclase varies more widely in abundance than any of the other constituents, and it also varies in habit. In some places, where it is definitely subordinate to plagioclase, orthoclase occurs as rather small and inconspicuous grains. In other places, where it is not much less abundant than plagioclase, it forms imperfect crystals of blunt oblong form, some of them over half an inch long, crowded with inclusions near their margins and not conspicuous except on weathered surfaces. In other places where the orthoclase is relatively abundant it has a poikilitic habit-that is, it forms irregular grains through which inclusions of all the other minerals are evenly distributed. Some of these poikilitic grains are as much as an inch in diameter. The essential dark minerals, biotite and hornblende; are present in roughly equal quantity, but the hormblende is the more prominent of the two because it forms the larger and more regular crystals. A few lustrous yellowish-brown crystals of titanite are visible in most specimens.

The microscope shows that orthoclase, as a rule, is second to plagioclase in abundance, that quartz is generally next; and that biotite and hornblende are a little scarcer than quartz and about equal to each other in quantity, though in a few specimens orthoclase is less abundant than quartz. No pyroxene, nor any substance presumably derived from it, is present-a point of sharp distinction from the diorite. As accessories, magnetite, titanite, and apatite are invariably present in moderate quantities, and a little zircon was noted in many specimens.

The plagioclase crystals are somewhat zoned. The main part of each crystal is generally a rather sodic andesine, between $\mathrm{An}_{30}$ and $\mathrm{An}_{40}$; toward the rims the anorthite percentage may dwindle to 15 or less, and in some internal thin zones or patches it may run up to 55 or even 65 . The average composition of the plagioclase is not far from $\mathrm{An}_{35}$, being only a little more sodic than that of the diorite.

The potash felspar of the granodiorite is all orthoclase, slightly perthitic; it is nearly all interstitial to the other minerals, though a few ill-defined phenocrysts of it have been seen. Ragged inclusions of orthoclase, associated with a minor proportion of plagioclase, are abundant in some large, well-formed crystals of hornblende, which also enclose many grains of biotite, magnetite, apatite, and titanite. - This orthoclase probably has replaced hornblende.

The porphyritic facies of the granodiorite occurs chiefly in the area lying northeast of Silver Lake. A typical fresh specimen, gathered on the road from Silver Lake to Thaynes Canyon close to the boundary between the Cottonwood and Park City quadrangles, clearly represents what was distinguished in the text of the Park City report ${ }^{52}$ as a facies of the Clayton Peak diorite

\footnotetext{
${ }^{2}$ Boutwell, J. M., and Woolsey, L. H., op. cit. (Prof. Paper 77),
} p. 79 . but not niàipped separately. The rock, viewed casually; appears very similar to the dominant facies: of the granodiorite. It is a little lighter in color, as the dark minerals are less abundant; their habit, however, is the same as in the rock near Alta. The most distinct difference from the granular facies consists in the texture, and this is not readily seen except on the weathered surface, where the feldspars appear somewhat sharply outlined and roughly cubical in form. Under the microscope the texture is seen to be definitely porphyritic, but it approaches the granular in that the groundmass is relatively coarse and is no greater in bulk than the aggregate of the phenocrysts. The fabric suggests that the magma had gone halfway to crystallizing with granitic texture, had then been abruptly though not greatly cooled, and had finished crystallizing more hastily to a finer texture.

The phenocrysts are seen under the microscope to be chiefly plagioclase (mainly about $A_{35}$ ), but there are many of biotite and of hornblende and a few of quartz; one large phenocryst of orthoclase was seen' in a hand specimen. The groundmass consists mainly of granular orthoclase and quartz, together with some biotite and hornblende and a little plagioclase. The accessory minerals are magnetite, apatite, titanite, and zircon. The character of the plagioclase and of the rock generally confirms the impression that the rock is closely allied to the granodiorite.

A more siliceous porphyry is exposed on the spur northeast of Silver Lake. Orthoclase is abundant among the phenocrysts of this rock as well as in the groundmass, where it occurs in poikilitic grains that enclose quartz and all the other minerals. A similar porphyritic rock is found on the dump of a caved tunnel northwest of Silver Lake. These rocks give the impression of being more allied in composition to the Little Cottonwood stock than to the Alta stock. Although no contact between these rocks and the two commoner facies of the granodiorite was seen, it is possible that they may represent dikes of the Little Cottonwood stock; at any rate the specimens collected illustrate several facies intermediate in character between the typical facies of the two stocks and indicate their close magmatic relationship.

The variations along the contact have not been studied in detail, but a specimen obtained near the portal of the Mountain Lake mine illustrates a common facies. It is about as dark as the diorite of the Clayton Peak stock but coarser. The microscope shows that plagioclase dominates markedly over orthoclase, which is about equaled in quantity by hornblende and by quartz; biotite is a little scarcer than these. Titanite is notably abundant, magnetite and apatite fairly so. The plagioclase crystals consist mainly of $A_{n_{5}}$ but contain some parts as calcic as $\mathrm{An}_{70}$ and some, on the rims, as sodic as $\mathrm{An}_{35}$; they are thus distinctly more calcic than those 
in the normal granodiorite or even those in the diorite, from which, moreover, this rock is distinguished by the absence of pyroxene.

\section{QUARTZ MONZONITE (LITTLE COTTONWOOD STOCK)}

GENERAL CHARACTER AND OCCURRENCE

The Little Cottonwood stock is exposed in the Cottonwood quadrangle along the southern third of its western boundary, the area shown on the map being about 4 square miles, but it extends southwestward to the base of the range in an area that is roughly estimated at 25 square miles and would be much greater were the mass not cut off here by the Wasatch fault. As it is, the outcrop of the mass is more than twice as large as that of the Alta and Clayton Peak stocks together. The relatively coarse texture of the rock may indicate that in volume also the mass is greater than either of the other stocks, but it may indicate, as suggested by Butler on pp. 90-91, that it has been more deeply eroded than the others.

The Little Cottonwood stock has been less thoroughly studied than the Alta and Clayton Peak stocks, and its unity, as the product of a single episode of intrusion, is not completely established. The rock of which it consists varies considerably in texture; some of it, especially that exposed in the lower part of the canyon of Cottonwood Creek, is coarsely and strikingly porphyritic, and some is only obscurely porphyritic (pl. 17, $A$ ) or hardly porphyritic at all. Chemically, to judge from ordinary petrographic study of a few specimens, the mass is fairly homogeneous except for a distinct basifuation for a short distance from the margin.

The quartz monzonite of the Little Cottonwood stock in what seems to be its dominant facies is best exposed, within the region mapped, in the glaciated outcrops along Gad Valley and in the adjacent steep north-facing slopes. The rock forms bold and extensive outcrops in some rugged peaks, especially Lone Peak, on the ridge south of Little Cottonwood Creek and west of the mapped area; good exposures and huge blocks of it abound also in the gorge through which the stream rushes from its upper, broad-bottomed valley to the base of the range; the specimen analyzed chemically (see p. 40) was taken near the upper powerhouse in this gorge. On the north side of Little Cottonwood Creek, not far from its mouth, the building stone used for the Mormon Temple at Salt Lake City was quarried, being broken from talus blocks or glacial boulders or both. A very coarsely porphyritic facies of the rock is exposed in the lower part of the canyon of Cottonwood Creek.

\section{RETATIONS}

The quartz monzonite was described in the report of the Fortieth Parallel Survey ${ }^{53}$ as being older than the sedimentary rocks adjoining it. Doubts were later cast upon this view by Geikie ${ }^{54}$ and Van Hise, ${ }^{55}$, which impressed S. F. Emmons, upon whose early field observa-

\footnotetext{
s King, Clarence: U. S. Geol. Expl. 40th Par. Rept., vol. 1, p. 45, 1878.
}

tions, necessarily hurried, the assignment of the rock to the Archaean was based. Emmons accordingly requested J. M. Boutwell to reexamine the contacts between the granitic rock and the adjoining sedimentary rocks. Boutwell found apophyses and other incontrovertible evidences of an intrusive relation. His observations were published in a paper by Emmons, ${ }^{56}$ who adopted the view that, contrary to his early impression, the granitic mass is intrusive. This view has never since been questioned; to modern eyes, unaffected by the once prevalent belief that any granitic rock was presumably Archaean, the intrusive relation seems obvious enough. The general attitude of the contact is considerably steeper than that of the bedding, as may readily be seen in views from the south (pl. 8), so that the strata in contact with the igneous rock at the base of the slope are considerably older than those along the contact high on the slope. This fact, interpreted by King ${ }^{57}$ as meaning that the siliceous sediments were deposited against a steep mountain side 30,000 feet high, may fairly be taken as evidence of intrusion. More direct evidence of this relation is readily found. The frozen contact between the igneous rock and the sedimentary rocks is exposed at many places; there are large and small inclusions of sedimentary rocks in the igneous rock, and small sheets and dikes of the igneous in the sedimentary rock. The adjacent sedimentary rocks show distinct and characteristic igneous metamorphism for hundreds of feet from the contact.

The contact is abruptly jogged in many places. The offsets roughly follow steep northeastward-striking fissures that are about normal to the general trend of the contact but are not, in general, faults; the fissures appear to be older than the intrusive body, though slight movement may have occurred on some of them later than the intrusion.

PETROGRAPHIC CHARACTER

The dominant facies of the quartz monzonite as exposed in Gad Valley is light gray, and its texture is everywhere porphyritic, though not in general conspicuously so. (See pl. 17; A.) Phenocrysts of potash feldspar are rather thinly scattered through the.rock. Most of them are less than 1 inch long, but some are as much as 2 inches. On freshly fractured surfaces or glaciated outcrops they are not very conspicuous or well defined, for their outer parts are crowded with inclusions and their boundaries are much indented; but on weathered surfaces they stand out in low relief and show rude crystal form. Hornblende and biotite occur sparsely in rather irregular grains.

For some yards from the contact the ferromagnesian minerals are more abundant than in the body of the

54 Geikie, Archibald, On the Archaean rocks of the Wasatch Mountains : Am. Jour, Sci., 3d ser., vol. 19, pp. 363-367, 1880.

55 Van Hise, C. R., Correlation papers-Archaean and Algonkian : U. S. Geol. Survey Bull. 86, pp. 294, 297-298, 1892.

${ }^{50}$ Emmons, S. F., The Little Cottonwood granite body of the Wasatch Mountains : Am. Jour. Sci., 4th ser., vol, 16, pp. 139-147, 1903.

${ }^{57}$ King, Clarence, op. cit., p. 124. 


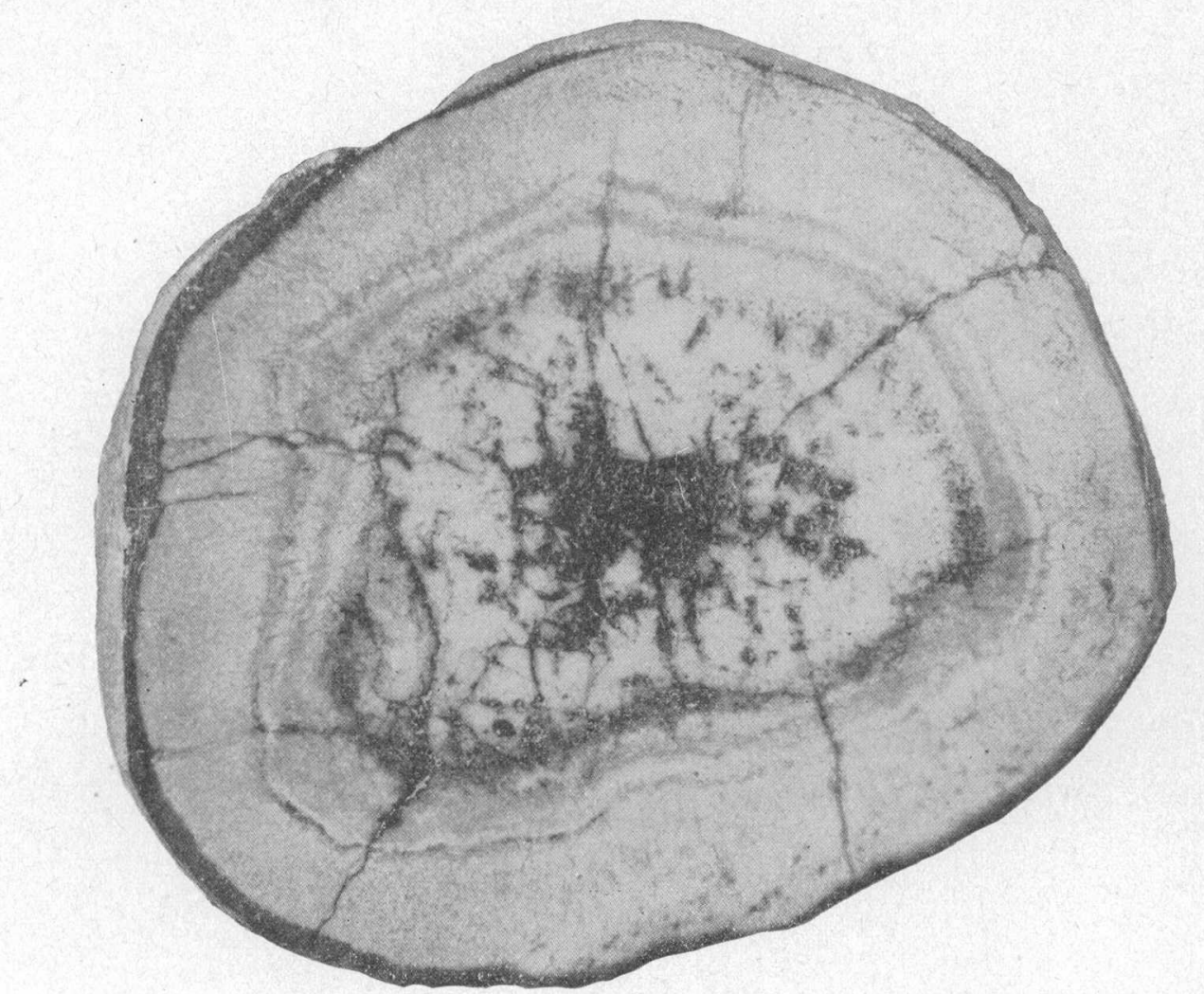

A. METAMORPHOSED NODULE OF CHERT FROM DEsERET LIMESTONE. Contains much tremolite. Natural size.

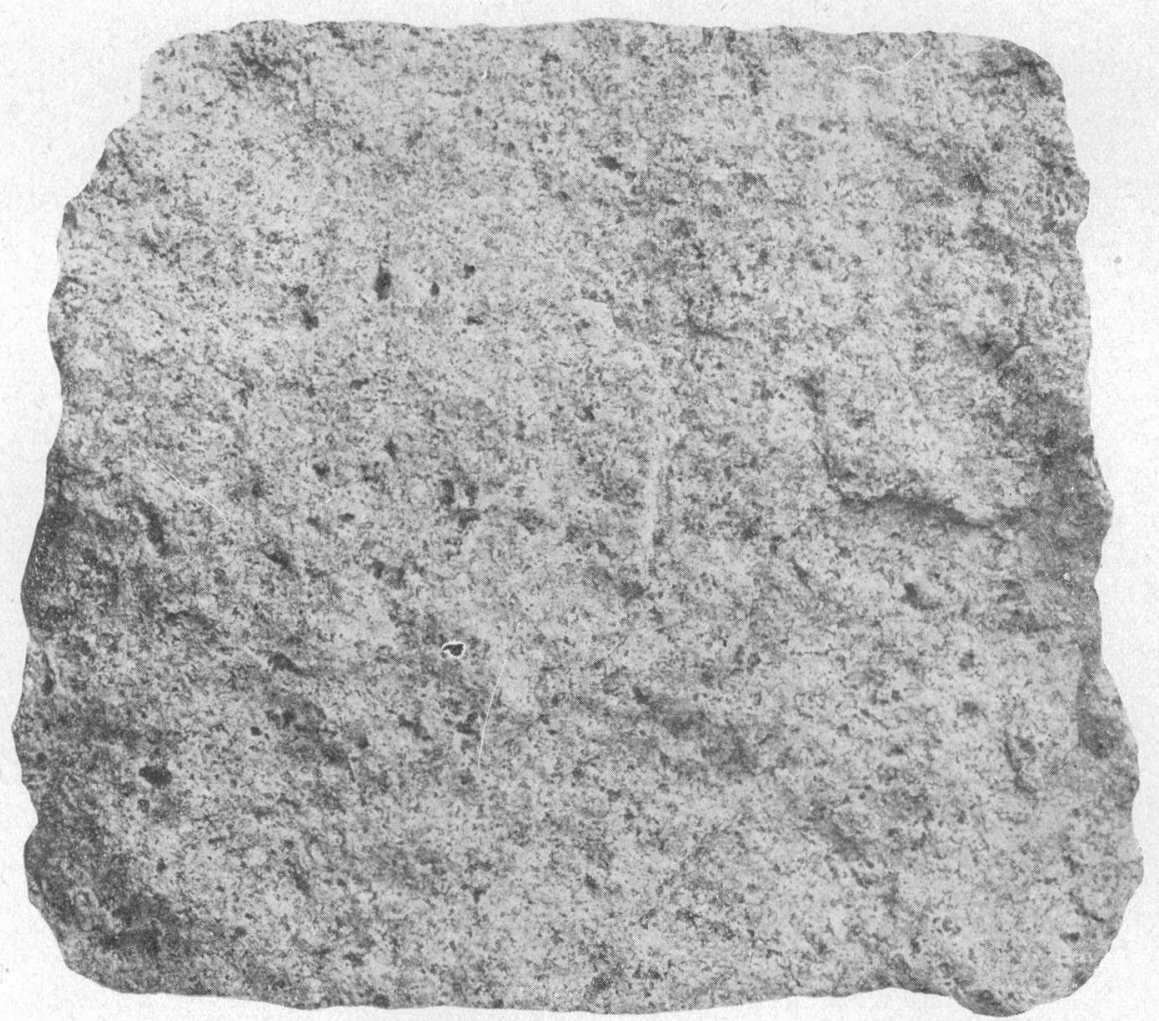

B. QUARTZ DIORITE FROM CLAYTON PEAK STOCK AT HEAD OF BIG COTTONWOOD CREEK.

Pitted appearance is deceptive. Dark specks are mainly hornblende and biotite. Slightly enlarged. 


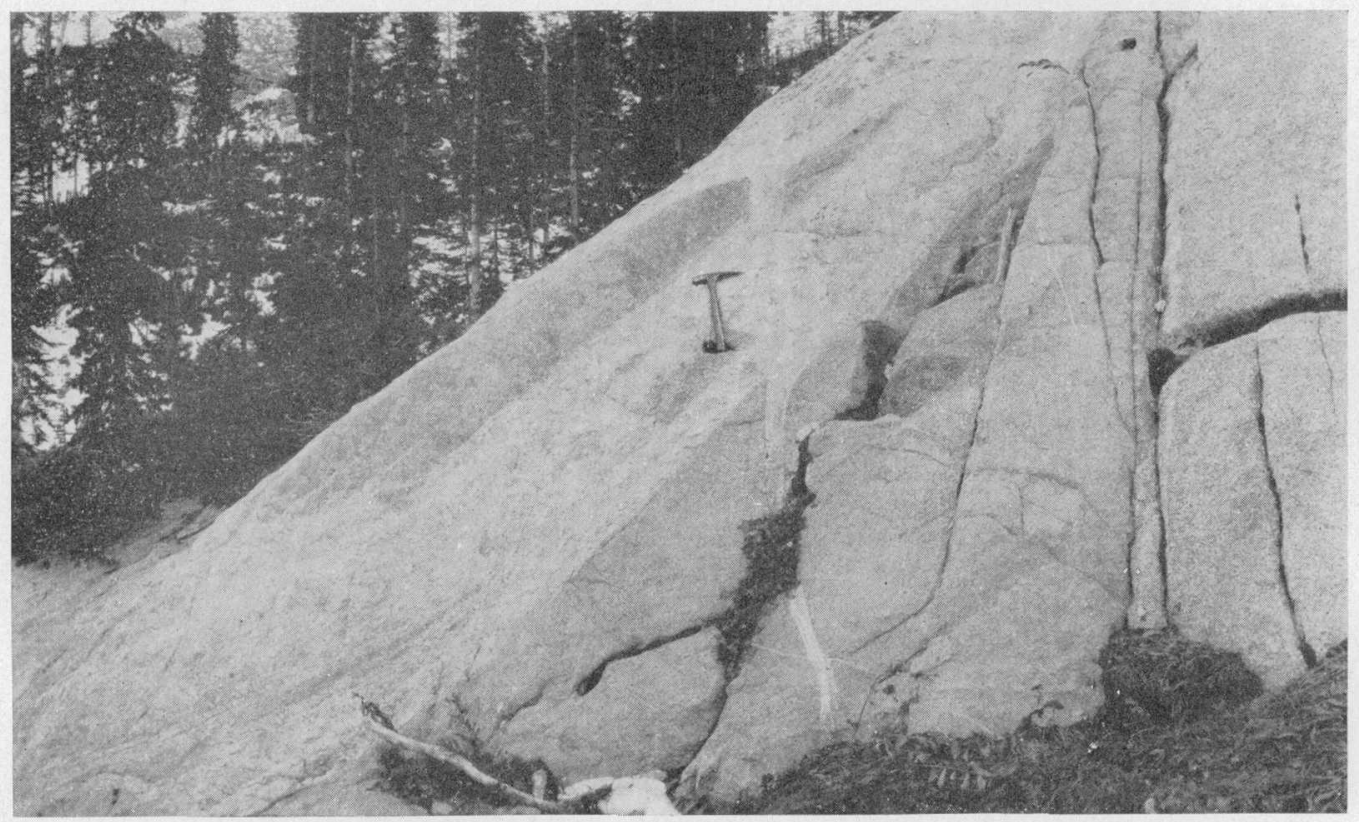

4. CONTACT OF QLARTZ DIORITE (CLAYTON PEAK STOCK) AND GRANODIORITE (ALTA STOCK), NEAR BIG COTTONWOOD MINE, SOUTH OF BRIGHTON.

Shows wedge-shaped mass of diorite in middle, enclosed in lighter-colored granodiorite, which is pegmatitic at left.

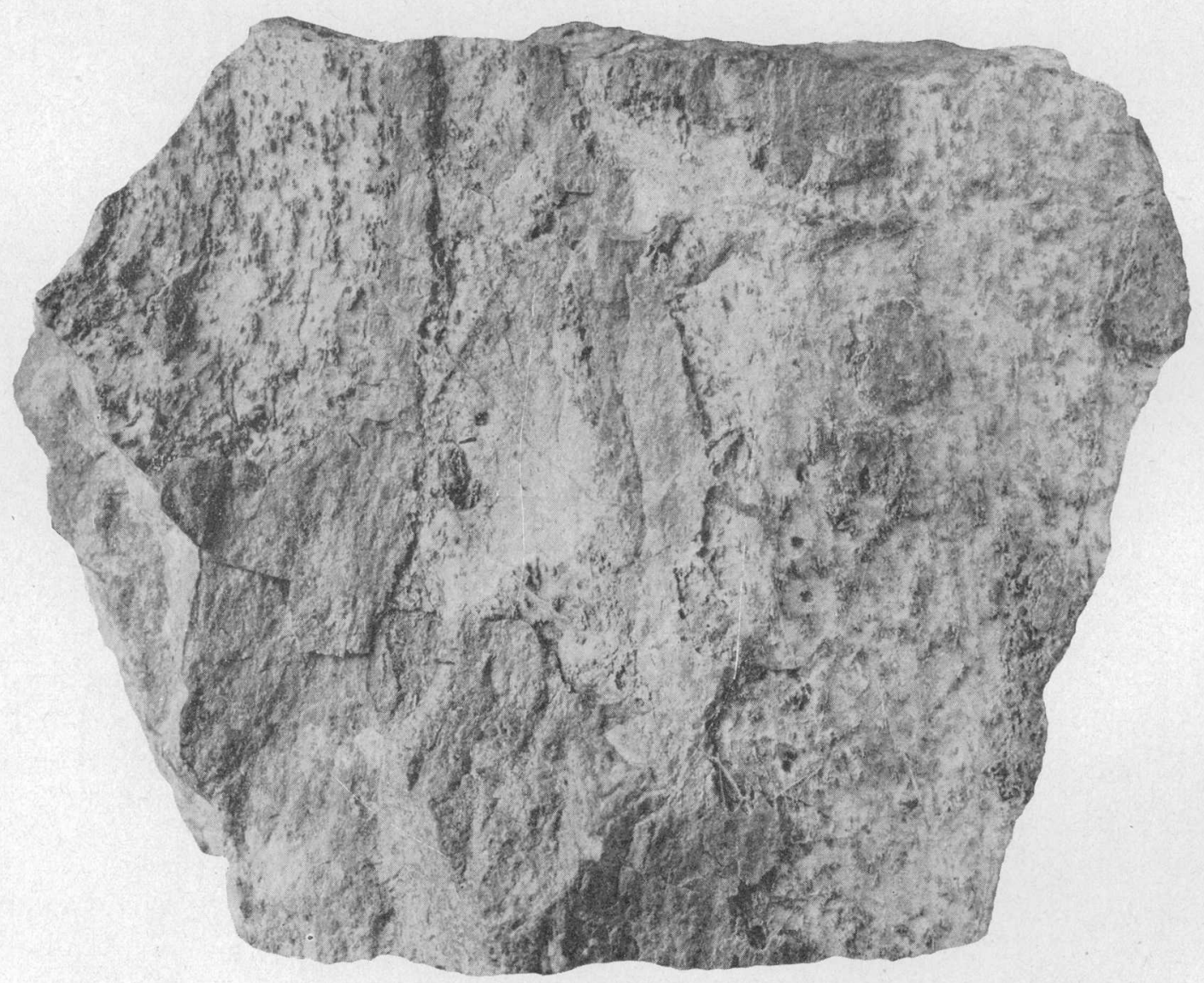

IIGHLY METAMORPHOSED DIORITE PORPHYRY, FROM SLOPE NEAR MICHIGAN-UTAH MINE. Large dark areas mainly garnet; remainder mainly anorthite, with grains of diopside in relief. Natural size. 
mass, and the plagioclase, as well as the orthoclase, is vaguely phenocrystic, though its phenocrysts are for the most part only about a quarter of an inch in diameter.

The monzonite is cut by dikes of aplite, but these are neither especially abundant nor unusual in composition. Some of them contain brilliant splintery hornblende. A rock probably belonging to dikes in the granitoid mass was seen in the form of boulders but not in place. This is a very coarse granite porphyry containing wellformed phenocrysts of orthoclase as much as 3 inches long and prominent roundish phenocrysts of quartz as much as half an inch in diameter.

Specimens of the distinctly porphyritic facies were collected in Gad Valley and the gulch draining it. The one that probably is most nearly representative of the main body of the rock was taken in Gad Valley Gulch (pl. 17, A). It is very light gray in general tone, though not much lighter than some parts of the Alta stock of granodiorite. In the fresh hand specimen its porphyritic texture is not clearly apparent, but on turning the specimen about in a bright light one soon identifies numerous phenocrysts of orthoclase by the glint from their unstriated, basal cleavage planes. The mineral is translucent and faintly tinged with grayish lavender. The boundaries of the largest phenocrysts roughly coincide with crystallographic planes, but they are indented by grains of other minerals, and most of the phenocrysts are speckled with inclusions, so that they do not stand out from the ground mass except on the weathered surface. The ground mass has a mediumgrained granitic texture. Its most abundant constituent is plagioclase, which is pure-white and translucent; quartz, which appears grayish, is fairly abundant, and there is a little interstitial orthoclase. The only conspicuous dark mineral is biotite, which is rather sparsely and unevenly distributed in irregular particles rarely more than 2 millimeters in diameter. A very little hornblende and some titanite and magnetite are visible under the lens.

This rock is not very different in general appearance from the granodiorite, though distinctly lighter, but is unmistakably distinguished by the obviously greater abundance of orthoclase and quartz, by the phenocrystic development of most of the orthoclase, and by the scarcity of hornblende. The orthoclase is estimated to be about 60 percent as abundant as the plagioclase.

The list of original minerals seen in thin section under the microscope, with a rough indication of their relative abundance, is as follows: Plagioclase $>$ quartz $>$ orthoclase $>>$ biotite $>>$ hornblende $>$ magnetite $><$ titanite $>$ apatite $>>$ zircon. A little secondary calcite, chlorite, sericite, and pyrite are found. The plagioclase could not be determined very exactly, but its average anorthite percentage is estimated to be a little less than 30 , or at least 5 points lower than that of the plagioclase in the Alta granodiorite. The orthoclase in the section is interstitial and represents irregular grains of late formation or the margins of phenocrysts, no entire phenocryst, nor any large part of one, being included in the section. The proportion of orthoclase would therefore be estimated at a lower figure from the section than from the hand specimen.

Another specimen' obtained in Gad Valley represents rock that occurs closer to the contact than the one just described. This rock is like the eastern facies of the granodiorite of the Alta stock in that it consists mainly of phenocrysts separated by a small proportion of granular groundmass. The phenocrysts of flesh-tinted orthoclase, which are fairly numerous, are about an inch in maximum length; those of plagioclase, which is greenish white, are about half as long but much more numerous. There are a few roundish phenocrysts of quartz. All these appear better defined than in the otherwise very similar rock from Gad Valley Gulch, because the biotite is crowded into and darkens the interstitial groundmass, which the microscope shows to consist of abundant quartz and orthoclase mixed with a little plagioclase and biotite. No hornblende was found. The rock contains no titanite but does contain clusters of very minute crystals, having very high refractive indices and double refraction, which appear to be brookite. These are mostly embedded in calcite, and both minerals may be alteration products of titanite. The average plagioclase of the rock is near $\mathbf{A n}_{35}$.

The rock exposed near the upper power house on Little Cottonwood Creek, an analysis of which is given on page 40, is intermediate between the rock of Gad Valley Gulch and the typical granodiorite of the Alta stock. It is finer grained and less definitely porphyritic than the Gad Valley facies; it is also somewhat darker, and it contains nearly as much hornblende as biotite. The largest crystals of orthoclase in the available specimens are less than half an inch long, and some crystals of plagioclase are nearly as large. Even the individuals of orthoclase having fairly good crystal form are ill defined, and some of the orthoclase is interstitial and poikilitic. The plagioclase and quartz are of the ordinary character. Biotite is about as abundant as in the rock of Gad Valley, also is present in only a little smaller quantity. The hornblende, though nearly as abundant, is not conspicuous, as it is in the Alta stock of granodiorite, but forms small irregular grains, usually clustered together with flakes of biotite. A little dark honeyyellow titanite is visible. The habit of the dark minerals and the greater abundance of orthoclase and quartz distinguish this facies from the granodiorite, though the difference is not striking.

The microscope discloses little further that is noteworthy. The plagioclase is not strongly zoned. The composition of the greater part of most crystals is near $\mathrm{An}_{30}$, that of the most calcic zones about $\mathrm{An}_{35}$, and that of the rims $A n_{20}$ to $A n_{10}$ or less; the average anorthite percentage is about $A n_{25}$ or a trifle more. This is about 10 points lower than the corresponding figure for the 
granodiorite and supplies an additional distinction between the two rocks. The orthoclase is estimated to be somewhat more than half as abundant as the plagioclise.

A marginal facies of the monzonite is exposed at a molybdenite prospect on the north side of Little Cottonwood Creek, near the point where it crosses the west boindary of the Cottonwood-quadrangle. This rock contains large phenocrysts of orthoclase like those in the rock of Gad Valley but more sparsely and irregularly distributed. The groundmass is similar in character to that of the analyzed facies but darker. Hornblende is much less abundant than biotite. Orthoclase occurs in considerable quantity as an interstitial constituent of the groundmaśs. The average plagioclase is near $\mathrm{An}_{30}$ in composition, being a little more calcic than that of analyzed rock.

If it is assumed that all the facies described represent a single intrusive body, the general petrographic character of the Little Cottonwood stock of quartz monzonite may be summarized briefly as follows: It is a light-gray rock of medium to coarse texture, commonly porphyritic because much of the orthoclase usually occui's in the form of phenocrysts. Orthoclase is 'somewhat more than half as abundant as plagioclase, the average composition of which is about $\mathrm{An}_{25}$ or $\mathrm{An}_{30}$. Quartz is moderately abundant. The only dark mineral invariably present is biotite, which is a little more plentiful than in ordinary biotite granite. Hornblende is present in most places and locally approaches though it nowhere quite equal's biotite in quantity. The usual accessories are titanite, magnetite, apatite, and zircon.

\section{CHEMICAL COMPOSITION OF PLUTONIC ROCKS}

Five analyses of specimens from the plutonic intrusive borlies are tabulated below.

Analyses of specimens from Little Cottonwood, Alta, and Clayton Peak stocks

\begin{tabular}{|c|c|c|c|c|c|}
\hline & 1 & 2 & 3 & 4 & 5 \\
\hline \multirow[t]{2}{*}{$\begin{array}{l}\mathrm{SiO}_{2} \\
\mathrm{Al}_{2} \mathrm{O}_{3} \\
\mathrm{Fe}_{2} \mathrm{O}_{3} \\
\mathrm{FeO}_{2} \\
\mathrm{MgO} \\
\mathrm{CaO} \\
\mathrm{Na}_{2} \mathrm{O} \\
\mathrm{K}_{2} \mathrm{O} \\
\mathrm{H}_{2} \mathrm{O} \\
\mathrm{H}_{2} \mathrm{O}+ \\
\mathrm{TiO} \\
\mathrm{ZrO}_{2} \\
\mathrm{P}_{2} \mathrm{O}_{5} \\
\mathrm{~S}_{2} \\
\mathrm{MnO} \\
\mathrm{CO}_{2} \\
\mathrm{BaO}_{2} \\
\mathrm{Cl}_{2} \\
\mathrm{FeS} \\
\mathrm{SrO}\end{array}$} & $\begin{array}{r}67.02 \\
15.78 \\
1.56 \\
2.80 \\
.1 .09 \\
3.31 \\
3.85 \\
3.67 \\
.29 \\
.63 \\
.37 \\
.04 \\
.26 \\
.03 \\
.02 \\
\hdashline .13 \\
\hdashline-.-- \\
\hdashline-.--\end{array}$ & $\begin{array}{r}65.27 \\
15.75 \\
2.31 \\
1.85 \\
1.62 \\
4.09 \\
3.92 \\
3.25 \\
.21 \\
.53 \\
.55 \\
.02 \\
.25 \\
-.-10 \\
.0 \\
\text { Trace } \\
.11 \\
.01 \\
.02 \\
.05\end{array}$ & \begin{tabular}{r}
63.46 \\
15.93 \\
2.61 \\
2.31 \\
2.27 \\
4.33 \\
3.66 \\
3.49 \\
.27 \\
.74 \\
.62 \\
.03 \\
.16 \\
-.09 \\
Trace \\
.15 \\
.05 \\
\hdashline.-- \\
.--
\end{tabular} & $\begin{array}{r}62.16 \\
17.17 \\
2.26 \\
2.78 \\
1.81 \\
4.70 \\
3.96 \\
3.58 \\
.03 \\
.60 \\
.53 \\
.01 \\
.17 \\
.04 \\
.06 \\
.17 \\
.0 \\
. .2\end{array}$ & $\begin{array}{r}59.35 \\
16.36 \\
2.90 \\
3.36 \\
3.08 \\
5.03 \\
3.73 \\
3.85 \\
.28 \\
.64 \\
.87 \\
.03 \\
.44 \\
-.07 \\
.07 \\
\text { Trace? } \\
.16 \\
.05 \\
.02 \\
.05\end{array}$ \\
\hline & 100.85 & 99. 91 & 100.17 & 100.03 & 100. 29 \\
\hline
\end{tabular}

Analysis 5 shows 0.01 percent each of $\mathrm{CuO}$ and $\mathrm{ZnO}$. Analyses 3 and 5 show faint traces of $\mathrm{LiO}_{2}$.
1. Quartz monzonite of Little Cottonwood stock, below upper power plant, Little Cottonwood Creek, west of Cottonwood quadrangle. R. C. Wells, analyst. In Butler, B. S., and others, Ore deposits of Utah: U. S. Geol. Survey Prof. Paper 111, p. 95, 1920.

2. Granodiorite of Alta stock. W. F. Hillebrand, analyst. Clarke, F. W., Analyses of rocks and minerals from the laboratory of the U. S. Geol. Survey: U. S. Geol. Survey Bull. 419, p. 95. 1910. Nos. 3 and 5 ale also printed in Prof. Paper 77, p. 79, in which the norm of No. 2 is given (p. 92), but no petrographic description. Called "granite" in Prof. Paper 77 (p. 92). The locality is given in Bull. 419 as "Big Cottonwood Canyon" and in Prof. Paper 77 as. "Little Cottonwood Canyon."

3. Granodiorite, east side of Brighton Gap, Park City quadrangle. Called "quartz diorite" in Professional Paper 77, p. 92. W. F. Hillebrand, analyst.

4. Granodiorite of Alta stock, dump of Steamboat tunnel, Snake Creek. Charles Milton, analyst. Wells, R. C.. Analyses of rocks and minerals from the laboratory of the U. S. Geol. Survey, 1914-36: U. S. Geol. Survey Bull. 878, p. 41, 1937.

5. Quartz diorite of Clayton Peak stock, three-fourths of a mile northeast of Clayton Peak, Park City quadrangle. W. F. Hillebrand, analyst.

In order of silica content, the quartz monzonite of the Little Cottonwood stock comes first and the diorite of the Clayton Peak stock last, as would be expected. 'The other oxides, however, vary somewhat irregularly, and potash is most abundant in the diorite.

Analysis 3, of a specimen obtained near Brighton Gap, presumably represents what is regarded by the writers of this report as a porphyritic facies of the granodiorite of the Alta stock (analysis 4). It resembles the granodiorite in composition a good deal more closely than it does the diorite represented by analysis 5 .

The rock of analysis 2 is not satisfactorily identified as to locality, but it may have come from the high country at the heads of both Big Cottonwood and Little Cottonwood Creeks. However, a remnant of the material, marked "Cd. U. 17 (the identifying number of the specimen given with the analysis) extra, analyzed," has unhesitatingly been assigned to the Alta stock of granodiorite, which occurs in both drainage basins. The specimen contains large and well formed crystals of hornblende, unlike any that have been seen in the quartz monzonite, and it does not contain a single phenocryst of potash feldspar. That mineral is, indeed, more inconspicuous than in most of the granodiorite, and the analysis shows a lower percentage of potash, and the norm a lower percentage of orthoclase, than any of the others.

Norms of the analyzed rocks have been calculated by James Gilluly as follows:

\begin{tabular}{|c|c|c|c|c|c|}
\hline \multicolumn{6}{|c|}{$\begin{array}{c}\text { Norms } \\
\text { [Cross-Iddings-Pirsson-Washington classification] }\end{array}$} \\
\hline & 1 & 2 & 3 & 4 & 5 \\
\hline Quart & 21.60 & 19.80 & 16.92 & 12.60 & 8.94 \\
\hline Orthoclase & 21.68 & 19. 46 & $20 ., 57$ & 21.13 & 22.80 \\
\hline Albite_-_- & 32. 49 & 33. 01 & 30.92 & 33. 54 & 31. 44 \\
\hline Anorthite & -13. 90 & 15. 85 & 16. 68 & 18. 63 & 16. 40 \\
\hline Corundum & 41 & & & & \\
\hline Dio & & 1. 97 & 3. 09 & 3. 62 & 4. 45 \\
\hline Hypersthene & 5. 87 & 3. 96 & 5.42 & & \\
\hline Magnetite _. & 2. 32 & 3. 25 & 3. 71 & 3. 25 & 4. 18 \\
\hline Ilmenite. & & 1.06 & 1. 22 & 1. 06 & 1. 67 \\
\hline Apatite. & 1. 01 & .67 & .34 & .34 & 1. 01 \\
\hline
\end{tabular}

Symbols: (1) I (II). 2. $2^{\prime \prime} .3(4)$; (2) II. 4(5). (2) 3. (3) 4; (3) I (II). 4. 2(3).(3) 4 ; (4) (I) II. 4. (2) 3. 3(4); (5) II. (4)5. 2 (3). $3^{\prime \prime}$. 


\section{CONTACT METAMORPHISM}

The contact metamorphism caused by the stocks is very widespread and greatly varied in its effects, but only a few of its salient features will be pointed out.

A metamorphic effect that is both widespread and readily preceptible is the bleaching of the limestones. In order to appreciate fully the extent to which this bleaching has occurred, one should become familiar with the limestone formations as they appear in places far from the outcrops of the stocks, especially in the basin of American Fork. There none of the limestones are white except for the two dolomitic beds that mark the top of the lower member of the Maxfield (p. 16) and the top of the Jefferson (?) (p. 20), and these are merely whitish on the surface and not throughout. Near Alta and in the heads of Silver, Honeycomb, and Solitude Forks, the Cambrian, Devonian (?), and Carboniferous limestones and dolomites are more or less bleached and recrystallized, the limestones being visibly coarsened and the dolomites taking on a texture like that of lpaf sugar. Some beds are more bleached than others; in the Madison, especially, many outcrops have a broad banding in blue-gray and white, for the most part parallel to the bedding, though where the activity has been more intense, as in the cliff east of Superior Gulch (pl. $7, A$ ), the bleaching commonly cuts across the bedding.

Perhaps as widespread as this bleaching, though less conspicuous, is the formation of tremolite in and around the nodules of chert that are characteristic of the Deseret and some other limestone formations. As a result of the movements involved in this change the chert nodules in dark limestone are partly replaced by white calcite before the enclosing limestone is bleached.

Metamorphic minerals other than tremolite that are widely distributed in dolomite and limestone are forsterite and brucite, the latter derived from periclase (pl. $21, B)$. These commonly occur together, and forsterite is accompanied in places by diopside. The silica in these minerals may be in part magmatic, though a possible nearby source in the sedimentary rocks can usually be found. The magnesia also must have been present, for the most part, in the original rocks, which were largely dolomitic.

The most thorough recombination of constituents, probably involving movements that were in the main of slight extent, has occurred in calcareous shales, especially those forming the upper member of the Ophir shale. In such rocks as these the lime in the carbonate, together presumably with a little magnesia and ferrous oxide, and the alumina in the clayey matter could readily recombine without addition of material to form rocks of somewhat the same character as those that now represent the upper shale member of the Ophir in the South Hecla mine. (See p. 126.) However, the impression persists that some magnesia and potash must have been added to form so much diopside and orthoclase as these rocks contain. This hypothesis might seem worth testing at some future time by chemical analyses of composite samples representing the least altered and the highly altered material.

Especial freedom of combination, resulting in coarse crvstallization, has occurred in mottled limestones with siliceous layers, such as those in the Ophir shale and the middle member of the Maxfield limestone.

Such non-calcareous originally argillaceous rocks as occur in the lower member of the Ophir shale and in the pre-Cambrian are far less conspicuously altered, on the whole, than the calcareous shales. In these also, however, the occurence of cordierite (p. 9) in some places and of orthoclase elsewhere in relatively large poikilitic grains appears to indicate local addition of magnesia and of potash. Metamorphism has had relatively small effect on the quartzite rocks.

Certain of the metamorphic minerals in this area consist wholly or in part of material derived from the magmas. Among these are ludwigite, tourmaline, scapolite, magnetite, and the sulfides in certain contact metamorphic deposits. Tourmaline is widespread in the metamorphosed shaly rocks; scapolite occurs, though not abundantly, in altered porphyries but was not found in the sedimentary rocks. Ludwigite is disseminated in some altered limestones, but it occurs most abundantly in association with magnetite, forsterite, and other silicates, in masses that obviously involved the replacement of Jarge bodies of calcareous rock. The largest of these is at the old Mountain Lake mine. Masses of silicates, chiefly amphibole and garnet, together with magnetite and sulfides, whose boundaries are sharply defined and cut across the bedding of the sedimentary rocks near the boundary of the Alta stock of granodiorite may readily be observed on Patsy Marley Hill and on the slope south of Alta. Similar bodies are further discussed in the description of the ore deposits (p. 92).

\section{MINOR INTRU'SIVE BODIES} GENERAL FEATURES

Although the great bulk of the igneous rock in the area occurs in the stocks, there are also many dikes and probably a few sills. Most of the dikes that traverse the sedimentary rocks are so closely similar in composition to one or another of the stocks that they are presumably offshoots from these, even where the connection is not actually visible. A few supposed sills on Big Cottonwood Creek are dioritic, perhaps not very different in composition from the diorite of the Clayton Peak stock, though their character does not indicate a close relationship to that mass. There are other dikes whose composition is more siliceous or less siliceous than that of any of the stocks. 
The most numerous class of the siliceous dikes consists of aplite and pegmatite. The dikes of this class are confined to the stocks and the sedimentary rocks closely adjacent to them. They are of a sort that occurs whereever plutonic rocks occur; those found in this area are not of remarkable character and have not been specially studied nor separately mapped. They contain, in general, the same minerals as the related stocks but a larger proportion of quartz and orthoclase, a more sodic plagioclase, and a relatively small quantity of the dark minerals. None of those seen in the quadrangle contain rare minerals.

The only other highly siliceous dikes in the district consist of a whitish alaskite porphyry that is remarkably uniform in composition. These dikes are few in number. The alaskite cuts dikes that are probably offshuots from the Alta or the Clayton Peak stock, and it is probably later than any of the stocks. There are a few dark dikes that may appropriately be called lamprophyres. Little.evidence is available regarding the relation of the lamprophyres to the other igneous rocks, but there is some indication that they are older than the Little Cottonwood stock, for they show what seems to be contact metamorphism near that stock.

\section{DIORITE PORPHYRY, GRANODIORITE PORPHYRY, AND} MONZONITE PORPHYRY

The sedimentary rocks, especially in the central part of the area, are cut by numerous dikes of gray porphyry, most of which trend northeasterward. The rocks in these dikes are similar in çomposition to the granular diorite, grandiorite, and quartz monzonite of the stocks, of which many of them are presumably offshoots. It is impossible, however, to correlate each dike with one or another of the larger intrusive bodies or even to classify the rocks of all of the dikes, many of which are altered. All the dikes intermediate in composition between the alaskite porphyry and the lamprophyres are therefore mapped in one color.

Dikes clearly related to the Clayton Peak stock are not well represented in the collection, and it is thought that they are in large part disguised by a kind of alteration that is described on pages 43-45. A specimen from a relatively unaltered dike, differing only texturally from much of the diorite, that traverses the Honeycomb Cliffs may be regarded as typical. It consists of a darkgray rock with rather small phenocrysts of plagioclase, hornblende, and biotite. The plagioclase phenocrysts are seen under the microscope to have the dusty appearance that is so persistent in the diorite of the Clayton Peak stock; in the composition of their cores too-about $\mathrm{An}_{45}$-they correspond to the plagioclase of the stock. Hornblende and biotite are about equally abundant. The hornblende is partly in aggregates; the biotite is reddish brown. The rock contains no pyroxene. A little quartz and orthoclase occur in the groundmass. There is a good deal of titanite in fine-grained aggregates, and its mode of occurrence, together with the granulated hornblende crystals and the presence of much pyrite, indicate that the rock has undergone some deep-seated alteration.

Dikes that are distinctly related in composition to the Alta stock of granodiorite are far more numerous than those related to the Clayton Peak-apart from those that are greatly altered-or to the Little Cottonwood stock. A great many dikes of granodiorite crop out in Albion Basin; many are crossed by the workings of the South Hecla mine (pl. 44), and several are exposed in Collins and Peruvian Gulches. One can be followed almost continuously from Snake Creek to the south slope of the Devils Castle ridge, a distance of 2 miles. What may be called the Tar Baby dike, which is less clearly related to the Alta stock, probably extends from the western boundary of the mapped area for at least 6 miles north-northeastward and is crossed in the KentuckyUtah tunnel.

The least altered specimen of the granodiorite porphyry was taken in Albion Basin. It is a medium-gray rock, containing fairly numerous phenocrysts of plagioclase about $5 \mathrm{~mm}$. in greatest length, conspicuous hornblende phenocrysts as much as $10 \mathrm{~mm}$. long, and smaller phenocrysts of biotite. The plagioclase, which is somewhat zoned, has an average composition near $\mathrm{An}_{35}$ or $\mathrm{An}_{40}$. The biotite is seen in thin section to be of olivebrown color and virtually unaltered. The hornblende also has a fresh look, but some of the masses having good crystal outlines are seen under the microscope to be aggregates rather than crystal units. The groundmass, which is microgranular, contains the minerals already named, together with a large proportion of orthoclase and quartz.

Noteworthy in this description is the evidence of the instability of the hornblende, shown by its partial recrystallization. This tendency has gone much farther in some other specimens. One from the north base of Mount Baldy, a coarsely porphyritic rock in which the phenocrysts have a larger volume than the groundmass, contains no hornblende at all, but the mineral evidently is represented by pseudomorphs of chlorite in felted aggregates more or less mixed with calcite. The biotite is replaced in part by chlorite that has uniform orientation.

In a handsome gray porphyry from a dump on the west side of Collins Gulch, about half a mile from its mouth, the phenocrysts of plagioclase-averaging about $\mathrm{An}_{40}$-are unusually fresh. So also is the biotite, being unaltered except for a very local change of color from the ordinary brown to green. Hornblende, on the other. hand, is altogether absent, but it seems to be represented by irregular fine-grained aggregates of green 
biotite mixed with more or less calcite. This change obviously has nothing to do with weathering; it probably was caused by hot rising solutions before the rock had cooled, and the calcite may have been carried up from the limestone beneath the Alta overthrust.

In a very dark gray porphyry from a dike northeast of the Devils Castle, in which the plagioclase (about $A n_{45}$ ) is fairly fresh, the hand specimen shows a single phenocryst of hornblende an inch long. The thin section, however, contains no hornblende and no original biotite. It does contain many polygonal patches of finegrained olive green mica, which appears to have replaced both original biotite and hornblende. The groundmass consists in large part of quartz, which may have replaced orthoclase whose potash went to the formation of secondary biotite.

A very dark greenish dike that crosses the ridge west of Collins Gulch appears more closely related to the granodiorite porphyries already described than to any other group. The phenocrysts are sparser than in the others, and the groundmass is coarser and contains less orthoclase and quartz. This rock contains phenocrysts largely altered to an unusually bluish green chlorite; the deep green hornblende phenocrysts are bundles of short splinters; and there is much of the usual olive green secondary biotite.

A larger collection of these dike rocks would doubtless have illustrated still more varied alterations of the ferromagnesian minerals-alterations that are not prevalent in the stocks and that are especially characterized by the formation of green secondary biotite. The fissures occupied by the dikes evidently gave passage to ascending hot solutions that could act upon the dikes and kept them from ineffectively spreading outward.

The rock of the Tar Baby dike resembles the first of the specimens of granodiorite porphyry that was described above except that it contains, throughout its length, fairly numerous phenocrysts of quartz, which are strongly corroded. On the east side of Honeycomb Fork the dike has been altered in such a manner that it has a light yellowish green color and its hornblende is replaced by actinolite and pale monoclinic pyroxene. The magmatic relations of this dike are uncertain; in mineral composition-in the presence especially of quartz phenocrysts and the absence of orthoclase phenocrysts -it resembles the more coarsely porphyritic rock found on the dump northwest of Silver Lake (p. 37).

The Little Cottonwood stock does not appear to have many long offshoots; it certainly has far fewer than the Alta stock, and hardly any dikes have been recognized in the area as having the character that would be expected in a dike facies of the Little Cottonwood quartz monzonite. The specimen that comes nearest to doing so was taken on the east side of Major Evans
Gulch, near its mouth. It consists of a medium-gray porphyry, which contains numerous phenocrysts of halflimpid plagioclase up to $12 \mathrm{~mm}$. long. It also contains many small phenocrysts of biotite and hornblende, a good many of corroded quartz, and a few of flesh-colored orthoclase. The average composition of the plagioclase is near $\mathbf{A n}_{30}$. The groundmass is microgranular and consists mainly of quartz and orthoclase.

\section{ENDOMORPHIC ALTERATION WITH ADDITION OF LIME}

The diorite of the Clayton Peak stock at some places near its contact with calcareous sedimentary rocks and the rock of many dikes that are certainly or probably formed from the same magma and cut calcareous rocks have undergone a characteristic alteration which is not due to weathering but to some deep-seated agency. Its most general effect on the appearance of the rock is a change of color from dark gray to light gray-green. Its most usual product is essentially a mixture of calcic plagioclase and diopside, with titanite as an abundant accessory. Garnet may be present even in rocks that are on the whole but slightly altered, and in later stages of alteration it may be very abundant. Scapolite has been formed at certain places near the head of Honeycomb Fork. The dominant chemical change expressed by these changes in mineral composition is an enrichment in lime, and the alteration is believed to have been effected by emanations from the magmas that crystallized as the Clayton Peak stock of diorite and the Alta stock of granodiorite, after these emanations had dissolved abundant lime during their passage through limestones.

The alteration did not everywhere follow the same course, and its gradations have not been fully traced at any one locality. It is therefore difficult to describe the effects of the process compactly; but an idea of its character may be conveyed by describing the significant features of a few typical specimens.

Incipient alteration of the typical diorite of the Clayton Peak stock is illustrated by a specimen taken a few rods north of Lake Solitude (pl. 17, $C$ ). A residual nodule of unaltered diorite shows the usual evenly granular texture and dark-gray color. This nodule is surrounded by a transitional zone a few millimeters wide, which is somewhat lighter in tone and more greenish in hue, and this grades into the main body of the specimen, which has a light gray-green color and a typical granular texture. Its chief constituent is white feldspar, but a dull-green mineral that might from its appearance be either pyroxene or amphibole is abundant.

The plagioclase in the least-altered part of the rock is faintly zoned andesine, crowded, as is usual in the Clayton Peak stock, with fine dust. Orthoclase, quartz, hornblende, and biotite are fairly abundant, and a little augite, partly enclosed in the hornblende, is present, 
Titanite, magnetite, and apatite are abuindant accessories, and a very little zircon is present. The rock is fairly fresh; some of the biotite is altered to chlorite, but the feldspar is only a little clouded.

A transitional zone, whose boundary against the leastaltered rock is fairly sharp, contains plagioclase having essentially its original character, and about as much orthoclase as the original rock. In other respects, however, it is distinctly altered : it contains neither biotite, amphibole, nor quartz, its magnetite has nearly all vanished, and the only ferromagnesian mineral it contains is a green monoclinic pyroxene. Titanite, though perhaps no more abundant, is better crystallized and hence more conspicuous than in the original rock, and apatite forms unsually large grains, most of which are enclosed in pyroxene.

In the outer part of the specimen, where it is uniformly altered, the plagioclase is without dusty inclusions, is not zoned; and is slightly more calcic than in the unaltered remnant-about $\mathrm{An}_{45}$ as compared with $\mathrm{An}_{35}$. Biotite, quartz, and amphibole are absent; orthoclase is scarce and is intergrown with the plagioclase. Apatite and titanite occur in normal quantity, but the magnetite has nearly all gone. The chief results of the alteration may be summarized as (1) slight increase in the lime content of the plagioclase, (2) decrease in the proportion of orthoclase, (3) total disappearance of quartz, biotite, and hornblende, (4) development of diopsidic pyroxene in quantity about equal to that of the biotite and hornblende combined, and (5) nearly complete disappearance of magnetite. Chemically, there has clearly been a decrease in potash and increase in lime.

The process of alteration is even more strikingly iilustrated by a specimen from the top of Mount Evergreen, to the east. The rock is diorite porphyry and forms a dike that is presumably an offshoot from the nearby Clayton Peak stock. The outcrop shows two types of rock, one dark greenish gray and the other pale greenish buff, and although the boundary between these appears in hand specimen to be very sharp the microscope shows that there is a rapid gradation from one to the other.

The dark rock is itself a little altered. It is greenish gray and is duller in luster than the freshest similar rock. Small white crystals of feldspar and dark-green crystals of amphibole are visible in the microcrystalline groundmass. The microscopic section of the dark part shows the feldspar phenocrysts to be mainly andesine near $\mathrm{An}_{40}$, their composition being about the same as that of the plagioclase crystals in the Clayton Peak stock of diorite. Like these, too, they contain characteristic dustlike inclusions, but unlike them they are only faintly zoned. The principal ferromagnesian mineral is a rather pale green hornblende, some phenocrysts of which contain ragged cores of augite. Biotite is sparingly enclosed in the minerals already named, and it originally formed a few phenocrysts, which are now altered to chlorite. Sparse crystals of splintery pale amphibole may be pseudomorphs after hypersthene. The groundmass contains abundant hornblende, plagioclase, and quartz, with only a little orthoclase and biotite. The most conspicuous accessory is titanite, which is more abundant than in the unaltered rocks of similar composition. A little common epidote and sporadic allanite and zircon are present. If this dark, leastaltered portion of the rock was originally a mere textural variant of the diorite, it has already lost some of its potash, without having undergone any other marked chemical alteration.

In the light-colored part of the rock the ferromagnesian mineral is almost exclusively a pale monoclinic pyroxene, apparently diopside. This mineral, like the hornblende, occurs in two generations, but it differs from the hornblende in habit; the pyroxene in the groundmass especially, instead of showing slender prismatic form, is irregular in outline and in part poikilitic. The phenocrysts of pyroxene have no characteristic crystal form, but a few of them contain residual cores of the hornblende which they have largely replaced. The light part of the rock contains no biotite, and the phenocrysts of plagioclase therein are virtually identical in appearance and composition with those in the dark part. The groundmass of the light material consists, apart from pyróxene and accessories, almost wholly of ragged interlocking laths of plagioclase, unaccompanied by quartz or orthoclase. The elimination of potash clearly has gone further in the light-colored material than in the dark material.

A dike on the southeast slope of Davenport Hill shows, in the least-altered facies, a dark greenish-gray color and a porphyritic texture. It is dappled with dark masses that prove, under the microscope, to be finegrained aggregates of hornblende and greenish biotite and evidently represent phenocrysts that have become recrystallized. Phenocrysts of dusty andesine (near $A n_{40}$ ) are conspicuous under the microscope. The groundmass contains all these minerals, together with abundant orthoclase and quartz. The usual accessories are present. The rock is a diorite porphyry, similar in composition to the diorite of the Clayton Peak stock, that has undergone some recrystallization but no marked chemical change.

A specimen taken a few yards from the one just described and clearly representing a more altered facies of the same dike is light gray-green on fresh fracture. Its constituents are not so readily distinguished here as on the weathered surface, where green pyroxene stands out in relief from a background of dull grayish-white feldspar. The microscope shows that the rock has a 
porphyritic texture about as coarse as that of the rock last described. It is composed essentially of anorthite and diopside. The phenocrysts consist of diopside and of plagioclase, whose extinction angles and refractive index indicate that it is near $\mathrm{An}_{90}$ or $\mathrm{An}_{95}$. Vesuvianite mixcd with garnet is developed locally. The rock is evidently much enriched in lime and almost devoid of potash.

Similar alteration that has gone even further is shown, in what was taken for a dike rock, on the Stuart fissure near the Michigan-Utah mine. A specimen taken here contains irregular, somewhat elongated masses of redbrown garnet a few centimeters in breadth, embedded in a light greenish-gray horny-textured matrix (pl. 16, B). This matrix is found, under the microscope, to consist of anorthite and diopside with accessory titanite and apatite. Its texture is not porphyritic but irregularly granular. Despite the lack of similarity in texture to diorite porphyry and despite the fact that the specimen has not been shown to grade into porphyry, it was believed, when taken, to represent a more advanced stage in the alteration already described; later, however, a specimen clearly representing calcareous shale of the Maxfield limestone proved to be very similar in character. In a somewhat similar specimen the garnet is accompanied by vesuvianite and a pale chlorite. Large masses of garnet, vesuvianite, etc., occurring" here and elsewhere, are regarded as products of advanced alteration.

Another facies of the alteration is characterized by the presence of scapolite, which has been found only in a narrow zone extending about a mile westward from Lake Solitude. Incipient development of the mineral is illustrated in a porphyritic dike west of the Honeycomb Cliffs, which contains hornblende, biotite, orthoclase, and perhaps a little quartz, and, in the groundmass, a little poikilitic scapolite. In a specimen from a neighboring dike, the hornblende and biotite are gone, and the only ferromagnesian mineral is diopside, but much orthoclase is still present; scapolite occurs here with about the same habit and abundance as in the rock just described. A crag on the divide between Honeycomb and Solitude Forks is made up largely of rock very similar in appearance to the common anorthite-diopside mixture but somewhat lighter and coarser. The gray-green body of a specimen taken at this locality consists essentially of scapolite and diopside. The refractive indices of the scapolite indicate that it contains about 60 percent of the marialite molecule. Ragged masses of garnet are conspicuous in the hand specimen, and a little orthoclase and magnetite (?) as well as the usual titanite and apatite are visible under the microscope.

\section{DIORITE OF BIG COTTONWOOD CREEK}

At the Confidence mine, just south of Big Cottonwood Creek and near the northwest corner of the mapped area; at the Maxfield mine, about 2 miles farther down the same stream; and at other places near these occur small injected steep-walled bodies of dark fine-grained diorite. Those at the Maxfield mine were taken by Butler to be dikes; those at the portal of the Confidence were thought by Calkins to be sills, their walls being about parallel to the bedding, though they might be dikes injected between the beds after the beds were tilted.

These bodies, lying mainly outside of the area mapped, have not been given a great deal of attention; they appear, however, to consist of rocks that are closely related though differing in detail. They resemble the diorite of the Clayton Peak stock more than any other of the stock-forming rocks but not closely enough to indicate that they are offshoots from that mass. Collectively they may be described as rather dark gray finegrained quartz-biotite diorites, having a granular texture that locally verges on the porphyritic. They consist essentially of plagioclase, quartz, orthoclase, and biotite, accompanied usually by hornblende, which is about as abundant as biotite in one of the specimens collected but is absent from another, both specimens being from the Maxfield mine.

In thin sections viewed under the microscope, all the specimens exhibit a strikingly conspicuous zonal banding of the plagioclase, which has a fairly regular crystal form. The maximum anorthite percentage in the cores of these crystals ranges from 55 in some specimens to 85 in others; that of the rims in all is near 15. The orthoclase and quartz are interstitial and partly intergrown. The proportion of orthoclase varies widely, but this feldspar is everywhere decidedly subordinate to plagioclase. The biotite is reddish brown and the hornblende a slightly brownish green; the persistence of these characteristic tints in different specimens, together with similarity in the character of the plagioclase and in texture, are evidences of close magmatic relationship between the several masses. As accessories, magnetite and apatite are rather abundant, titanite less so, and zircon scarce.

\section{LAMPROPHYRIC DIKES}

GENERAL FEATURES

The dike rocks classed in the present report as lamprophyres are varied in character, but they all contained originally somewhere near 50 percent of ferromagnesian minerals. They are dark gray, mostly with a greenish cast, and fine-grained. Many show megascopic phenocrysts of biotite or hornblende and pseudomorphs after phenocrysts of other unidentified ferromagnesian minerals, probably olivine or pyroxene or both, which have been completely replaced. Some contain large grains of quartz; only a few contain phenocrysts of feldspar. Most of the lamprophyric dikes occur in a zone extending northeastward from Superior Gulch to the slope east 
of Honeycomb Fork, and three of them are cut by the Kentucky-Utah tunnel; the zone thus extends for at least 6 miles. Other lamprophyric dikes are found farther south, between Gad Valley and Collins Gulch, in the South Hecla mine, and in the headwater basins of American Fork and Mary Ellen Gulch.

These rocks, like most lamprophyres, are greatly altered. Most of the specimens contain much calcite, and the dikes from which these come have walls that consist mainly of limestone; the few specimens that contain little or no calcite are from dikes in tillite and quartzite. The plagioclase is generally more calcic in the less altered specimens than in the more altered ones, where much of it is albite, the anorthite percentage having evidéntly been lowered as a result of alteration. Chlorite, presumably an alteration product of olivine and pyroxene, is abundant in some specimens that contain perfecly fresh biotite. This remarkable immunity of the biotite, combined with advanced alteration of the other minerals, and especially with albitization of the plagioclase, are of course characteristic of lamprophyres in general.

If the lamprophyric rocks of this area were less altered, it might be possible to subdivide them into several types, but, since it is impossible to infer the original composition of most of the specimens, it seems practicable only to distinguish those that contain phenocrysts of biotite from those that do not. Dikes of both types have been found in the western part of the area, but only those without biotite phenocrysts have been found in the eastern part.

These lamprophyres may be related to two much fresher dikes of what was described as picrite porphyry, found in the Park City district, ${ }^{58}$ which contain phenocrssts of biotite and of olivine that is only partly replaced by serpentine.

\section{LAMPROPHYRES WITH PHENOCRYSTS OF BIOTITE}

Lamprophyre containing many conspicuous phenocrysts of biotite is exposed near station 5 in the Frederick tunnel and at the bottoms of the two raises from the Frederick and Columbus-Rexall tunnels to the West Toledo workings. Probably the rocks at both places belong to the narrow zone of anastomosing dikes that is exposed on the surface east of the Superior fault at about the level of the Superior tunnel. A dike found on the east slope of Gad Valley strikingly resembles in appearance the dike followed by the West Toledo raises, though when examined microscopically it shows some marked differences which appear to be due to a different mode of alteration.

In hand specimens the biotite phenocrysts of all the lamprophyre that contains them are seen to have a subparallel arrangement and to be for the most part be-

\footnotetext{
${ }^{5 s}$ Boutwell, J. M., op. cit. (Prof. Paper 77), pp. 88-91.
}

tween 1 and 2 millimeters in diameter. They are embedded in a fine-grained but visibly crystalline groundmass of dark-greenish to brownish-gray color. The microscupe shows that in the specimens collected from the Frederick and Columbus-Rexall workings the phenocrysts of biotite have a deep greenish-brown color in a narrow peripheral zone, but the inner part of each crystal is a much paler brown; both parts are nearly uniaxial. None of the biotite is altered to chlorite, and its freshness is the more remarkable in view of the advanced alteration which has affected other minerals. The ferromagnesian minerals, probably of two or three species, that originally were present as phenocrysts have been wholly replaced. Some pseudomorphs, possibly after augite or olivine, consist mainly of calcite, which encloses biotite, chlorite, and in some places quartz; others, which may represent original hornblende or augite, consist of fine-grained biotite, fibrous amphibole, and other minerals. One specimen contains large welldefined areas of granular quartz, enclosing grains of caicite and biotite, which may be inclusions of sedimentary rock. The groundmasses of these rocks are finegrained and consist largely of calcite and biotite or chlorite, together with colorless minerals, which include quartz, orthoclase, and a plagioclase that from comparison of its refractive indices with that of balsam is estimated to be albite or sodic oligoclase. Apatite, pyrite, and cloudy masses probably of some titanium mineral are relatively abundant.

The specimen from the east side of Gad Valley came from a dike whose walls are of siliceous rocks, whereas those above described cut calcareous shales and limestones; and it is probably because of this difference in wall rcck that the Gad Valley dike is relatively fresh and virtually free from calcite. The most conspicuous mineral in it is biotite of a uniform deep red-brown tint, nearly all in fairly large and well-formed crystals and hardly any in the fine-grained aggregates or disseminated particles that suggest a secondary origin. Almost as abundant as the biotite is an amphibole, which is almost colorless in thin section and whose splintery or fibrous habit and local intergrowth.with feldspar suggest that, even if not strictly secondary, it has undergone molecular rearrangement. More abundant than either is a feldspar in irregular untwinned areas and oblong carlsbad twins, which appears to be orthoclase or possibly soda orthoclase. The rock contains a few partly resorbed phenocrysts of quartz, a small quantity of interstitial quartz, and a little feldspar that is probably oligoclase. Titanite and a little apatite were found, but no magnetite nor pyrite.

LAMPROPHYRES WITHOUT BIOTITE PHENOCRYSTS

The lamprophyric dikes that are cut by the workings of the Alta Tunnel \& Transportation Co. (pl. 37) and 

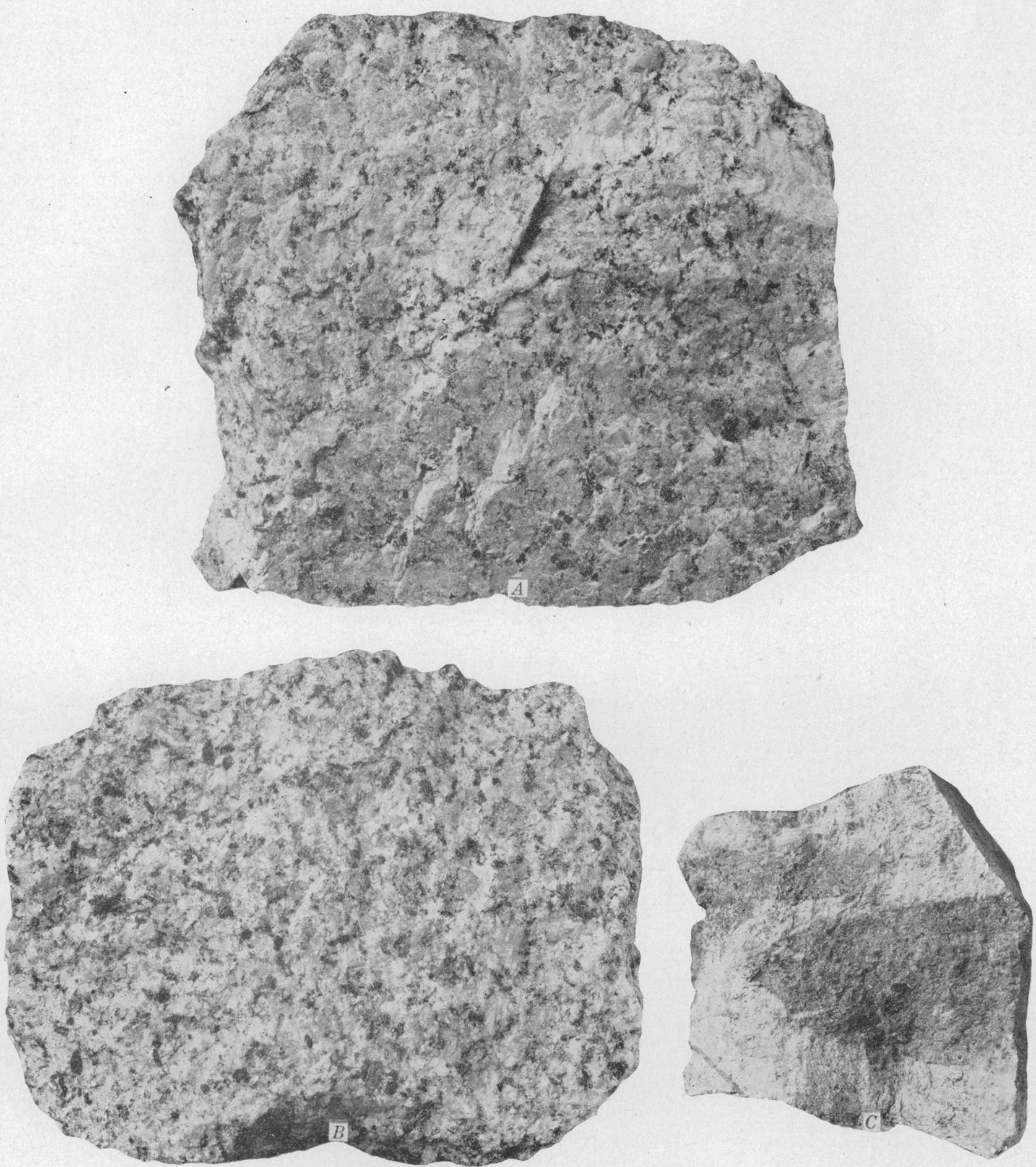

A. QUARTZ MONZONITE OF LITTLE COTTONWOOD STOCK.

From Gad Valley. Shows ill-defined phenocrysts of orthoclase. Slightly reduced.

B. GRANODIORITE OF ALTA STOCK.

Analyzed specimen from dump of Steamboat tunnel. Note conspicuous prisms of hornblende. Natural size.

C. PARTLY ALTERED DIORITE PORPHYRY FROM OFFSHOOT OF CLAYTON PEAK STOCK. Specimen collected near Lake Solitude. Dark parts are almost unaltered. Natural size. 


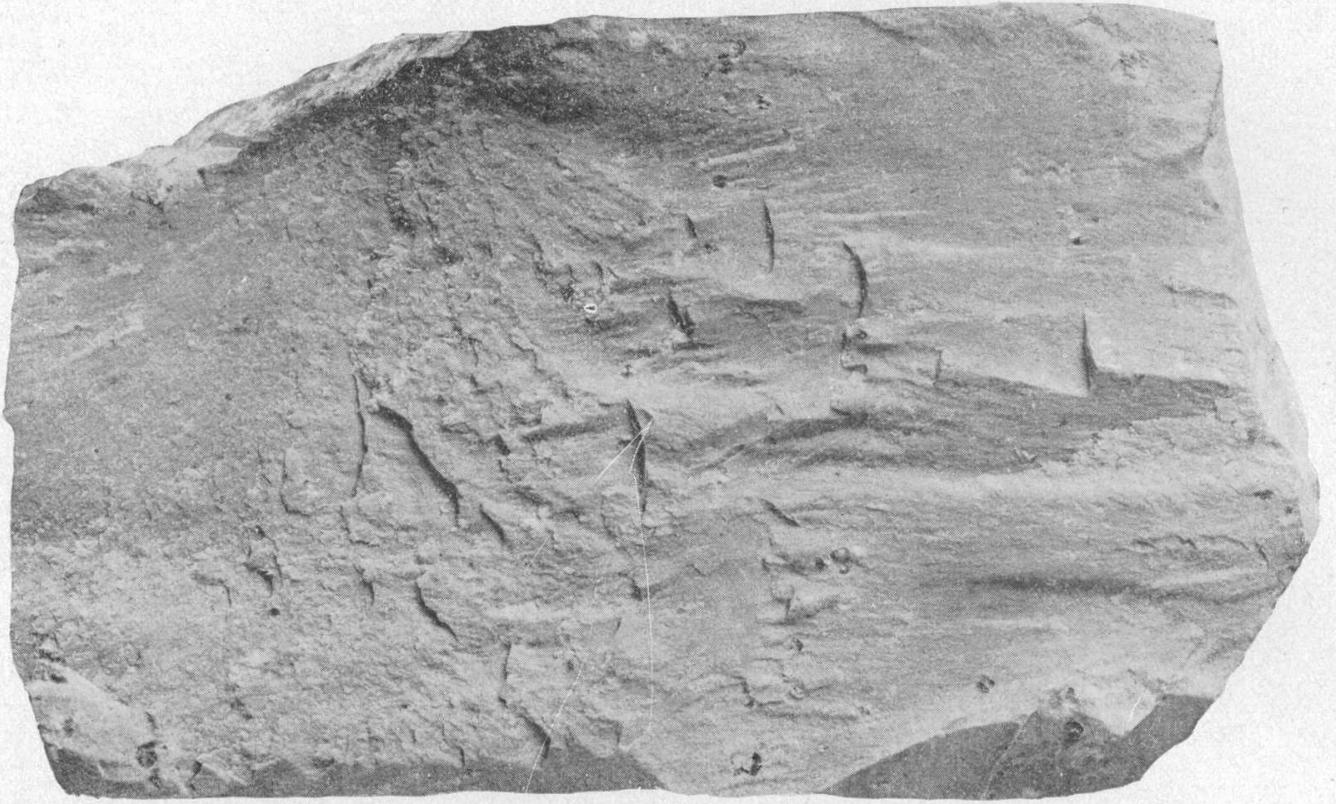

A. ALASKITE PORPHYRY OF GRIZZLY DIKE.

Specimen collected near Grizzly tunnel. Shows phenocrysts of quartz (dark) and feldspar (light). Natural size.

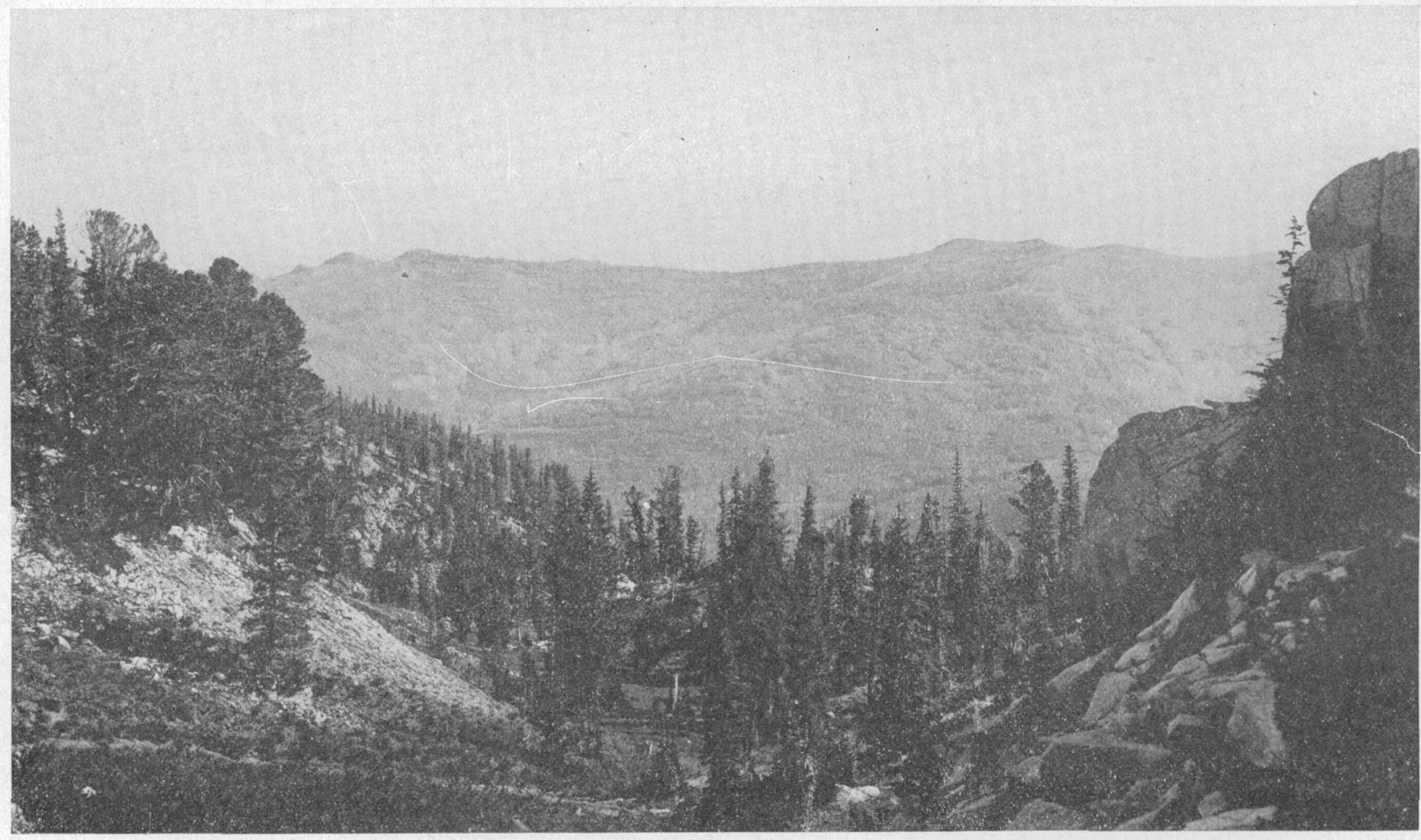

B. VIEW ACROSS BIG COTTONWOOD CANYON FROM HEAD OF SOLITUDE FORK.

In foreground, granodiorite (right) and bleached limestones. In background, Pennsylvanian to Triassic strata with simple structure. 
exposed on the surface east of Silver Fork are of a dull dark-green color that suggests the presence of abundant chlorite, and all of them effervesce with acid. They are without phenocrysts of biotite, and many of them contain sparse, relatively large grains of quartz, which may be either phenocrysts or inclusions. These traits are shown also by the rock of some of the dikes cut by the Columbus-Rexall and Frederick tunnels. The lamprophyric dike in the East No. 1 workings of the South Hecla has no biotite phenocrysts. Similar rock found as float on the slope west of Superior Gulch also contains these characteristic grains of quartz but is brownish gray and comparatively fresh looking farther east.

At several places on the slope west of Superior Gulch fragments of a dike rock have been picked from the float, though not found in place, which resemble the rock last described in their dark color-though they are brownish rather than greenish-gray-and in containing sporadic large grains of quartz. They are, however, much fresher than the dikes east of Silver Fork, and they are free from calcite, probably because they cut no calcareous rocks but only quartzite, shale, and tillite. Fresh-looking hornblende is abundant and readily visible to the naked eye, and weathered surfaces are pitted, apparently because of the weathering out of this and other ferromagnesian minerals.

Under the microscope these specimens, though strikingly similar in megascopic appearance, show considerable differences. Their chief minerals are plagioclase, hornblende, and biotite. The average composition of plagioclase ranges from about $\mathrm{An}_{40}$ to $\mathrm{An}_{80}$-much more calcic than in the lamprophyres already described. The color of the amphibole is mostly a rather deep brown in one specimen but pale green in others. Biotite of a red-brown hue is in some places about equal to the hornblende in quantity, in other places subordinate. It occurs in aggregates of small flakes; indicating secondary origin, rather than in large euhedral crystals. Interstitial quartz and orthoclase are scarce or absent. Dusty apatite is a conspicuous accessory; magnetite is usually but not always found. The character of the biotite and the variable appearance of some of the other minerals suggest that the rock has undergone slight metamorphism, probably by emanations from the Little Cottonwood stock of quartz monzonite.

A dike followed by the east drift of the Frederick tunnel, leading to the Columbus-Rexall workings, is somewhat similar in composition to the rocks just described, but it contains abundant calcite, pyrite, and chlorite. The chlorite may in part be secondary after hornblende, none of which, however, is now present. Finely divided biotite is abundant. The plagioclase seems to be near $\mathrm{An}_{10}$ in composition.

A specimen somewhat similar to those found west of Superior Gulch was taken from a small dike on the crest northeast of Twin Peaks. This rock consists essen- tially of green and brown hornblende, finely divided green biotite, and plagioclase (near $\mathbf{A} \dot{n}_{50}$ ), but it also contains considerable epidote, a mineral not found in the specimens of lamprophyre already described.

A specimen from the brow of the spur that extends westward from the Prince of Wales shaft is so similar in texture to the one last described that it is taken to be similar in original composition, though it contains no original ferromagnesian constituents. The phenocrysts again group themselves into two classes, the most numerous consisting mainly of green chlorite and others mainly of calcite. The groundmass contains abundant laths of albite or sodic oligoclase, having an average refractive index distinctly below that of balsam. This sodic felspar was probably formed by albitization of a much more calcic felspar. The groundmass contains a little quartz, intergrown with orthoclase, but most of it consists of calcite and chlorite.

The workings of the Alta Tunnel \& Transportation Co. cut a group of five parallel dikes, one of which is followed by the drift that leads to the vertical shaft; and at least two smaller dikes cross the tunnel farther north. The dikes are no fresher underground than in their surface exposures. The freshest material collected in the workings was taken from the thickest of the dikes where it is crossed by the Quad drift. Here the greater part of the dike is so softened by decomposition that it can readily be dug into with a pick, and although this soft material encloses harder spheroidal masses from which specimens were taken, even the hardest rock is much decomposed, as indicated by its grayish-green color and ready effervescence on the application of acid. Sporadic grains of quartz up to 3 millimeters in diameter are visible.

Under the microscope the rock shows chloritic pseudomorphs after phenocrysts of some ferromagnesian mineral. The groundmass consists in greater part of albite laths, much clouded with sericite and calcite. It also contains abundant laths of brown hornblende, which have been replaced in greater part by an undetermined opaque grayish substance and in lesser part by a palebrown fibrous mineral of moderate double refraction.

The freshest specimen taken on the surface near the Aita tunnel came from a narrow dike exposed southeast of the portal. The body of the rock is aphanitic, and its color is very dark gray. tinged with greenish brown. The only constituent identifiable in the hand specimen is a single grain of quartz about 1.5 millimeters in diameter. Under the microscope the rock is found to be porphyritic, but the phenocrysts have been wholly replaced, giving rise to pseudomorphs of two kinds. Those that are in general the larger consist mainly of talc, accompanied by a little calcite and enclosing crystals that are probably magnetite. The form, structure, and composition of these pseudomorphs suggest that they represent olivine. Pseudomorphs of smaller aver- 
age size consist mainly of an olive-green micaceous mineral, possibly related to iddingsite, of moderately high double refraction, with some calcite. The forms of some of these pseudomorphs suggest that they were derived from augite. No olivine or augite has been found, however, in this or any other of the lamprophyres of the district. The groundmass of this specimen consists mainly of plagioclase and brown hornblende, both of them in slender laths whose arrangement suggests a marked flow structure. The hornblende and plagioclase are both so fresh that neither mineral can have formed any of the phenocrysts; since these are now wholly replaced. The plagioclase crystals are composed in greater part of labradorite-bytownite, $\mathrm{An}_{70}$; merging into oligoclase on the rims. The groundmass contains a little orthoclase and quartz and a good deal of calcite.

The Kentucky-Utah tunnel cuts at least three lamprophyric dikes. A specimen from one of them shows the same general character as those taken in and near the Alta tunnel. The rock evidently contained ferromagnesian phenocrysts, some of which have been replaced mainly by calcite and some mainly by chlorite. These lie in a panidiomorphic groundmass consisting mainly of plagioclase and brown hornblende, both considerably altered.

A lamprophyric rock of doubtful classification forms a sheet or dike at the head of Major Evans Gulch. It is dark-gray, fine-grained, and thickly spangled with small flakes of biotite, which the microscope shows to be greenish brown. This mineral, together with calcitic pseudomorphs with forms that suggest augite, is embedded in a cryptocrystalline aggregate of feldspar that appears almost isotropic and whose refractive index indicates that it is near albite. Apatite in fine needles and magnetite in small grains are abundant.

A rock tentatively classed with the lamprophyres but of rather dioritic facies occurs at the west end of Miller Hill, cutting Cambrian rocks thrust over pre-Cambrian quartzite. It is a dark-gray rock of medium-fine grain, in which hornblende, forming slender prisms about 2 millimeters long, is the most conspicuous mineral. Under the microscope idiomorphic crystals of normally colored biotite appear in subordinate quantity. About equal to the hornblende in quantity is slightly clouded feldspar, near $\mathrm{An}_{10}$ in composition. A little interstitial quartz is present, and apatite is rather abundant. The rock appears comparatively fresh: it contains only a little calcite, and a little chlorite, derived mainly if not wholly from the biotite. It seems difficult in this case to account for the low percentage of anorthite in the plagioclase as a result of alteration.

\section{ALASKITE PORPHYRY DIKES}

GENERAI CHARACTER AND RETATIONS

The most sharply defined rock type that forms dikes in the area is a whitish alaskite porphyry, almost with- out ferromagnesian minerals and bearing rather sparse and inconspicuous phenocrysts of quartz and alkalic feldspar. This rock occurs only in dikes, of which it forms comparatively few. The largest and most accessible of these dikes passes along the north side of Alta and has a northeasterly strike. It may be called the Grizzly dike, because it is prominently exposed near the Grizzly tunnel, at the head of City Rock Gulch. The most southwesterly of its known outcrops lies near the south base of Superior Mountain, a quarter of a mile within the west boundary of the quadrangle. It is not continuously traceable eastward from there; much of it is concealed beneath glacial deposits on the slope north of Little Cottonwood Creek. Exposures undoubtedly représenting segments of this dike are found, however, at irregular intervals along a zone extending northeastward to the slope east of Lake Solitude, so that the dike extends at least 5 miles. The irregularities in its course indicate that it is slightly offset by several faults, although few actual intersections of faults with the dike have been seen. In the Honeycomb Cliffs there are two dikes of this character.

Other dikes of alaskite porphyry occur in the southeastern part of the area. The most prominent is conspicuously exposed near the Galena tunnel, north of American Fork and west of Dry Creek. The trend of this dike is about north-northeast, but it zigzags and branches. It is probably the same that crops out prominently on Snake Creek near the most westerly tunnel of the Steamboat mine.

The intrusion of the alaskite porphyry, as of the other igneous rocks, obviously occurred much later than the deposition of the latest pre-Quaternary sedimentary rocks. Regarding the relation of these dikes to the large granular intrusive bodies the evidence is not altogether satisfactory. The most definite clue is afforded by the fact that in the Honeycomb Cliffs a dike of diorite porphyry, presumably an offshoot of the Clayton Peak stock of diorite, is cut through diagonally by a dike of alaskite porphyry. The Grizzly dike also cuts a dike of altered diorite porphyry in the Grizzly tunnel, and a dike of alaskite porphyry, which may be called the South Park dike, apparently cuts a dike of granodiorite porphyry near the Steamboat tunnel. Neither the Grizzly nor the South Park dike, however, has been observed to cut the Clayton Peak stock, the later Alta stock of granodiorite, or the Little Cottonwood stock of monzonite.

\section{PETROGRAPHY}

The alaskite porphyry in its weathered outcrops is in general a creamy or yellowish white but is stained in places with orange or red ocher. It breaks with a conchoidal fracture rather than in polygonal joint blocks (pl. 18, A), and near the walls of the dikes it has a rude platy parting parallel to the walls. Unweathered specimens of this porphyry are dull white or very pale gray, 
with a faint tinge of green. The greatest part of the rock consists of a groundmass having a fine stony texture. Sparsely strewn through this base are crystals of white feldspar, which do not stand forth in contrast to the groundmass, and of clear quartz, which is conspicuous because it appear's dark. No ferromagnesian minerals, as a rule, are visible to the naked eye.

'The alaskite porphyry is very susceptible to alteration, and in even the freshest specimen taken, which was obtained near the Grizzly tunnel, much alteration is visible under the microscope. This specimen shows a fer phenocrysts of quartz and of orthoclase, which encloses a little calcite and sericite but is not much clouded with kaolin. Several large polygonal areas of calcite are probably pseudomorphs after plagioclase. A strip of calcite and colorless mica presumably represents a crystal of biotite. A few small grains of magnetite are present. The groundmass consists mainly of quartz and orthoclase in nearly equal quantity, the quartz in roundish grains and the orthoclase interstitial. Flecks of calcite and of sericite are abundant; they may in part be decomposition products of plagioclase.

In most of the few specimens of this rock that are available the feldspar phenocrysts are almost wholly replaced by calcite and sericite. In one hand specimen, however, which is flecked with rusty cavities that may represent weathered-out orthoclase, all the feldspar phenocrysts revealed by the microscope are of albite. It may reasonably be supposed that the two specimens which have been described were alike originally, because the rock type to which they belong is remarkably uniform in megascopic appearance and is sharply distinct from any other occurring in the region. The fact, then, that the feldspar phenocrysts in one are of albite alone and in the other of orthoclase alone would be due to the effect of differing agencies of alteration at the two localities where the specimens were taken. A perfectly fresh, well-crystallized specimen of the rock presumably would contain rather sparse phenocrysts of both orthoclase and albite, as well as of quartz, and sporadic ones of biotite, in a groundmass consisting mainly of quartz and orthoclase but containing also a little albite.

\section{QUATERNARY DEPOSITS}

The Quaternary deposits of the area, all of them much younger than the igneous rocks, include glacial deposits, landslides, talus, alluvial fans, and valley alluvium.

\section{GLACIAL DEPosits}

The work of glaciers in this règion has been described by Atwood. ${ }^{50}$ In relation to the main purposes of the study upon which the present report is based, the glacial geology of the area was regarded as of minor importance and was not especially studied; but a few brief notes

\footnotetext{
${ }^{\infty} \Delta$ twood, W. W., Glaciation of the Uinta and Wasatch Mountains : U. S. Geol. Survey Prof. Paper 61, 1009.
}

concerning it may serve to attract the attention of glaciologists to a field in which they can find much to do. The Cottonwood-American Fork area probably exemplifies the work of glaciers as fully às any area of the same size in the Wasatch Mountains, and glaciological study of the area would be greatly aided by the excellent contour map on the scale of 1:25,000 which is now available, whereas Atwood had to be content with a map published on a scale of $1: 250,000$.

Characteristic sculptural features carved by glaciers have been pointed out on page 5 . The most outstanding are the $U$-shaped valleyss and the cirques. (See pl. 2.) Ice was of course most likely to accumulate and cut cirques on northward-facing slopes at high altitude, but the influence of surrounding topographic features and of structure have also been influential in places. Mineral Flat, for example, is obviously the floor of a capacious glacial cirque, though its altitude is little more than 10,000 feet. Glacial action here seems to have been favored by structure-plucking along the Alta overthrust having been perhaps relatively easy-by the great height of two adjacent peaks, and by the great extent of the basin to the south, which evidently held a large glacier.

The south-facing Major Evans Gulch, on the other hand, though its head is as high as Mineral Flat, seems to have been but slightly glaciated in the last glacial stage, because its lack of the favorable conditions that obtained at Mineral Flat. The basin south of Twin Peaks, again, was deeply excavated, despite its southward aspect, by virtue of its great altitude.

The most extensive morainic deposits in the area lie in the valley of Big Cottonwood Canyon, between Brighton and the mouth of Days Fork. Those in the valley bottom are characterized by their hummocky surface interspersed with boggy places, and they consist predominantly of boulders of diorite and granodiorite from the Clayton Peak and Alta stocks, which are widely exposed at the head of the valley. A great lateral moraine forms the crest of the spur north of Brighton, and others well expressed by the contours (pl. 1) lie east of Brighton and on the slopes west of Giles Flat. At the mouth of Mill D South Fork is a terminal moraine which evidently diverted the lower part of the stream into its present northwestward course.

Little Cottonwood Canyon contains no such extensive morainic deposits as Big Cottonwood Canyon within the mapped area, though it is the only canyon in the Wasatch whose moraines protrude into Salt Lake Valley. A bulky accumulation of moraine lies near the mouth of Gad Valley Gulch. A terminal moraine of a late stage near the western boundary of the area is shown in plate 2, $A$, and moraines in Albion Basin are conspicuous in plate 2, $B$. A few morainic boulders were found near the brow of the hill south of Alta at an altitude of 9,600 feet. The bench west of Alta is strewn with 
morainic material, the large boulders there being mainly of granodiorite, which interferes considerably with the working out of the complex structure.

The upper canyon of American Fork, north of Miller Hill, contained in late Wisconsin time a glacier about a thousand feet deep. The morainic material on the gentle slope northeast of the summit seems mainly to have been deposited by this glacier, though some contribution may have been added by a small glacier which probably once lay on the north side of Miller Hill.

The east-facing head of Mary Ellen Gulch is a hanging valley containing a great mass of moraine near its brink, doubtless marking a pause in the recession of the glacier. Lateral moraines loop around the spur west of the lower part of Mary Ellen Gulch and slope gently westward along the slope above Graveyard Flat. The relation of these moraines to a pre-Wisconsin landslide are discussed below.

\section{LANDSLIDES}

Only a few of the many landslides in the area were considered large enough to map. Some of them, such as the one south of Snake Creek, the one west of Dry Fork, and the one east of Mill D South Fork, are subdued in character and probably of rather early postGlacial age. Two others are remarkable enough to merit further description. One, which may be called the Graveyard Flat slide, is very large and of unsually great age, having been formed before the last glaciation. The other, the Albion Basin slide, is much more recent, but for that reason it presents a striking example of fresh landslide topography.

\section{GRAVEYARD FLAT LANDSLIDE}

The most remarkable landslide in the area is in the valley of American Fork between Major Evans Gulch and Mary Ellen Gulch. It is named for Graveyard Flat, which has been carved from it. The slidden mass is of unusually great size, but its chief interest depends on its great age; it came to its present position before the last glaciation, in pre-Wisconsin time.

The material forming the slide is exposed in many cuts along the road between the two forks. In some exposures, where it has the southeasterly dip that prevails in this vinicity, it might be taken for rock essentially in place, perhaps loosened a little by creep; elsewhere, however, the fragments are thoroughly jumbled. On Graveyard Flat there are blocks 30 feet or more in length that have a deceptive resemblance to natural ledges, but the dip of the bedding in them is altogether different from that of nearby strata that are clearly in place. In the post-glacial gorge below the road shattered, loosely-cemented masses of Cambrian shale and limestone are exposed in which an obscure bedding can be seen; but that bedding dips in general toward the stream in exposures on the southeastern as well as the northwestern side of the valley.

All these facts can be explained as the result of a great landslide that came down from the slope northwest of Graveyard Flat. The geologic conditions on this slope are favorable in a most unusual degree to sliding. Over most of an area of about a quarter of a square mile the bed-rock surface is a dip slope, inclined about $25^{\circ}$, of shale belonging to the upper shale member of the Ophir, whose thickness here is hardly more than 100 feet. A rock mass lying on such a surface, when it once became loosened, might slide down it with relatively high speed.

The time at which the sliding occurred is indicated, in a measure, by the distribution of morainic material on the slope and on Graveyard Flat. The flat and the terrace across the stream to the east are parts of an old valley floor carved on the slidden material; and they are strewn with undisturbed morainic deposits. Still more-pertinent evidence is afforded by the usually well preserved lateral moraine, sloping gently down-valley, which extends along the lower part of the recess left by the landslide. This moraine and that on the flat must have been deposited not only after the great slide had taken place, but after it had been largely removed by erosion to form a flat-bottomed valley.

The sequence of events recorded by these features is believed to have been essentially as follows: First the valley, in pre-Wisconsin time, was scoured out by a glacier almost to its present depth. The slopes were thus oversteepened, and soon after the glacier withdrew in the pre-Wisconsin inter-glacial stage the inadequately supported rock on the dip slope of shale to the north gave way, moving, not necessarily with catastrophic violence, but with impetus enough to carry it part way up the opposite slope of the valley. When, in Wisconsin time, a new glacier came down the valley it partly removed the slidden material to form a flat-bottomed trough whose floor was about 200 feet higher than the one that held the earlier glacier. This Wisconsin glacier deposited the morainic material. which now mantles the flat and part of the adjacent slope. Finally, after the glaciers withdrew, post-Wisconsin stream erosion has carved a gorge through the slidden material and a little way down into bedrock.

\section{ALBION BASIN LANDSLIDE}

The Albion Basin landslide is about three-quarters of a mile broad at its head, beneath the cliffs of Devils Castle, from which a narrowing tongue extends northward more than a mile. The slidden mass is most clearly distinguished from talus by the length and gentle slope of this tongue, near the lower end of which are isolated blocks of limestone more than 20 feet in diameter. The slide was probably in the main the result of a single immense rock fall from the glacially oversteepened cliffs of limestone.

\section{ALIUVIUM}

Alluvial deposits wide enough to map occupy only a small fraction of the area here described. The largest alluvial tract is on Big Cottonwood Creek and extends 
from the ranger station to the lower end of Reynolds Flat. The alluvium here seems to have been deposited in the hollow behind a terminal moraine. Many other alluvial areas both in the main valleys and their hanging tributaries likewise lie behind morainic dams, at places where there formerly were small ponds.

In Little Cottonwood Canyon the largest alluvial area is the one, about a mile long, that contained most of the town of Alta. This flat is not terminated by a moraine; the stream, on the cuntrary, enters a little gorge in bedrock near the Columbus-Rexall tunnel. The alluvium seems rather to have been deposited along a part of the canyon that was overdeepened by glacial scouringperhaps even in a shallow rock basin.

TALUS AND ALLUVIAL FANS

Talus has accumulated since the retreat of the ice at the bases of the cliffs formed by glacial erosion. The smaller areas are not shown on the map, but the approximate boundaries of some of the larger areas are shown. The choice of areas to be mapped has not been determined by any consistent limit of size; the bodies of talus mapped either are especially conspicuous, such as those on the north side of the Twin Peaks or in the west head of Mill D South Fork, or conceal complex bedrock structure, such as that north and south of the Kennebec tunnel. Some of the talus, such as that near the Monte Cristo shaft, consists of coarse angular blocks and has an uneven surface, which indicates that it is still annually affected by creeping movements; some, such as part of that near the Kennebec tunnel, is thickly mantled with vegetation and must long have been quiescent.

Some of the larger alluvial fans, also, are mapped. The material composing the fans is intermediate in character between talus and valley alluvium, but it is rather more easily delimited from the alluvium than from the talus and is therefore mapped in the same color pattern as talus. -

\section{STRUCTURE}

\section{GENERAL OUTLINE}

Some help toward understanding the very complex geologic structure of the Cottonwood-American Fork area may perhaps be obtained from the generalized map forming plate 19 and from the following attempt to outline the sequence of events that is recorded in this structure.

During an immense time-interval that began long before the Cambrian period and continued to the end of the Cretaceous, the part of the crust that underlay the area here described underwent but little deformation. For most of this time it was receiving sediments. When, at the beginning of the Cambrian, and again at the beginning of the Devonian period, it was uplifted, eroded, and again submerged, it was merely tilted and broadly warped, to so slight a degree that the resulting angular unconformities can be directly observed in only a few favorable exposures. Those far more pronounced movements that produced folds and faults began with the Laramide revolution, which occurred in late Cretaceous and early Tertiary time.

The earliest deformation of a more decided character was pretty certainly a folding on axes that strike nearly north and south. Some such folding must have preceded the formation of the overthrust faults, which are the oldest features that are conspicuous on the generalized map forming plate 19 .

The overthrusts dip for the most part eastward, but they originally dipped westward, their present easterly dips being a result of deformation. They form part of a zone of overthrusting-one of the dominant features in the structure of the North American Cordillera-which, crossing the international boundary, extends far northward into Canada and southward into Montana, Utah, Nevada, and southern California. Throughout this vast region the upper plates on the thrust faults moved for the most part eastward over surfaces that dipped gently westward, and in the main their dips are westward still, although they have in places been greatly deformed.60 The fact that the faults in the area here described also moved eastward on surfaces that originally dipped toward the west is proved by the drag folds associated with the thrust faults.

The most spectacular group of these drag folds is shown in plate $20, A$. Here the axial planes of the folds in the shale below the thrust lean strongly eastward, and they would still do so if the crust were tilted so as to make the thrust plane horizontal.

When drag folds were persistently looked for, they were found in many places; and they had the same general attitude relative to the adjacent thrust planes as that shown in plate 20, $A$. Exposures of Cambrian shale on the slope north of the Columbus tunnel show similar crumpling on a much smaller scale. The quartzite in Mount Baldy is thrown into several small open folds leaning eastward, which are best seen on the south slope of the mountain, from Mineral Flat. The Madison limestone, with its stratification marked by blue and white bands, is exposed beneath the Alta overthrust in a cliff on the west slope of Mount Baldy, where it shows folds that are sharper and of more marked eastward inclination than those in the quartzite. The most strongly recumbent folds that have been seen in the area are in the Humbug formation on the west side of

\footnotetext{
${ }^{60}$ Some examples of these overthrusts, in part deformed, are described in the following publications:

Willis, Bailey, Stratigraphy and structure, Lewis and Livingston ranges, Montana: Geol. Soc. America Bull., vol. 13, pp. 313-343, 1902. Blackwelder, Eliot, New light on the geology of the Wasatch Mountains, Utah : Geol. Soc. American Bull., Vol. 21, pp. 517-542, 767, 1910. (Eastward dip regarded as original.)

Emmons, W. H., and Calkins, F. C., Geology and ore deposits of the Philipsburg quadrangle, Montana: U. S. Geol. Survey Prof. Paper 78, pp. $146-150,1913$.

Blackwelder, Eliot, Wasatch Mountains revisited (abstract) : Geol. Soc. America Bull., Vol. 36, No. 1, pp. 132-133, 1925. (Eastward dip regarded as a result of deformation.)
} 
Silver Fork Canyon. These appear to lie beneath a relatively small overthrust. Their attitude is not fully. known, because they are cut diagonally by the slope, but they suggest eastward rather than westward overthrusting. The drag folds on every other fault where they were observed indicate that the block above the thrust has moved eastward relatively to that beneath the thrust. This conclusion was presented before the Geological Society of Washington in $1921 .{ }^{61}$

The major thrust faults evidently were formed, and the movement upon them probably had reached its full extent, before the igneous rocks were intruded. The Grizzly overthrusts, for instance, near the MichiganUtah mine are cut across by the intrusive contact of the Alta stock of granodiorite, which is not faulted nor sheared along the course of the overthrust. Dikes of various kinds also cut across the overthrusts-though in one instance a late overthrust apparently cut across a dike (see p. 59.) - and the ore-bearing fissures cut the overthrusts and were the feeders of ore deposits that extended along thrust contacts.

The time at which the thrust faults were deformed is another question. A tilting to the east would be a natural result of the persistence of the eastward push that originally caused the thrust faulting, once the movement upon these faults was in some way obstructed. The view advocated in a previous discussion of the structure ${ }^{62}$ was that the eastward tilting had been substantially completed, by the persistence of the same forces that had produced the early north-south folds, before the period of intrusion; that the intrusion of the stocks had been contemporaneous with the formation of the Uinta anticline; and that the thrust faults, after having been tilted eastward, were arched by the Uinta folding at essentially the same time that the stocks were being intruded. On further consideration this view still seems to be at least partly valid, but to have been carried too far.

The most unassailable concrete fact involved in the problem is that the Alta stock of granodiorite cuts across the Grizzly overthrusts, and it seems virtually certain that in general the stocks are later than the overthrusts. It still seems probable, moreover, though not certain, that the stocks were intruded contemporaneously with the uplift along the Uinta axis.

The Alta overthrusts, on the other hand, with their general north-south course, must have been preceded by some of the folding on north-south axes which characterizes the Wasatch Mountains. It therefore still appears highly probable that the crustal movements that gave birth to the Wasatch began earlier than those that gave birth to the Uinta.

${ }^{61}$ Calkins, F. C., Thrust faulting in the Cottonwood district, Wasatch Mountains, Utah [abstract]: Washington Acad. Sci. Jour., vol. 11, No. 17, p. .422, 1921.

${ }^{2}$ Butler, B. S., and others. The ore deposits of Utah : U. S. Geol. Survey Prof. Paper 111, p. 252, 1920.
The pushing that first produced the eastward overthrusts and later tilted them eastward may, however, have been renewed after the Uinta uplift had been established and the stocks, or some of them, had been intruded. It has been pointed out by Eardley ${ }^{63}$ that the Uinta structure would offer the resistance to continued overthrusting that, as above suggested, would result in jamming and eastward tilting. On several of the faults the eastward sliding had certainly amounted to many miles before the jamming occurred, there is no evident reason for supposing that the overthrusts in this area are especially small or local.

The time relation between the tilting of the Grizzly overthrust and the intrusion of the Alta stock is not obvious. It seems easiest to imagine that the intrusion occurred later than the tilting, but it is quite thinkable that both the overthrust and the stock were tilted eastward during the movement of the Silver Fork fault, which was later than the intrusion. It seems possible, however, that far more vigorous deformation of the overthrusts occurred later than the intrusion of the Alta ,stock.

An indication that this may be so consists in the highly localized steepening and even overturning of the overthrusts and the strata in the vicinity of Alta, which is especially. well displayed on the slope east of the South Hecla-mine. It can hardly be an accident that this maximum deformation is confined to the area in which the outcrops of the Alta and Little Cottonwood stocks are nearest together. The Alta stock of grandodiorite is here in contact with the Cambrian shales and limestones, not separated from them by the more competent Tintic quartzite and older strata; and it is conceivable that an eastwaid push, occurring after the granodiorite solidified, caused these relatively soft strata to crumple against the resistant igneous mass. This hypothesis is not, indeed, supported by the presence of any marked shearing in the granodiorite, nearby or elsewhere, nor by any evidence that this rock has itself been affected by thrust faulting; all the stocks obviously were intruded later than most of the thrust faulting. It is likewise conceivable that the granodiorite exerted a westward push, in the nature of underthrusting, while it was being intruded, but here again the evidence is not conclusive. If the granodiorite played either an active or a passive part in this deformation, the little Cottonwood stock may have played a similar part. These two intrusive bodies are nearer together on the surface in this vicinity than anywhere else. The Little Cottonwood stock is thought to be the later, and its intrusion might have exerted an eastward push, resisted by the already solidified mass of granodiorite.

The overthrust that have thus far been mentioned have brought older rocks upon younger, but a few low-

63 Eardley, A. J., Structure of the Wasatch-Great Basin region : Geol. Soc. America Bull., vol. 50, no. 8, p. 1304, 1939. 
angle faults in the area have brought younger rocks over older. Such faults are not extensively exposed in this area, although one or more of them have a vast extent in an area to the south which is being studied by $\mathbf{A}$. A. Baker. Mr. Baker will in time be better qualified than the present writer to express an opinion as to when these anomalous overthrusts occurred; meanwhile some reasons are suggested further on (p. 60) for believing that they are much younger than the overthrusts of the more usual type, and younger than some of the normal faults.

Of the faults other than the overthrusts, a few are earlier than the overthrusts or contemporaneous with them. A few may have occurred within the period during which the igneous rocks were being intruded, and some small ones may be due to settling of the crust above the cooling and contracting stocks; such adjustment might account for some of the faults that are in part normal and in part reverse, though other causes, such as later deformation might have come into play. At any rate the fissures of northeasterly strike, many of which contain dikes, were probably formed during the intrusion of the stocks. Faulting has occurred on some of these fissures that are feeders to the ore deposits; and a few of the dikes appear. to follow. small faults, the movement having probably occurred during or a little before the injection of the dikes. Most of the normal and steep reverse faults, however, are younger than the intrusive bodies.

By far the greatest of these north-south faults is the Silver Fork fault, which, unlike most of the other normal faults in the area, has a low dip. This immense dislocation is thrown by other faults, but its relation to some others is unknown; it is younger than the intrusive rocks and the principal mineralization.

The youngest, on the whole, of the faults appear to be the steep ones, some of them normal and some reverse, that strike nearly north and south. Some. of these are shown on plate 19, where one of them, the Montezuma, is shown to throw the Snow fault, which is presumably a branch of the Silver Fork fault and of the same age. The greatest of the steep north-south faults are the Superior faults, both of which are about vertical and have their downthrow on the east side, as do most of the other faults of this class.

In a few places, notably along the south side of Mineral Flat and on the slope southeast of the Devils Castle. are examples of what seems to be block faulting, in which movement may have occurred simultaneously on faults that meet at large angles. It is difficult to work such movements into a chronological scheme.

\section{FOLDS}

\section{UINTA ARCH}

The broad eastward-pitching anticline regarded as a composite of the Uinta arch and the west limb of the
Logan syncline is much obscured by faults and intrusive bodies, but it is expressed by the dips-chosen as being the more persistent-that are plotted on the generalized map (pl. 19). The oldest rocks crop out in the western part of the area, and the later formations, broadly speaking, succeed one another in order of decreasing age to the northeast and southeast. Plate $6, \mathrm{~A}$ shows a section of the western part of the north limb of the fold. The youngest strata in the area crop out, with a northeasterly dip, in the northeast corner of the Cottonwood quadrangle.

Inspection of the combined Cottonwood-Park City map ${ }^{64}$ seems to show that this fold is essentially a westward continuation of what Boutwell ${ }^{65}$ called the Park City arch. In the area shown by the Park City map, that fold strikes a little north of east and pitches northeastward, but its general form can be better judged on the more comprehensive Cottonwood-Park City map" just cited, and still better on the geologic map of the State which forms plate 4 of Professional Paper 111. From inspection of the State map it is clear that the Park City anticline and its westward prolongation are part of the Uinta anticline. In the area considered in this report the strike of the anticline is about eastnortheast, its pitch is eastward, and its axis, though it cannot be located with precision, may. be regarded as passing somewhere near Alta.

\section{OTHER FOIDS}

Apart from the Uinta arch, the area contains no folds that can be traced for any considerable distance. There is a faint suggestion of a syncline near Devils Castle, and the beds plunge steeply northward near Sunset Peak. There are also some open folds in Miller Hill.

Undulations in steeply dipping tillite, shale; ; and quartzite are well exposed in the slope west of Superior Gulch. (See section $C-C^{\prime}$, pl. 4, and pl. 7, A.) The beds here form a syncline flanked on the east by an anticline, both leaning over toward the east. This same structure, in part, seems to continue southward to the ridge east of Twin Peaks. (See section 'E-E', pl. 4.) Its character suggests the agency of an overriding pressure from the west, such as would have resulted, had it continued long enough, in the forming of recumbent folds or of overthrusts that dip westward.

Although the thrust planes appear, in most sections, to be virtually parallel to the strata, crumples clearly related to the thrusting can be seen at many places, notably south of Carbonate Peak (pl. 20, $A$ ), on the slope north. of the Columbus tunnel, and on the west slope of Silver Fork Canyon opposite the Prince of Wales shaft. The character of the crumpling is discussed beyond (p. 54),

\footnotetext{
${ }^{4}$ Butler, B. S., and others, The ore deposits of Utah:.U. S. Geol. Survey Prof. Paper 111, pl, 27, 1920.

${ }^{6}$ Boutwell, J. M., Geology and ore deposits of the Park City district, Utah : U. S. Geol. Survey Prof. Paper 77, p. 94, 1912.
} 
for the sake of the light it throws on the history of the thrust faults.

\section{OVERTHRUST FAULTS}

GENERAL FEATURES

The faults that are here described as overthrusts are, or were originally, of low dip: steep reverse faults are described elsewhere together with the normal faults. The prevailing strike of the overthrusts is northward, though their outcrops are in a measure convex toward the east like those of the sedimentary strata and in at least one locality the overthrusts deviate abruptly from the prevailing local strike of the beds. Their dipsagain like those of the strata-are prevailing eastward at low angles, but in some places the overthrusts dip gently westward, and on the slope south of Alta eastward dip steepens, passes through verticality, and becomes a reverse dip to the west.

The original dip of these overthrusts was not eastward. Had it been so, and had the upper plate on each of the faults accordingly moved westward, the structure of this region would present.a striking exception to that of a long belt in the Cordillera, including parts of Utah and Montana and extending into Canada. In this vast area there are many thrusts faults whose prevailing dip is westward, and which caused relative eastward movement of the upper plate on each fault. In the Cottonwood-American Fork area, all of the drag folds which in places are associated with the overthrusts indicate relative eastward movement of the overriding mass; and, although in most exposures that can be taken in at a glance there seems to be a striking parallelism between the overthrusts and the bedding, a study of more extended sections indicates that the bedding dips, on the whole, more steeply eastward than the overthrusts-a relation that, like the drag folds, indicates relative eastward movement of the over-riding blocks.

The prevailing easterly dip of the overthrusts, then, is a result of later movement; and this movement was similar to that which originally produced the overthrusts in being an eastward pushing over. The effect of such a movement is vividly displayed in the eastwardleaning flexure of the contorted tillite in Superior Peak (pl. 7, A) which may have been produced either at the same time as the Alta overthrust or later. It is easy to imagine the effect of a continued stress of this character on a west-dipping overthrust when for some reason the eastward sliding of the upper plate was arrested: the fault plane would first become tilted eastward, and it might, by a persistence of the stress, at last be overturned. Renewed fracture might occur and result in the formation of later, west-dipping, overthrusts, but very few of these appear to have been formed in the Cottonwood-American Fork area.

The area thus contains overthrusts that have been deformed to a degree that is unusual if not unique in America, though far short of that which has produced the repeated overturning and rolling out that have occurred in the Alps.

The overthrusts exposed west of the Silver Fork fault, along the north side of Little Cottonwood Canyon and in the canyon of Mill D South Fork, were formerly named, ${ }^{68}$ in order from west to east: the Alta overthrust, the Columbus overthrust, and the Reed \& Benson thrust zone. The overthrusts east of the Silver Fork fault were called the Grizzly overthrusts and were regarded as possibly equivalent to the Reed \& Benson thrust zone. Further study and reconsideration has modified some of these opinions. It has tended to emphasize the fact that the fault originally called the Alta overthrust is associated with several others, which together with the main fault may appropriately be considered as constituting the Alta thrust zone. The Columbus overthrust now seems distinctly subordinate in magnitude to the Alta or even the Reed \& Benson thrust zones. The relation of the Grizzly overthrusts to those west of the Silver Fork fault is still uncertain, but it now seems more likely than it formerly did that the Grizzly thrusts are equivalent to the Alta. A lower overthrust in this zone, which brings the Madison limestone over the Deseret, has been recognized since the publication of the earlier reports.

The Grizzly overthrusts reappear south of the Alta stock. Correlation from north to south among the overthrusts west of the Silver Fork fault, on the other hand, is 'somewhat a matter of conjecture. The main Alta' overthrust is cut off by the Silver Fork fault in Mineral Flat, and the several overthrusts exposed south of the head of American Fork, between Mary Ellen Gulch and Silver Fork, appear to have been originally beneath this main overthrust. They are probably to be regarded as part of the Alta thrust zone, which, if this view is correct, is even thicker and more complex to the south than it is in the latitude of Alta.

All the overthrusts thus far mentioned have pushed older rocks over younger ones. Recent field work by Baker ${ }^{67}$ has shown that in a large area adjoining the Cotton-American Fork area on the south, east, and southwest there are extensive overthrusts that have pushed younger rocks'over older ones. The occurrence of such anomalous overthrusts in the region was suspected in 1919 by the writer, who then made a rude notebook sketch in American Fork Canyon to show the discordance between the nearly horizontal strata (later learned to be Weber) forming the upper part of Mount Timpanogos and the steeply dipping, highly contorted Mississippian and older strata exposed lower down on the north side of the canyon.

\footnotetext{
Butler, B. S., and others, The ore deposits of Utah: U. S. Geol. Survey, Prof. Paper 111, p. 245, 1920.

${ }^{07}$ Baker, A. A., and Williams, J. S., Permian in parts of Rocky Mountain and Colorado Plateau regions: Am. Inst. Petroleum Geol. Bull., vol. 24 , No. 4 , p. 625,1940 . The reference here is very brief, but Mr. Baker has shown some of these contacts in the field to the writer, with whom he has discussed them orally.
} 


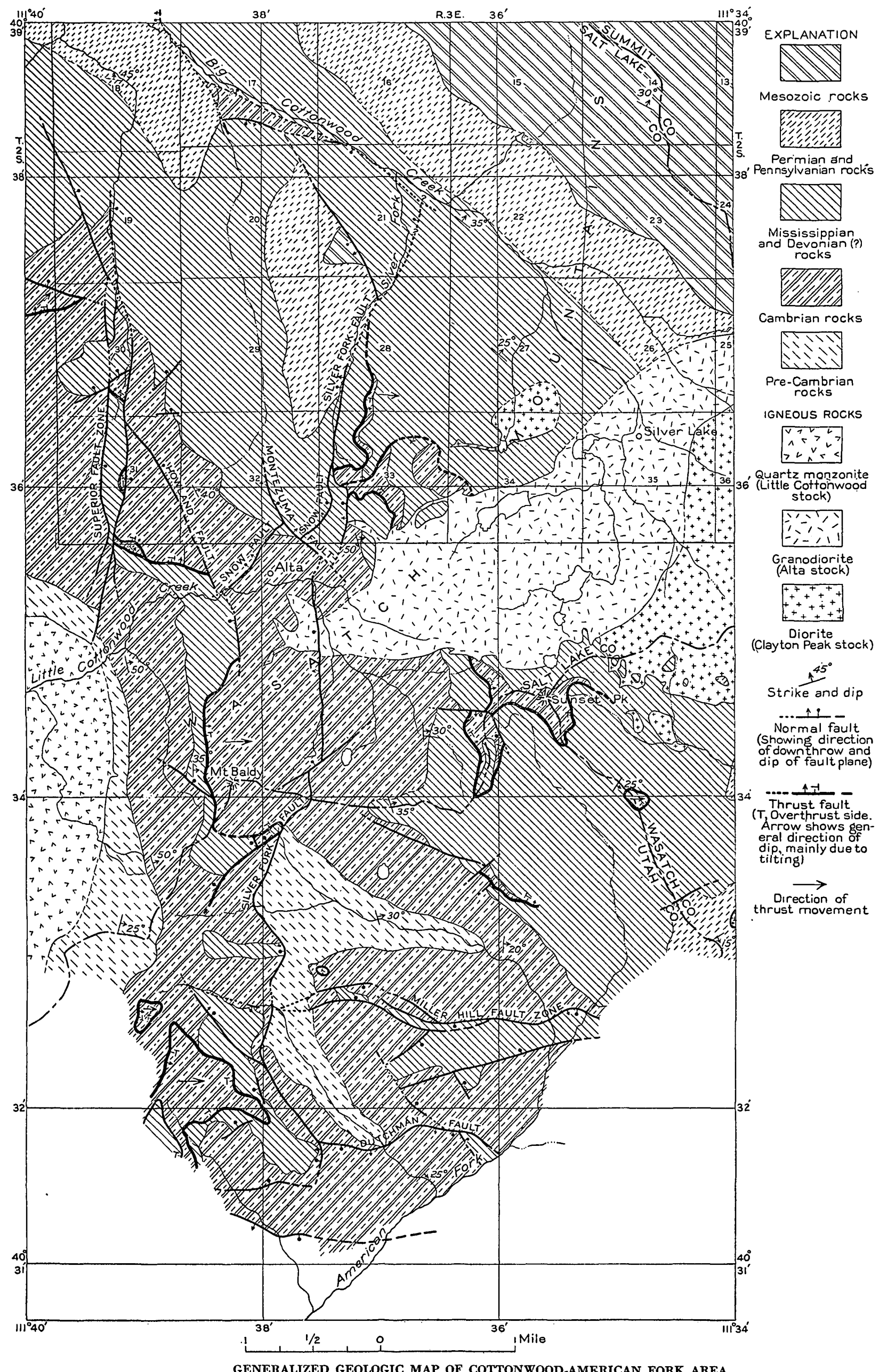




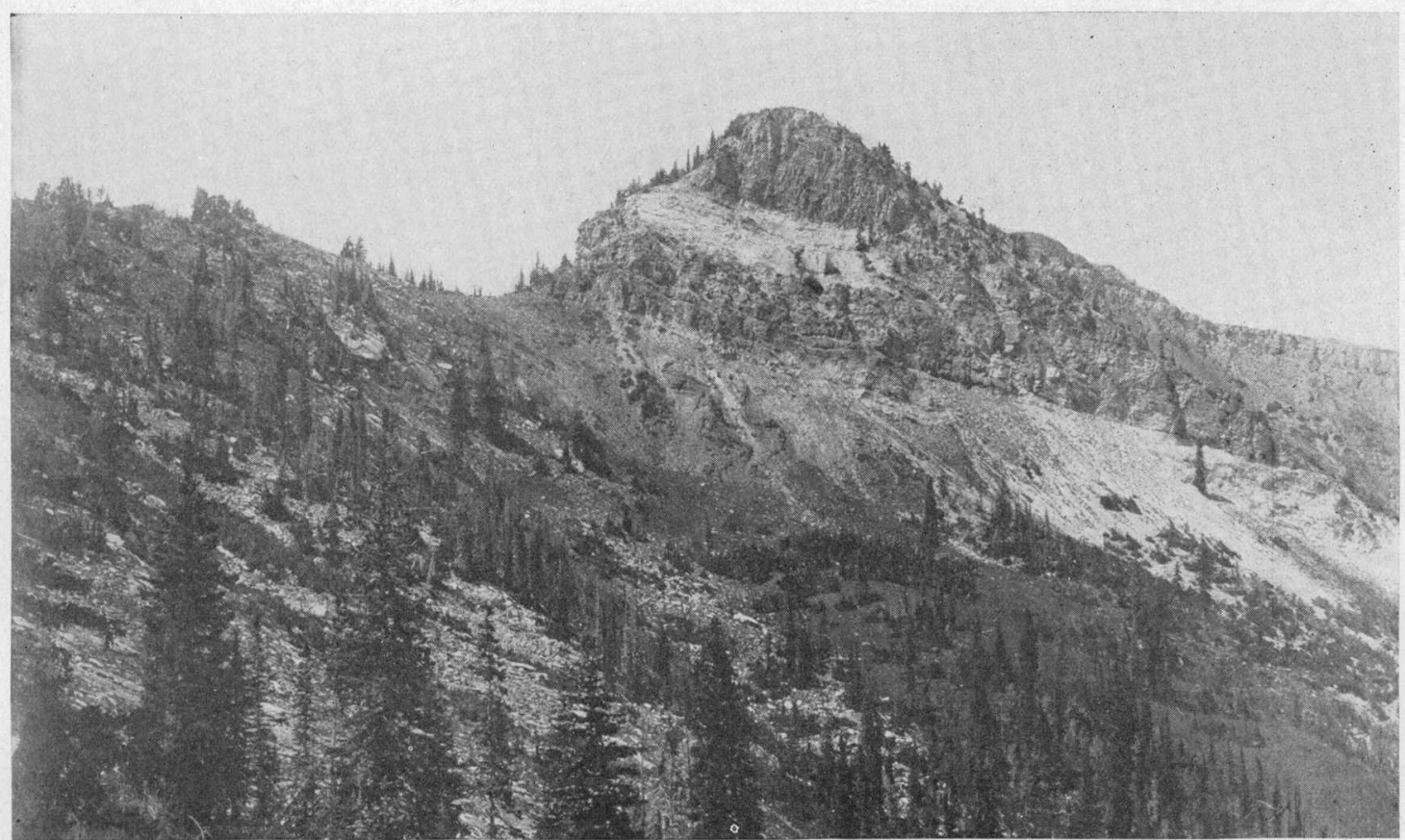

4. ALTA OVERTHRUST NORTHWEST OF MONTREAL HILL

From the saddle, the main fault slopes down toward the right. Smooth fissure a little higher marks a minor parallel fault. Rock above the overthrust is Tintic quartzite; beds below are Ophir shale, with drag folds leaning eastward.

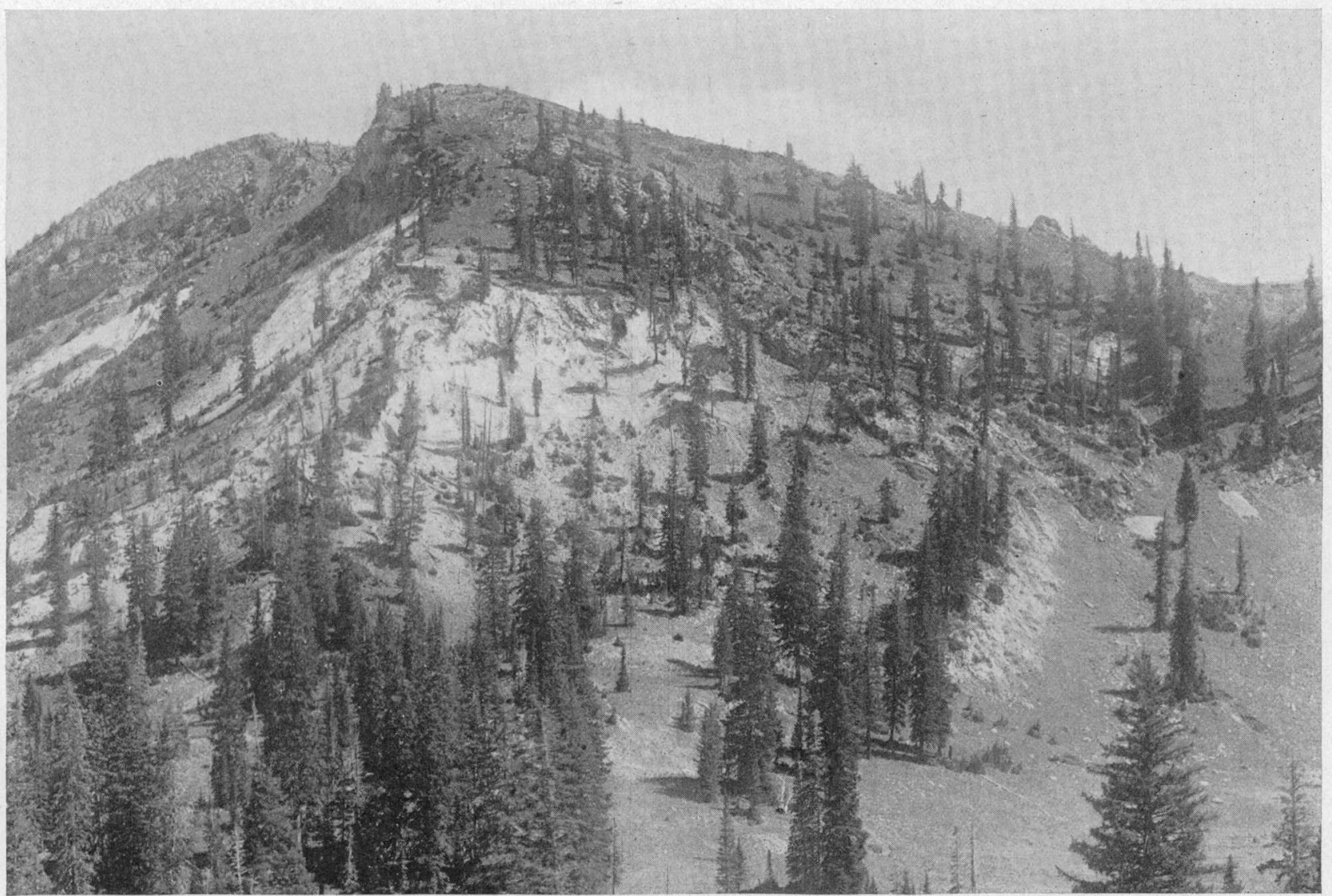

B. SILVER FORK FAULT ON DAVENPORT HILL.

Breceia of Silver Fork fault slopes down toward the right from summit of hill and is joined by breceia of Snow fault near lowest dump. 
The only overthrust of this unusual kind that is certainly exposed in the Cottonwood-American Fork area is on the narrow divide northwest of Miller Hill, but a fault of low dip on the ridge west of Major Evans Gulch may be the same one or another of the same kind and may be an extension of one of those mapped by Baker. There is also reason to suspect that thrusting parallel to the strata, without materially disturbing the sequence of the beds, has occurred near the base of the Deseret in the Devils Castle ridge; and there may be a fault of this class in the Tom Moore tunnel.

\section{ALTA THRUST ZONE}

The westernmost and most conspicuous of the overthrust faults in the section along Little Cottonwood Canyon was recognized independently in 1912 by Lough$\operatorname{lin}^{68}$ and by Hintze ${ }^{69}$ and was named by Hintze the Alta overthrust. It is best exposed on the steep southfacing slope east of Superior Gulch (pl. 7, $A$ ), where it dips about $25^{\circ} \mathrm{E}$. At the foot of the western part of the slope is an outcrop of Cambrian quartzite, which is overlain successively by the Ophir shale, by a thin remnant of the Maxfield limestone, and by the Jefferson (?) dolomite, the Madison limestone, and part of the Deseret limestone, all in their normal order. Upon the cherty Deseret limestone and nearly conformable to it in dip lies a second thick layer of quartzite. The geologists of the Fortieth Parallel Survey called this the Ogden quartzite and regarded it as of Devonian age. In fact however, this is the same Cambrian quartzite that forms the base of the slope and has been thrust over the Deseret limestone on the Alta overthrust. The fault contact appears simple in a distant view, but detailed study has shown that the quartzite is separated from the Deseret limestone for a short distance by a wedge or lens of crumpled Ophir shale and Maxfield limestone lying between two over'thrusts and split by another.

The complexity that, as will presently appear, is but faintly indicated at this place makes it appropriate to use the term Alta thrust zone rather than Alta overthrust. If any one fault in the zone is entitled to be called the Alta overthrust proper it should be the one that brings the Tintic in contact with the Deseret. This fractuie, however, may not be the main fault in the sense of having the largest throw. It is probably the latest in the zone, so far as initial movement upon it is concerned. It probably bevelled the lower thrusts after very extensive movement upon them had taken place and they had been tilted eastward, and its throw is probably less than that on the lowest thrust in the zone.

In that small area of Cambrian shale and limestone east of Superior Gulch there emerges on the surface the ragged edge of a large mass of such rocks, the size

\footnotetext{
as Loughlin, G. F., Reconnaissance in the Wasatch Mountains, Utah : Jour. Geology, vol. 21, pp. 439-443, 1913.

ov Hintze, F. F...lr.. A contribution to the geology of the Wasatch Mountuins, Utah : New York Acad. Sei. Annals, vol. 23, p. 133, 1913.

and relations of which are best seen underground. Iñ. a large part of the Cardiff mine, for example (pl. 35); inclüding most of the main tunnel and 800 levels, thể Tintic quartzite rests directly on the Deseret limestone; but in descending the main incline we find that these two formations are separated by a wedge, thickening: downward, of Ophir shale. 'In the southern part of the Columbus-Rexall tunnel (pl. 38), and in the Columbús workings on the same level (pl. 40), the complexity of the Alta thrust zone is displayed even more fully. The contact between the Deseret limestone and the rocks thrust over it is exposed in several crosscuts extending westward from the Columbus-Rexall tuinnel. The rock beneath the lowest overthrust is everywhere Deseret limestone, but in none of the crosscuts is the rock overly:ing the lowest fault surface quartzite $;$ in most of them it is Cambrian shale or limestone. In the northern part of these workings, the thrust zone pinches to a singlêt fissure, so that a little south of the raise on the main ore kody to the Cardiff 600-foot level the quartzite is directly in contact with the Deseret limestone, where it remains;; for the most part, in the ground at about this level farther north. The Columbus-Rexall workings are thus, to a large extent, in a great wedge or lens consist: ing mainly of Ophir shale, together with some Maxfield limestone; but even within this mass consisting mainly of post-Tintic, pre-Madison rocks there are one or two lenses of Tintic quartzite.

Separate from these lenses is the easternmost body of quartzite in the Columbus workings, which overlies the thrust fault seen at the top: of the No. 3 inclined shaft. This fault, formerly called the Columbus, is now thought by the writer (Calkins) to be the uppermost fault in the Alta thrust zone, because of its alinement with the fault contact between the quartzite and the Deseret lime stone in the raise. This alinement can be seen by examining plates 38 and 40 together.

The quartzite above the overthrust at the No. 3 shaft pinches out within a short distance to the southeast on the tunnel level; and it pinches out with equal abruptness downward, so that no quartzite appears even on the 300 level. Similar convergence eastward of the bedding-illustrated in section $C-C^{\prime}$, plate 4 -with an underlying thrust fault is exemplified elsewhere in the area, and it seems an expectable result of eastward overthrusting. Probably because of this convergence, the Alta thrust zone in the Wasatch drain tunnel (pl. 39), so far as exposed, contains no rocks older than the Maxfield limestone. The only contact representing the Alta fault zone that has been definitely recognized is crossed by the tunnel near the entrance to the main branch leading northward. Here, within a few feet, it is possible definitely to identify the cherty Deseret limestone on the west side, and limestone or dolomite with the crinkly markings characteristic of the Maxfield on the east side, of a very tight fissure dipping about $55^{\circ} \mathrm{NE}$., which 
unquestionably marks the lowest fault in the Alta thrust zone. The same contact has been located with less accuracy further northwest on the same level.

Although the writer was unable to put his finger upon any other overthrust fault in the drain tunnel; at least one other such fault presumably crosses the tunnel between the main branch and the shorter branches which, about 500 feet farther east, extend to the north and south. Both these branches are in the upper shale member of the Ophir, which dips in general steeply eastward, and the contact with the younger Maxfield limestone to the west would appear most probably to be on a thrust fault; its very obscurity would indeed be characteristic of a thrust fault rather than of some other kind of fault. The east branch of the main north branch also crosses a contact between limestone on the west and shale on the east that is presumably this same thrust fault, being, indeed, marked by a tight fissure. Further east in the tunnel one or minor thrust faults may be crossed, but here the ground is so broken that no such faults were positively identified. If there are any of them here they are probably all in the Alta thrust zone.

Both the general complexity and the local simplicity shown by the Alta thrust zone in the middle part of the Cottonwood quadrangle are exemplified both north and south of Little Cottonwood Canyon.

To the north, the nearest good exposures of the Alta overthrust are not on the surface, where its outcrops are few and short, but in the workings of the Tar Baby mine (pl. 33). Near the south end of the lower Tar. Baby tunnel the overthrust has the same simple character as in much of the Cardiff and as in the cliff east of Superior Gulch: it is a single fissure, dipping gently eastward, along which the Tintic quartzite rests immediately upon the Deseret limestone. But farther north in the workings, and in the Tar Baby upper tunnel, the fault overlain by quartzite swings abruptly so as to strike nearly due easst and dip southward; and the lowest member of the thrust zone in the outer part of the Tar Baby and American Metals workings brings Cambrian rocks upon the Deseret.

The northernmost exposure in the area (pl. 20,A), near the Carbonate mine, is perhaps even more striking in appearance than that east of Superior Gulch; the structural and stratigraphic relations, however, are strikingly different in the two places. In the northern exposure, as in the other, the thrust is parallel to the bedding of the Tintic quartzite in the upper plate, but the underlying rock is Ophir shale, crumpled but in general almost vertical. Here the overthrusting took place mainly on a single fissure, above which, however, is a minor fault which may be either the Columbus or a part of the Alta thrust zone. The rocks in the outer part of the Tar Baby tunnel are in a much faulted layer that forms part of the Alta thrust zone. This layer thickens eastward, but it pinches out to the south, where the Tintic quartzite immediately overlies the Deseret limestone as it does in most of the Cardiff mine.

The Alta overthrust was not followed northwestward beyond the area mapped. It would be more difficult to trace in this direction, where it must in general have quartzitic rocks on both sides, than it was farther south, but as its throw where it was last seen was very great it must persist for many miles and may connect with some one of the overthrusts studied by Blackwelder and by Mansfield ${ }^{70}$ farther north.

To the south in the segment between Little Cottonwood Creek and the head of American Fork, the Alta thrust zone has somewhat the same character as in the ridge north of Little Cottonwood Canyon. This is especially true of the western part of the segment, where the Tintic quartzite overrides Mississippian limestones on a single fault. It seems to cut lower stratigraphically into the underlying beds toward the south, and the limestone immediately beneath the fault in places on the slopes of Mount Baldy may be Madison rather than Deseret.

In the ground immediately east of Collins Gulch, on the other hand, including that explored by the easterly workings of the South Hecla mine, the structure of this zone is bewildering in its complexity. Wherever the thrust fault that cuts off the Diseret limestone is exposed in the mine its.hanging wall, which consists of quartzite so nearby on the surface, is Ophir shale. No quartzite is exposed in the mine, apart from the quartzite below the overthrust in the Sells tunnel. The sedimentary rocks in the southern and eastern workings are dominantly Ophir shale, thought by Calkins to be mainly of the upper member, with some limestone, thought to be Maxfield, which is repeated on a minor thrust fault. The limestone in the extreme southeastern end of the Dwyer level, at least, is certainly Maxfield, for it shows a pisolitic structure which metamorphism and shearing have not altogether effaced. The dips are prevailingly eastward except near this southeastern end of the workings, where they are westward but are beileved to be reverse dips.

This belief is in harmony with observations made at the surface, on the slope facing Little Cottonwood Creek east of the South Hecla mine. Here the dip of both the bedding and the thrust faults steepens downward, and in some of the lowest outcrops the bedding, at least, shows reverse dips toward the west as low as $30^{\circ}$; and it is fairly certain that the thrust faults themselves are locally inverted.

The highly localized overturning of beds and probably of overthrusts in this vicinity, presenting as it does a striking contrast to the uniform low easterly dips on the upper part of the opposite slope of Little Cottonwood Canyon, offers another though perhaps related problem, which has been discussed on p. 52 .

\footnotetext{
${ }^{70}$ Mansfield, G. R., Geology, geography, and mineral resources of part of southeastern Idaho; U. S. Geol. Survey Prof. Paper 152, pp. 150-159, 1927.
} 
The structure in this vicinity, even though it is fairly well exposed, is far from being fully deciphered and still farther from being fully understood. An attempt to draw a structure section correlating the observations made on the surface with those made underground did not lead to a result that could be offered with confidence. It seems reasonable to suppose that here as well as farther north a thick wedge of Ophir shale and Maxfield limestone lies between the Tintic quartzite and the Deseret limestone, but it is so difficult to account for all the fucts by this hypothesis alone that one is tempted to postulate some early faulting-perhaps on the Howland fault-prior to the thrusting, even though the geologic mine maps show that some, at least, of the movement on that fault occurred later than the thrusting (see pls. 38 and 44 ).

The Alta overthrust, in its simple form as a contact between Tintic quartzite and Madison limestone, disappears under the talus on the south side of MountBaldy, and at the east side of Mineral Flat it is cut off by the Silver Fork fault. South of this locality there is no thrust fault whose upper side consists of Tintic quartzite, and no fault that can positively be identified as the main Alta overthrust. The quartzite that forms most of the top of Mount Baldy may have extended far to the south before it was eroded away, or it may have pinched out in this direction within a short distance. However this may be, it seems reasonable to correlate the overthrusts southwest of Mary Ellen Gulch, as a group, with the Alta thrust zone. The overthrust of greatest throw in the southern part of the mapped area crosses the divide between Mary Ellen and Major Evans Gulches nearly at the same place as the aerial tramway. Here the overthrust brings the lower part of the Maxfield limestone over beds near the top of the Madison, whereas in Major Evans Gulch it brings Ophir shale over Jefferson (?) dolomite. Its general dip is southwestward, and the rocks above it dip. southward at slightly steeper angles. At least two higher overthrusts are proved by the repetition of characteristic beds in the Maxfield, the white bed in particular being repeated near the top of the 10,500-foot peak, of which it forms the summit. Lower overthrusts affect the Ophir shale and Tintic quartzite; and the lowest of all -perhaps to be grouped with the thrusts east of the Silver Fork fault near the Albion shaft-brings preCambrian beds over the Cambrian quartzite in the ridge west of the head of Mary Ellen Gulch.

Some of these overthrusts apparently branch, but their courses are obscured in places by talus, especially on the southwest slope of the 10,500-foot peals. Near the head of Major Evans Gulch, a fenster has been eroded through an overthrust that is well exposed on the west side of the gulch, and the lower thrust block is aparently cut by a north-south fault, which is regarded as older than the overthrust. The mapping here, however, is somewhat conjectural, the contacts being much obscured by waste on the northern and eastern slopes of the basin.

\section{COLUMBUS OVERTHRUST}

Thê name "Columbus overthrust" ${ }^{11}$ was applied to the thrust fault that lies a little below the top of the 10,271-foot hill near the head of Superior Gulch. The fault was so named because it was believed, when the preliminary report was written, to be the one followed down ward by the No. 3 shaft in the Columbus workings; but more complete geologic mapping of the Columbus and Columbus-Rexall workings has led the writer (Calkins) to believe that the fault at the shaft is the uppermost member of the Alta thrust zone, continuous with the contact between Tintic quartzite and Deseret limestone from which most of the Cardiff ore body was taken. (See pl. 40 and section $C-C^{\prime}$, pl. 4.) If this. belief is justified, the Columbus overthrust, though well exposed on the surface north of the Columbus portal, where it brings Tintic quartzite over Ophir shale, is not exposed in the Columbus workings. The name, however, is retained, because it has been used in print and because the fault is exposed at the surface of the ground underlain by the Columbus workings.

The dip of the Columbus overthrust in its westernmost outcrop on the crest is about $25^{\circ}$ (pl. 7, $A$ ). It is tlirown down on the west side of a small fault near the point where the trail crosses the crest. On the steep. slope north of this crossing, near the mouth of the caved Rexall prospect tunnel, the thrust contact is exceptionally well exposed. There it brings tillite over quartzite, is essentially parallel to the bedding, and is attended. with no erumpling and little brecciation. Its dip is about $65^{\circ} \mathrm{E}$, having steepened by $40^{\circ}$ in a distance of less than half a mile.

The known outcrop of the Columbus thrust is confined to the triangular area bounded by the Alta thrust and the Superior and Howland faults, but the fault may extend much farther to the north and south. Near the northernmost outcrop of the Alta thrust within the mapped area there is a minor thrust above it and much nearer to it than the Columbus thrust is to the Alta thrust on Little Cottonwood Creek; this minor fracture may be the Columbus thrust.

The Columbus overthrust may extend also south of Little Cottonwood Creek as far as the Alta thrust has been traced. Throughout this distance, at any rate, there is a thrust fault a few hundred feet above the Alta, having a throw apparently of the same order as that of the Columbus. On the slope southeast of the South Hecla mine the first or second mapped thrust above the Alta may be the Columbus. This fault may also cut Mount Baldy, where there is a flat-lying thrust, both walls of which consist mainly of Cambrian quartzite

${ }^{71}$ Butler, B. S., and others, The ore deposits of Utah : U. S. Geol: Survey Prof. Paper 111, p. 245, 1920. 
but which brings the quartzite over the Ophir shale east of the summit.

\section{REED \& BENSON THRUST ZONE}

Several thrust faults above the Columbus thrust are remarkably well exposed on the west slope of $\operatorname{Reed} \&$ Benson Ridge (pl. $6, B$ ) and may therefore appropriately be grouped as the Reed \& Benson thrust zone. All the thrust faults above the Columbus or its supposed equivalent in the area west of the Silver Fork fault are regarded as belonging to this same zone, though it is not possible to trace individual fractures very far.

The most striking exposures of this group of thrusts are in the cliffs east of Mill D South Fork, depicted in plate $6, B$; and the relations observed there are shown, in generalized fashion, on structure section $B-B^{\prime}$, plate 4. There are here at least three mappable tinrusts, the lowest of which, on the line of section $B-B^{\prime}$, causes the duplication of a part of the Ophir shale; the others cause Cambrian limestones to override beds rather low in the Madison limestone. The rocks along the thrusts are nowhere conspicuously brecciated. On the part of the slope south of the latitude of Montreal Spring the faults are almost strictly parallel to the bedding, and here the most conspicuous evidence of their presence is the repetition of the bed of hard, white-weathering dolomite which marks the top of the lowest division of the Cambrian limestones and which is a striking feature of the view forming. plate $6, B$.

The oliffs farther north-about east to northeast of the Tar Baby mine-consist of Devonian and Mississippian dolomite and limestone, uninterrupted by Cambrian strata on the surface. Here it is the whitish bed at the top of the Jefferson (?) that serves as the best horizon-marker, in the same way that the similar Cambrian bed does farther south, being repeated in one section by at least three thrust faults. These overthrusts are nearly as smooth as those to the south, but the bedding in places is far from parallel to them, because the limestones are locally much contorted and are bent into a recumbent anticline whose axial plane leans northward. The significance of this remarkable structural feature, so discordant with the general structure of the area, is not understood; it seems to have been caused by a northward push, and is evidently related to the anomalous east-west course of the Alta overthrust in the two Tar Baby tunnels.

Two east-west faults, one near the Sampson mine and one in the cliffs northeast of the Tar Baby mine, appear to be tear faults essentially contemporaneous with the overthrusts.

South of the locality of their best exposures, toward the divide between Big and Little Cottonwood Creeks and southeastward along the north side of Little Cottonwood Canyon, the faults of the Reed \& Benson zone are fewer-only one being found in some places-and rather inconspicuous. The Emma overthrust, near the top of the Jefferson (?), which is economically important but inconspicuous and not mapped, probably belongs to this zone.

South of Little Cottonwood Creek, several overthrusts that probably belong to the Reed \& Benson zone as above defined are exposed in the upper part of the ridge east of Collins Gulch. They here involve Cambrian limestone and shale, mostly of the Ophir formation. They have a nearly horizontal attitude and in part a low westward dip.

The throw on the Reed \& Benson faults, though presumably less than that on the more conspicuous main Alta overthrust, probably amounts in all to several miles. The parallelism of most of them to the bedding implies a fairly large throw, for such parallelism could not exist at the very beginning of the break. Further evidence that the throw is large is afforded by the fact that the base of the Devonian (?) limestone lies on different parts of the Maxfield limestone, with which it is slightly unconformable, (p. 18) in different blocks. In the lowest block it lies near the base of the Maxfield limestone, whereas in the higher blocks it lies at a much higher stratigraphic level. The great difference in the position of the unconformity, which involves but little discordance of attitude, in adjoining blocks indicates that the blocks were originally far apart.

\section{GRIZZLY OVERTHRUSTS}

The Grizzly thrust zone, so called in Professional Paper 111 because its lowest member crops out near the Grizzly tunnel and at the head of Grizzly Gulch, is probably an eastward continuation of some of the thrusts already mentioned. It seemed most likely, when the preliminary report was written, that it was equivalent to the Reed \& Benson zone, but that opinion was perhaps determined in too great a measure by a reluctance to postulate so huge a throw for the Silver Fork fault as would be necessitated if the Grizzly was equivalent to the Alta thrust zone: This consideration, however, is of doubtful value, and it now seems to be outweighed by one or two facts that favor a correlation of the Grizzly with the Alta zone. The first and most significant fact is that the lower Grizzly'thrust has a footwall of Deseret limestone, as the lowest Alta thrust has for a long distance. A further fact, of more doubtful significance, is that the unconformity at the base of the Jefferson (?) dolomite rests at widely different levels on the two sides of the Grizzly thrust zone-as low as the lower shale member of the Ophir shale in the block below and on the upper member of the Maxfield limestone in the block above. This difference indicates a large movement on these overthrusts, and a similar difference, in the same sense, exists between the blocks below and above the Alta thrust zone. But the stratigraphic level of this unconformity differs greatly on the two sides of a thrust fault in Mill D South Fork that was thought to be in the Reed \& Benson zone. The equivalence of the Grizzly zone to the Alta zone 
thus appears, on the whole, highly probable but not absolutely certain; the name Grizzly will therefore be retained for the thrust faults east of the Silver Fork fault.

What is probably the greatest thrust of this zone may be called the Grizzly thrust proper. This fault was first recognized in 1917 from the fact that the base of the slope above the Michigan-Utah mine consists of Deseret limestone with large lumps of chert, whereas the upper part of the slope consists of Cambrian limestones, highly metamorphosed but still identifiable. The strata above and below the overthrust dip eastward into the hill at about the same angle, and the thrust contact, which is not marked by strong brecciation and has been healed to some extent by metamorphic recrystallization, is inconspicuous. The thrust as here mapped follows the base of a ledge of magnesian limestone in which abundant forsterite has been developed by contact metamorphisim.

Farther north the thrust is more clearly visible. In its northermmost good exposure, in the gulch southeast. of the portal of the Alta tunnel, it brings dark blue-gray mottled and "wormy" Cambrian limestone over blue and white cherty Madison or Deseret limestone. The Cambrian is overlain, about 50 feet above the thrust, by the vuggy Jefferson (?) limestone, and it pinches out a short distance to the north. The overthrust is cut off by the Silver Fork fault close by. This thrust is penetrated, not far below the Annie tumnel, by the shaft leading to the Alta tunnel. It there brings oolitic Maxfield limestone over cherty Deseret limestone. (See pl. 37.) The Grizzly thrust is readily traceable southward, also, from the vicinity of the Alta tumnel to the Silver Fork fault on the north side of Davenport Hill. On the barren sides of the glaciated basin at the head of Silver Fork the rock beneath the fault is everywhere Madison and Deseret, while that above the fault ranges from some of the lowest beds of the Madison down to the upper part of the Ophir shale. These overriding strata dip eastward in the main and steepen toward the east.

On the spur west of the Prince of Wales shaft and on the slope south of it there is conclusive evidence of another thrust above the Grizzly. The course of this upper thrust both northward and southward is in doubt, however, and its mapping is tentative. It was not identified on the south slope of Davenport Hill, and it may there have merged with the main Grizzly thrust.

An overthrust fault below the main Grizzly overthrust was recognized in the shaft connecting the Annie and Alta tunnels (pl. 37). This fault brings the upper part of the Madison limestone over cherty Deseret limestone, and is thus entirely within the mapping unit composed of the Madison and Deseret limestones. It has not been mapped on the surface.

A still lower possible overthrust in the Alta tunnel, marked by a coarse porous breccia, seems to be genetically unrelated to the thrust faults already described, being certainly much younger and possibly one of the anomalous overthrusts discussed further on (p. 60).

The Grizzly thrust zone is cut off by the Alta stock of granodiorite, but it reappears south of the stock. A thrust fault that crops out on the sides of Sunset Peak and that is readily traceable in the nearby hills despite its displacement by later faults has about the same throw as the lower Grizzly thrust, having:brought Cambrian limestone over Madison limestone, and it is thought to be most probably the same thrust. It is possible that the lower overthrust cut by the shaft in the Alta-tunnel workings is represented by a thrust which causes the duplication of a large part of the Madison limestone and is well exposed where it crosses the ridge east of Devils Castle. Thrusts, or faults interpreted as such, at lower stratigraphic levels crop out for short distances about $11 / 2$ miles southeast of the Devils Castle, in a small area hàving extremely còmplex structure.

\section{SOME OTHER OVERTHRUSTS}

A few known or probable overthrusts have been found that have not been traced for long distances and cannot be correlated with any of the principal faults or fault zones already described.

A thrust presumably higher thian the lower Grizzly or any branch of it is indicated by two patches of Madison limestone, one of which rests on the Humbug formation south of the Steamboat mine and the other on the Weber quartzite northeast of the Ant Kriolls. There is some evidence of a small thrust (not mapped) in the Thaynes formation near the pond about a mile north of Scott Hill. Thrust faulting is also strongly suggested in outcrops seen from a distance on the high hilltops north of Cottonwood Creek and a little northwest of the mapped area.

At least two overthrusts at lower stratigraphic levels than any thus far described crop out south of the Albion tunnel. They bring tillite over Tintic quartzite, and are perhaps to be correlated with one at the head of Mary Ellen Gulch that has pushed pre-Cambrian rocks onto the Tintic.

Formations of all ages from pre-Cambrian to Triassic are thus involved in the overthrusting that has occurred in this area. The greatest movement has occurred in the Alta thrust zone, which was first discovered.

OVERTHRUSTS BRINGING YOUNGER OVER OIDER ROCKS

An overthrust on which younger rocks are clearly pushed over older ones is exposed on the divide between American Fork and Mary Ellen Gulch, northwest of Miller Hill. Here a cap of Ophir shale and Maxfield limestone rests, with a flat contact that cuts across the bedding of both those formations, on Tintic quartzite. A remarkable feature of this tiny remmant of a thrust plate is that it contains a dike, which apparently is older 
than the fault, whereas all the dikes of the area, so far as known, are younger than the thrust faults of the usual kind. This fact may form a rather narrow basis for so broad a deduction, but it seems to indicate that this capping is not a remnant of a sliver pushed along under a thrust fault roughly contemporaneous with the Alta overthrust, but records a much later episode of thrust faulting, presumably the same that has such tremendous results in the regicn under study by $\mathbf{A}$. A. Baker. It seems likely that such thrusting of younger upon older rocks would in general take place under lighter load, and hence in general at a later date, than the more usual thrusting of older upon younger rocks.

A fault that may be one of these unusual overthrusts is exposed southwest of the Earl-Eagle mine, near the head of Major Evans Gulch. (See section $F-F^{\prime}$, pl. 4). The fault, within the area mapped, has a low dip southward. The rock above it is mainly limestone interbedded with a little sandstone, and is assigned to the Mississippian Humbug formation; the rocks below the fault belong to the Maxfield limestone and the Ophir shale of the Cambrian series. The throw must therefore amount to many thousands of feet. This fault seemed hard to account for until Mr. Baker, who saw it in the writer's company, suggested that it might be one of those anomalous overthrusts which he had found farther south, and one of which had been traced to a locality not far from the mouth of Major Evans Gulch. As the fault barely overlaps the mapped area it has not been followed far enough to prove or disprove this hypothesis.

A thrust fault that has not materially altered the sequence of the strata appears to be exposed in the cliffs southeast of the Devils Castle. Between half and threequarters of a mile from that group of crags, the Deseret limestone is exposed in precipitous cliffs, in which the general continuity of the bedding, with uniform gentle easterly dip, presents a striking contrast to the complex faulting on the gentler slopes below. 'Some faults of considerable throw point toward these cliffs but do not, so far as observed, affect the rocks in them. Their abrupt disappearance would seem to indicate that they have not merely died out but have been cut off, and it seems possible that they end at a thrust fault along the base of the Deseret limestone. 'There is at this horizon a fissure which coincides with the bedding in most places but locally diverges a little from it. Bed-faulting at this horizon would be made especially easy by the presence of the shale which usually, occurs there, but of which there is little in the best exposure, where it may for the most part have been faulted out.

The relations of this fault both to the adjacent strata and to the faults on the slope below indicate that it occurred relatively late: The nearly undisturbed con- dition of the adjacent beds, coupled-as it is not along the less conspicuous faults in the Reed \& Benson zone p. 58) - with the fact that the beds are in their normal sequence, indicates that the movement has not been very extensive.

The inner part of the Tom Moore tunnel (pl. 41) and its two northernmost branches cross what appears to be a thrust fault of relatively small throw, on an extremely irregular surface that in places brings younger rocks upon older. An excellent exposure at one place shows a tight contact bending through about $90^{\circ}$ on a radius of less than a foot, probably because of an irregularity in the fault surface rather than subsequent deformation.

\section{NORMAL FAULTS AND STEEP REVERSE FAULTS} GENERAL FEATURES

Among the faults other than overthrusts in the area, normal faults, with dip toward the downthrow side, are apparently in the majority, but some of these faults dip steeply in the direction of upthrow and some, according to the letter of the definition, are in part normal and in part reverse. The direction of dip of some faults that are shown by their course on the surface to be steep is unknown, and it is therefore impossible to classify each one of these faults as being either normal or reverse.

In this region as in some others, there seem to be a good many steep reverse faults, and mining geologists may find it practically useful to bear that fact in mind. An ore body cut off by a steep fault is generally presumed to have moved downward on the side toward which the fault plane dips, as the well-known ore body of the Emma mine actually did. It is best, however, to attack such a problem without assuming that the fault is of the type that is, perhaps -unfortunately, called "normal", and to ascertain the direction of movement, if possible, by the usual methods of field geology before undertaking exploratory development work.

The faults are not obviously systematic in strike. It is found, however, on projecting their courses through a common center, that strikes approximating the cardinal directions north and east are much commoner than those very close to northeast or northwest. Sheaves of special density extend about north-northwest and westnorthwest. The widest segment that is free from known faults of appreciable throw is bisected by a line striking N. $60^{\circ} \mathrm{E}$., but that is not far from the average strike of the mineral-bearing fissures. Faults whose strike is nearly north are especially common north of Little Cottonwood Creek, while east-west faults are more numerous in the southern part of the area.

The relative ages of the faults; as already remarked, are not fully known. The overthrusts are older than most of the others, but a few steep faults have been found that are possibly older than the overthrusts, though they may be contemporaneous tear faults. Most of these old faults strike nearly east or a little north of east, though one in Peruvian Gulch strikes northwestward; but some faults of the same general strike are comparatively late. 
Fissures that strike eastward or a little north of east are numerous in the cliffs on the west side of Reed \& Benson Ridge; many are well expressed by the contours (pl. 1), and some can be recognized in the photographs that form plate 6 . Of these fissures, which have, so to speak, a strong family resemblance, some are tearfaults, some are filled with dikes, and some are at least slightly mineralized. It seems probable, at least, that these fissures belong to the same system as the mineralized fissures in the Cardiff and Tar Baby mines, which, however, strike more nearly northeastward.

These considerations indicate that the fissures of easterly.or northeasterly strike, which are so conspicuous throughout the area because of their topographic expression, their mineralization, and the dikes that many of them contain-which constitute the chief expression of this fissure system on the map (pl. 3)-were of comparatively early origin. It seems possible, even, that they resulted from strains set up by overthrusting, though the mineral-bearing fissures are all, so far as known, later than the thrust faults, which are commonly more or less displaced at their intersections with these fissures.

There is some presumption, likewise, that faults of general east-northeast strike are comparatively old. Some of them are so, but some are not; in the southern part of the area, for example, the east-west Yankee fault is older than the northeastward-striking Belorophan fault, but the east-west Mountain Dell fault throws the Pacific ore-bearing fissure, which strikes nearly northeast. The Secret Lake fault, also, dislocates the Silver Fork fault and must be relatively late. It is probable that movement occurred more than once on many faults, which would help to account for a difference in age between faults of similar strike, and it is perhaps on the fissures of easterly to northeasterly strike that movement has been renewed most frequently. It is the last movement of all that usually determines the supposed age of a fault.

The Silver Fork fault, unique among the normal faults of the area in its great length and throw, is younger than the intrusive rocks and the ore-bearing fissures but is thrown by other faults, and the same statements are true of the Snow fault, which is apparently a branch of the Silver Fork fault.

In some areas of complex faulting, such as that near the Albion tunnel and that along the south side- of Mineral Flat, relative movement probably occurred between blocks rather than slices; in such a case two faults meeting at a large angle would be classed, according to the last movement on them, as of the same age.

The youngest faults of the area, apparently, are steep ones of northerly strike, the greatest of which are the Superior faults. Some of these cut the Snow fault as well as the dikes and veins.

Because of uncertainties regarding the relative ages of the faults, the order in which they are described is 'determined by position rather than age. The Silver Fork fault will be described first because it forms a very important geologic boundary, which divides the area lengthwise into two nearly equal parts.

\section{SILVER FORK FAULT}

A great dislocation alined with the general course of Silver Fork was recognized by Hintze, ${ }^{72}$ who appropriately named it the Silver Fork fault. Especially clear evidence of the great throw of this fault can readily be seen in the gorge of Little Cottonwood Creek southeast of Alta. The west wall of the gorge consists mainly of limestone, the east wall mainly of Cambrian (?) tillite. Both formations dip eastward, and the fault plane as exposed in a prospect on the west side of the gorge dips about $45^{\circ} \mathrm{W}$. The fault is most simply interpreted as a normal one, whose throw at this place amounted to at least 2,000 feet. A little farther south the fault cuts granodiorite of the Alta stock.

North of Little Cottonwood Creek this great fault may be traced to the north boundary of the Cottonwood quadrangle, though its exact position is not every. where known: It is displaced by the Montezuma fault, under the drift-covered floor of the Little Cottonwood Valley, so that it crosses the divide between Cottonwood and Little Cottonwood Creeks a few yards-east of the summit of Davenport Hill. The breccia along it is very conspicuous on the north side of this hill (pl. $20, B)$. The relations in the immediate vicinity of this place, in so far as they are shown on the map, might be explained by a relatively slight overthrusting movement from the west, resulting in the uplift and the removal by erosion of the Grizzly overthrust on this side; but there are evidences against this hypothesis which the map does not fully express. Normal faulting is most obviously indicated by the fact that the youngest of the Carboniferous rocks east of the fault and beneath the overthrust is Deseret and considerably older than the youngest rock west of it-the Humbug formation. A more important piece of evidence is this: the unconformity between the Cambrian and post-Cambrian formations immediately east of the fault and below the Grizzly overthrust is near the top of the Cambrian shale-almost at its lowest known level-whereas both on the slope west of Honeycomb Cliffs and near the Montezuma.tunnel it is nearly at its highest observed level. This difference in the position of the unconformity indicates that the rocks on the two sides of the Silver Fork fault were once far apart, and that can best be explained by supposing that they are in different thrust-fault blocks.

The simplest explanation of the facts is that the block abuve the Grizzly overthrust is the same (aside from smaller fractures) as the block west of the Silver Fork

${ }^{72}$ Hintze, F. F., Jr., A contribution to the geology of the Wasatch Mountains, Utah: New York Acad. Sci. Annals,-vol. 23, p. 139, 1913. 
fault, in both of which blocks the unconformity just mentioned is at a high stratigraphic level. The fault would accordingly have caused a downthrow to the west whoze least possible measure would be the difference of stratigraphic level between the rocks just east and just west of the summit of Davenport Hill. This stratigraphic throw would be, like that in the Little Cottonwood gorge, about 2,000 feet; the movement on the fault plane would be some hundreds of feet more, and the vertical displacement considerably less. But to restrict the downthrow to this minimum value it is necessary to correlate the Grizzly thrust zone with the Reed \& Benson thrust zone; the throw would be much grcater if the Grizzly overthrust were equivalent, as appears more likely, to the Alta overthrust.

The Silver Fork fault zone is reached by the westerly drifts of the Silver King tunnel of the Alta Consolidated mine (pl. 46), where it appears as a thick breccia in which the principal fissures have a low dip to the west. The fault may be thrown by certain steeper faults on the southwest slope of Davenport Hill; its exact course is difficult to follow here in the crushed, thick-bedded limestones. The complication is even greater on the northerly slopes of the hill, which consist of one huge mass of limestone breccia produced by converging faults; but the course of the main fault can be followed pretty closely down the slope and along Silver Fork to a point about as far north as the Alta tunnel, where beds near the middle of the Humbug formation are brought down against Madison limestone beneath the Grizzly overthrust, which is well exposed on the slope to the east. The minimum throw of the fault here is therefore of the same order as in Little Cottonwood Canyon.

The position of the Silver Fork fault north of the Alta tunnel is in part uncertain. It might naturally be supposed that the lower part of Silver Fork Canyon; alined as it is with the general course of the fault to the south, had been eroded along this great fracture, but this pretty certainly is not the case. The rocks on the two sides of the canyon near its mouth appear to be in their normal stratigraphic relation to each other, and the beds on the slope north of Big Cottonwood Creek in line with the course of Silver Fork are wholly undisturbed. The regularity of the strike and dip (see pl. $-18, B$ ) and the absence of visible faults along the portion of this slope that lies within the Cottonwood quadrangle present, indeed, a remarkable contrast to the complexity of structure which prevails almost everywhere in the mapped area south of Big Cottonwood Creek. It is only at a place almost directly north of the point where the stream leaves the quadrangle that there is a break in the parallel outcrops of the strata. Here, just north of the quadrangle, there is a short gulch, of which the southeast side consists of Madison limestone and the northwest side of the Park City and Thaynes forma- tions. This relation indicates a great fault, and the large springs that rise near the middle of the gulch presumably issue from the fault fissure. The fault crosses the ridge at the head of the gulch about threequarters of a mile north of the mouth of Mill D North Fork. There the rocks east of the fault are near the base of the Morgan (?) formation; those west of the fault are not well exposed, but the character of the float and the occurrence of Thaynes limestone lower down to the southwest indicate that they are high in the Ankareh formation. The fault this appears to have a throw here of about 5,000 feet, and it can hardly be other than the Silver Fork fault.

How the fault contact just described is connected with the fault so clearly indicated near the Alta tunnel is not fully understood. When the preliminary report forming part of Professional Paper 111 was published, it was believed that the Silver Fork fault might be offset on a fault along Big Cottonwood Creek. It is now considered improbable that any fault follows the valley of this stream for so long a distance as to justify the name "Big Cottonwood fault," previously used. ${ }^{73}$ The closeness near the Belden tunnel of the Deseret limestone to the Ophir shale does indeed suggest a fault with downthrow to the north, and a hypothetical small fault is accordingly shown on the map (pl. 3) and on section $A-A^{\prime}$, plate 4 , but this proximity might almost if not quite be accounted for by assuming that the unconformable contact between the Devonian (?) limestone and the Cambrian, concealed beneath the Quaternary deposits that form the floor of the valley, lies at about the same unusually low level as it does near Grizzly Gulch (p. 61).

- The Cottonwood Metals tunnel, at the north end of the ridge east of Days Fork, crosses a fault zone about 500 to 550 feet from its portal. The observed fissures in this zone dip southward at angles of $60^{\circ}$ to $15^{\circ}$, and there is some doubt as to the details of the movement, but the net result of the faulting, at the surface, is to bring limestone high in the Madison on the south against beds near the top of the Cambrian quartzite on the north. The abundant gouge and the wide fracture zone attending this fault remind one of the appearance of the Silver Fork fault in its best exposures, and it seems impossible to doubt that this is the Silver Fork fault itself. But the course of the fault from this locality to the vicinity of the Alta tunnel remains largely problematic. The most definitely established fault found between these localities is exposed in the throat of the prospect shaft shown on the map about half a mile northwest of the mouth of Honeycomb Fork. This fault strikes about N. $20^{\circ} \mathrm{W}$., dips about $65^{\circ} \mathrm{W}$., and brings Woodside shale on the west against Madison limestone on the east. This relation implies a throw of at least 3,000 feet, but the

\footnotetext{
${ }^{73}$ Butler, B. S., and other, The ore deposits of Utah: U. S. Geol. Survey Prof. Paper 111, p. 247, 1920.
} 
steepness of the fault, and the lack of brecciation along it, throw doubt on its being the Silver Fork fault. There is indeed no satisfactory evidence that this great fault makes a shortcut across the hills between the two localities already named at which it can clearly be seen, and that it could do so without some expression in the topography seems unlikely. The fault last mentioned may be subsidiary to the Silver Fork fault, but it seems likely that the main fault follows the general course of Silver Fork to a point somewhere near its mouth, then turns abruptly and runs northwestward to Reynolds Flat, being concealed throughout this distance under the floor of the valley of Cottonwood Creek except for its brief emergence near the Cottonwood Metals tunnel.

Southward from the exposure near the Alta tunnel the Silver Fork fault can readily be traced into Mary Ellen Gulch. Its exact location near the Albion shaft is indeed somewhat doubtful, because the structure there is extremely complex and in places both walls of the fault consist of Tintic quartzite. (See section $D-D^{\prime}$, pl. 4.) For two or three miles farther south the fault is free from such complications. In the pass northwest of Miller: Hill (section $E-E^{\prime}$, pl. 4) it can be located within a few feet, and there its throw can be estimated closely. It there cuts out all of the Tintic quartzite, all of the Ophir shale, a little of the pre-Cambrian, and probably at least 200 feet of Maxfield limestone, a wedge of which tapers out near the pass between the Silver Fork fault and another that is exposed in the throat of a shaft. The stratigraphic throw on the Silver Fork fault alone is thus about 2,000 feet, the throw on the fault surface being somewhat more and the vertical throw considerably less.

South of this pass the Silver Fork fault is much obscured by glacial deposits and structural complexities. It is assumed to be later than the Yankee fault, though their junction has not been seen, and it can be identified with some confidence for about a mile farther. Here, however, as in the northern part of the Cottonwood quadrangle, the course of the fault becomes problematic. If the fault held its general nearly southward course it would come down the slope north of Graveyard Flat. But this slope is for the most part a dip slope, eroded in the upper member of the Ophir shale, and it can hardly be traversed by any large south-trending fault. The main Silver Fork fault is therefore believed to swing eastward across the lower part of Mary Ellen Gulch and to become identical with what has been called the Dutchman fault. The location of the Dutchmanor Silver Fork-fault south of the Dutchman mine is uncertain. No fault of similar magnitude has been recognized, according to A. A. Baker, ${ }^{74}$ in the pass at the head of Baker. Fork, which is about in line with the course of the fault where it disappears under the Quater-

${ }^{74}$ Oral communication. nary deposits in the valley of American Fork, so that the fault may be dying out toward the south.

Thus the Silver Fork fault, by reason of its great throw and persistence, and of its erratic course near both the northern and the southern ends of the mapped area, invites further study beyond the limits of that area. Its origin, also, presents an intriguing problem. Both its irregular course and its low dip suggest that it is a result of stretching rather than of gravity alone. It seems possible, on the other hand, that although the fault is normal its low-dipping, crooked fissure may originally have been formed by thrusting. In section $C-C^{\prime}$, plate 4, the Silver Fork fault and other similar faults appear, at first glance, more like overthrusts than the overthrusts themselves.

\section{SNOW FAULT}

The Snow fault and the Silver Fork fault converge on the north slope of Davenport Hill, and they are very similar in character; both are normal and have low dips westward, and the wall rocks of both are greatly shattered. It seems probable, therefore, that the two are contemporaneous and may be regarded as branches of a single fracture.

The Tom Moore tunnel (pl. 41) affords the best opportunity to see this fault in cross-section. The fault there has two main branches, between which is a shattered mass of Cambrian shale and limestone, probably belonging to the Ophir shale. The fault here brings the middle, shaly part of the Maxfield either against Deseret limestone below the Alta overthrust or against Maxfield limestone just above that overthrust. It is difficult to estimate the throw implied by this relation, but it must amount to several hundred feet. The average dip of the fault is about $30^{\circ}$ northwestward.

The fault is also extensively exposed in the Columbus workings (pl. 40). The outer part of the Columbus tunnel follows the fault, along which the rocks are greatly shattered, and the east drift along the Brain fissure ends in the Snow fault zone. What seems to be a branch of the Snow fault is followed by a drift on the 400 level, where it contains sulphides that may have been dragged in, though they have rather the solid look of mineral formed in place. 'The inner part of the Wasatch drain tunnel is in the shattered rocks of the Snow fault zone, the main displacement being, apparently, on a fault that brings Ophir shale in the Alta thrust zone down against the Madison limestone of the mass below the Alta overthrusts.

The Snow fault is thrown by the Montezuma fault and throws the dikes and ore-bearing fissures, but its relation to some of the other faults is uncertain because its intersection with them is not exposed. It is difficult to understand what becomes of the fault west of the Columbus tunnel, for the strata in line with its course to the southwest are nowhere greatly displaced. 


\section{SUPERIOR FAULT ZONE}

GENERAL CHARACTER

A great fault along Superior Gulch was recognized by Hintze ${ }^{75}$ and named by him the Superior fault. In the preliminary sketch in Professional Paper $111^{\pi 6}$ it was pointed out that, although the view looking northward toward the head of Superior Gulch (pl. 7, A) gives the general impression of one great fault with downthrow on the east, two distinct and conspicuous faults extend northward from the divide at the head of Superior Gulch; and these two faults were distinguished as the West Superior and East Superior faults. Both are about vertical, though the dip of both is westward in some places and eastward in others. Each causes a maximum downthrow to the east of several hundred feet, but they seem to die out northward, and neither has certainly been traced as far north as the mouth of Mill D South Fork.

On the geologic map the effect of the Superior faults is most conspicuous in the upper part of the basin of Mill D South Fork, where these faults form the sides of a strip occupied mainly by the Madison and Deseret limestones and bounded on both sides by Cambrian quartzite. It would be natural to infer from this dis-. tribution that a wedge of limestone has been dropped into the quartzite. Downward movement of the limestone has in fact occurred on the West Superior fault; but, as Hintze ${ }^{77}$ pointed out, the throw on the East Superior fault also is down to the east, for the quartzite east of the fault belongs to the block above the Alta thrust and the limestone west of it belongs to the block below the thrust. The quartzite west of the West Superior fault belongs to this same lower block. The true relations are shown with almost diagrammatic clearness on the steep slope facing Little Cottonwood Creek. (See pl. 7, $A$ and sections $B-B^{\prime}$ and $C-C^{\prime}$, pl. 4.)

The East Superior and West Superior faults cannot be individually traced far southward from the head of 'Superior Gulch, but several faults extending in this direction cause a general downthrow to the east in what may be called the Superior fault zone.

EAST SUPERIOR FAUTT

The best exposures of the East Superior fault are in the Cardiff mine. The lower tunnel reaches the fault about 750 feet from the portal and follows it, on a slightly sinuous course whose' direction averages a little west of south, for about 900 feet. In this tunnel the fault fissure almost everywhere dips eastward at angles of $80^{\circ}$ or more, though the dip of the east wall reaches $90^{\circ}$ and even becomes very steep to the west at one place.

\footnotetext{
${ }^{75}$ Hintze, F. F., Jr., A contribution to the geology of the Wasatch Mountains, Utah: New York Acad. Sci. Annals, vol. 23, p. 138, pls. 3, 4 ; 4 A, 1.913.

${ }^{78}$ Butler, B. S., and others, op. cit., p. 248

${ }^{77}$ Hintze F. F., Jr., op. cit., p. 138.
}

The upper tunnel, 600 feet higher, reaches the fault about 120 feet from the portal and drifts along it for 1,100 feet. Its course on this level, though not straight, averages nearly south, and its dip is nearly everywhere to the west, at angles of $72^{\circ}$ to nearly $90^{\circ}$, except near the south end of the drift, where it strikes N. $12^{\circ} \mathrm{E}$. and dips $82^{\circ}$ E. Flutings and striae were noted at many places, and most of these dip southward, at angles of $48^{\circ}$ to $70^{\circ}$. The fault thus has on the average a nearly vertical dip, but it varies considerably in dip as well as in strike and therefore cannot be called, without qualification, either normal or reverse. The movement, as indicated by the striae, was relatively downward and southward on the east, and it may have amounted to as much as 1,000 feet. The fault cuts off the Cardiff ore body, which has been removed by erosion west of the fault.

The fault clearly continues down the valley, keeping close to the stream, as far as a locality a little north of the Tar Baby lower tunnel, where Cambrian rocks on the west are in contact with Madison limestone on the east. Its course between this locality and the Cardiff mine is much obscured by morainic and other surficial deposits, and just to the north it disappears beneath a moraine. It must be cut by the Tar Baby lower tunnel, but it is not especially conspicuous there and is only tentatively identified on the mine map (pl. 33). A fault that brings Deseret limestone against Cambrian rocks near Doughnut Falls is regarded as the northward continuation of the East Superior fault. Its throw is about the same here as near the Tar Baby lower tunnel, but it seems to diminish rapidly northward, and the fault may be represented on the north of Big Cottonwood Creek, about opposite the mouth of Mill D South Fork, by a slight shift in the banded rocks of the Thaynes formation, with downthrow on the east.

In Superior Gulch the East Superior fault splits into two branches, which are soon lost and have not been identified south of Little Cottonwood Creek nor in the Wasatch drain tunnel.

\section{WEST SUPERIOR FAULT}

The West Superior fault is perhaps represented south of Superior Peak by a branching fault of general northeasterly strike. It can readily be traced northward from the head of Superior Gulch to the vicinity of the Tar Baby lower tunnel. On the divide between the Cottonwood Creeks, it brings Jefferson dolomite against beds near the base of the Ophir shale, which implies a throw of something like 500 feet. It is well exposed near the road east of the Baby McKee shaft, where it brings Mississippian limestone against Ophir shale and dips about $65^{\circ} \mathrm{W}$., which makes it locally a reverse fault. The same rocks are in contact in the Howell tunnel (pl. 34). west of the Cardiff mine, less than 100 feet from the portal. The West Superior fault is cut 
in exploratory workings of the Cardiff mine (pl. 35) but is there very tight; as is usual where a fault brings two limestones together.

The American Metals branch of the Tar Baby lower tumnel (pl. 33) crosses two essentially vertical branches of the fault, having a total throw of probably more than 600 feet, for they bring Maxfield and. Jefferson (?) dolomites on the east against quartzite on the west. The fault is crossed by the Price tunnel about 150 feet from its portal, where it brings gray limestone of unknown dip on the east against eastward-dipping Ophir shale on the west. The fault there strikes N. $5^{\circ} \mathrm{W}$. and dips $80^{\circ} \mathrm{E}$.

Farther north the fault seems to swing northwestward, unless, as seems possible from the areal relations, the East Superior and West Superior faults cross one another. north of the Tar Baby mine. However, a fault assumed to be the West Superior is fairly conspicuous on the slope west of Doughnut Falls and is lost in the moraine farther north. In the Cottonwood Consolidated tunnel, southwest of these falls, the fault is crossed about 1,200 feet from the portal, according to a geologic map made by Mr. T. T. Van Winkle.

The course of the West Superior fault south of the divide between $\mathrm{Big}$ Cottonwood and Little Cottonwood Creeks is uncertain. A little south of the crest the surface in line with the general course of the fault is covered with old talus and soil which extends down to about the 9,600-foot contour, and there is room in the area so covered for the fault to do any one of several things. It may converge with the Superior fault, as shown on the preliminary map (pl. 27) in Professional Paper 111, and a branch of it may well do so, but it seems more probable that the main fault swings southwestward as shown in plate 3 . The essential fact seems to be that both the East Superior and the West Superior faults splay out on this slope and lose their individuality.

\section{FAULTS BETWEEN THE SUPERIOR AND SILVER FORK FAULT} ZONES

The divide between Big Cottonwood and Little Cottonwood Creeks is crossed by several steep faults that strike nearly north, most of them having a relatively small throw. The downthrow of most of them is on the east side; several are known to be reversed faults, and none is known to have a "normal" dip throughout. Some of them are traceable on the steep, high slopes, where they are marked by prominent limestone breccias, but are so obscured by waste and glacial drift on the lower part of the slope, near Alta, that their relations are not clear. Some of the largest of these faults are shown in plate 3 and will be described in order from west to east.

\section{HOWLAND FAULT}

The Howland fault, the northern part of which was called the Ophir fault in Professional Paper 111, is one of those that is most extensively exposed in mine workings. It is named for the Howland tunnel, which crosses it not far from the portal, and it is crossed or followed at many places in the Columbus-Rexall workings. (See pl. 38 and sec. $C-C^{\prime}$, pl. 4.) It has two branches, both essentially vertical, whose course is shown in the mine maps and which are conspicuous on the geologic map (pl. 3).

The main fault, called the west branch north of the junction of the two branches; strikes about north-northwest from Little Cottonwood Creek. Near the creek, on the surface, it brings the crumpled shales of the lower member of the Ophir down against the layer of Tintic quartzite that overrides the Deseret limestone to the west, and its throw must there be somewhat more than 200 feet. It becomes obscure in the quartzite farther up the slope, but it is conspicuous on the west-facing slope near the head of Mill D South Fork (see plate 6, $B)$. On this slope a throw of more than 500 feet on this fault seems to be necessitated by the distribution of the Cambrian shales and limestones, although, for some reason not understood, the throw appears to be much less a short distance south of the divide. The Howland fault is apparently cut off by the East Superior fault, beyond which it has not been recognized. Possibly it is a branch of the East Superior fault; the two are alike in having essentially vertical though varying dips and in being marked by striae that dip southward.

The east branch of the fault branches again near the divide; both its branches are lost in the head of Days Fork.

The Howland fault extends southward across the valley of Little Cottonwood Creek and has been traced for about half a mile up Collins Gulch.. It is exposed in the outer part of the South Hecla mine, where it has its usual essentially vertical dip.

\section{FLAGSTAFF FAULT}

The Flagstaff fault passes about 150 feet west of the Flagstaff tunnel and strikes a little west of north. Its downthrow is on the east, and its dip in a conspicuous ledge of breccia northwest of the tunnel is $65^{\circ} \mathrm{W}$., so that there, at least, it is a steep reverse fault. At the divide a small vertical fault striking northward branches from it. The throw on the fault is about 150 feet, and it causes the nearest conspicuous outcrops of the white bed at the top of the Jefferson (?) dolomite and of the similar bed in the Maxfield limestone to stand at nearly the same level. The fault becomes lost in the brush-covered moraine on the lower part of the slope toward Little Cottonwood Creek, and its relation to the Snow fault was not determined.

TOM MOORE FAULT

A fault of unusual character is cut by the Tom Moore tunnel (pl. 41) about 600 feet from the portal. It strikes northwestward and dips about $50^{\circ} \mathrm{SW}$. The 
rock in the footwall is limestone that contains large lumps of chert and is clearly of Deseret age; the rock in the hanging wall is Ophir shale. The fault is nevertheless normal, for the Deseret limestone belongs to the thrust block below the Alta thrust zone, while the older rock in the hanging wall must belong to one of the thrust slices in the Alta thrust zone. A thrust fault, presumably in this zone and probably thrown by another fault that dips eastward, is crossed by the tunnel near its. portal. The Tom Moore fault does not necessarily have a large throw, and the fault is not conspicuous on the surface. It seems probable to the writer (Calkins) that this fault is an old one, perhaps older than the overthrusts; it apparently does not offset the Grizzly dike.

VALLEJo (SOUTE STAR OR BURGESS?) "FAULT

The Vallejo fault was so named ${ }^{78}$ because it passes just east of the Vallejo tunnel, which is 500 feet southeast of the Flagstaff tunnel. The same fault is called the South Star, after a tunnel a few yards west of the Vallejo, on an unpublished map by J. J. Beeson, and what may be the same one is called the Burgess, from the tunnel 1,000 feet southeast of the Flagstaff, on R.T. Walker's unpublished map of the Tom Moore tunnel.

The fault has been traced northward to the vicinity of the Eclipse shaft, which lies a little west of its course, and it is especially well exposed in the cliffs southeast of the shaft. Here the downthrow, which is to the east, is about 150 feet, as measured by the displacement of the white crinoidal bed in the Deseret. . Its dip as measured in two or three places in this vicinity is about $70^{\circ} \mathrm{W}$, or in the direction of upthrow, so that the fault is here of the steep reverse type. Its most probable equivalent in the Tom Moore tunnel (pl. 41), however, is vertical. The relation of this fault to the Snow fault has not been satisfactorily determined.

\section{RLIINOIS (TIGER TRAIL?) FAULT}

An essentially vertical fault downthrown less than 100 feet on the east is well exposed near the trail to the old Tiger tunnel and hence was.called by Beeson the Tiger Trail fault, where it brings Deseret against Madison limestone. The fault is followed below the trail by the gulch that contains the portal of the Illinois tunnel. It seemed to be dying out before it reached the Snow fault.

There is evidence underground of a fault, called the Illinois fault after the Illinois tunnel, extending southward about in line with the Tiger Trail fault. This fault may throw the Snow fault. It is not clearly shown on the surface.

MONTEZUMA FAULT

The slumping of the surface rock toward the old caved stopes of the Emma mine has left exposed, beside the

\footnotetext{
${ }^{78}$ Butler, B. S., and others, The ore deposits of Utah: U .S. Geol. Survey Prof. Paper 111, p. 250, 1920. This name was mistakenly applied on the first edition of the topographic map to the Montezuma tunnel.
}

portal of the Montezuma tunnel, a smooth overhanging fissure wall that strikes N. $42^{\circ}$. W. and dips $70^{\circ} \mathrm{NE}$. Halfway up the slope between this place and the Cottonwood divide the Tiger cabin, now destroyed, leaned against the boldly cropping breccia of a fault that strikes N. $15^{\circ} \mathrm{W}$. and dips $80^{\circ} \mathrm{W}$. It is believed that both exposures represent a continuous fracture, which may be called the Montezuma fault. If this is true, the fault is normal at the Montezuma tunnel and reverse at the Tiger tunnel, the downthrow at both places being to the east; and its change of strike appears to take place at an angle or a very short curve. Observations along the line of section $C-C^{\prime}$, plate 4 , indicate that as a whole the fault is normal.' Continuity is argued by two other facts: the dip of the fissure in a prospect near the bend is $85^{\circ} \mathrm{E}$., or intermediate between the opposing dips already mentioned, and the downthrow north of the bend, as measured by the crinoidal bed of the Mississippian, is approximately equal to that southeast of the bend, which, as measured by the Emma ore body, amounts to about 300 feet.

\section{HIAWATHA FAULT}

The Hiawatha normal fault is best exposed in the extreme eastern part of the Bay City level of the Emma mine (p1. 41). It there strikes about north-northwest and dips about $55^{\circ} \mathrm{E}$, and it brings Madison limestone on the east against Jefferson (?) dolomite on the west. It is thought to cut off the Emma ore body, which supposedly lies too deep beyond it to be mined profitably. On the surface the fault is all in Carboniferous rocks and is very obscure; it is mapped only in part and somewhat tentatively.

\section{OTHER FAULTS NEAR ALTA}

The ground on the gentle slope northwest of Alta is broken by a great number of minor faults, only a few of which are shown on the geologic map forming plate 3 . Many of these are shown in the maps of the Tom Moore tunnel workings (pl. 41), where most of the contacts are faults. Some of the most complex faulting in the area seems to have occurred within the limits of the Alta townsite itself, as may be seen in the road cut east of the Tom Moore tunnel. Here the rocks appear to be all or mainly Cambrian shale, dolomite, and limestone, but they are not all assignable to their respective formations and are lumped on the map as Maxfield limestone. The slope south of Alta contains not only deformed overthrusts but later steep faults. In the slope northeast of the Emma mine are a few small faults of northeasterly strike, not shown on the map.

\section{MINOR FAULTS IN GRIZZLY GULCH AND HONEYCOMB FORK}

The Cambrian shale and quartzite along the bottom of Grizzly Gulch are displaced by several small faults that are not shown on the geologic map (pl. 3), and at the west they are brought into contact with limestone 
by a fault, which dips about $50^{\circ} \mathrm{NW}$. and which may be a part of the Silver Fork fault zone. The whitish limestones along the lower part of the gulch are clearly broken by many faults but are so much altered that their stratigraphic position can hardly be determined, so that the throws of the faults cannot be measured. The gentle slopes north and south of the rocky stream channel are strewn with morainic material, which further obscures the structure and adds to the difficulty of mapping.

The limestone beds exposed in the Honeycomb Cliffs are deformed and folded and are cut by strong northeasterly fissures, most of which contain dikes. : At many of these fissures there is so abrupt a discordance in the attitude of the strata on the two sides as to suggest faulting, but at only óne fissure, which contains no dike, has a fiult of appreciable throw been proved. This Honeycomb fault, to use the obvious name, is reverse and dips for the most part rather steeply to the northwest, but at the base of the cliff it is sharply contorted as a result of later movement.

\section{SOME FAUITS NEAR MILL D SOUTH FORK}

The faults near Mill D South Fork, other than the overthrusts and the Superior and Howland faults, all depart widely from the northerly trend that generally prevails north of Little Cottonwood Creek; they strike about east, northeast, and southeast. Many of them are poorly exposed, the structure in the canyon bottom north of the Cardiff mine being especially obscure. The more interesting of these faults are described below.

\section{CARBONATE FAULT}

The Carbonate fault, which is nearly vertical, cuts off the ore in the Carbonate mine. (See pl. 32.) It there brings Maxfield limestone against Tintic quartzite, so that its throw must be more than 500 feet, and it is conspicuous for some distance to the south; but it becomes obscure in the quartzite, and its relation to the Alta overthrust has not been observed. It is presumably later than the overthrust, but it seems to be cut off by the West Superior fault and has not been identified east of it.

\section{EVARENA FAULT}

The Evarena fault, which extends northeastward from the Superior fault near the Cardiff mine, is named for a mining claim that parallels it on the northwest side. A downthrow to the northwest of about 300 feet is indicated by the offsetting of Cambrian strata and of the Reed \& Benson thrust zone, as inferred from scattered outcrops on a gentle slope that is partly mantled with talus. The fault has formed a strong breccia in the Mississippian limestone to the east, and the main fissure in this breccia dips $75^{\circ} \mathrm{NW}$., so that the fault is a normal one.

$$
\text { SAMPSON AND RETATED FAULTS }
$$

The Sampson fault, which passes a few rods south of the Sampson shaft, is chiefly remarkable for its am- biguous relation to two overthrusts; it apparently offsets the upper of these and is cut off by the lower. These relations are taken to mean that the Sampson fault is a tear fault, formed within the period of overthrusting.

Another east-west fault of similar relations is postulated to explain the apparent abutting of older against younger limestones of the Madison east of Montreal Spring, but this fault is hardly proved. On the other hand, a well-exposed but partly inaccessible eastwardtrending vertical fault south of the Sampson fault is thought to be younger than the overthrusting, and a fault in the cliffs a little north of east from the Tar Baby mine seems to be similar to the Sampson fault in its relations to the overthrusts.

\section{FAULTS IN ALBION BASIN}

Many faults are exposed in the sides of Albion Basin, at the head of Little Cottonwood Creek. As they are not crossed by accessible mine workings the exact dips of none of them are known, but the course of the outcrops shows that most of them are steep.

The one that has been traced farthest-apart from the Pittsburg fault, which is mainly in the basin of American Fork-is the Secret Lake fault, which strikes northeastward and has its downthrow on the northwest side. It clearly offsets the Silver Fork fault and probably cuts the Pittsburg fault.

Farther northwest are several other faults of northeasterly strike, the most conspicuous, because of its marked topographic expression, being a quarter of a mile west of the Albion tunnel. A block of Cambrian limestone and shale has been relatively upraised between this fault and a nearly parallel one about 700 feet to the southeast.

Very complex faulting, a combination of overthrusts with steep faults that strike in various directions, has occurred in a small area extending for half a mile southward from the Albion shaft.

The faults on the east side of the basin include a normal fault of unusually low southwesterly dip, which displaces an overthrust of the Grizzly zone about 400 feet. (See sec. $D-D^{\prime}$, pl. 4.) In case it ever needs a name, this might be called the Standard fault, because its outcrop is largely in the Standard claims.

\section{FAULTS IN AND NEAR PERUVIAN GULCH}

The most remarkable fault in Peruvian Gulch may be named the Iron Blossom fault, after the claims that contain most of its outcrop. It has an unusual northwesterly strike, an apparently steep though unmeasured dip, and a downthrow on the north of about 300 feet. It almost certainly is older than, or contemporaneous with, the Alta overthrust, for although the intersection of the two faults is concealed by quartzite talus the overthrust is well enought located so that a displacement on it of several hundred feet would be apparent.

Two other faults having northwesterly strike and 
steep dip like the Iron Blossom fault were mapped farther north on the eastern side of the gulch.

An unusual fault, which might be called the Louise - fault because of its prominence at the Louise mine, cuts across the divide between Peruvian and Collins Gulches about a quarter of a mile northwest of Mt. Baldy. This fault has a low dip northward, is normal, and displaces the Alta overthrust in such fashion that the Deseret limestone is exposed in a window between the two faults.

Two steep north-south faults in Peruvian Gulch and one a little west of it, all having their downthrow on the east, may in a general way represent the Superior fault zone. All are dying out southward, none of them having been recognized at the head of the Peruvian Gulch.

\section{FAULTS NEAR UPPER PART OF AMERICAN FORK}

WEST OF SILVER FORK FAULT

South and southwest of Mineral Flat, rocks of Ophir to Madison age are faulted in much the same complex fashion as in some areas similarly related to the Silver Fork fault farther to the northeast. The faults are all steep but are varied in strike. Conditions here are favorable to mapping on the whole, but the relations of the faults are not altogether clear at some of their intersections. The movements have apparently been to some extent in the nature of block faulting.

\section{NEAR PITTSBURG MINE}

The longest fault that crops out mainly in the drainage basin of American Fork is the Pittsburg fault, which is crossed by the tunnels of the Pittsburg mine. This fault has been traced almost continuously from the Serret Lake fault southeastward for a distance of about a mile and a half. Its dip, observed in the Pittsburg mine (fig. 6) is northeastward and nearly vertical; it is normal, its downthrow being on the north, and its maximum throw is at least 500 feet, being great enough to bring the Maxfield limestone against the Tintic quartzite. This fault may be continued southeastward by a fracture that lies southwest of its course, but this is not certain; the fault may be said to get lost in an area of especially complex faulting, partly overthrusting, southwest of the 10,589-foot peak.

The Pittsburg fault seems to be slightly displaced northwest of the mine, but in the mine workings it cuts off ore-bearing fissures. These fissures or others related

- to them are conspicuous in the south slope of Devils Castle, where two of them contain dikes. One of the dike-filled fissures deeply incises the quartzite cliff west of Pittsburg Lake, and the quartzite is dislocated in the same cliff by three faults.

Some of the most complex faulting in the Cottonwood-American Fork area has occurred about three quarters of a mile east of Pittsburg Lake. The mapping shown in plate 3 is much simplified. At least one thrust fault crops out on the slope and is traceable to the ridge overlooking Dry Fork, and some faults of northeasterly strike appear to be cut off by it.

\section{IN DRY FORK CANYON}

An area of very complex faulting is crossed by Dry Fork near its mouth. The mapping here is necessarily much generalized because of the marginal position of the area and the poor exposures.

Farther up the canyon, on its east side, are two faults in Mississippian rocks. The better-exposed of these passes with a.northwesterly strike through the brow of the hill above the Galena tunnel, and it might appropriately be called the Galena fault. It dips $60^{\circ} \mathrm{E}$. and has a downthrow on the east of about 500 feet. It apparently is cut off at the south by a fault that strikes about east-northeast, but the relations of these two faults has not been directly observed.

The divide between Dry Fork and Snake Creek is crossed, half a mile south of Sunset Peak, by a fault of northwesterly strike, with a dip of $70^{\circ} \mathrm{S}$., which is interpreted as a tear fault contemporaneous with the Grizzly overthrust. The difficulty in assuming it to be later than the thrust lies in the fact that the rock south of it belongs to the Humbug formation, whereas the overthrust north of it rests upon the Deseret.

Another probable tear fault passes just south of the top of Sunset Peak. This fault appears to offset the overthrust on the west side of the peak, but no jog in the outcrop of the overthrust was detected east of the peak either on this fault or on another a little farther north.

\section{FAULTS IN MILIER HILI}

The rocks of Miller Hill have been much faulted, the faulting revealed in the old, much-caved mine-workings (pl. 50) being so intricate that to work it out seemed impracticable. It is probably near the summit of the hill, in the ground honeycombed by these workings, that the structure is most complex, but complex faulting is characteristic of the entire hill. On the gentle slopes which make up most of the top of the hill many of the details of this faulting are obscured by waste or by old glacial deposits, and the relations of the faults are largely uncertain. Little evidence of faulting is seen in distant views of the quartzitic rocks that crop out along the northern and southwestern sides of the hill, though the talus-filled gully west of the summit marks the place where several converging faults come down into Mary Ellen Gulch. The eastern slope of the hill, on the other hand, which consists of softer shales and limestones, is cut by at least three large faults.

\section{MOUNTAIN DELL (PACIFTC) FAULT}

The northernmost large fault in Miller Hill is sometimes called the Pacific fault, being thus designated on the maps of the American Smelting and Refining Co., 
and the authors of this report, whether or not they originated this name, have used it orally. The name is open to the objection, however, that the main ore-bearing fissure in the Pacific mine is known as the Pacific fissure and is itself on a fault, though one that is too small to have been mapped on the surface. This ore-bearing fissure, or vein, is the only structural feature to which the name "Pacific" was applied in Professional Paper 111. ${ }^{20}$ In order to avoid confusion, then, the fault which cuts off the Pacific ore-bearing fissure at the south (pl. 47) will here be named the Mountain Dell fault, because it is followed on several levels of the Mountain Dell workings (pl. 48), west of the Pacific mine:

The Mountain Dell fault strilies about east and west, and exposures, now inaccessible, in the Pacific and Mountain Dell workings show that it dips on the average about $50^{\circ} \mathrm{S}$. It is normal, and on the slopes of American Fork Canyon it brings Mississippian limestones on the south against Cambrian quartzite and shale on the north, so that its throw must be more than 1,000 feet. The fault crosses American Fork, and it leaves the mapped area about half a mile northeast of the mouth of Dry Fork, in an area of very complex faulting which has not been worked out in detail and is generalized on the map. The throw on the main fault is near its maximum both here and at the Mountain Dell mine, but west of the latter place the fault forks, diminishes in throw, and becomes hard to follow. Its probable continuation at the brink of Mary Ellen Gulch passes near the portal of the Wyoming tunnel, with a throw hardly more than half as great as the maximum for the Mountain Dell fault, and disappears under talus on the steep slope to the west. Its intersection or junction with the Silver Fork fault is presumably concealed under the large moraine in the head of the gulch, so that the relative age of the two faults is unknown. As both faults are postmineral, and as no fault like the Mountain Dell appears to reach the divide between Mary Ellen and Major Evans Gulches, it seem possible that movement on the two faults occurred simultaneously.

\section{MILIER HILL FAULT}

A fault about parallel to the Mountain Dell fault passes almost through the very summit of Miller Hill. This fault, unlike the other, has its downthrow on the north and has a displacement of only about 200 feet. Its dip is not known; its convexity toward the north suggests a southerly dip, which would make it a reverse fault, but this course may be due to a gradual change in strike. The Miller Hill fault becomes lost in the talus at the west, and has not been recognized west of the Silver Fork fault.

\section{TEXXN FAULT}

The fault of east-northeasterly trend that passes a little south of the Texan tunnel may be called the Texan

\footnotetext{
${ }^{70}$ Butler, B. S., and others, The ore deposits of Utah : U. S. Geol. Survey Prof. Paper 111, p. 251, 1920.
}

fault. Its general course was thought to be well established by the straightness of the boundary that, in the main, divides Mississippian rocks on the north from Cambrian limestones on the south. The dip of the fault is not known, but its straight course indicates that it is steep. Its maximum throw can hardly be much less than 1,000 feet, but its throw apparently diminishes westward, and the fault has not been recognized in the walls of Mary Ellen Gulch.

\section{DUTCHMAN (SILVER FORK?) FAULT}

The great fault that is cut by the workings of the Dutchman mine may appropriately be called the Dutchman fault, even though it seems to be a part of the Silver Fork fault. (See p. 61.) The Dutchman fault is cut in the Whirlwind tunnel also, but neither there nor in the Dutchman mine was it well enough exposed to permit of the determination of its dip and strike, being obscured by muck derived in part from the black shaly beds at the base of the Deseret.

The course of the fault over the ridges and ravines indicates that it strikes nearly east and dips about $45^{\circ}$ S. Its throw near the-Dutchman mine, where it brings Deseret limestone on the north against Ophir shale on the south, must be well over 1,000 feet, but a little farther west the Whirlwind fault subtracts, as it were, some hundreds of feet from its apparent throw. West of Mary Ellen Gulch its apparent throw is still less, probably because it is there nearly parallel to the bedding. Its course south of the mapped area is unknown. (See p. 63.)

$$
\text { WHIRLWIND FAULT }
$$

The Whirlwind fault is so named after the Whirlwind tunnel, west of the Dutchman mine. This tunnel is about parallel to the fault but does not expose it, nor is the fault well exposed on the surface, but its position is fairly well established on the slope west of the tunnel, where it brings Mississippian limestones on the east against Ophir shale on the west. Its dip is not known. It is mapped as being thrown by the Dutchman fault, but the relation of the two is not clear; it may continue northwestward past the tunnel whose elevation is marked on the map as 9,181 feet.

A fault west of the Whirlwind fault, parallel to it but having the downthrow on the west, is mapped somewhat conjecturally; its course is much obscured by waste and glacial debris, and its throw must be small.

\section{OTHER FAULTS}

A fault of northeasterly strike, which may be called the Louise fault from a claim that it crosses, lies north of the Texan fault. Its downthrow is on the southeast side, though a minor fault in line with it to the northeast has its downthrow on the other side.

Two faults of northwesterly strike with small downthrow to the south pass south of the. Midwest tunnel. 


\section{FAULTS WEST OF MARY ELLEN GULCH}

YANKEE FAULT

The Yankee fault extends up the main headwater branch of Mary Ellen Gulch, which passes near the portal of the Yankee mine. It dips steeply northward and is a normal fault of large throw, bringing rocks as late as Mississippian on the south against Cambrian quartzite and shale on the north. The course of the fault up the gulch is largely concealed, but the movement on it evidently accounts for the fact that the rocks on the south side of the gulch are consistently younger than those in line of strike with them on the north side.

The Yankee fault is exposed at several places in the Yankee mine (pl. 51), where it dips about $80^{\circ}$ to $85^{\circ} \mathrm{N}$. The fault, or other fissures parallel to it, have been mineralized, and it is displaced by several faults that strike northeastward, the most prominent of these being the Belorophan fault, which is also mineralized. The Yankee fault is thus decidedly older than the mineralization. It is presumably cut off at the east by the Silver Fork fault, beyond which it has not been recognized. The Mountain Dell fault can hardly be a continuation of the Yankee, for it has a much lower dip and is later than the mineralization of the Pacific fissure, which is on a fault about parallel to the Belorophan.

\section{BELOROPHAN AND ASSOCIATED FAULTS}

Detailed work by the geologists of the American Smelting and Refining Co. has shown that the Yankee ground is cut by many faults of northeasterly strike, the most important of which, both structurally and economically, is the Belorophan, which is conspicuous on the geologic map of the area (pl. 3) and on the map of the mine (pl.51). This fault strikes northeastward, dips about $45^{\circ} \mathrm{NW}$, and has a downthrow on the west of about 100 feet. It may be continued north of the moraine in the gulch by one or more of the faults that converge with the Silver Fork fault near the pass northwest of Miller Hill.

Other faults associated with the Belorophan may be seen on plates 3 and 51 . One of these which is fairly conspicuous on the north side of Mary Ellen Gulch near its head may be called the Silver Bell fault, because of the fact that the fault fissure or others just north of it have been mined at the little Silver Bell mine, from which a little rich silver ore was mined years ago. This fault resembles the Belorophan in some respects, though it has a more easterly strike; it dips about $60^{\circ} \mathrm{NW}$. and is normal.

The Yankee workings expose some faults of very low dip, in part roughly parallel to the bedding, which have displaced the mineralized fissures. Probably the most extensive of these is the Footwall fault, which, if rightly identified, crosses the Yankee tunnel near its portal; with a northeasterly strike and a dip of $45^{\circ}$ SE. According to the geologic sections made for the company, this fault has a flatter dip elsewhere, and it faults the ore bodies throughout a large part of the mine.

GLOBE FAULT

A fault laving a northwesterly strike that is unusual passes half a mile southwest of the Yankee mine. It may be called the Globe fault because it is largely in the Globe claims. It dips $70^{\circ} \mathrm{NE}$. and is normal. Its throw must be more than 500 feet at the rim of the gulch but apparently decreases toward the south, where, however, its course is uncertain.

As a glance at the geologic map (pl. 3), will show, faults are too numerous on the slope west of Mary Ellen Gulch to be described individually; presumably there are many more than it was feasible to map. They range from northwest to northeast in strike and show little system except for the three step.faults near the brow of the mountain. Little was determined regarding the relative ages of the faults to each other, or even to the overthrusts; their junctions with which are all covered with talus or waste. It seems impossible to prove that all of them are younger than the overthrusts.

\section{FAULTS IN MAJOR EVANS GULCH}

In Major Evans Gulch it was possible to map a few faults that are well exposed at certain contacts, but these must be far short of the total number.

Perhaps the most noteworthy fault in the gulch other than the overthrusts is the Earl-Eagle fault, striking nearly north and dipping steeply westward. It is not of very great throw; it brings the middle part of the Maxfield limestone on the west against the lower part on the east: It is interpreted on the map (pl. 3) as being older than the overthrusts, but this relation has hardly been proved. What may be the same fault is exposed about half a mile south of the lower Earl-Eagle tunnel.

The other faults found in the gulch range in strike from north-northeast to east-southeast. Some have the downthrow on the north side, some on the south side. Those whose dip is known are normal, excepting the small steep reverse fault exposed in the Hobnail tunnels. The dips of the two faults that have been traced farthest-which cross the gulch about a mile and half a mile, respectively, from its mouth-are not known. The course of the one to the north suggests a south dip, which would make it a reverse fault; the course of the one to the south indicates more convincingly a moderate dip to the south, which would make it a normal fault. This latter fault, which has an estimated throw of at least 600 feet and may extend for several miles, will be called the Major Evans fault. It is possibly continuous with a fault that has been traced by A. A. Baker ${ }^{80}$ on

\footnotetext{
80 Oral communication.
} 
an aerial photograph of an area enst of the Bay State tunnels.

\section{MINERALIZED FISSURES}

The movement that has occurred along most of the mineralized fissures has apparently been slight, and these fissures are not.marked by strong breccias such as those that follow some of the faults; there has, however, been considerable displacement on the Brain fissure in the Columbus mine (pl. 40) and on its supposed eastward continuation in the Alta Consolidated mine (pl. 46); and the Yankee fault, which has a large throw, is in part mineralized. Many of the fissures inconspicuous at the surface, being recognized only as seams or narrow breccias, which are stained brown with oxides of iron and manganese. The brecciation is most marked in certain beds of limestone or dolomite.

The mineralized fissures range in strike from north through northeast to east. Most of those noted near Mill D South Fork strike about N. $35^{\circ}-40^{\circ}$ E. and dip $60^{\circ}-65^{\circ} \mathrm{NW}$; the Carbonate fissure, however, strikes about $\mathrm{N}$. $75^{\circ} \mathrm{E}$. and $\operatorname{dips} 70^{\circ} \mathrm{N}$. Most of the principal fissures near Alta strike N. $60^{\circ}-70^{\circ}$ E. and dip $60^{\circ}-65^{\circ}$ $\mathrm{N}$, but the Brain fissure dips more steeply northward in places. Those in the American Fork district appear to belong to two systems, one of northeasterly and one of easterly strike. The stopes of the Miller mine extend in both directions, the longest N. $85^{\circ}$ E., and in the Yankee mine both the Yankee fault, striking eastward, and later fissures, such as the Belorophan, that strike northeastward are mineralized. The Pacific vein and the Dutchman vein belong to the northeasterly system. Farther northeast again two systems are found. In the Barry-Coxe mine, on the north slope of the pass between Silver Lake and Park City, the mineralized fissures strike about north and east; the northerly fissures are the more heavily mineralized.

\section{HISTORY OF MINING}

By V. C. Hetkes

\section{THE FIRST PROSPECTORS}

Lt. John C. Frémont, in his explorations of the Rocky Mountains, passed through Utah, which was then a part of Mexico, in 1842 and briefly referred to it in his report. It was then a wilderness; not a single white man, so far as known, at that time resided within the present limits of the State. The Mormons, in their exodus from Illinois, came to Utah in 1847. . In 1848, by the treaty of peace with Mexico, Utah was part of the territory ceded to the United States.

The discovery of gold in California in 1849 helped to save the founders of Salt Lake City ${ }^{81}$ from nakedness; the people who made up the trains bound westward for the land of gold were starving, but they were better clad than the Mormons, who were glad to sell them grain and vegetables in exchange for clothing. In March

\footnotetext{
81 Bancroft, H. H., Nevada, Colorado, and Wyoming, p. 65, 1890.
} $462585-43-6$
1849 the inhabitants of Salt Lake City met and organized the State of Deseret. On September 9, 1850, Congress defined the boundaries of Utah. ${ }^{\text {s2 }}$ The Territory as then organized was bounded on the west by California, on the north by latitude $42^{\circ}$, on the east by the summit of the Rocky Mountains, and on the south by latitude $37^{\circ}$.

The earliest interest of the Mormons in mining arose from their need of lead for making bullets. It was for this purpose, according to the records of the Mormon Church, ${ }^{83}$ that Isaac Grundy, a Virginian, who came. to Salt Lake City in 1847, was several years later called upon by Brigham Young to develop the lead mines near the place called Minersville. Grundy built a lead furnace $^{84}$ in the Lincoln district, Beaver County, Utah, said to be the first west of the Rocky Mountains.

In general, however, the president of the Mormon Church did not encourage Mormons to engage in mining, although he was not disposed to hinder the Gentiles from doing so. His attitude is described in the following statement by Raymond, ${ }^{55}$ who visited Salt Lake City in 1868:

I had an interview with Mr. Brigham Young, president of the Church of Latter Day Saints, and with several leading members of that church. They expressed a cordial desire for the completion of the railroad, and a willingness to have all the natural resources of Utah developed and utilized; disclaimed any hostility to mining, but admitted that they discouraged their own people from engaging in it because they thought agriculture would be far more profitable. Mr. Young expressed the opinion that the ores of Utah had never yet been skillfully treated. "What we used to call lead", said he, "and dig and melt up into bullets, these fellows call silver now! But if anybody is fool enough to come and mine for it, he may do so, and welcome!"

The earliest prospecting of any consequence was done by soldiers. The withdrawal of the military force from Camp Floyd (near Fairfield), where 6,000 to 8,000 men had been kept since the arrival of Johnston's army in 1858, to join the Union army in the Civil War in 1861 left the Territory without military protection and emboldened the Indians to such a degree that they became exceedingly troublesome, not only within the settlements of Utah but all along the line of overland trave] from the Sierra Nevada to the Missouri River, threatening by their depredations to cut off all overland communication. The difficulty was obviated only by sending to the Territory a portion of the California Volunteers, then enrolled to serve in the Civil War. The troops arrived in Utah in October 1862, under the command of Gen. P. E. Connor, and the post knowu as Camp Douglas, about $2 \frac{1}{2}$ miles east of Salt Lake City, was then established. The fact that mineral deposits abounded soon became known to the troops,

82 Gannett, Henry, A gazetteer of Utah: U. S. Geol. Survey Bull. 166, p. 3,1900 .

s3 Historian's oflice, Mormon Church, Salt Lake City.

84 Eissler, Manual, Metallurgy of argentiferous lead, preface, $1 . \$ 91$.

85 Raymond, R. W. Mineral resources of the States and Territorieg west of the Rocky Mountains for 1868, p. 168, 1869. 
and from time to time permission was obtained by squads of the men to go into the mountains and prospect. It was on one of these exploration expeditions that Capt. A. Heitz and party made the first discovery of argentiferous galena in Bingham Canyon. ${ }^{86}$

\section{EARLY CONDITIONS IN THE COTTONWOOD AREA}

The cutting and use of timber in the Cottonwood area, long unrestrained, was carried on from the earliest settlement. The timber was cut freely for lumber and for making charcoal. Immense quantities also were annually destroyed by forest fires, the result of carelessness or neglect. Lumber mills were active along Big Cottonwood Creek and around the lakes at the head of the canyon, and although none of them now survive, the sites of some of them are commemorated by such names as "Mill D South Fork" and "Mill F Flat." The lakes later known as Silver Lake and Twin Lakes were then called Lower, Middle, and Upper Mountain Lakes, and it was from these lakes that the first mining district organized in the Wasatch Mountains and the third in Utah Territory took its title, "Mountain Lake mining district." The settlers of the valley for many years continued to obtain their supply of timber from Big Cottonwood Canyon. Raymond ${ }^{87}$ states that the first legitimate mining location was made by Silas Brain in August 1865; this was on the north side of the little Cottonwood Canyon near Alta, but the exact location is not given. In $1869 \mathrm{~J}$. B. Woodman discovered the Emma ore body, and this discovery gave a great impetus to prospecting in the region. Raymond reviews the early findings of mineral in Utah as follows: ${ }^{88}$

The first silver-lead veins were found in the Oquirrh Range, in Bingham Canyon, and in the mountains bordering:Rush Valley. In October 1862, the United States volunteers from California, under the command of General Connor, arrived in Utah, and established the post known as Camp Douglas. Many experienced California miners were in this command and, naturally enough, took every favorable opportunity for prospecting the hills and valleys in the vicinity. * * * In 1864 , when Company $\mathrm{L}$ was stationed at the Government reserve in Rush Valley, many lodes of argentiferous galena were found. In the same year many locations were made by parties of nersons emigrating from the Western States to California, and about this time the town of Stockton was laid out. The land was "taken up" for the purpose by Gen. P. E. Connor, J. F. Rogers, Joseph Clark, and J. J. Johnson. The first mining district was organized in December 1863, and was named "West Mountain mining district." It embraced the whole of the Oquirrh range of mountains lying west of Jordan Valley. At a meeting of the miners, held June 11, 1864, this large district was subdivided, the eastern slope of the mountains retaining the name of "West Mountain mining district" and the western slope was called the "Rush Valley mining district."

After the organization of the West Mountain and Rush Valley districts, the soldiers at Camp Douglas

\footnotetext{
so Murphy. J. R., The mineral resources of the Territory of Utah, p. 1 , Salt Lake City, 1872.

${ }_{87}$ Raymond, R. W., Statistics of mines and mining in the States and Territories west of the Rocky Mountains for 1871, p. 321,1873 .

88 Idem, p. 304
}

formed the third district to be organized in Utah out of the greater portion of the Wasatch Range, naming it the Wasatch mining district, but at a meeting held July 20, 1864, it was renamed the Mountain Lake district. The new district embraced within its limits that part of the range between the Warm Springs north of Salt Lake City and the head of Utah Lake, described in the Daily Union Vedette, published at Camp Douglas July 22, 1864, as follows:

Beginning at the junction of Parley's Creek with Jordan River, thence up the right bank of said creek to the original eastern boundary line of the Wasatch mining district, thence along the eastern margin boundary to the head of Utah Lake, thence along the eastern margin of said lake to the head of Jordan River, thence along the eastern bank of said river to the point of starting.

A year or so later (1869-70), the district was divided and separately organized into the Big Cottonwood, Little Cottonwood, and American Fork districts. At about the same time the eastern part of the district, in the Park City area, was subdivided into the Uinta, Snake Creek, and Blue Ledge districts.

\section{REGULATIONS GOVERNING MINING LOCATIONS}

The California laws were followed to some extent in formulating the regulations of each district, although in some districts local rules differing slightly from the California laws were made. Records of miners' meetings and some of the minutes signed by the first recorders elected to the early organized mining districts of the seventies are in the files of the surveyor general at Salt Lake City and are of some interest. The organizers in the Cottonwood-American Fork area ruled that no person or company of persons should be entitled to hold more than 200 feet as the discoverer of a lode, nor more than 200 feet for each person who located, and the total length was not to exceed 3,000 feet.

In the Little Cottonwood district the law regarding width of claim was like that of the Mountain Lake district; it provided that the extent of a claim on any mineral vein should be 200 feet along the lode for a width of 50 feet each side of the lode, including all dips, spurs, angles, depths, widths, offshoots, etc. The organizers of the American Fork district, on July 21, 1870, adopted the ruling that "the surface width requisite for mining purposes or for the convenient working of the same should not exceed 100 feet on each side of the wall of said vein or lode." At a meeting of miners in the American Fork district on July 21, 1873, it was decided to adopt the United States law of May 10, 1872, giving the locator the right to hold 1,500 linear feet along the course of any mineral vein or lode and 300 feet on each side of the middle of the vein at the surface. Many claims were patented under the old law and subsequently incorporated with all the advantages of the enlarged area locatable under the law of May 10, 1872. 


\section{EARLY SHIPIMENTS AND EXPERIMENTS IN} SMELTING

The first shipment of ore from Utah Territory ${ }^{80}$ was a carload of copper ore from Bingham, shipped to Baltimore by the Walker Brothers in June 1868. This ore was hauled by wagon to Uintah, a station on the Union Pacific Railroad in Weber County near Ogden. This railload was completed to Ogden March 3, 1869, and the transcontinental line connected through to the coast May 10, 1869. The construction of the Utah Central Railroad from Ogden was started May 17, 1869, and completed to Salt Lake City, 37 miles distant, January 10, 1870. A railroad extending southward from Salt Lake City, the Utah Southern, was begun May 1, 1871, and completed to Provo in December 1873.

The first discovery of silver-bearing ore in the Wasatch Range, credited to General Connor himself, was in Little Cottonwood Canyon, but its exact location is not certain. Nothing was done toward active development until the fall of 1868, when, for the first time, operations were started on the mines by Woodhull, Woodman, Chisholm, Reich \& Co. The first shipment of galena ore from Little Cottonwood Canyon, amounting to one carload, was made by the Walker Brothers in July 1868, and several more shipments were made in the fall of that year by the same firm.

The California Volunteers were stationed at Camp Douglas, and Company $\mathrm{L}$ was at Camp Relief, in the Rush Valley district of the Oquirrh Range. General Connor furnished the means for starting a small smelting furnace near Stockton, in Rush Valley. ${ }^{90}$ His soldiers had already made several important discoveries of mineral in both the West Mountain and the Cottonwood districts, but Stockton was a favorite for smelting experiments. There was a sort of rivalry ${ }^{91}$ between Rush Valley and the Cottonwoods to see which district would make the first successful furnace run. A'n account of the first attempt in the Cottonwoods, made in 1866, ${ }^{02}$ follows:

A number of finely developed veins of galena have been uncovered and about a dozen of them tested. The average assay is $\$ 1.25$ to the ton in silver, and as much as $\$ 26$ in gold is found. Last year [1866] 30 tons of bullion [ore] were taken out of the North Star lodes which assayed here $\$ 280$, and the same bullion assayed at the Philadelphia mint $\$ 297$. The mine is owned by James P. Bruner, of Philadelphia and his agent, A. A. Hurst, Esq. There is already erected one Scotch hearth, one stack furnace, one cupel furnace, a water wheel, fan, and dwelling house.

The failure to get results from the first smelting venture is noted in the following account ${ }^{93}$ of a later and more successful experiment:

We are assured firom a very reliable source of perfect success of the smelting company in Little Cottonwood Canyon. Lhese works have been constructed under the immediate super-

\footnotetext{
${ }^{80}$ Murphy, J. R., The mineral resources of the Territory of Utab, p. 4, Salt Lake City, 1872.

no Dafly Union Vedette, Apr. 22, 1864; Aug. 26, 1866 ; and Sept. 17, 1866.

or I.dem, August, 25, 1866 .

Q3 Daily Union Vedette, May 2s, 1867.

so Idem, Oct. $26,1867$.
}

vision of a Mr. Reese, a practical German metallurgist of high standing in his profession, engiged by $A$. A. Hurst, of the North Star mine, in Little Cottonwood Canyon. We are promised early next week the sight of nearly 1,000 pounds of silver in bar, the same being the result of the first run of the furnaces during the present week. The amount, we are informed, was extracted entirely from the cinders made by Dr. Congar and others in their abortive attempts to manipulate the ores of the North Star lode.

Bruner's furnace, where these unsuccessful tests were made, was a mile west of the Emma mine, east of the village of Central. Such failures as those made by Dr. Congar did not deter others from erecting furnaces to treat the ores, and the first important successes were made near the mouths of Big Cottonwood and Little Cottonwood Canyons. The first big success at turning out bullion was achieved at the furnaces built by the Woodhull Brothers, who in June 1870 completed their works, consisting of one cupola and blast and one reverberatory. These works were situated at the junction of the State road with Big Cottonwood Creek, and, although of small capacity, they did good service in practically testing some of the ores. ${ }^{94}$ The result was a production of 5,000 pounds of bullion in 36 hours from the ores of the Monitor, Magnet, and other Cottonwood mines. The bullion was valued at $\$ 500$ to the ton in silver. It was said to be the first run of bullion in the Territory ${ }^{95}$ and created considerable excitement. Raymond gives the following additional information:

The metal was hauled to town and stacked up in front of the Elephant store, where it attracted large numbers of people who were curious to see the pioneer bars of Utah. The Woodhull Works are capable of working about 10 tons daily. Mr. Milton Robbins is about to put up smelting works. He will have the able assistance of Mr. Charles C. Ruegar, who will take the active management and the construction of the furnaces in hand. Mr. Ruegar has studied in Germany and has spent considerable time among the mines of California. He appears to be well fitted for his work. Mr. Leipold Balbach, a cousin of the Balbach Brothers, of Newark, N. J., has been visiting the mines of Utah, and was so impressed with their extent and richness that be telegraphed to parties in the East (be tells me) that he thinks best to erect smelting works in the valley, and these are to be put up. There are others here who engage in buying ores, and the mines are attracting persons from different quarters.

Colonel Buell's reduction works, at the mouth of Little Cotton wood Canyon, proved to be the next efficient furnaces to operate. Construction of the smelter started November 1,1870 , and it was producing bullion on January 14, 18 7 . These works ${ }^{96}$ had two hexagon furnaces of the improved Piltz pattern. They became the property of the Flagstaff Silver Mining Co., Ltd., which operated them for several years. Halfway up the canyon, at Tanners Flat, west of the area here mapped,

0.4 Murphy, J. R., The mineral resources of the Territory of Utah, p. 5 , 1872.

o Raymond, R. W., Statistics of mines and mining in the States and Territories west of the Rocky Mountains for 1870, p. 223, 1871.

${ }^{90}$ Murphy, J. R., The mineral. resources of the Territory of Utah, p. 6, Salt Lake City, 1872. 
were the works of Jones \& Pardee, ${ }^{97}$ a one-shaft furnace that was started in March 1871 and operated for 2 years. The Davenport smelter, treating Davenport ore in two vertical blast furnaces, occupied a site nearby in 1872 and operated until 1875. Water was used as motive power for the machinery.

Robbins \& Co. built smelting works costing about $\$ 80,000$ at the junction of the State road and Little Cottonwood Creek and began to operate them in the spring of 1870 . The works ${ }^{98}$ consisted of a large reverberatory roasting furnace with a smelting hearth underneath and were the first successfully to use coal from the Green River fields as fuel. Near the mouth of Silver Fork in the canyon of Big Cottonwood Creek, according to Raymond; a cupola furnace was completed and put into operation by Wightman \& Co. on September 20, 1871. Murphy ${ }^{99}$ called this the Homansville Smelting Works. Slag can still be found at the site, which is not far from the Kentucky-Utah tunnel.

The: Saturn Silver Mining Co., Ltd., started a smelter in May 1872 at Sandy, on Little Cottonwood Creek west of the base of the mountains. It adjoined the site of the Mountain Chief or Mingo works, half a mile south of the Utah Southern Railway station, and was afterward the property of the Mingo Co. The equipmen: consisted of three vertical blast furnaces with a capacity of 20 tons daily. The ores treated at the smelters at Sandy came mostly from Little Cottonwood and Bingham, though small lots came from the Big Cottonwood, 'Tintic, and other districts. The Last Chance smelter' was situated at Sandy, at the place where the publicsehool building now stands.' This plant, which was afterward known as the Flagstaff smelter, had three cupola blast furnaces and used steam as motive powe: for the blast engines. ${ }^{1}$ On Big Cottonwood Creek, about 5 miles north of Sandy and 7 miles from Salt Laks City, several smelters were constructed within a mile of each other. The Wasatch Silver-Lead Works was built. in 1872, to treat the Reed \& Benson and Emma ore, from Little Cottonwood Canyon, and the Spanish mine ore. from Bingham Canyon. This smelter was destroyed by fire in February 1878. The Germania smelter was started November 26,1872 , and had a $\$ 150,000$ plant $f_{0}:$ manufacturing lead products, such as white and red lead and litharge. In 1875 the Galena five-stack smelter was built on the Jordan River. In 1876-77 the old Telegraph smelter, which had a sampling mill and five waterjacket furnaces, was built at Midvale. It closed in August 1880.

The smelting business was greatly depressed during the first half of $1875,{ }^{2}$ but at the end of the year 11 fur-

\footnotetext{
${ }^{07}$ Raymond, R. W., Statistics of mines and mining in the states and Territories west of the Rock Mountains for 1871, p. 321, 1872.

${ }^{08}$ Idem, p. 301.

o9 Murphy, J. R., op. cit., pp. 6, 29.

1 Utah Min. Gazette, April 11, 1874, p. 281.

2 Raymond, R. W., Statistics of mines and mining in the States and? Territories west of the Rocky Mountains for 1875, p. 268, 1876.
}

naces were in operation. Mr. Billing, of the Germania works, started his furnaces in May, and the others followed. An important advance made in 1875 was the first use of Utah coke in smelting the ores. Before that time coke was a most expensive item in smelting, costing from $\$ 30$ to $\$ 35$ a ton delivered, with all the disadvantages of purchasing at a great distance-in Indiana or Pennsylvania. San Pete coke was delivered to the Germania works at $\$ 28$ a ton.

In 1872 the old Telegraph smelter charged $\$ 16$ a ton for smelting. Most of the fluxes then came from Utah, Nevada, and Wyoming; ${ }^{3}$ limestone was shipped from Warm Springs, north of Salt Lake City, iron ore from the vicinity of Rawlins, Wyo., and charcoal from Truckee, Nev., and Piedmont, Wyo.

In 1870 the miners and smelters ${ }^{4}$ were dependent upon the railway companies to get their ore and bullion to the markets, and during the summer of 1871 shipment of ore was paralyzed by a new and increased schedule of freight rates. Only the Emma Co., which had a contract with the railway at low rates, was able to continue. The rates were subsequently reduced, though not to the former levels, being placed at $\$ 18$ a ton for ore and $\$ 20$ for bullion from Salt Lake City to Omaha. Charcoal was brought by rail from 'Iruckee, Nev., and could be had in large quantities at 25 cents a bushel. The Utah charcoal cost 22 to 30 cents, but was frequently inferior in quality or uncertain in supply.

The average daily production of base bullion in the Salt Lake Valley in July 1871 was 15 tons, produced by the treatment of 280 tons of ore. The furnaces were operated very irregularly, and so unskillfully that salamanders or large clinkers were frequently formed. The loss of lead and silver in the shaft furnaces was often very great, half the lead being lost in the slag or up the chimney. ${ }^{5}$

\section{TRANSPORTATION}

Transportation of ore and supplies was always one of the most difficult problems of zinining operators in this area, particularly in the Little Cottonwood district. Snow falls in great quantity during the winter, accumulating to a depth of 6 to 20 feet or more, and many lives have been lost in avalanches of snow. Various plans have been made, but none carried out, to tunnel from Alta to the Big Cottonwood Creek side of the divide, where better wagon roads of more even grade could be used. After the completion of the Utah Southern Railway to Sandy in May 1871, two narrow-gage railroads ${ }^{\circ}$ were commenced in 1872 and completed in 1873, one from Sandy to Wasatch and the other to Bingham. In 1875 Alta was connected with the valley by the Wasatch \& Jordan Valley Road (steam), which extended its line

3 Salt Lake Tribune, Nov, 22, $18 \% 2$.

4 Raymond, R. W., Statistics of mines and mining in the States and Territories west of the Rocky Mountains for 1871, p. 300, 1873.

5 Idem, n. 301.

- Salt Lake Tribune, Nov. 22, 1872. 
6 miles into the canyon to Wasatch and built a singletrack mule tramway from that point to the Emma mine. ${ }^{\text {? }}$ All but the last 4 miles was enclosed in sheds, and sheds for that portion were completed in 1876. Freights to Sandy were reduced $\$ 2.50$ a ton from the rate previously paid of $\$ 7.50$ in summer and $\$ 8$ in winter. ${ }^{8}$ The total yearly receipts of this railroad for 1874 were $\$ 38,000$; for $1875, \$ 566,000$; and for $1877, \$ 150,0000^{\circ}$

Huntley ${ }^{10}$ says that the rise between Sandy and Alta, the terminal points of the railroad, was $4,5361 / 2$ feet. The freight rates at the time of his visit (October 1880) were $\$ 4$ a ton for ore assaying over 30 ounces of silver, $\$ 3.50$ a ton for ore assaying between 30 and 15 ounces, and $\$ 2.75$ a ton for ore assaying less than 15 ounces. During 1880 , the census year, the railroad shipped 6,343 tons of ore, and also 5,385 tons of granite from Wasatch for the Mormon Temple at Salt Lake City.

The railroad and mule tramway operated until the panic of 1892, when the tracks were removed. Even the grading for the old mule tram that ran along the side of the mountain for 8 miles into Alta soon disappeared, except in places where stone riprapping had been built.

New rail connections were completed in November 1914. The broad-gage line of the Salt Lake \& Alta Railroad Co. used a part of the old grade and connected Wasatch with Midvale, 11 miles distant. The Denver $\&$ Rio Grande Railroad Co. took this part of the property over September 1,1917 . In the meantime the narrow-gage road to Alta was being rebuilt under many financial difficulties, and it was completed by the Little Cottonwood Transportation Co. in 1917. Shay engines and 20-ton ore-dump cars were used. At first the terminus of the road nearest to Alta was the Columbus- Rexall ore bin; later the line was extended to the South Hecla ore bin. Lower down the canyon from these mines the Salls and Michigan-Utah mines loaded ore, the latter from its aerial tramway terminus at Tanners Flat.

About 300 tons of ore daily was hauled during the summer of 1919 to Wasatch and there dumped into broad-gage cars. The railroad rate over the narrowgage line effective September 15, 1919, was $\$ 2$ a ton on ore valued between $\$ 15$ and $\$ 35$ a ton. On ore valued between $\$ 35$ and $\$ 55$ a ton the rate was $\$ 2.90$ a ton, and on ore of greater value $\$ 3$. From Wasatch $\$ 15$ ore was carried on the broad-gage line to the smelters at Midvale, Murray, or Garfield for 80 cents a ton, $\$ 15$ to $\$ 30$ ore at $\$ 1.10$ a ton, and ore of greater value at $\$ 1.50$ a ton.

During the winter, when the narrow-gage railroad

\footnotetext{
${ }^{7}$ Raymond, R. W., Statistics of mines and mining in the States and Territories west of the Rocky Mountains for 1875, p. 271,1576 .

${ }^{8}$ Idcm for 1.872 , p. 246 (extracts from annual report of the Flagstaff Mining Co.), 1873.

WEng. and Min. Jour., Jan. 12, 1.878, p. 33.

${ }^{10}$ Huntley, D. B., The mining industries of Utah: 10th Census D. S. (18s0), vol, 13, p. 422,1885 .
}

could not operate because of the deep snows, the ore was hauled by 4 -horse sled outfits 8 miles from Alta to Vasatch. The sleds carried from 3 to 6 tons of ore to the load, and as many as twenty 4 -horse teams were on the road during the period of heavy snows. In the spring and summer the thawing snow and the resulting bad condition of the roads added to the difficulties and cost of hauling ore and supplies. At times there was difficulty in obtaining enough teams to do the hauling. The rates for hauling from the mines to Wasatch were generally uniform, ranging from $\$ 3$ to $\$ 3.75$ a ton.

In recent years the railway tracks have been torn up, and a good automobile road, which utilizes part of the old railway grade has been built in Little Cottonwood Canyon. The Big Cottonwood district is now connected with Salt Lake Valley by a motor road that follows Big Cottonwood Creek and crosses the Wasatch divide to Park City. In summer an automobile stage runs from Salt Lake City to Silver Lake (Brighton), a resort near the head of the canyon.

\section{ELECTRIC POWER}

Nearby hydroelectric plants furnish the only power used in the three districts, there being two power lines into Alta. The Wasatch Power Co. operates a plant in Little Cottonwood Canyon, and an 11,000-volt transmission line of the Utah Power \& Light Co. extended from the Cardiff mine, in Big Cottonwood Canyon, to the Emma mine, in Little Cottonwood Canyon. The niills in the American Fork Canyon are directly connected with the Snake Creek hydroelectric power plant of the Utah Power \& Light Co. In 1919 a compressor was operated by water power near the head of American Fork.

\section{MINING}

As the sides of the canyons are steep, most of the mines in Alta and the other parts of the CottonwocdAmerican Fork area have been operated through tunnels, which penetrate only to relatively shallow depths. The lower, or Dwyer, adit of the South Hecla mines (altitude 8,601 feet) develops the property in some places to a depth of 1,100 or 1,200 feet, though the average depth is only 500 feet. On nearly the same lerel as the Dwyer adit is the Columbus, from which there is a shaft down 450 feet. The Wasatch drain tunnel, which connects with the Flagstaff-Columbus workings and is the deepest in the region, has its portal at an altitude of 8,067 feet. On the Michigan-Utah property the Solitude tunnel from Solitude Lake (altitude 9,300 feet) has ore in a winze below the tunnel level. The Columbus-Rexall (Howland) adit enters at an altitude of 8,573 feet; the main Cardiff tunnel is a little higher, but its workings are in great part lower. The deepest Emma workings are 350 feet below the level of the Bay City tunnel, which enters at an altitude of 8,775 feet. The Alta tunnel extends from Silver Fork Canyon 
at an altitude of 8,536 feet for 3,550 feet southeastward. The Kentucky-Utah tunnel, near Cottonwood Creek at
8.150 feet, has been driven in the same general direction for more than 8,000 feet.

Development and transportation tunnels of the Big Cottonwood, Little Cottonwood, and American Fork districts, showing altitude at portal and approximate length

\begin{tabular}{|c|c|c|c|c|c|c|c|c|}
\hline \multicolumn{3}{|c|}{ Big Cottonwood } & \multicolumn{3}{|c|}{ Little Cottonwood } & \multicolumn{3}{|c|}{ American Fork } \\
\hline Name & $\begin{array}{l}\text { Lengthth } \\
\text { (feet) }\end{array}$ & $\begin{array}{c}\text { Altitude at } \\
\text { portal } \\
\text { (feet) }\end{array}$ & Name & $\begin{array}{l}\text { Length } \\
\text { (feet) }\end{array}$ & $\begin{array}{c}\text { Altitude at } \\
\text { portal } \\
\text { (feet) }\end{array}$ & Name & $\begin{array}{l}\text { Length } \\
\text { (feet) }\end{array}$ & $\begin{array}{l}\text { AItitude at } \\
\text { portal } \\
\text { (feet) }\end{array}$ \\
\hline $\begin{array}{l}\text { Woodlawn } \\
\text { Solitude } \\
\text { Great Western } \\
\text { Cardiff } \\
\text { Alta } \\
\text { Price } \\
\text { Victor } \\
\text { Cottonwood Coalition } \\
\text { Kentucky-Utah } \\
\text { Cottonwood Metals } \\
\text { Maxfield }\end{array}$ & $\begin{array}{l}1,800 \\
3,200 \\
8,500 \\
2,400 \\
3,550 \\
1,800 \\
2,000 \\
3,600 \\
8,000 \\
1,700 \\
2,400\end{array}$ & $\begin{array}{l}9,275 \\
9,100 \\
8,906 \\
8,800 \\
8,536 \\
8,400 \\
8,375 \\
8,150 \\
8.150 \\
-7,200\end{array}$ & $\begin{array}{l}\text { City Rock } \\
\text { Wellington } \\
\text { Flagstaff } \\
\text { Grizzly } \\
\text { Cleves } \\
\text { Rustler } \\
\text { Copper Prince } \\
\text { Albion } \\
\text { Montezuma } \\
\text { Burgess } \\
\text { Illinois } \\
\text { Old Emma. } \\
\text { Phoenix } \\
\text { Cabin (Golconda) } \\
\text { Bay City } \\
\text { Quincy } \\
\text { Tom Moore } \\
\text { Dwyer } \\
\text { South Columbus } \\
\text { Columbus Rexall (How } \\
\text { land) } \\
\text { Wasatch } \\
\text { Wow }\end{array}$ & $\begin{array}{r}1,275 \\
500 \\
1,200 \\
1,750 \\
1,800 \\
1,000 \\
2,200 \\
3,000 \\
1,220 \\
670 \\
600 \\
370 \\
1,700 \\
1,050 \\
1,700 \\
6,000 \\
4,000 \\
3,500 \\
1,200 \\
5,400 \\
5,538\end{array}$ & $\begin{array}{l}9,850 \\
9,884 \\
9,564 \\
9,470 \\
9,375 \\
9,307 \\
9,300 \\
9,191 \\
9,180 \\
9,167 \\
9,040 \\
9,000 \\
8,933 \\
8,874 \\
8,775 \\
8,711 \\
8,672 \\
8,601 \\
8,583 \\
8,573 \\
8,067\end{array}$ & $\begin{array}{l}\text { Pittsburg } \\
\text { Earl Eagle } \\
\text { Wyoming } \\
\text { Mormon } \\
\text { Sierra } \\
\text { Mineral Flat. } \\
\text { Silver Dipper } \\
\text { Holden (Live Yankee) } \\
\text { Bog } \\
\text { Pacific } \\
\text { Miller Hilli } \\
\text { Dutchman }\end{array}$ & $\begin{array}{l}500 \\
2,000 \\
1,400 \\
1,200 \\
300 \\
2,500 \\
500 \\
1,700 \\
1,500 \\
1,000 \\
2,200 \\
1,200\end{array}$ & $\begin{array}{l}9,909 \\
9,860 \\
9,851 \\
9,773 \\
9,716 \\
9,550 \\
9,167 \\
9,140 \\
8,600 \\
7,825 \\
7,750 \\
7,650\end{array}$ \\
\hline
\end{tabular}

Most of the deeper workings of the mines are wet, but the water has occasioned no difficulty except in mines operating below tunnel levels, such as the Emma and Maxfield, where constant pumping was necessary to keep the mines in a workable condition.

The shrinkage and top-slicing systems of mining were employed in the last large-scale operation of the Emma mine and of other mines of the area. By the shrinkage system the ore is broken down in the stope and drawn off through short raises just rapidly enough to leave a space of several feet between the accumulated ore and the top of the stope, thus permitting the miners to work on top of the broken ore. The top-slicing system, which is the more commonly used, is operated by extending raises through the ore body to the hanging wall, then widening them at the top. In the immediate vicinity of each raise the ore is caved into it; farther away it often becomes necessary to shovel the ore. Very little timber, compared to that needed in most other regions, is used in mining operations. J. J. Beeson, in a report for the stockholders of the Emma mine, states that no timbers were required in the stopes in early mining work. In the stope, from 30 to 40 feet wide and over 30 feet high, that had been mined out below the Montezuma fault the top and sides remained perfectly solid, and the stope is now represented by a great open cave.

\section{MILLING}

Attempts were made in 1873 to treat the Emma second-class ore by concentration of the heavier minerals. ${ }^{11}$

\footnotetext{
${ }^{11}$ Raymond, R. W., Statistics of mines and mining in the States and Territories west of the Rocky Mountains for 1873 , p. $273,1874$.
}

The jigged material was probably mixed with the shipping ore. In the following year 6,000 tons of secondclass ore was concentrated and 300 tons of first-class ore shipped.12 In 1884 part of the old Carrie Steel mill (10 stamps), hauled from Camp Floyd, was set up at the mouth of Little Cottonwood Canyon to work the low-grade ores of the McKay, Revolution, and other mines. ${ }^{13}$ Not long afterward (November 17, 1888) the works were sold at sheriff's sale. No other record is found of milling plants until the Columbus Consolidated concentrator was put into operation in 1905 , using rolls, tables, and jigs from the equipment of two old mills that had served their time in other districts. Ore from the Flagstaff and Columbus mines was treated in this concentrator until it was destroyed by fire, in January 1914. The Continental-Alta concentrator was built in 1905 at Tanners Flat, at the terminus of the MichiganUtah aerial tramway, but was worked only a short time, with poor results. In the American Fork Canyon a concentrator was built at the mouth of the Dutchman adit in 1916. Some ore from the Dutchman and Pacific mines was treated, but after a short period of operation the mill was torn down and rebuilt at the entrance of the Pacific (Blue Rock) tunnel. Very little ore was treated at the new location, and the mill was closed on account of litigation. The equipment of the Pacific mill consisted of one Blake crusher, one set of rolls, a Hardinge tube mill, four Deister cone classifiers, four Deister sand tables, and six double-deck Deister slimers. This mill was afterward remodeled but was later burned

${ }^{12}$ I.dem for 1874, p. 335,1875

13 Director of Mint Rept. for 1884, p. 422, 1885. 
down. Another concentrator, of 50 tons capacity, was built at the Belorophon mine in 1918 by the American Leasing Co., which operated the Live Yankee property through its adit. The Nilline plant was situated in Mary Ellen Gulch and was equipped with a Dodge crusher, rolls, two.Harz jigs, and an Overstrom table. In 1932 the American Smelting \& Refining Co. acquired the Live Yankee property, which it operated through what is known as the Yankee mine, and constructed an aerial tram to carry the ore to the lower part of American Fork Canyon. At the Albion mine, near Alta, in 1917, and at the Cardiff and Maxfield, in the Big Cottonwood district, in 1916, small jigging plants were used, but these were later dismantled.

\section{BIG COTTONWOOD DISTRICT}

The earliest locations in the drainage basin of Big Cottonwood Creek appear to have been made in 1868 and 1869. On March 17, 1870, this basin, which was originally part of the Mountain Lake district, was declared to be a separate district. ${ }^{14}$ The first location subsequent to this date was made in May or June, 1870. A meeting was called shortly afterward, at which a set of mining laws for the new district was passed. The district is about 16 miles east and west by 6 miles north and south. Little work was done toward the development of any claims until the spring of 1871. A small settlement was started at this time, and later the village of Argenta was laid out a quarter of a mile east of the Maxfield mine. At one time it boasted of 200 inhabitants, and in the eighties it was still the post office of the region,,$^{15}$ but the buildings have since disappeared. A triweekly stage connected Argenta with Sandy, 14 miles west.

The localities most advanced in mining development in 1871 were on Silver Fork, Honeycomb Fork, and Carbonate Peak. ${ }^{16}$ The Davenport, Teresa, Wellington (later a part of the Antelope), Highland Chief, Wandering Boy, Antelope, Prince of Wales, Congress, Lone Star State, Rock Island, Beckwith, Maxfield, Hidden Treasure, Copper, Scott, Reed \& Benson, and the Ophir all had ore in sight in April 1871.17 The Davenport, Teresa, Wandering Boy, Maxfield, and Prince of Wales had each yielded some ore for shipment in the fall of 1870. More than 200 locations had been recorded in this district by April 1871. At the end of 1880, only a few of the properties previously mentioned were producing, although between 300 and 400 of the 1,354 locations noted by Huntley ${ }^{18}$ in that year were still being held. In 1920 many of these claims formed a part of some

\footnotetext{
14 Murphy, J. R., Mineral resources of the Territory of Utah, p. 28, 1872 .

15 Frolseth, B. A. M., personal interview, April 4, 1921.

${ }_{10}$ Murphy, J. R., Mineral resources of the Territory of Utah, p. 28, 1872.

${ }^{17}$ Raymond, R. W., Statistics of mines and mining in the States and Territories west of the Rocky Mountains for 1871, p. 319, 1872.

18 Funtley, D. B., Mining industries of Utah : 10th Census U. S. (18s0), vol. 13 , p. 427,1885 .
}

20 groups owned and operated by as many mining companies.

None of the mines on the north side of Big Cottonwood Creek have been producers of note, and in recent years the production from this tract has been small. The Red Bell, a mile west of the Maxfield, had an output of lead-silver ore in 1917-18, and the Hayes mine, $21 / 2$ miles to the north, produced some rich gold ore containing copper in 1904; the Scottish Chief mine in 1903 and 1904 yielded 152 tons of silver-lead ore containing a little copper, and the American group in 1917-18 produced two lots of silver-lead ore. Between 1916 and 1919 the Iowa Copper mine, on Scott Hill, shipped over 900 tons of copper ore containing considerable silver and gold. The history and production of the individual properties will be found in the description of the mines and mainly under the titles of the smaller groups of claims as they were developed, rather than under the larger groups into which much of the area has now been consolidated.

\section{LITTLE COTTONWOOD DISTRICT}

In the early seventies Alta, near the head of Little Cottonwood Creek, Central City, a little farther down the same stream, and Forest City, in American Fork Canyon, were well known as the supply points and headquarters for the two districts. During an interval of more than half a century snowslides and fires have destroyed nearly all the old landmarks in these towns. The first building put up at Alta was a steam sawmill with boarding house attached, erected in 1868, ${ }^{19}$ by Bishop Samuel A. Wooley and Nathan Davis, of Salt Lake City. The Miller brothers, who discovered the Miller mine, in American Fork Canyon, built the third cabin at Alta. Central City was soon abandoned, and its telegraph office was moved to Alta in 1871. Alta was a flourishing town with 180 dwelling houses in 1873. At that time there were seven restaurants, two lodging houses, and many saloons, one blacksmith shop, two shoemakers, several carpenters, one shooting gallery, two druggist shops, two assayers, four medical men, one minister (Presbyterian), one lawyer, two breweries, a court house, and a prison. The Cottonwood Observer, a semiweekly, was published by a Mr. Webb. Two stage lines were operated into the camp. The town of Alta was laid out in 116 oblong blocks, generally 300 by 175 feet, with ten streets running east and west and eleven running north and south.

The earliest recorded mining claims in the camp ${ }^{20}$ were the Pittsburg, St. Lewis, North Star, Atlantic Cable, General Grant, Ohio, Mount Pleasant, Great Eastern, Giant Western, Chicago, Morning Star, and Evening Star, located by Silas Brain in August 1865, and the Susquehanna and Shenandoah, located at the same time by $\mathrm{H}$. Poole, both locators acting under Dr.

10 Utah Min. Gazctte, Salt Lake City. Aug. 30. 1873.

$20 \mathrm{Murphy,} \mathrm{J.} \mathrm{R.,} \mathrm{Mineral} \mathrm{resources} \mathrm{of} \mathrm{the} \mathrm{Territory} \mathrm{of} \mathrm{Utab,} \mathrm{p.} \mathrm{22,} 1872$. 
O. H. Congar, agent for the New York \& Utah Prospecting \& Mining Co. Dr. Congar and his company are credited with being the first to undertake the opening of a road to the mines, which was completed to Gerard's mill, at Central City. He also, in the summer of 1866, built the Bruner smelting furnace to test the ores. Attemps were soon made to construct and work other furnaces, and after some unsuccessful trials Dr. Congar, in September 1866, succeeded in producing about 3,000 pounds of silver-lead bullion worth $\$ 300$ a ton in silver. In $1869 \mathrm{~J}$. B. Woodman sunk a shaft a short distance below the North Star clain and followed indications of ore until he suddenly opened the first large ore deposit of the Emma mine. ${ }^{21}$ The next locations were those of the Monitor and Magnet, August 18, 1868, and the Western Star, October 23, 1868.

The Emma mine was located in December 1868, although not recorded until June 10, 1869. Raymond first described the discovery of its ore body, as follows:

The Emma mine is one of the most remarkable deposits of argentiferous ore ever opened. Without any well-marked outcroplings, there was nothing upon the surface to indicate the presence of such a mass of ore except a slight discoloration of the limestone and a few ferruginous streaks visible in the face of a cut made for starting the shaft. Some of the earliest locators in the canyon assert, however, that in the little ravines below this shaft large masses of galena, some weighing over 100 pounds, were found upon the surface and in the soil. After the discovery of the deposit, by means of the shaft, a tunnel was run in so as to intersect it in depth. This tunnel extends in a northwesterly direction and is 365 feet long. It intersects the ore mass where it was about 60 feet long and 40 feet wide, measured horizontally: From this level, called the first floor, ore has been mined above and below until an excavation or chamber has been formed, varying from 20 to 50 feet in width and from 50 to 70 in length, and 77 in height above the tunnel level, and 50 in depth below.

In August last a portion of the ore below the tunnel level was still standing, but the mine had produced from 10,000 to 12,000 tons of ore, assaying from 100 to 216 ounces of silver per ton of 2,000 pounds, and from 30 to 66 percent of lead, averaging about 160 ounces of silver and from 45 to 50 percent of lead. The total value of this ore, at the cash price paid for a large part of it in riverpool, 36 pounds, or $\$ 175$ in round numbers, was about $\$ 2,000,000$.

This ore was extracted at comparatively little cost. Most of it was stoped from below upward and was delivered by chutes into the cars upon the tramway laid in the tunnel. In general, the ore was soft and easily excavated by picks and shorels, without the aid of gunpowder. It consisted chiefly of ferruginous and earthy-looking mixtures of carbonate and oxide of lead, oxide of iron, and antimony, mixed with nodules of galena. It appears to have resulted from the decomposition of argentiferous galena and other sulfureted and antimonial minerals containing silver. The ore may be said to be without gangue and does not require hand sorting or separating by mechanical means from worthless veinstone. This ore was shoveled up and put into sacks for shipment without any other delay or expense. The larger part was shipped overland by railroad to New York and thence by steamer to Liverpool.

The Little Cottonwood district was organized, accord-

\footnotetext{
at Raymond, R. W.. Statistics of mines and mining in the States and Territories west of the Rocky Mountains for 1871, pp. 321-322, 1872 .
}

ing to.Murphy, ${ }^{22}$ in 1870 . It was divided into localities, each bearing a distinctive name. This became a necessity owing to the multiplicity of mining claims located and their close proximity to each other. The localities were known by the names Emma Hill (sometimes called Montezuma Hill), Granite Hill, Wellington Hill, Peruvian Hill, and Frederick Hill. In 1872 the principal mines on Emma Hill were the Emma, Flagstaff, Vallejo, Titus, Ohio, Highland Chief, Savage, Montezuma, Last Chance, Hiawatha, Western Star, Revolution, Monitor, Magnet, Morning Star, Caledonia, McKay, Stoker, North. Star, Brain, Emily, Relief, Paris Belle, Flora Temple, Cincinnati, and Chicago.

In 1869 , according to Raymond, ${ }^{23}$ from 50 to 100 mineral veins had been located in the Cottonwood area, but very few of them had been opened. Most of the work had beèn done on the Lone Star, Magnet, Illinois, Ida, and Monitor claims. The shaft of the Ida was 100 feet deep and exposed a vein 2 feet wide in the bottom. Woodhull \& Co. had already shipped to San Francisco, through Walker Brothers, 15 tons of ore from the Monitor and Magnet claims, in order to ascertain its value and the best way of treatment. Later the development of the Emma mine ${ }^{24}$ gave the needed impetus to mining, and in the summer of 1870 a great change in the condition and prospects of Utah mines was effected. The completion of railway connections with the east and west had a stimulating effect on mining in Utah Territory. Eli B. Kelsey, in a letter to Dr. Raymond, dated December 20, $1870,{ }^{25}$ says:

The mineral developments in Utah are still in their infancy, and but a few mining camps have as yet been established. * * * The "Mountain Lake" district, of which [Little] Cottonwood Canyon forms the chief feature, lies southeast of Salt Lake and distant about 25 miles from the terminus of the Utah Central Railroad. The first fully developed mine in Utah, the Emma, is in this canyon. * * * At a depth of 127 feet the prospectors struck mineral which now yields a clear profit on shipments unade to Swansea, Wales, of nearly $\$ 120$ a ton. * * * There are mauy mineral lodes now being worked in Little Cottonwood and adjacent canyons-Big Cottonwood and American Fork-which yield ore equal to and in some cases far exceeding in value the ore taken from the Emma mine, but in quantity the Emma mine has no equal in Utah.

According to the Salt Lake Tribune of January 4, 1873, the firm of Walker Brothers of Salt Lake City purchased in May 1870 a one-sixth interest in the Emma mine for $\$ 30,000$. Further particulars were given as follows :

In the summer of 1871. a half interest in the mine was sold to New York capital for $\$ 750,000$. In the winter of $1871-72$ the Emma Silver Mining Co. of Utah was incorporated, stocked, and placed upon the London market at 1,000,000 pounds, sterling. Fifty thousand shares of 20 pounds each were issued; 25,000 of them were immediately taken up, and the lemaining 25,000 were retained by the vendors of the mine. The quantity of ore

${ }^{22}$ M Lurphy, J. R., op. cit., p. 51.

23 Raymond, R. W., Statistics of mines and mining in the States and Territories west of the Rocky Mountains for 1869, p. 320,1870 .

24 Idem for 1870, p. $218,1872$.

2: Idem, p. 219. 
taken out of the mine during the year 1872 was 10,500 tons, and the average value was about $\$ 100$ per ton, making a total value of $\$ 1,050,600$. The proportion of silver was 100 ounces to the ton of ore and 45 percent lead. The average daily quantity of ore when the mine is working is about 60 tons, and 100 tons can be mined when the property is worked to full capacity. It is equipped with a steam-hoist engine of 150 tons capacity per day. Dividends have been declared and paid monthly at the rate of $11 / 2$ percent on the capital stock. In the spring of 1.872 the mine was flooded with water, an experience quite new in the history of the mine and which caught the company unprepared for such a disaster. Two large Knowles steam pumps have been since erected and are of sufficient capacity to keep the mine dry. An ore house has been constructed, also a tramway for conveying the waste matter from the mine.

From the foregoing statement it is evident that the
Walker Brothers were then the persons most active in the mining affairs of the district. They reported ${ }^{26}$ the shipment of 4,200 tons of galena ore, mostly from the Emma mine, during the 6 months ending December 31,1870 . The ore assayed 35 percent of lead and $\$ 182$ a ton in silver and returned a net value of $\$ 125$ a ton. According to Charles Smith, of the Emma Silver Co. ${ }^{27}$ the total ore shipped in 1870 , commencing in July, was 5,293 tons. Of this quantity 2,968 tons was shipped to Chicago, Boston, Newark, and New York, and 2,325 tons shipped to San Francisco, Reno, and Truckee. The following table, made up by Huntley, ${ }^{28}$ shows the extent of some of the workings in the Little Cottonwood area at the time of the census of 1880 .

Mines in Little Cottonwood district in 1880

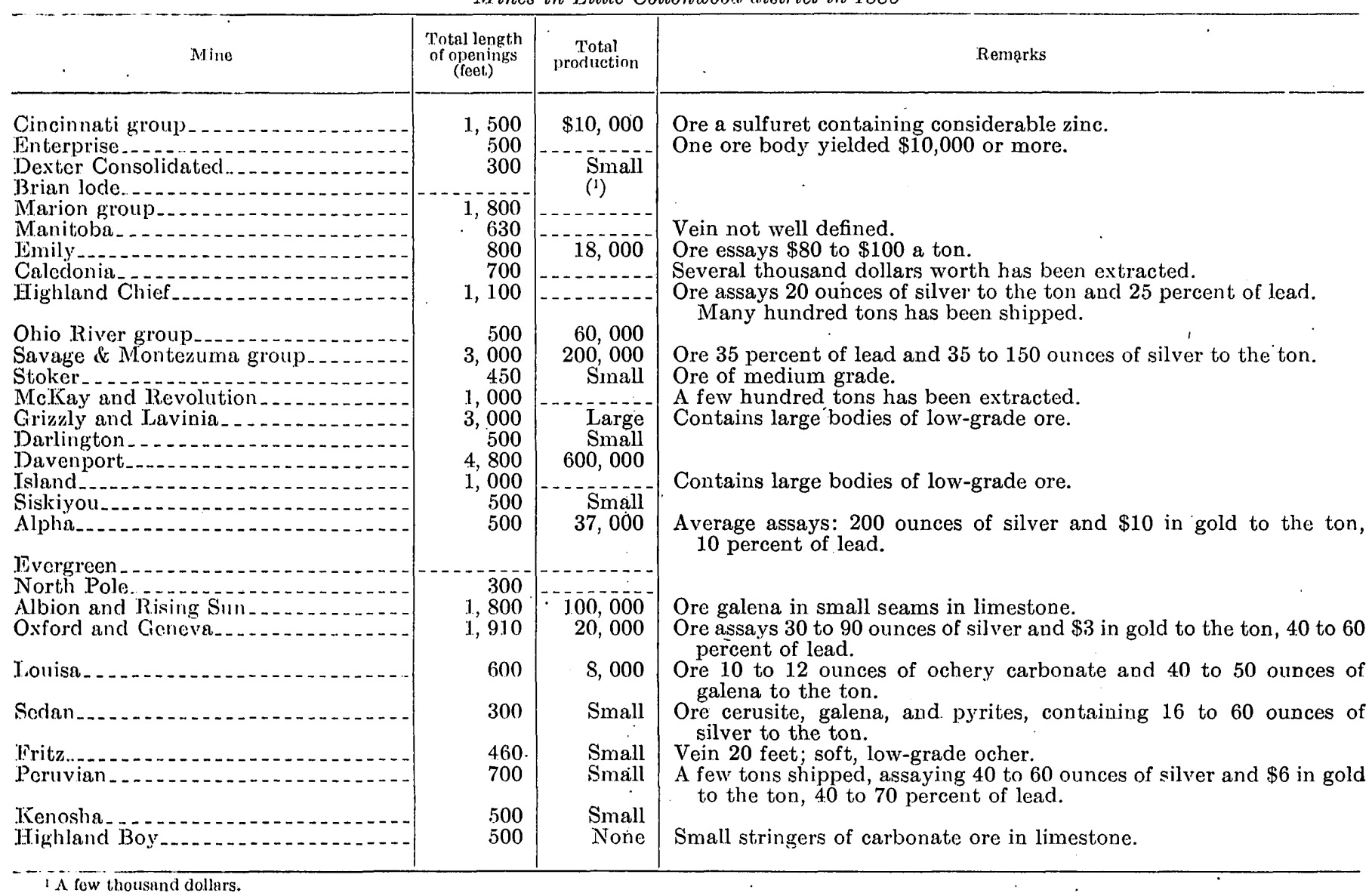

Huntley also makes the following statements on certain development tunnels :

The topography of this district is very favorable for the location of tunnel sites. Accordingly, in early times, work was hegun upon a great many. They have cost fortunes but have rarely been successful in finding ore; and though all are still claimed, few are worked more than is sufficient for assessment work. These tumnel sites are a great drawback to the district in a legal way. They were located before many of the present claims ; they ran in all directions, and, in case large and rich ore bodies should be found, some of them might be used to make serious legal difficulties. The following are the principal tunnel sites in the order of their situation, beginning at the west, on the north side of Jittle Cottonwood, and continuing in a semicircle around the head of the canyon:

Frederick tunnel.-This was driven to develop the Frederick and Crown Prince claims. These are parallel veins, $\mathbf{7 0}$ feet apart, 3 and $4 \frac{1}{2}$ feet wide, dipping $54^{\circ} \mathrm{N}$. in limestone and between limestone and quartzite. The ore is a carbonate, 1.8 inches wide, and averages 60 ounces silver and 35 percent lead. The claims were located in 1870 and were worked until 1873, when water and galena were encountered at a depth of 337 feet. The value of the ore sold was estimated at $\$ 35,000$. The mines were leased until May 1876, when the tunnel was begun. ***

${ }^{20}$ Raymond, R. W., Statisties of mines and mining in the States and Territories west of the Rocky Mountains for 1869, p. 221, 1870 .

27 Idem, p. 222.

2 Huntley, D. B., 10th Census U. S. (1880), vol. 13, pp. 425-426, 1885. 
Howland tunnel.-Work was begun on this several years ago. It has been relocated several times and was, at the period under review, known as the Solitary. Its length is 600 feet. * * *

Geneva tunnel.-Abandoned. Length unknown.

Lady Emma tunnel.-Length, 370 feet. Relocated and called the Prince of the Hills. ****

Chicago tunnel.-Length, 600 feet. Relocated and called the Fitzgerald tunnel.

Vallejo tunnel.-Used in the early development of the Vallejo mine.

Utah tunnel.-Relocated as the Burgess and used to work the Vallejo mine.

Gladiator tunnel.-Length, about 1,000 feet. Used to work the North Star mine.

Great Salt Lake Tunnel \& Mining Co.-This is better known as the Buffalo tunnel. It was located in 1871, is 600 feet in length, and was regularly worked, 275 feet having been run in 1870 . This company has located two claims, the Buffalo and another, having 9 -inch veins, containing galena and pyrites. Three small bodies were found. The ore sold for about $\$ 80$ per ton and yielded a few thousand dollars. The Allegan mine, operated through this tunnel, has about 550 feet of cuttings and yielded a few thousand dollars some.years ago.

Bay City tunnel.-Length, 1,700 feet. * * * Main adit of Emma mine.

Illinois tinnel.-Length, 800 feet. * * *

Equitable Tunnel \& Mining Co.-This company's tunnel is about 1,500 feet in length, with side drifts and winzes amounting to 900 feet, and is situated above the Bay City. ****

Little Cottonwood tunnel.-Relocated and called the Buckland. It is 600 feet.long and was run to tap the Savage and Montezuma group.

Reliance tunnel.-Abandoned. Little work done.

Manhattan tunnel.-Abandoned and relocated as the McKay and Revolution. Length, 500 feet.

Elk tunnel.-Abandoned.

Phoenix tunnel.-Owned by the Equitable Tunnel \& Mining Co. Length, 700 feet.

Herman tunnel (known as the Tilden).-Length, 500 feet.

Emma Hill tunnel.-Length, 900 feet.

Victoria tunnel.-Length, 900 feet. Used to work the Victoria, Imperial, Emma May, and Alice mines. These have a large amount of cuttings, and have shipped considerable ore, and are being worked upon lease.

Christiana tunnel (known as the Oneida).-Length, 250 feet.

Brewer \& Lapham tunnel.-Length, 150 feet. Located to develop the Darlington mine.

\section{AIMERICAN FORK DISTRICT}

Little work was done on the mining claims in the American Fork district until the fall of 1870 . The Miller mine, on a deposit discovered in September 1870, was the principal early producer. The Sultana smelter was built in 1871-72 for the reduction of Miller ore and ran irregularly until the spring of 1875. The Miller ore bodies gave out soon thereafter; the mine was closed in December 1876 and was in the hands of lessees at different periods to the end of 1880 . Huntley ${ }^{29}$ estimates the production of ore from the Miller mine to the end of 1880 at 13,000 to 15,000 tons, assaying from 40 to 54 percent of lead, 30 to 47 ounces of silver, and $\$ 2$ to $\$ 10$ in gold to the ton. The Wild Dutchman deposit was discovered in 1872 and worked by the company until September 1876, when it was leased. Its total produc-

\footnotetext{
${ }^{20}$ Huntley, D. B., 10th Census U. S. (1880), vol. 13, p. 444, 1885.
}

tion to 1880 was estimated at 7,900 tons of ore, averaging 45 ounces of silver to the ton and 40 percent of lead. The Pittsburg, Sunday, Silver Bell, Orphan, Queen of the West, Live Yankee, Whirlwind, Noncompromise, and, in the Silver Lake section, south of American Fork, the Milkmaid and Wasatch King were the other producers prior to 1880 .

During the period 1881-90 development work was done, but very little ore was shipped, probably not averaging over 100 tons a year. The aggregate shipments of the Belorophon, Live Yankee, Milkmaid, Miller, Silver Bell, Sultana, Wild Dutchman, and E. H. Bailey \& Co. in 1886 amounted to only. about 80 tons. ${ }^{30}$ In 1891 the Wild Dutchman, North Star, Kalamazoo, and Live Yankee properties yielded an aggregate of 100 tons of ore. ${ }^{31}$ Estimates were made for the remaining years of this decade, and it is presumed that the average annual production was no greater than in 1891 .

The figures of production for 1901 were estimated from the best records available. Those for the period 1902-24 were collected by the United States Geological Survey, those for 1925-33 by the United States Bureau of Mines. Total ore mined between 1870 and 1880 is estimated at 39,950 tons; in 1881-90, 990 tons; in 1891$1903,1,000$ tons; and in 1901-33, 92,084 tons, making the total output of ore 134,024 tons. This figure, used in seeking the average metal contents of the ore produced, gave $\$ 6.10$ in gold and 16.03 ounces of silver to the ton and 12.09 percent of lead; the value, including small quantities of copper (increasing in recent years) and zinc, was $\$ 37.77$ to the ton. Most of the mine output of 1.917 and 1918 was of milling grade. Lead-silver ore with a notable average gold content predominated during the entire period under review. The quantity of zinc ore shipped has never been large, though some recent shipments from some of the mines contain a fairly high proportion of zinc.

\section{PRODUCTION}

By V. C. HetKes

\section{LITTLE AND BIG COTTONWOOD DISTRICTS TOTAL PRODUCTION}

The Little Cottonwood district has yielded a production of metal annually since 1867 and may be expected to continue productive for many years. No complete records were kept of the annual production in the early days, but enough data to make very close estimates possible are found in the statistical reports on mines and mining in the States and Territories west of the Rocky Mountains for the years 1867 to 1876 . Between 1875 and 1880 no statistics were compiled by the Government, and for these years the figures in the mining journals and the Salt Lake Tribune are used. The operations and statistics of many of the most prominent producers from

\footnotetext{
30 Director of Mint Rept. for 1886, p. 224, 1887.
}

${ }^{31}$ Idem for 1891, p. 224, 1892. 
1870 to 1880 were ably reviewed by Huntley. ${ }^{32}$ During the succeeding years the reports of the Director of the Mint gave fragmentary figures until 1901, and the statistics from that year to the end of 1933 have been compiled by the United States Geological Survey and the United States Bureau of Mines.

In recent years (1901-40) the largest producers in the Little Cottonwood district have been the Wasatch Mines group, which includes the Columbus Consolidated group and the Flagstaff; the Continental-Alta, reorganized as the Unity and later as the Michigan-Utah Mining Co. (including the early producing claims known as the Darlington, Grizzly, Regulator, and Lavinia); the City Rocks, now part of the Michigan-Utah group (including the Utah, an early producer) ; the South Hecla (including the Alta Hecla, South Columbus, and Wedge); the Emma Consolidated; the Columbus-Rexall; and the Sells. The South Hecla, Emma, and Sells mines are now owned by the Alta United Mines Co.

In the Big Cottonwood district very few properties have in recent years produced any ore. The more productive have been the Black Bess group of the MichiganUtah Mining Co., the Maxfield, and the Cardiff, which for several years was highly productive and has been on the whole the largest producer in the region.

It is impossible to segregate the production of the Big and Little Cottonwood districts, and all the available statistics have been combined in the tables below.

Gold, silver, copper, leal, and zinc produced in Big and Little Cottonwood mining districts, 1867-1940, in terms of recovered metals [Comptled by V. C. Heikes, revised and brought to date hy C. N. Gerry, U. S. Bureau of Mines. Additions since 1927 from U. S. Bureau of Mines, Mineral Resources and Mineral Yearbook, chapters by C. N. Gerry, Paul Luff, and T. H. Miller]

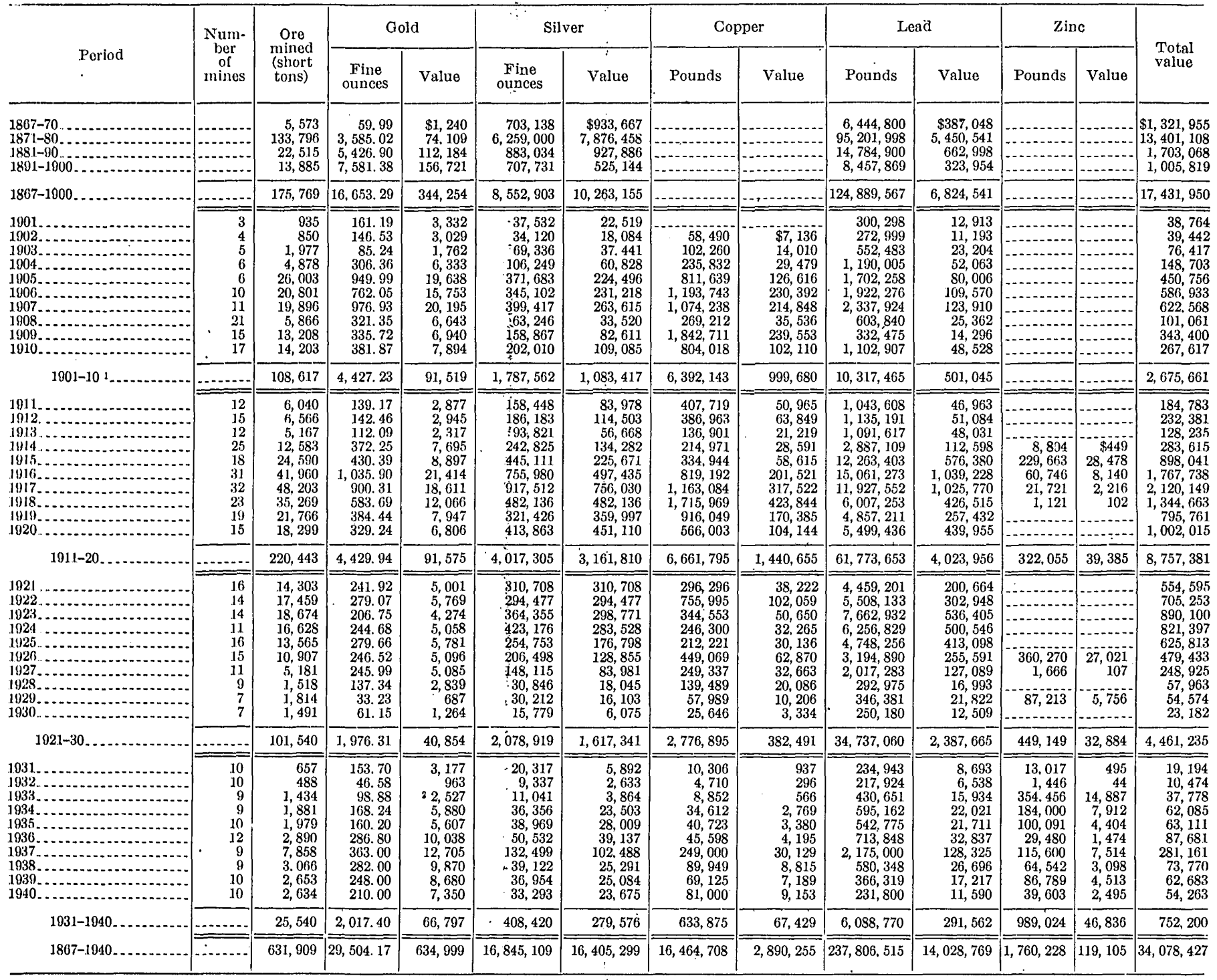

1 Within the period covered by this total the Columbus Consolidated Co. operated its concentration mill from 1904 to 1912, producing 15,172 tons of copper-lead con-

centrates. In 1905 the Continental Alta produced lead concentrates, and in 1910 some copper-lead concentrates were recovered from Columbus Extension ores.
3 A verage weighted narket price $\$ 25.56$ per ounce.

si Huntley, D. B., op. cit., pp. $422-430$. 
Between 1871 and 1880 the largest producers were the Emma (the ore body in the old workings having been largely depleted by 1873), Flagstaff, North Star, Vallejo, Joab Lawrence Co., City Rocks, Grizzly and Lavinia, Davenport, Savage and Montezuma, Rəed \& Benson, and Prince of Wales. According to Huntley, ${ }^{33}$ the Emma mine had yielded to June 1, 1880, ore aggregriting 27,451 tons, for which $\$ 2,637,727$ was received. The rich ore bodies of the Flaggstaff mine gave out in December 1873 after having yielded about 31,000 tons, which probably assayed, in round numbers, $\$ 10$ in gold and 60 ounces of silver to the ton and 40 percent of lead and which sold for $\$ 80$ a ton. Between 1874 and 1879 about 69,000 tons of ore was produced from the Flagstaff; probably assaying $\$ 4$ in gold and 30 ounces of silver to the ton and 20 percent of lead, and was sold for $\$ 30$ a ton, making a total from the beginning, of about $\$ 4,550,000 .^{34}$ The Prince of Wales and Antelope deposits were discovered about 1870 and had a recorded production of over $\$ 1,000,000$ to the end of $1884 .^{35}$ Subsequent records of the Prince of Wales in the reports of the Director of the Mint to 1890 show not over 10,121 tons of ore shipped, averaging probably 105 ounces of silver to the ton and 30 percent of lead.

The Flagstaff produced ore between 1881 and 1890, the Joab Lawrence, or Vallejo, and City Rocks were almost continuously productive to 1891 , and the Maxfield was the heaviest shipper in 1884, 1887, 1888, and 1890. In 1891 and 1892 the Maxfield and Flagstaff were the principal producers. Between 1891 and 1900 little or no mention of these districts was made in the reports of the Director of the Mint. The figures given in the foregoing table for 1891-1900 are differences between the known output of the other districts in Salt Lake County and the total for the county as given by the Director of the Mint in the reports for each year.

\section{PRODUC'TION BY ORES}

The character of the ores produced and the average metal content and average value are shown in the following descriptions and tables.

\section{DRY OR SILICEOUS ORES}

The dry or siliceous ores shipped to smelters from the Big and Little Cottonwood districts comprise gold

\footnotetext{
${ }^{33}$ Huntley, D. B., op. cit., pp. 423-424.

${ }^{34}$ Idem, p. 428.

${ }^{35}$ Director of Mint Rept. for 1884, p. 421, 1885.
}

and silver ores carrying copper and lead sulfides too small in amount to be of value. The contributors of such ores from 1903 to 1918 were the Scottish Chief, Big Mitt, Columbus Extension, Noah, Red Bell, Alta Michigan, Alta Utah, Old Emma, Alta Wasatch, Morning Star, and South Hecla.

Siliceous ore, with average metallic content, produced in Big and Little Cottonwood districts and shipped to smelters, 1903, 1909, 1914, 1916-18, and 1920-40

\begin{tabular}{|c|c|c|c|c|c|c|}
\hline Year & $\begin{array}{l}\text { Ore } \\
\text { (short } \\
\text { tons) }\end{array}$ & $\begin{array}{c}\text { Gold } \\
\text { (value } \\
\text { per ton) }\end{array}$ & $\begin{array}{c}\text { Silver } \\
\text { (ounces } \\
\text { per ton) }\end{array}$ & $\begin{array}{c}\text { Copper } \\
\text { (percent) }\end{array}$ & $\underset{\text { (percent) }}{\text { Lead }}$ & $\begin{array}{l}\text { A verage } \\
\text { gross value } \\
\text { per ton }\end{array}$ \\
\hline 1903 & 104 & $\$ 0.79$ & 22. 09 & & 1. 63 & $\$ 14.10$ \\
\hline 1909 & 10 & 36. 80 & .90 & i. 17 & & 40. 20 \\
\hline 1914 & 67 & 3. 99 & 4. 84 & 1. 54 & 1. 95 & 8. 94 \\
\hline 1916 & 38 & .84 & 2. 47 & 1. 34 & 1. 93 & 11. 71. \\
\hline 1917 & 9,120 & 17 & 41. 26 & 12 & 3. 13 & 40. 19 \\
\hline 1918 & 2.176 & 42 & 11. 61 & 1. 81. & 2. 56 & 24: 63 \\
\hline 1920 & 705 & 1. 13 & 24. 67 & 2. 11 : & 1. 92 & 38. 86 \\
\hline 1921 & 217 & 1. 25 & 36. 34 & 1. 49 & 2. 94 & 44. 10 \\
\hline 1922 & 5 & 4. 13 & 10. 80 & 26 & 2. 19 & 18. 04 \\
\hline 1923 & 3 & 28 & 108.67 & 33 & 3. 08 & 94. 69 \\
\hline 192 & 7 & 30.65 & 23. 00 & 98 & .08 & 49. 53 \\
\hline 192 & 39 & 10. 12 & .46 & 1. 28 & & 14. 00 \\
\hline 1927 & 55 & 2. 84 & 17. 96 & .09 & 56 & 13. 97 \\
\hline 192 & 32 & 61.57 & 3. 03 & 27 & 54 & 64. 75 \\
\hline 192 & 9 & 6. 64 & 18. 78 & 20 . & 3. 41 & 21. 66 \\
\hline 193 & 7 & 31. 13 & 14. 71 & 14 & & 37. 16 \\
\hline 193 & 32 & 28. 23 & .63 & 02 & .35 & 28. 71 \\
\hline 1932 & 17 & 14. 36 & 46. 47 & 05 & 43 & 27.78 \\
\hline 193 & 41 & 28. 12 & 2. 61 & 22 . & 85 & 29. 94 \\
\hline 193 & 213 & 8. 80 & 8. 33 & $68^{\circ}$ & 49 & 15. 64 \\
\hline 193 & 361 & 5. 96 & 7. 68 & 37 & 1. 90 & 13. 61 \\
\hline 1936 & 321 & 77 & 8. 54 & 21 & 1. 89 & 9.50 \\
\hline 1937 & 822 & 4. 00 & 7. 29 & $31^{-}$ & 1. 51 & 12. 16 \\
\hline 1938 & 654 & 2. 03 & 11. 02 & 45. & 2. 37 & 12. 21 \\
\hline 1939 & 1,013 & 2. 07 & 9. 31 & 38 . & 2. 06 & 11. 11 \\
\hline 1940 & 1,155 & 2. 88 & 1.0. 53 & 31 & 1.80 & 12. 86 \\
\hline
\end{tabular}

\section{COPPER ORE AND CONCENTRATES}

Copper ores and concentrates are here defined as those carrying over 2.5 percent of copper. Shipments of them were made most frequently by the City Rocks, Columbus, and Cardiff properties, and less frequently by the Wasatch-Utah, Alta Hecla, South Columbus, South Hecla, West Columbus, Blue Point, Copper Apex, Mountain Lake, Iowa Copper, Consolidated Jefferson, Columbus Extension, White Captain, Alta Emerald, Carbonate, Morning Star, Big Cottonwood, Great Western, South Hecla Extension, Evergreen, Woodlawn, Columbus-Rexall, Alta Consolidated, Wasatch Mines, Alta Michigan, and Flagstaff mines. 
Copper ore and concentrates, with average metallic content, produced in Big and Little Coltonwood districts and shipped to smelters, $1908-40$

\begin{tabular}{|c|c|c|c|c|c|c|}
\hline Year & $\begin{array}{l}\text { Ore } \\
\text { (short } \\
\text { tons) }\end{array}$ & $\begin{array}{c}\text { Cold } \\
\text { (value } \\
\text { per ton) }\end{array}$ & $\begin{array}{c}\text { Silver } \\
\text { (ounces } \\
\text { per ton) }\end{array}$ & $\begin{array}{l}\text { Sopper } \\
\text { ercent) }\end{array}$ & $\begin{array}{c}\text { Lead } \\
\text { (percent) }\end{array}$ & $\begin{array}{c}\text { Average } \\
\text { gross value } \\
\text { per ton }\end{array}$ \\
\hline $\begin{array}{l}1903 \\
1904 \\
1905 \\
1906 \\
1907 \\
1908 \\
1909 \\
1910 \\
1911 \\
1912 \\
1913 \\
1914 \\
1915 \\
1916 \\
1917 \\
1918 \\
1919 \\
1920 \\
1921 \\
1922 \\
1924 \\
1925 \\
1926 \\
1927 \\
1928 \\
1929 \\
1930 \\
1931 \\
1932 \\
1933 \\
1934 \\
1935 \\
1937 \\
1938 \\
1939 \\
1940\end{array}$ & $\begin{array}{r}30 \\
30 \\
2,743 \\
3,608 \\
207 \\
214 \\
9,907 \\
2,463 \\
1,356 \\
813 \\
328 \\
165 \\
134 \\
170 \\
3,374 \\
11,251 \\
7,885 \\
114 \\
288 \\
3,677 \\
635 \\
179 \\
1,221 \\
246 \\
556 \\
287 \\
13 \\
11 \\
1 \\
6 \\
6 \\
49 \\
34 \\
99 \\
206 \\
503 \\
782\end{array}$ & $\begin{array}{r}\$ 2.40 \\
.70 \\
4.22 \\
2.04 \\
1.14 \\
20.83 \\
.54 \\
1.49 \\
.65 \\
.68 \\
.53 \\
.61 \\
1.19 \\
1.12 \\
.85 \\
.42 \\
.38 \\
.73 \\
.79 \\
.62 \\
.35 \\
.85 \\
.83 \\
.67 \\
.56 \\
.65 \\
.44 \\
24.29 \\
20.67 \\
-.55 \\
.55 \\
.86 \\
.42 \\
.70 \\
.57 \\
.34\end{array}$ & $\begin{array}{r}32.10 \\
23.60 \\
67.29 \\
44.06 \\
18.61 \\
11.05 \\
12.24 \\
24.79 \\
26.72 \\
20.89 \\
35.68 \\
58.54 \\
20.58 \\
2.54 \\
9.64 \\
9.63 \\
9.06 \\
33.34 \\
46.51 \\
12.09 \\
30.41 \\
9.16 \\
22.63 \\
16.41 \\
13.64 \\
12.66 \\
15.54 \\
3.73 \\
3.00 \\
11.17 \\
18.33 \\
39.29 \\
6.34 \\
27.69 \\
23.00 \\
16.33\end{array}$ & $\begin{array}{r}11.00 \\
14.15 \\
6.41 \\
6.93 \\
8.03 \\
4.42 \\
8.22 \\
9.05 \\
7.85 \\
5.27 \\
6.70 \\
7.75 \\
9.14 \\
6.01 \\
7.23 \\
5.46 \\
3.90 \\
7.36 \\
7.44 \\
6.81 \\
8.92 \\
10.33 \\
9.50 \\
9.94 \\
9.52 \\
5.47 \\
8.13 \\
2.67 \\
6.85 \\
8.84 \\
5.67 \\
10.69 \\
5.17 \\
10.84 \\
5.45 \\
4.25\end{array}$ & $\begin{array}{r}1.37 \\
4.02 \\
.98 \\
1.03 \\
1.36 \\
1.47 \\
1.02 \\
.81 \\
1.48 \\
.73 \\
\\
.93 \\
2.68 \\
1.49 \\
1.57 \\
1.49 \\
2.08 \\
2.47\end{array}$ & $\begin{array}{l}\$ 50.17 \\
50.60 \\
66.70 \\
61.70 \\
48.88 \\
39.59 \\
28.30 \\
37.94 \\
34.43 \\
38.96 \\
42.84 \\
53.60 \\
43.95 \\
32.37 \\
48.29 \\
37.03 \\
25.06 \\
66.36 \\
70.11 \\
32.18 \\
45.74 \\
38.92 \\
43.89 \\
37.28 \\
36.91 \\
28.52 \\
28.29 \\
30.23 \\
30.15 \\
15.91 \\
23.46 \\
48.04 \\
19.69 \\
41.22 \\
29.47 \\
24.04\end{array}$ \\
\hline \multicolumn{7}{|c|}{ Concentrates } \\
\hline $\begin{array}{l}1909 \\
1911^{1}\end{array}$ & $\begin{array}{r}152 \\
8\end{array}$ & $\begin{array}{l}\$ 0.36 \\
10.62\end{array}$ & $\begin{array}{r}13.54 \\
1.87\end{array}$ & $\begin{array}{l}9.67 \\
7.90\end{array}$ & & $\begin{array}{r}\$ 32.55 \\
31.37\end{array}$ \\
\hline
\end{tabular}

1 No production between 1912 and 1940.

\section{LEAD ORE AND CONCENTRATES}

In greneral, the crude lead ores and concentrates are here defined as those containing over 4.5 percent of lead. Shipments were made most frequently during the decade 1910-20 by the Maxfield, Columbus, Emma, Albion, Golconda, Cardiff, and Flagstaff, and less frequently by the North Star, Caledonia, Cabin, Silver King, Alta Consolidated, Michigan-Utah, Carbonate, South Hecla, Sells, Continental Alta, City Rocks, Columbus Wedge, Black Bess, Columbus Extension, Reed Peak, West Toledo, Hayes, Scottish Chief, Phoenix, Copper Apex, silver Mountain, South Columbus, Frederick, Progress, East Columbus, Baby McKee, Prince of Wales, Wasatch Mines, Alta Hecla, Howell, Alta Tiger, Democrat, Woodlawn, Peruvian, Highland Chief, Louise, South Fecla Extension, and Red Bell mines.
Lead ore and concenirates, with average mietallic content, produced in Big and Little Cottonwood districts and shipped to smelters, $1908-40$

\begin{tabular}{|c|c|c|c|c|c|c|}
\hline & & & & & & \\
\hline Year & $\begin{array}{c}\text { Ore } \\
\text { (short } \\
\text { tons) }\end{array}$ & $\begin{array}{c}\text { Gold } \\
\text { (value } \\
\text { per ton) }\end{array}$ & $\begin{array}{c}\text { Silver } \\
\text { (ounces } \\
\text { per ton) }\end{array}$ & $\begin{array}{c}\text { Copper } \\
\text { (percent) }\end{array}$ & $\begin{array}{c}\text { Lead } \\
\text { (percent) }\end{array}$ & $\begin{array}{c}\text { A versge } \\
\text { gross value } \\
\text { per ton }\end{array}$ \\
\hline 1903 & 977 & $\$ 1.03$ & 55. 50 & 2. 51 & 16. 41 & $\$ 51.67$ \\
\hline 1904 & 2,975 & 1. 84 & 28. 28 & 3. 30 & 16. 49 & 38. 31 \\
\hline 1905 & 6,724 & .88 & 14. 56 & 84 & 25. 02 & 35.91 \\
\hline 1906 & 558 & 2. 59 & 19. 98 & 75 & 16. 04 & 37. 35 \\
\hline 1907 & 1,708 & .96 & 17. 27 & 1. 13 & 16. 36 & 34. 24 \\
\hline 1908 & 687 & .97 & 23. 66 & 82 & 16. 17 & 29.25 \\
\hline 1909 & 191 & .70 & 28. 30 & 1. 71 & 25. 11 & 41.44 \\
\hline 1910 & 447 & .70 & 38. 83 & 40 & 15. 82 & 36.62 \\
\hline 1911 & 2,213 & .53 & 28. 58 & 1.04 & 15. 53 & 32.25 \\
\hline 1912 & 1,945 & .32 & 40.35 & 1. 84 & 15. 12 & 44. 82 \\
\hline 1913 & 3,918 & .37 & 15. 12 & .16 & 11. 87 & 20.45 \\
\hline 1914 & 1,607 & .61 & 18. 30 & 5 & 11. 82 & 21. 37 \\
\hline 1915 & 23,720 & .37 & 18. 29 & .59 & 25.75 & 35. 94 \\
\hline 1916 & 32,368 & .52 & 20.13 & 6 & 21. 43 & 46. 34 \\
\hline 19 & 35,185 & .39 & 14. 06 & 8 & 15. & 44. 16 \\
\hline 1918 & 21,606 & .29 & 15. 87 & 92 & 13. 07 & 39.95 \\
\hline 1919 & 13,3 & .35 & 17. 99 & 1. 00 & 17. 82 & 43. 14 \\
\hline 1920 & 13,765 & 39 & 19. 88 & 1.05 & 15. & 50.89 \\
\hline 1921 & 13,398 & .32 & 20. 27 & .78 & 16. 24 & 37.20 \\
\hline 1922 & 12, & 22 & 18. & 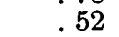 & 20 . & 42: 95 \\
\hline 1923 & 17,861 & 21 & 19. 59 & 74 & 21. 20 & 48. 12 \\
\hline 192 & 15,9 & .30 & 25. & 4 & 19 & 49.54 \\
\hline 192 & 13 & .40 & & 6 & 17. & 46. 22 \\
\hline 1926 & 8,262 & 42 & 18. 65 & 1. 08 & 16. 75 & 41. 90 \\
\hline 192 & 1,640 & 1. 99 & 35.07 & 76 & 17. 44 & 45. 82 \\
\hline 192 & 315 & 1. 45 & 15. 19 & 2. 01 & 11. 28 & 29. 22 \\
\hline 19 & & .46 & 25. & 1.05 & 14. & 36. 10 \\
\hline 19 & & 2. 57 & 23. & .73 & 19. & 32.81 \\
\hline 193 & 39 & 4. 81 & 45. & .8 & 26 . & 39. 08 \\
\hline 1932 & 46 & 1. 51 & 19. & 4 & 22 & 21. 30 \\
\hline 19 & 374 & 3 & 2 & .8 & & 31.57 \\
\hline 1934 & 1,085 & 3. 55 & 25. 93 & 43 & 19 . & 35.76 \\
\hline 1935 & 1,322 & 2. 57 & 26. 21 & 1. 15 & 17. & 37. 40 \\
\hline 19 & 2,494 & 3. 91 & 18. 96 & .88 & 13. & 32. 75 \\
\hline 19 & 6,497 & 1. 41 & 18. 86 & 1. 73 & 15. & 38. 35 \\
\hline 1938 & 2,051 & 4. 04 & 12. 43 & .94 & 11. & 24. 83 \\
\hline 193 & 942 & 6. 46 & 15. & .2 & 13. 37 & 30. 34 \\
\hline 1940 & 567 & 6. 23 & 13. 66 & .37 & 10.53 & 27. 34 \\
\hline
\end{tabular}

\begin{tabular}{|c|c|c|c|c|c|c|}
\hline$\because$ & & & Concentra & & & \\
\hline 1905 & 2,763 & $\$ 0.13$ & 11. 44 & 1. 41 & 4. 88 & $\$ 1.6 .10$ \\
\hline 1918 & 314 & & 15. & 49 & 25. & 54. 13 \\
\hline 1926 & 321 & 50 & 59. 65 & 2. 79 & 48.75 & 123. \\
\hline 1927 & 44 & 59 & 47. 66 & 63 & 27. 47 & 63.96 \\
\hline $\begin{array}{l}1928 \\
\end{array}$ & 6 & 06 & 132. 77 & 1. 51 & 46.79 & 136. 36 \\
\hline 1929 & 90 & 42 & 64.58 & .96 & 45. 11 & 95.04 \\
\hline 1930 & 201 & 37 & 20. & 1. 17 & 24.24 & 35. 61 \\
\hline 1931 & 56 & 2. 03 & 33. 20 & 1. 18 & 23. 69 & 31.35 \\
\hline 1932 & 2 & 73 & 25 . & 1. 00 & & 36. \\
\hline 1933 & 37 & 1. 58 & 27.00 & 97 & 46. 69 & 46. 82 \\
\hline 1934 & 18 & .72 & 18. 78 & 1. 35 & 51 . & 53. 06 \\
\hline 193 & 3 & 1. 17 . & 61. & 4. 00 & 53. & 94.65 \\
\hline 1936 & 15 & 1. 12 & 27.13 & .99 & 62.64 & 81. 58 \\
\hline 1937 & 120 & .88 & 23. & 2. 66 & 50 . & 85.31 \\
\hline 193 & 9 & & 63. 33 & 3. & 46. & 90.0 \\
\hline 1939 & 14 & & 62. 43 & 3. 33 & 50.77 & 97.03 \\
\hline 1940 & - & & 18. 50 & & 39.88 & 53. 84 \\
\hline
\end{tabular}

1 Includes 4 tons irom lead-zinc ore.

\section{ZINC ORE}

Zinc ore of shipping grade was found in the Carbonate mine of the Big Cottonwood district, and in the Wasatch Mines at Alta. Shipments were made from the Carbonate mine in 1916. Lessees on the Albion dump at Alta have shipped some zinc concentrates. The output 
shown below came largely from the Carbonate mine. The Columbus-Rexall and Wasatch Mines each produced a carload in 1915.

Zinc ore, with average metallic content, produced in Big and Little Cottonwood districts and shipped to smelters, 1914-401

\begin{tabular}{r|r|r|r|r|r}
\hline Year & $\begin{array}{c}\text { Ore (short } \\
\text { tons) }\end{array}$ & $\begin{array}{c}\text { Silver } \\
\text { (ounces } \\
\text { per ton) }\end{array}$ & $\begin{array}{c}\text { Lead } \\
\text { (percent) }\end{array}$ & $\begin{array}{c}\text { Recover- } \\
\text { able zinc } \\
\text { (percent) }\end{array}$ & $\begin{array}{c}\text { Average } \\
\text { gross value } \\
\text { per ton }\end{array}$ \\
\hline 1914 & 17 & - & - & 25.89 & $\$ 26.41$ \\
1915 & 437 & -19.91 & 2.08 & 23.59 & 70.65 \\
1916 & 94 & 6.91 & 26.23 & 53.55 \\
\hline
\end{tabular}

1 No production from 1918 to 1940.

COPPER-LEAD ORE AND CONCENTRATES

Copper-lead ore and concentrates are classified in the same way as copper and lead ores. Shipments were made most frequently during the decade 1901-10 by the Columbus, Continental Alta, South Columbus, City Rocks, Alta Consolidated, Michigan-Utah, Prince of Wales, Copper Apex, Gypsy Blair, Caledonia, Columbus Extension, Wasatch Mines, Alta Utah, ColumbusRexall, and Henefer mines.

Copper-lead ore and concentrates, with average metallic content, produced in Big and Little Cottonwood aistricts and shrpped to smelters, $1908-40$

\begin{tabular}{|c|c|c|c|c|c|c|}
\hline Year & $\begin{array}{c}\text { Ore } \\
\text { (short tons) }\end{array}$ & $\begin{array}{l}\text { Gold } \\
\text { (value per } \\
\text { ton) }\end{array}$ & $\begin{array}{c}\text { Silver } \\
\text { (ounces } \\
\text { per ton) }\end{array}$ & $\begin{array}{l}\text { Copper } \\
\text { (percent) }\end{array}$ & $\begin{array}{c}\text { Lead } \\
\text { (percent) }\end{array}$ & $\begin{array}{l}\text { A verage } \\
\text { gross value } \\
\text { per ton }\end{array}$ \\
\hline $\begin{array}{l}1903 \\
1904 \\
1905 \\
1906 \\
1907 \\
1908 \\
1909 \\
1910 \\
1911 \\
1912 \\
1913 \\
1914 \\
1915 \\
1916 \\
1917 \\
1918 \\
1919 \\
1920 \\
1921 \\
1922 \\
1923 \\
1927 \\
1928 \\
1929 \\
1930 \\
1931 \\
1932 \\
1934 \\
1940\end{array}$ & $\begin{array}{r}866 \\
844 \\
112 \\
4,336 \\
7,413 \\
1,149 \\
857 \\
1,961 \\
1,120 \\
2,093 \\
890 \\
727 \\
204 \\
7,168 \\
486 \\
227 \\
501 \\
3,715 \\
400 \\
1,080 \\
810 \\
3,099 \\
355 \\
205 \\
21 \\
6 \\
3 \\
97 \\
.40\end{array}$ & $\begin{array}{r}\$ 0.82 \\
.88 \\
.55 \\
1.06 \\
2.05 \\
.66 \\
.94 \\
.66 \\
.33 \\
.80 \\
.77 \\
.39 \\
.22 \\
.36 \\
.47 \\
.18 \\
.36 \\
.14 \\
.47 \\
.60 \\
.57 \\
.48 \\
.27 \\
.71 \\
1.25 \\
1.28 \\
-.-59 \\
.79 \\
. .88\end{array}$ & $\begin{array}{l}16.60 \\
\text { 1.8. } 11 \\
\text { 1.6. } 37 \\
31.68 \\
38.49 \\
\text { 18. } 93 \\
25.75 \\
31.32 \\
44.56 \\
31.09 \\
25.65 \\
28.06 \\
38.04 \\
13.63 \\
27.74 \\
22.96 \\
18.45 \\
32.06 \\
44.69 \\
16.16 \\
\text { 17. } 37 \\
26.94 \\
27.46 \\
30.99 \\
26.29 \\
79.67 \\
46.33 \\
53.09 \\
12.98\end{array}$ & $\begin{array}{l}\text { 3. } 40 \\
\text { 4. } 23 \\
\text { 4. } 35 \\
\text { 4. } 98 \\
\text { 4. } 93 \\
\text { 6. } 56 \\
\text { 6. } 58 \\
\text { 5. } 09 \\
\text { 5. } 29 \\
\text { 4. } 05 \\
\text { 4. } 51 \\
\text { 4. } 40 \\
\text { 6. } 24 \\
\text { 2. } 65 \\
\text { 5. } 12 \\
\text { 2. } 89 \\
\text { 3. } 11 \\
\text { 3. } 12 \\
\text { 4. } 87 \\
\text { 5. } 67 \\
\text { 5. } 00 \\
\text { 2. } 82 \\
\text { 2. } 66 \\
\text { 3. } 09 \\
\text { 3. } 20 \\
\text { 5. } 00 \\
\text { 9. } 07 \\
\text { 8. } 25 \\
\text { 3. } 92\end{array}$ & $\begin{array}{r}15.40 \\
7.20 \\
10.73 \\
8.66 \\
6.48 \\
6.57 \\
8.65 \\
9.86 \\
13.86 \\
11.00 \\
8.93 \\
9.78 \\
9.50 \\
6.65 \\
10.75 \\
6.40 \\
8.80 \\
15.75 \\
9.06 \\
5.72 \\
5.51 \\
22.84 \\
21.37 \\
11.35 \\
13.28 \\
12.92 \\
6.67 \\
10.82 \\
11.43\end{array}$ & $\begin{array}{r}\$ 32.04 \\
28.40 \\
34.20 \\
51.68 \\
54.00 \\
33.54 \\
38.88 \\
39.18 \\
49.64 \\
43.19 \\
38.09 \\
35.34 \\
50.28 \\
31.56 \\
69.81 \\
46.53 \\
41.92 \\
71.82 \\
65.87 \\
38.35 \\
37.22 \\
51.93 \\
48.79 \\
42.40 \\
32.92 \\
43.00 \\
28.49 \\
56.32 \\
30.40\end{array}$ \\
\hline \multicolumn{7}{|c|}{ Concentrates } \\
\hline $\begin{array}{l}1904 \\
1905 \\
1906 \\
1907 \\
1908 \\
1909 \\
1910 \\
1911 \\
1912 \\
1915 \\
1930^{t}\end{array}$ & $\begin{array}{r}275 \\
2,956 \\
3,249 \\
3,216 \\
1,090 \\
438 \\
2,152 \\
291 \\
426 \\
21 \\
51\end{array}$ & $\begin{array}{r}\$ 0.37 \\
1.44 \\
.73 \\
.97 \\
.69 \\
.56 \\
.34 \\
.26 \\
.05 \\
.52 \\
.78\end{array}$ & $\begin{array}{l}22.28 \\
27.89 \\
11.57 \\
25.10 \\
20.95 \\
18.13 \\
28.88 \\
31.00 \\
35.23 \\
23.76 \\
46.67\end{array}$ & $\begin{array}{r}3.45 \\
\text { 4. } 38 \\
3.90 \\
4.23 \\
4.04 \\
\text { 7. } 50 \\
3.60 \\
5.04 \\
7.06 \\
4.90 \\
12.55\end{array}$ & $\begin{array}{r}15.93 \\
10.34 \\
12.41 \\
12.51 \\
10.27 \\
9.32 \\
13.27 \\
7.88 \\
10.19 \\
7.13 \\
12.93\end{array}$ & $\begin{array}{r}\$ 35.82 \\
41.83 \\
37.80 \\
47.72 \\
31.08 \\
37.49 \\
36.75 \\
36.39 \\
54.19 \\
36.48 \\
64.32\end{array}$ \\
\hline
\end{tabular}

${ }^{2}$ No production from 1931 to 1940 .
LEAD-ZINC ORE

Lead-zinc ore was shipped in small quantity from the Albion mine in 1917 and from the Woodlawn in 1915 and 1916. In 1918 the Badger mine produced 9 tons of lead-zinc ore, which yielded 4 tons of lead concentrate and 2 tons of zinc concentrate.

\begin{tabular}{l}
$\begin{array}{l}\text { Lead-zinc ore with average metallic contents produced in Big and } \\
\text { Little Coitonwood districts and shipped to smelters, } 1926-401\end{array}$ \\
\hline Year \\
\hline
\end{tabular}

1 No production in 1927 to 1932,1936 , and 1937 .

Zinc concentrates from lead-zinc ore with average metallic contents produced in Big and Little Cottonwood districts and shipped to smelters, $1926-40^{1}$

\begin{tabular}{|c|c|c|c|c|c|c|c|}
\hline Year & $\begin{array}{l}\text { Ore } \\
\text { (short } \\
\text { tons) }\end{array}$ & $\begin{array}{c}\text { Gold } \\
\text { (value } \\
\text { per } \\
\text { ton) }\end{array}$ & $\begin{array}{c}\text { Silver } \\
\text { (ounces } \\
\text { per } \\
\text { ton) }\end{array}$ & $\begin{array}{l}\text { Copper } \\
\text { (percent) }\end{array}$ & (pead 1 (percent) & $\underset{\text { (percent) }}{\operatorname{Zinc}}$ & $\begin{array}{c}\text { Average } \\
\text { gross } \\
\text { value per } \\
\text { ton }\end{array}$ \\
\hline 2 & 577 & $\$ 0.16$ & 9. 78 & 1. 68 & 4. 27 & 26. 64 & $\$ 57$. \\
\hline & 2 & .11 & & 1.00 & & & 40 \\
\hline & 84 & 03 & 2. & 11 & & & 72 \\
\hline & 14 & 07 & 4. & 3. 04 & & & 43. \\
\hline & 2 & & 2. & .90 & 2. & 36. & 23. \\
\hline & 57 & 02 & & 64 & & & \\
\hline & 13 & 24 & & 69 & & & \\
\hline & 3 & 12 & & 1. 5 & & & \\
\hline & 5 & 49 & & 33 & & & \\
\hline & 132 & 53 & & 1. 01 & & & \\
\hline & 19 & & 7. & 1. 01 & & & \\
\hline & 34 & & 6. & .84 & & & 40 \\
\hline & 12 & & 2. 17 & & 2. 32 & 31.68 & 43. \\
\hline
\end{tabular}

1 No production in years for which no production is shown.

\section{DIVIDENDS}

Dividends aggregating several million dollars are reportêd to have been paid to stockholders by mining companies operating in the Little Cottonwood and Big Cottonwood districts. Some of the published statements follow, but many of them are discredited by old residents, who say that the early managements were very expensive. Raymond ${ }^{36}$ gives a statement furnished by N. M. Maxwell, superintendent of the Flagstaff mine, as follows:

The product of the Flagstaff furnaces during 1872 was 3,000 tons of metal containing:

$$
\begin{aligned}
& \text { Silver -...-_._- } \$ 390, C 00 \text {; average per ton, } \$ 130 \\
& \text { Gold _-_-_-_-_- 120,000; average per ton, } 40 \\
& \text { Lead__._._.....- 240,000; average per ton, } 80 \\
& 750,000
\end{aligned}
$$

The capital of the company is $£ 300,000$, on which 30 percent in dividends have been paid during the last three months, and 24

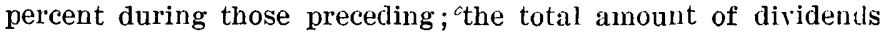
paid being $£ 76,000$.

${ }^{36}$ Raymond, R. W., Statistics of mines and mining in the States and Territories west of the Rocky Mountains for 1872, p. 247, 1873. 
In a later report ${ }^{37}$ Raymond says:

This splendid mine has produced during 1873 , according to the directors' report, 15,000 tons of ore of an average value of $\$ 54$ per ton in the ore-market. The same report says the expenses for mining ought to have been $\$ 5$, hauling $\$ 8$, establishment charges $\$ 4$, total $\$ 17$, leaving $\$ 37$ profit per ton. Yet there was not only 30 profit made, but in the fall the company was very heavily in delt: and the value of the shares depreciated rapidly in London.

According to Huntley, ${ }^{3 s}$ who reviews conditions in the district up to October 1880, the Emma mine, worked by English managers, paid $\$ 300,000$ in dividends (one authority says $\$ 1,300,000$ ) up to September 1874 , when it was attached for an indebtedness of $\$ 300,000$. It was then idle until October 1877. The Flagstaff mine, when owned by the English company, paid dividends that amounted to about $\$ 350,000$.

From all available data the dividends paid by the mining companies in the Little and Big Cottonwood districts to the end of 1919 were as follows: Emma, $\$ 300,000$; Flagstaff, $\$ 350,000$; Columbus Consolidated, $\$ 212,623$; Vallejo and Titus (Joab Lawrence), \$180,000; Maxfield, $\$ 118,000$; Cardiff, $\$ 675,000$; South Hecla, $\$ 78,907$; and Columbus-Rexall, $\$ 14,656$. If $\$ 700,000$ is estimated to cover the dividends realized from other properties, including the Prince of Wales, the total dividends exceeded $\$ 2,500,000$.

\section{AIMERICAN FORK DISTRICT}

The American Fork district, organized July 21, 1870, is largely in Utah County, on the headwaters of American. Fork. It extends from Silver Fork (a tributary of American Fork and not to be confused with the Silver Fork of Big Cottonwood Creek) eastward to Snake Creek, a distance of 10 miles, and from the first high ridge of the mountains south of the canyon northwestward to the divide, where its northern boundary meets the southern boundary of the Little Cottonwood district, also a distance of about 10 miles.

Little development work was done in the district until the fall of 1870 , but a great many locations were made in the following spring and summer. Several

s linymond, R. W., Statistics of mines and mining in the states and 'Territories west: of the Rocky Mountains for 1873, p. 260, 1874 .

${ }^{38}$ Euntley, D. B., 1Uth census U. S. (1880), vol. 13, p. 423, 1885. mining locations quickly proved to be of great value, among them the Miller, which sold for $\$ 190,000$ in $1872 .^{39}$ Other mining claims sold for sums ranging from $\$ 5,000$ to $\$ 50,000$. These were the Cumberland, Wyoming, Hibernia, Southern Spy, War Eagle, and Wild Dutchman.

The following table shows the development on some of the properties in the American Fork district at the time of the 10th census (1880) as reported by Huntley:

Developments on mines in American Fork district, 1880

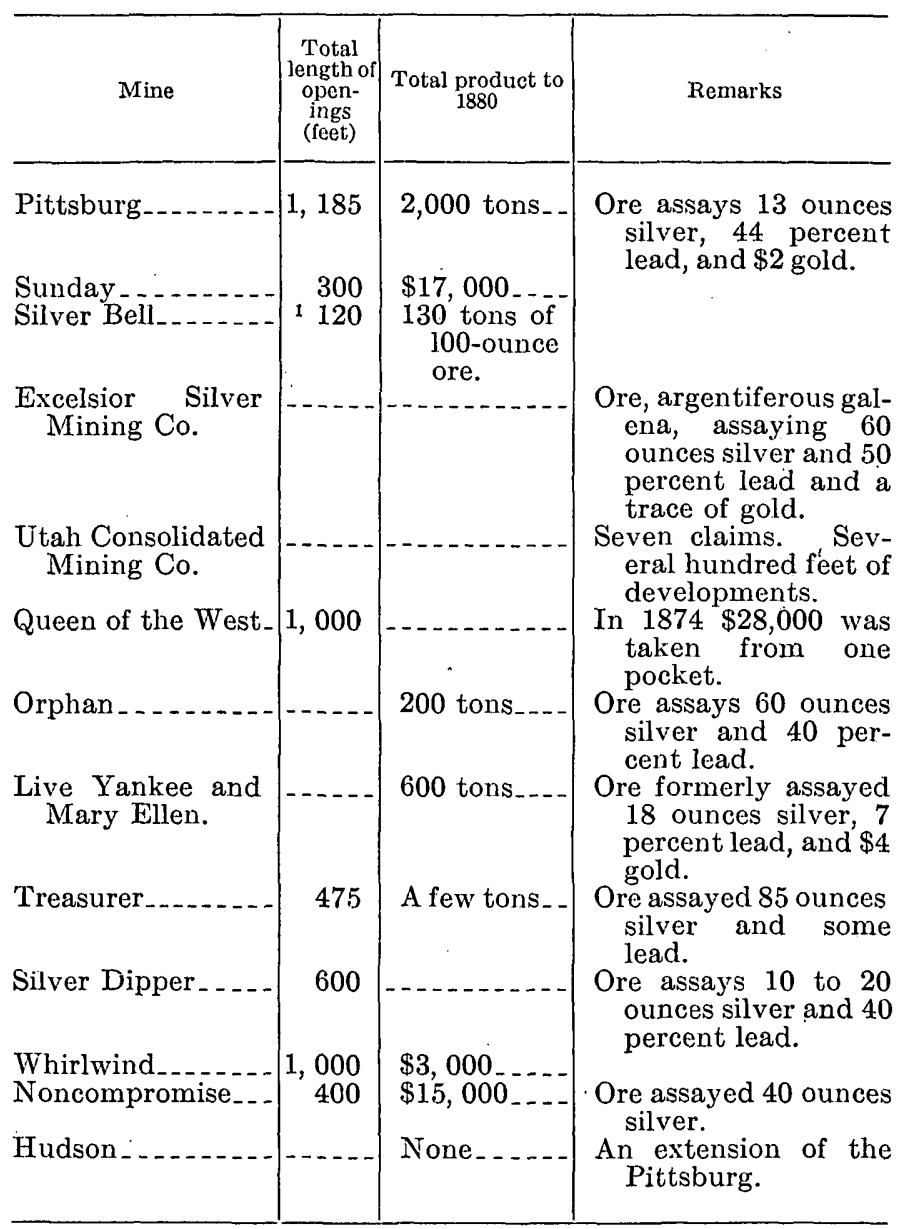

1 Incline, also some tunneling work.

${ }^{30}$ Murphy, J. R., The mineral resources of the Territory of Utah, p. 32, Salt Lake City, 1872. 
GEOLOGY AND ORE DEPOSITS OF COTTONWOOD-AMERICÁN FORK AREA, UTAH

Gold, silver, copper, lead, and zinc produced in American Fork district, 1870-1940, in terms of recovered metals

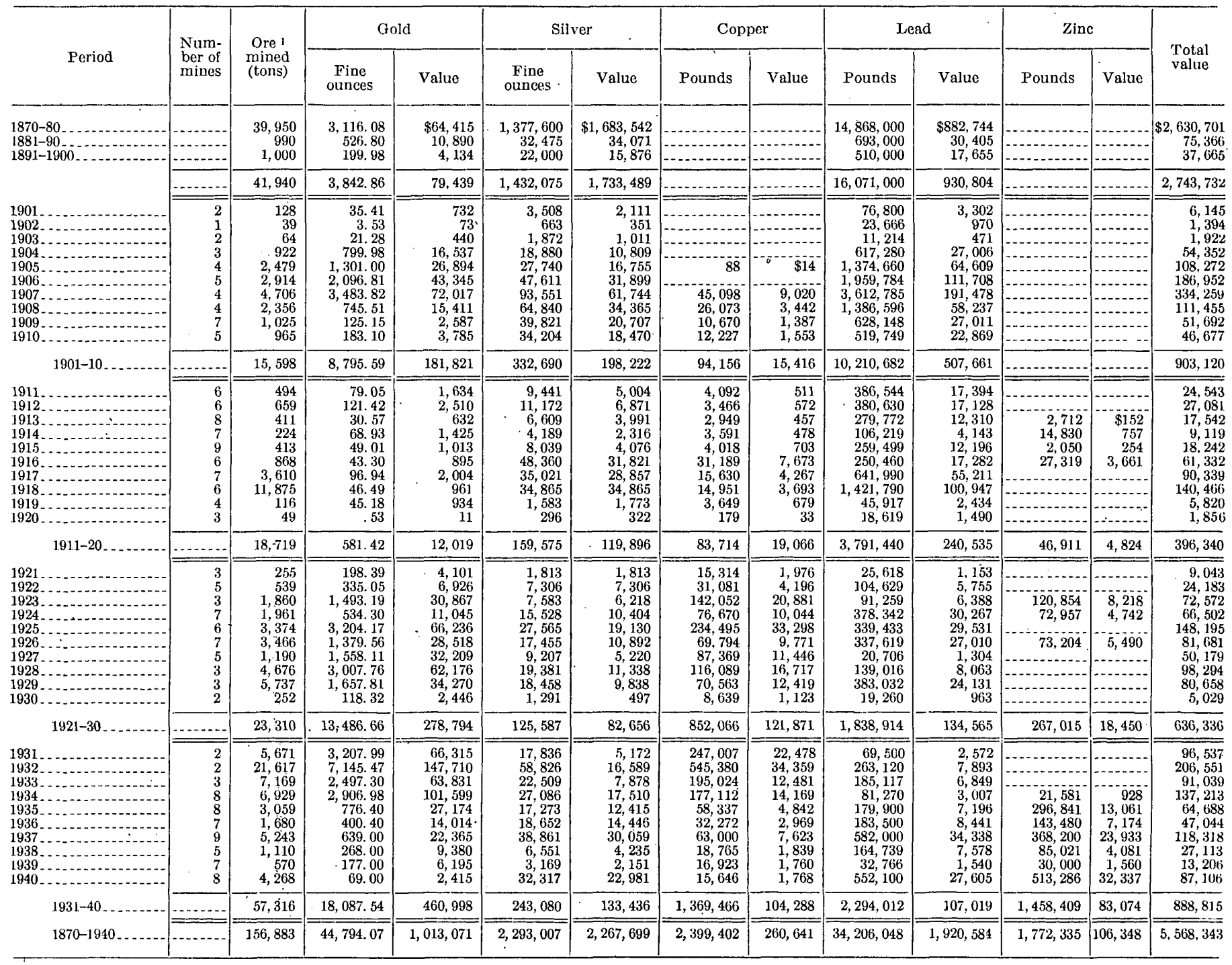

I Includes milling ore.

\section{ORE DEPOSITS}

BY B. S. BUTLER

\section{MINERALOGY}

In the following paragraphs all the minerals in the rocks and ores of the area are listed, and their mode of occurrence briefly indicated. The arrangement follows that in Dana's "System of Mineralogy."

\section{NATIVE METALS}

Gold.-Gold is present in small amount in nearly all the ores of the area. In the oxidized ores, at least, it presumably occurs as metallic gold.

Silver.-Native silver is reported from the area but is not common.

Copper.-Native copper has been found in the oxidized ores but is relatively rare.

\section{SULFIDES}

Bismuthinite.-Bismuthinite, bismuth trisulfide, $\mathrm{Bi}_{2} \mathrm{~S}_{3}$ (sulfur 18.8 percent, bismuth 81.2 percent), is re- ported as occurring in considerable quantity in the Sells mine.

Molybdenite.-Molybdenite, molybdenum disulfide, $\mathrm{MoS}_{2}$ (sulfur 40 percent; molybdenum 60 percent), occurs in veins in the intrusive stocks, notably in the Alta-Gladstone and Third Chance mines, and probably in some of the sulfide ores in the sedimentary rocks, for some of the oxidized ores contain wulfenite. Molybdenite has not been found, however, although it has been looked for, in the sulfide ores from which the wulfenitebearing ores are apparently derived.

Tungstenite.-The first known occurrence in the world of tungsten disufide $\mathrm{WS}_{2}$ (tungsten 75 percent, sulfur 25 percent), is in the lead-silver ores of the Old Emma mine, where this mineral is found in small quantity. It was one of the latest sulfides to be cleposited and apparently in part replaced earlier sulfides (pl. 25, $A, B)$.

Galena:-Galena, lead sulfide, PbS (sulfur 13.4 percent, lead 86.6 percent), is the common primary lead 


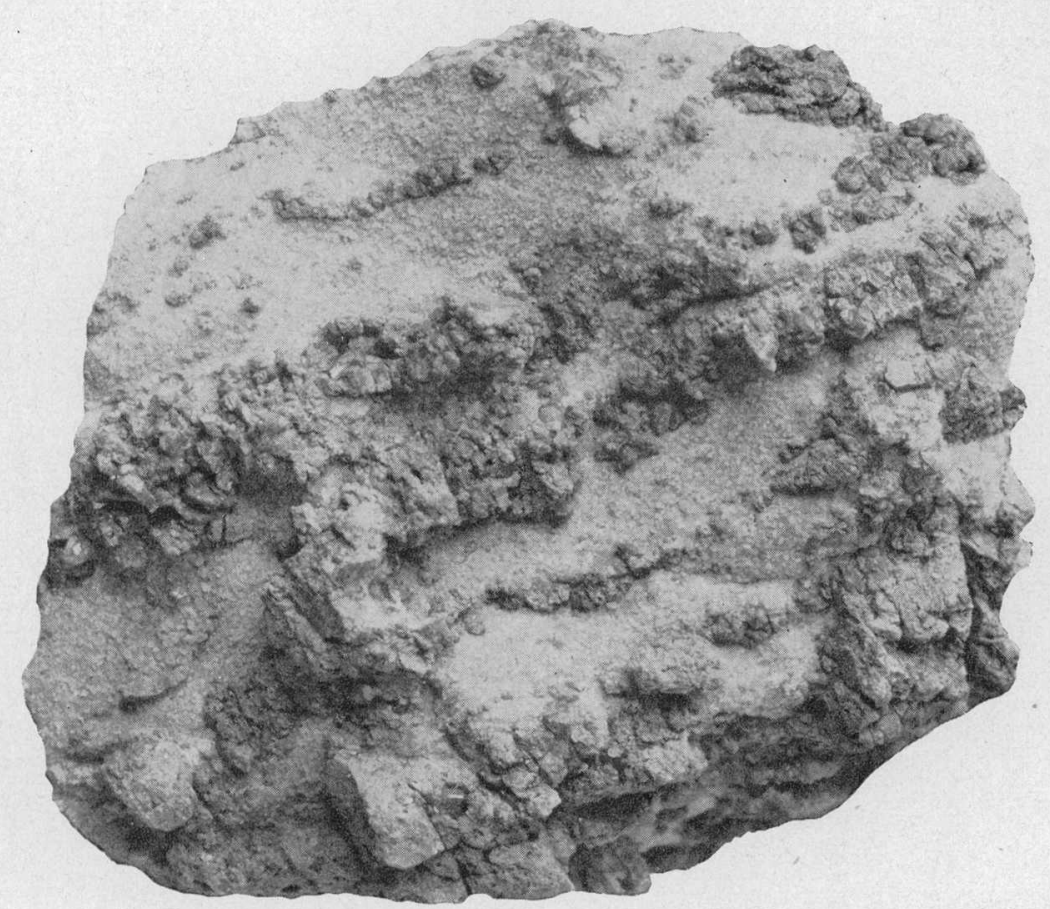

A. METAMORPHOSED MAXFIELD LIMESTONE WITH GARNET.

Specimen from middle member cropping out on slope at head of Grizzly Gulch. Slightly reduced.

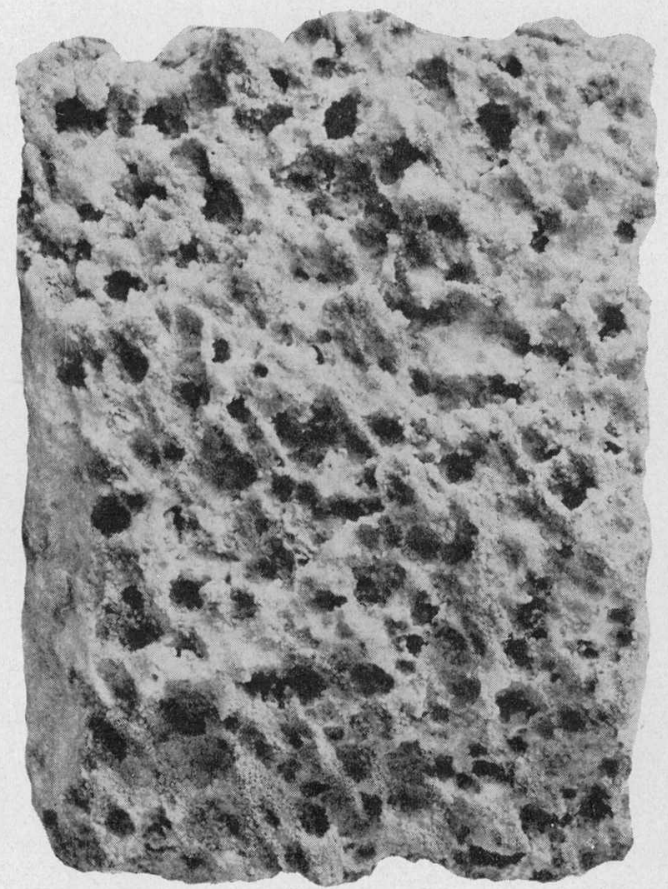

B. WEATHERED BRUCITE-BEARING MISSISSIPPIAN LIMESTONE.

Specimen from slope north of Lake Solitude. Slightly reduced.

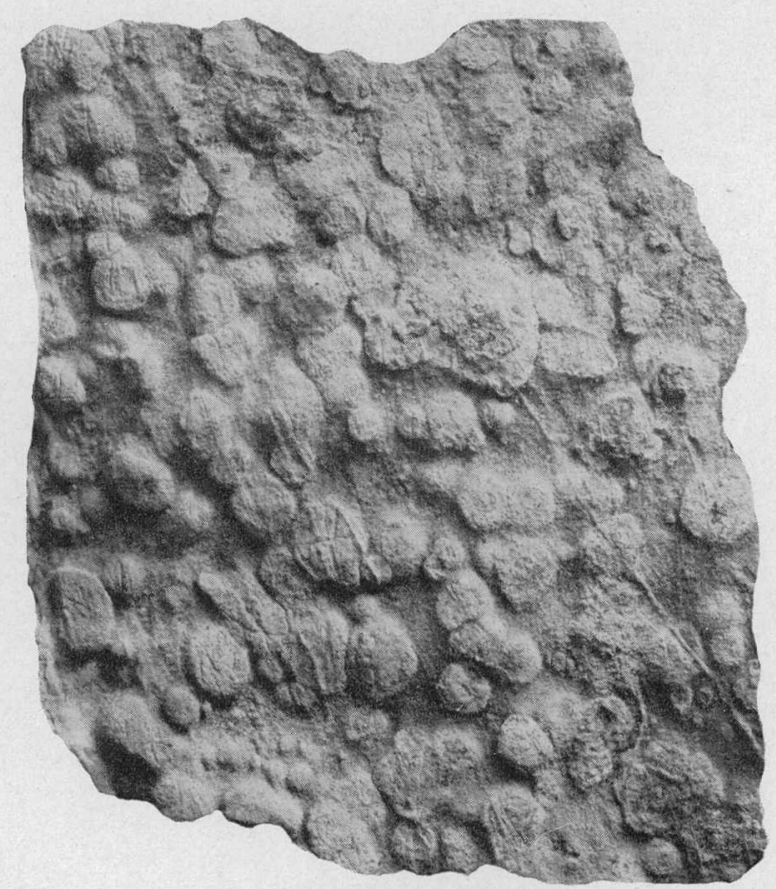

C. METAMORPHOSED DOLOMITE WITH FORSTERITE. Specimen collected near Grizzly tunnel. Slightly reduced. 


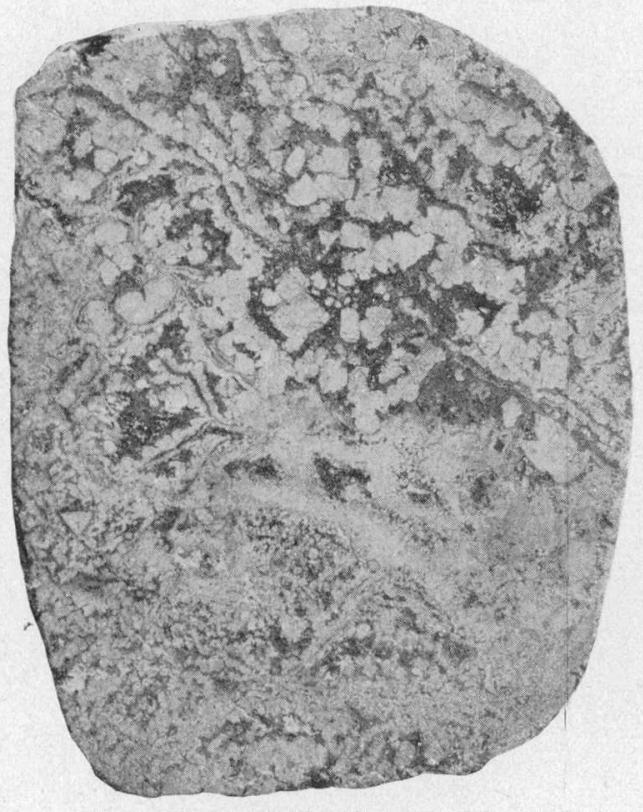

A. REPLACEMENT BRECCIA OF PYRITE AND OTHER SULFIDES.

Specimen from Belorophan mine. Light areas pyrite. $\times 1 \frac{114}{}$.

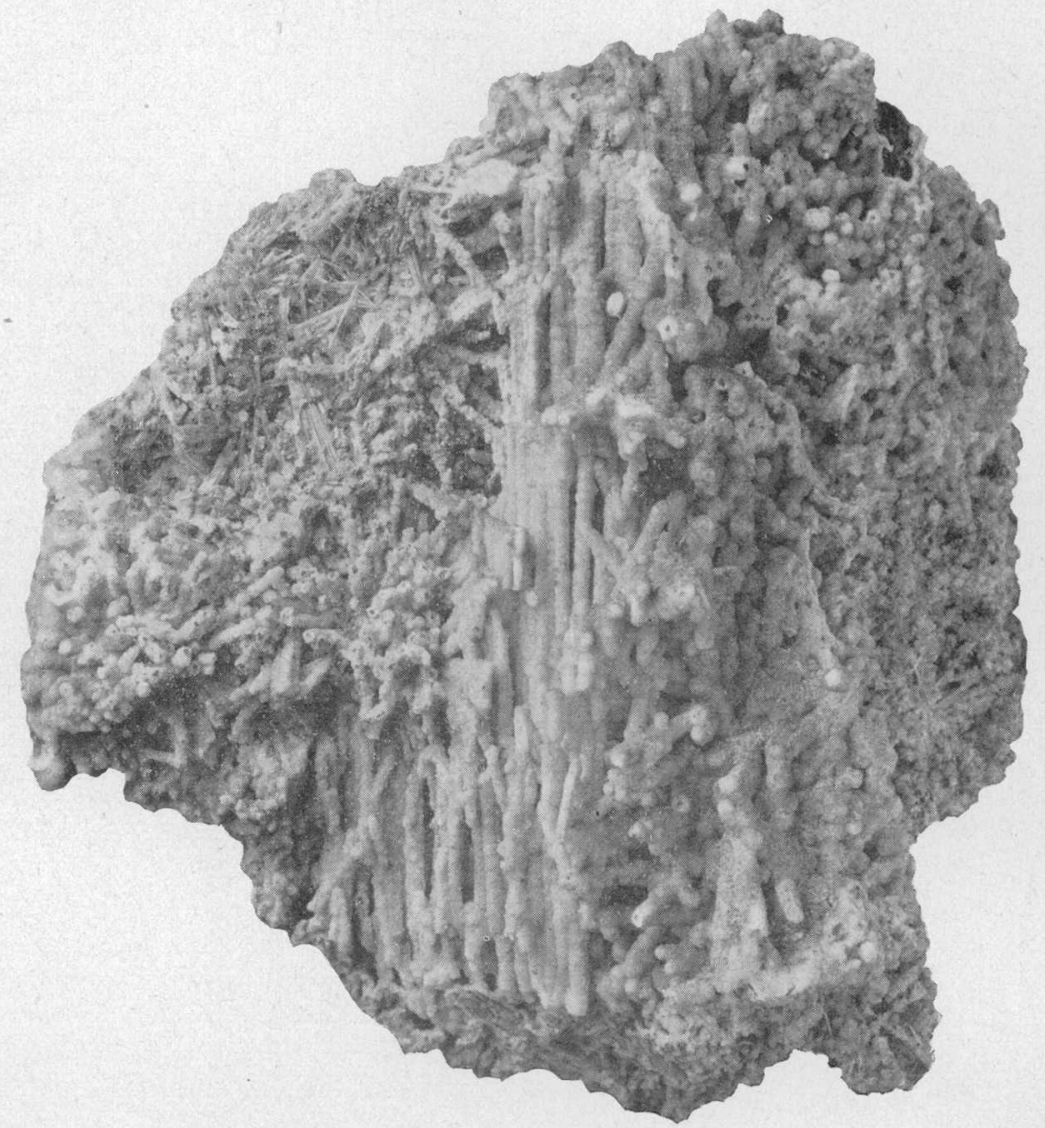

B. SMITHSONITE DEPOSITED ON CERUSITE CRYSTALS

Specimen from South Hecla mine. Natural size.

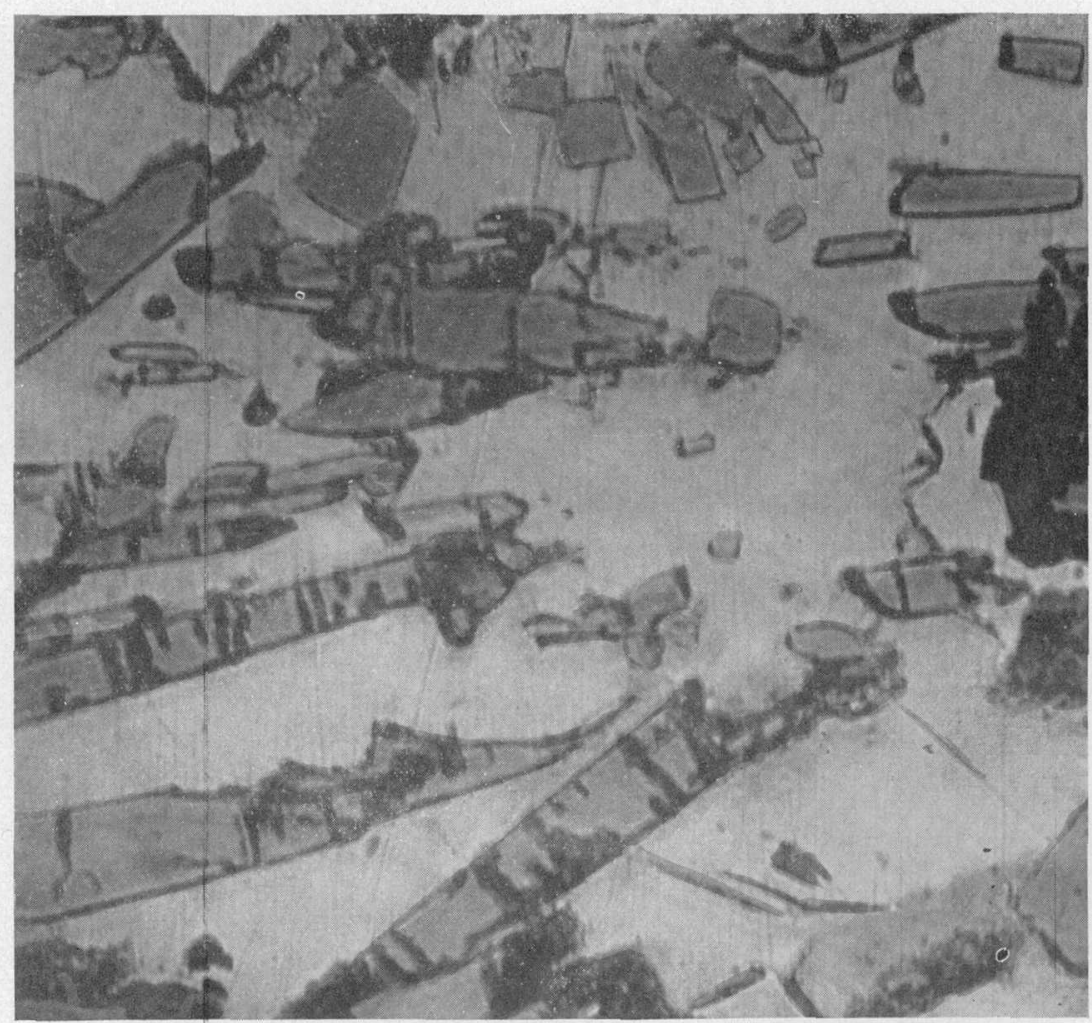

C. PHOTOMICROGRAPH OF LUDWIGITE AND SULFIDES IN SPECIMEN FROM MOUN TAIN LAKE MINE.

Needle-shaped areas are ludwigite. $\times 200 \pm$. 
mineral of the area and is present in most of its deposits. It forms microscopic intergrowth with tetrahedrite. (See pl. 26, $B$ ).

Argenitite (silver glance).-Argentite, silver sulfide, $\mathrm{Ag}_{2} \mathrm{~S}$ (sulfur 12.9 percent, silver 87.1 percent), is present in most of the primary ores and is probably an abundant primary silver mineral.

Chalcocite.-Chalcocite, cuprous sulfide, $\mathrm{Cu}_{2} \mathrm{~S}$ (sulfur 20.2 percent, copper 79.8 percent), occurs sparsely in many deposits. It is the principal copper mineral in some of the ore from the Steamboat tunnel, where it accompanies forsterite (pl. $25 C, 26, C$ ). Here it includes small remnants of bornite and has apparently been formed by the alteration of that mineral. It has also replaced galena locally (pl. 24, B).

Sphaterite (zinc blende, blende, black jack).-Sphalerite, zinc sulfide, $\mathrm{ZnS}$. (sulfur 33 percent, zinc 67 percent), is the primary zinc mineral of the ores and occurs in many of the deposits. A honey-yellow sphalerite from the Old Albion mine was analyzed by George Waring in connection with an investigation of zinc ores, and he has kindly furnished the following analyses to the Geological Survey.

Analysis of selected very.brittle honey-yellow sphalerite from Albion mine

[W. Geo. Waring, analyst] *

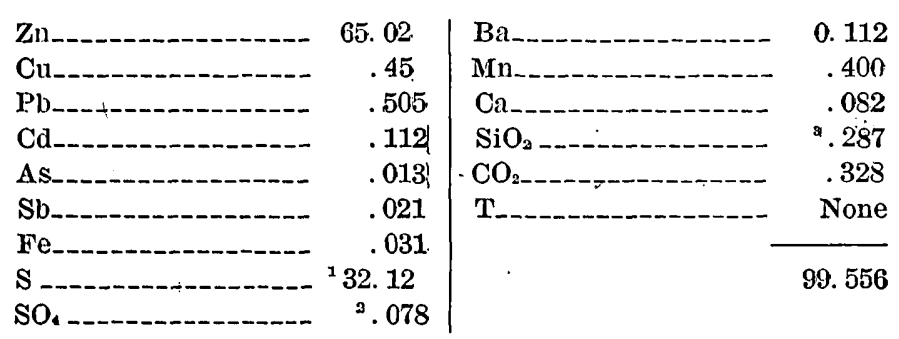

1 The $S$ calculated from the first 7 elements determined amounts to 32.156 percent on the assumption that they are all present as sulfides. If the $\mathrm{Fe}$ is present as $\mathrm{FeCO}_{3}$ instead of as $\mathrm{FeS}_{2}$, the computed total $\mathrm{S}$ would be decreased to 32.138 and the $\mathrm{CO}_{3}$ would be increased. The $\mathrm{S}$ actually determined is 32.12 .

${ }^{2}$ Not determined but computed from the weight of $\mathrm{BaSO}_{4}$ found, on the assumption that the $\mathrm{Ba}$ is present in the sample as sulfate.

- Calculated from the percentage of $\mathrm{Ca}$ and $\mathrm{Mn}$ found.

Analysis of a specimen of sphalerite with band of rhodochrosite and calcite, including cubes of galenite

[The sphalerite in this specimen is the same as in the preceding analysis of selected material. W. Geo. Waring, analyst]

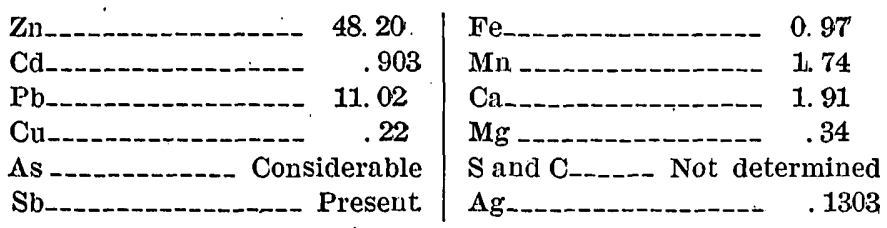

Mr. Waring makes the following additional statement regarding the sphalerite:

I find that it contains no trace of thallium but that it is distinctly radioactive. Its radioactivity as measured in the $\mathbf{A}$ chamber of the electroscope is equivalent to more than 0.03 percent of $U_{3 s}$. I was interested in making this test because $\mathrm{I}$ had found that a sample of triboluminescent sphalerite from Columbia, Mex- ico, imparted a positive electrostatic charge to the electrode, counteracting the natural leak of the instrument very materially.

The yellow sphalerite from the Albion mine is very decidedly triboluminescent. Some of the sphalerite from the Bog mine, in the American Fork Canyon, is beautifully crystallized, this locality being well known for its sphalerite crystals.

Covellite.-Covellite, cupric sulfide, $\mathrm{CuS}$ (sulfur 33.6 percent, copper 66.4 percent), occurs in small amount, principally replacing sphalerite but also replacing galena (pl. $26, A, D$ ) or tetrahedrite (pl. $24, D$ ).

Bornite--Bornite, $\mathrm{Cu}_{5} \mathrm{FeS}_{4}$ (sulfur 25.6 percent, copper 63.3 percent, iron 11.1 percent), occurs in small amount in several mines. It is the principal copper mineral in the Mountain View mine, where it is associated with magnetite, forsterite, and ludwigite.

Chalcopyrite (copper pyrites).-Chalcopyrite, CuFe$\mathrm{S}_{2}$ (sulfur 35 percent, copper 34.5 percent, iron 30.5 percent), is present in small amount in several of the mines but is most abundant in the contact deposits. It has replaced both bornite ( $p l .28, B$ ) and chalcocite in ores from the Steamboat tunnel, on Snake Creek. Microscopic particles of it occur in some of the sphalerite of the area.

Pyrite.-Pyrite, iron disulfide, $\mathrm{FeS}_{2}$ (sulfur 53.4 percent, iron, 46.6 percent) is abundant in practically all the primary ore deposits of the area and is common in the altered rocks. It is generally earlier than the other sulfide minerals. Beautifully crystallized pyrite occurs in the Bog, Yankee, and Columbus-Rexall mines.

\section{SULFO SALTS}

Jamesonite.-Jamesonite, $\mathrm{Pb}_{4} \mathrm{FeSb}_{6} \mathrm{~S}_{14}$ (sulfur 21.9 percent, antimony 35.1 percent, lead 40.3 percent, iron 2.7 percent), is present, probably in small quantities, in the lead-silver ores of many of the deposits.

Bournonite.-Bournonite, $\mathrm{Pb}_{2} \mathrm{Cu}_{2} \mathrm{Sb}_{2} \mathrm{~S}_{6}$ (sulfur 19.8 percent, antimony 24.7 percent, lead 42.5 percent, copper 13.0 percent), is present in small amount in the primary ores of the Little Cottonwood district, especially in those from the Albion mine. It was formed at the same time as galena, sphalerite, and tetrahedrite.

Aikinite.-Aikinite, $\mathrm{Pb}_{2} \mathrm{Cu}_{2} \mathrm{Bi}_{2} \mathrm{~S}_{6}$, occurs in the Sells mine (p. 128).

Tetrahedrite.-Tetrahedrite, of variable composition but essentially $\mathrm{Cu}_{6} \mathrm{Sb}_{2} \mathrm{~S}_{6}$ (sulfur 23.5 percent, antimony 29.8 percent, copper 46.7 percent), is the principal copper mineral of the lead-silver deposits. Many of the tetrahedrite ores are high in silver, and in these ores silver is probably a part of the tetrahedrite, proxying for copper.

Enargite.-Enargite, $\mathrm{Cu}_{3} \mathrm{AsS}_{4}$ (sulfur 32.6 percent, arsenic 19.1 percent, copper 48.3 percent), is present in small amounts in some of the deposits. It was seen most abundantly in ores from the Columbus-Rexall and Michigan-Utah mines. 


\section{HALOIDS}

Cerargyrite (horn silver, silver chloride).-Cerargyrite, $\mathrm{AgCl}$ (chlorine 24.7 percent, silver 75.3 percent), is reported from the area and is probably present though certainly not abundant.

\section{OXIDES}

Quartz.-Quartz, $\mathrm{SiO}_{2}$, is present in nearly all the ore deposits of the area and is abundant in some of them. It is also a constituent of most of the igneous and sedimentary rocks of the area.

Bismite.-Bismite, $\mathrm{Bi}_{2} \mathrm{O}_{3}$ or $\mathrm{Bi}(\mathrm{OH})_{3}$, occurs as an alteration product of bismuth sulfide in the Sells mine.

Cervantite.-The oxide of antimony, $\mathrm{Sb}_{2} \mathrm{O}_{4}$, is reported by Silliman in the oxidized ores of the Old Emma mine.

Periclase.-Periclase, $\mathrm{MgO}$, occurs very sparingly in contact-metamorphosed limestone and dolomite. It is always embedded in pellets of brucite, which is much more abundant and appears to have been formed by the hydration of the periclase ' $(\mathrm{pl} .21, B$ ), probably at a late stage in the metamorphic process.

Massicot.-Massicot, lead monoxide, $\mathrm{PbO}$, is reported as occurring in the oxidized ores of the Old Emma mine.

Hematite.-Hematite, iron sesquioxide, $\mathrm{Fe}_{2} \mathrm{O}_{3}$ (oxygen 30 percent, iron 70 percent), of the variety specularite has been noted in veins in quartzite at the Bog mine, American Fork district.

Spinel.-Spinel, $\mathrm{MgAl}_{2} \mathrm{O}_{4}$, occurs in the area as a contact mineral. It is abundant near the foot of Lake Solitude.

'Brucite--Brucite, $\mathrm{Mg}(\mathrm{OH})_{2}$, occurs abundantly in the contact zone as an alteration product of periclase, residual grains of which are found here and there embedded in brucite (pl. 21, $B$ ).

Magnetite.-Magnetite, $\mathrm{Fe}_{3} \mathrm{O}_{4}$ (oxygen 27.6 percent, iron 72.4 percent), is present in nearly all the contact zones and is locally abundant. It is also a constituent of all the igneous rocks.

Pyrolusite.-Pyrolusite, $\mathrm{MnO}_{2}$, is present in small quantity at many localities and has been mined to a small extent from the Michigan-Utah property.

Psilomelane.-Psilomelane, a hydrous manganese manganate, $\mathrm{H}_{4} \mathrm{MnO}_{5}$ ? (usually impure), is common as black earthy masses or stains in many of the ore bodies, especially around the margins of oxidized ore bodies.

"Limonite."-_Limonite" is present in all the oxidized ores, and is still being deposited near the Bog and Belorophan mines.

\section{Carbonates}

Calcite.-Calcite, calcium carbonate, $\mathrm{CaCO}_{3}$, is the chief constituent of limestone and is present as a gangue mineral in most of the ore deposits of the area.

Dolomite.-Dolomite, carbonate of calcium and mag- nesium, $\mathrm{CaMg}\left(\mathrm{CO}_{3}\right)_{2}$, occurs in much of the limestone of the district, especially in that of the Cambrian system, and is present as a gangue mineral in some of the ores.

Siderite.-Siderite, $\mathrm{FeCO}_{3}$, occurs as a gangue mineral in some of the ores, having been noted especially in the Columbus-Rexall mine.

Rhodochrosite.-Rhodochrosite, carbonate of manganese, $\mathrm{MnCO}_{3}$, occurs as a gangue mineral on the lower levels of the Cardiff mine.

Smithsonite.-Smithsonite, $\mathrm{ZnCO}_{3}$ (zinc 51.96 percent), is present in small amount in many of the oxidized ores. It has been mined from the Carbonate mine and occurs in the South Hecla mine (pl. 22, B).

Cerusite.-Cerusite, lead carbonate, $\mathrm{PbCO}_{3}$ (lead, 77.5 percent), is an abundant constituent of all the oxidized lead deposits (pl. 22, B).

Hydrozincite.-Hydrozincite, basic zinc carbonate, $\mathrm{Zn}_{5}\left(\mathrm{CO}_{3}\right)_{2}(\mathrm{OH})_{6}$, occurs in the oxidized ores, where it is associated with smithsonite.

Malachite.-Malachite, $\mathrm{Cu}_{2}\left(\mathrm{CO}_{3}\right)(\mathrm{OH})_{2}$ (copper 57.4. percent), is present in variable amounts in many of the oxidized deposits.

Azurite-Azurite, $\mathrm{Cu}_{3}\left(\mathrm{CO}_{3}\right)_{2}(\mathrm{OH})_{2}$ (copper 55 percent), like malachite, is present in the oxidized ores of many of the deposits.

Aurichalcite--Aurichalcite, $5(\mathrm{Zn}, \mathrm{Cu})\left(\mathrm{CO}_{3}\right)_{2}(\mathrm{OH})_{6}$, is abundant in the oxidized ores of the Carbonate mine, which is a well-known locality for this mineral:

\section{SILICATES}

Orthoclase and microline.-Orthoclase, $\mathrm{KA}_{1} \mathrm{Si}_{3} \mathrm{O}_{s}$, is a constituent of most of the igneous rocks, and microcline is present in some of the monzonite. Orthoclase occurs in some of the sediments, both as clastic grains and as a product of metamorphism.

Plagioclase group.-The plagioclase feldspars are common constituents of the igneous rocks of the region and occur in the sediments. The occurrence of anorthite in altered diorite is noteworthy.

Pyroxene group.-Diopside is abundant in altered diorite and in altered limestone. Augite is a constituent of some of the igneous rocks, and hypersthene occurs in the diorite of the Clayton Peak stock: Wollastonite occurs in metamorphosed calcareous rocks at the Maxfield, South Hecla, and Giles (Little Dolly ) mines.

Amphibole group.-Hornblende is a common constituent of the igneous and metamorphic rocks. Tremolite is the most abundant and widespread contact mineral in the metamorphosed limestones. Actinolite occurs in contact rock at the Big Cottonwood prospect.

Cordierite.-Cordierite, $\mathrm{Mg}_{2} \mathrm{Al}_{4} \mathrm{Si}_{5} \mathrm{O}_{18}$, occurs in some of the older metamorphosed argillaceous rocks.

Garnet group.-Garnet, principally andradite, is abundant as a contact mineral in calcareous sedimentary rocks and in altered diorite (pl. 16, B). 
Olivine group.-Forsterite, $\mathrm{Mg}_{2} \mathrm{SiO}_{4}$, is locally abundant in the contact-metamorphosed magnesian limestones and dolomite of the area $(\mathrm{pl} .21, C)$. Olivine has probably been present in certain lamprophyric dikerocks, but all of it is now replaced.

Scapolite.-Scapolite occurs in metamorphosed diorite and limestone.

Vesuvianite.-Vesuvianite, a basic calcium-aluminum silicate, is abundant in parts of the contact zones, where it is associated with garnet (pl. 21, A).

Zircon.-Zircon, $\mathrm{ZrSiO}_{4}$, is a minor accessory in some of the igneous and metamorphic rocks.

Andalusite.-Andalusite, $\mathrm{Al}_{2} \mathrm{SiO}_{5}$, is associated with cordierite in metamorphosed argillaceous rocks.

Epidote group.-Ordinary epidote, $\mathrm{HCa}_{2}(\mathrm{Al}, \mathrm{Fe})_{3^{-}}$ $\mathrm{Si}_{3} \mathrm{O}_{13}$, is abundant in the contact-metamorphosed sediments and occurs in altered igneous rocks, which also contain cerium- and, rarely, manganese-bearing epidotes.

Calamine.-Calamine, $\mathrm{H}_{2} \mathrm{Zn}_{2} \mathrm{SiO}_{5}$ (zinc 54.2 percent), occurs in the oxidized ores but is nowhere abundant.

Tourmaline.-Tourmaline, a complex silicate of boron and aluminum, is a scarce constituent of some of the metamorphosed sedimentary rocks.

Zeolites.-An undetermined zeolite occurs very sparsely in altered diorite.

Muscovite.-Muscovite, $\mathrm{H}_{2} \mathrm{KAl}_{3}\left(\mathrm{SiO}_{4}\right)_{3}$, occurs as an original constituent of sediments and as a contact-metamorphic mineral. The variety sericite is present in several of the ore deposits in limestone, where it may form a selvage at the margin of the ore. It has also been formed by alteration of intrusive rocks along the walls of veins.

Biotite.-Biotite, $\mathrm{H}_{2} \mathrm{~K}\left(\mathrm{Mg}, \mathrm{Fe}^{\prime \prime}\right)_{3}\left(\mathrm{Al}, \mathrm{Fe}^{\prime \prime \prime}\right)\left(\mathrm{SiO}_{4}\right)_{3}$, is an original constituent of most of the igneous rocks in the area. Secondary biotite is abundant in some of the metamorphosed shaly sedimentary rocks and in some altered dike rocks.

Chlorite group.-The chlorites, variable hydrous silicates of iron, magnesium, and aluminum, are common alteration products of the dark silicates of the igneous. rocks and are present in contact-metamorphic rocks.

Serpentine.-Serpentine, $\mathrm{H}_{4} \mathrm{Mg}_{3} \mathrm{Si}_{2} \mathrm{O}_{9}$, is an alteration product of magnesian minerals in all classes of rocks. The forsterite in metamorphosed limestones has mainly been replaced by what seems to be deweylite, which is like serpentine but contains more water.

Chrysocolla.-Chrysocolla, $\mathrm{CuSiO}_{3} \cdot 2 \mathrm{H}_{2} \mathrm{O}$ ( silica 34.3 percent, copper oxide 45.2 percent (copper 36 percent), water 20.5 percent), is present in small amounts in the oxidized ores of the area.

\section{TITANOSILICATES}

Titanite.-Titanite, calcium titanosilicate, $\mathrm{CaTiSiO}_{5}$, occurs in many of the igneous and metamorphic rocks.

\section{PHOSPHATES AND ANTIMONATES}

Apatite.-Apatite, presumably fluorapatite, ( $\mathrm{CaF}$ ) $\mathrm{Ca}_{4}\left(\mathrm{PO}_{4}\right)_{3}$, is an accessory constituent of all the igneous rocks and of some of the metamorphic rocks.

Collophanite.-Collophanite, hydrous calcium phosphate, essentially $\mathrm{Ca}_{3} \mathrm{P}_{2} \mathrm{O}_{3} \cdot \mathrm{H}_{2} \mathrm{O}$, occurs in the phosphatic beds of the Park City formation.

Bindheimite.-Bindheimite, hydrous antimonate of lead, occurs in the oxidized ores of the area.

\section{BORATES}

Ludwigite.-Ludwigite, $\left(\mathrm{Mg}, \mathrm{Fe}^{\prime \prime}\right)_{4} \mathrm{Fe}_{2}{ }^{\prime \prime \prime} \mathrm{B}_{2} \mathrm{O}_{10}$, has been formed by replacement of calcareous rocks in the contact zones. It is especially abundant around the head of Dog Lake but is also present in the contact zone on the Michigan-Utah, South Hecla, and other properties (pl. 22, $C$ ).

Magnesioludwigite.-Magnesioludwigite, $\mathbf{M g}_{4} \mathrm{Fe}_{2}{ }^{\prime \prime}$ $\mathrm{B}_{2} \mathrm{O}_{10}$, is found in the Mountain View mine, at the head of Little Cottonwood Canyon. It occurs in the same manner as ludwigite, but it is distinguishable from ludwigite, which is nearly black, by its distinctly green color. It contains only 2.55 percent of $\mathrm{FeO}$.

\section{SULFATES}

Barite.-Barite, barium sulfate, $\mathrm{BaSO}_{4}$, is present as a gangue mineral in several of the mines of the area, notably the Pacific, Dutchman, and Yankee mines of the American Fork district. A vein consisting chiefly of barite crops out at the head of Dry Fork.

Anglesite.-Anglesite, lead sulfate, $\mathrm{PbSO}_{4}$. (lead 68.3 percent), is commonly the first alteration product of galena, though it in turn may be altered to cerusite or plumbojarosite. All the oxidized lead ores contain a little anglesite.

Gypsum.-Gypsum, hydrous calcium sulfate, $\mathrm{CaSO}_{4} 2 \mathrm{H}_{2} \mathrm{O}$, occurs in and near the oxidized ore bodies but is nowhere abundant.

Jarosite.-Jarosite, $\mathrm{K}_{2} \mathrm{Fe}_{6}(\mathrm{OH})_{12}\left(\mathrm{SO}_{4}\right)_{4}$, occurs in the oxidized ores of the area. As it is difficult to distinguish from plumbojarosite its amount is uncertain.

Plumbojarosite.-Plumbojarosite, $\mathrm{PbFe}_{6}(\mathrm{OH})_{12}$ $\left(\mathrm{SO}_{4}\right)_{4}$, is one of the common oxidation products of the ores of the area. It has been noted as especially abundant in the Cardiff, Cabin, Alta Consolidated, South Hecla, and Pittsburg mines.

Beaverite.-Beaverite, $\mathrm{HCuPbFe} e_{2}(\mathrm{OH})_{7}\left(\mathrm{SO}_{4}\right)_{2}$, is probably present in some of the basic ferric lead sulfate that contains a notable proportion of copper.

\section{TUNGSTATES AND MOLYBDATES}

Scheelite. - Scheelite, calcium tungstate, $\mathrm{CaWO}_{4}$, often with some molybdenum, occurs in the South Hecla Mine and probably at other places in the area; it also occurs west of the area, on Deer Creek in the basin of American Fork. 
Powellite.-Powellite, calcium tungsto-molybdate, $\mathrm{Ca}(\mathrm{MoW}) \mathrm{O}_{4}$, occurs in the South Hecla mine.

Stolzite.-Stolzite, lead tungstate, $\mathrm{PbWO}_{4}$; occurs in the oxidized ores of the Old Emma mine. According to old descriptions, the oxidized ore mined in the early days from this mine contained a relatively large amount of a mineral that was called wulfenite but that now seems probably to have been stolzite, which might well have been formed by the alteration of the galena and tungstenite in the primary ores.

Wulfenite.-Wulfenite, lead molybdate, $\mathrm{PbMoO}_{4}$, occurs sparingly in many of the oxidized ores, being especially conspicuous in ores from the Michigan-Utah, Alta Consolidated, and Flagstaff mines.

\section{GENERAL GEOLOGIC RELATIONS OF THE ORE DEPOSITS}

Although the geology of the area has been described in preceding pages, its broader relations to the ore deposits may be briefly summarized here.

The sedimentary rocks of the Wasatch Mountains range from pre-Cambrian to Jurassic in age, though because of unconformities the complete series is not present. Thrust faulting, probably of early Tertiary age, has greatly increased the apparent thickness of the sedimentary series. After this faulting the sedimentary rocks were invaded by intrusive masses, from which they dip outward in general at low angles, though in detail this is not everywhere true. These granular intrusive rocks are exposed within a broad belt extending northeastward across the area. They include three bodies of slightly different composition-the Little Cottonwood stock, west of Alta; the Alta stock of granodiorite, just east of Alta; and the Clayton Peak stock of diorite, which adjoins the Alta stock on the east.

In addition to these relatively large intrusive masses, there are numerous dikes and other small bodies.

The intrusion and the arching of the sedimentary rocks were accompanied by fissuring and faulting, in general parallel to the row of intrusive bodies. The fissures are in places occupied by dikes, and they provided channels through which the mineralizing solutions passed to form the ore deposits in the sedimentary rocks. After the intrusion of some dikes there was further fissuring before mineralization, and after both intrusion and mineralization there was faulting, mainly along fractures of nearly north-south diection, though there are some large faults that strike more nearly eastwest. The east-west faults are especially prominent in the American Fork district. They were doubtless formed in part before the mineralization, but movement has taken place on some of them since mineralization.

RELATIONS OF FAULTS TO ORE DEPOSITS

Faulting occurred both before and after the deposition of the ores. The earliest faults were steep eastwest faults that preceded or accompanied the thrust faulting. Such faults occur, for example, near the Sampson mine, in the valley of Mill D South Fork, near the Alta tunnel, and in Peruvian Gulch. These faults, of course, did not displace the ore deposits, but they faulted the beds favorable to the deposition of ore, and their recognition is therefore quite as important as that of the faults that are later than the ore.

The thrust faults are important in their relation to the ore deposits for two reasons. First, in a given area they may repeat the limestone beds that are favorable to ore deposition and thus increase the probability that ore deposits replacing such beds will be found. Second, the movement along the thrust faults has crushed and brecciated the adjacent beds, and these crushed rocks are favorable to the deposition of ores, even where the rocks from which the breccias were formed.were not especially favorable to replacement.

The north-south thrust zone doubtless also influenced the movement of the invading magna, which coming in along the east-west axis tended to spread somewhat along this north-south fault zone, as indicated by dikes in the canyon of Big Cottonwood Creek. Subsequent mineralization produced a similar distinct bulging, both to the north and to the south, where the northeastwardtrending mineralized belt crosses the thrust zone. The Big Cottonwood district, on the north, and the American Fork district, on the south, are partly in this bulge.

Faults that followed the intrusion of the stocks and the deposition of the ores are numerous throughout the mineralized area. The movement on them ranged from a few feet to hundreds of feet. The interpretation of these later faults is an important aid to the finding of ore bodies that are cut off by them.

Probably most, though perhaps not all, of the northsouth faults are later than the ore deposits. There has been movement on the Silver Fork and Montezuma faults and on certain faults exposed in the Flagstaff mine, for example, later than the deposition of the ores. The East Superior and West Superior faults are also probably later than the ores, though this has not been fully demonstrated.

The east-west faults in the American Fork district seem to have been initiated before mineralization, and the main ore deposits are grouped in the Live YankeeMiller-Pacific zone and the Dutchman zone of eastwest faults. There has, however, been post mineral movement on some of the east-west faults of this district.

\section{RELATION OF INTRUSIVE ROCKS TO ORE DEPOSITS}

The intrusive rocks of the Little Cottonwood and Clayton Peak stocks are locally mineralized, but no large ore deposits have been found in them. The ore deposits, however, are closely associated with the stocks. The important deposits thus far discovered are but a short distance to the north or south of the intrusive bodies or in areas where the stock is still covered by the 
sedimentary rocks. As has been argued in detail elsewhere, ${ }^{40}$ ore deposits tend to be formed near the upper parts, or apices, of intrusive stocks. Where stocks have been deeply eroded, the rocks that contained the most of the ore deposits have been removed. In the belt of intrusive rocks extending through the Wasatch Ringe the Little Cottonwood stock has been far more deeply eroded than the Alta and Clayton Peak stocks; only a few small ore deposits are known to be associated with the Little Cottonwood stock.

The most productive ground in the Big and Little Cottonwood districts is in the block west of the great Silver Fork fault. This block has been lowered relatively to the area to the east by about 3,000 feet since the ores were formed. In other words, the belt of sedimentary rock that roofs the stock at Alta does not represent an original saddle in the crest of the stock, but a portion of the roof, originally at a much higher level, that has been preserved from erosion because it was lowered by faulting.

In the American Fork district the largest deposits have been found east of the Silver Fork fault. The structure, and the presence of numerous dikes, suggest that the productive part of the district may be underlain by a subsidiary stock whose crest lies approximately parallel to the upper American Fork Canyon.

\section{CLASSIFICATION OF ORE DEPOSITS}

All the deposits of proved commercial importance lie in the sedimentary rocks, though some small veins in the intrusive rocks have been prospected and a little ore has been shipped from them. The deposits in the sedimentary rocks can be referred to two general classes, contact deposits and deposits associated with fissures in the sedimentary rocks, although these classes grade into each other and the proper classification of some of the deposits is uncertain. The contact deposits are of minor importance. The far more important and numerous deposits associated with fissures may be subdivided into fissure deposits and bed deposits. Deposits associated with thrust faults might be regarded as a particular variety of bed deposit, but they are described under a separate heading.

\section{VEINS IN INTRUSIVE ROCKS}

The intrusive rocks of the Little Cottonwood, Alta, and Clayton Peak stocks have been much jointed and in places sheared and crushed, and over considerable areas they have been mineralized along the joints. The weathering of the sulfides, which always include pyrite, stains the rocks with oxide of iron. Such staining is notable in the Little Cottonwood stock from Gad Valley Gulch eastward for a.mile or more and at many localities in the Alta and Clayton Peak stocks. Pyrite is the most abundant mineral in the veins in the intru-

\footnotetext{
${ }^{\circ 0}$ Butler, B. S., Relations of ore deposits to different types of intrusive bodies in Utah : Econ. Geology, vol. 10, pp. 101-122, 1915.
}

sive rocks, but chalcopyrite, galena, and molybdenite are present.

The Alta-Gladstone vein, about 2 miles southwest of Alta, in the Little Cottonwood stock, consists mainly of coarsely crystalline quartz, pyrite, molybdenite, and a little white carbonate, probably calcite. The coarsely crystalline quartz is strongly suggestive of pegmatite, though neither feldspar nor muscovite was recognized in the vein. The wall rock is altered to an aggregate of quartz and muscovite, in which sulfides are disseminated. In the vein the sulfides show a tendency to segregate. In the portion accessible at the time of visit the vein material along one wall consisted largely of coarsely crystalline pyrite, and the remainder contained molybdenite, some pyrite, and much quartz.

Ore that may be in the same vein-zone as the AltaGladstone deposit is developed in the workings of the Third Chance property, high on the south side of Little Cottonwood Canyon and just outside the western boundary of the Cottonwood quadrangle but shown on the map. The country rock here is quartz monzonite of the Little Cottonwood stock. The ore seems to be pockety. The best showing, in October 1936, was in an open cut at the intersection of two fissures, one striking N. $60^{\circ} \mathrm{W}$. and dipping. $52^{\circ} \mathrm{S}$, the other striking N. $37^{\circ}$ E. and standing vertical. Some ore very rich in molybdenite and containing a little molybdite was seen in place. A short distance west is an adit about 130 feet long, with branches aggregating another 100 feet and a winze about 15 feet deep. Two cars of high-grade ore are said to have been shipped from'the winze, which is near the intersection of two fissures trending about north-northeast and northwest. Only a little molybdenite was seen elsewhere in the underground workings. East of the winze is a pocket containing terminated crystals of quartz as much as 2 inches in diameter and some pyrite which was deposited after the quartz. Pyrite and quartz accompany all the molybdenite, and much quartz and muscuvite have been formed by alteration of the monzonite near the sulfide deposits.

Small veins containing molybdenite are said to occur at several places in the Little Cottonwood stock, but they have been prospected only slightly.

In Gad Valley Gulch veins containing pyrite, galena, sphalerite, and chalcopyrite in a quartz gangue have been prospected. The largest vein seen was about 1 foot thick and could be traced for 300 to 400 feet.

In the basin at the head of Little Cottonwood Creek the intrusive rock is cut by east to northeast joints and fissures, which contain quartz-sulfide veins. Pyrite is the most abundant sulfide, but some galena and molybdenite are present. Similar veins occur in the intrusive rocks around the head of Big Cottonwood Creek, though copper appears to be more abundant at this locality. Some of the rocks south of Silver Lake show a rather pronounced copper stain, which has resulted from the oxidation of sulfide veins along the joints. Southeast 
of Silver Lake there has been considerable prospecting in the intrusive rock. This work was not accessible at the time of visit, but apparently it did not reveal any ore.

\section{DEPOSITS IN SEDIMENTARY ROCKS}

\section{CONTACT DEPOSITS}

DEPOSITS CONTAINING SULFIDES

The alteration of the sedimentary rocks by the fluids given off from the intrusive bodies-contact metamorphism-is described elsewhere; discussion in this place, therefore, may be confined largely to contact-metamorphic deposits of metallic minerals that have proved to be of value or that have encouraged prospecting. The contact deposits are mostly adjacent to the stocks or to large dikes that are offshoots from the stocks, but some of them are associated with relatively small dikes of aplite and altered diorite, especially near the heads of Little Cottonwood Canyon and Honeycomb Fork.

Contact alteration of limestone and dolomite has resulted in their recrystallization and their partial replacement by silicates, oxides, and sulfides. The most widespread effect has been the recrystallization; next in extent has been the formation of silicates. The silicates have resulted in part from the combination of the materials already present in the impure limestones, as is well shown by the alteration of cherty limestone to tremolite and the alteration of the shaly Cambrian beds to garnet, epidote, diopside, vesuvianite, forsterite, and other silicates. In alteration of this type, without important additions of material, sulfides are rare and iron oxides are relatively rare. There are also areas where rather pure limestone has been converted to silicates accompanied only by small quantities of sulfides or of iron oxides. In other localities magnetite is abundant, and here sulfides are usually present in variable but always small amounts. The accompanying silicates include garnet (andradite), diopside, vesuvianite, forsterite, muscovite, and small amounts of other species. At several localities ludwigite is abundant (pl. 22, $C$ ). This mineral is especially conspicuous in deposits near Dog Lake, at the head of Big Cottonwood Creek, but is also present in contact zones on the Michigan-Utah and South Hecla properties and at 'other localities. The ludwigite appears to have been formed contemporaneously with the silicates and with part of the magnetite, though the magnetite continued to be formed after the deposition of ludwigite had ceased. Sulfides also were possibly formed contemporaneously with ludwigite and magnetite, but in large part they were later. Chalcocite veins cutting forsterite (pl. 29, $B$ ) are present in specimens from the Steamboat tunnel. The chalcocite contains small remnants of bornite and seems to have resulted from the alteration of bornite; both chalcocite and bornite have been partly replaced by chalcopyrite.

Magnesian spinel and periclase (oxide of magnesium) are rather abundant in some places, especially near the heads of Silver, Honeycomb, and Solitude Forks. The periclase is almost wholly altered to brucite.

The contact deposits are of low grade; they have not been extensively prospected and have yielded comparatively little ore. Such deposits have been most extensively developed around the head of Dog Lake, in the Michigan-Utah and Alta Consolidated mines, in Grizzly Gulch, along the south contact of the Alta and Clayton Peak stocks near Lake Catherine, in the basin at the head of Little. Cottonwood Canyon, and in the South Hecla mine. The ores that have been shipped from these deposits consist largely of magnetite, with minor quantities of copper-iron sulfides. They are low in copper and precious metals; it was the value of the iron as a flux that made it possible to ship them profitably under existing transportation conditions. If it were possible to exploit these low-grade deposits at a profit, they might well yield a rather large amount of ore.

\section{DEPOSITS CONTAINING SCHEEUTTE}

In view of the need for increasing the tungsten supply of the country, an attempt was made in 1941 to find workable deposits of scheelite in the CottonwoodAmerican Fork area. The mineral had not been recognized there in the course of the Survey's previous work, although the widespread contact metamorphism in calcareous rocks, together with the occurrence of tungstenite in the Emma mine, made it seem probable that scheelite might be found if specially looked for. The same idea had occurred aleady to several persons interested in the mining industry of the area, and scheelite or other fluorescent substances had been found with the aid of the ultraviolet lamp in several places. Little more was done in the further search made on behalf of the Survey than to confirm these findings.

The results of the search have on the whole been disappointing. Fluorescent material has been found at many places, but in small quantity; and most of the many specimens of intensely metamorphosed calcareous rocks that were taken have failed to show even traces of scheelite. This fact should not be regarded as cutting off all hope that workable deposits of scheelite exist in the areas from which these specimens came. Some of the localities that might beforehand seem especially favorable could not be satisfactorily examined because they were covered with snow at the time of the latest visit. Further examination of the dumps of the old Big Cottonwood and Mountain Lake mines south of Brighton, and of dumps and outcrops at the head of Solitude Fork, seems desirable, although the specimens obtained hitherto from these places have given almost wholly negative results.

Showings of fluorescent material thought to be scheelite are said to have been found at places on Patsy Marley Hill, on the slope east of the South Hecla mine, and elsewhere. It was not feasible to verify these reports without knowing precisely where the materials 
had been found, and there may be some good showings regarding which no first-hand testimony can be given here. Further prospecting for scheelite in the area still seems justified.

Anyone, however, who is looking for scheelite with the aid of the ultraviolet light should keep in mind the fact that fluorescence can be obtained from many substances that are not scheelite and that have no commercial value. In the bleached limestones of the contactmetamorphic zones, notably on the dump of the Maxfield mine and in Grizzly tunnel, a diffuse, bluish fluorescence is given off under the lamp by what must be nearly pure limestone or by limestone that encloses a small proportion of some metamorphic mineral. In places there are fluorescent haloes, giving a bluish light, around remnants of chert nodules that have been largely replaced by tremolite and calcite. Elsewhere fluorescent light of a reddish or golden color is given off by calcite that has little visible impurity. Scheelite and powellite, on the other hand, appear under the ultraviolet lamp as well-defined spots having respectively a bluish or a yellowish fluorescence.

So far as is known to the writer (Calkins) from direct observation, the best showings found thus far occur in the South Hecla mine and on Deer Creek, a stream that joins American Fork some distance west of the area shown in plates 1 and 3 .

The known occurrences in the South Hecla mine are mostly in metamorphosed shale belonging to the upper shale member of the Ophir, which forms the dominant country rock in the East One workings (pl. 44). One of the best showings, in which the mineral has been definitely identified by Miss Glass as scheelite low in molybdenum, is south of the drift along the Copper fissure. Here the scheelite occurs in flat crystals, the largest about $5 \mathrm{~mm}$. across, in flat openings along joints in the highly altered shale, which contains garnet and calcite. There are several other similar though. less striking occurrences in the middle part of the East One workings.

In the southeastern branch of East One (pl. 44), there is a still more impressive occurrence having a markedly different character. Here the fluorescent material is powdery, adhering readily to the fingers, and glows under the lamp with a distinctly yellowish color that indicates powellite rather than scheelite, an indication confirmed by the measurements of refractive index made by Miss Glass, which indicate a high percentage of molybdenum. This material occurs in a porous zone, extending northeastward, in garnetiferous metamorphosed shale.

Fainter showings of what appears to be scheelite have been found in the western part of the Dwyer level, along the contact between the Ophir shale and the Maxfield limestone. The Maxfield limestone at the face of the South Columbus tunnel, also, contains a small proportion of fluorescent material.
Miss Glass' determination of fluorescent minerals in the two best samples from the South Helca mine follows:

No. 41-C-31 (From spur near Copper fissure). About 15 crystals from $5 \mathrm{~mm}$. to $1 \mathrm{~cm}$. in diameter embedded on one side of large rock sample, and associated with sulfides, carbonates, andradite, etc.

Optical properties of the colorless transparent crystals: Uniaxial. Optically pósitive. Omega $=1.930$, epsilon $=1.947$. (Det. in white light.) The optical data indicate that this mineral is scheelite with a low Mo content; that is to say, it has slightly higher indices than does pure $\mathrm{CaWO}_{4}$.

No. 41-C-32 (From southeastern branch of East One). White to greenish yellow powder encrusted on and disseminated through porous grossularite rock.

Optical properties: Uniaxial positive. Omega $=1.962$, epsilon $=1.975$. These data show that the molybdenum content In this scheelite sample is higher, grading toward powellite. The scheelite-powellite mineral in this sample is variable, however. Some grains were lower and some higher than the figures given here for the most abundant patches.

The other showings mentioned as noteworthy are rear the head of Deer Creek, about 5 miles in an air line west-southwest of Dutchman Flat, on a property in which Messrs. Larsen and Farnsworth of Salt Lake City are the chief owners. The observations made in the hour or two spent on this property may be summarized as follows: The country rock is mainly limestone interbedded with sandstone, apparently belonging to the Humbug formation. The rocks are intensely metamorphosed, evidently by the quartz monzonite of the Little Cottonwood stock, of which there are many boulders in the canyon. The high ridges west of the stream appear from a distance to be of Tintic quartzite, which may be thrust over the Humbug formation. The sedimentary rocks are cut by a diorite dike, which is largely replaced by pyrrhotite and chalcopyrite; and the best showings of scheelite that were seen by the writer are in this dike. Some scheelite was seen also in metamorphic rock that apparently represents a sandstone bed, and a little in white limestone containing wollastonite, vesuvianite, diopside, and garnet. Assays showing as much as 3 percent of $\mathrm{WO}_{3}$ are said to have been obtained from samples collected on the property.

\section{DEPOSITS ASSOCIATED WITH FISSURES}

The fissure deposits include those that occur mainly as fissure fillings and deposits that have replaced the rock in and near the fissures. As the replacement extends farther from the fissures the fissure deposits grade into the bed deposits. Replacement of the walls of fissures in limestone is in general so extensive that the deposits in limestone will be described under the head of bed deposits.

Typical fissure deposits are characteristic of the quartzites and the siliceous shale of Cambrian and preCambrian age. They occur in the Cambrian and preCambrian quartzite both above and below the Alta overthrust. Fissure deposits in the Cambrian quartzite have been developed in the Howell, American Consolidated Copper, and Cardiff mines, on Mill D South 
Fork; others are the Toledo and Defiance veins, in Little Cottonwood Canyon. The Pacific, Bog, Silver Dipper, and Yankee mines, in the American Fork district, have exploited fissure deposits in Cambrian and pre-Cambrian quartzite. The ore and gangue minerals have been formed mainly as a cement for shattered quartzite along fissures, but it has to some extent replaced the quartzite.

The primary minerals differ considerably in the different veins. In the Howell and the American Consolidated Copper mines, the sulfides are mainly pyrite, galena, and sphalerite, with some tetrahedrite, and the gangue is mainly quartz. In the Cardiff mine, the principal primary ore minerals are pyrite and tetrahedrite, with some galena, in a quartz gangue. The pyrite, which was the earliest sulfide, was greatly shattered and was recemented by tetrahedrite. (See pl. 23, A.) In the Pacific, Yankee, and Water Fall mines, barite is at least locally an abundant gangue mineral. In the Bog mine, there are small stringers that contain specularite but no sulfides. The pink quartzite adjacent to these specularite stringers is not noticeably bleached, though bleaching has occurred adjacent to the sulfide veins.

The production from the veins in quartzite has been relatively small. The Toledo, Pacific, Cardiff, and Live Yankee veins have had the largest yield, and some ore has been mined from many others, such as those in the Howell, American Consolidated Copper, Silver Dipper, Water Fall, and Bog mines.

\section{BED DEPOSITS}

The bed deposits have been the most productive in the area; they include most of the bonanzas that made the area famous in the early days. Typically these deposits have been formed by the replacement of certain beds of limestone adjacent to crosscutting fissures; they are therefore more or less tabular in form, lie roughly parallel to the bedding, and pitch with the intersection of the replaced beds and the fissures-commonly to the northeast. Where the replacement has extended only a short distance from the fissures, the deposits have more nearly the form of "chimneys" than of tabular deposits. The somewhat similar deposits associated with thrust faults are discussed on page 95 .

Certain beds in the sedimentary series appear to have been especially favorable to the deposition of ores, though it is a rather striking fact that a given bed does not seem to be uniformly favorable throughout the district.

The lowest bed in which commercially important bed deposits have formed is the limestone member of the Ophir formation. This limestone has been especially productive in the Columbus Consolidated and the Alta Consolidated, north of Little Cottonwood Creek, the South Hecla, Peruvian, Native Copper, and Albion mines, south of Little Cottonwood Canyon, and in the Pittsburg mine of the American Fork district.
The next higher important ore-bearing strata are the dark, "wormy", and mottled dolomites immediately above and below the prominent white dolomite stratum in the Cambrian Maxfield limestone. So far as observed, no large ore bodies have been found in the white dolomite itself, which, however, is useful as a horizon-marker. Ore has been found in these dark beds at the old Reed \& Benson mine and at other places on both sides of Reed \& Benson Ridge. The deposits of the Carbonate mine are in these strata, and so apparently are the lower deposits in the Michigan-Utah and Alta Consolidated mines. The deposits of the Miller mine, in the American Fork district, are at approximately this horizon. It has frequently been said that the ore bodies of the Flagstaff, Old Emma, and certain other mines are in the same strata as the Reed \& Benson deposits, but this statement is an error due to the confounding of the Cambrian white bed with a somewhat similar bed at the top of the Jefferson (?) dolomite. The white bed of Cambrian dolomite, which can readily be traced from the Reed \& Benson mine, crops out conspicuously on the slope west of the Flagstaff tunnel with an eastward dip that, if projected, would bring it close to the portal and very little below the strata that carry the Flagstaff ores. Just west of the tunnel, however, there is a fault with downthrow to the east, in consequence of which this bed crops out below the foot of the Flagstaff dump.

The outcrops east of the Flagstaff tunnel that have sometimes been taken for a continuation of the Cambrian bed represent a stratum about 150 feet above the top of the Cambrian. This light-colored bed, together with adjacent beds, forms another important ore-bearing zone-the third in ascending order. The bed consists of pale-gray fine-grained dolomite, which is brittle and has broken into small pieces near fissures (pls. 14, $A, 43$, and $42, A$ ). It is probably a combination of favorable chemical and physical properties that has caused these limestones to be the most productive of the district. The deposits of the Flagstaff-Emma zone are in or near this dolomite, and others occur at nearly the same horizon in the Michigan-Utah mine, in the Prince of Wales mine, and probably in the South Hecla mine.

Above this zone there is no well-defined bed from which a large production has been derived, but at a horizon near the base of the chert series there is a bed that has been mineralized at several places, and ore has been mined from it in the Alta Consolidated, Michigan-Utah, South Hecla, Alta tunnel, and possibly other mines. At many places this horizon is marked by a thin bed of very dark carbonaceous shale, which is regarded as the basal bed of the Humbug formation.

Mineralization has occurred at horizons other than those mentioned, and at some of them productive ore deposits have been formed.

The ore minerals of the bed deposits are similar to those in the deposits associated with the thrust faults, 


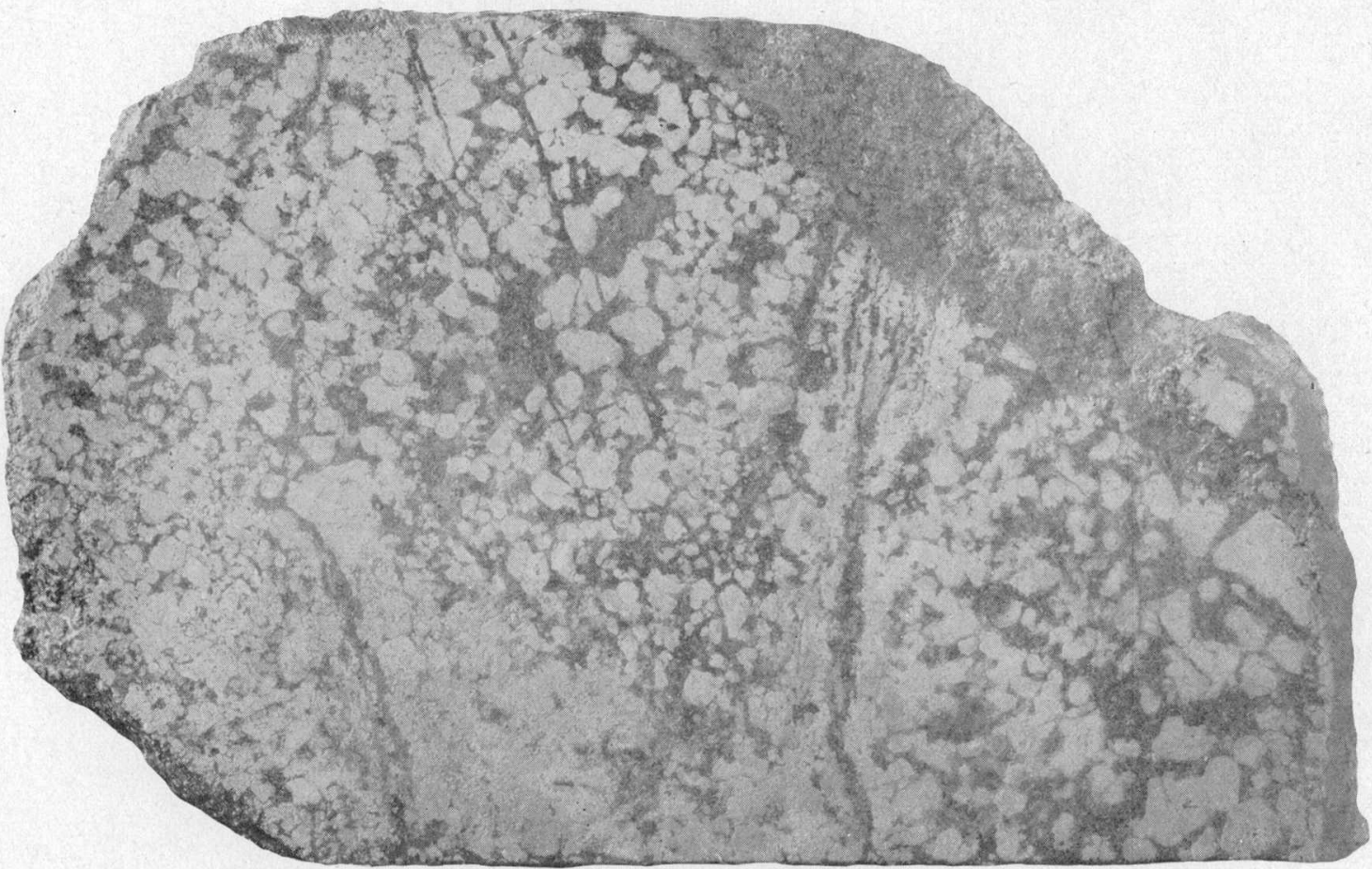

A. ORE FROM CARDIFF MINE.

Light areas pyrite. Natural size.

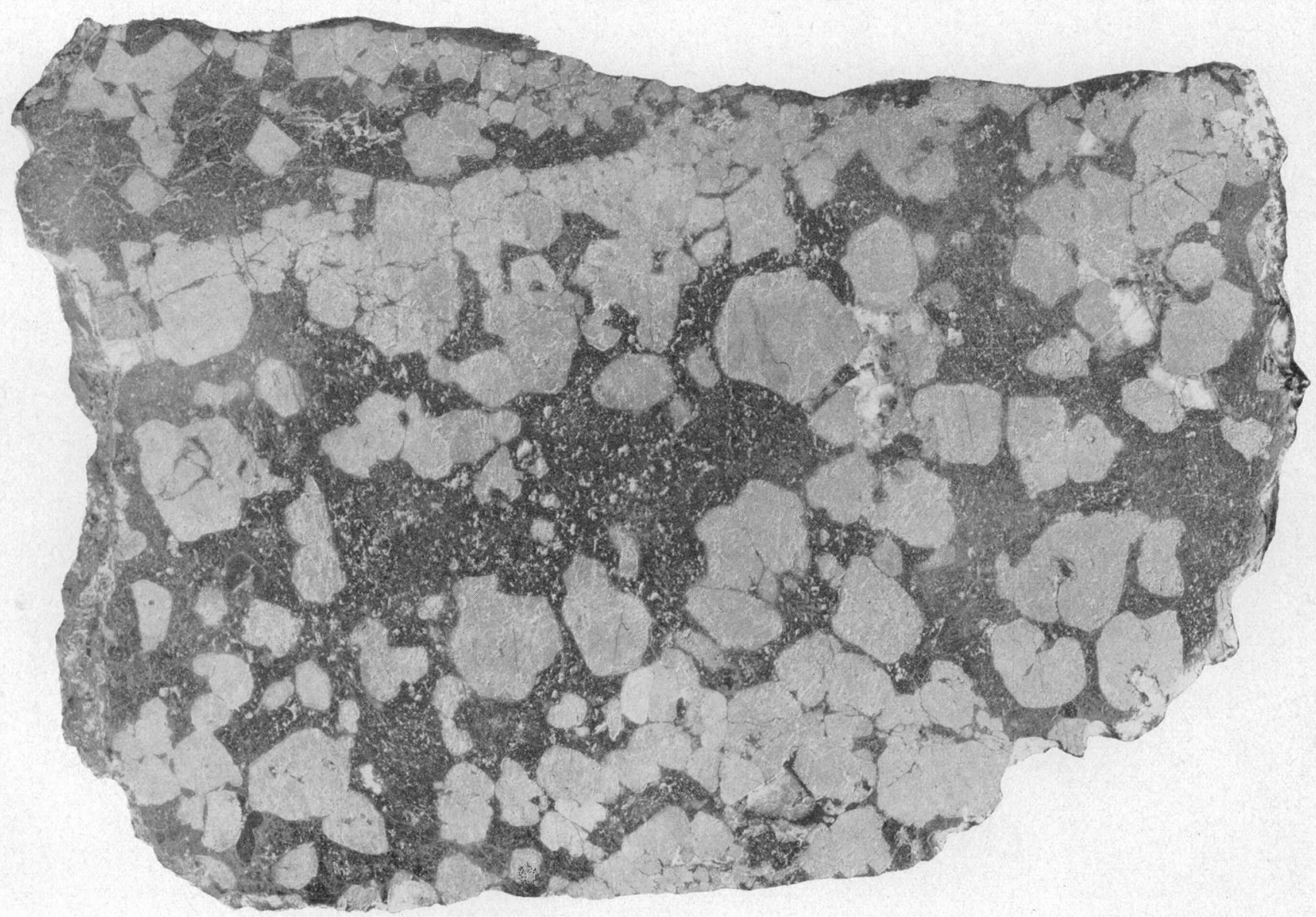

B. ORE FROM COLUMBUS-REXALL MINE.

Light areas pyrite. Natural size. 

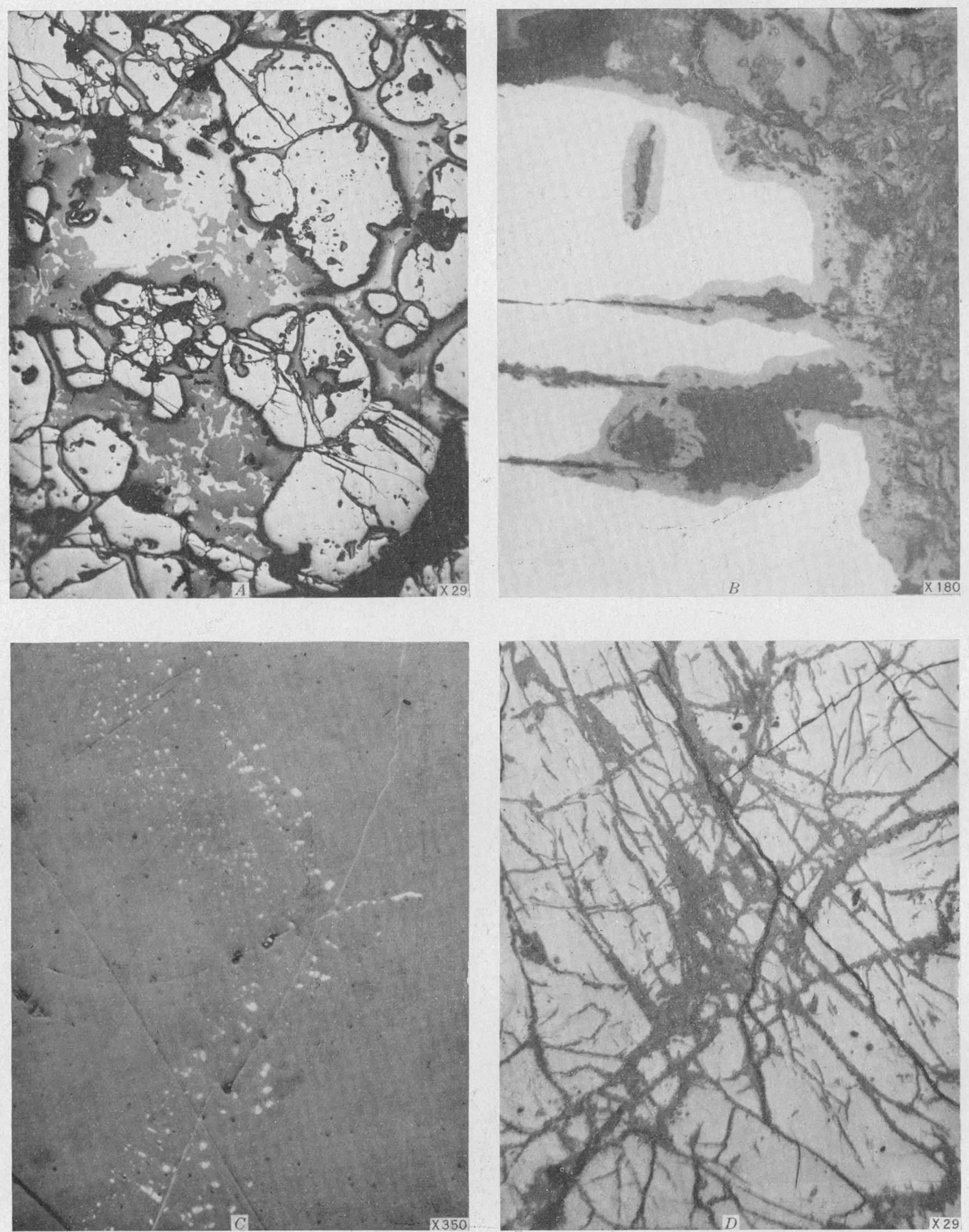

PHOTOMICROGRA.PHS SHOWING RELATIONS OF SULFIDES.

Photographed by M. N. Short.

A: Pyrite (large rounded grains) partly replaced by bornite (gray) and chalcopyrite (white). B. Chalcocite (gray) replacing galena (white). Cardiff mine. C. Blebs of chalcopyrite in sphalerite. Maxfield mine, D, Covellite (dark) replacing tetrahedrite (light). Cardiff mine. 

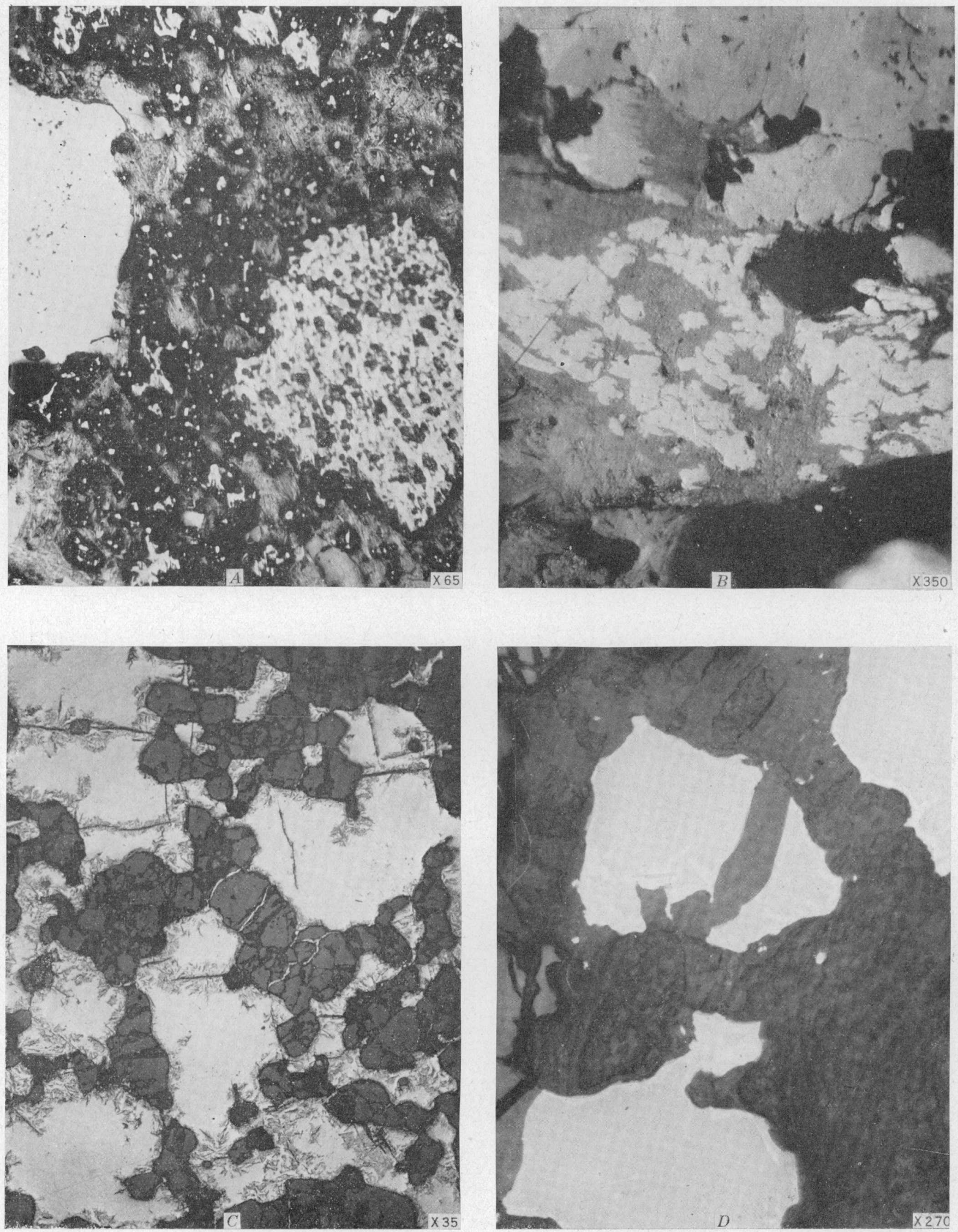

PHOTOMICROGRAPHS SHOWING RELATIONS OF SULFIDFS.

Photographed by M. N. Short.

A. Tungstenite (light-gray, striated) intergrown with galena (white) and pyrite (gray). Old Emma mine. B. Tungstenite (gray) replacing galena (white). Old Emma mine. C. Chalcocite (light) replacing forsterite (dark). Steamboat tunnel. D. Chalcopyrite (white) replacing bornite (gray). Steamboat tunnel. 

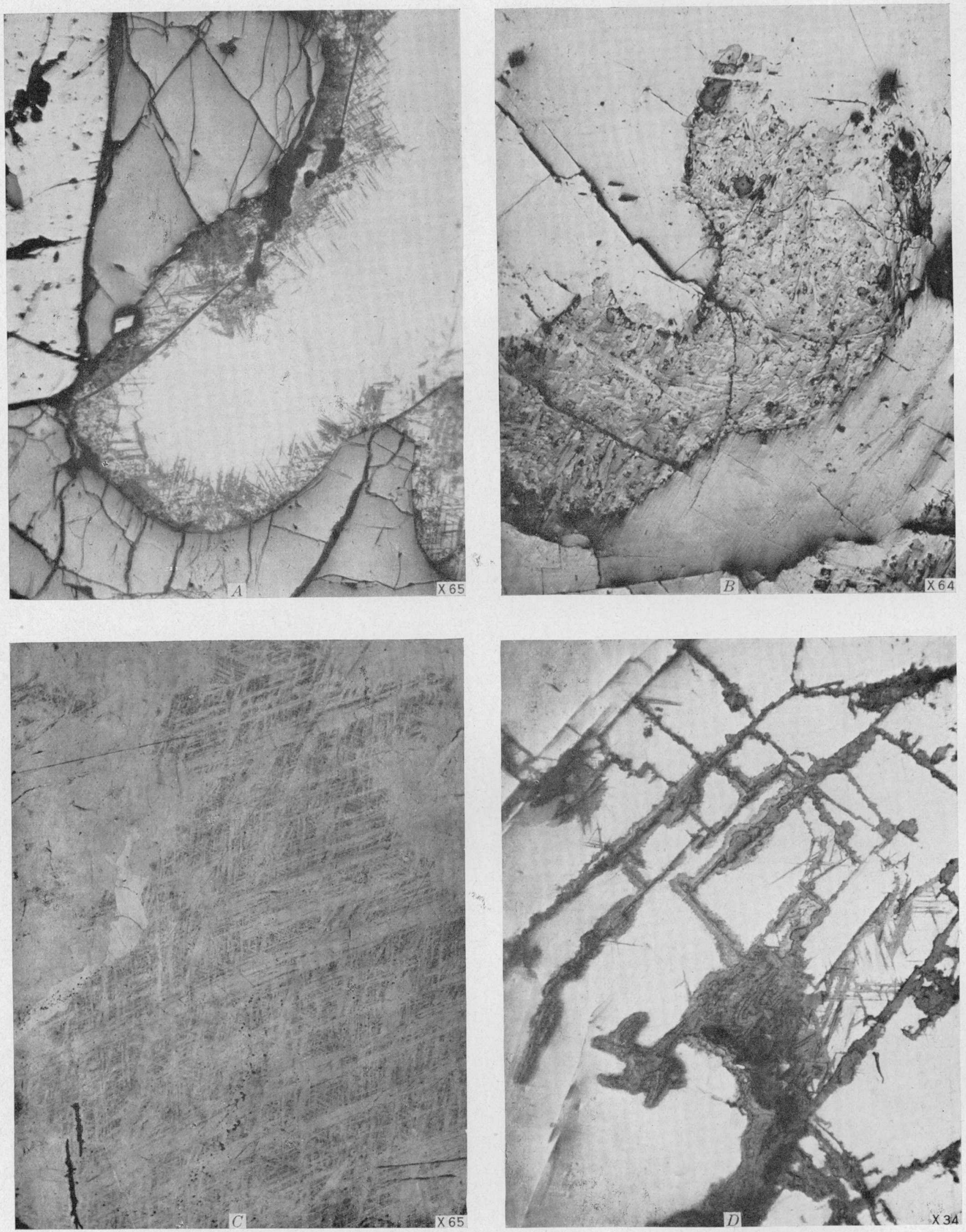

PHOTOMICROGRAPHS SHOWING RELATIONS OF SULFIDES.

Photographed by M. N. Short.

A. Central area, covellite replacing galena. Old Emma mine. B. Central area, intergrowth of galena and tetrahedrite. Columbus-Rexall mine. C. Chalcocite with grating strueture. Steamboat tunnel. D. Anglesite and covellite replacing galena. Cardiff mine. 

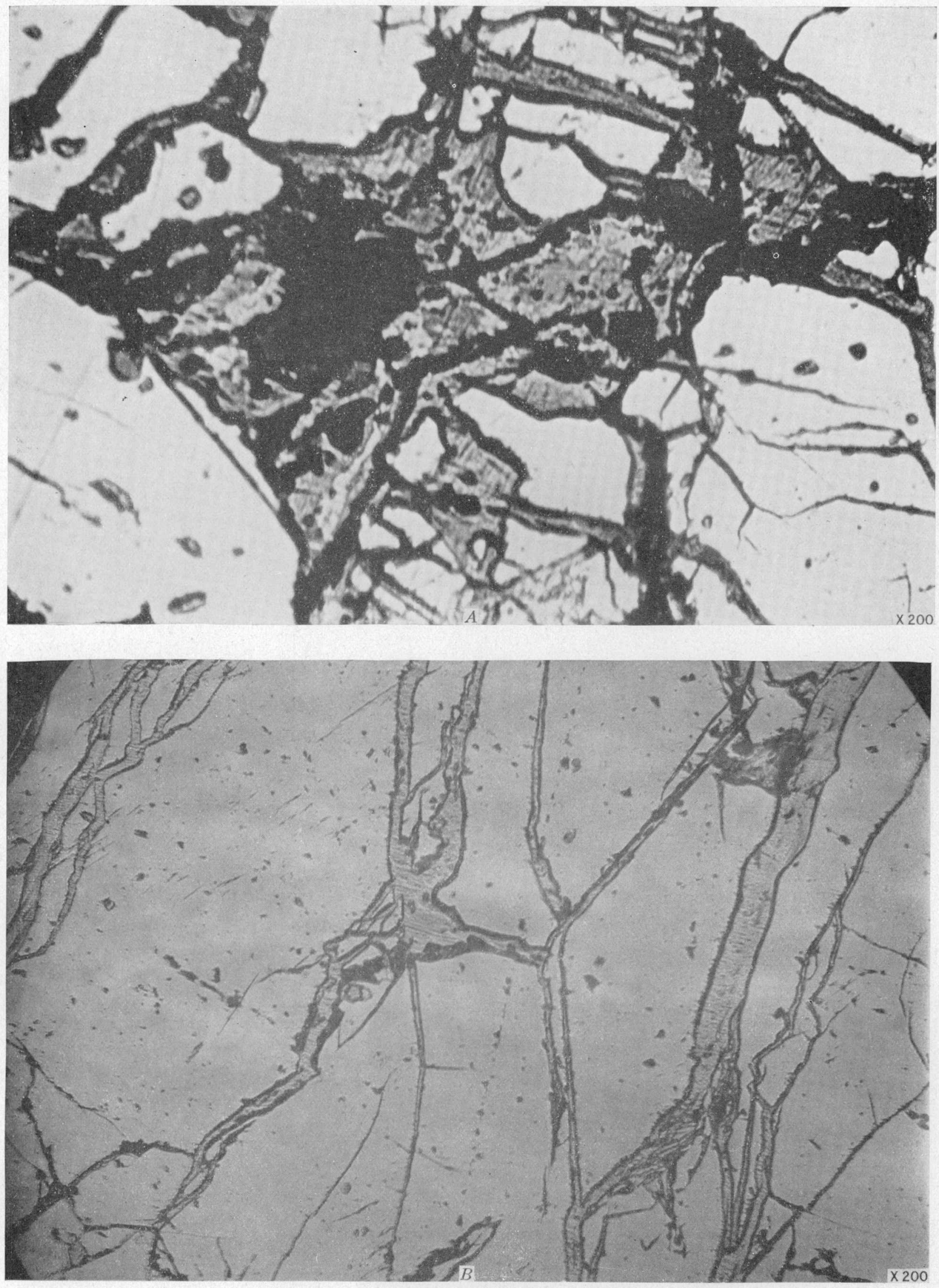

PHOTOMICROGRAPHS SHOWING RELATIONS OF SULFIDES.

Photographed by M. N. Short.

A. Sphalerite (gray) replacing pyrite (white). Cardiff mine. B. Chalcopyrite (veins) replacing pyrite. Columbus-Rexall mine. 

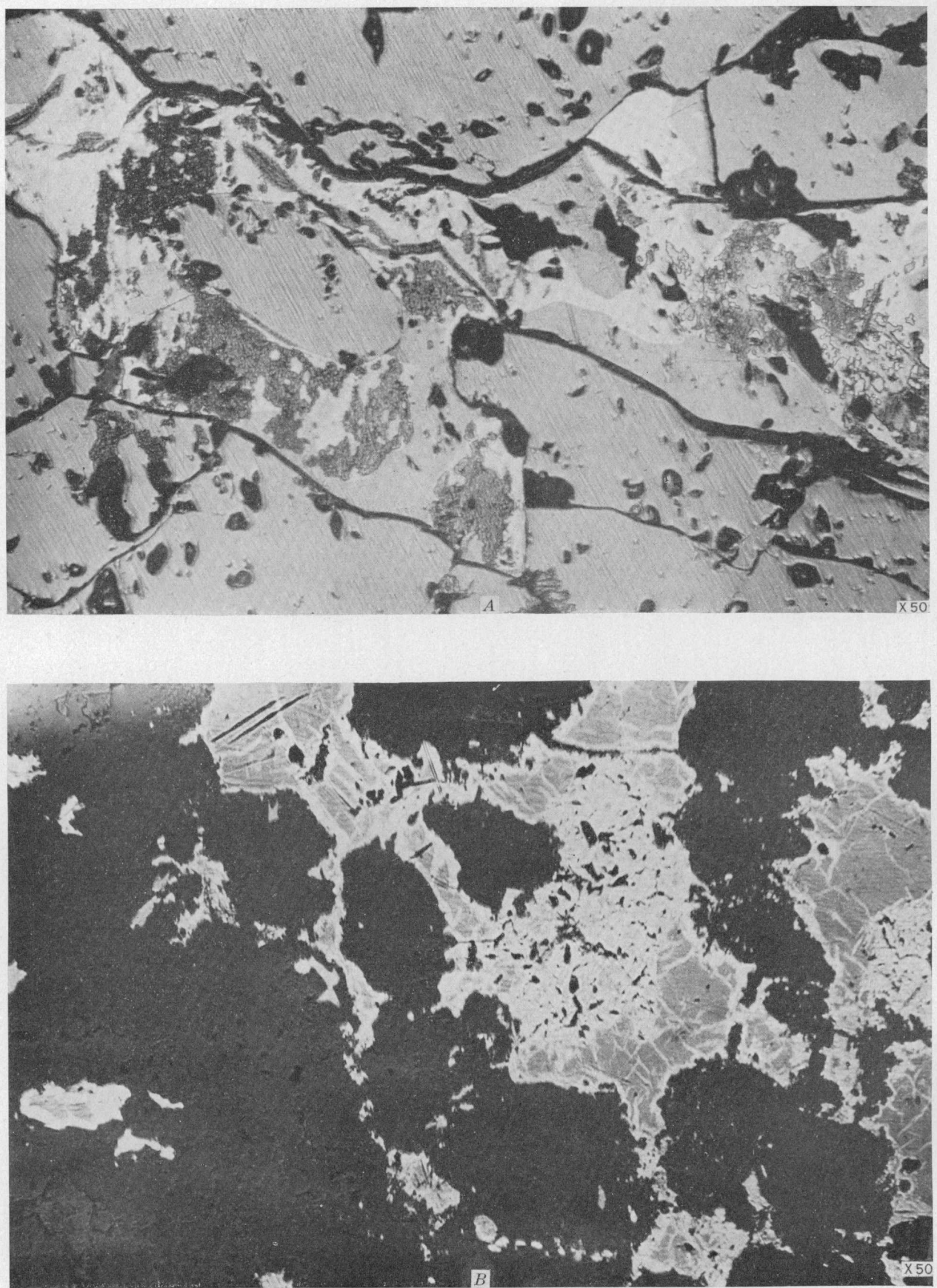

PHOTOMICROGRAPHS SHOWING RELATIONS OF SULFIDES. 


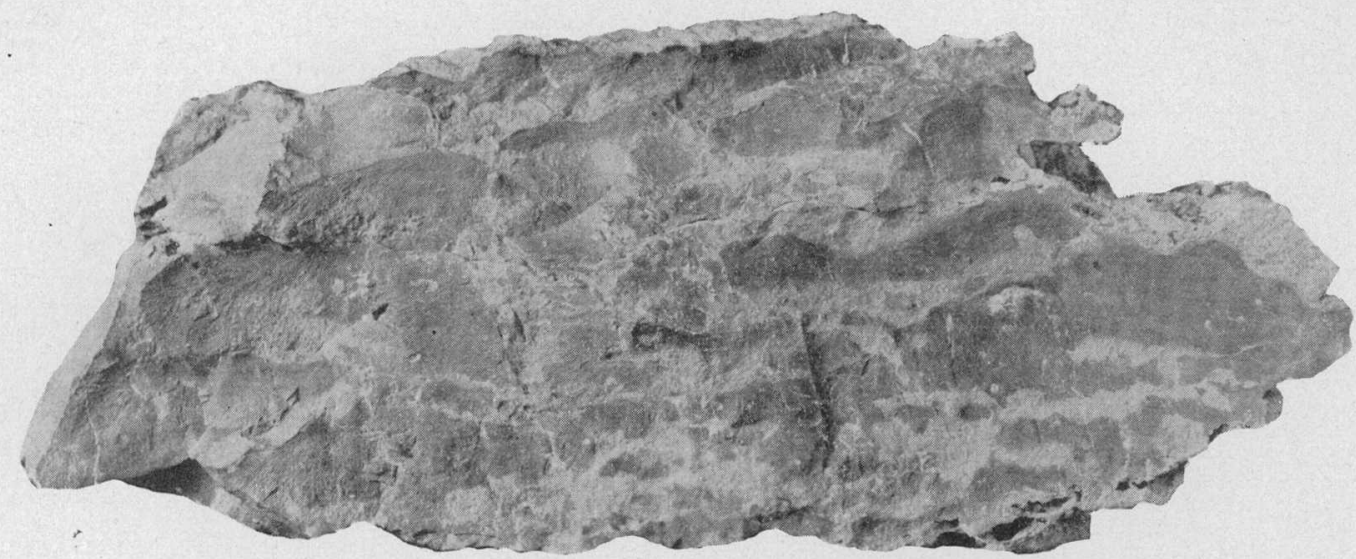

A. MiNeralized LIMESTONE FROM CARBONATE MINE.

Speeimen shows mottling common in Maxfield limestone. Half natural size.

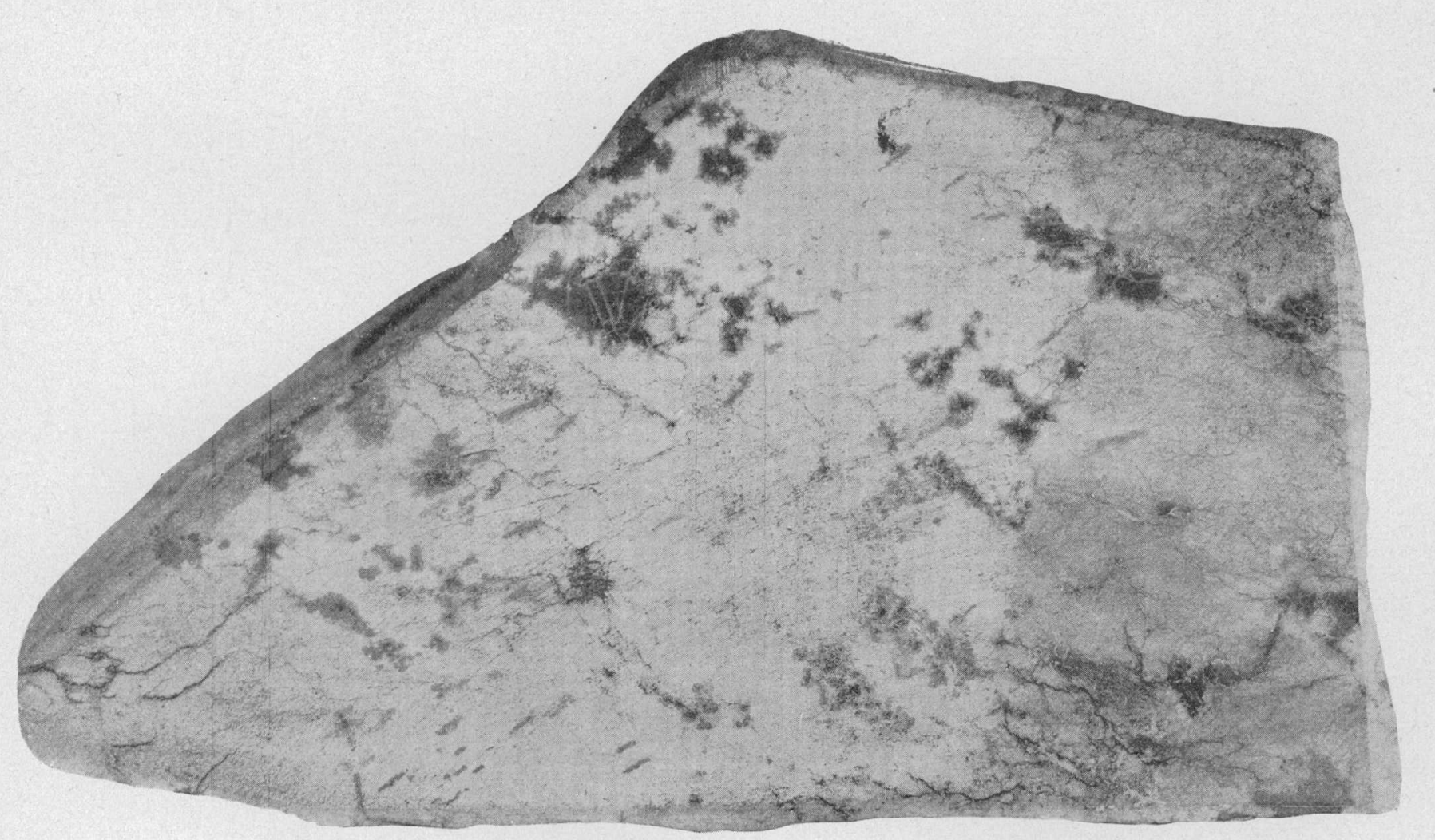

B. CHALCOCITE IN LIMESTONE WITH FORSTERITE, STEAMBOAT TUNNEL.

Dark areas chalcocite. $\times 132$. 
so that the minerals of the two kinds of deposits will be discussed together.

\section{DEPOSITS ASSOCIATED WITH TRUST FAULTS}

Next to the bed deposits those associated with thrust faults, described on pages 54-60, have been the most productive.

Such deposits have been most extensively mined along the Alta overthrust, which, in the longitude of Collins Gulch and Mill D South Fork, has caused Cambrian quartzite to override cherty Carboniferous limestone, although these formations are separated in places by large and small lenses of the Ophir formation, which are exposed at the surface on the spur east of Superior Gulch and near the head of Mill D South Fork, and are encountered in the workings of the Columbus-Rexall mine. Similar lenses are probably present south of Little Cottonwood Canyon, where there has been comparatively little development along the Alta overthrust. There has commonly been much crushing and brecciation of the limestone in the lower block, though the amount of brecciation seems to have depended considerably on the character of the rock that overlay the limestone: where the overriding rock was quartzite the limestone beneath was generally more strongly brecciated than where the overriding rock was shale. The larger deposits have been found where quartzite rests directly on limestone, and the lenses of Ophir shale are generally regarded as unfavorable to the occurrence of ore. The principal deposits that have been developed on the Alta thrust are the Cardiff, Columbus-Rexall, and Wasatch, north of Little Cottonwood Creek, and the CottonwoodAtlantis, at the head of Collins Gulch.

Cambrian quartzite is thrust over the Ophir formation in the Columbus Consolidated mine, on what is regarded by some as the Columbus thrust but by Calkins as the uppermost thrust in the Alta zone. (See p. 57.) Here a large ore deposit was formed in Ophir limestone immediately beneath the thrust fault.

In the eastern part of the area, near the MichiganUtah and Prince of Wales mines and in the limestone area south of the Alta stock, there are two overthrusts which may be the Alta and Columbus thrusts, upraised by the Silver Fork fault. These thrusts are wholly in limestone formations. Near the Michigan-Utah mine the lower thrust brings the Jefferson (?) dolomite upon the cherty Humbug limestone, and the upper thrust brings Cambrian limestone upon Madison limestone. Some of the deposits of the Michigan-Utah mine are associated with these overthrusts.

Above the Columbus overthrust, in the western part of the district, is a zone of complicated thrust faulting that has been designated the Reed \& Benson zone. Faults in this zone are conspicuous in the west face of Reed \& Benson Ridge and along the east side of Collins Gulch. The movement along any one of the faults has been small compared with that on the lower thrusts, but at some localities the faulting has repeated the Ophir formation and the limestone immediately above it in a most complicated manner.

Other thrusts of minor displacement have produced zones of brecciation which have been favorable places for the formation of ore deposits. Slight thrust movement, along favorable beds, probably has determined the location of some ore bodies that are classed as bed deposits.

The thrust faulting preceded the formation of the ore-bearing fissures, and the zones of crushing along the thrust faults have been replaced by solutions from the fissures in the same manner that favorable limestone beds have been replaced to form bed deposits. The crushed zones are, indeed, mostly about parallel to the bedding. The ore shoots of deposits associated with the thrust faults follow the intersections of the breccia zones with the fissues. A thrust fault may cut across the limestone beds, usually at low angles, and the fissure, when followed either lengthwise or vertically, may cut several different beds. These beds are likely to be replaced to different degrees, for although any rock is more readily replaced when it has been crushed than when it has not, the rock of certain beds is much more readily replaced than that of others. The ore shoots therefore pinch and swell as they pass from bed to bed.

\section{COMPOSITION OF BED REPLACEMENT AND THRUST-FAUIT} REPLACEMENT DEPOSITS

The composition of the deposits along thrust faults and of the bed deposits may be described in the same terms.

In most of the deposits the earliest sulfide to be formed was pyrite, which was deposited in great abundance and was accompanied by varying amounts of iron carbonate and probably manganese carbonate. The deposition of pyrite was followed in most places by that of chalcopyrite, bornite, tetrahedrite, enargite, galena, and sphalerite. Some deposits contain other minerals in various proportions, such as tungstenite, formed at a late stage, in the Old Emma deposit and bismuthinite in the Sells mine. The composition of the gangue varies considerably. Quartz, for example, is so scarce in some deposits that it can hardly be found without careful search, while in others it is abundant; in the Old Emma deposit is a large "chimney" consisting almost entirely of quartz. Iron and manganese carbonates occur in many of the deposits, probably in most, but are not very abundant. Barite is scarce in most of the deposits that have replaced limestone. It is most abundant in the Miller and Yankee mines, in the upper tunnel of the Mineral Flat property, and in some other prospects of the American Fork district.

\section{PARAgENESIS}

The deposition of pyrite was followed by that of other sulfur-bearing minerals, which surround pyrite crystals 
and fill fissurcs in the pyrite. (See pls. 22, $A, 23,24, A$, 27.) The general relations indicate partial replacement of the pyrite, though locally there is evidence of replacement of a carbonate that has formed a matrix for pyrite crystals. Galena, sphalerite, tetrahedrite, and enargite seem to have been deposited at essentially the same time, though the proportion of each is very different in different deposits. In the sulfide ore of the Columbus-Rexall mine, tetrahedrite was abundant (pl. 26, $B$ ), but in the Old Emma deposits galena was far more abundant than tetrahedrite. In some of the sulfide ore from the Cardiff mine sphalerite was an important constituent. Chalcopyrite is nowhere a conspicuous mineral, though it was plentiful in parts of the sulfide body of the South Hecla mine. Bornite is present in varying amounts in some deposits as a primary mineral $(\mathrm{pl} .25, D)$. These copper-iron sulfides appear to be generally most abundant in the deposits formed during the early stages of the replacement of pyrite. In the ore from the ColumbusRexall mine, for example, minute fractures in the pyrite crystals are filled with chalcopyrite (see pl. 27, $B$ ), but the larger fractures and the spaces between the crystals are occupied by minerals, such as tetrahedrite and enargite, that do not contain as much iron. The replacement of pyrite by tetrahedrite is common to nearly all the bed and thrust-zone deposits that contain notable amounts of copper.

Sphalerite also fills fissures in pyrite and in magnetite (pl. 28, $A$ ). In the Cardiff mine, pyrite is cut by veinlets of sphalerite (pl. $27, A$ ), and the sphalerite in turn is partly replaced by covellite, doubtless of secondary (supergene) origin. Much if not most of the sphalerite contains many minute specks of chalcopyrite (pl. 24, $C$ ), which commonly show a roughly linear arrangement that suggests deposition along lines of weakness in the sphalerite.

In the Old Emma mine the latest sulfide mineral deposited was probably tungstenite ( $\mathrm{pl} .25, A, B)$. It appears to fill fissures in or partly to replace quartz, pyrite, and galena. This is the first known occurrence of tungstenite in the world, and the extreme rarity of this sulfide calls for explanation. Oxygen compounds of tungsten occur commonly in deposits formed at relatively high temperature, but.some occur in deposits formed at low temperature or low pressure, such as hotspring deposits. The larger tungsten-bearing deposits are not associated with abundant sulfides, but tungsten minerals in small amount are not unusual in sulfide deposits. In these respects tungsten resembles tin, which also commonly occurs as a compound with oxygen but only rarely as a compound with sulphur; and the sulfide of tin, like the tungsten sulfide, seems to have been formed at relatively low temperature. The fact that the sulfide of tungsten has been found only in the Old Emma mine is therefore not easy to explain. Perhaps the sulfide actually occurs in many other deposits but has been overlooked or mistaken for graphite or molybdenite, which it strongly resembles in general appearance. It is possible on the other hand that the sulfide is not stable at high temperatures and that the tungsten, except under very unusual conditions, is all precipitated as compounds with oxygen before a temperature low enough for the formation of the sulfide is reached.

\section{ALTERATION}

Alteration of the ore deposits by surface solutions has been extensive and profound, and much of the ore that has been mined from the area has been oxidized ore, but the relative scarcity of copper in the deposits, and consequently of secondary copper sulfides in the altered ores, has made alteration less conspicuous here than in some other districts of Utah. Perhaps the greatest economic importance of alteration was in rendering the ores more amenable to the simple metallurgical methods of the early days, so that the deposits could be worked with profit at a time when profitable treatment of sulfide ores would have been impossible.

\section{WATER LEVEL AND RELIEF}

The relief of the region is strong, and there is an outlet for ground water from most of the mine workings to the mountain valleys. Most of even the deeper workings are, or could be, drained by tunnels of no very great length. As all the mines are far above the level of the Salt Lake Valley, there may be a slight movement of water below the deepest workings. There appears, however, to be an upper limit of saturation, which nearly reaches the surface under the present main valley bottoms and rises somewhat under the mountain ridges. In places the ground is found to be saturated considerably above this general limit, because of damming by dikes änd gouges. Thus water and sulfide ore were present in the upper (quartzite) workings of the Cardiff mine, even though the ores in the thrustcontact deposit at greater depth were largely oxidized.

The seasonal variation of the water level is considerable. There are few opportunities to measure this variation quantitatively, but in the workings below the Solitude tunnel of the Michigan-Utah mine the water rises to the tunnel level in spring and sinks considerably below that level in fall and winter. In general, it may be said that oxidation of the ores in the more permeable deposits has extended about to the levels of the adjacent valleys and that below those levels sulfide ores are to be expected.

\section{COPPER}

Although most of the deposits of the district contain a little copper, the only ones chiefly valuable for copper are the contact deposits. These deposits are commonly dense and composed chiefly of relatively stable minerals, such as magnetite, garnet, forsterite, and vesuvianite, which do not readily break down under weathering conditions. Few of them contain abundant pyrite; most of them contain considerable carbonate. In such 
deposits there has been little tendency to form deep zones of leaching and correspondingly rich zones of secondary sulfide; the oxidation of the copper sulfides has resulted mainly in the formation of copper carbonates almost in place, without extensive enrichment or impoverishment.

In the Steamboat tunnel some ore was mined in which copper was present mainly as chalcocite, enclosing remnants of bornite, in a gangue of forsterite. (See pls. $25, C, 28, B, 29, B$.) In some specimens both bornite and chalcocite have been partly replaced by chalcopyrite. There was no opportunity to study this occurrence underground, and its general relations are therefore unknown.

\section{LEAD}

The oxidized lead-silver deposits exemplify two principal modes of alteration. In some of them the principal lead mineral is the carbonate, cerusite, associated with the sulfate, anglesite; in others the basic ferric sulfate of lead, plumbojarosite, is abundant. In the alteration of the lead deposits, whether to carbonate or to basic sulfate, there has been no extensive movement of the lead.

In the deposits in quartzite the carbonate is common and the basic sulfate relatively rare. In the deposits in limestone, on the other hand, and especially in those whose primary ores contained abundant pyrite, plumbojarosite and allied minerals: are relatively abundant. Apparently, then, the formation of the basic sulfate was favored by the presence of limestone, as the writer has observed not only in this district but in many others. It seems probable that the neutralization of the sulfuric acid resulting from the oxidation of the pyrite has been a necessary condition for the formation of the basic sulfate, and that the acid was neutralized by the limestone.

. Some of the deposits in which basic sulfates were abundant are those of the Cardiff, Cabin, South Hecla, Alta Consolidated, and Pittsburg mines. Probably these sulfates were present also in the oxidized ore of the Old Emma mine. Old reports describe the ore as containing abundant oxide of lead, but the sulfate, plumbojarosite, then an undescribed species, might readily have been mistaken for the oxide, which it somewhat resembles.

\section{SILVER}

Silver, like lead, appears to have moved but little during oxidation. It apparently is present mainly in the lead carbonate of the oxidized deposits, though in what combination is unknown; but some of the basic iron sulfates are said to be rich in silver, and they may contain argentojarosite, the silver sulfate of the jarosite type.

\section{zINC}

Zinc is present in most of the deposits but is abundant in relatively few. Zinc sulfide ore has been shipped from the old Albion and Yankee mines, and it occurs in the Bog upper tunnel; the ore being taken from the Dutchman mine also is rich in sphalerite. Oxidized zinc ore has been mined from the Carbonate mine, in the Big Cottonwood district. In the Carbonate mine, as in other mines of the State, the oxidized zinc ore lies around and below bodies of lead ore. There was evidently a movement of solutions outward from the original sulfide body to a replaceable limestone, with which the zinc sulfate resulting from the oxidation of sphalerite reacted to form zinc carbonate. The Car-. bonate mine is one of the best-known localities in the West for the beautiful mineral aurichalcite, the doublecarbonate of zinc and copper. Calamine, the zinc silicate, is rare in the area.

Other oxidized zinc deposits of commercial importance may possibly be present in some of the old mines that are not accessible to examination, but it does not seem probable that the area can become a large producer of zinc.

\section{ANTIMONY}

The oxidation of tetrahedrite has resulted in the formation of bindheimite and probably other antimony compounds. These are present in small amounts in many of the ores.

\section{MOLYBDENUM}

Molybdenum occurs in the oxidized ores as wulfenite, the lead molybdate. This mineral is rather abundant in several of the mines, notably the Michigan-Utah, Alta Consolidated, and parts of the Old Flagstaff and South Hecla. An examination of remnants of sulfides in these mines has not revealed the presence of the sulfide of molybdenum, molybdenite. A little of the oxide, molybdite, accompanies molybdenite in an open cut on the Third Chance property.

\section{TUNGSTEN}

Tungsten is present in the sulfide ore of the Old Emma mine as the sulfide tungstenite. (Șee p. 86.) In early descriptions of the oxidized ores wulfenite is mentioned as rather abundant. Re-examination of some of the oxidized ores revealed the presence of a mineral which resembled wulfenite but which on chemical examination by $R$. C. Wells proved to be stolzite, the lead tungstate. It seems probable that this mineral was mistaken for wulfenite and that it was as abundant in the oxidized ores as tungstenite is in the sulfide ores. Apparently there was not much movement of tungsten during the oxidation of the tungstenite.

\section{GENESIS OF ORE DEPOSITS}

As the genesis of Utah ore deposits has been discussed in considerable detail by the writer ${ }^{41}$ in another publication, it seems permissible to discuss the subject here more briefly than would otherwise be desirable.

41 Butler, B. S., and others, Ore deposits of Utah : U.' S. Geol, Survey Prof. Paper 111, pp. 150-215, 1920. 
The close relation of most of the ore deposits of Utah to intrusive rocks is strikingly apparent. This relation is of two kinds and may be discussed under two heads(1) the position of the deposits as related to the bodies of intrusive rocks and (2) the derivation of the material of the deposits from the intrusive rocks.

\section{POSITION RELATIVE TO INTRUSIVE ROCKS}

The intrusive rocks of western Utah occur mainly in three fairly well defined east-west belts-in the Park City-Cottonwood-Bingham belt, the Tintic-Deep Creek belt, and the Beaver County belt-and a large proportion of the metal production of the State has come from these belts. This fact, in itself, strongly suggests a causal relation between igneous intrusion and ore deposition, and the impression is confirmed by detailed study. ${ }^{42}$

In each belt several bodies of intrusive rock have been uncovered by erosion and themselves more or less deeply eroded. In any one belt, the relative amount that has been eroded from each intrusive body can be roughly estimated from the character of the intrusive rock itself and from the ages of the surrounding rocks. The more deeply eroded bodies are consistently the more siliceous, or granitic, in composition and coarse in average texture; those that have been less eroded are dioritic to monzonitic in composition and finer in texture. In general, also, the less deeply eroded stocks are surrounded by younger rocks than the more deeply eroded stocks.

The most productive ore deposits of Utah are associated with intrusive bodies that have been eroded but a short distance below their tops, whereas relatively few small deposits are associated with intrusive bodies that have been deeply eroded.

The suggested explanation for all these relations is as follows: When the molten material entered the relatively cool rocks, the upper portion solidified rapidly, and it therefore represents approximately the composition of the molten material as it entered. The lower parts cooled slowly, so that a large proportion of the relatively heavy minerals, which crystallized earliestmainly those containing iron, magnesium, and calciumhad time to sink, leaving the portion from which they were thus removed rich in silica and poor in the elements just named. Thus the upper part of an intrusive body may be dioritic or monzonitic, a lower part granitic, in composition. As crystallization went on, the lighter and more mobile materials, such as waters and vapors carrying silica and metals in solution, tended to rise to the top of the intrusive mass and to pass into fissures in the solidified portions of the intrusive rocks or in the rocks surrounding the intrusive body, under conditions that would favor the formation of ore deposits. It is therefore in these higher, less siliceous, portions of intrusive masses, and in their wall rocks, that ore

\footnotetext{
2 Beeson, J. J., Mining districts and their relation to structural geology : Am. Inst. Min. Met. Eng. Trans. (reprint) No. 1500, Sept. 1925.
}

bodies would be most likely to occur; the lower, more siliceous portions would be less favorable.

No large ore deposits associated with stocks of granitic composition have, indeed, been found in Utah. The deposits in such highly productive metalliferous districts as Tintic, Bingham, and Park City are associated with monzonitic and dioritic intrusives. In the Park CityCottonwood-Bingham belt a correlation between composition of the stocks and their relations to the sediments is well shown. 'Of the intrusive bodies in this belt, the Little Cottonwood stock has the largest area of exposure and is the most siliceous in composition. Eastward into the Park City district and westward into the Bingham district the intrusive rocks are progressively less siliceous and are in contact with progressively younger strata. ${ }^{43}$ Its composition and area both indicate that the Little Cottonwood stock is more deeply eroded than those either to the east or to the west in the same belt, and the ages of the strata into which the stocks respectively were intruded confirm this indication; the rocks in contact with the Little Cottonwood stock within the mapped area are all of pre-Cambrian age. Toward the east the rocks exposed are progressively younger, till in the Park City area Triassic and Jurassic rocks are present. The same is true toward the west, where late Carboniferous strata surround the intrusive rocks of the Bingham district. This relation also indicates that there has been deeper erosion in the area drained by Little Cottonwood Creek and the streams just north and south of it than farther to the east or the west. This deeper erosion probably is due to two causes-(1) the great fault'along the front of the range has relatively elevated the rocks of the area, as is shown by the uplift of the pre-Cambrian rocks to a higher altitude than they occupy either to the east or to the west; (2) the Little Cottonwood stock may have been intruded to a higher altitude than those to the east or to the west. Either of these causes or both together would have caused the Little Cottonwood stock to stand higher than the neighboring intrusive bodies and hence to be more vigorously eroded.

The ore-forming solutions tended to collect in and around the upper portion of each intrusive body, and the more this upper portion has been eroded the less ore will remain. Large deposits would therefore not be expected in the deeply eroded area of the Little Cottonwood stock, and to date they have not been found there, whereas large deposits have been found farther east, where the intrusive bodies have been less deeply eroded.

The largest deposits of the Cottonwood districts are contained in the downthrown block between the Silver Fork and East Superior faults. It is probable that most of the movement on these faults has occurred since the ores were deposited and that if this block had retained its original position, which was hundreds of feet higher

48 Butler, B. S., and others, op. cit., flg. 8. 
than its present position, the principal ore deposits of the area would long since have been destroyed by erosion. Ore deposits at least equal in extent with those remaining have probably been removed from the portions that were not thus faulted down and protected. In support of this idea we may look toward the east, where erosion has cut less deeply into the intrusive bodies and their surrounding rocks. In the Park City district there are ore deposits of greater extent than any that.have yet been found in the Cottonwood area, and it seems certain that the surface in the Park City area is nearer to the top of the intrusive stocks than in the Cottonwood area. The conditions, then, in this as well as in other districts, indicate that the apices or tops of stocks are the most favorable places for the deposition of ores.

\section{CHEMICAL RELATIONS OF VEIN MATERIALS TO IGNEOUS ROCKS}

The chemical as well as the geographic relations of the ore deposits to the igneous rocks can be more clearly understood by considering a wide region than by studying any one district. Since these chemical relations have already been discussed in considerable detail for the State, ${ }^{44}$ only a summary of them will be given here.

In several districts, but especially in the Deep Creek district, pegmatitic dikes, which have been derived from a differentiation of the material that formed the igneous rock, contain ore minerals and grade into typical ore veins. For example, tourmaline-bearing pegmatitic dikes grade into quartz - tourmaline - scheelite - copper veins and these, again, into the more ordinary quartzcopper veins. Here there can be little doubt that the material of the dikes and of the veins was derived from the same source as the intrusive rocks. The contact deposits in limestone adjacent to the intrusive rocks of the district, moreover, since they contain the same relatively rare elements as the pegmatite dikes, evidently were derived from the same kind of solutions and, it is therefore reasonable to suppose, from the same source. This is true of the tourmaline-scheelite-copper contact deposits, which very closely resemble the tourmalinequartz-scheelite pegmatite veins; and the deposits of this type grade into those that contain lead, zinc, silver, and other metals.

Gradation through a series of widely different deposits is thus unusually well shown in the Deep Creek district, but less complete series are also present in the other districts. In the San Francisco district there are tourmaline-quartz-copper veins that correspond with one type in the Deep Creek district; in the Bingham, Tintic, and other districts quartz-copper veins are common; and in all the districts the composition of the contact deposits suggests derivation from the same solutions as the veins in the intrusive rocks. The contact deposits in turn

\footnotetext{
"Butler, B. S., and others, Ore deposits of Utah: U. S. Geol. Survey Prof. Paper 111, pp. 188-195, 1920.
}

grade into deposits, farther from the intrusive rocks, that contain lead, zinc, and silver.

In the Cottonwood area the deposits in the intrusive rocks are small and of little economic importance, but they are of the same type as those in other districts of the State. The contact deposits of this area are rather numerous, and in chemical composition they resemble those of districts in which derivation from the intrusive rock is more clearly shown. The deposits that contain abundant ludwigite, which are closely analogous to the tourmaline-bearing contact deposits of other districts, are especially indicative of derivation from an intrusive source. As in moșt other contact deposits, the iron content is high. Gradation from contact deposits, containing such silicates as garnet, epidote, and vesuvianite, together with iron oxides, ludwigite, and the ore minerals, to replacement veins, of which silicates are not characteristic, is well shown in some of the deposits of this area. It is exemplified, for example, in the Maxfield mine, where the silicates become less abundant as the distance from a large dike increases, and in some of the veins in the South Hecla, Michigan-Utah, and other mines.

The source of the solutions that formed the ore deposits cannot, indeed, be traced so clearly and completely in this area as in some of the other districts of the State; but some of the Cottonwood deposits closely resemble deposits, in other districts, that undoubtedly had the same source as the intrusive rocks-a fact which strengthens the belief that the ore solutions of this area , also had an igneous source.

\section{CONDITIONS FAVORABLE TO THE DEPOSITION OF THE ORES}

In the preceding section it has been pointed out that certain positions relative to the stocks have been most favorable to the deposition of the ores, and that the metal-bearing solutions probably came from the same source as the intrusive bodies. It is desirable now to inquire what other physical and chemical conditions were especially favorable or unfavorable to the formation of ore bodies.

The ore bodies are classed in another section (pp. 91-96) as contact deposits, fissure deposits, and bed deposits. The deposits of each class differ in certain chemical, mineralogic, and physical characters from those of the other classes. For example, the contact deposits and the veins that are transitional from them to the more typical replacement veins are characterized by the presence-many of them by the abundance- of minerals containing ferric iron, especially magnetite, garnet, and ludwigite; in some parts of the contact zones hematite is relatively abundant. In the typical replacement veins; on the contrary, ferric minerals were not deposited, and even such as were present in the wall rocks of these veins have commonly been altered to ferrous minerals, being apparently unstable under the 
conditions under which the replacement veins were formed. As the writer ${ }^{45}$ has suggested elsewhere, this reduction of ferric minerals may have been effected, wholly or in part, at temperatures somewhat lower than those at which the contact deposits were formed, by a transfer of oxygen from these minerals to sulfur and sulfides, which thus became oxidized to sulfuric acid and sulfates.

The effect of differences in conditions on the stability of ferric oxide is well illustrated in the Bog mine. The red quartzite is cut by small fissure veins of two types, one consisting mainly of quartz and specularite, the other of quartz and sulfides. The wall rock of the quartz-specularite veins is not notably changed, but that of the quartz-sulfide veins is bleached by reduction or removal of ferric oxide.

In the contact deposits replacing limestone or dolomite, ferric iron seems especially abundant-more abundant relatively than in the igneous rock from which the solutions forming the deposits are believed to have come, and certainly more abundant than in the deposits that are farther from the contact or in siliceous rocks. The calcareous rocks thus appear to have been especially favorable for the deposition of ferric minerals by magmatic solutions. The deposits formed in such rocks are characterized by abundance of calcium, carbon, and oxygen, and, in magnesian limestone or dolomite, of magnesium.

Although the interactions between the many elements in the sedimentary rocks and those in the magmatic solutions must have been extremely complex, it is reasonable to assume that the action of $\mathrm{CO}_{2}$ and $\mathrm{H}_{2} \mathrm{O}$ was especially potent, and that it largely determined the distinctive characters of the contact-metamorphic deposits in limestone. Enormous quantities of $\mathrm{CO}_{2}$ must have been liberated by recombinations of magnesium and calcium to form silicates and by the dissociation of magnesium carbonate to form periclase. Some light on the part that was played by this $\mathrm{CO}_{2}$ may be gained from investigations that have been made by metallurgists into certain reactions of iron, carbon, and oxygen-relations which are of great practical importance in the commercial reduction of iron.

In a previous paper ${ }^{46}$ the writer suggested that a great deal of ferrous iron might have become oxidized by $\mathrm{CO}_{2}$ released when limestone was being silicified. His argument was based on the experiments in metallurgy discussed by Findlay. ${ }^{47}$ Lasky ${ }^{48}$ afterward pointed out that later experimental work does not entirely bear out

\footnotetext{
${ }^{45}$ Butler, B. S., Ore deposits of Utah : U. S. Geol. Survey Prof. Paper 111, pp. 184-195, 1920.

${ }^{6}$ Butler, B. S., Suggested explanation for the high ferric oxide content of limestone contact zones: Econ. Geology, vol. 18, pp. 398, 404, 1923.

17 Findlay, Alex, The phase rule and its applications, pp. 313-319, New York, Longmans Green \& Co., 1917.

${ }^{18}$ Lasky, S. G., The systems iron oxides : $\mathrm{CO}_{2}: \mathrm{CO}$, and iron oxides : $\mathrm{H}_{2} \mathrm{O}: \mathrm{H}_{2}$, as applied to limestone contact deposits : Econ. Geology, vol. 26 , pp. $485-495,1931$.
}

Findlay's conclusions, and he questions whether abundant hematite could be formed by the oxidizing effect of $\mathrm{CO}_{2}$ on ferrous iron, though he believes that abundant magnetite could thus be formed. He reaches the same conclusion concerning the oxidizing effect of $\mathrm{H}_{2} \mathrm{O}$ on ferrous iron.

Too much weight should not, of course, be given to the results of laboratory experiments when interpreting the effect of highly complex natural conditions. Field evidence, however, seems in this case to point in the same direction as experimental evidence. Whatever the reason may be, ferric iron is abundant in the limestone contact zones and ferrous iron becomes increasingly abundant outward from the contact. Conditions in the contact zone thus seem clearly favorable to the oxidation of iron, whether or not $\mathrm{CO}_{2}$ is the oxidizing agent. If the oxidation is effected by $\mathrm{CO}_{2}$, it would appear that if a solution containing ferrous iron entered a zone in which $\mathrm{CO}_{2}$ was highly concentrated and the temperature was favorable, the ferrous iron would in part be oxidized to ferric iron, while $\mathrm{CO}_{2}$ was being reduced to $\mathrm{CO}$. The reaction would be: $3 \mathrm{FeO}+\mathrm{CO}_{2}=$ $\mathrm{Fe}_{3} \mathrm{O}_{4}+\mathrm{CO}$. The temperature most favorable to this reaction, at atmospheric pressure, is about $490^{\circ} \mathrm{C}$. The temperature at which contact deposits form has not been very closely determined, but the character of the quartz ${ }^{49}$ in them indicates that it is below $575^{\circ} \mathrm{C}$. and Lindgren estimated that it is $300^{\circ}$ to $600^{\circ} \mathrm{C} . .^{50}$ There is little doubt that some of the dikes in the limestones of the Cottonwood area solidified before contact metamorphism was completed, for they are highly altered by the same process, which must have persisted at temperatures far below the solidifying temperature of the dikes. (See p. 43.) The abundance of magnetite and ferric minerals in the limestone contact zones seems to support the conclusion; reached from other evidence, that the contact deposits were formed at about $500^{\circ} \mathrm{C}$. At lower temperatures the reducing tendency of $\mathrm{CO}$, formed at the expense of $\mathrm{CO}_{2}$, and that of sulfur and its compounds would seem to be increasingly unfavorable to the formation and stability of ferric compounds.

To sum up, then, it would appear that in limestone contact żones, where heat and chemical action were liberating $\mathrm{CO}_{2}$ from carbonates and high temperature favored the oxidation of $\mathrm{FeO}$ by reduction of $\mathrm{CO}_{2}$, ferric compounds might be expected to form. At greater distance and lower temperatures, where $\mathrm{CO}_{2}$ was not being liberated and where, perhaps, the $\mathrm{CO}$ formed in the zone of higher temperature behaved as a.reducing agent, the tendency to oxidation of iron would decrease and at last give way to reduction: The temperature favorable to the reduction of $\mathrm{Fe}_{2} \mathrm{O}_{3}$ by $\mathrm{CO}$ would also be favorable for the oxidation of $\mathrm{SO}_{2}$ at the expense of ferric iron, so that at such temperatures

49 Wright, F. E., and Larsen, E. S. : Am. 'Jour. Sci., 4th ser., 'vol.' 27, pp. $421,447,1909$.

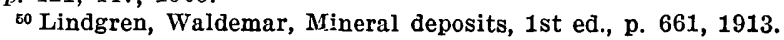


ferric compounds would not be deposited and any that were present would probably be reduced. The temperature most favorable to the formation of $\mathrm{SO}_{3}$ by the reaction $\mathrm{SO}_{2}+\mathrm{O}$ is about $400^{\circ} \mathrm{C}$., or about $100^{\circ}$ below the most favorable temperature for the oxidation of $\mathrm{FeO}$ by $\mathrm{CO}_{2}$.

The deposition of sulfides is perhaps controlled by reaction between water and hydrogen sulfide according to the equation $2 \mathrm{H}_{2} \mathrm{O}+\mathrm{H}_{2} \mathrm{~S}=\mathrm{SO}_{2}+3 \mathrm{H}_{2}{ }^{51}$ This reaction displaces to the right above $200^{\circ} \mathrm{C}$. and to the left below that temperature. Above $200^{\circ} \mathrm{C}$., therefore, $\mathrm{H}_{2} \mathrm{~S}$ could not exist in the presence of water and the sulfur would be in a more highly oxidized condition. When the temperature had decreased to $200^{\circ}, \mathrm{H}_{2} \mathrm{~S}$ would begin to form and would precipitate the metals that had been carried in oxidized compounds, such as chlorides, fluorides, or sulfates. The order of precipitation would be determined in part by the electrode potentials of the metals and in part by the abundance of the metals in the solution. The potential of the metals would tend to cause the deposition first of iron sulfide and then, successively, of zinc, lead, copper, and silver. The combination of copper and iron in chalcopyrite would place that mineral between the sulfides of iron alone and of copper alone.

From the foregoing considerations we might expect that near the contact, immediately after intrusion and in the early stages of mineralization, the conditions would be favorable to the formation of minerals rich in ferric iron; and such appears to be the case. At greater distance from the contact and in the later stages of mineralization near the contact, the conditions would favor the reduction of ferric compounds and the oxidation of $\mathrm{CO}$ and of sulfur compounds. The abundant formation of sulfide is apparently not favored by the first reaction and does not take place till $\mathrm{H}_{2} \mathrm{~S}$ can form in the solutions.

In the Cottonwood area sulfides have been deposited in the contact zone-abundantly enough in places to form low-grade ores-but the sulfides have formed later than the magnetite and andradite and occupy small fissures in them. The sulfides in these deposits were formed after the contact zone had largely cooled, and the conditions most favorable to the formation of the contact minerals were not favorable to the formation of sulfides. This fact is of practical importance. In following a sulfide vein the presence of garnet or magnetite may be generally taken as an unfavorable sign; as soon as these minerals become abundant the quantity of metal, other than iron, in the vein is greatly reduced. In passing from the contact zone into zones at greater distance from the intrusive rocks the sulfides become more abundant and, as already noted, the ferric minerals are absent, though ferrous carbonate and ferrous silicates may be present.

\footnotetext{
Zles, E. G., The fumarolic incrustations in the Valley of Ten Thougand Smokes: Nat. Geog. Soc. Tech. Papers, Katmai series, vol. 1, No. 1, 1924 .
}

The primary sulfides have not all formed at the same time. As a rule pyrite has been the first to form; this has been followed by chalcopyrite and bornite, and these in turn by sphalerite, galena, and tetrahedrite. In several deposits, and possibly in most, pyrite has been replaced in part by other sulfides.

Primary sulfate minerals are scarce in most of the deposits of the region. Barite is most abundant in the American Fork district and seems to be especially so in the deposits in the quartzite, as in the Pacific and Yankee mines. In the Yankee, Miller, and Dutchman mines, however, it occurs also in shale and limestone near the quartzite.

The general scarcity of primary sulfates in the district is possibly due to the fact that the deposits of the area occur mainly in limestone. Their relative abundance in the American Fork district may mean that barium was more abundant there than in the Big and Little Cottonwood districts, where barite is scarce even in quartzite. It should be noted, however, that the Cambrian quartzite in the Cottonwood districts hás been thrust over limestones, through which the ascending solutions must have passed before they reached the quartzites.

\section{SUMMARY OF GENESIS}

In this region, as in the neighboring regions, all of the deposits, varied though they are in composition, form, and relations, are believed to have derived their metal content from solutions that emanated from the intrusive bodies. The differences in the mineral constitution of the deposits is largely due to the fact that the deposits were formed at different temperatures and pressures; and an understanding of the effects of these conditions is likely to be helpful in prospecting.

\section{FUTURE OF THE DISTRICT}

The Cottonwood-American Fork area has produced metals for more than 70 years. The production for the last 20 years compares favorably with that of other periods except the decade 1871 to 1880 , when some of the rich "bonanzas" were being worked, and short periods later when rich deposits were discovered and mined. The records of the metal output of the district, therefore, do not indicate approaching exhaustion.

Little ore is in sight in the area at present, but this has nearly always been true. This has been so partly because of the nature of the deposits and partly because until recently much of the ground has been controlled in small areas, by companies or individuals whó were not financially able to carry on extensive development. In recent years there have been many consolidations, and these tend to bring together holdings that will permit extensive and systematic developments.

The extreme complexity of the geologic conditions in the area have been shown in the preceding pages of this report. An attempt has been made to present the larger features of structure and ore occurrence, so that 
they may be of use in future development, but no attempt has been made to study and describe the entire area in the detail necessary for the planning of mining development. It is perhaps needless to say that any campaign of development should be preceded by a detailed and careful study of the local geologic conditions. A large amount of unproductive development work has been done in this area, and it was of course inevitable that part of this work should prove unproductive. But a great deal of barren work might have been saved by giving to a detailed geologic study a mere fraction of the effort and expense that was given to development.

Future development may perhaps be aided by stating certain generalizations, some but not all of which are already well recognized by the mining men of the district.

No large deposits in intrusive stocks have yet been found and there is little reason to hope that the area contains any such deposits.

Contact deposits are rather abundant, and some of them are doubtless large, but they are generally of low grade and are not known to have undergone important secondary enrichment. Their outcrops are not gossans as that term is generally used, and if they are not profitable a short distance below the surface there is little likelihood of their being rich at greater depth.

The bed deposits thus far developed have been confined to a few favorable beds of limestone, and the recognition of these beds is therefore an important factor in prospecting. Promising indications in other beds should not be passed by, but the chances of finding valuable deposits seem to be best in these favorable beds.

The limestone breccia zones along thrust faults have been favorable places for the deposition of ore, and these zones where crossed by mineralizing fissures are worthy of prospecting.

In the lead-silver deposits there has been but little movement of the metals during alteration, and the deposits are likely to be as rich and as large a short distance below the surface as at greater depth. Reasons have been given on pages 98-99 for believing that where erosion has been deep the richer ore deposits have been removed and that great depth is not likely to prove favorable.

Some of the ore bodies have been cut by faults in such a way that the downthrown part does not crop out at the present surface and the upthrown part has been completely removed by erosion. Such deposits must be sought without the guidance afforded by surface croppings.

The more easily discovered deposits have doubtless already been found and extracted. Much ground, however, is still unprospected, and there is reason to expect that deposits will continue to be found. The cost, or the chance of finding a new deposit on a given property, will depend in large part on the operator's under- standing of the geology of the area in general and on his realizing that it pays to have the geology of his property studied in detail before undertaking extensive operations.

The writer does not believe that the geologic conditions in this area warrant the hope of finding deposits equal in size and richness. to those in the Park City, Tintic, or Bingham districts. Past production points to the same conclusion. Valuable deposits may nevertheless be found in the future, as they have been in the past.

\section{THE IMINES}

By B. S. BUtler and F. C. CALKINS

In the following descriptions of mines the material relating to history and production has been mainly prepared by V. C. Heikes and C. N. Gerry. For mines that were not accessible at the time of study the attempt has been made to present the best available information recorded by previous observers.

Since this work was begun there have been many consolidations of properties. Some of the descriptions were prepared before the consolidations were made, and in others it has been found most effective to describe the properties under the grouping that existed when the properties were being mined. Each property is described under the heading that seems most likely to identify that property in the reader's mind. Plate 30 shows the claims in the district but not the boundaries of the holdings of different companies. The principal tunnels are shown in their relation to the topography in plate 1.

There has been considerable development in some of the mines since they were examined, regarding which only a general statement is made.

\section{BIG COTTONWOOD DISTRICT MAXFIELD \\ HISTORY AND PRODUCTION}

The Maxfield Mining Co..$^{52}$ was incorporated in 1879, and it is said to have produced 22,000 tons of ore up to the end of 1890. At that time it was shipping at the rate of 500 tons a year. Although the records of the company are incomplete for the first 20 years, those available indicate that the tenor of the shipping ore was fairly uniform and that it carried, in the years preceding 1915, an average of 0.17 ounce of gold and 50 ounces of silver to the ton, 20 percent of lead, and 1.5 percent of copper. To the end of 1906 the total value of the mine's output was estimated ${ }^{53}$ at $\$ 1,053,000$ and the dividends paid to stockholders at $\$ 118,000$. From 1906 to the end of 1919, lessees and the company shipped nearly 5,000 tons, mostly of hand-picked ore but partly a product from the jigs. The cost of the earlier developments, ${ }^{54}$ including the 1,500 -foot adit, amounted to

${ }^{82}$ Huntley, D. B., 10th Census U. S. (1880), vol. 13, p. 428, 1885. Jones, M. E., Internal commerce of the United States, 1890, p. 889, 1891. * Thomas, A. L., Jr., personal interview, 1907.

s. Jones, M. E., op. cit., p. 889. 
$\$ 22,500$, and $\$ 43,650$ was spent on machinery and buildings to the end of 1890 . In 1915 and 1916 about $\$ 250$,000 more was spent by the Boston Development Co. for a small jigging plant and the extension of the adit through limestone to a point 2,400 feet from its portal, gaining a depth below the crest of the mountain of 1,200 feet. In a winze sunk 218 feet below the adit level a watercourse was encountered, and in order to cope with this a large electric pumping plant in two units, capable of handling 1,500 gallons of water a minute, was installed. Active operations by the Boston Development Co. ceased in 1917, and the mine was allowed to fill with water. Only one lot of ore, probably from the waste dump, was shipped in 1919. Since 1919 little ore has been produced from the mine.

\section{GEOLOGY}

The Maxfield mine (pl. 31) is about 7 miles from the mouth of Big Cottonwood Canyon and about half a mile west of the area shown on the geologic map. The ore body crops out in Maxfield Gulch, a few hundred feet north of its junction with the main canyon. The sedimentary rocks are the Cambrian quartzite, the Cambrian shale with interbedded limestone (Ophir formation), a little of the overlying Cambrian limestone, and Devonian (?) and Carboniferous limestones, the base of which at this locality lies but a short distance above the Ophir formation. All these rocks are cut by dikes of monzonitic porphyry. The largest dike, which crops out in Maxfield Gulch northeast of the mine workings, is several hundred feet wide and can be followed along the west fork of the gulch to an altitude of 400 or 500 feet above the canyon. Dikes cut the limestone in the Baker mine, east of the Maxfield, others are exposed in road cuts along Big Cottonwood Canyon, and others are cut at several places in the northeastern extension of the Maxfield workings, both on the main tunnel level and at higher levels. Small dikes and sills of the porphyry extend along fissures and along certain of the beds.

The limestone adjacent to the dikes has commonly been altered to a mixture of silicates and calcite. Epidote and mica are the most abundant minerals, but garnet and diopside are also present. Wollastonite, a mineral that is not common in the area as a whole, is rather plentiful here; it may have been formed by alteration of cherty material, as tremolite has at countless other places in the area. Magnetite, hematite, and sulfides are nearly or quite lacking. In many places the porphyry as well as the limestone appears to have been metamorphosed, indicating that it had solidified before the alteration was completed.

Numerous fissures in the limestone strike from a few degrees west of north to N. $20^{\circ}$ E. and dip irregularly. The Alligator fissure, which may be the same as the Logger fissure, on the opposite side of Big Cottonwood Canyon, is perhaps the most regular; it has in general a steep westerly dip, but its attitude varies considerably at depth.

The larger ore deposits of the mine have been formed in a bed of banded blue and white limestone near the base of the Madison limestone. The ore has replaced the limestone adjacent to fissures, forming chimneys of varying size. The deposits so far developed appear to form a northwestward-pitching zone near the porphyry dikes. This belt has been followed from the outcrop in Maxfield Gulch to the bottom of the Alligator extension winze (pl. 31), a distance of more than 1,300 feet. In the older workings several pipes of ore have been followed to the porphyry dikes. Near the dikes the lead and silver content decreases so much as to become unprofitable, although the limonite persists. The limestone adjacent to fissures near the dikes is partly replaced by silicates, including mica, wollastonite, and epidote, and ore is rarely found where the limestone has been so replaced-a fact which suggests that the ore solutions came up along the dikès and passed into the fissures. The absence of ore and the presence of silicates near the dikes may be interpreted as indicating that the temperature there was too high to allow the deposition of the ore minerals.

The ore below the tunnel level in the northeastern part of the mine is mainly sulfide, consisting chiefly of pyrite, galena, sphalerite, and tetrahedrite. There is relatively little quartz gangue, and the adjacent limestone is not highly silicified. The deposits worked in the southeastern part of the mine were above water level and were largely oxidized. In this part of the mine, quartz is far more abundant than elsewhere and occurs at many places in well-formed crystals that evidently were deposited in open spaces.

Later operations were conducted through a tunnel from Big Cottonwood Canyon which intersects the ore zone about 1,000 feet from the portal. The ore zone has been followed for a distance of more than 1,000 feet northwest, and to a depth, in the Alligator extension winze and main shaft, of about 140 feet vertically below the tunnel. In the summer of 1916 ore was being extracted at this depth from the Alligator shoot.

Some prospecting has been carried on from the turnel level in the Madison limestone or Jefferson (?) dolomite below the main Maxfield ore bed, and some small shoots of ore have been developed. There had been no prospecting of the limestone member of the Ophir shale in the Maxfield mine when it was studied.

\section{BIG COTTONWOOD MONARCH}

The Big Cottonwood Monarch mine is on the south side of Big Cottonwood Canyon, about half a mile above the Maxfield mine. The country rock is Carboniferous limestone cut by diorite dikes. In 1916 a tunnel had been driven about 600 feet and for most of its length was in or near a diorite dike. There had also been some 
prospecting by a shaft. No ore had been developed in either tunnel or shaft.

\section{BAKER}

The Baker mine is about a quarter of a mile up Maxfield Gulch from Cottonwood Canyon, east of the Maxfield mine, but west of the mapped area. The rock is limestone, probably Madison, cut by diorite dikes. Several outcrops of veins containing limonite and a little lead have been developed to a slight extent. The deepest working in 1916 was said to be 75 feet. Development in 1916 was being carried on through a tunnel that crosscut the limestone and was intended to cut the fissures exposed on the surface at a depth of about 500 feet. In June 1916, when the tunnel was about 900 feet long, it had encountered no fissure that seemed worth developing.

\section{IOGGER}

F. F. Hintze made the following observations on the Logger developments in 1916. : The mine is on the south side of Cottonwood Canyon just above Mineral Fork and about half a mile west of the mapped area. The rocks are Cambrian quartzite and a decomposed basic dike. The development consisted of a tunnel about 300 feet above the canyon bottom that had been driven about 300 feet along the dike, which stands nearly vertical, strikes about N. $30^{\circ}$ E., and is from 6 to. 20 feet in width. Sulfides of iron, lead, and copper had been encountered along the west wall of the dike.

\section{DOLIY VARDEN}

The Dolly Varden mine is at Argenta, in Big Cottonwood Canyon about one-eighth of a mile above the Maxfield mine. The sedimentary rocks encountered in the workings consist of the upper member of the Ophir shale and the overlying limestone. A dike of porphyry 10 to 12 feet wide is exposed near the mouth of the tunnel. An ore shoot is said to crop out in a small gulch west of the tunnel. The ore formed an irregular pipe, which is said to have been followed down to the tunnel level. According to Huntley ${ }^{55}$. the total production to 1880 was valued at $\$ 25,000$.

\section{SUNNYSIDE}

The Sunnyside tunnel is in Big Cottonwood Canyon, about midway between the Maxfield mine and the mouth of Mill D South Fork. The tunnel cuts a porphyry dike intruded into Carboniferous limestone. The limestone adjacent to the dike contains garnet and other contact minerals, and a little zinc ore is said to have been found:

\section{CONFIDENCE}

The Confidence mine is in Big Cottonwood Canyon, just below the mouth of Mill D South Fork. The country rock consists of Pennsylvanian and Mississippian limestone that has been intruded by dikes or sills of fine-

${ }^{55}$ Huntley, D. B., Mining industry of Utah : 10th Census U. S. (1880), vol. 13 , p. $430,188 \bar{J}$. grained diorite. The limestone has been partially altered to silicates. In 1916 the lower tunnel had been driven about 200 feet along the strike of the beds near pyritic shale beds that are believed to lie at the base of the Pennsylvanian. The upper tunnel had been driven about 500 feet, approximately along the strike of limestone beds above the pyritic shale. Near the mouth of the upper tunnel is a shallow winze, filled with water at the time of visit, in which some lead and zinc ore is said to have been found.

\section{PROSPECTS ON DAYS FORK}

There are several prospects in the canyon of Days Fork, but they have made no important production. Some properties that are located mainly in the canyons of Little Cottonwood Creek and Mill D South Fork but extend into Days Fork are described further on.

\section{COTTONWOOD METALS}

The Cottonwood Metals (Watrous) group of claims lies.mainly south of Big Cottonwood Creek and east of Days Fork. Near the mouth of Days Fork the Cambrian quartzite and shale are brought by the Silver Fork and associated faults into contact with younger formations which, on the ridge between Days Fork and Silver Fork, include the Woodside shale. The main tunnel starts in the Ophir formation and passes into the Cambrian quartzite, then through faults which successively bring in the Ophir formation and Carboniferous limestones, into which the tunnel has been advanced for several hundred feet.

An easterly branch of the tunnel extends for several hundred feet along the contact of the limestone member of the Ophir and the lower shale member of that formation. Some fissures cutting the Ophir formation have been encountered, and on these there has been some mineralization, but no commercial ore bodies have been found.

\section{SILVER MOON}

The Silver Moon group is about halfway up Days Fork. The country.rock is Deseret limestone. In 1916 two shallow shafts had been sunk in fissures and encountered a little ore. At that time a tunnel was being driven from the bottom of the canyon to cut the fissures that had been prospected at the surface.

\section{GIPSY BLAIR}

The Gipsy Blair claims are near the head of Days Fork. The country rock is the Deseret limestone. Small stringers of ore have been encountered in shallow workings, and some ore is said to have been shipped. The main development has been a tunnel driven along a bed of brecciated limestone. In 1916 the tunnel was in about 700 feet but had encountered no ore.

\section{CARBONate}

HISTORY AND PRODUCTION

The Carbonate mine was the largest producer of lead ore in the area during 1877 and 1878,-and it yielded 
scme carbonate zinc ore in 1914,1915 , and 1916. The Kessler Mining Co. claimed possession in 1878 of the Sailor Jack, Baker, Defiance, Carbonate, and Ebel claims and of the Baker tunnel, 1,016 feet long. ${ }^{50}$ The large ore chamber of the Carbonate mine was an excavation 60 feet long, 20 feet wide, and 26 feet high. Very little waste was taken out of this chamber, which is said to have produced 4,208 tons of ore, for which the smelter yaid $\$ 256,688$, or an average of $\$ 61$ a ton. The ore, all gray carbonate, carried 55 to 65 percent of lead and 50 to 60 ounces of silver to the ton. During some of the earlier operations the ore was hauled down Little Cottonwood Creek. In $1878^{67}$ from 40 to 60 tons a day was shipped during the winter as long as the roads could be kept open. Since the seventies most of the work on the property. has been done by lessees. In 1913 some ore averaging 4 ounces of silver to the ton, 3.7 percent of copper, and 6.3 percent of lead was shipped. Altogether 658 tons of ore was shipped between 1913 and 1916, most of it averaging 23.59 percent of recoverable zinc, which was paid for at zinc plants. The present owners estimate that the total output amounted to $\$ 1,250,000$. Smelting works were erected at Hilliard, Wyo., chiefly for the purpose of reducing the ore from the Carbonate mine. Bullion shipments from Hilliard in $1877,{ }^{58}$ during 4 months' operation of the smelter, contained a total of 932 ounces of gold, 168,813 ounces of silver, and 2,590,263 pounds of lead. The Wells Fargo agency reported that the bullion shipped in 1878 contained 513 ounces of gold, 164,848 ounces of silver, and 1,698,670 pounds of lead.

The Silver Mountain property on Kesslers Peak had in $1884^{59}$ an adit 600 feet long intersected at the depth of 350 feet by a shaft. The adit was driven along the vein and is said to have encountered ore at intervals through the entire distance. In 1884 about 170 tons was sold, bringing about $\$ 36$ a ton at the smelter. Up to the end of 1880 the ores assayed $\$ 3$ in gold and 50 ounces of silver to the ton, and 35 percent of lead. ${ }^{60}$ The total output of the property in 1884 was 1,170 tons. The following review of the early history is given in the report of the Director of the Mint.

The mine of the Kessler Mining Co. covers part of the ground of the old Provo claim. It was worked by a New York company in 1872,1873 , and 1874. Little ore was obtained, and it was abandoned. About 1875 a prospector discovered the carbonate ore body while overhauling the old dump, so says tradition. The mine was bought by the Carbonate Co., of Salt Lake City, which extracted large quantities of ore. In January 1879, after the large discovery ore body had been nearly all extracted, the mine was sold to the Kessler Mining Co., of New York' Oity. This company took out considerable ore and did much prospecting, but ceased work some months previous to the writer's visit, at

${ }^{50}$ Eng. and Min. Jour., Jan. 11, 1879, p. 30.

on Eng. and Min. Jour., vol. 25, p. 201, Mar. 23, 1878.

88 Salt Lake Tribune, Jan. 1, 1878 and 1879

60 Director of Mint report upon production of precious metals in the U. S. for 1884 , p. 422,1885 .

${ }^{60}$ Euntley, D. B., Mining industries of Utah : 10th Census U. S. (1880), vol. 13, p. 430,1885 . which time the mine was worked by a few lessees. The property consists of the following overlapping unpatented claims: Carbonate, 1,500 by 200 feet, Little Giant, Sailor Jack, Alturas, Baker, and Defiance.

\section{GEOLOGY}

The Carbonate mine is on the divide between Mineral Fork and Mill D South Fork, and the mine workings pass through the top of the divide. The summit just north is sometimes called Carbonate Peak, and a higher one about half a mile north of the mine and just west of the mapped area is known as Kesslers Peak.

The country rock consists of the Tintic quartzite, the Ophir formation, the Maxfield limestone, the Jefferson (?) dolomite, and the Madison and Daseret limestones. The Carbonate fault, a short distance south of the mine, brings the Maxfield limestone on the north against the Tintic quartzite on the south.

For much of the information in the following paragraphs and for the map (pl. 32) the writer is indebted to Mr. George H. Ryan, who was manager for the Trimetals Leasing Co., which was operating the mine at the time of visit. The map is based on a compass survey of the accessible workings made by Mr. Ryan.

The ore bodies are in the spotted and mottled Cambrian limestones at essentially the same horizon as the deposits of the old Reed \& Benson mine. The limestone is cut by fissures that strike about N. $75^{\circ} \mathrm{W}$. and dip steeply south. Fissures that strike in other directions seem to have less relation to the ore bodies, though one; striking about N. $40^{\circ}$ E. and dipping northwest (corresponding in general attitude to most of the ore fissures of the district), may be more closely related than is apparent. The rocks have been broken since the primary mineralization by nearly vertical- north-south joints, which have influenced the deposition of the secondary deposits, notably the oxidized zinc ores.

The ore has replaced certain beds of limestone adjacent to the fissures. The replacement appears to have been controlled by the composition of the limestones and by the degree to which they are fractured. Near the margins of the deposits in the coarsely mottled limestone, the more soluble part of the limestone has been replaced, the rest remaining as a porous skeleton. (See pl. 29, A.) The deposits are largely oxidized, but the original minerals were probably sulfides of lead, iron, zinc, and copper, together with some manganiferous mineral. ' In the process of oxidation the lead remained essentially in place, but much of the zinc, iron, manganese, and copper were leached into the adjacent limestone, where they were in part precipitated. The oxidized zinc deposits occur mainly beneath the old lead stopes and for some distance up along their sides, and along the north-south joints. Iron and manganese are rather abundant in the oxidized zinc ores, manganese being especially abundant near the margins of the deposits. Some of the lead ore is said to have consisted largely of galena, and much galena must have remained after the other sulfides had been 
largely oxidized. Copper was not abundant in the ore, though small bodies of good copper ore were found. Beautiful specimens of the copper-zinc carbonate, aurichalcite, have been collected in the mine.

The following description of the early operations of the mine is given by Huntley: ${ }^{61}$

The ore is found in several bodies near the surface on the hanging-wall side of a stratum or belt of limestone. The largest body was just below the surface and was lenticular in shape, its dimensions being 200 by 100 by 50 feet. It was timbered by 365 square sets but had caved in. The gangue, if such it may be called, which surrounds the bodies and also serves as a connecting link between them, consists of a valueless ocher or limonite. It is very abundant, sometimes fine and soft, at other points hard and siliceous. 'Occasionally heavy spar, oxide of manganẹse, and stains of malachite are found. The ore is an ocher, containing cerusite and galena, and assays from 30 to 50 percent lead and from 30 to 100 ounces of silver. A fissure vein, called the "Sailor Jack," connects with this body and has been the cause of much litigation. *** The total product of the mine prior to October 1877 is estimated at $\$ 120,000$. Between the above date and the beginning of the census year [1880] 4,549 gross tons, averaging about 8 percent moisture, were sold for $\$ 261,044.41$.

\section{AMERICAN METAL MINING CO.}

A group of claims formerly owned by the American Consolidated Copper Co. but now owned by the American Metal Mining Co., lies on and near Montreal Hill. The country rock consists of the Tintic quartzite, the Ophir formation, a few feet of the Maxfield limestone, most of which is cut out on an unconformity, the Jefferson (?) dolomite, and the Madison limestone. Most of the ground lies west of the West Superior fault, and all the development up to 1920 had been done in that part of the ground. In 1920 development work by way of the Tar Baby lower tunnel was begun, and it was being carried on as late as 1936. (See below and pl. 33.)

The area is crossed by several fissures, among the most prominent of which are the Garfield, Silver King, and Gustavus Adolphus. All of these strike N. $35^{\circ}-40^{\circ}$ E. and dip 50 $0^{\circ}-60^{\circ} \mathrm{NW}$. Another fissure, probably a branch of the Garfield, strikes N. $10^{\circ}$ E. and dips about $60^{\circ} \mathrm{W}$. The old tunnel, now caved, is mainly in the Tintic quartzite but passes through considerable shale. The Garfield fissure and its branch carry ore containing pyrite, sphalerite, and galena in a quartz gangue. The fissures have been cut by a long adit, and the Garfield fissure has been followed by drifts to the southwest and northeast. Northeastward it pinches at the contact between the quartzite and the shale. No prospecting for a continuation of the fissure in the limestone above the shale had been undertaken, but shallow pits in the limestone had revealed small quantities of lead carbonate with a high silver content, which may be connected with northeasterly fissures. The Silver King fissure was cut by the tunnel 1,200 feet from the portal. In the summer of 1916 a short drift on this fissure ex-

\footnotetext{
6r.Huntley, D. B., op. cit., p. 430.
}

posed vein quartz and a little sulfide. The ore in the Gustavus Adolphus fissure shows the same type of mineralization but contains less zinc and more silver than that from the Garfield fissure. Small amounts of oxidized ore mined from shallow workings are said to have yielded 1,000 ounces of silver to the ton, but the oxidized ores are very superficial and almost negligible.

Prospecting had been done to the north of Montreal Hill, but at the time of visit this work was not accessible. So fär as learned, no large bodies of ore had been encountered.

\section{TAR BABY \\ WORKINGS}

The Tar Bay property has been worked, in the main, through the Tar Baby lower tunnel, on Mill D South Fork northeast of Montreal Hill (pl. 33), and the same tunnel has also been used for some years by the American Metal Mining Co. At the end of 1936, about 5,000 feet of work had been done from this tunnel in Tar Baby ground and 2,000 feet in American Metal ground. Work was then being done only in the American Metal branch. The upper Tar Baby tunnel, close to the road and 250 feet higher than the lower, is about 1,900 feet long. It is now caved; but it was open some years ago and was then plotted by pacing traverse. The more recent development has been done through the Tar Baby workings.

\section{GEOLOGY}

The surface of the Tar Baby and American Metal holdings is mantled in greater part with talus, moraine, and alluvium; but there are some good exposures near the creek and on the slope to the east. The gorge of the creek near the working tunnel is partly eroded along a fault, believed to be the East Superior, that brings cherty Deseret limestone against Cambrian rocks which are further dislocated by other faults. The geology of the properties can best be studied, however, in the workings, which reveal a surprising complexity of structure.

The rocks exposed, both underground and on the surface, include all the sedimentary formations from Tintic quartzite to Deseret limestone and a single dike, consisting of granodiorite porphyry, which is sometimes called the Tar Baby dike. The dips of the sedimentary rocks are almost everywhere eastward; the westward dip of the Ophir limestone about 200 feet south of the portal is a reverse dip. The dips vary widely in steepness, and the strike departs considerably in places from its average of about north-northwest, but no definite folds can be traced.

The structure is especially characterized by faulting, and the greatest of the faults is the upper Alta overthrust, which in the southern part of the Tar Baby workings has been explored on three levels. Here the hanging wall of the overthrust is Tintic quartzite and the footwall Deseret limestone, as in a large part of the Cardiff mine. In the drift along the overthrust to the 
north, the hanging wall is still quartzite and the footwall limestone; but some of this limestone appears to be older than Deseret. It is uncertain whether these older rocks come in because the bedding of the limestone converges north ward with the fault or because branch overthrusts diverge northward from it; the latter hypothesis appears the most probable in view of what is disclosed in the more northerly workings. At any rate the overthrust apparently bends eastward, on a very short curve, near the middle of the workings, and in the drift that follows it eastward its footwall consists of Ophir shale. The Tar Baby dike here follows the contact for a short distance.

The overthrust has this same easterly course in the upper tunnel, where the hanging wall is quartzite and the footwall consists of Ophir shale and Maxfield limestone dipping eastward. The same sequence of beds is traversed in a long crosscut extending eastward from the lower tunnel.

In the northern part of the lower workings there are a few reverse faults of low or moderate eastward dip whose hanging walls are of Ophir shale or Maxfield limestone. These faults are presumably lower branches of the Alta overthrust, corresponding to those exposed in the cliff above the Frederick tunnel. One reversefault contact near the entrance to the American Metal branch dips westward and possibly represents the west limb of an arch in the thrust surface; but in that case the footwall rocks would presumably also be arched, and so far as observed they all dip eastward. This contact, then, may represent a different, west-dipping overthrust, one or two of which have been found in other workings.

The East Superior fault has not been positively identified in the Tar Baby. workings, which presumably cross it, but what seems to be its most probable location is indicated on plate 33. The West Superior fault, on the other hand, is readily recognizable where it is crossed by the American Metal branch of the tunnel near its western end. It here has two branches, both nearly vertical, the western one of which has the greater throw; and the aggregate effect of the movement has been to bring Jefferson limestone on the east down against Tintic quartzite on the west. The Tar Baby dike, also, is cut off and, to judge from its few surface outcrops, probably offset northward on the west side of the fault.

Both the American Metal and the Tar Baby branches, near their inner ends, cross fault contacts of low dip. These presumably are on a single fault, which has not been recognized on the surface. The fault is almost certainly normal; at its western crossing its footwall is quartzite and its hanging wall limestone that seems most probably to be Cambrian; at its eastern crossing its footwall is Mississippian limestone and its hanging wall quartzite, presumably that above the Alta overthrust, which is so well exposed nearby.
MINERALIZATION

Ore has been mined at several places in the lower workings_from both properties, but no large ore body has yet been developed.

The conditions most favorable to the formation of such a body would have seemed, beforehand, to be present in the ground explored by the southernmost of the Tar Baby workings." Here, as in the most productive part of the Cardiff mine, the Alta overthrust has brought the Tintic quartzite in contact with the Deseret limestone and is cut by fissures of northeasterly strike. Several carloads of ore is said to have been taken from one of the fissures, but unfortunately the mineralization does not, to any great extent, either penetrate the quartzite or bed out along the contact. Years ago some ore consisting partly of galena was taken from a raise where the overthrust bends eastward and is cut by the dike, but the precise relations and amount of this ore were not determined. All the ore taken from the Tar Baby property appears to have been taken from places near the main, or upper, Alta overthrust.

In the American Metal property, the quartzite hanging wall of this overthrust has been eroded away. Minor thrust faults lower in the thrust zone are cut by the workings east of the West Superior fault, but west of that even these have been removed by erosion. Good ore is said to have been taken from several places in these workings. Most if not all of it seems to have come from steep fissures rather than from bed deposits. The westernmost and highest raise in the mine, in 1936, followed the intersection of two fissures west of the West Superior fault.

\section{KENNEBEG}

The Kennebec Consolidated Mining Co. has a large group of claims, mainly on Reed \& Benson Ridge, between Days Fork and Mill D South Fork. The group includes the old Reed \& Benson mine, the Ophir, and the Excelsior. The complicated geology of this ridge is discussed on page 58 and need be but briefly summarized here.

The rocks include Tintic quartzite, Ophir shale, Maxfield limestone, the Jefferson (?) dolomite and a little of the Madison and Deseret limestones. The structure is exceedingly complex; the Alta overthrust and the Reed \& Benson thrust zone have caused some formations to be repeated several times. In the Alta thrust zone Cambrian rocks are thrust over the Deseret limestone. This fault does not crop out on the Kennebec ground but has been reached through the workings of the Cardiff mine. The faults of the Reed \& Benson thrust zone have resulted in repetitions of the Ophir formation and the overlying Maxfield, Jefferson (?) and Madison, which crop out prominently on the west face of Reed \& Benson Ridge.

The ore deposits that have been developed occur, so far as ascertained, in the spotted and mottled Cambrian 
(Maxfield) limestone at the intersections of these beds posits on the tunnel level are in the Cambrian limestone, with the fissures of general northeasterly trend. The but whether or not this is true of the deposits opened

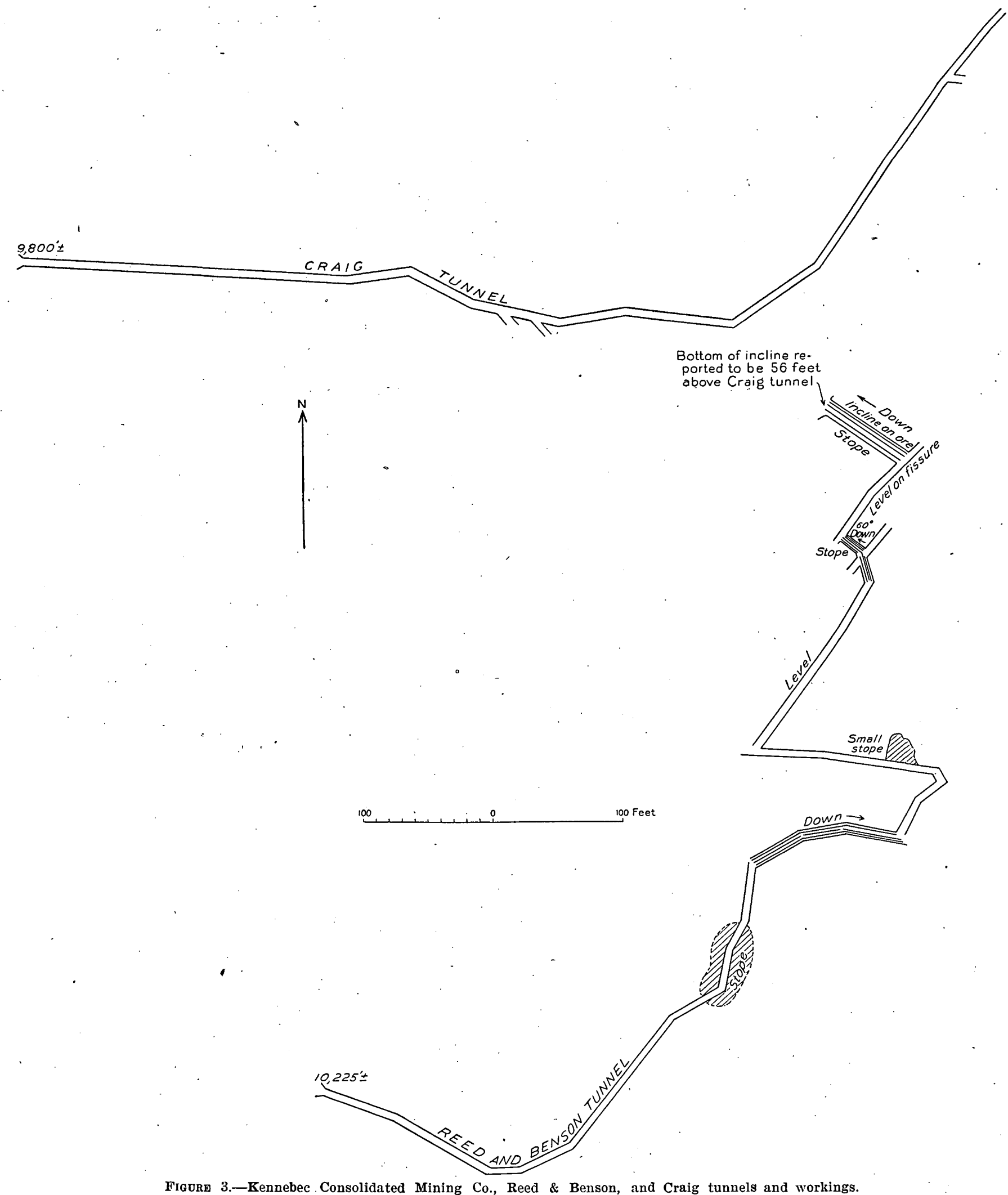

largest deposits in the old Reed \& Benson mine, were below the tunnel level is not known. Smaller bodies of worked by means of a tunnel and a series of winzes and drifts below the tunnel level. (See fig. 3.). The deore on the east side of the ridge are in the same limestone as those of the Reed \& Benson tunnel. 
Two tunnels have been driven below the Reed \& Benson tunnel (fig. 3), but neither of them has encountered ore. In 1919 the Alta thrust fault was being prospected in Kennebec ground from the 800 level of the Cardiff mine, but no important body of ore had been found. Huntley ${ }^{22}$ described the early workings as follows:

The Reed \& Benson mine * * * was located in 1870 and was worked vigorously from September 1871 until April 1878 . Since then it has been idle or leased to a very limited extent. * * The ore occurs in a vein or chimney * * * in about 20 irregular lenticular bodies, which branch at all angles from the chimney, on its footwall side. These do not, as a rule, extend more than $\mathbf{7 5}$ feet from the main chimney and vary from 6 inches to several feet in width. One outcropped as a lowgrade ocher. The largest is about $\mathbf{1 7 0}$ feet from the surface. The ore is of the kind usually found in this limestone formation-namely, a yellow and red oxide of iron carrying argentiferous cerusite and galena. It is claimed that the total shipments have areraged 120 ounces silver and 35 percent lead per ton. The mine is developed by a 3S0-foot tunnel, in which there is a whim on a 400 -foot incline, dipping $35^{\circ}$ NNE. Below this there are four windlasses, which carry the incline down 400 or 500 feet deeper. In general, the mine may be said to have been opened frcm the surface 1,100 feet on the dip $\left(35^{\circ}\right)$ by an irregular incline following the chimney. Near the surface the ore extended 100 feet and the workings 200 feet horizontally; but in the bottom of the incline not over 40 feet of drifting have been done. The openings have a total length of 1,950 feet.

The Ophir is a few hundred feet southwest of the Reed \& Benson. * * * It was discovered in 1870, purchased by Reed \& Goodspeed in 1871, leased until May 1878, and worked steadily since by about $10 \mathrm{men}$. Ore is found in three bodies in a 30 -foot stratum of compact dark-blue limestone. A stratum of white limestone above carried no ore. The outcrop was a pipe $2 \frac{1 / 2}{2}$ feet in diameter of low-grade ocher. The shape of the bodies is that of a flattened or an elongated ball, the largest being 50 by 20 by 15 feet. They are 4 and 10 feet apart and rot over 50 feet from the surface. At the period under review drifting was being carried on upon a seam of ocher in the expectation of finding another body. The total cuttings did not exceed 700 feet. During the census year 173 tons of ore similar to that of the Reed \& Benson, excepting that it was of lower grade, assaying only about 45 percent lead, 42 ounces silver, with 3 percent moisture, were sold for $\$ 8,581$. The previous product was estimated at $\$ 22,000$.

\section{HOWELI}

The main development on the upper levels of the Howell mine extends along the Baby MacKee fissure, in the Cambrian quartzite. The fissure strikes N. $35^{\circ}-$ $40^{\circ}$ E. and dips steeply northwest. It has been opened along the strike for about 600 feet. (See pl. 34.) The ore has apparently formed shoots in the fissure, and it has been stoped at several places, both above and below the upper tunnel level. The original minerals of the -ore were quartz and sulfides of iron, lead, zinc, and copper. The ore has been partly oxidized, but.on and below the upper tunnel level it contains much sulfide.

Operations after 1917 consisted mainly of prospecting in the lower tunnel, the portal of which is a little northwest of the lower dump of the Cardiff mine: The

\footnotetext{
${ }^{69}$ Huntley, D. B., Mining Industries of Utah: 10th Census U. S. (1880), vol. 13, p. 429, 1885.
}

tunnel was started in the Madison limestone, but about 125 feet from the portal it crossed the West Superior fault, beyond which the Ophir shale is exposed for a short distance. . The shale is underlain by Tintic quartzite, which is the country rock throughout the greater part of the level. The basal conglomerate of the Tintic and a little tillite were exposed at the inner end in 1921.

What is believed to be the Baby MacKee fissure on the lower tunnel level is filled with white sericitic mica and pyrite and is said to contain some silver. Other fissures cut by the tunnel are mineralized and contain some ore, but no commercial ore bodies were found in them.

\section{IAST CHANCE}

The Last Chance claim is on Montreal Hill. Some ore is said to have been taken from replacement deposits in limestone on this claim near the top of the hill. In 1916 a tunnel was being driven from the north side of the hill with the expectation of encountering some of the fissures that are exposed on the surface, but this work is not known to have revealed commercial ore bodies.

\section{PRICE}

The Price group of claims lies east, north, and west of Montreal Hill. It includes a part of the block lying between the East Superior and West Superior faults. West of the latter fault the property is traversed by the Alta thrust fault, which here brings lower beds of the Tintic quartzite over the upper part of the same quartzite and the lower and middle members of the Ophir formation. The thrust fault is probably though not certainly displaced by the Carbonate fault, which is better exposed near the Carbonate mine than in the Price group. In 1916 the upper tunnel west of Montreal Spring had been driven southward in the block between the faults for about 350 feet without encountering ore. In 1919 a lower tunnel was being driven westward in the block west of the West Superior fault. The tunnel starts in glacial drift; the first bedrock that it encounters is Ophir shale near its contact with the Cambrian quartzite. In October 1919 it had been driven 500 feet due west in quartzite and thence about S. $80^{\circ}$ W. for 100 feet. The quartzite is below the Alta:thrust.

\section{CARDIFF}

\section{HISTORY AND PRODUCHION}

The Cardiff mine (pl. 35), near the head of Mill D South Fork, is the youngest large producer in the area. The owners were incorporated as the Cardiff Mining \& Milling Co. in 1906. A fissure vein of lead-coppersilver ore with quartzite walls was found in 1910, and an adit driven on the East Superior fault cut the fissure; which came to be called the Cardiff fissure, about 1,90() feet from the portal. This discovery gave new impetus to mining in the district, and in 1912 a lower adit on what is called the 600 level was started in the hope of finding ore at depth. About 2,400 feet from the portal this adit entered an ore body averaging 10 feet thick; 
along the intersection of the Cardiff fissure with a limestone-quartzite thrust contact. From the lower adit level an inclined winze was sunk to follow the ore down the thrust plane, which has an average dip of about $25^{\circ}$. The winze has gone about 900 feet, on the incline, below the tuninel, and the ore body has been opened for a length of about 300 feet along the fault. It is said that about 200,000 tons of ore averaging $\$ 30$ a ton was thus developed. Other ore bodies were later found on the same contact at its intersections with other fissures; one of these bodies, 800 feet south of the main working winze, was 5 feet thick and 9 feet wide and was continuous for a horizontal distance of over 200 feet along the strike of the fissure.

Shipments of ore from the property began in 1918, and during the next two years they averaged as much as 125 tons a day during the summer. The ore was hauled by auto tractors to the smelters in the valley. The total output of the mine to the end of 1919 was 70,847 dry tons, averaging 10 cents in gold and 15.51 ounces of silver to the ton, 0.82 percent of copper, and 26.61 percent of lead. Dividends paid to stockholders to the end of 1919 amounted to $\$ 675,000$.

\section{GEOLOGY}

The rocks exposed in the Cardiff mine are the cherty Deseret limestone, the Tintic quartzite, and the Ophir shale. The property is traversed by two north-south faults with downthrow on the east, the West Superior and East Superior. East of the East Superior fault the quartzite above the Alta overthrust forms the surface; between the two faults erosion has removed the quartzite, leaving the underthrust limestone exposed; west of the West Superior fault the limestone and the underlying shale have in turn been stripped away from the quartzite below the thrust. (See structure section $B-B^{\prime}, \dot{\text { pl. }}$ 4.)

The East Superior fault as exposed in the workings of the Cardiff mine is essentially vertical, in places dipping a few degrees from the vertical to the east or west. The main Alta overthrust where exposed in the mine dips eastward about $25^{\circ}$, thought its dip varies somewhat from place to place. This thrust is cut off by the East Superior fault and crops out in Cardiff ground for only a short distance, where a lens of Cambrian shale and limestone between Carboniferous limestone and the overthrust quartzite is exposed. The Howland fault, striking northwestward, crosses Cardiff ground. It is not exposed in the mine, but it apparently meets the East Superior fault not far within the portal of the main tunnel (pl. 35) and presumably displaces the Alta overthrust in depth. It seems to cross the lower tunnel about 300 feet from its portal. The northernmost rock in place exposed in the tunnel is Deseret limestone, but beside the portal is a knob consisting of the limestone member of the Ophir shale, and there must be a fault between the two exposures.
The hanging wall of the Alta overthrust, in Cardiff ground, consists mainly of Tintic quartzite, the footwall mainly of the cherty. Deseret limestone; but Cambrian shale and limestone lie in the fault zone at many places, especially on the higher levels and in the lower part of the main winze. The ore is mainly associated -with fissures that strike northeastward and have steep dips. Vein deposits have been formed in these fissures both above and below the overthrust, but the greater part of the ore in the mine makes out from the fissures along the overthrust and replaces brecciated limestone in the thrust zone.

The main ore body, which extends along the intersection of the Cardiff fissure and the thrust contact, was first entered on the lower tunnel level several hundredl feet east of the West Superior fault. In following the shoot westward and upward before the West Superior fault was reached, shale belonging to the Ophir wass encountered; the lens of Ophir in the fault zone thus extends northward beyond the Cardiff fissure. The ore shoot pinched out in this shale. The extent of the mineralization varies considerably at different points along the dip of the ore body, apparently because some beds of limestone were more favorable to mineralization than others. So far as observed, mineralization has been comparatively slight in the shaly beds and the most cherty limestone, yet most of the ore has been formed in the Deseret limestone, which in general is more or less cherty. The fissure has been prospected in the limestone below the thrust fault, and some ore has thus been developed.

The ore is largely oxidized above the 600 or lower tunnel level. Downward from the tunnel level it contains an increasing proportion of sulphides, mainly galena, pyrite, sphalerite, and tetrahedrite.. The chief primary gangue minerals are residual limestone, quartz, and mixed carbonates. Sericitic mica is rather abundant in places, and some rhodochrosite is found on the lower levels. - Oxidized ore is present in decreasing amount to the 15th level (1939), about 500 feet vertically below the tunnel level. The most highly oxidized ore consists mainly of cerusite and limonite, together with rather abundant plumbojarosite, though it contains considerable galena. Some of it is said to contain oxide of lead. Copper carbonates are locally rather abundant, and oxides of manganese, associated in places with zinc carbonate, are conspicuous on the margins of the deposit. The shipments for 1915, which consisted of oxidized ore, are reported by the company to have averaged 38.2 percent of lead, 13.4 ounces of silver to the ton, and 3 percent. of copper.

The sulfide ore consists essentially of galena, pyrite, tetrahedrite, and sphalerite in varying proportions (pls. $23, A, 24, B, D, 26, D, 27, A)$.

The vein in the upper tunnel follows the Cardiff fissure, which strikes N. $35^{\circ} \mathrm{E}$. and dips $65^{\circ} \mathrm{NW}$. and is here in the quartzite above the Alta overthrust. 'The 


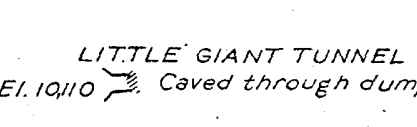
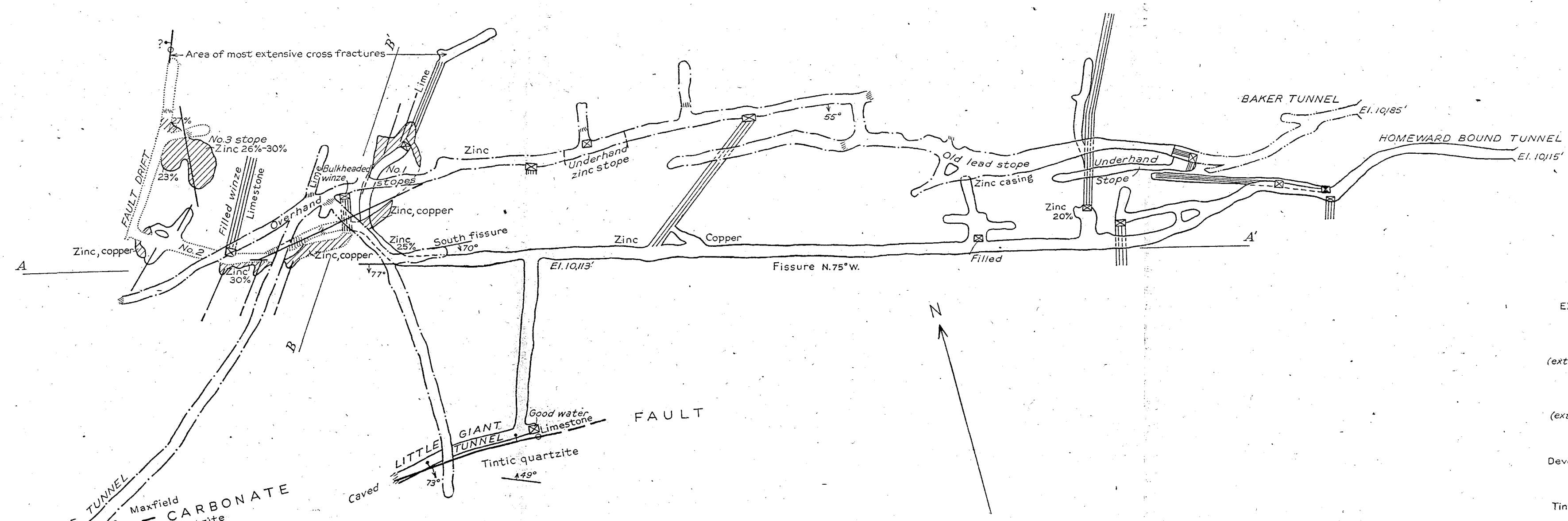

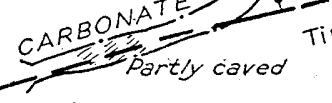

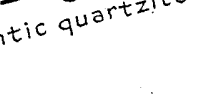

sw.

NE. W.
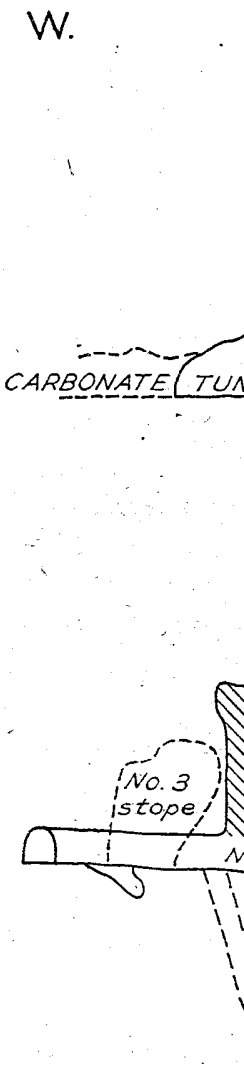

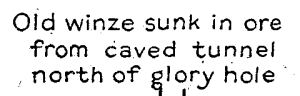
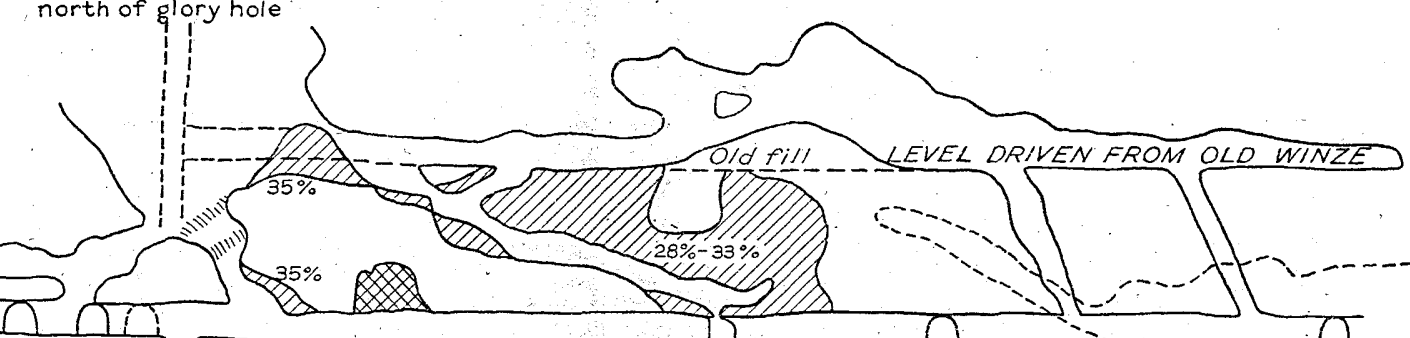

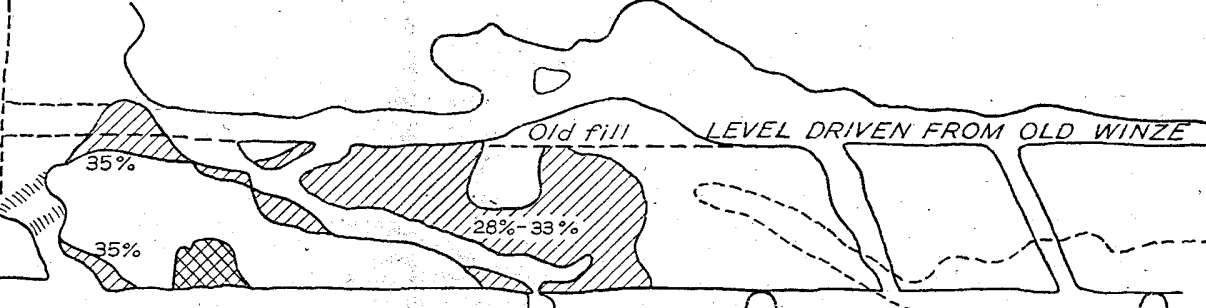

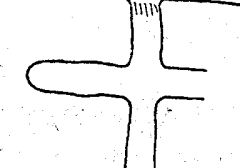

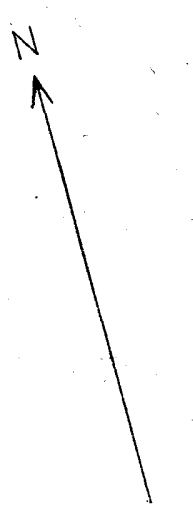

PLAN

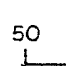

$\sqrt[50]{1}$

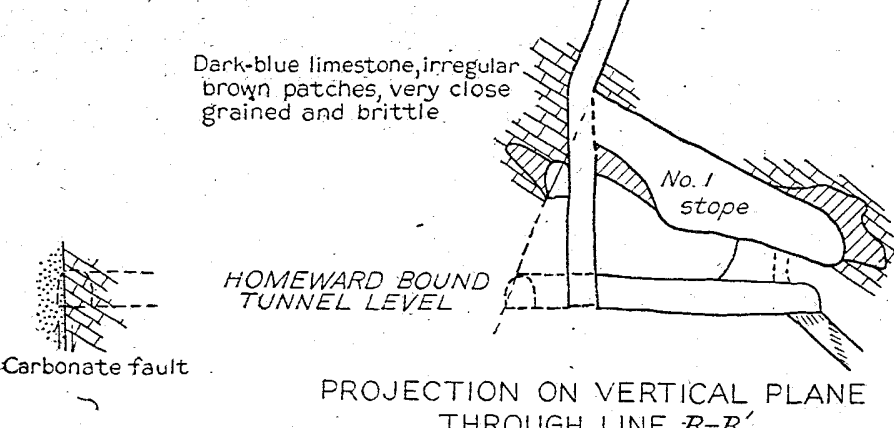

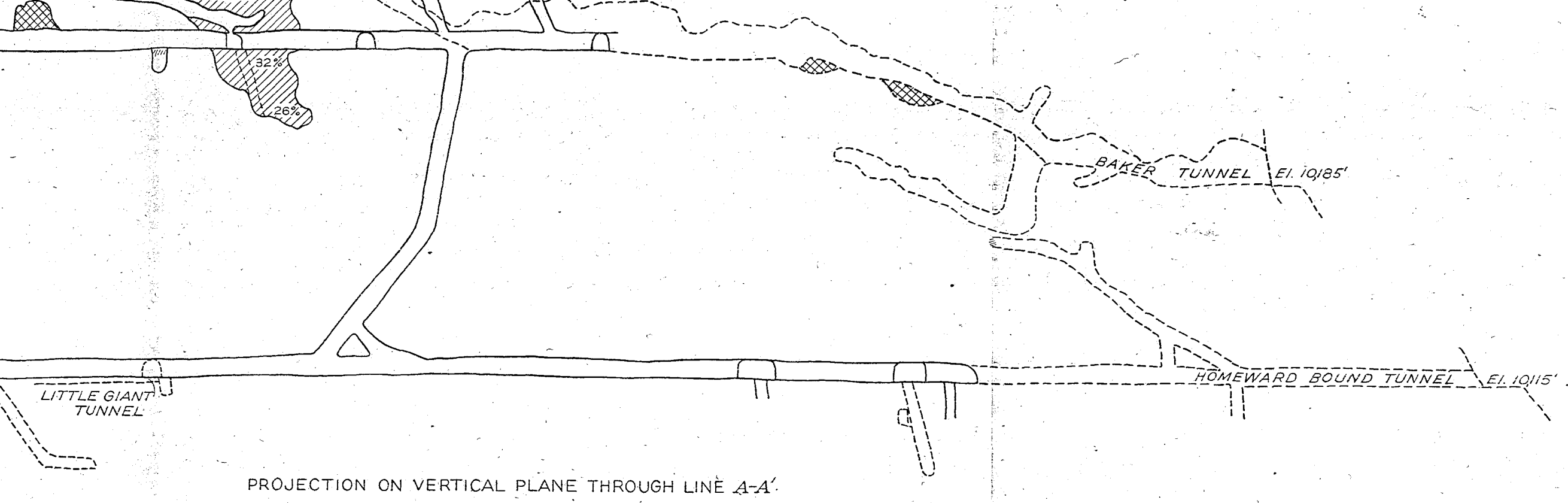

PROJECTION ON VERTICAL PLANE THROUGH UNE A-A' PLAN AND SECTIONS OF CARBONATE MINE. 
GEOLOGICAL SURVEY

PROFESSIONAL PAPER 201 PLATE 34
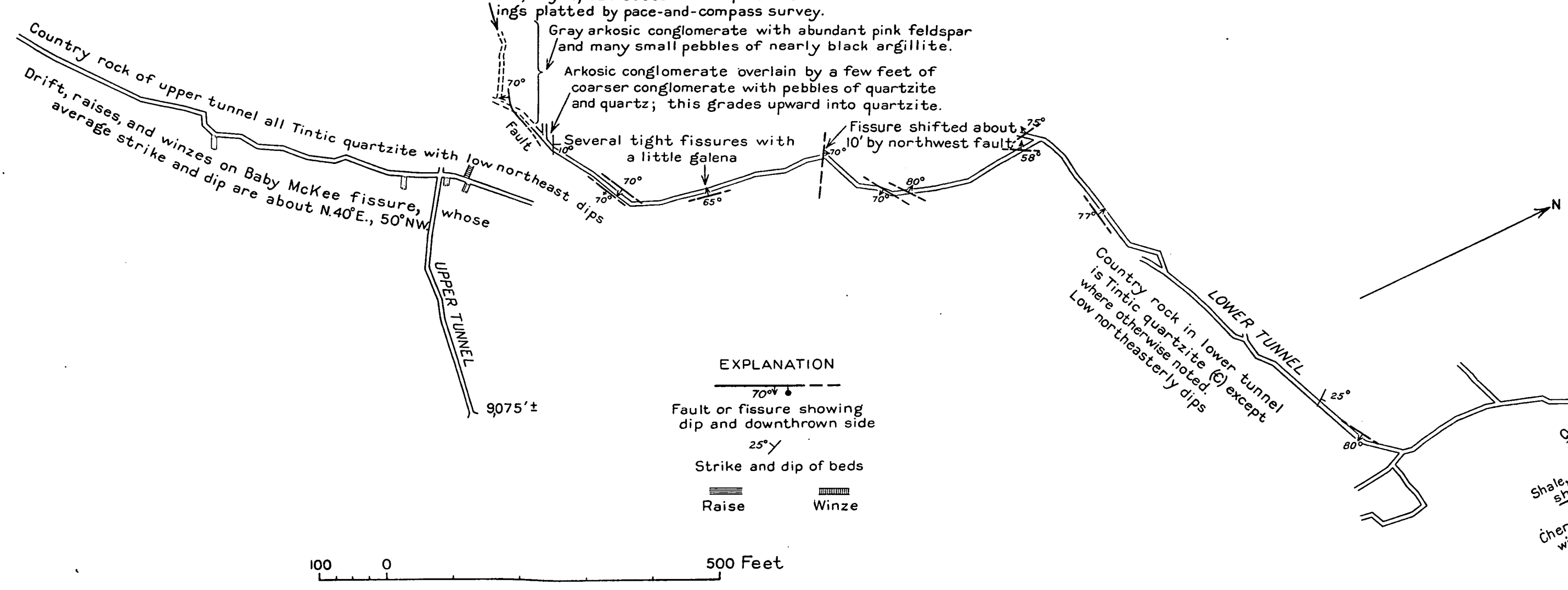

HOWELL MINE, UPPER AND LOWER TUNNELS. 
ore consisted of pyrite and tetrahedrite and a minor quantity of galena in a quartz gangue. A qualitative test proved the presence of a little zinc in the tetrahedrite, although zinc blende was not detected, even by microscopic study. Tetrahedrite containing a notable amount of zinc has been reported from the Park City district also. The sulfides formed relatively pure layers or lenses 1 to 6 feet thick, separated by layers of white quartz and unreplaced quartzite. The ore mined was said to contain about 12 percent of copper, a good proportion of silver, and $\$ 1$ to $\$ 2$ in gold to the ton. Galena was said to increase above the upper tunnel and, locally at least, to mark the upward termination of pay ore. The ore in this vein was practically free from oxidation at and below the level of the upper tunnel. At higher levels, in a vein on which the old Cardiff shaft was sunk, lead carbonate ore was found to a depth of 150 feet below the shaft collar.

The Alta thrust contact has been prospected in the Cardiff workings south of the main Cardiff fissure; and other fissures have been found which contain ore shoots having the same general relation to the thrust as the main, or Cardiff, shoot. These have yielded considerable ore but much less than the main shoot. The No. 1 vein, about 800 feet southeast of the Cardiff fissure, has been the most productive. In following this vein above the tunnel level a lens of Cambrian limestone was encountered in the thrust zone.

Although, in pursuance of the plan of grouping the mines by districts, the other mines of the Big Cottonwood district will now be described, the reader may find it advantageous to pass next to the description of the Frederick and adjacent workings (p. 117), whose geology is closely related to that of the.Cardiff mine.

\section{REEDS PEAK}

The Reeds Peak group of claims is on the lower part of Mill D South Fork. In 1939 the development consisted of a tunnel, now caved, extending westward from a point just under the road for about 1,700 feet. No ore had been encountered in the tunnel. The outer part of the tunnel is in Madison limestone, and it crosses the West Superior fault and enters Ophir shale about 900 feet in, according to a geologic map made by Mr. T. T. Van Winkle.

\section{COTTONWOOD CONSOLIDATED}

The Cottonwood Consolidated group of claims lies on the west side of the middle part of the canyon of Mill D South Fork. The rocks exposed on the property consist of the Cambrian quartzite, the Ophir shale, and the Maxfield, Jefferson (?), the Madison limestone above the Ophir.

The older workings consisted of two tunnels in Cambrian quartzite and Ophir shale near the West Superior fault. A later tunnel extends westward from a point near the canyon bottom. This tunnel started in the
Maxfield limestone. In 1916 it had been driven about 300 feet.

The Kentucky-Utah is an extensive property lying south of Big Cottonwood Creek, between Silver Fork and Solitude Fork. It was formed by consolidating several groups, including the Big Cottonwood Coalition, Copper King, and Woodlawn. An account of the Woodlawn, written before the consolidation, is given on page 1.14; the observations made in the Copper King workings and in the lower tunnel will be summarized here.

The Copper King group (see pl. 1) is at the head of the gulch between Silver and Solitude Forks. The country rock here is Mississippian limestone, dipping northeastward and traversed by a fracture zone that strikes northeastward and has a steep southeasterly dip. An ore deposit in this zone has been developed by a tunnel and several winzes. The ore, which is largely oxidized, has its principal value in copper. Most of it appears to have been deposited in fractures, though some of it has replaced limestone. Where the downward projection of the fracture zone was opened by the tunnel, fissures that are somewhat mineralized were cut and small shipments of ore were made from them, but no large ore bodies were developed.

The lower tunnel on the southwest side of the valley of Big Cottonwood Creek, at an altitude of 8,148 feet, is represented in a generalized fashion on plate 1. The tunnel and its branches aggregate more than 9,000 feet in length.

The sedimentary rocks in this tunnel dip in general northeastward, although they are locally folded in the inner part; the youngest beds are. accordingly exposed in the outer part of the tunnel and successively older beds further in. The northernmost beds exposed in the tunnel are of sandstone interbedded with limestone and are assigned to the Humbug formation. Some of the sandstone is hard; some is-so soft that it can readily be dug with a pick. Most of the rock in the tunnel is limestone and dolomite, which is assigned to the upper part of the Deseret. Dolomite is much more aboundant on the whole than limestone; much of it is bleached, and some of it is a soft white sugary mass. . Chert is rare except in the innermost part of the tunnel, near what was the working face in. November 1941; these cherty beds are believed to belong to the lower, cherty part of the Deseret.

The tunnel crosses two dikes of granodiorite porphyry, nearly vertical and striking a little north of east, about 320 feet and 660 feet respectively from the portal. The one farther south has been followed westward by a drift 400 feet long. A specimen from this dike is distinctly porphyritic; the phenocrysts are andesine, quartz, hornblende, and biotite. The rock resembles that of the dike in the Tar Baby workings, and it prob- 
ably belongs to the same dike. Three greenish-black dikes of lamprophyre, striking east-northeast and dipping steeply southward, are crossed at about 4,000 to 4,500 feet from the portal. In a specimien of what seemed to be the freshest obtainable rock the phenocrysts, which may have consisted of olivine and pyroxene, are wholly replaced, mainly by calcite and chlorite. There is no biotite nor any indication that it was originally present.

About 2,000 feet further in, the tunnel entered the large dike of diorite that is exposed in and near the Woodlawn mine. The diorite, as well as the adjoining rocks, is intensely altered; specimens of it are gray green and consist mainly of calcic feldspar and diopside, accompanied by titanite and locally by garnet. The innermost part of the tunnel is in the dark gray diorite that is typical of the Clayton Peak stock.

No sandstone was noted inward from the first porphyry dike, which may therefore have been injected along a fault. The fault could not be seen on the surface, but the place where it should crop out is covered with a moraine. No evidence of any other considerable fault was recognized in the workings, which appear to lie between the two main branches of the Grizzly thrust zone.

Some indications of ore appear to have been followed in the outer part of the tunnel without finding any large ore body. The most encouraging developments are in the southern part of the workings. Here a fissure zone had been followed, at the end of November 1941, for about 500 feet southwestward from the main tunnel. Some ore of the contact-metamorphic type, containing magnetite, pyrite, and calcopyrite, had been taken out and had given good assays for silver, copper, and gold. No large body, however, had yet been developed.

The conditions appeared favorable to the formation of scheelite, and the workings were accordingly examined with the ultraviolet lamp. No more than slight and very local fluorescence was obtained, however, and it is improbable that any large quantity of scheelite is exposed in the tunnel. A mine car full of muck from the working face showed much fluorescence, but specimens of this material that were taken out showed no fluorescence the next day, whether wet or dry, and they cannot contain any appreciable quantity of scheelite. The cause of this temporary fluorescence is unknown, but it is mentioned as an instance of what might wrongly be taken as an indication of scheelite.

\section{QUEEN BESS}

The Queen Bess mine is on the ridge between Honeycomb Fork and Solitude Fork. The rocks exposed at the surface are of Mississippian age. The property has been developed by tunnels extending along a northeasterly fissure which appears to be associated with a dike. The mine was not operating at the time of visit, and the underground workings were not examined.

\section{EVERGREEN}

The Evergreen group is on Evergreen Mountain, west of Silver Lake. The contact between the Alta stock and the Madison limestone crosses the property. The limestone adjacent to this stock has been highly metamorphosed and in places consists largely of silicates and magnetite, together with sulfides of iron and copper. The principal prospecting on this group has been done in the contact zone. In 1916 a tunnel had been driven about 1,500 feet, with some lateral works.

\section{SCOTTISH CHIEF}

The earlier workings of the Scottish Chief mine were in the lower part of the Thaynes formation, which is here strongly metamorphosed by the nearby Alta stock of granodiorite and converted to a hard whitish and greenish hornfels containing diopside and scapolite. The ore is said to have replaced limestone that is fissured and cut by a dioritic dike. The dike is probably of granodiorite porphyry, for such rocks, similar to that forming the Alta stock of granodiorite and clearly belonging to an offshoot from the Alta stock, form part of the dump. Some of the porphyry has been altered to a pale-green pyroxene-bearing rock, similar to that described on page 43 , enclosing residual unaltered masses.

The mine was idle and caved when the area was mapped and was not examined. This and adjacent mines are geologically a part of the Park City district, and any future development of the area that includes them is likely to be connected with Park City developments.

\section{SILVER KING COALITION MINES CO.}

During 1925-26 the Silver King Coalition Mines Co. acquired several groups, including the American and Iowa Copper, in the Cottonwood area adjacent to the company's older holdings in the Park City district. These groups extend along the north side of Mill F East Fork of Big Cottonwood Creek.

The sedimentary rocks exposed include part of the Park City formation and the Woodside shale and Thaynes formation. They were affected by the metamorphic action of the Alta stock of granodiorite and are cut by dikes that are probably offshoots from that stock. Late developments in this area have not been examined.

\section{AMERICAN}

The American mine, west of Scott Hill, was developed by means of a tunnel starting near the top of the Park City formation. This tunnel has been driven several hundred feet in the Park City formation, and two winzes have been sunk along the mineralized bed to depths of about 130 and 90 feet. The rocks here are 
cut by a diorite dike, and there has been considerable alteration of the limestone to contact silicates.

Rather strong mineralization with iron and manganese has occurred in some beds along fissures. Copper ore that is mainly oxidized but contains a little sulfide is present in one bed but is not clearly associated -with cross fissuring. Picked ore is said to yield 6 to 8 percent of copper, but no large body has yet been developed.

\section{IOWA COPPER}

The Iowa Copper mine is at the south base of Scott Hill, about $11 / 2$ miles north-northeast of Brighton. The sedimentary rocks in the vicinity are the Weber quartzite, the Park City formation, and the overlying Triassic rocks. The Clayton Peak stock is but a short distance to the south, and the sedimentary rocks are metamorphosed and are cut by several dikes. The prospecting has been largely confined to the Park City formation.

In 1916 ore was being mined from a replacement body associated with a fissure striking N. $55^{\circ} \mathrm{E}$. The replaced bed was from 6 inches to 2 feet in thickness; and the ore was said to contain from 15 to 20 percent of copper. A tunnel starting near the canyon bottom had been driven about 2,800 feet; its general direction is northeasterly but in places it runs eastward or south of east. The ore body mentioned was reached by a north crosscut, which begins about 275 feet from the portal and encounters the fissure about 150 feet from the main tunnel.

GILES

The Giles group is in Big Cottonwood Canyon about a mile north of Silver Lake. Most of the bedrock on the property is buried beneath glacial deposits: As the metamorphosed limestone that crops out near the mine is separated from other bodies by glacial drift and has yielded no fossils, its stratigraphic position is not certain, but probably it is not far below the Weber quartzite.

In 1916 the lower tunnel, shown on the map near the Big Cottonwood road as the Little Dolly tunnel, had been driven a little south of east for about 1,300 feet, and there were several hundred feet of crosscuts and drifts. At the time of visit a fissure striking S. $70^{\circ} \mathrm{E}$. and showing some mineralization was being followed. There has also been considerable prospecting by a tunnel several hundred feet above the Little Dolly tunnel, and it is reported that some mineralization was found there.

\section{MOUNTAIN LAKE}

The Mountain Lake group, which consists of 98 claims, lies partly in the head of Big Cottonwood Canyon and partly in the drainage basins of Snake Creek and Dry Fork. Only a part of it, therefore, is in the Big Cottonwood district, but all of it may be described here for convenience.
In the head of Big Cottonwood Canyon, the most work has been done at the Mountain Lake mine. Much prospecting has been done also along the granodiorite contact northeastward from Lake Catherine, especially southeast of Lake Martha. The most extensive opening in Snake Creek Canyon is the Steamboat tunnel, which starts near Snake Creek and extends northwestward for perhaps 4,000 feet. All the tunnels are blocked by caving, and no maps of them were obtained except a smallscale plat and section of the Steamboat tunnel.

Some copper ore was shipped from the-Mountain Lake mine to the Tintic Smelter in 1907. Other shipments from the group may have been made, but no record of them is available.

The sedimentary rocks in most of this large area belong to the Madison, Deseret, and Humbug formations. The lower part of these Mississippian strata is overridden by Cambrian shale and limestone on the Grizzly overthrust, which is well exposed on the slopes of Sunset Peak, in the western part of the group. Northeast of the peak, these Cambrian beds pinch out between the fault and the overlying Jefferson (?) dolomite. The overthrust cannot be followed for more than a short distance further, because the dolomites and limestones that lie both above and below it are somewhat similar and are made more so by metamorphism, which has bleached and recrystallized them and obscured their bedding. Apparently the fault is bent downward in this direction, though less markedly than the bedding of the rocks above it.

The northern part of the property is traversed by a crooked contact between the calcareous sedimentary rocks and the granodiorite and diorite of the Alta and Clayton Peak intrusive stocks. Smaller bodies of diorite like that of Clayton Peak, and dikes of varied composition, crop out near the head of Snake Creek. The Steamboat tunnel is said to have cut, successively, a few hundred feet of limestone, about 1,000 feet of diorite, some hundreds of feet more of limestone, and finally about 2,000 feet of granodiorite. Fresh granodiorite now forms a large part of the surface of the dump, and the best specimens of this rock, including the material for the chemical analysis on page 40 , obtained in the region were collected here. Contact metamorphism is very intense along the exposed contacts, especially in the limestone salient southeast of Lake Martha, and it prevails to such a degree in much of the property as to indicate that intrusive rocks lie at no great depth below the surface.

The most prominent body of ore minerals on the property is on the ridge between Lake Martha and Dog Lake, where a mass of limestone that projects into the granodiorite has been subjected to especially intense metamorphism. By replacement of this limestone, large masses consisting chiefly of magnetite, ludwigite, and forsterite, but containing smaller amounts of pale amphibole and other silicates and a little pyrite and born- 
ite, have been formed. The bornite at the surface has been partly altered to malachite. The largest mass of metallic minerals at this locality has an irregular outline, with a maximum width of about 50 feet and a length of at least 200 feet. It has been prospected by several shallow workings and by a tunnel which starts ini the granodiorite and cuts the contact about 500 feet from the portal. Its character on the tunnel level is much the same as on the surface except that the sulphides are but little oxidized. Between this locality and Lake Catherine the contact has been prospected at several places.

Small bodies of ore are said to have been encountered about 2,000 feet from the portal of the Steamboat tunnel

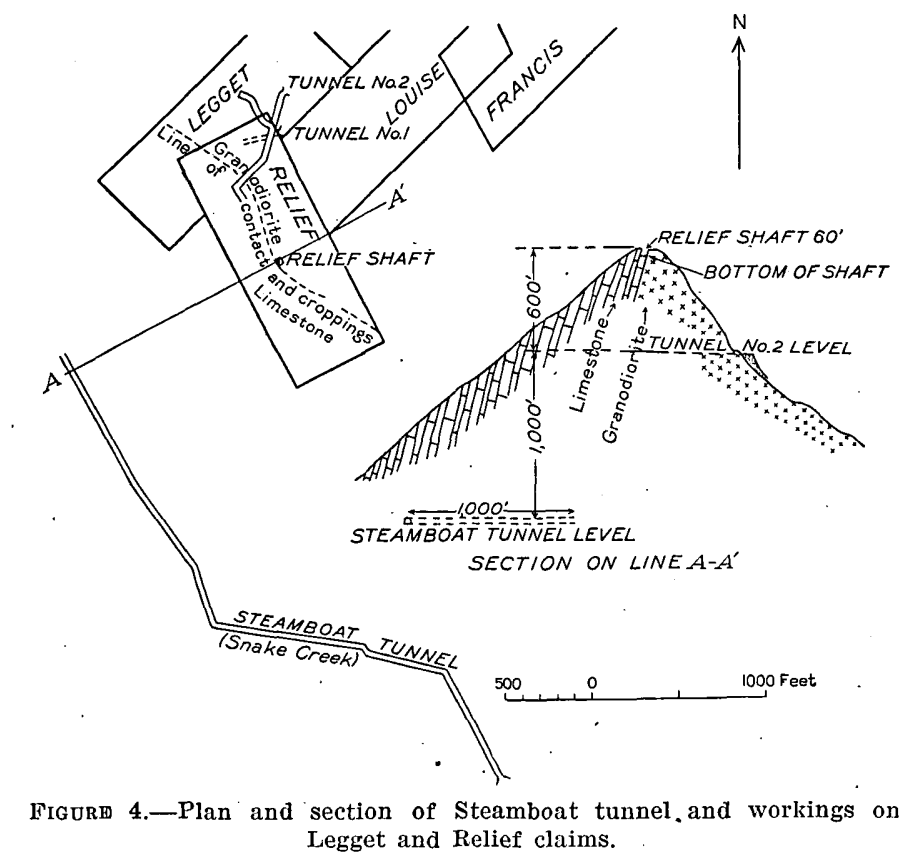

(fig. 4), at or near the contact of limestone and intrusive rock. In the material on the dump that is said to have come from this locality, mica and forsterite are abundant. The copper minerals are bornite, chalcocite, and chalcopyrite, the relations of which are discussed on p. 97. Some of the material on the dump contained a high percentage of copper. (See pls. $25 C, D, 26, C$, $29, B$.)

\section{WOODLAWN}

The ground controlled by the Woodlawn Copper Mining Co. lies mainly on the ridge between Honeycomb Fork and Solitude Fork. The Woodlawn mine was idle for several years prior to 1915 , when the main working tunnel was extended southward about 1,800 feet, and several shipments of copper ore, zinc ore, and lead ore were afterward hauled to the smelters.

The sedimentary rocks exposed on the property are mainly Carboniferous limestones. They are cut by one large irregular dike and by several smaller ones. The large dike as exposed in the Gardner tunnel and on the ridge consists of highly metamorphosed diorite. (See p. 43.) A strong fissure striking about N. $70^{\circ} \mathrm{E}$. and dipping about $60^{\circ} \mathrm{N}$. cuts the limestone. 'This fissure has been prospected through the Mannahansett tunnel (altitude 9,629 feet) from the Solitude Fork side, and through three tunnels, the New Sensation (9,794 feet), the Clarke (9,576 feet), and the Gardner (9,267 feet), from the Honeycomb side. A shaft was being sunk from the lower tunnel level in 1921. (See pl. 36.) The New Sensation tunnel follows the fissure and shows ore almost continuously. The Clarke tunnel has been driven along the fissure but shows little ore. A winze 160 feet below this tunnel is said to be in ore at the bottom, but it was not examined.

The main features of the geology on the Gardner level are shown in plate 36 . The tunnel passes for nearly 1,000 feet through massive white limestone and dolomite, supposed to be Jefferson (?) and Madison, with dips prevailingly eastward at low angles. It then crosses the large dike of altered diorite, which is about 180 feet wide. South of this intrusive body the country rock is mainly limestone, but a dike of alaskite porphyry about 25 feet thick and a thinner dike of granodiorite or diorite porphyry are crossed near the face, which was about 1,750 feet from the portal in July 1921. The limestone in the inner part of the mine is much disturbed, and the beds appear to form a local southwardpitching anticline. This disturbance may be associated with thrust faulting, for the Grizzly overthrusts pass near the workings, though their exact location is uncertain. The fissure followed by the higher tunnels is crossed about 1,230 feet from the portal and 75 feet south of the diorite. The crushed zone along this fissure is about 5 feet wide and contains ore, largely oxidized, in which there are stopes on both sides of the tunnel. Farther south is a breccia, crossed by two or three other fissures, which also contains ore, some of it being below the Gardner tunnel level.

\section{PRINCE OF WALES}

FISTORY AND PRODUCTION

The Prince of Wales, like many other mines in the area, was worked extensively in the early days and was then idle for a long period, after which considerable work was done and some ore shipped by lessees.

The Prince of Wales and Antelope group of claims, ${ }^{63}$ at the head of Silver Fork Canyon, became producers in the fall of 1870. The claims were opened and developed by the Walker Brothers, of Salt Lake City, who were the locators. In 187.4 a shaft 420 feet deep and 1,670 feet of tunnel work represented the total development. The Silver Fork adit was 320 feet long, the Honeycomb tunnel 750 feet, and the Antelope tunnel

63 Raymond, R. W., Statistics of mines and mining in the States and Territories west of the Rocky Mountains for 1871, p. 319, 1872. 
320 feet, and there was about 3,000 feet of stoping. Much of the ore taken out contained 130 ounces of silver to the ton and 45 percent of lead. Litigation proceedings between 1871 and 1875 caused the consolidation of the Highland Chief with the Prince of Wales group, and later another claim, the Wellington, was included in the enlarged Antelope and Wandering Boy patented claims. All these claims were mentioned in early reports as producers. Huntley ${ }^{64}$ says that 30 men were employed in 1880 and that in the following year many men were working under a leasing contract from the owners, who have since continued in this way to keep the mine open.

To the end of 1918 the Prince of Wales group had produced 10,459 tons of ore, much of it averaging 105 ounces of silver to the ton and 30 percent of lead. The tenor of the ore for 5 years after 1908 averaged 68 ounces of silver and $\$ 2$ in gold to the ton, 29 percent of lead, and 1 percent of copper.

\section{GEOLOGY}

The Prince of Wales group lies mainly on the ridge between Silver Fork and Honeycomb Fork of Big Cottonwood Creek (pl. 37). The rocks on the surface are Cambrian, Devonian (?), and Carboniferous dolomites and limestone. These rocks are in large part bleached and show much evidence of metamorphism, but the only igneous rocks̀ exposed in the property are some lamprophyre dikes.

The structure of the ridge is far more complex than a casual inspection would indicate. The lower Grizzly overthrust, though very tight, can be followed around the basin southwest of the Prince shaft, and there is at least one higher overthrust. The lower overthrust can readily be traced to the north, as shown on the geologic map; the upper ones are more obscure: The thrusts where they are most distinct have thrust Maxwell limestone over Deseret limestone. A lower overthrust, unmapped, which is crossed by the vertical shaft from the Alta tunnel, duplicates part of the Madison and Deseret limestones. A great thickness, therefore, of Mississippian limestone is cut by the fissures passing through the ridge. The ridge is crossed by several northeast fissures, of which the Prince is the most conspicuous, its course being marked by a row of mine openings extending southwestward from the Prince of Wales shaft. This fissure dips about $60^{\circ}$ to $65^{\circ} \mathrm{N}$. and is a normal fault of small throw.

Only a small part of the workings of the Prince mine are accessible, and the relations of the ore deposits to the different beds has not been fully determined. The ore that was being taken from the workings of the lower (Annie) tunnel level (pl. 37) on the Honeycomb Fork side in 1916 and 1917 occurred in dolomite, probably of Jefferson age, which is ore-bearing in many parts of the

ar Huntley, D. B., Mining industries of Utah : 10th census U. S. (1880), vol. 13, p. 428,1885 . district. In the workings on the lower level the orebearing stratum has apparently been repeated three times by relatively small reverse faults. So far as observed, mainly in the lower levels, the ore was formed by replacement of this dolomite, and the vein is nearly barren in the Cambrian beds and in the overlying blue and white Madison beds and the cherty Deseret limestone.

The ore in these lower levels was partly oxidized but contained considerable galena. Its average value was about $\$ 140$ a ton.

Huntley ${ }^{65}$ gives the following description of the Prince of Wales deposits:

The ore-bearing formation is said to be a bedded vein, dipping about $45^{\circ} \mathrm{NW}$. in blue and white limestone. Four distinct chimneys or shoots of ore, 130 feet, 260 feet, and 260 feet apart, have been found. They occur where the limestone is white, metamorphic, and soft, while the barren spaces between these shoots contain the vein only as a narrow seam in hard blue limestone. These shoots outcropped at the surface, or were covered by a few feet of drift, as low-grade, ocher-stained seams of limestone and clay. Good ore was found by sinking a few feet. The Antelope and Prince of Wales shoot is from 2 inches to 4 feet (average, 12 inches) wide; 120 feet long, and has been followed on the dip 1,200 feet. The Highland Chief shoot is from 2 inches to 3 feet (average, 8 inches) wide, 75 feet long, and 800 feet deep. The Wellington shoots are each about from $2 \frac{1 / 2}{2}$ to 7 feet (average, 3 feet) wide, from 10 to 30 feet long, and 700 feet deep. The ore from the first assays about 140 ounces silver and 45 percent lead; that from the second, 100 ounces silver and 40 percent lead; and that from the third and fourth, 60 ounces silver and 50 percent lead. The ore is a soft brownish-yellow ocher, containing argentiferous cerusite and galena and occasional stains of oxides of manganese and copper.

In 1916 and 1917 work was being carried on from the Annie tunnel on the Honeycomb Fork side and drifting on the vein below the old tunnel level was in progress. The ore, whose thickness ranged from that of a knife blade to a little more than 6 inches, consisted mainly of galena surrounded by oxidation products. The ore bodies, so far as developed on the lowest level, seem to be smaller than those at higher levels, but the content of silver seems to be quite as high as in the upper workings.

\section{ALTA TUNNEL \& TRANSPORTATION CO.}

HISTORY AND DEVELOPMENT

The Alta Tunnel \& Transportation Co. owns 250 acres of mineral land in Silver Fork Canyon, embracing the Lucky Dutchman group of 16 claims and the old Alta tunnel ground; its property lies, in general, north and west of the Prince of Wales group. A transportation and drainage adit with its portal 8,500 feet above sea level has been driven about 4,000 feet (pl. 37). It was expected to drain several adjoining mines in its path, with workings about 800 feet higher than the adit level. One of these is the Prince of Wales and Antelope group, described elsewhere. In 1919 the driving of the adit was discontinued, and about 1,500 feet from the

\footnotetext{
es Idem, p. 428.
} 
portal a drift was driven eastward, on a fissure called the No. 5, and opened up considerable ore. The first ore encountered carried about 36 percent of zinc with some lead and silver; carbonate of lead and some sulfide lead ore containing silver was found later by raising. A winze heading on the Annie tunnel, and several drifts at different levels, all on the Prince fissure, were afterward connected with the Alta tunnel by a vertical raise that rises about 400 feet above the tunnel. Several small shipments of lead ore have been made from the property.

The ore shoot on the No. 5 dike fissure has been followed for about 300 feet above the tunnel level and is said to have yielded ore valued at about $\$ 60,000$. Ore was being taken from the Prince fissure in the upper levels by lessees in 1934, and some has presumably been mined by the company but in what amount is not known. Other fissures, including the Cooper, have been cut in the tunnel workings but as yet are not known to contain important ore bodies.

\section{GEOLCGY}

What has been said regarding the geology of the Prince of Wales property applies in large part to the ground of the Altá 'Tunnel \& Transportation Co.: the rocks are chiefly Mississippian limestones mostly dipping at low angles northeastward, duplicated in part by two or three thrust faults and cut by several dikes of lamprophyre. The Alta tunnel, however, reaches the Tintic quartzite, and the western part of the property overlaps the Silver Fork fault. To say merely that this fault here brings the Humbug formation down against the Madison limestone is far from giving a full measure of the throw of this huge dislocation, for the Madison of the footwall side is in a block originally separated by several higher thrust blocks from the Humbug of the hanging-wall side.

The Alta tunnel and the workings connected with it, which are all east of the Silver Fork fault, reveal many interesting details of structure. The strata dip in general northeastward, and the straight main tunnel, which trends a little east of south, thus in general reached lower and lower beds as it was driven, its por- tal being in the Madison limestone and its face in the Tintic quartzite. The sequence Madison-Jefferson (?) is repeated, however, by faulting, partly at least on the Dutchman fault, which may cross the tunnel in two places because of cross-faulting. This fault is orebearing in places. The strike and dip of the beds also deviate considerably in places from their prevailing attitudes.

The Jefferson (?) dolomite is underlain, near the entrance to No. 5 east drift, by crystalline limestone, mottled in gray and white, which is taken to be a remnant of the limestone member of the Ophir shale. The unconformity at the base of the Jefferson (?) is thus near its lowest observed level, as in the Silver King tunnel and on Patsy Marley Hill to the south.
The No. 5 drift follows a lamphophyre dike of steep south dip, in a fissure that may be the Cooper. Some ore was mined in this drift, mainly from a shoot developed by the Christmas stope, mainly above but partly within a coarse, highly porous breccia that is perhaps the most puzzling structural feature in the mine. The breccia, which is followed by the Quad drift, is many feet thick and has no sharply defined walls, but it seems to lie about parallel to the bedding. It may mark a fault, and perhaps a thrust fault; but it differs profoundly in character from the tight contacts that mark most of the thrust contacts, especially those between limestones metamorphosed by intrusion after the thrusting. The open character of the breccia is evidence that it was formed under comparatively light load and therefore much later than the typical overthrusts. Further evidence in the same direction is given by the presence in the breccia, at the Christmas stope, of fragments of lamprophyre, a rock that was certainly intruded later than the movement on most of the overthrusts. It seems remarkable to find ore minerals replacing the breccia and filling spaces between the firagments, as they do in places, and these relations may be the result of a late reconcentration of material previously deposited in the No. 5 fissure.

The raise to the Annie level passes through two thrust faults. The lower, which is crossed by the vertical shaft and inferred rather than directly observed, causes the repetition of part of the Deseret limestone. The upper, which is the lower Grizzly overthrust, is crossed by the inclined raise in the Prince fissure about 50 feet below the Annie level and by the east drift on the 120 level; it brings gray Maxfield limestone over cherty Madison limestone. This contact is very tight, and no ore seems to have made out along it.

Several fissures of northeasterly strike have been encountered in the Alta tunnel, but no one of these can be identified as the Prince of Wales fissure, which has been the most productive in this area and the opening of which at depth was one of the objects of driving the tunnel. This fissure dips from $70^{\circ}$ to $60^{\circ}$, flattening slightly with increased depth so far as followed. It is distinct for more than 300 feet below the Annie tunnel, where it becomes so tight that it could not be definitely identified farther downward. On the Alta tunnel level a fissure has been opened that is approximately where the projection of the fissure from the Annie workings would reach that level. This fissure, however, is occupied for a large part of the distance that it has been opened on the Alta tunnel level by the No. 2 lamprophyre dike, which dips steeply southward, whereas the Prince of Wales fissure dips northward. All the dikes in this part of the area strike in general parallel to the fissures but are nearly vertical, so that the Prince of Wales fissure would intersect them at a high angle if projected in its dip. Whether it passes through the dikes on its normal dip, as a very tight crack, or turns into No. 2 
dike, which shows the most evidence of mineralization where exposed, was not evident from developments at the time of visit.

\section{LITTLE COTTONWOOD DISTRICT}

FREDERICK TUNNEL

The Frederick tunnel (see pl. 38), owned by the Hellgate Mining Co., starts from Little Cottonwood Canyon a quarter of a mile east of Superior Gulch. It has prospected principally the limestone beneath the Alta overthrust, though the thrust zone, which lies high above the tunnel, has been prospected to a slight extent on the surface and in the Hellgate drift above the tunnel level. The tumnel extends a little west of north for about 2,500 feet. It starts in the lower shale member of the Ophir formation and passes for about 1,300 feet through lower, middle, and upper Ophir, which are cut by several lamprophyric dikes. The remainder of the tunnel is in the limestones and dolomites overlying the Ophir formation. These strata include a part of the Maxfield-here reduced to a small thickness by preMississippian erosion-the Jefferson (?), and part of the Madison. About 1,800 feet from the portal, in the Watson claims, the tumnel cuts a northeast-striking fissure, which contains some pyrite and has been prospected by a short drift and a raise. Another fissure was cut about 2,300 feet from the portal and was followed northeastward for more than 900 feet. For a part of the distance the fissure is filled with a lamprophyre dike, and some of the rock along it is mineralized. At a point nearly underneath the old Toledo shaft a raise of about 35 feet connects the Frederick workings with those of the Columbus-Rexall mine. The Hellgate drift, above the tunnel level, reaches the Alta thrust zone. It was inaccessible at the time of visit because of bad air.

\section{WEST TOLEDO}

The West Toledo group lies in Superior Gulch and extends over the divide to the north. It has been developed mainly through the Superior tunnel and through the Frederick tunnel, which starts in the Rettich group.

Since the examination by the writer a raise has been driven from the Columbus-Rexall level to the Alta overthrust, and it is reported that oxidized lead ore, including well-crystallized cerusite, was encountered on what is supposed to be the Toledo fissure.

\section{SUPERIOR}

The Superior tunnel is in Superior Gulch. (See pl. 1.) On the surface the rocks include the Cambrian quartzite, the Ophir shale, and the overlying Cambrian, Jefferson (?), and Madison limestones. These are cut by several lamprophyre dikes, which have a northeasterly trend and some of which occupy mineralized fissures. The Alta overthrust fault crops out on the upper east slope of Superior Gulch, and the Superior faults and branches from them pass through the gulch, producing a rather complicated structure. (See pl. 3.) The developments are mainly in the Cambrian quartzite west of the Superior fault. The tunnel extends a few degrees west of north for about 1,000 feet. About 700 feet from the portal a northeast striking fissure filled with a decomposed dike rock is encountered, and this fissure has been followed for several hundred feet. The dike is fissured, indicating some movement after its intrusion. Ore occurs mainly alongside the walls of the dikes, though there is some within the dike. The ore minerals are galena, pyrite, sphalerite, tetrahedrite, and probably some chalcopyrite; the gangue is mainly quartz. No extensive bodies of ore have been encountered.

\section{RETTICH}

The Rettich group lies in Little Cottonwood Canyon near the mouth of Superior Gulch. The Frederick tunnel passes through this group for about 1,700 feet. It has also been prospected to a slight extent by other workings, especially along the outcrop of the Alta thrust fault, where some mineralization has occurred and where, it is said, some ore has been mined.

In 1926, a raise was being driven from the Frederick tunnel to prospect the Alta overthrust fault in the Rettich ground.

\section{COLUMBUS-REXALL}

PRODUCTION

The Columbus-Rexall Consolidated Mines Co. was formed in 1915 and held 15 patented claims, covering about 200 acres of mineral ground, which was a consolidation of the property of the Columbus Extension and Rexall Silver \& Copper Mining Companies. The property was later acquired by the Wasatch Mines Co. and is now controlled by the Mineral Veins Coalition Mines Co. The property lies on both sides of the divide between Big Cottonwood and Little Cottonwood Creeks, and is opened by a 5,400-foot adit with total workings of about 14,000 feet.

In July 1917 an ore deposit was opened in the Rexall ground at a point about 5,000 feet from the portal of the adit, almost directly under the mountain divide. The ore was found in Deseret limestone under the Tintic quartzite, which is thrust over the limestone by the Alta overthrust. The depth here from the surface is 1,350 feet, and the ore consists of sulphides. The ore body yielded 1,900 tons of ore, assaying 13.9 percent of copper and 3.8 percent of zinc, with $\$ 7.65$ in gold and 32.9 ounces of silver to the ton. In December 1919 a raise above the 800 -foot level cut 6 feet of ore assaying 41 ounces of silver to the ton and 19 percent of lead. This ore was followed toward the Cardiff property, with which the Columbus-Rexall workings were connected early in 1920. The ore shipped from the body discovered in 1917 had amounted, at the end of 1919 , to 8,779 tons, averaging $\$ 5.73$ in gold and 9.21 ounces of silver to the 
ton, 7.18 percent of copper, and a little lead. In 1919 some low-grade copper ore was shipped, averaging 33 cents in gold and 5.56 ounces of silver to the ton and 5.56 percent of copper. The copper-lead ore shipped during 1919 averaged 12 cents in gold and 8.96 ounces of silver to the ton, 3.87 percent of copper and 7.62 percent of lead. In recent years the mine was being worked by lessees.

\section{GEOLOGY}

The geology of this group is similar to that of other deposits lying along the Alta overthrust fault, which is discussed on pp. 55-57, and the mine map (pl. 38) overlaps those of the Cardiff and Columbus mines. The rocks penetrated by the workings include the Deseret limestone beneath the Alta overthrust and the Cambrian quartzite above it. Between the Deseret 'limestone and the overthrust quartzite is a lens or wedge, thickening southward, composed mainly of the upper portion of the Ophir shale but containing some of the Cambrian quartzite and of the Maxfield and possibly of later limestones. This mass is very complex in structure, being cut by thrust faults parallel to the Alta and by at least one that dips westward. (See section $C-C^{\prime}$, pl. 4.) The sedimentary rocks are cut by some dikes occupying northeastward-striking fissures.

The Howland fault, followed by part of the Columbus Rexall tuninel, strikes a little west of north and dips about $70^{\circ} \mathrm{W}$. in the southern part of the workings. Toward the north the fault divides into two branches. The east branch is very well defined; the west branch is less so, but in the Water Tank drift the Ophir shale of the lens is brought into contact with the Deseret limestone by a fault that strikes a little west of north and dips $85^{\circ} \mathrm{W}$., which is taken to be the continuation of the west branch of Howland fault. Again, about 1,800 feet farther north a north-south fault dipping $80^{\circ}$ $\mathrm{W}$. is encountered. These two exposures make a fair alinement with the western branch, and it seems probable that they represent a single normal fault with downthrow of probably 200 feet or more. The rocks are also cut by northeast fissures that show but little evidence of movement.

The prospecting in the Columbus Extension portion of the workings has been done mainly along the upper branch of the Alta thrust, the hanging wall of, which is quartzite. Along this fault on the tunnel level the quartzite-lies partly on the upper member of the Ophir shale and partly on Maxfield limestone. The largest deposit developed in this part of the property is near the intersection of the thrust contact with a northeastward-striking fissure. The Water Tank crosscut, in the Bluebird claim, has prospected the lens lying in the fault but apparently not either the highest or lowest thrust contact. There has also been some prospecting in the Oxford claim along a fissure striking a little north of west in the quartzite above the upper thrust. This fissure contained some pyrite. A strong fissure striking about $\mathrm{N} .60^{\circ} \mathrm{E}$. and dipping about $80^{\circ} \mathrm{N}$. has been followed in the Extension fraction. The strike is about the same as that of the Toledo fissure; the dip is considerably steeper, but if an average between the dip on the tunnel level and that in the Toledo shaft is taken, the projection of the Toledo fissure to the tunnel level from the shaft almost coinuides with the fissure in question. There has been some mineralization of this fissure in the lower limestone. Where it crosses the lower thrust contact on the tunnel level the upper member of the Ophir shale rests on the limestone, a condition that usually has not proved favorable to mineralization.

The largest ore body developed in the Rexall section lies just beneath the thrust fault, which is here a simple fracture bringing the quartzite directly upon Madison limestone. So far as developed it extends up the contact in a direction a little north of west, apparently along a fissure that does not correspond to the prevailing strike of the ore fissures of the district. There are several northeast fissures in this area, but none of them have thus far been shown to be closely connected with valuable ore bodies.

The ore in the main ore body has its greatest value in copper but contains some lead and zinc. The principal primary minerals are pyrite, tetrahedrite, enargite, bornite, galena, and chalcopyrite, with a little quartz gangue. Pyrite was evidently the earliest mineral deposited, and the later minerals occur in fractures and replace the pyrite. (See pl. 23, B.) There are bodies of pyrite that have not been sufficiently enriched to be ore, and a good deal of such material has been left in the mine. On the tunnel level the minerals are practically unaltered, but in the upper levels they are almost entirely oxidized.

COLUMBUS CONSOLIDATED AND WASATCH DRAIN TUNNEL HISTORY AND PRODUCTION

The old Columbus Consolidated mine and the Wasatch drain tunnel (pls. 39, 40), which passes beneath it, may conveniently be described as a unit, although they constitute only a part of the property of the Mineral Veins Coalition Mining Co., which is the successor of the Wasatch Mines Co. The latter company, incorporated in 1913, was a consolidation of the Columbus Consolidated, Flagstaff, and Superior-Alta groups. The company's property covers 900 acres of ground near Alta, including two mill sites, one at Tanners Flat and the other at the mouth of Little Cottonwood Canyon. The principal workings on the property other than the Columbus mine and the drain tunnel are the Flagstaff mine and the Tom Moore tunnel, which will be described further on in separate sections.

The Columbus Consolidated mine first produced some silver-lead ore of shipping grade in 1902, whereupon a concentration mill was constructed for treating lower 


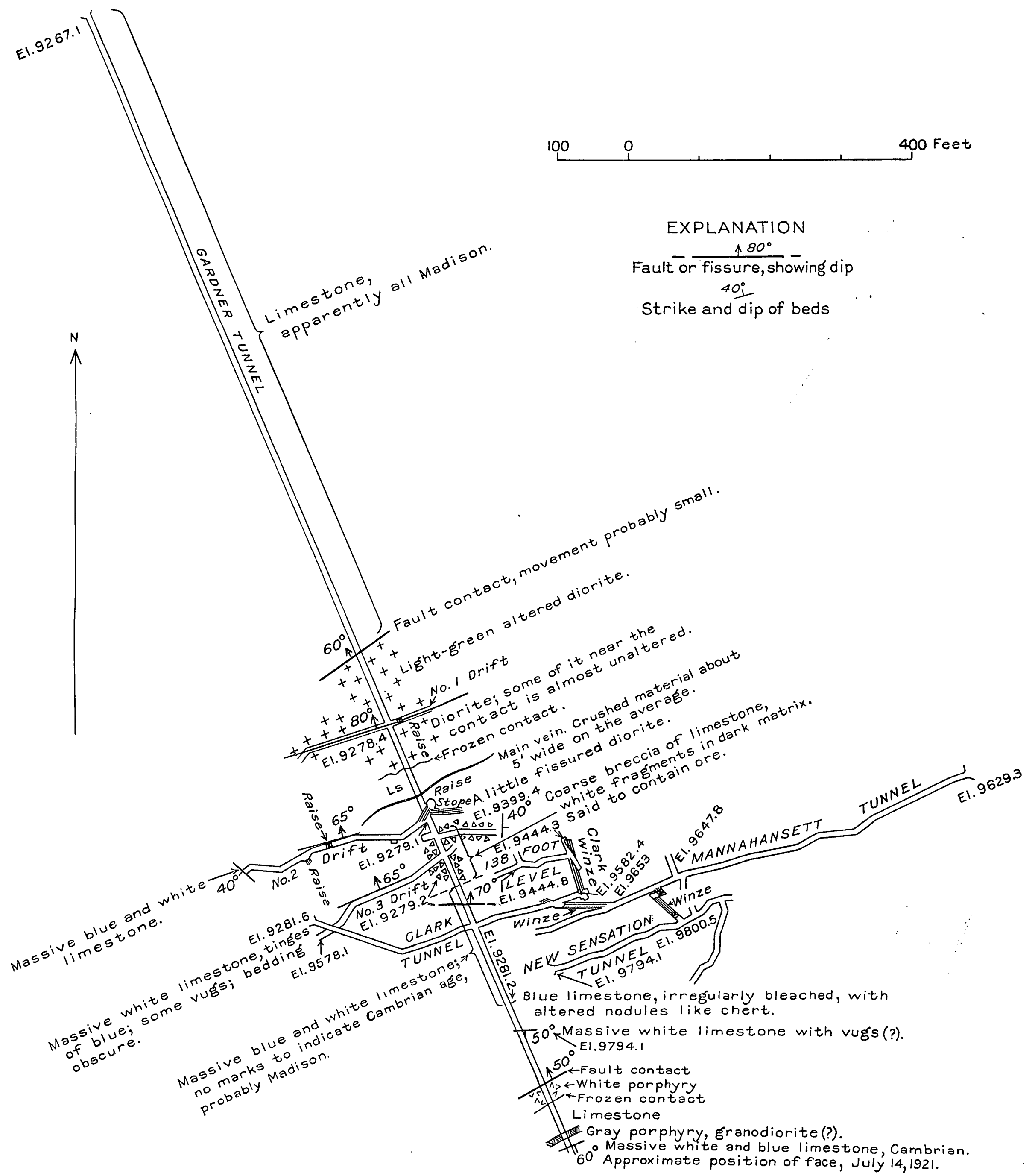


grade ore. The first concentrate was shipped in 1904, and the last mill ore was treated in 1912. Shipments of crude smelting ore were discontinued in 1913, and operation of the mine ceased when the mill was destroyed by fire in January 1914. From 1902 until 1913 about 54,000 tons of milling ore yielded 13,644 tons of concentrate, averaging 85 cents in gold and 23.83 ounces of silver to the ton, 4.46 percent of copper, and 11.94 percent of lead. The ore directly smelted amounted to 32,792 tons, averaging $\$ 1.40$ in gold and 32.88 ounces of silver to the ton, 6.64 percent of copper, and 4.49 percent of lead. Most of the ore came from the Brain fissure, opened by two adits 1,250 feet apart on practically the same level $(8,580$ feet). The Howland and Columbus tunnels were connected on the Brain fissure. The Howland at one time was equipped with electric traction.

In 1907 a drainage adit was started about three-quarters of a mile down the canyon from the portal of the Howland tunnel to unwater the Columbus and adjoining properties, but it was not driven far. In 1916 the Wasatch Mines Co. started an adit a little farther down the valley, at an altitude of 8,067 feet (pl. 39), which was driven straight northeast for about 6,000 feet. A crosscut was driven 5,300 feet from the portal and extended about 430 feet in a northerly direction to reach the proper point for starting a raise from the tunnel lever to unwater the Columbus workings. This crosscut intersected three ore-bearing fissures. A raise on the third, evidently the Brain fissure, connected with the Columbus workings, which were unwatered and prepared for production in October 1920. Drifting was continued on the drain tunnel level along the Brain fissure for a distance of about 900 feet. The "Pipe Raise" ore body was intersected in this drift, and a raise was driven to develop it. Some ore was mined between the drain tunnel level and the old workings, and some from a winze extending down from the drain tunnel level, but no very large body of ore seems to have been developed.

GEOLOGY

The rocks penetrated by the Columbus workings and the drain tunnel represent all the sedimentary formations from the tillite (Cambrian?) to the Deseret (upper Mississippian). The only igneous rock that is conspicuous in the property is the Grizzly dike of alaskite porphyry, which cuts the crumpled Ophir shale in the knob north of the portals of the Columbus mine. The structure is complex, its main features being the Alta thrust zone, the Snow fault, the Howland fault, and the Brain and Garfield fissures.

The geology of the Columbus workings can be studied together with that of the adjoining Columbus-Rexall workings, the plates representing the two having been so drawn that they may be overlapped. The lower levels in Columbus ground are shown on plate 40 with the upper workings, and the long geologic section ex- posed in the drain tunnel proper are shown on a smaller scale in plate 39 .

The Howland tunnel affords a long cross section of the structure. It passes eastward from the Howland fault into Tintic quartzite and then into a thick mass of crumpled Ophir shale and limestone, which is above the lower thrust of the Alta thrust zone, to the great overthrust followed downward by the No. 3 shaft. This overthrust, formerly thought to be the Columbus, is now believed by the writer of this paragraph (Calkins) to be the uppermost fracture in the Alta thrust zone, mainly for the reason that it alines with the single fracture which represents that zone at the raise on the main ore body. Eastward from the overthrust the main crosscut passes through some quartzite, then more Ophir, and ends in the shattered and heavy ground of the Snow fault zone. The Snow fault was followed for some distance from its portal by the old Columbus tunnel, which is mainly in Ophir shale.

The levels between the Howland tunnel and the drain tunnel have been examined only in part, being not everywhere accessible and being much obscured by iron stain because of their having been for several years under water. However, some of the main features visible on the upper levels have been found on these lower levels. The upper thrust is near the east end of the accessible part of the 400 level, and the lower thrust, beneath which the Deseret limestone lies, is probably crossed by the crosscut that extends southward from the western part of that level, though its exact location is not certain. The longest drift on the 400 level extends along the Brain fissure, in Ophir shale and limestones presumably of Cambrian age, between the highest and lowest thrust faults of the Alta thrust zone. The rock above the higher thrust is here Ophir shale, the quartzite having pinched out, and the rocks within the thrust zone are also, on the average, at a higher stratigraphic level here than above. Both relations result from a general convergence eastward between the bedding of the rocks above the lower Alta thrust with the several thrust faults. The bedding of the Deseret limestone, on the other hand, remains nearly parallel throughout a large area to the lowest overthrust of the Alta zone. These relations are indicated somewhat diagrammatically in section $C-C^{\prime}$ of plate 4.

The drain tunnel, west of the main branch to the north (pl. 39) affords a remarkable cross section of beds, dipping generâlly eastward, from a stratigraphic level some hundreds of feet below the top of the Cambrian (?) tillite to one high in the cherty Deseret limestone. All the formations between these are represented, though the Maxfield is thinned by pre-Jefferson (?) erosion and some of the Ophir is cut out by faulting in what seems to be the Howland fault zone.

In its last few hundred feet, the tunnel crossed at 
least three faults, striking northward and dipping westward at low to moderate angles. These appear to be in the Snow fault zone, though they strike more northwestward than the main Snow fault does on the surface. The one 300 feet from the face, which dips $40^{\circ} \mathrm{W}$., may bring Maxfield, on the west, down against Madison belonging to the block below the Alta thrust zone, on the east. The next fault mapped, dipping $55^{\circ} \mathrm{W}$., whose footwall is Ophir shale, need have only a moderate throw, since the Maxfield limestone on the surface above is much thinned, and might here have been entirely removed, by pre-Devonian erosion. The rock in the face of the tunnel as mapped was confidently assigned to the Jefferson (?) dolomite. The shale beneath it is most probably that which lies at or near the base of this formation at many places, and the very flat fault which goes into the roof nearby may be a west-dipping overthrust of small throw, later than the great east-dipping overthrusts.

The workings north of the tunnel include a drift on the so-called No. 5 fissure, which is probably the Brain, and a drift and winze on a fissure of more northerly strike, dipping westward, wherein some of the vein matter that is left is partly oxidized. The course of the lower Alta overthrust northwest of the tunnel is obscure, as it so commonly is where both walls of the fault are limestone. Its course as tentatively shown on plates 39 and 40 cannot however be seriously in error, and some of the evidence for the mapping is given in the notes on those plates.

The most prominent ore-bearing fissures in Columbus ground are the Brain and Garfield. The mineralization has come in by way of the fissures, especially the strong Brain fissure. It has made out from the fissures into limestone, and the strongest shoots of ore are on the intersection of the Brain fissure and the thrust faults. Only part of the developments have been examined. From observations and reports, however, it appears that the largest shoot of ore followed the intersection of the Alta thrust and the Brain fissure on the upper levels. The shoot steepens below the tunnel level to nearly vertical. It is said to have been followed below the Wasatch drain tunnel level. There was also a rich shoot at the intersection of the Brain fissure with the upper overthrust, but the ore did not extend beyond the limestone, which tapered out against the overthrust a short distance above the tunnel level. This contact had not been encountered on the drain tunnel level, where it lies below the Snow fault. The Brain fissure is also mineralized between the faults, west of the lower Alta overthrust fault and east of the upper one, where it has been followed until cut off by the Snow fault.

$O$ The Garfield fissure, which lies south of the Brain fissure, cuts the much crushed and faulted beds of the Ophir shale including the limestone member, and the main mineralization in this fissure has been replacement of the limestone. Other fissures have produced shoots of ore at their intersections with favorable limestone beds.

The primary minerals in the deposits were mainly pyrite, tetrahedrite, and galena, the ore containing a higher percentage of copper than most deposits of the district. In the upper parts of the deposits the sulfides were partly oxidized. In the Garfield fissure sphalerite was locally rather abundant:

\section{FLAGSTAFF}

HISTORY AND PRODUCTION

What is commonly known as the Flagstaff mine consists of the Flagstaff tunnel, about half a mile northwest of Alta, the 900-foot Flagstaff shaft, which heads underground at the tunnel level, and drifts that extend from the shaft at several levels below the tunnel. Later developments for the purpose of mining the Flagstaff ores include the Tom Moore tunnel, to be described separately, and the Burnswood tunnel. All these workings are in the property of the Mineral Veins Coalition Mining Co.

The early operations of the Flagstaff mine were interestingly described by Raymond. ${ }^{66}$ The mine, according to Raymond, was served in the seventies by furnaces situated at the mouth of the canyon and at Sandy. In 1872 these furnaces, using charcoal as fuel, were treating 20 tons of ore a day. During 3 months ending September 15,1872 , ore amounting to 1,467 tons was reduced, producing 619 tons of bullion. Water power for operating the blowers to the furnaces was supplied by a ditch from Little Cottonwood Creek. The bullion was hauled 7 miles from the furnaces at the mouth of the canyon to the railway station at Sandy. The total product of the furnaces in 1872 amounted to 3,000 tons of metal, containing an average of $\$ 130$ in silver, $\$ 40$ in gold, and $\$ 80$ in lead, valued in all at $\$ 750,000$.

In $1873^{67}$ the Flagstaff smelter was idle, although the mine was worked steadily until November, having produced in 10 months 15,000 tons of ore averaging $\$ 54$ a ton, but the expenses of mining were so heavy that the company was in debt at the end of the year. Most of the ore mined in 1873 was smelted at the Last Chance and Flagstaff smelting works, in Sandy, but 2,595 tons was sampled at the Pioneer Sampling Works, in Salt Lake City, and shipped to other works. According to the official statement ${ }^{68} 14,767$ tons of ore was taken from the mine in 1874 and 3,521 tons of argentiferous lead obtained at the Last Chance smelting works. The lead had an average value of $\$ 207.25$ a ton. The total value of the metal output of the Flagstaff mine prior to 1880 is estimated at $\$ 4,550,000$. About 300 tons of lead-silver ore was taken out of the Flagstaff workings by the Consolidated Flagstaff Mines Co. in 1906, 1907, and 1908, and from 1913 to 1920 lessees and the Wasatch Mines

\footnotetext{
${ }^{60}$ Raymond, R. W., Statistics of mines and mining in the States and Territories west of the Rocky Mountains for 1872, p. 246, 1873.

or Idem for 1873 , p. 260,1874

os Idem for 1874, p. 260, 1875 .
} 
Co. shipped 1,262 tons of ore, part of which was mined near the surface. The principal value was in lead, silver, and copper, but some zinc ore was shipped in 1915 .

The increase in the value of gold has made it profitable during the last few years to mine old stope fillings in the upper part of the Flagstaff workings, and a considerable shipment has been made from them.

\section{GEOLOGY}

The geology of the Flagstaff mine proper (pl. 41) is far simpler than that of the Columbus workings. The Flagstaff workings are in large part inaccessible, but the distribution of the levels indicates that they lie near an irregular inclined surface dipping northeastward. Observations in the accessible workings show that this surface lay for the most part in the Jefferson (?) dolomite, which is much brecciated, as if by thrust faulting roughly parallel to the bedding and so small in throw that it could not be mapped on the surface. A small thrust fault that brings the Maxfield over a sliver of - Jefferson (?) dolomite is crossed in the tunnel but not mapped on the surface. The beds are crossed by faults later than the thrusting, the largest of these being the steep Flagstaff reverse fault, which is conspicuous on the surface but apparently intersects the tunnel level a little too far west to have been accessible when the mine was visited by the writer of this description.

The ore deposits in Flagstaff ground have been formed mainly by replacement of limestone adjacent to fissures. Prospecting has been very largely confined to a single zone, roughly parallel to the bedding and extending from the Flagstaff tunnel to the Old Emma cave. The upper limit of this belt closely coincides with a white, finely laminated dolomite taken to be at the top of the Jefferson (?). The ore deposits occur as shoots where this limestone and those below it are intersected by fissures. The more prominent fissures strike northeast, and the ore makes out into the limestone from the fissures as bed deposits. Little of the old stoped ground could be examined, but from maps it appears that the beds were replaced farther from the fissures in the upper than in the lower part of the deposits, so that above the 300 foot level the deposits from the different fissures coalesced, forming a nearly continuous bed deposit. . Below. the 300 -foot level the shoots narrowed, and in the lower levels many were little more than fissure fillings. Plate 41 shows the generalized outline of the stopes, as drawn on company maps. There was apparently also a change, with depth, in the character of the mineralization. The upper, broader parts of the stopes yielded fairly highgrade lead-silver ore, but the narrow shoots at greater depth in many places consisted mainly of limonite with little lead or silver.

Some fissures striking west of north contain ore, and it has been suggested that the main ore deposits are associated with these fissures. From the rather scanty observations that were possible, however, it seems more likely that the main ore channels were the northeast fissures. The area is crossed by several of the northsouth faults, which displace the fissures and the ore bodies, but there seems to have been no serious difficulty in relocating faulted ore bodies.

The main ore body was mined through the Flagstaff tunnel and the Flagstaff underground inclined shaft. Prospecting. below the main ore bodies for continuations was carried on through the Flagstaff shaft and tunnels lower than the Flagstaff, the lowest workings being in the Tom Moore tunnel, ,near the bottom of Little Cottonwood Canyon, but none of the lower workings revealed valuable bodies of ore. The ore zone has been prospected to the northwest as far as the Eclipse shaft, at the head of Days Fork.

Only a little sulfide ore from this property was seen, but it apparently consisted. mainly of pyrite and galena. The ore mined was chiefly an oxidation product of these minerals, consisting mainly of limonite and lead carbonate with considerable residual galena, though plumbojarosite may have been an important constituent of this ore, as it is of many other ores of the district.

\section{CABIN}

The Cabin claim is on the north side of Little Cottonwood Canyon between the ground of the Wasatch Mines and that of the Emma Silver Mines Co. (pl. 41).

The claim is crossed by the Reed \& Benson thrust zone, which duplicates the upper part of the Maxfield limestone, the Jefferson (?) dolomite, and the lower part of the Madison limestone. The limestones are rather highly bleached, and recognition of the different limestone strata is difficult. The Snow fault passes under the workings and is exposed in the Golconda tunnel, where it brings limestone against the lower member of the Ophir shale.

The ore bodies that were being worked when the mine was examined occur where a white limestone is cut by a fissure striking west of north. The ore makes out from the fissure into fractures in the limestone, forming a very irregular series of pipes and shoots. Most of the ore bodies have been relatively small, but the ore is of high grade. Some of the ore bodies of the old workings appear to be associated with the fissure striking northeast. 'The original minerals were probably galena, pyrite, and some copper mineral. Much of the ore mined has been oxidized and consists of limonite and carbonate of lead accompanied in some places by a large percentage of plumbojarosite. There is also considerable residual galena in the oxidized ore.

The deposit was originally developed by an incline from the surface, but later operations have been carried on through the Golconda tunnel.

\section{TOM MOORE TUNNEL}

The Tom Moore tunnel (pl. 41) reveals a multitude of faults, which involve rocks ranging from Ophir shale 
to Deseret limestone. The outermost part of the tunnel is wholly or mainly in Cambrian rocks, doubtless in a block above the Alta overthrust. These are cut by one or more faults and by the Brain fissure and the Grizzly dike. About 600 feet in from the portal the tunnel crosses the Tom Moore fault, striking northwestward and dipping about $55^{\circ} \mathrm{SW}$., which brings the Cambrian rocks down against the Deseret limestone below the thrust. The very presence of this limestone indicates that the lower thrust of the Alta zone is near at hand, and it reaches the tunnel about 1,300 feet from the portal. A little further in, the Snow fault is encountered, here having two branches, with a strike of about north-northeast and a dip of about $30^{\circ} \mathrm{W}$. It here brings rocks of the Ophir shale and perhaps of the Maxfield limestone, all extremely shattered, down against either the Deseret limestone or a mere corner of Cambrian limestonce above the Alta overthrust.

The Maxfield limestone here, as on the divide west of Flagstaff Mountain, is represented by about as great a thickness as anywhere in the Cottonwood-American Fork area-a fact which accords with other evidence that the inner part of the tunnel is in rocks above the Alta overthrust. The middle member is especially well exposed in the northern part of the tunnel.

Farther in, the tunnel crosses many other faults, some of which are shown on plate 41 .

\section{EMMA \\ HISTORY AND PRODUCTION}

The Emma mine, now controlled by the Alta United Mines Co., has changed hands many times in its long and eventful history.

The Emma claim was located in December 1868, by F. B. Woodman, and the Emma ore body was discovered in the following year.

In 1870 the Walker Brothers purchased an interest in the mine. This firm reported the shipment of 4,200 tons of galena ore, mostly from the Emma mine, in the last half of 1870 . The ore averaged 35 percent of lead and $\$ 182$ a ton in silver and returned a net value of $\$ 125$ a ton. The total amount of ore shipped in 1870 was 5,293 tons.

Early in 1871 a half interest in the mine was sold to T. W. Park and H. H. Baxter for $\$ 375,000$, and subsequently a one-sixteenth interest was sold to this pair for about $\$ 100,000$ more, subject to a claim in litigation for one-third of the property by J. E. Lyon. Park, Baxter, and Lyon, by forcing production to the utmost, extracted between April 25 and September 1, 1871, 5,638 tons of ore from which a net profit of $£ 158,268$ was won. The ore was sold in Great Britain, and these sensational profits enabled the promoters to float a sale of the mine to an English company, which was capitalized at $£ 1,000,000$. After dividends were paid at the rate of $11 / 2$ percent a month until about the end of 1872 the ore body above the faúlt was exhausted; on June 11, 1872 , Clarence King declared, in a letter to the secretary of the British company, that not over 280 tons of ore was in reserve. ${ }^{69}$ The spectacular collapse of the English company created an international incident, because of the participation by the American minister, General Schenck, in its flotation, and led to an exhaustive exam. ination by the Committee on Foreign Affairs of the House of Representatives. The report of this investigation makes most interesting reading, revealing, as it does, the manner in which a truly remarkable ore deposit was utilized more as a basis of financial market rigging than as a mineral resource.

During the years 1873, 1874, 1878, and 1879 much low-grade ore was concentrated by jigs. When, in 1877, the American Emma Co. began work after reorganization of the property, it first prospected the old ore bodies and then leased the Bay City tunnel, which was 1,700 feet long and 90 feet below the lowest old workings of the Emma. This tunnel had been run by a St. Louis company at a cost of $\$ 75,000$ and had been abandoned in 1876. Under the American Emma Co. a connection was made with the lowest workings of the old mine, and a shaft was sunk to a depth of a little more than 300 feet below the Bay City tunnel. This shaft was sunk on the hanging-wall side and about 300 feet $^{70}$ northeast of the place where the Montezuma fault (the fault that cut off the ore body) was crossed in the Bay City tunnel, or a little over 1,600 feet from the portal of the Bay City tunnel. Drifts were driven from this shaft at 119, 208, and 283 feet below the Bay City tunnel, and it is said that attempts were made to go still deeper. But on account of the large amount of water that had to be pumped, and probably also because of financial difficulties, the property was closed and the workings allowed to fill with water. For perhaps 30 years from $^{\circ}$ this time, very little work was done on the property except by an occasional lessee who gouged out small quantities of ore from the upper workings.

Various combinations were effected to work parts of the 91 acres that were held under the names of the Old Emma Mines Co., Emma Copper Co., Emma Consolidated Mines Co., and Emma Silver Mines Co. The holdings of the Emma Silver Mines Co. included the following patented claims: Emma, lot 37 of 5.51 acres; Cincinnati, lot 94 of 5.509 acres; North Star, South Star, Allegan, Hiawatha, Last Chance, Caledonia, Montezuma, Savage, Revolution, Mackay, Dickman, and Cohen. Nearly all these claims are mentioned as producers of rich ore in the early printed reports of the United States Commissioner ${ }^{71}$ of Mining Statistics. The Vallejo and North Star, adjacent claims, situated

\footnotetext{
${ }^{6}$ King, Clarence, Letter, Exhibit C, Emma mine investigațion : 44th Cong., 1st sess., H. Rept. 579, p. 634, 1876.

${ }^{70}$ Beesen, J. J., Report on the property of the Emma Silver Mining Co., p. 15, Nov. 25, 1919.

${ }^{71}$ Raymond, R. W., Statistics of mines and mining in the States and Territories west of the Rocky Mountains, 1869-1875.
} 
between the Emma and Flagstaff, were part of the Joab Lawrence property, organized in 1879 , which was taken into the recent consolidation. Huntley ${ }^{72}$ described the early conditions as follows:

The North Star was one of the earliest claims of the district, having been located in 1865, and has yielded largely. There are said to be large bodies of low-grade oxide of iron ore in the lower levels, but little had been done for some time excepting a small amount of "tribute" work. The Vallejo was worked in $1872,1873,1874,1875$, and 1877 by severat companies, and much ore was extracted. It was being worked on an extensive scale at the time of the writer's visit. The ore was fine and contained from 20 to 45 percent lead, from 15 to 90 ounces silver, from 20 to 35 percent iron, and from 9 to 14 percent of moisture. It was in great demand among the smelters, owing to the lack of silica and the presence of so much iron. A low grade of ore containing from 40 to 50 percent of iron, no lead, and a few ounces of silver was also shipped. The following table shows the price received per ton for some lots of ore in February and March 1880.

\begin{tabular}{|c|c|c|c|}
\hline \multirow{2}{*}{$\begin{array}{l}\text { Woight } \\
\text { (pounds) }\end{array}$} & \multicolumn{2}{|c|}{ Assay value } & \multirow{2}{*}{$\begin{array}{l}\text { Price } \\
\text { received } \\
\text { (per ton) }\end{array}$} \\
\hline & $\underset{\text { (percent) }}{\text { Lead }}$ & $\begin{array}{c}\text { Silver } \\
\text { (ounces) }\end{array}$ & \\
\hline $\begin{array}{r}111,855 \\
76,225 \\
56,877 \\
54,376 \\
74,011 \\
130,304 \\
140,525\end{array}$ & $\begin{array}{r}5 \\
41 \\
42 \\
35 \\
12 \\
43 \\
6\end{array}$ & $\begin{array}{r}5 \\
48 \\
65 \\
39 \\
15 \\
54 \\
9\end{array}$ & $\begin{array}{r}\$ 10.00 \\
66.50 \\
85.10 \\
52.25 \\
17.50 \\
73.75 \\
12.00\end{array}$ \\
\hline
\end{tabular}

The ore was transported from the mine to the tramway of the Wasatch \& Jordan Valley Railway by a wire-rope tramway.

The Joab Lawrence property maintained a steady output for several years, the company having distributed more than $\$ 180,000$ in dividends; but prior to its sale to the new company, the property had been closed for many years, and the owner was loath to disclose the early figures of production to the Geological Survey.

In order to develop the Emma property and find the faulted portion of the lost Emma ore body, the new operator's undertook diamond-drilling from the Bay City tunnel level, under the guidance of J. J. Beeson, who had made a careful study of the geologic structure. The drilling was begun early in August 1916, and in the latter part of September the fourth diamond-drill hole intersected the ore body at a depth of 208 feet. This hole showed the ore body to have a thickness of about 30 feet. Three other drill holes were put down in rapid succession to the northeast, and the ore body was proved to extend on its dip at least 150 feet beyond the Montezuma fault. (See fig. 5.) Shortly after the ore was located the mine was unwatered and put into running condition. The first shipment of ore from the part of the ore body on the east side of the Montezuma fault left the mine early in January 1917. In that year about 9,000 tons of ore was shipped to the

\footnotetext{
79 Huntley, D. B., Mining industries of Utah : 10th census U, S, (1880), vol. 13, p. $4.24,1885$.
}

United States Smelting, Refining \& Mining Co.'s smelter at Midvale, Utah, the net returns from which, after smelting charges and certain freight charges had been deducted, amounted to more than $\$ 251,000$. The mine continued to operate until August 1918, making a total production of 10,362.55 tons of ore, from which the net smelter returns were $\$ 273,742.05$, an average net value of $\$ 26.41$ a ton, or a gross value of about $\$ 35$ a ton. ${ }^{73}$

According to the records of the Geological Survey, 10,378 tons of ore shipped in 1917 and 1918 averaged 14 cents in gold and 39.89 ounces of silver to the ton and 3.42 percent of lead. This ore contained 0.1 percent of copper.

The mine. was closed in August 1918 and a receiver appointed because the company had not done adequate development work beyond the point where ore could be economically mined and was without sufficient funds to continue. Operations were resumed in 1919, in which year 431 tons of ore was shipped.

According to the published records ${ }^{74}$ of past production of the Emma mine, its output in 1880 was 778 tons, obtained by lessees and from the jigs, which sold for $\$ 55,071.54$. According to Charles Smith, of Salt Lake City; whose accounts of ore sales included all but the first few hundred tons sold, the total production of the mine up to June 1, 1880, was 27,451 tons, for which $\$ 2,637,727.44$ was received. Beeson ${ }^{75}$ estimates that the total output of the mine to the end of 1918 was valued at $\$ 3,825,000$.

\section{GEOLOAY}

The geology of the Emma mine (pl. 41) is related to that of the adjacent Tom Moore tunnel. The rocks exposed in the company's claims are Cambrian shale and limestone, Jefferson (?) dolomite, and Madison limestone. In part of the area the limestones are much bleached by metamorphism and are therefore rather difficult of separation. This alteration increases the difficulty of working out the structure, which, as in all the other properties in this part of the district, is too complex to be described in detail and must be gathered mainly from the map (fig. 5). The area is crossed by the Reed \& Benson thrust zone and by higher minor thrust faults, which are not conspicuous but have locally thickened and brecciated the limestones. The area is also crossed by several north-south faults, of which the Montezuma is the most prominent. The Snow fault passes north of the workings on the property. The eastermost workings drift on and cross the Hiawatha fault, which is about parallel to the Montezuma.

The occurrence of the ores is in general similar to that in the Flagstaff and other deposits to the northwest. They have been formed mainly by replacement of one or more beds in the Jefferson (?) dolomite and the lower

${ }^{73}$ Beeson, J. J., Report on the property of the Emma Silver Mining Co., p. 17, Nov. 25, 1919.

7 Huntley, D. B., op. cit., p. 423

${ }^{75}$ Beeson, J. J., op. cit., p. 31. 


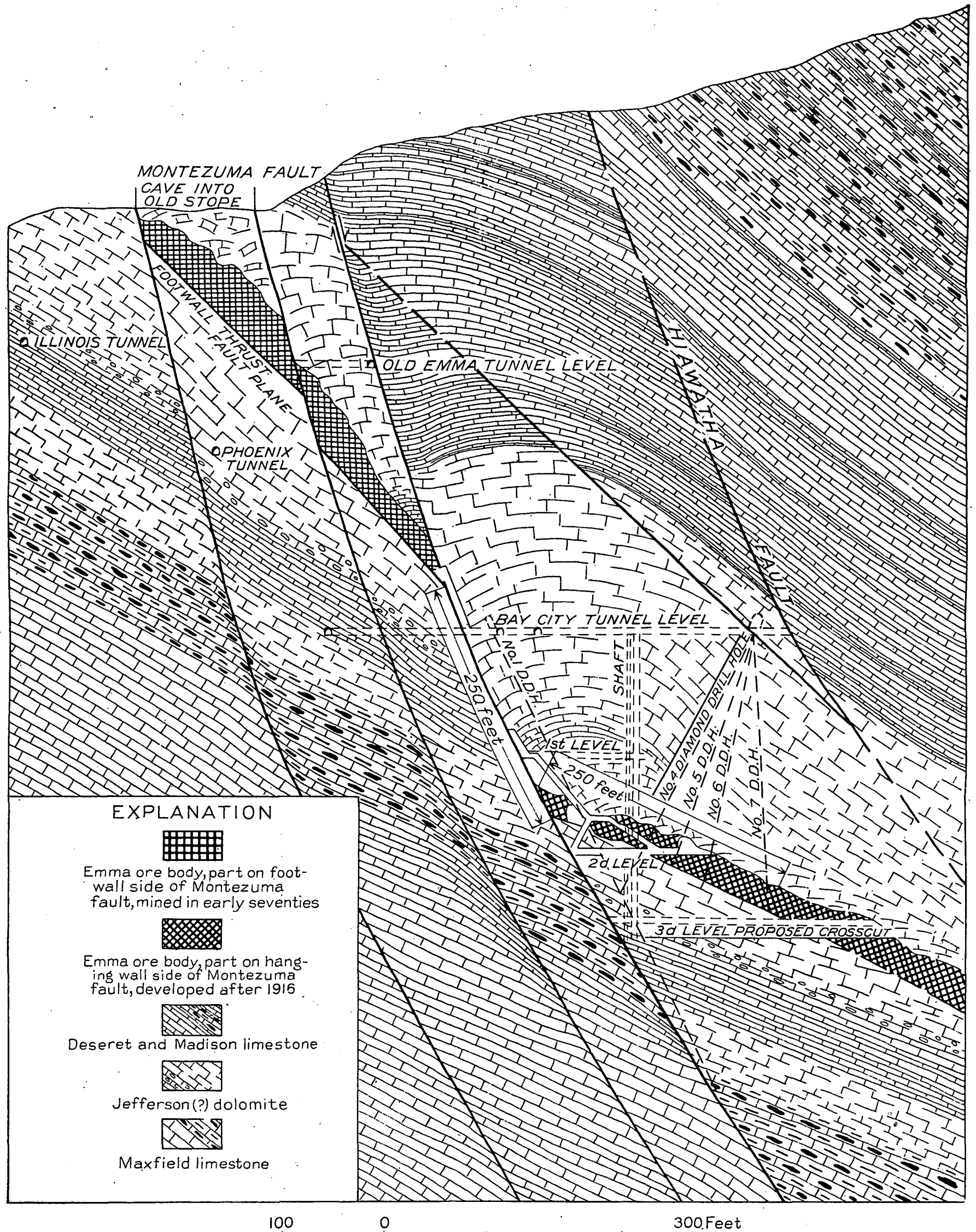

Figure 5.- Section through Emma ore body, showing structure and location of drill holes. After J. J. Beeson. 
part of the Madison limestone. Most of the ore shoots appear to be associated with northeast fissures, though there are a few small deposits associated with northwest fissures. The largest body of ore that has been developed was the Old Emma shoot, a replacement deposit in a breccia zone that probably represents a minor thrust fault. (See pl. $43, A$.)

A geologic cross section (fig. 5) made by J. J. Beeson, geologist of the company, shows the workings and the positions of the main ore shoots.

The ore bodies in this area, as in that to the northwest, appear to decrease in size with increase in depth. This is notably true of the Old Emma body so far as developed. The north-south faults that cross the area have displaced the ore bodies. The largest, the Montezuma fault, with downthrow to the east, displaced the Emma ore body 250 feet.

'The primary mineralization in the Old Emma deposit consisted mainly of the deposition of pyrite and galena in a gangue of quartz or of unreplaced limestone. There are lesser amounts of sphalerite, tetrahedrite, and tungstenite. In the lower workings the ore body contains a core composed mainly of quartz with only a very small percentage of metallic minerals. Around this center the percentage of metallic minerals increases, and there is a further change from ore in which the main gangue is quartz to ore in which unreplaced limestone is the principal gangue (pl. 42, $B$ ) with the metallic minerals occurring mainly as a cement around angular fragments of limestone. (See pl. 42, A.)

In some of the veins in the northwestern part of the property there is considerable manganiferous siderite, which on oxidation gives rise to hydrous oxides of iron and manganese.

The deposits that have been mined in the ground of the Emma Silver Mines Co., except that in the east, or footwall, side of the Montezuma fault, have been partially oxidized. The writer had no adequate opportunity to study the oxidized ores, which were mostly extracted long ago, but from published descriptions they evidently consist mainly of oxides of iron, with which were mingled oxidized compounds of lead, silver, copper, and zinc, but contained residual sulfides. Wulfenite (lead molybdate) is especially mentioned by Silliman as being an abundant minor constituent of the ore, but it seems probable that the supposed wulfenite was really stolzite, which is present in the oxidized ores. Silliman's description would indicate that stolzite in the oxidized ore was quite as abundant as tungstenite in the sulfide ores.

\section{SOUTH HECLA}

HISTORY AND PRODUCTION

The South Hecla mine, which lies just across the valley from the Columbus tunnel, is the largest mine within the mapped area that lies south of Little Cotton- wood Creek. The South Hecla Mining Co., later absorbed by the Alta Merger Mines Co. and now controlled by the Alta United Mines Co., owned 43 claims, covering an area of about 600 acres, southwest of Alta. These formerly constituted several groups, including the South Columbus, Alta-Hecla, and other well-known properties held by the Alta-Quincy, Columbus-Wedge, and Ivanhoe companies. The early history of the camp does not refer to the finding of any great quantity of rich ore near the surface in this territory. The consolidated gruup of claims was developed by two main adits, the Quincy and the Dwyer, 6,000 feet and 3,500 feet long, respectively, driven in a southerly direction and opening up about 7 miles of workings. The Dwyer adit is 8,548 feet above sea level, the Quincy adit 110 feet higher. Development work in the property to the end of 1920 - and it has not been greatly extended since then-comprised 10,400 feet of tunnels, 17,215 feet of drifts and crosscuts, 3,200 feet of raises, and 1,084 feet of shafts. Only silver-lead ore of smelting grade, most of it oxidized, has been mined by the company, considerable low-grade oxidized ore being left in the stopes. In 1916 the company shipped 7,961 tons of silver-lead ore; which contained 68 cents in gold and 20.68 ounces of silver to the ton, 7.76 percent of lead, 0.4 percent of copper, 4.6 percent of zinc, and 4.9 percent of iron.

In 1918 a new body of copper-silver sulfide ore was found in the Dwyer tunnel, and 4,000 tons shipped to the smelter averaged 41 cents in gold and 10.4 ounces of silver to the ton, 5.3 percent of copper, 25 percent of iron, and 15 percent of silica. The total output of the mines from 1911 to the end of 1919, including the output of the several companies taken into the consolidation, was 44,302 dry tons, averaging 56 cents in gold and 17.46 ounces of silver to the ton, 1.35 percent of copper, and 6.34 percent of lead. Two dividends were paid to shareholders in 1916 and 1919 , amounting to $\$ 78,894.95$.

The most important early producer developed by the Quincy tunnel was the Rustler, which had its big output prior to 1885 and according to the present owners shipped ore amounting to $\$ 900,000$ in value. This estimate is based on examination of the old stopes and on many assays taken from the remaining ore pillars. All the ore was mined 400 feet or more above the Quincy tunnel level.

GEOLOGY

The sedimentary rocks exposed on the South Hecla property range from pre-Cambrian to Carboniferous. They are cut by numerous dikes of granodiorite porphyry, which have a general northeasterly strike, and by at least one dike of lamprophyre. The porphyry dikes are mainly if not wholly offshoots from the Alta stock of granodiorite, which lies not farr to the east and which has more or less strongly metamorphosed all the sedimentary rocks penetrated by the workings. (See pl. 44.) 
The geologic structure is a southward continuation of that in the Columbus-Rexall and Columbus workings, on the north side of the canyon (p. 117). The Alta and the higher thrust faults, and the Howland fault, pass through the ground, producing an exceedingly complex structure. Some nearly north-south faults of small throw affect the ore bodies. One of these faults is cut by the Dwyer tunnel and the East No. 1 drift and in the East No. 2 drift from that tunnel. Another has faulted the east ore body in the East No. 1 workings. The largest of these north-south faults is the Howland (p. 65), which, however, has not so large a throw here as farther north. The area is crossed by several orebearing fissures or fissure zones, the most prominent of which are the Wedge and the Kate Hayes; all of these strike northeastward and dip steeply to the northwest.

The structure is especially well displayed in the Dwyer tunnel workings, for they have a wide extent east and west and the Sells tunnel is virtually a westward extension of them. The beds dip in general northeastward throughout the mine, but the general aspect of the rocks is strikingly different in the eastern and the western parts of the Dwyer level.

$A n^{\circ}$ observer entering the Sells tunnel and passing northeastward through it and the western part of the Dwyer workings to the portal of the Dwyer tunnel (pl. 44) would cross a geologic section that, beginning a few hundred feet below the top of the Tintic quartzite, passes upward stratigraphically through the Ophir, the Maxfield-much reduced in thickness by pre-Jefferson (?) erosion-the Jefferson (?) dolomite, the Madison, and most of the cherty Deseret limestone. He would cross or follow several minor faults, but the first areally important fault that he would reach would be the Howland, which passes near the portal. A large dike of granodiorite porphyry, which in places is composite, is prominent in this western part of the mine, and further east the workings are partly in what may be a cupola or pipe extending from the Alta stock of granodiorite. The Wedge fissure is conspicuous near the east end of the drift, but its westward extent is somewhat uncertain, and the workings follow several other fissures.

A striking change in the aspect of the walls occurs a little east of the portal, where the No. 1 East drift crosses the lowest overthrust of the Alta thrust zone: The thrust here brings Cambrian shale over the Deseret limestone, instead of quartzite as at the surface. East of this great fault the dominant country rock is Ophir shale, all of which impressed the writer (Calkins) as probably belonging to the upper shale member of the Ophir, though the area next to the Alta overthrust is colored as lower Ophir on an unpublished map by R. T. Walker. The shale of this western area is overlain by limestone-Maxfield if the shale is upper Ophir-upon which is thrust what Walker and the writer agree to be upper Ophir shale. Near the easternmost point in the workings the shale is faulted against limestone that is clearly marked as Maxfield by a pisolitic texture not wholly effaced by metamorphism; and this in turn is faulted against more shale, believed also to be upper Ophir, by what may be an inverted thrust fault. The dips of the bedding and of faults in this vicinity are westward and are probably overturned as they are on the surface to the north.

These eastern workings cut several fissures and dikes, and a southern branch reaches coarse granodiorite that probably is part of the Alta stock.

The Quincy level also exposes the lowest Alta overthrust. East of this great fault there has been very extensive prospecting in the Ophir shale, which is intensely metamorphosed and cut by many dikes of granodiorite; west of the fault a drift on and near the Kate Hayes fissure extends through Deseret limestone into the Madison. Most of the mining that has been done from this level was on the Kate Hayes fissure in the Deseret limestone, but stoping has been done in several other places. So far as known, none of the stopes reach the Alta overthrust.

\section{ORE DEPOSITS}

Two types of ore deposits have been developed in the mine-contact deposits and replacement deposits associated with fissures. These types, however, are not entirely distinct.

Most of the contact deposits are rather closely associated with dikes that occupy fissures resembling the other ore-bearing fissures in attitude, though dikes have not everywhere been exposed where deposits of this type have been found. The deposits are in general similar to those in other parts of the district, consisting mainly of magnetite, pyrite, chalcopyrite, and at some places bornite, in a gangue of garnet and other silicates. In the South Columbus tunnel ludwigite is rather abundant, but little sulfide is associated with this mineral. Here, as elsewhere in the area, the contact deposits are on the whole of relatively low grade, though some ore from them has been shipped.

The main production from the mine has come from the replacement deposits associated with fissures. This has come principally from four ore bodies, three of which are associated with the Wedge fissure system and one with the Kate Hayes fissure.

The No. 1 ore body is in the west workings of the Dwyer tunnel. The ore shoot occurs in a breccia zone at the intersection of the Wedge fissure and a bed of limestone near the base of the cherty Deseret limestone. It has been developed from below the Dwyer level to the surface. The ore in this shoot is mainly oxidized, consisting of carbonate of lead and the basic lead-iron sulfate plumbojarosite, together with oxide of iron in the upper part and some residual sulfide throughout. Copper minerals and probably some antimony compounds are present to a minor extent. The principle value of this ore is in lead and silver. The gangue 


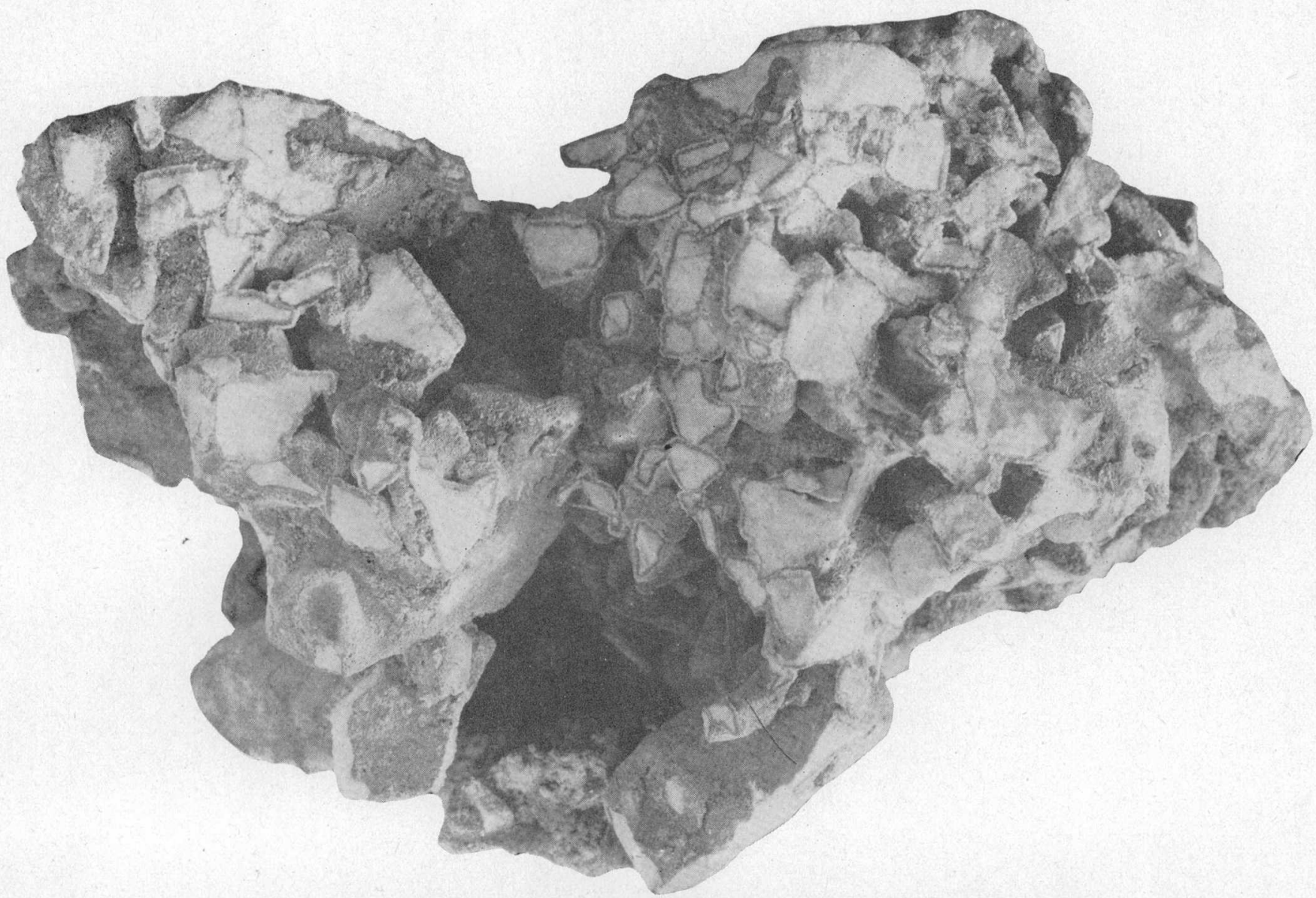

A. LIMESTONE BRECCIA, OLD EMMA MINE.

Slightly reduced.

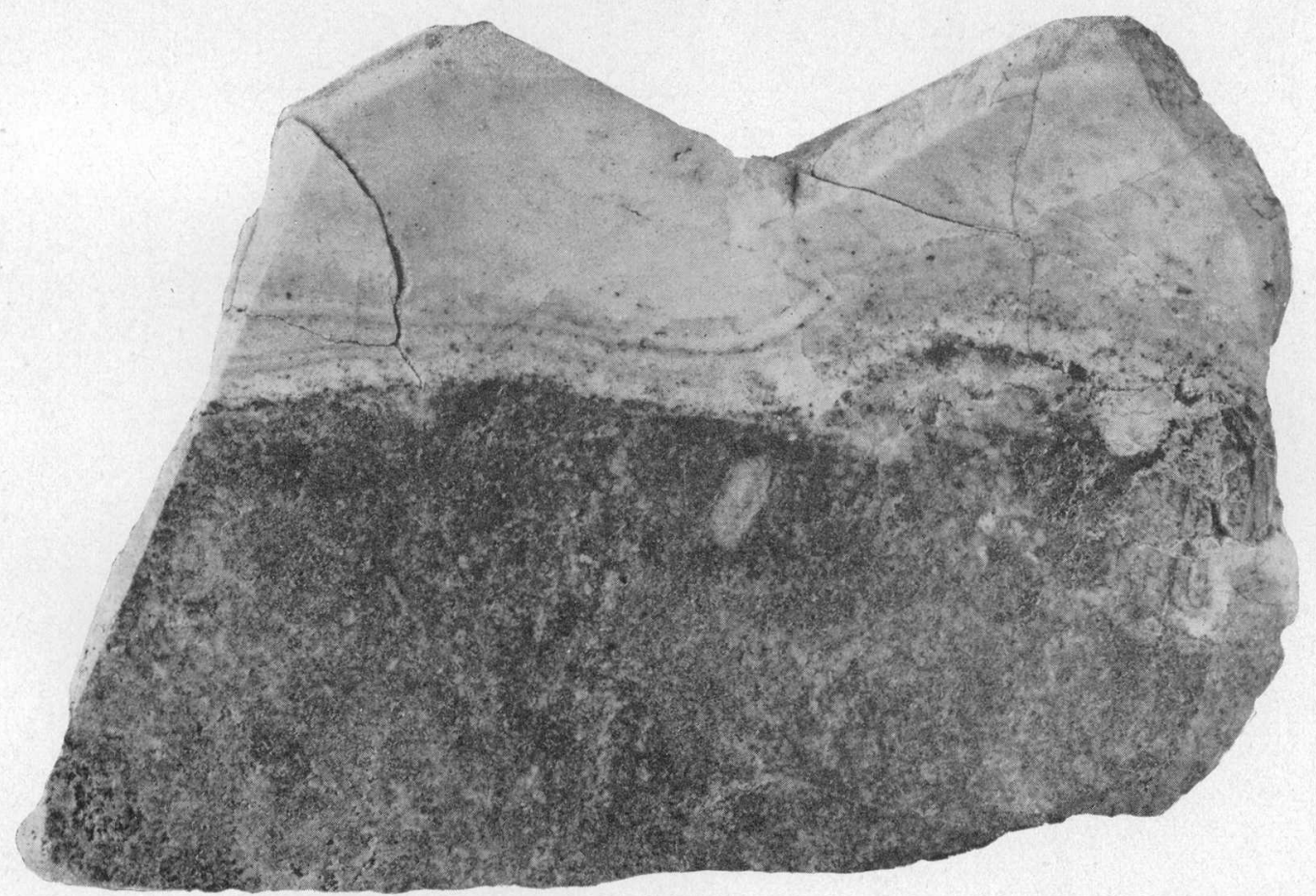

B. REPLACEMENT BANDING IN LIMESTONE ORE, OLD EMMA MINE.

Natural size. 


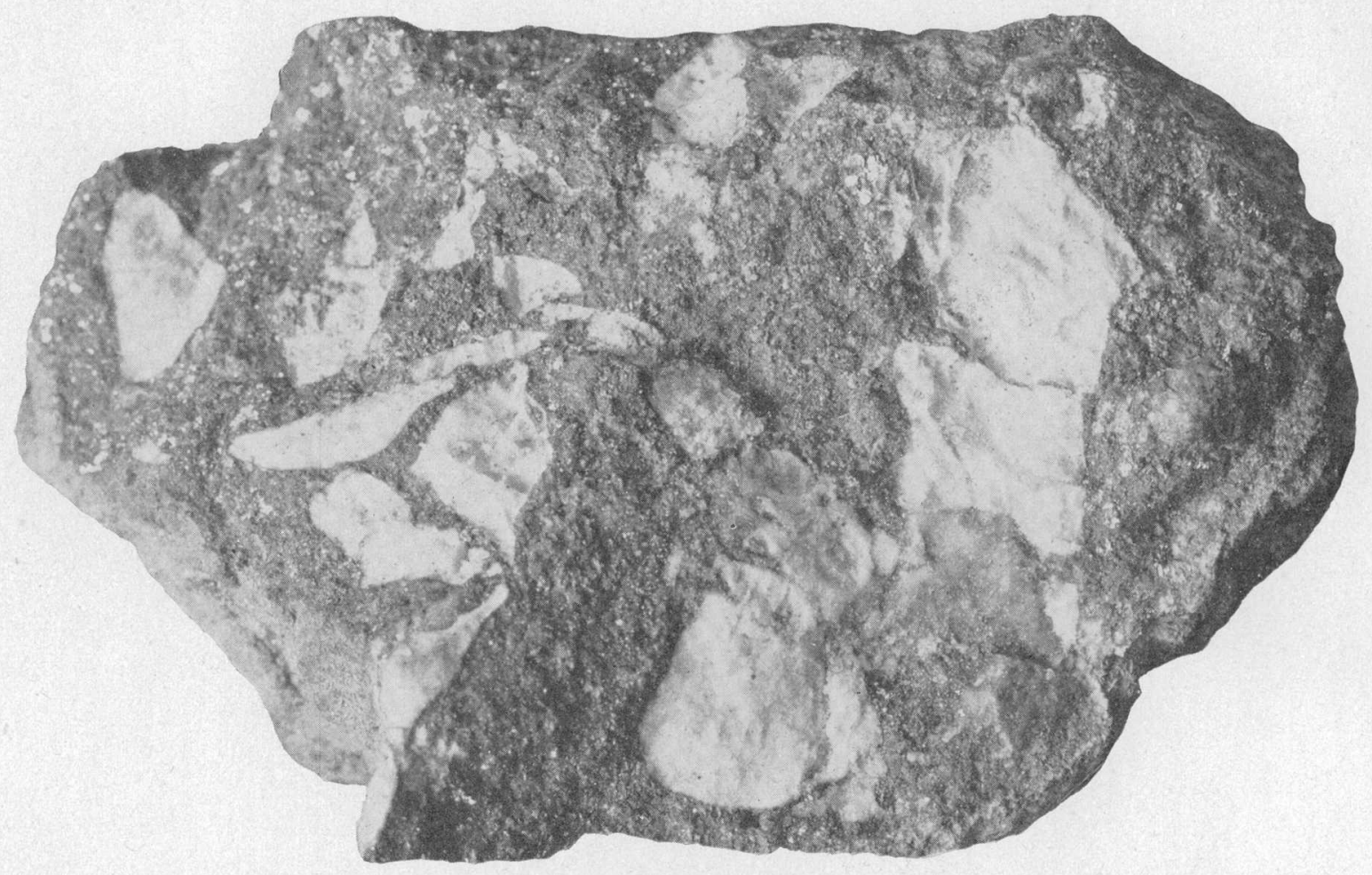

A. MINERALIZED LIMESTONE BRECCIA, OLD EMMA MINE.

The limestone is magnesian. $\times 1 \frac{112}{2}$

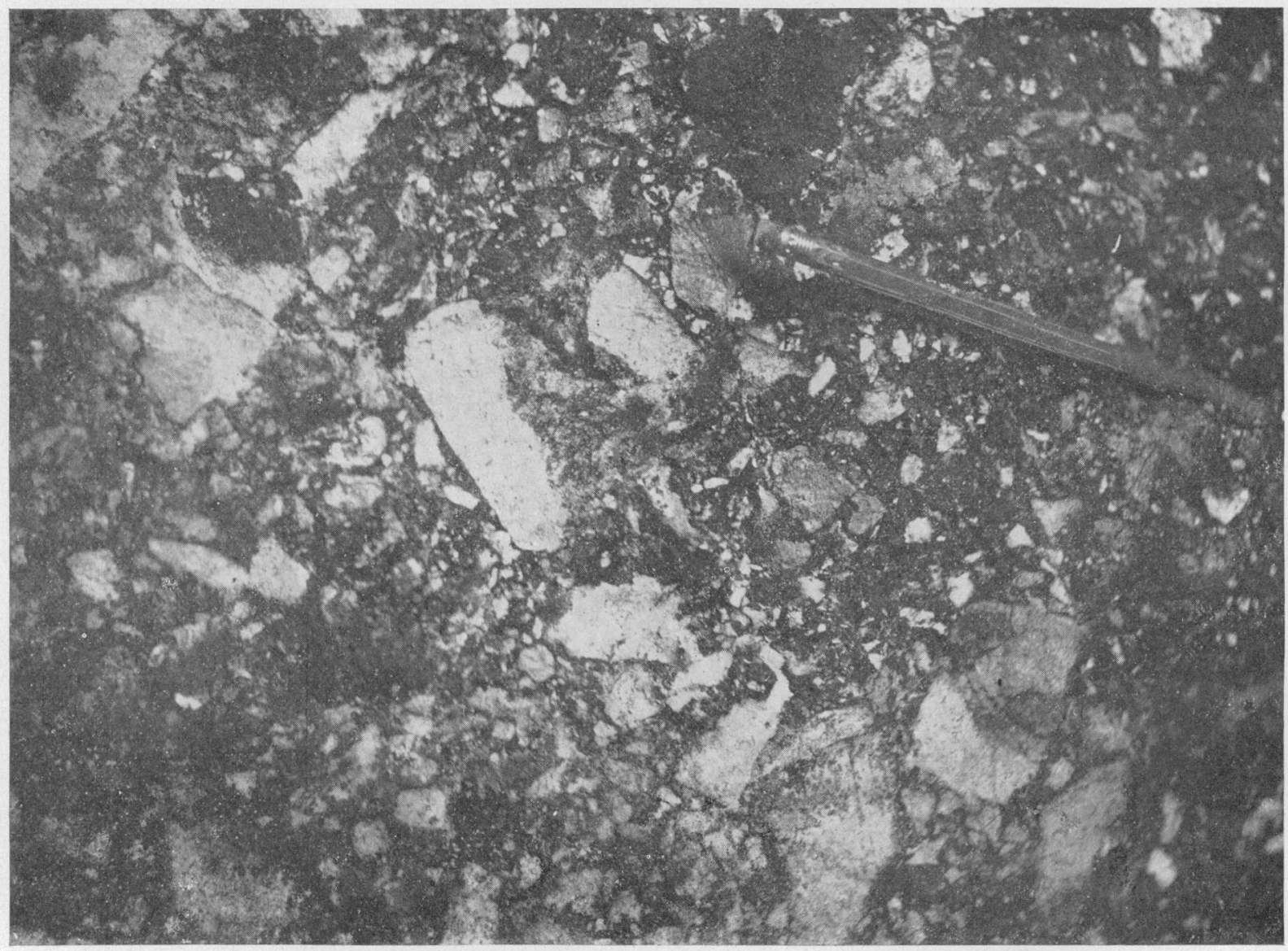

B. MINERALIZED LIMESTONE BRECCIA, NO. I SHOOT, SOUTH HECLA MINE,

About half natural size. 
consists mainly of unreplaced masses of limestone breccia (pl. $43, B$ ), and it is a common practice to screen much of the ore to remove these fragments of limestone.

The No. 2 ore body, which is also developed by the west Dwyer workings, lies farther west and somewhat lower in the limestone series than the No. 1 body. Like the latter body, it has been formed by the replacement of brecciated limestone adjacent to the Wedge fissure, but it pitches to the west across the bedding and is rather closely associated with a porphyry dike, which occupies a fissure along which the limestone appears to have been brecciated before the dike was intruded. There was further brecciation when the Wedge fissure was formed, and physically favorable conditions were thereby produced. The shoot has been followed from a point a short distance above the Dwyer level to the surface. The ore is similar in character to that of the No. 1 shoot.

The ore body that has been developed on the Kate Hayes fissure is in the East No. 4 drift from the AltaQuincy tunnel. It was formed by replacement of limestone breccia adjacent to the Kate Hayes fissure. The breccia to the east dips with the bedding of the limestone, probably at about the same stratigraphic horizon as the No. 1 shoot. The ore is similar in character to that of the shoots just described.

In the east workings, in the northern part of the property, the ore thus far developed is above the main, or lower, Alta overthrust fault. The rocks above this fault consist mainly of the Ophir formation, with some of the overlying limestones, which have been repeated by overthrust faults. The East ore body was formed by replacement of what is taken to be the Maxfield limestone, below one of the thrust faults. The ore shoot, which has been followed from the Dwyer level to the surface, occurs where the limestone member is crossed by the Wedge fissure. The limestone has been followed southwestward, but without finding any other important ore shoot.

Considerable ore is said to have been produced from an ore body developed near the south end of the Rustler tunnel, but this body was not examined. It is possibly on the Kate Hayes fissure system.

The primary ore of the South Hecla mine consists of pyrite with varying proportions of tetrahedrite, enargite, and bornite, and some galena and sphalerite. The principal value of this ore is in its copper and silver content.

It is not impossible that other ore bodies may be found in the South Hecla mine. The thrust contact between the Tintic quartzite and the Deseret limestone, on which the largest ore bodies in the Columbus Rexall and Cardiff mines were formed, is prominent at the surface on the west side of Collins Gulch, but its outcrop is all south of the area underlain by the South Hecla workings. There may be ore bodies where this thrust contact is crossed by fissures south of the Kate Hayes fissure, but there may be no such intersections within the boundaries of the property.

The thrust contact between the Ophir shale and the Deseret limestone seems to deserve more exploration than it has received. This contact has indeed been followed on the Dwyer level for several hundred feet and has been crossed on the East No. 3 drift of the AltaQuincy tunnel, but apparently it has not been fully prospected where crossed by the ore-bearing fissures that under favorable conditions have made ore shoots.

Occurrences of scheelite in the mine are described on page 97 .

The South Columbus tunnel (pl. 44), east of the Dwyer and in the Alta United property, goes straight southeastward for nearly 1,300 feet, and has branches about 500 feet in aggregate length. Most of it is in highly metamorphosed shale of the upper shale member of the Ophir, but the outermost part is in the limestone member of the Ophir and the inner end is in the Maxfield limestone. The general strike of the beds is such that they converge northward at an acute angle with the course of the tunnel. Their dips are mainly northwestward at angles of $35^{\circ}$ to $90^{\circ}$, but are prevailingly near $45^{\circ}$; all these are interpreted as reverse dips. The rocks are cut by many fissures, mostly of northeasterly strike and steep north dip; and there probably has been some dislocation on these, but there is no evidence of any large fault.

A 12-foot dike of granodiorite porphyry crosses the tunnel about 220 feet from its portal; this is probably the same as the nearest dike exposed in the Dwyer tunnel. Lamprophyre that may belong to the dike exposed in the southeastern part of the Dwyer East One workings is exposed at two places in the South Columbus, where the rock seems to be broken by small faults.

The South Columbus workings did not reveal any ore body so far as known, though it crosses fissures that were productive on or above the Dwyer level. The most interesting observations to be made in the workings relate to the Maxfield limestone near the face of the straight tunnel. This rock is largely dolomite, as determined by testing with 10 percent $\mathrm{HCl}$. It contains ludwigite in small aggregates, and at the face it shows some fluorescence, under the ultra violet lamp, that is probably due to scheelite.

\section{SELIS}

The Sells group of 16 claims, acquired by the South Hecla Mining Co. in 1922 and now belonging to the Alta United Mines Co., is on the south side of Little Cottonwood Canyon and west of the South Hecla mine. It was worked from the Dwyer adit of the South Hecla Co., but it was connected for ventilation with the old Lexington tunnel, now commonly called the Sells tunnel (pl. 44). An aerial tram 2,000 feet long, with a capacity 
for carrying 10 tons of ore an hour, was erected in 1918 to connect the portal of the Lexington tunnel with the narrow-gage railroad to Wasatch. The Sells Mining Co. was incorporated in 1914, and during the same year it shipped a small quantity of silver-lead ore. Shipments of ore were continued in 1916 and for some years later, and at the end of 1919 they had amounted to 4,013 tons, containing an average of $\$ 1.03$ in gold and 29.22 ounces of silver to the ton, 7.29 percent of lead, and about 0.5 percent of copper. All the ore contains some bismuth, and two car lots contained over 3 percent of bismuth, which was paid for at the lead smelting works. The most abundant original bismuth mineral was probably aikinite, which has been altered in part to bismite.

Specimens of the bismuth ore were examined by M. N. Short, who made the following statement concerning it:

Aikinite, $\mathrm{Cu}_{2} \mathrm{~S} .2 \mathrm{PbS} \mathrm{Bi}_{2} \mathrm{~S}_{3}$, Sells Mine, Alta, Utah.

Aikinite is of unusual interest because it has hitherto been reported only from Beregov, in the Ural Mountains of Russia. In the Sells mine it is associated with tetrahedrite and galena. All three minerals are closely intergrown and apparently were deposited at the same time. Crossing all three minerals is a network of microscopic veinlets containing covellite and a transparent gray mineral, probably cerusite or anglesite. In places the veinlets also contain irregulár yellow patches of bismite $\left(\mathrm{Bi}_{2} \mathrm{O}_{3}\right)$.

Aikinite has the following properties:

Under the reflecting microscope: Color galena white, slightly darker than galena. Hardness about the same as galena and gofter than tetrahedrite. Strongly anisotropic in polarized light; polarization colors with incandescent lamp creamy white, dark brown, black.

Etch tests: $\mathrm{HNO}_{3}$, quickly effervescences and leaves white coating on surface; $\mathrm{HCl}$, negative; $\mathrm{KCN}$ negative; $\mathrm{FeCl}_{3}$, stains faintly light brown; $\mathrm{KOH}$, negative; $\mathrm{HgCl}_{2}$ negative.

The mineral gives excellent microchemical tests for copper, lead, and bismuth.

The Sells workings, like the western part of the Dwyer level, are in the rocks below the Alta overthrusts. The sedimentary rocks, which dip eastward, are older than those in the adjacent part of the South Hecla; they consist of the Cambrian quartzite, the Ophir shale, the Maxfield limestone, the Jefferson (?) dolomite, and part of the Madison. These rocks are cut by dikes and fissures of northeasterly strike as in the South Hecla ground and by two faults of northwesterly strike.

The ore deposits thus far developed are similar in occurrence to those of the South Hecla mine. The deposits in the Skipper tunnel were not examined but are said to have been formed by replacement of limestone adjacent to the Skipper fissure. In the Lexington workings the main ore shoot developed was formed by the replacement of brecciated limestone which probably is mainly Jefferson (?) but in part Cambrian. This shoot has been followed for several hundred feet above the Lexington tunnel. The tunnel also cuts the limestone member of the Ophir shale. At the intersection of the fissure and the limestone member on the Lexing- ton level some mineralization has occurred, but there is little ore. At the time of visit it was planned to prospect this limestone by a raise, and it is reported that ore was encountered in the raise.

\section{NATIVE COPPER}

The Native Copper group is in Peruvian Gulch, south of the Sells mine. The sedimentary rocks include the Cambrian quartzite, the Ophir shale, and the overlying Maxfield limestone: The northern tunnels of this group have prospected a fissure in the quartzite containing some high-grade copper ore, but no large body has been developed.

The southern tunnel starts in the Ophir shale, and in 1919 had been extended into the overlying Maxfield limestone. For much of its length the tunnel closely follows a diorite porphyry dike, along which the adjacent rocks are considerably disturbed. Much of the prospecting in this tunnel and practically all the ore developed has been in the limestone member of the Ophir shale.

\section{PERUVIAN CONSOLIDATED MINING CO.}

The Peruvian Consolidated Mining Co. owns property in Peruvian Gulch next to the Oxford and Geneva, two early patented claims which adjoin it on the south. Between 1911 and 1919 about 700 tons of ore was shipped, averaging $\$ 1.24$ in gold and 6.76 ounces of silver to the ton and 14.43 percent of lead. Some of the ore contained a little copper.

The outcropping sedimentary rocks are similar to those on the properties to the north-namely, the Cambrian quartzite, the Ophir shale, and the overlying Cambrian, Devonian (?), and Mississippian limestones. These rocks are cut by several dikes of diorite porphyry with northeasterly strike. They are displaced, also, by east-west faults (pl. 4), and in the lower tunnel a fault striking about. N. $20^{\circ} \mathrm{W}$., with downthrow to the west, repeats the Ophir on that level.

The ore has replaced brecciated limestone along a fissure that strikes northeastward. Mineralization has occurred both in the limestone member of the Ophir shale and in the overlying Maxfield limestone.

\section{PROSPECTS IN AND NEAR PERUVIAN GULCF}

There are some prospects, on fissures striking northeast, in the quartzite west of the Ophir shale. None of these were operating at the time of visit, but the ore seems to consist mainly of pyrite and tetrahedrite, with some galena, in a quartz gangue.

Many prospects have been opened near the head of Peruvian Gulch south of the Peruvian mine, but none of these were in operation at the time of visit and little could be seen of the workings. The ore here, as farther to the north, appears to be associated with fissures of northeasterly strike. 
COTTONWOOD-ATLANTIS MINTNG CO.

The ground of the Cottonwood-Atlantis Mining Co. is on Mount Baldy. The sedimentary rocks there include Mississippian limestone below the Aita thrust and Tintic quartzite and Ophir shale above it. The limestone is exposed at the surface through the overthrust in a "window" bounded on the northwest by a fault.

These rocks are cut by several dioritic dikes, which have a general northeasterly trend and some of which occupy fissures that have later been ore channels. The most prominent structural feature is the Alta overthrust. Other thrusts in the quartzite are most conspicuous near the top of Mount Baldy, where they bring Tintic quartzite over Ophir shale. There has also been some movement on the fissures occupied by dikes, along which ore solutions rose.

Mineralization has taken place along fissures in certain of the beds of Mississippian limestone, in the limestone breccia along the Alta thrust, and in the quartzite above the Alta thrust. Most of the ore taken from the property has come from the deposits in the fault breccia and from the Defiance fissure in the overthrust. quartzite.

ALBION

HISTORY AND PRODUCTION

The Albion Consolidated Mining Co. owned many mining claims adjoining the South Hecla mines. Its property was acquired by the South Hecla Mining Co. in 1921-22 and is now part of the Alta United holdings. The group covers about 580 acres, including the claims of the former Albion Mining Co., Alta Germania Mines Co., and Mineral Flat Mining Co. The Mineral Flat property extends into the head of American Fork Canyon. The Albion, one of the early patented claims, was operated by the Wellington Mining Co. It was located July 19, 1870, near the summit between Little Cottonwood and American Fork Canyons, and according to the present-operators it produced from shallow workings about $\$ 1,000,000$ worth of ore. According to Raymond, ${ }^{i 6}$ the developments in 1872 consisted of an inclined shaft 200 feet deep and about 800 feet of drifts. The ore deposit was about 30 feet wide, with an ore layer about 4 feet thick on each wall and a horse of the country rock between. The ore was rather pockety but yielded something over expenses. One body of ore, estimated at 600 tons, was uneovered at a depth of about 100 feet. In 1873 about 300 tons of ore, sampled in Salt Lake City, and various small lots sold to the smelters, assayed 52 to 56.5 ounces of silver to the ton and 28 to 34 percent of lead. ${ }^{77}$ For 1874 the entire output was about 70 tons of ore, which assayed about 65 ounces of silver to the ton and 50 percent of lead. ${ }^{78}$

\footnotetext{
${ }^{70}$ Raymond, R. W., Statistics of mines and mining in the States and Territories west of the Rocky Mountains for 1872, p. 248, 1873.

7 Idem for 1873, p. $261,1874$.

78 Idem for 1874, p. $336,1875$.
}

According to the Director of the Mint, shipments amounting to 200 tons of ore were made in 1886 and an unspecified quantity of ore was shipped in 1887.

A 20-ton smelting furnace, ${ }^{79}$ probably the one at Tanners Flat, was owned by the Wellington Co., but no record of the quantity of ore treated there has been found.

The old Albion workings are inaccessible, the lower tunnel being caved and the shaft filled with water. Its location is shown in plate 1 , and the upper workings are shown with more detail in plate 45 . In recent years most of the development work in Albion ground has been done from the Quincy tunnel, 6,000 feet long, the portal of which is near that of the Dwyer tunnel of the South Hecla Co. A small jig concentrator at the old shaft was operated by lessees in 1917 but subsequently dismantled.

Between 1905 and 1918 nearly 700 tons of lead-silver carbonate ore was shipped, averaging $\$ 2.76$ in gold and 41.53 ounces of silver to the ton, 23.84 percent of lead, and about 0.3 percent of copper.

\section{GEOLOGX}

The Albion ground is mainly west of the Silver Fork fault. The sedimentary rocks exposed at the surface on this side of that great fault include Tintic quartzite, Ophir shale, and Maxfield limestone, all of Cambrian age. East of the Silver Fork fault the sedimentary rocks are Tintic quartzite and the underlying Cambrian (?) tillite. The area contains many dikes having a general northeasterly strike.

The sedimentary rocks, especially those near the old Albion shaft, have been overturned in places and have undergone thrust faulting and normal faulting. (See pl. 3.)

The ore deposits have been formed by the replacement of limestone adjacent to northeast fissures. The largest production has come from the old Albion mine, in which the ore was mainly in the limestone member of the.Ophir shale where that rock is cut by the Wellington fissure: There are several of these intersections, for, because of the complex faulting already noted, the limestone member of the Ophir is several times repeated. Most of the ore has been obtained above the upper tunnel level, though some ore has been mined through a winze below the upper tunnel. The lower tunnel was not accessible at the time of visit, but little ore is said to have been encountered on that level. In recent years prospecting in Albion ground has been carried on mainly from the AltaQuincy tunnel of the South Hecla mine. At the time of visit the workings from the Alta-Quincy tunnel had not reached a point beneath the old Albion workings. They are in the Ophir shale and the Cambrian, Jefferson (?), and Carboniferous limestones above the lower Alta thrust fault but beneath the thrust zone cut by the uppertunnel workings. Ore minerals had been encountered

${ }^{70}$ Salt Lake Tribune, Jan. 31, 1873. 
along dikes and also on fissures, but no large body of ore had been found.

The Mineral Flat portion of the group, in the head of American Fork Canyon, has been developed by two tunnels. The country rocks on the surface near these tunnels are Cambrian, Jefferson (?), and Madison limestones and shales broken by many small faults; all are in the block beneath the. Alta overthrust and are cut off at the east by the Silver Fork fault. The upper tunnel starts in the upper member of the Ophir shale, is in this member for about 300 feet, and in Cambrian limestone nearly an equal distance. At about 300 feet from the portal the tunnel cuts a fissure striking $\mathrm{N}$. $45^{\circ} \mathrm{E}$. and dipping $65^{\circ} \mathrm{NW}$. This has been prospected for about 300 feet to the east, and some ore replacing Cambrian limestone has been found. A fault striking northwest passes only a few feet west of the portal of the tunnel, and the tunnel apparently runs nearly parallel to this fault. The ore, so far as could be judged from material on the dump, was an oxidized leadsilver ore with rather abundant barite gangue.

The lower tunnel is driven about N. $20^{\circ}$ W., across the trend of the fissures, for about 2,500 feet. At the time of visit no work was being done, and it was impossible, because of bad air, to examine more than about half the length of the tunnel. The portal is in the limestone member of the Ophir shale, which is succeeded by the upper shale member. About 285 feet from the portal the tunnel passes out of the upper Ophir and from that point is in Maxfield limestone to the east and west drifts, which was as far as it could be examined. The thickness of Maxfield limestone thus traversed is considerably greater than that found at most places below the Alta thrust fault, and the Jefferson (?) dolomite was probably reached not far beyond the drifts. So far as is known to the writer, no ore was found in the lower tunnel.

\section{DAVENPORT}

The Davenport claim, which extends about northnortheast across Davenport Hill, is 1,800 feet long and 100 feet wide. It was located by-Tim Sullivan on June 17, 1870, and later patented as lot 45 . To the end of 1871 fully 2,500 feet of development work, consisting of several inclined shafts and drifts and a tunnel 600 feet long, had been done, and considerable ore was exposed on the lower levels. About 3,000 tons of ore had then been shipped. According to Raymond, ${ }^{80}$ it was, an earthy-looking oxidized ore, largely lead carbonate, derived from the decomposition of argentiferous antimonial galena. It averaged 90 ounces of silver to the ton, yielded in all 575 tons of lead bullion, and had a total value of $\$ 200,000 .^{81}$ In 1872 the mine was sold with the Matilda claim nearby to an English com-

\footnotetext{
${ }^{80}$ Raymond, R. W., Statistics of mines and mining in the States and Territories west of the Rocky Mountains for 1871 , p. 319, 1872.

${ }^{81}$ Utah Min. Gazette, vol. 1, p. 181, Salt Lake City, Jan. 31, 1874
}

pany. ${ }^{82}$ Smelting works are said to have been then in course of construction near the mouth of Little Cottonwood Canyon, where most of the ore was smelted, and some lots are supposed to have been reduced at Tanners Flat, below the village of Central. The Davenport and Matilda were worked continuously up to May 1873 , when a new management took possession. At that time ${ }^{83} 765$ tons of ore was stored at the furnaces and 200 tons at the mine. The ore deposit in the Davenport had so far (1873) averaged 5 feet in width. It was very ferruginous, and it ordinarily contained at least 60 or 70 ounces of silver to the ton but only 12 to 18 percent of lead. Because of this poverty in lead it could not be smelted without great loss. The new manager therefore arranged to buy rich lead ore to mix with the Davenport ore, but before these arrangements could be carried through the eastern financial panic of 1873 caused the mine to be closed. Huntley ${ }^{84}$ says that the total output up to the end of 1880 was valued at $\$ 600,000$. No records of production after 1880 have been found, and since 1901 no production has been reported to the Geological Survey.

\section{ALTA CONSOLIDATED}

HISTORY AND PRODUCTION

The Alta Consolidated Mining Co. owns about 120 acres of mineral ground, which covers the mineralized zone between the Emma and Michigan-Utah mines. Most of the later development has been carried on from the Silver King adit, which is the main level, and the Lower Copper Prince (Brooklyn) adit, where most of the early development work was done. (See pl. 46.) In 1905 some lead ore was shipped from the Silver King adit. From its organization in 1911 to the end of 1919 the company shipped nearly 4,500 tons of ore. This ore averaged 12 cents in gold and 30.21 ounces of silver to the ton, 10.9 percent of lead, and 2.22 percent of copper. A company of the same name shipped to the Pioneer sampler, near Salt Lake City, 969 tons of ore in 1877 and 232 tons in 1878, but no record of the content was kept, and it is not known what claims were developed by the company at that time. Some magnetite was shipped from the Copper Prince tunnel probably in 1919 .

$$
\text { GEOLOGY. }
$$

The oldest sedimentary formation exposed in the property is the Tintic quartzite, and the youngest is the Deseret limestone, but the Maxfield limestone is cut out by the erosional unconformity at the base of the Jefferson (?) dolomite, which is in contact with the limestone member of the Ophir shale in some places and with the lower part of the upper shale member of that formation in others. The sedimentary rocks have been considerably metamorphosed by the Alta stock of grano-

\footnotetext{
82 Raymond, R. W., op. cit. for 1872 , p. 248,1873 .

83 Raymond R. W., op. cit. for 1873, p. $261,1874$.

8s Huntley, D. B., 10th Census U. S. (1880), vol. 13, p. 426,1885
} 
diorite, which is exposed within a short distance to the south, and they are cut by a prominent alaskite porphyry dike (the Grizzly dike) striking northeast. The Grizzly overthrust fault repeats the Cambrian limestone near the top of the ridge. The Silver Fork fault crops out in the steep gulch west of the main workings, and where it crosses Grizzly Gulch it brings the Carboniferous rocks on the west into contact with the Cambrian on the east. Where exposed in the upper workings the fault dips $45^{\circ}-50^{\circ} \mathrm{W}$. and is marked by a wide zone of heavy ground. It cuts off the fissures and ore bodies.

Several fissures striking N. $40^{\circ}-60^{\circ}$ E. and dipping steeply to the north cross the property. The fissure known as the Brooklyn and thought by some to be the Brain is the most prominent and is, like the Brain, a normal fault of small throw. It is followed by the main drift in the Silver King tunnel. Other fissures are the Silver King, Hoboken, and Davenport. The main structural features of the property are shown in plate 46.

The mine contains two types of ore deposits-contact deposits and replacement deposits associated with fissures. The contact deposits are closely associated with offshoots from the Alta and Clayton Peak stocks. They consist of magnetite, contact silicates, and some pyrite and chalcopyrite, all of which have replaced limestone or other calcareous rocks. Under very favorable conditions some ore of this type has been shipped, but under ordinary conditions it has not paid. Replacement deposits have been found on several of the fissures already noted, the largest being the Brooklyn fissure. Only a few of the limestone beds have been replaced extensively enough to form strong shoots of ore. The limestone member of the Ophir shale has been a favorable bed, and a bed near the base of the Jefferson (?) dolomite contains shoots of ore. There are also small shoots of ore at the base of the Deseret limestone. In the Hoboken workings and in the Bone tunnel pockets of ore have been developed rather continuously along the intersection of this bed with the Hoboken fissure. The largest deposits in this zone appear to have been formed near its intersection with a fissure containing an. alaskite porphyry dike.

In the upper workings the ore was largely oxidized, but in the lower workings on the level of the Prince tunnel it is mainly sulfide.

\section{MICHIGAN-UTAH}

HISTORY AND PRODUCTION

The Michigan-Utah Consolidated Mines Co. held 70 mining claims (48 patented), which with a mill site cover 470 acres of mineral land in the Little and Big Cottonwood districts. The property extends from the head of Grizzly Gulch, a headwater branch of Little Cuttonwood Creek, into the Honeycomb and Solitude Forks of Big Cottonwood Creek. Consolidation at various times has brought together into one group the property formerly operated by the Black Bess, City Rocks, Utah Mines Coalition, Lavinia, Grizzly, Darlington, Regulator, and Continental-Alta or Unity Mining Cos. to form what became known as the Michigan-Utah mine.

Several formerly producing mines of local fame are included in the group, but the complete records of early output were not available. From 1901 to the end of 1919 the output records of the Black Bess, City Rocks, Continental-Alta, and Michigan-Utah Cos. have been very complete. Altogether 50,681 dry tons of ore, including a very small output of concentrate, was shipped during this period. Its average content was 52 cents in gold and 16.5 ounces of silver to the ton, 9.12 percent of lead, and 1.2 percent of copper, but many of the shipments were sensationally rich in silver and carried high percentages of lead and copper. During the war period several cars of high-grade manganese ore was marketed. In 1905 the Continental-Alta Co. built a 5-mile Riblet aerial tramway, with a maximum capacity of 200 tons of ore daily, and after the formation of the Utah Mines Coalition, about 1911, the City Rocks mine was equipped with an aerial tramway, which was connected with the Riblet tramway. All the ore from these properties was thus delivered to Tanners Flat, and thence by narrowgage railway to Wasatch, where it was transferred to the standard-gage Salt Lake \& Alta Railroad running to the valley smelters. When the tramway was built a concentration mill was erected at Tanners Flat, but it operated only a short time.

The mines are opened through several adits, and the developments consist of about 65,000 feet of workings. (See pl. 46.) The deepest adit is the Solitude tunnel, whose portal is west of Solitude Lake, in the basin of Big Cottonwood Creek, at an altitude of 9,102 feet. This tunnel was driven westward for 2,000 feet, all in limestone, and connected by a 300 -foot raise with the Cleves tunnel, 1,800 feet long, which was driven eastward from the head of Grizzly Gulch. Some workings on the City Rocks fissure extend as much as 200 feet vertically downward from the Solitude level.

\section{GEOLOGY}

The sedimentary formations that crop out on the Michigan-Utah property include the series from the Tintic quartzite (Cambrian) to the Desseret limestone (Mississippian). The quartzite and a part of the Ophir are exposed in Patsy Marley Hill, as the brow of the spur south of Grizzly Gulch is called. Here the Jefferson (?) dolomite rests on lower Ophir shale, the unconformity at the base of the Jefferson (?) being stratigraphically at the lowest level that it reaches in the Cottonwood-American Fork area. In the slope that is penetrated by the main tunnels, on the contrary, above the Grizzly overthrusts, the same unconformity lies near its highest stratigraphic level. This contrast affords evidence of the greatness of the movement on 
these overthrusts, and parallels the similar contrast presented by the blocks above and below the Alta thrust zone west of the Silver Fork fault.

The area is bordered on the south by the Alta stock of granodiorite, and several dikes from this body extend into the sedimentary rocks. A prominent dike, also, of white alaskite porphyry, referred to as the Grizzly dike further back, extends northeastward across the area, and several dioritic dikes, partly altered to diopside and garnet ( see pls. $16, B, 17, C$ ), cross the area with a general northeasterly strike. The general dip of the strata near the principal mine workings is low to the east, but in the Honeycomb Cliffs the beds exhibit minor open folds. The most prominent structural feature in the Michigan-Utah hill is the Grizzly overthrust zone, perhaps the eastward extension of the Alta thrust zone, brought up by the Silver Fork fault (section $C-C^{\prime}$, pl. 4). In the preliminary report the hill was said to be traversed by a single thrust, but fuller : study has shown that there are two thrusts nearly parallel and close together. The lower thrust brings the Jefferson (?) dolomite over the Deseret limestone, which is stratigraphically much higher; the upper thrust brings Maxfield limestone over Madison limestone. The thrusts are rudely parallel to the bedding, but the beds above them, near the mine, rarely dip more than $10^{\circ} \mathrm{E}$., while those below them generally dip $20^{\circ}-30^{\circ}$ E. In the plane of the City Rocks fissure the upper thrust crops out on the west side of the ridge just below the dump of the City Rocks tunnel. It dips into the hill at a low angle and reaches the level of the Topeka tunnel between raises 11 and 12 . Beyond this it rises with a somewhat steeper westerly dip and crops out below the mouth of the Butte tunnel in Honeycomb Fork. It is thus bent into a troughlike form, being lower under the top of the hill than at the outcrops on each side.

A few small reverse faults are visible in the Honeycomb Cliffs but are obscure on the Little Cottonwood side of the hill. Several northeasterly fissures also are conspicuous in the cliffs, and the strongest of these are readily traceable on the western slope. The most.important are the City Rock fissure and the GrizzlyLavinia zone, on each of which there are several tunnels and other openings.

The Grizzly' tunnel (pl. 46), which has been mapped in somewhat more detail than the others, exemplifies many of the geologic features of the property as a whole. In its outer part the country rock is the cherty, bleached Deseret limestone below the Grizzly overthrusts. These overthrusts are crossed about 1,700 to 1,800 feet in from the portal. The upper one is probably on a very tight fissure, of low northeasterly dip, beyond which the crinkly markings characteristic of the Maxfield limestone are faintly visible in places. The lower thrust was not precisely located but may be about 100 feet outward from the upper one, at a place where some winzes have been sunk, perhaps because of ore-showings along this fault. The massive white limestone or dolomite, free from chert, near this place, probably represents a slice of Jefferson (?) dolomite between the two overthrusts. The Jefferson (?), with its characteristic vugs, is well exposed in the No. 2 crosscut.

The sedimentary rocks are cut by at least two dikes. The oldest of these consists of highly metamorphosed diorite porphyry; mainly green but blotched in places with reddish-brown garnet. About 800 feet in from the portal this dike is cut at an acute angle by the Grizzly dike of alaskite porphyry, which is vertical, being exposed directly underneath in the Copper Prince tunnel. This dike is cut off near the overthrusts by a fault, striking northwestward and dipping northeast, beyond which it has not been found, having probably been shifted southeastward. A dikelike mass consisting of a breccia or conglomerate of granodiorite and other igneous rocks is followed in a drift southwest of the No. 2 crosscut-

At least two well-marked fissures, belonging to the Grizzly-Lavinia zone, have been developed from the Grizzly tunnel. The identity of the individual fissures beyond the cross fault that cuts off the dike is not altogether clear.

Contact deposits.-Contact alteration has occurred in varying degree all along- the contact of the Alta stock of granodiorite with the sedimentary rocks and in the rocks adjacent to the dikes that extend into the sedimentary rocks from the stock. At many places the product of this alteration consists largely of magnetite with subordinate amounts of silicates and sulfides, the latter usually altered at the surface to oxide and carbonates. These bodies as a whole carry but a low percentage of copper and little gold and silver, though parts of them have a fairly high content of copper. It has been possible by sorting the ores to make a product that was marketable when prices were high; in general, however, the contact deposits are of too low grade to be profitably mined at average prices and at existing costs of transportation. For this reason they have not been much developed, although much superficial prospecting has been done in them. There are some deposits associated with the altered dikes that are closely allied to contact deposits, wherein the sulfides have formed by the replacement of limestone or dike rock and are usually associated with garnet and other contact minerals. The Stewart fissure has yielded some ore from this type of deposit.

Replacement fissure deposits.-The production of the Michigan-Utah group has come principally from replacement fissure deposits. The fissure systems most extensively developed are the City Rocks fissure and the Grizzly-Lavinia system, farther north. Similar deposits in Patsy Marley Hill have yielded small amounts of ore. 
The strongly marked City Rocks fissure has been followed from the Little Cottonwood side of the ridge to the Black Bess shaft, in Honeycomb Fork, and can be traced on the surface with less certainty considerably farther to the northeast. It dips steeply to the - north.

The City Rocks fissure has been developed by four principal tunnel levels (see pl. 46)-the City Rocks Discovery, the City Rocks, and the Cleve, on the Little Cottonwood side, and the Solitude, on the Big Cottonwood side. It has been followed to a depth of 200 feet below the Solitude tunnel level. During the spring and summer the workings below this level are filled with water, but it is said that in fall and winter the water sinks considerably and that little water enters the workings in the dry season.

At the time of visit most of the old stopes along the City Rocks fissure were inaccessible, but from old maps and information furnished by the company officials it appears that the ore occurs mainly in shoots following the intersection of the fissure with certain beds of limestone and with some highly brecciated sheets, not parallel with the bedding, which probably were formed by thrust faulting. Below the thrust-fault zone the ore shoots that replace certain beds dip eastward with the bedding of the limestone. Above the faults, also, the shoots coincide in general with the bedding, which is nearly horizontal. Below the City Rocks tunnel there is a relatively thin shoot, and above it there is a relatively thick ore shoot extending upward beyond the City Rocks Discovery tunnel. The fissure crosses several dikes, which have been mineralized and in places contain ore. Some ore that apparently was formed by replacement of the dike is said to have been relatively high in silver.

The ore is axidized to the Solitude level, and oxidation is said to have extended to the deepest. workings, but residual sulfide occurs throughout the mine. The ores consist of limonite and oxidized lead minerals, mainly carbonate (cerusite) with some sulfate (anglesite), and residual galena. Wulfenite (lead molybdate) is locally abundant. Oxide of manganese is also abundant in places, notably on the levels between the Cleve and Solitude levels and above the Cleve level in a fissure a little to the north of and parallel to the City Rocks, which has yielded some manganese ore.

The Grizzly-Lavinia fissure zone, developed mainly in the tunnels so named, strikes about N. $40^{\circ}$ E.; the most productive fissure dips steeply to the north, and a less productive fissure has a steep southerly dip. The Grizzly fissure for a part of the distance that it has been developed is closely associated with an alaskite porphyry dike. Fissures later than the dike cut the dike in places, though more commonly they follow one or the other of its walls. A fault striking N. $50^{\circ} \mathrm{W}$. and dipping about $40^{\circ} \mathrm{N}$. has apparently thrown both dike and fissure to the south in the eastern part of the workings. Several of the limestone beds near the fissures are rather highly brecciated. This fracturing has probably resulted from a combination of causes, including the overthrust faulting, the intrusion of the alaskite porphyry dike, and the subsequent fissuring. The alaskite porphyry dike when fissured became brecciated with little formation of impervious gouge, such as was formed along some of the basic dikes, and it therefore did not.interfere with the passage of the mineralizing solutions.

Much of the ore has formed through partial replacement of the brecciated limestone. As mined, it contains much unreplaced limestone, and much of it is screened in order to remove the barren rock. Oxidation has been almost complete as deep as the fissure has been developed. The ore minerals are similar to those of the City Rocks vein.

Other fissures in the Michigan-Utah Hill have been somewhat developed and have yielded some ore. Near the top of the hill, some manganese ore was extracted during the war from a fissure north of the City Rocks fissure. Where exposed the manganese vein has a width of 10 to 15 feet, but its thickness evidently varies greatly from place to place.

The latest developments in the area are east and north of the main Grizzly-Lavinia developments and extend eastward into Honeycomb Fork. The ore here forms in a series of shoots, probably in the Jefferson (?) dolomite, between the two overthrust faults. It appears to end abruptly at the upper overthrust, though there has been so little development in the Cambrian limestone above the thrust that this is not certain. The shoots below the tunnel level have been developed by winzes, but the downward extension had not been outlined at the time of visit in 1926.

A strong fissure crosses Patsy Marley Hill, striking N. $25^{\circ}$ E. and dipping steeply to the northwest. A shoot of ore associated with this fissure was developed in the Jefferson (?) dolomite a short distance above the Ophir shale and yielded considerable ore in 1919. The mineralization was similar to that of the replacement deposits in the City Rocks and Grizzly fissures.

\section{AMERICAN FORK DISTRICT} BILVER DIPPER

The Silver. Dipper mine, south of the upper part of American Fork, is developed on a fissure, in pre-Cambrian quartzite, that strikes N. $45^{\circ}-50^{\circ}$ E. and dips $50^{\circ}-60^{\circ} \mathrm{NW}$. This fissure has been followed southwestward on the lower tunnel level for about 225 feet, where it appears to be cut off by a break striking S. $80^{\circ}$. W., which, about 70 feet farther inward, is in turn cut by a break striking $\mathrm{S} .50^{\circ} \mathrm{W}$.

The northeastward-striking fissure first mentioned is the only one from which ore has been taken. Its width 
ranges from 1 foot to 4 feet. The principal gangue is coarse-grained white quartz. Pyrite is abundant, especially along the walls of the fissure and in places throughout the fissure. The principal ore mineral is

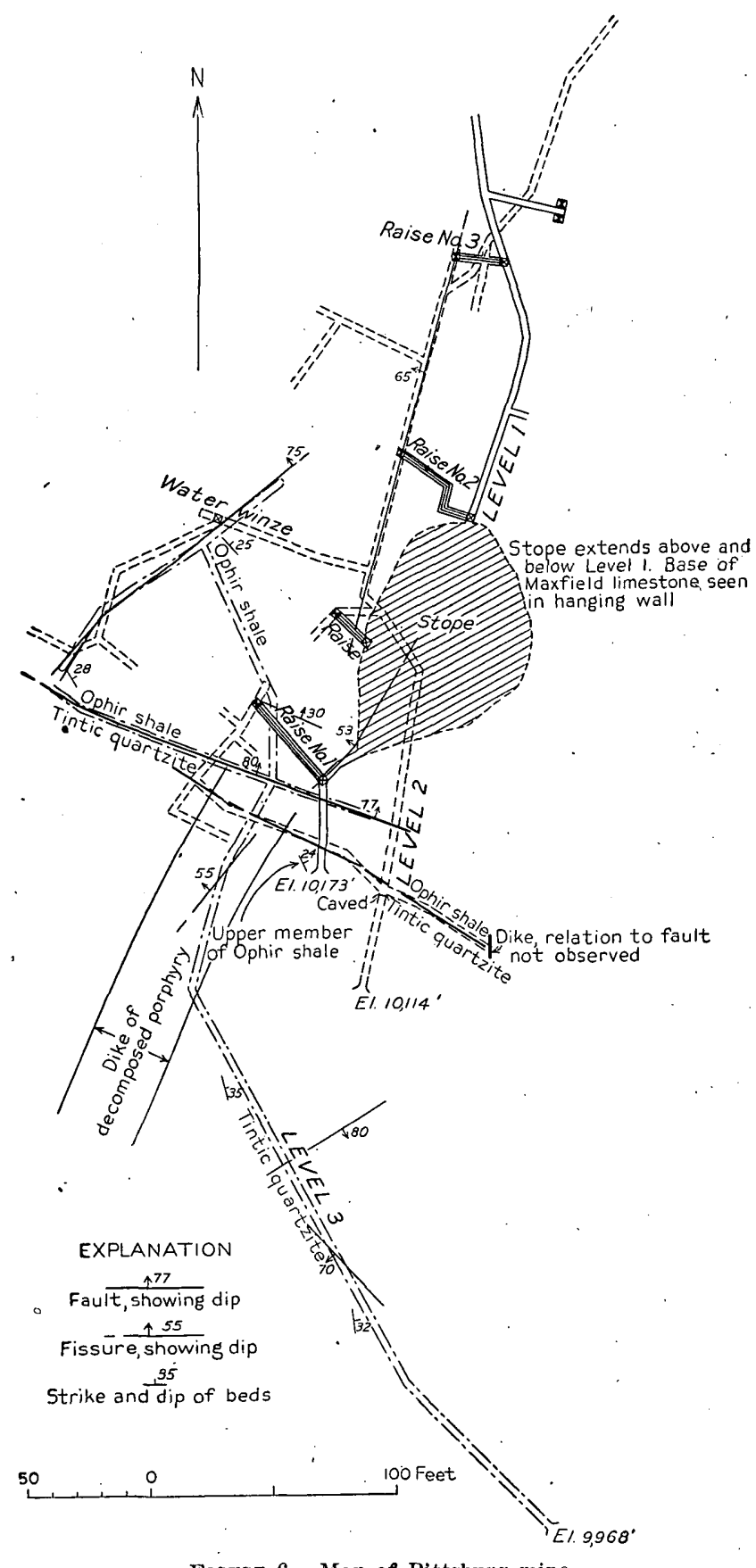

Fiauri 6.-Map of Pittsburg mine.

galena, which is especially abundant near the center of the vein. Tetrahedrite and sphalerite are present in variable amounts.

No reliable information as to the grade of the ore was obtained, but the material shipped is said to have been sorted so that it contained about 45 ounces of silver to the ton and 40 percent of lead.
PITTSBURG

HISTORY AND PRODUCTION

The Pittsburg mine (fig. 6), southwest of the Devils Castle, was located in April 1871. In 1879 the owners of the mine bought the Morgan furnaces, ${ }^{85}$ later known as the Hanauer smelter, near Salt Lake City. The production records of the mine were not available to the Geological Survey.

The Hudson and War Eagle patented claims were operated in $1880^{86}$ separately from the Pittsburg patented claim. In 1872 the Pittsburg claim was said to be well developed by drifts and shafts, and to have a large amount of ore in sight. This ore was said to assay only 10 to 30 ounces of silver to the ton, but to be rich in lead, some of it containing over 40 percent. ${ }^{87}$ The average of the ore shipped by lessees in 1905 and 1909 was 40 cents in gold and, 9.45 ounces of silver to the ton and 38.30 percent of lead.

\section{- GEOLOGY}

The sedimentary rocks exposed on the Pittsburg property include those from the Cambrian quartzite to the Mississippian limestones. The most prominent structural feature is the Pittsburg fault, which is normal, with downthrow to the north and a dip of about $80^{\circ}$ N. Near the Pittsburg mine (fig. 6) this fault brings upper Ophir into contact with quartzite at the surface near the portal of the upper tunnel; in the lower tunnel it brings the lower shale of the Ophir against the Tintic quartzite, in which there is a thoroughly decomposed dike; and the upper and middle members of the Ophir are exposed in the mine workings. A little fresher porphyry, apparently a sheet, occurs north of the fault. The rocks are cut by a mineralbearing fissure, striking about $\mathrm{N} .40^{\circ} \mathrm{E}$. and dipping about $55^{\circ}$ to $65^{\circ} \mathrm{NW}$., which is cut off by the Pittsburg fault. The ore bodies thus far developed were formed by replacement of the limestone member of the Ophir shale adjacent to the fissures, mainly between levels No. 3 and No. 2, and in the lower part of the Maxfield dimestone, which forms the walls of the old stopes above level 1.

To the depth of developments in 1919 , the ore was mainly oxidized but contained some residual galena. The ore exposed in the mine contained much plumbojarosite, together with lead carbonate and iron oxide. The first stage of alteration apparently formed the basic lead-iron sulfate plumbojarosite, which subsequently broke down to lead carbonate and iron oxide. The ore in the limestone member. of the Ophir contains much

\footnotetext{
86 Eng. and Min. Jour., vol. 27, p. 302, Oct. 25, 1879.

${ }^{86}$ Director of Mint report upon statistics of production of precious metals in the United States for 1880, p. 129, 1881.

${ }^{87}$ Raymond, R. W., Statistics of mines and mining in the States and Territories west of the Rocky Mountains for 1872, p. 249, 1873; idem for 1873, p. 274,1874 .
} 


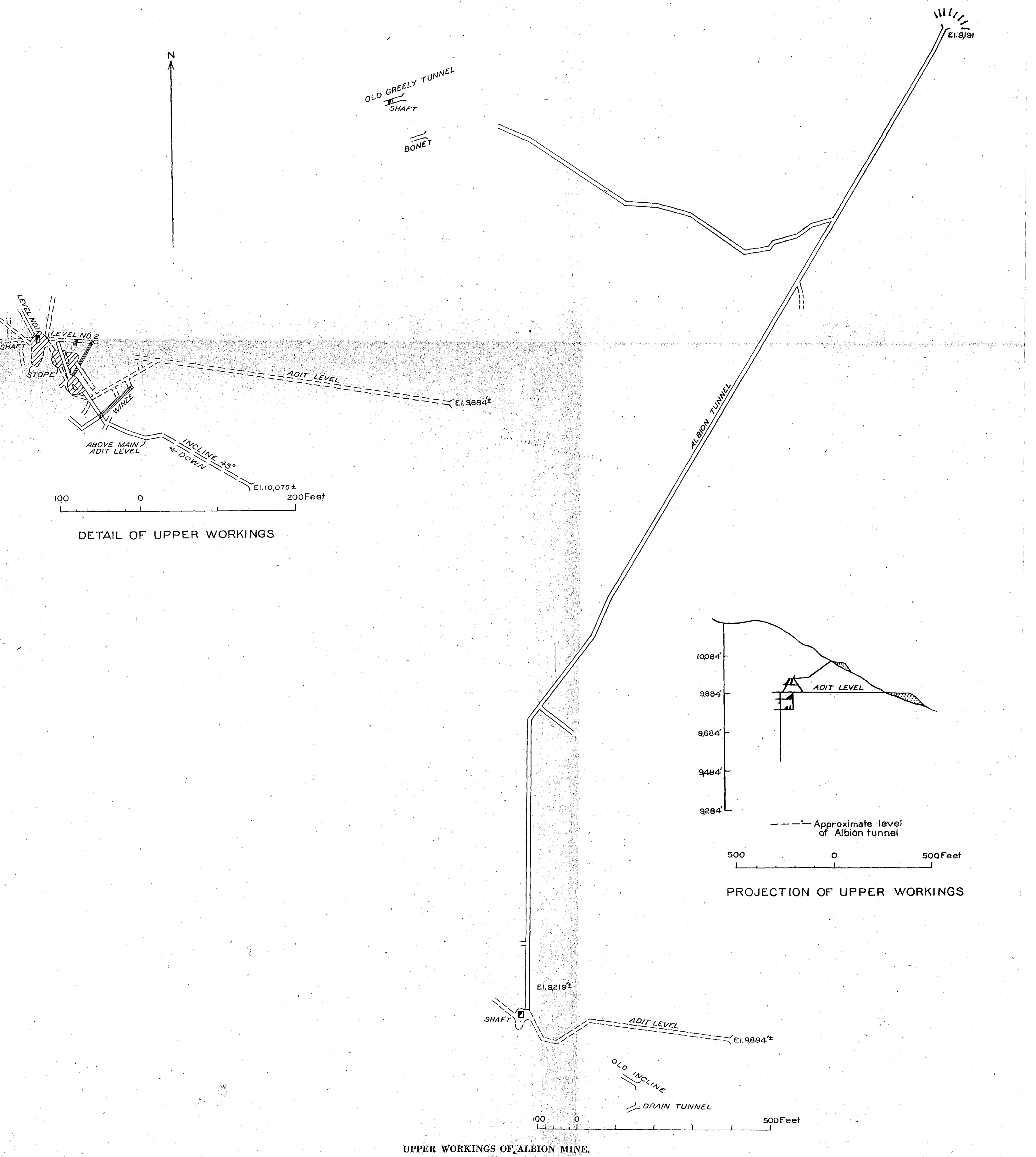


sericitic muscovite ("talc"), and that in the Maxfield limestone above the Ophir contains some of this mineral. The ore exposed in September 1919 was said to average as sorted about 30 percent of lead and 5 ounces of silver to the ton.

\section{SOUTH PARK}

The South Park Mining \& Development Co. owns a large tract lying mainly in Dry Fork Canyon but extending to American Fork. On the western part of the property the Ophir formation is exposed. In the eastern part the sedimentary series is present well up into the Carboniferous limestones. Dikes of granodiorite porphyry and alaskite porphyry cross the property. Prospecting has been carried on at two localities. On the ridge between Dry Fork and Snake Creek there was a little prospecting of a vein, and the Galena tunnel, which was driven to cut this vein at depth, is said to have revealed some good ore.

In the western part of the tract, in American Fork Canyon, a tunnel driven in the limestone member of the Ophir was about 285 feet long in 1919. At that time several fissures striking north and a little west of north had been cut, but nothing had been found that gave promise of a strong mineralized fissure.

\section{WATER FALI}

The Water Fall mine, in American Fork Canyon, was not accessible at the time of visit. It appears to follow a fissure in the quartzite, striking about N. $30^{\circ} \mathrm{E}$. and dipping steeply northwest. The fissure nearly parallels the Silver Fork fault, which probably cuts the fissure south of the point where it crosses American Fork. The Silver Fork fault here brings the lower member of the Ophir shale against the Cambrian quartzite. G. F. Loughlin, ${ }^{88}$ who examined the deposit in 1912, says of it:

It is marked by pinches and swells, and the swells are about 4 feet thick. The ore minerals are galena, pyrite, tetrahedrite, and a little zinc blende in a gangue of quartz. It has been opened by two tunnels that extend northward and southward from the creek bed where it crosses the vein. The south tumnel in 1912 was 300 feet long and the north tumel about 50 feet. The tumnels are driven under a bench and for several hundred feet can be but 50 to 100 feet below the surface.

\section{PACIFIC}

HISTORY AND PRODUCTION

For several years, beginning in 1905 , the Blue Rock group of six claims, covering about 120 acres in American Fork Canyon near the mouth of Dry Fork, was under active development (pl. 47). About 800 feet of tunnel work and a raise opened up encouraging showings of ore under the management of the Pacific Gold Mining \& Milling Co. (incorporated in 1901). Small lots of lead-silver ore shipped in 1907 and 1909 contained an

\footnotetext{
${ }^{88}$ Butler, B. S., and Loughlin, G. F., A reconnaissance of the Cottonwood-American Fork mining region, Utah : U. S. Geol. Survey Bull. 620 , p. 206, 1915.

462858-43-10
}

average of 30 ounces of silver to the ton and 15 percent of lead. Some dump ore was jigged by a lessee in 1913. The Fissures Exploration Co. leased the Blue Rock mine for 3 years and hauled the ore for a time to a 65 -ton concentration mill, costing $\$ 20,000$, which was erected in 1916 at the portal of the Dutchman tunnel. This mill was put in commission in December 1916, turning out lead concentrate which assayed 55 cents in gold and 14.9 ounces of silver to the ton and 30.1 percent of lead. The insoluble content of the concentrate was 10.15 percent, iron 23.9 percent, zinc 2.15 percent, and sulfur 30.6 percent. The smelter paid $\$ 40.25$ a ton for the concentrate, less a working charge of $\$ 3.20$. The milling ore was hauled about 1 mile to the mill by wagon. During the following year the mill was moved to the portal of the Blue Rock tunnel and enlarged to treat 150 tons of ore a day. It operated but a short time and was closed indefinitely December 11, 1918.

During the time the lessees operated they drove 700 feet of drifts on a persistent fissure vein called the $\mathrm{Pa}$ cific fissure. Some ore of shipping grade was mined in 1917 , but most of the ore mined was put through the mill, where 3 tons of ore made 1 ton of concentrate. The entire output of concentrate averaged about 17 cents in gold and 15.88 ounces of silver to the ton, 34.99 percent of lead, and 0.34 percent of copper. In 1929 the mill was remodeled to treat ore that had been developed the preceding year in the fissure zone to the south of the earlier development. Lessees were working the mine in 1936.

GEOLOGY

The most conspicuous feature on the geologic map near the Pacific mine is a fault which was formerly called the Pacific, but which it now seems best, in order to avoid confusion with the Pacific ore-bearing fissureitself a fault-to call the Mountain Dell fault, because of its extensive development in the Mountain Dell workings. This fault strikes nearly east-west and dips about $55^{\circ} \mathrm{S}$. It is normal, bringing Madison limestone on the south against Tintic quartzite on the north, and its maximum throw is probably more than 1,000 feet. The mine workings (pl. 47) are mainly in the Tintic quartzite and Ophir shale, and these form the country rock of the Pacific fissure, which strikes about N. $45^{\circ} \mathrm{E}$. on the average and dips about $50^{\circ} \mathrm{NW}$. The Pacific fissure itself, and the Copper fissure which branches from it, are normal faults of undetermined but rather small throw. In the north part of the lower workings, a fault contact was seen between a footwall of pebbly quartzite presumably near the base of the Tintic and a hanging wall of quartzite free from pebbles, characteristic of the main body of the Tintic. The zone of crushed quartzite along the fissure varies in thickness from a few feet to several inches; some of the stopes are 18 feet wide in places. Other, smaller faults are exposed in the workings, the most conspicuous of which is called the Variegated fault because its fissure is filled with a sheet of 
breccia, several feet thick, that consists of contrasting light-colored quartzite and dark shale. This fault is steep and strikes about $\mathrm{N} .70^{\circ} \mathrm{W}$., and it has shifted the Pacific fissure about 18 feet.

The so-called Copper fissure is a fissure of steeper dip and more easterly trend than the Pacific ore-fissure has on the average, which diverges in the northern part of the mine from what is taken to be the main Pacific fissure. The relations at this place are not altogether clear, however, and it seems possible that the Copper tissure is a continuation of the Pacific, offset by minor faults, rather than a branch.

The mineralization in the Pacific fissure was far from uniform. Although there is some ore throughout the fissure it lies in shoots having a flat southwesterly pitch and apparently enclosed in the Cambrian quartzite close under the Ophir shale. (See pl. 47.) The high-grade ore, so far as observed, forms rather small lenticular bodies within the larger shoots of lower-grade ore. The ore minerals of the main shoot are principally pyrite and galena, though sphalerite is abundant locally. Vein quartz is present but not abundant. Barite was noted' as an abundant gangue mineral in places but is said not to form a large part of the ore. In the Copper vein tetrahedrite appears to have been the chief ore mineral.

The vein was not accessible on the upper level at the time of visit. Loughlin, ${ }^{89}$ who examined the mine in 1912, says of it:

Above the tunnel the dip flattens and the vein narrows upward until it coincides with a bedding plane at or near the shale contact. In the southern part of the mine the ore is continuous from the shale contact, 130 feet up the dip from the tunnel, to and beyond the lowest workings; 70 feet down the dip from the tunnel. The pay ore pinches northward as well as upward. The ore consists of galena and pyrite in a gangue of quartz and barite. The galena diminishes upward, and near the shale contact granular pyrite is the only ore mineral. The barite tends to be localized in the lenticular shoots.

\section{BORUSSIA}

The Borussia claim is located in the quartzite on the south side of upper American Fork Canyon. It is developed by three tunnels.

The Borussia fissure at the mouth of the upper tunnel, which was caved at the time of visit, strikes $\mathrm{N} .65^{\circ} \mathrm{E}$. and dips $85^{\circ} \mathrm{NW}$. In the open cut at the portal of the tunnel, the fissure is as much as 3 feet in width and is filled with crushed quartzite. Galena is irregulariy distributed through the crushed zone and probably forms some rich shoots.

The intermediate tunnel shows a little ore near the portal. The lower tunnel was not accessible but does not appear to have yielded ore. Most of the ore taken from the fissure appears to have come from the upper tunnel.

\footnotetext{
${ }^{80}$ Butler, B. S., and Loughlin, G. F., A reconnaissance of the Cottonwood-American Fork mining region, Utah : U. S. Geol. Survey Bull. 620, p. 207,1915 .
}

'The Bog group is on the north side of upper American Fork. The name is derived from the bog iron which has been deposited on part of it by water coming from pyritic veins in the quartzite.

The country rocks are pre-Cambrian and Cambrian quartzite and shale, cut by small dioritic dikes and by several northeasterly fissures that are conspicuous in the cliffs above the mine.

The upper tunnel is driven on a fissure of northeasterly strike, which has been followed for several hundred feet. Most of the ore has been found in one shoot, east of a fault that displaces the fissure a few feet. This shoot has been developed above the level and for a short distance below it. The vein filling is mainly quartz; pyrite and sphalerite are the most abundant sulfides, and galena and a little tetrahedrite are present. The minerals commonly occur in open vugs and are exceptionally well crystallized.

Near the end of the tunnel there is a seepage of acid water from which limonite is precipitating abundantly. The tunnel is partly filled with stalactites and stalagmites of limonite, and limonite is precipitated from the water after it has left the tunnel. This limonite is apparently derived from the oxidation of pyrite by waters seuping from the surface.

'The lower tunnel, in September 1919, was being driven to intersect fissures that are exposed at the surface. At the time of visit no large fissure had been reached, though some mineralization along seams in the quartzite had been revealed. A little galena is present in one place, and veinlets of quartz and specularite in another.

In 1942 some work was being done in the upper tunnel; to which a new automobile road had recently been made, and some good ore was said to have been exposed; but the mine has not been revisited by the writers of this report in recent years.

\section{MILLER HILI MININGG CO.}

The Miller Hill Mining Co. controls a large tract lying between the Pacific mine on the north and the Dutchman and Whirlwind mines on the south. 'The property includes the old Mountain Dell group: (See pl. 48.) The sedimentary rocks that occur in the property include the series from the Cambrian quartzite to the Madison limestone.

In the Mountain Dell group the rocks are cut by the strong eastward Mountain Dell fault, which there brings the Jefferson (?) dolomite and Madison limestone against the Maxfield limestone, the Ophir shale, and the Tintic quartzite. This fault is clearly shown on the company map and section of the Mountain Dell workings (pl. 48), which were not accessible at the time of visit. The upper tunnel level is apparently in the Ophir shale and Tintic quartzite. So far as known, no ore was found in the workings. 
The Holston tunnel is entirely in Maxfield limestone. The tunnel follows a break in the limestone but did not reveal any ore.

The Miller Hill tunnel was not accessible at the time of visit. It starts in the Ophir shale and passes through the Ophir into the Tintic quartzite. It is said that a fissure about 2,000 feet from the portal was followed for some distance but no ore was found.

The Alice tunnel was driven about N. $25^{\circ} \mathrm{W}$. for about 500 feet, thence turns more westerly and is said to extend for 300 feet farther. It starts in the Maxfield limestone and then penetrates in succession the upper shale member, the limestone member, and the lower shale member of the Ophir formation. It did not encounter any ore.

\section{TEXAN}

The Texan Mining Co. controls a large group on Miller Hill. The sedimentary rocks on the property include those from the Tintic quartzite to the Madison limestone. A small dioritic dike cuts the sedimentary rocks in the upper tunnel. The principal development work has been done through two tunnels. The upper tunnel was driven about 900 feet N. $30^{\circ} \mathrm{W}$. in Cambrian, Devonian (?), and Carboniferous limestone. The lower tunnel, which was driven about 1,100 feet $\mathrm{N}$. $65^{\circ}$ W., passes through Cambrian limestone and the Ophir formation and ends in Cambrian quartzite. No ore has been developed in either tunnel. The rocks in this vicinity have been greatly shattered, so that close timbering is necessary in the tunnels.

\section{TREASURE CONSOIIDATED}

The Treasure Consolidated group adjoins the Miller group on the south. The rocks exposed are the Ophir shale and the overlying Maxfield (Cambrian) limestone. Two tunnels have been driven - the Oliver, in the Cambrian limestone, and the Sierra, which penetrates the Cambrian limestone and probably the Ophir shale. No production is recorded.

\section{DUTCHMAN \\ HISTORY AND PRODUCTION}

The Dutchman mine, formerly called the Wild Dutchman, is at the southeast base of Miller Hill; half a mile northeast of the mouth of Mary Ellen Gulch. (See pl. 49.) The Wild Dutchman deposit, as it was first called, was discovered in 1872 , and soon thereafter the mine was sold to the Omaha Smelting \& Refining Co., of Nebraska, which worked it until September 1876 . After that time the mine was worked intermittently by various lessees until 1917 , when some ore was milled in a 100-ton concentration plant, erected by the Fissures Exploration Co. at the portal of the Dutchman tunnel. The concentrator was subsequently dismantled and reerected at the mouth of the Pacific (Blue Rock) tunnel. According to the report on precious metals of the
Director of the Mint for 1880, the development work, consisting of tunnels, drifts, shafts, and winzes, then amounted to 20,000 feet. Very little additional work was done after 1880. After 1872 several thousand tons of ore was produced, but early records are not available. Lessees were working in the lower tunnel in 1936, 1939, and 1942. From 1901 to the end of 1916 lessees of the Dutchman produced 2,492 tons of ore, averaging 89 cents in gold and 47.58 ounces of silver to the ton and 27.89 percent of lead. About half of 1 percent of copper was contained in the total ore shipped. In 1939 and 1942 ore very rich in galena and sphalerite was being mined below the lower tunnel.

According to the estimate made by Huntley and the output recorded by the Geological Survey, the total mine production to 1917 amounted to 10,392 tons.

The ore was mainly a lead-silver ore, though zinc is said to have been relatively abundant in the lower workings. . Barite appears to have been present in much of the ore and was locally abundant.

Huntley ${ }^{90}$ describes the Dutchman mine as follows:

The ore-bearing formation is a bedded vein, from 3 to 40 feet (average, 20 feet) wide, in dolomite, dipping $40^{\circ} \mathrm{SE} . * * *$ The gangue in general consists of from 2 to 3 feet of shale upon the footwall and a soft clay containing fragments of șilica, and strongly stained by oxide of iron, locally known as "lime porphyry." The ore occurs in scattered egg-shaped bunches of from a few pounds to 600 tons. Five large ore bodies have been found, one 20 feet from the surface. The ore is the usual ochery carbonate of lead found in a lime formation and contains small amounts of heavy spar. At the water line, in the 450-foot tunnel level, a large body of base ore was found. This consisted of iron and copper pyrites, galena, and a very large percentage of zinc blende. A porphyry dike is said to cut through the footwall into the vein near the large bodies of ore. * * * The total product of the mine is estimated at 7,900 tons, averaging 45 ounces silver and 40 percent lead.

Loughlin, ${ }^{91}$ who visited the mine in 1912 , describes it as follows:

The principal vein of the Dutchman mine, seen in 1912, strikes N. $40^{\circ}$ E. and dips vertically or steeply southeastward. Its width ranges from a mere streak up to 8 feet. Its greatest width is attained in a dark-blue limestone bed which overlies airgillaceous beds. The vein, for most of its course, lies along the contact of a narrow poryphry dike. It ends abruptly on the northeast against a dense, blocky argillaceous limestone, which probably marks a northwesterly fault but which could not be studied closely.

A minor vein parallels the main vein. Both have been followed up to the cemented talus that caps the bedrock, and several masses of ore are said to have been found in the talus. The ore mined from both veins is mostly a sandy mixed lead and zinc carbonate. That mined by lessees in recent years is said to average about 30 percent of lead, 9 to 17 percent of zinc, and 50 ounces of silver to the ton. Remnants of primary ore are com-

${ }^{90}$ Huntley, D. B., 10th Census, U. S. (1880), vol. 13, pp. 444-445, 1885.

${ }^{01}$ Butler, B. S., and Loughlin, G. F., A reconnaissance of the Cotton wood-American Fork mining region, Utah : U. S. Geol. Survey Bull. 620, p. 208,1915 . 
posed of galena and blende in a barite and carbonate gangue. Quartz is inconspicuous.

GEOLOGX

The Dutchman workings (pl. 49) are in a wedge of Devonian and Mississippian limestone, bounded on the north and west by two great faults, the Dutchmanwhich may be a part of the Silver Fork fault-and the Whirlwind. The limestone penetrated by the workings is apparently dislocated by several other faults, but the structure is far from being thoroughly understood.

The greater part of the ore produced by the mine has been taken from the No. 1 tunnel. The workings on this level have a definite northeasterly trend, but the drifts do not follow the bedding nor, so far as is shown by the writer's observations and the company map, do they follow any one persistent fissure. They seem, rather, to extend along an ill-defined fracture zone in which most of the individual fissures strike at various angles to the general trend. Most of the fissures observed are fairly steep. The general dip of the limestones on this level is eastward, though very irregular in detail; and the workings, in their northeasterly course, pass first through much of the Jefferson (?) dolomite, then through the Madison, then into the Deseret, whose base is marked by characteristic black shaly beds. Although the most easterly workings on this level were inaccessible at the time of the writer's visit, the company map indicates that they are in limestone, so that they presumably do not extend across the Dutchman fault. No indication was recognized on this level of any large fault, though the complex fissuring near the illdefined boundary between Jefferson (?) and Mảdison, and the abnormally small thickness of the Madison, suggest a fault with downthrow on the east. A thin br:mching dike of a rock, probably a lamprophyre, that is largely altered to brown clayey material is cut in the eastern workings.

The structure on the lower tunnel level is- not easily reconcilable with that on the level above. The most striking discrepancy consists in the fact that a drift extending north-northeast from the first fork of the tunnel penetrates Tintic quartzite, certainly beyond the Dutchman fault, within such a distance that this fault, if steep and not itself displaced by a later fault, would be crossed in the upper workings. If, however, the Dutchman fault is an extension of the Silver Fork fault, it may have a low dip. This drift, from which some ore was taken, may extend along the same fracture zone as the upper workings.

The country rocks in the lower workings correspond in the main to the same formations as those on the No. 1 level. The adit, south of the first forks, is in Madison limestone. The westward crosscuts are in the Jefferson (?) dolomite. The rock of the north-northeast drift is largely concealed, but some of it seems also to be Jefferson (?) dolomite. There is some indication of a south-dipping normal fault near the entrance to this drift. The most remarkable feature of this level is the fact that its most northerly spurs are blocked and flooded by soft muck, much of which is blue black and pretty certainly derived from the black shale at the base of the Deseret. The distribution of the muck suggests that it lies along a fault of east-west strike; but no such mucky fault was seen on the upper level. It therefore seems possible that a thrust fault of low southward dip rises through the floor of the lower level and has not been reached by even the northernmost spurs on the upper level. Such a fault, later than the Dutchman fault, might account for the nonappearance of the latter on the upper level. The surface exposures, encumbered as they are by moraine, give little aid in the testing of this hypothesis.

The only ore being mined in 1939 was a mass, a few feet in diameter, of coarsely crystalline entirely unoxidized sulfide consisting mainly of galena and sphalerite. It lay in a breccia of limestone and of altered dike rock, evidently part of the same dike exposed on the No. 1 level; the entire mass is permeated by blue-black muck. Similar ore was being mined in the fall of 1942 at a deeper level from a mass" surrounded by dark mucky ground. These masses may be parts of a large vein, perhaps containing a large amount of ore, that has been broken into many pieces as a result of complex faulting.

It was said by one of the lessees that a carload of ore shipped in October 1941 contained about 16 ounces of silver, 13 percent of lead, 34 percent of zinc, and 0.02 ounce of gold, and that the average value of the ore during the two years that the lease had run had been about $\$ 22$ a ton.

\section{WHIRLWIND TUNNEL}

The Whirlwind tunnel (pl. 49), just west of the Dutchman No. 1, was driven N. $20^{\circ}$ W. for a distance said to be about 1,100 feet. It is now blocked 600 feet from the portal by the same kind of black muck that is so abundant in the lower Dutchman workings. An opening was spaded through this obstruction by two young assistants at the time of the writer's visit, and he was thus enabled to reach the face, which was then about 950 feet from the portal. The tunnel then terminated in quartzite, which was in contact with limestone at the Dutchman fault. The Whirlwind fault, as shown by surface outcrops, is about parallel to this tunnel and not far to the west, but it has not been reached by the workings.

The muck pile apparently marks the boundary between Deseret limestone to the north and Madison to the south. The only dips noted were low and westward, away from the Jefferson in the nearby Dutchman No. 1. The structural relation between the two limestones was 
not adequately studied, but it seems possible, in view of what was later found in the Dutchman workings, that they are separated by the flat fault that was thought to pass between the lower and No. 1 Dutchman tunnels.

\section{BAY STATE}

The Bay State mine is on the east side of American Fork Canyon, midway between the Dutchman and Pacific mines (fig. 7). The lowest tunnel, which was open in 1939, enters in Madison limestone and reaches the Deseret about 250 feet from the portal. The beds dip about $40^{\circ} \mathrm{E}$. Three fissures about parallel to the bedding are crossed, and the easternmost has been drifted

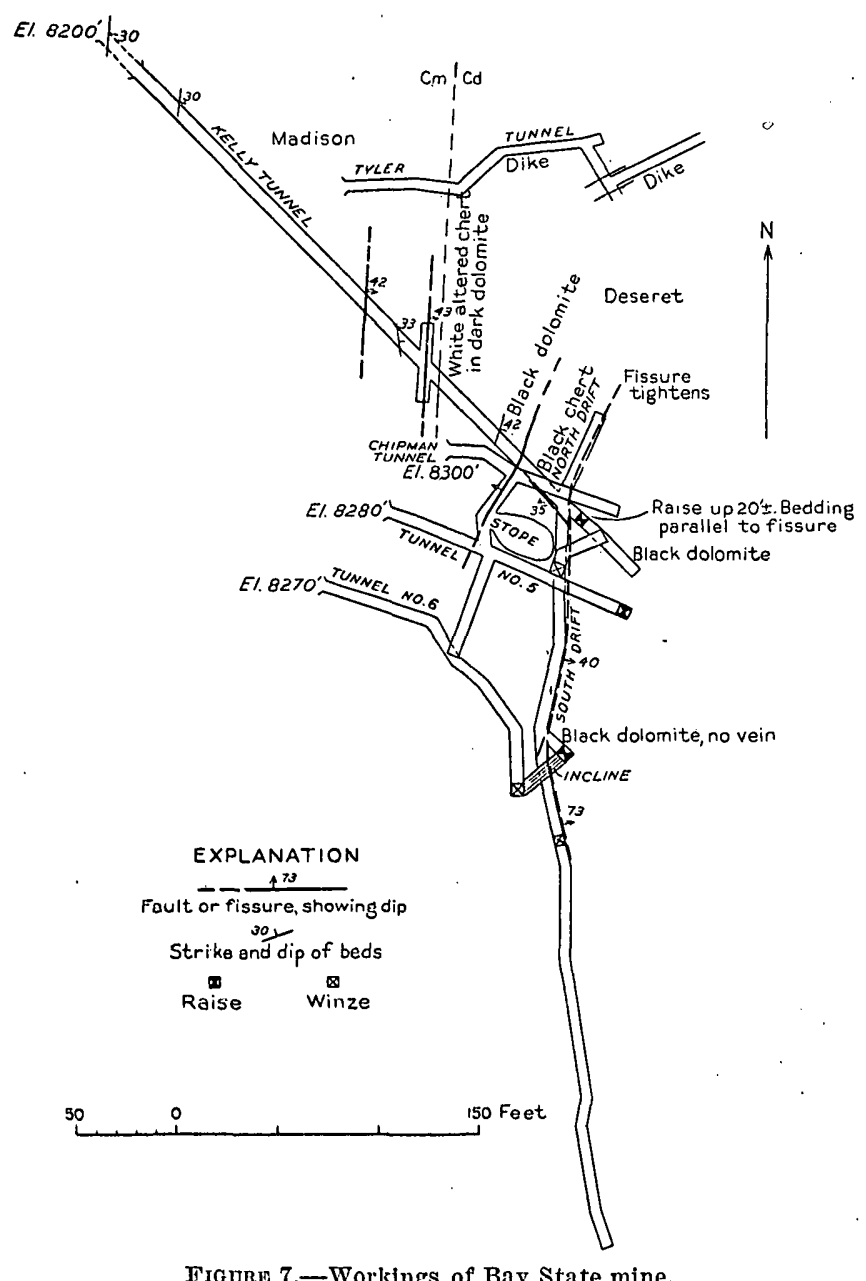

on for about 250 feet. The principal ore developed is a bed deposit on a fissure striking nearly north. The ore has its chief value in lead and silver, and contains about 1 ounce of silver to each percent of lead, but some sphalerite was seen in fragments of limestone on the dump. From 1915 to 1919 about 40 tons of ore was shipped. Considerable prospecting has been done on a diorite porphyry dike, striking $\mathrm{N}$. $80^{\circ} \mathrm{E}$., which inter- sects the limestone, and some stibnite and its oxidation products have been found in the dike and the adjacent limestone.

\section{MILLER MINING \& SMELTING CO.}

HISTORY AND PRODUOTION

The Miller property is near the top of Miller Hill (pl. 50). In 1872 the Miller mine was the most advanced in the district and had already produced 2,400 tons of ore, said to contain $\$ 10$ in gold and 70 ounces of silver to the ton and 62 percent of lead. Several hundred tons of this ore was reduced in the Sultana furnaces, erected in 1871-72 for the reduction of the Miller ores by Sevenoak \& Co. at Forest City, near the junction of American Fork and Mary Ellen Gulch, about 3 miles from the mine. Another lot of 110 tons was shipped at the same time to the smelter of Buel \& Bateman, at the mouth of Little Cottonwood Canyon. The Sultana smelter ran irregularly until the spring of 1875 , when the ore bodies were exhausted, and the mine was closed in December 1876.

In 1873 the Wyoming mine, which is a part of the Miller group, was developed by two tunnels. These workings were evidently on the same body of ore found in the Last Hope tunnel of the Miller mine. In 1904 lessees opened up considerable new ore in the Wyoming, which in 5 years yielded 11,959 tons of ore. From 1904 to 1919 , inclusive, the ore produced from the Miller group by lessees amounted to 13,087 tons, which included two small lots of zinc ore. This shipping ore averaged $\$ 13.30$ in gold and 15.90 ounces of silver to the ton and 32.25 percent of lead. The ore also carried a fraction of 1 percent of copper.

The Sultana smelter was built at a cost of $\$ 90,000$ and was described by Eilers ${ }^{92}$ as follows:

The works are located near the head of American Fork Canyon, Utah. The ores smelted come from the Miller mine, nearby, and consist of very ferruginous oxidized ores of lead, containing much galena and very little quartz-too little, in fact, to permit the formation of a fluid slag in smelting the ore alone. This fact, however, was not understood by those running the works in the summer of 1872. The ore contained, according to many assays, 40 to 42 ounces of silver and 0.4 to 0.6 ounce of gold per ton and $\mathbf{5 6}$ percent of lead.

There are three circular furnaces of the Piltz pattern, $\boldsymbol{9}$ feet high above the tuyeres. The section of the hearth of No. 1 is 28 by 36 inches. It has six water tuyeres with $2 \frac{1}{2}$-inch nozzles. The size of Nos. 2 and 3 in the hearth is 24 by 32 inches. They have four tuyeres each, of the same size as No. 1. They lie about 6 inches above the slag spout and are inclined inward, so that they must blow directly on the metal bath, thus occasioning volatilization of lead.

थ2 Raymond, R. W., Metallurgical processes : Statistics of mines and mining in the States and Territories west of the Rocky Mountains for 1872 , p. $352,1873$. 
All the furnaces are provided with the automatic tap.

\section{Charge}

Charcoal : 6 scoops

$$
=1.8 \text { bushels at } 16 \mathrm{lbs} .=28.8
$$
lbs.

Ore: 5 shovels at $20 \mathrm{lbs} . \quad=100 \mathrm{lbs}$.

Slag: About $3 / 4$ shovel at $16 \mathrm{lbs} .=12 \mathrm{lbs}$.

$$
\overline{112 \mathrm{lbs}} \text {. }
$$

Smelted in 24 hours : 240 charges $=12$ tons of ore or 13.44 tons of charge.

Coal [charcoal] consumed: $432=3.45$ tons.

bushels

Coal consumed per ton of charge $:=513.6 \mathrm{lbs} .=25.68$ percent. 32.1 bushels

Coal consumed per ton of ore: $36=576 \mathrm{lbs} .=28.8$ percent. bushels

The product per furnace at these works in 24 hours was 4 to 4.5 tons of lead, containing 85 to 121 (rarely) ounces of silver and 1.2 to 1.45 ounces of gold. This shows an enormous loss of lead and of the precious metals. There are two causes for this, both evident at once to the observer. The first is the flaming top of the furnaces, out of which a roaring bundle of fire issues continually, tearing along great quantities of fine ore and coal, which are deposited in a thick layer on the roof of the smelting building and in the vicinity. The second is the fact that the slag produced is far too basic, thus enveloping metallic lead and matte and preventing separation.

In 1871-72 a narrow-gage railroad was constructed up the American Fork Canyon to within 4 miles of the Sultana smelter. It was said to have cost about $\$ 240$,.000 , but this was doubted by Huntley, ${ }^{93}$ who gives the following further information:

At the same time 25 stone charcoal kilns, 15 at the smelter ano 10 at the end of the railroad, were constructed. Everything was done on a grand scale. At times 200 men were employed. The ore bodies gave out, and the company shut down the mine in December 1876, since which time it has only been worked on lease. The coal kilns, which were of the beehive pattern and held about 25 cords each, ran almost continuously from 1872 to 1877, making coal for the Salt Lake smelters. The track was taken up in 1878, and the iron sold. The bottoms of the old furnaces were torn up to get the large amount of lead contained in them, and the old slag dumps were profitably picked over four times to find scraps of lead, unreduced ore, and matte. In the winter of 1871-72 a siphon tap, or, more properly speaking, lead well, was invented at this smelter by Mr. J. S. Gorham, almost contemporaneously with those constructed at Eureka, Nev., by Mr. Arentz. The mining property consists of nine patented and overlapping locations adjacent to the Miller, on the summit and western slope of a very high and precipitous ridge $21 / 2$ miles north of Forest City. The fact that a large part of the old workings are filled up renders it difficult to give a full description of this mine.

\section{GEOLOGY}

The sedimentary rocks of the Miller mine (pl. 50) include those from the Tintic quartzite to the Madison limestone. These are cut by small dikes of dioritic rock, usually striking north of east.

The structure of this whole area is complex, as is shown by the general geologic map (pl. 3) and it was not feasible to make a geologic map of the workings, since they are largely inaccessible. The more prominent

\footnotetext{
os Huntley, D. B., 10th Census U. S. (1880), vol. 13, p. 444, 1885.
}

faults have a general east-west trend. A conspicuous fault striking a little north of east has an upthrow on the south that brings up the Cambrian quartzite in the flat east of the Ting camp. North of this and nearly parallel is another fault exposed on the west side of the hill but apparently turning more southward until it is cut off on the greater fault. Farther northwest in the saddle the Ophir shale and the underlying quartzite have a fault contáct, and still farther along the ridge a small block of upper Ophir and overlying Cambrian limestone has been faulted down against the Cambrian quartzite. North of Miller Peak two nearly parallel faults striking northwest bring a block of Carboniferous limestone down into the Cambrian limestone. There are also some minor faults that it has not been practicäble to show on the map.

The mine was idle at the time of visit, and the opportunity for a study of the underground conditions was entirely inadequate for an understanding of the deposit. The mine was examined in 1872 by J. P. Kimball and in 1912 by Loughlin, whose abstract of Kimball's report is quoted farther on. Ryan ${ }^{94}$ described the mine in 1917. The main ore body appears to have been formed by the replacement of highly shattered beds of Maxfield. (Cambrian) limestone near the middle of the formation. The ore shoots follow the intersection of these beds and a fissure or fissures striking a little north of east. There are many slips and minor faults in the workings examined, but so far as indicated by the maps and reports the stopes were fairly continuous in the old southwest portion, which was worked in the early days. This body cropped out on the southeast slope of the hill and is said to have been followed continuously to the northeast until it ended sharply on a fault.

Some years later another body was discovered in workings on the north side of the hill. This shoot has generally been regarded as the faulted continuation of the western shoot, since it has the same general direction and is at the same stratigraphic horizon. It is higher and farther south than the western shoot. After continuing for several hundred feet, it in turn ended abruptly, and it is said to have ended at a fault. Although the writer was unable to verify this statement by underground observation, a fault with downthrow to the north is exposed on the surface that would have about the right position to produce the effect reported. Some prospecting has been carried on to locate a further continuation of the ore shoot, but as yet without favorable results. The following description of the mine is adapted from Loughlin, ${ }^{95}$ who examined it in 1912 and summarized the earlier report by J. P. Kimball:

The only bedded deposits in the American Fork district are those of the famous old Miller mine, on Miller Hill, just east of the divide between the head of American Fork canyon and Mary

94 Ryan, G. H., Geology and ore deposits of Miller Hill, American Fork mining district, Utah : Salt Lake Min. Rev., vol. 19, p. 21, Aug. 15, 1917.

${ }^{25}$ Butler, B. S., and Loughlin, G. F., A reconnaissance of the Cottonwood-American Fork mining region, Utah: U. S. Geol. Survey Bull. 620 , p. $220,1916$. 
Ellen Gulch. According to Huntley, ${ }^{00}$ the mine "was discovered in 1.870 and was sold the following year for $\$ 120,000$ or over." It was examined in 1872 by J. P. Kimball, of whose established report the following abstract has been made:

The earliest workings were inaccessible in 1872 . The "vein" then worked lies near the base of the limestone series and follows the bedding, which dips $15^{\circ}-25^{\circ}$ SE. The ore cropped out on the southwest side of the hill and was followed along the footwall for about 120 feet, when it "rolled" downward for a short distance and again followed the bedding. Below the roll (at the car tunnel) the "vein" was 17 feet thick. The footwall was clearly defined, but the top of the ore body graded into the limestone. The footwall was a bed of "tight lime" with a streak of clay selvage marking the contact with the ore. The hanging wall was shaly, much fractured, and partly altered to "ocherous matter." Fragments of the hanging-wall rock were found throughout the vein. The east side of the old incline showed either a steep pitch, a horse of loosened rock, or a fault causing the abrupt disappearance of the vein material on this side. Not enough work had been done at the time to determine the structure.

Quartz and calcite were generally absent, except as a "residue of country rock." The ore minerals were galena, cerusite, and "plumbic ocher," all carrying silver. Considerable hydrous ferric oxide was present, presumably an alteration product of pyrite, and green and blue stains of copper carbonate were found in drusy cavities in the hanging wall. Black manganese stains commonly accompanied the iron oxide.

Cerusite, both black and white, was the most abundant of the three lead minerals. The black variety probably owed its color, in Kimball's opinion, to finely divided silver sulfide, and was the rich ore of the mine, "containing 83 percent lead, along with some 76 ounces of silver to the ton." This black variety must have been largely galena, for pure cerusite contains only 76 percent of lead, whereas galena contains 86 percent. It occurred in granular masses in the lower and middle parts of the "vein." Some of the masses were 1 to 6 feet in diameter and constituted from 10 to 16 percent of the total ore shipped. The white variety, carrying about 60 ounces of silver to the ton, was the predominant ore and in a concentrated form occupied the lower half of the ore body. It was arranged in lenticular layers, separated by thin seams of clay and "plumbic ocher." "Perfectly pure lenses" of it, 3 to 5 feet thick, had the consistency of quicksand. The "plumbic ocher" occurred in irregularly distributed masses or lenses in the lower part of the vein and carried as much as 36 ounces of silver and 2.45 ounces of gold to the ton. Some gold was also present in the ferric oxide. The upper part of the "vein" consisted of brecciated limestone and ferric oxide, the former more or less impregnated with copper salts and partly oxidized galena. The ore body was said to be the largest deposit of lead carbonate known.

The accompanying table of assays, taken from Kimball's report, represents the western ore bodies of the mine, worked up to 1872.

The average value per ton of base bullion produced from these ores at the old Sultana smelter in American Fork Canyon for 60 working days was as follows: Lead, $\$ 140.70$; silver $(60.36$ ounces), $\$ 86.47$; gold (0.97 ounce), $\$ 22.27$; total, $\$ 249.44$.

According to Huntley, ${ }^{97}$ ore was found in six or eight large bodies which began within 70 feet of the surface in a belt of dolomite. About 4,800 tons was extracted from the largest body. In addition to the minerals mentioned by Kimball, wulfenite was present in the oxidized ore, and a little zinc blende and pyrite were found below water level (500 feet). The total production of the old workings was estimated to have been between 13,000 and 15,000 tons, assaying 40 to 54 percent of

${ }^{00}$ Funtley, D. B., 10th Census U. S. (1880), vol. 13, pp. 444-445, 1885. or Huntley, D. B., op. cit., pp. $444-445$. lead and 30 to 47 ounces of silver and $\$ 2$ to $\$ 10$ in gold to the, ton. These figures do not range as high as some of those given by Kimball.

Assays of ore from Miller mine

\begin{tabular}{|c|c|c|c|}
\hline Kind of ore & $\begin{array}{l}\text { Lead (per- } \\
\text { cent) }\end{array}$ & $\begin{array}{l}\text { Silver (ounces } \\
\text { to the ton) }\end{array}$ & $\begin{array}{l}\text { Gold (ounces } \\
\text { to the ton) }\end{array}$ \\
\hline 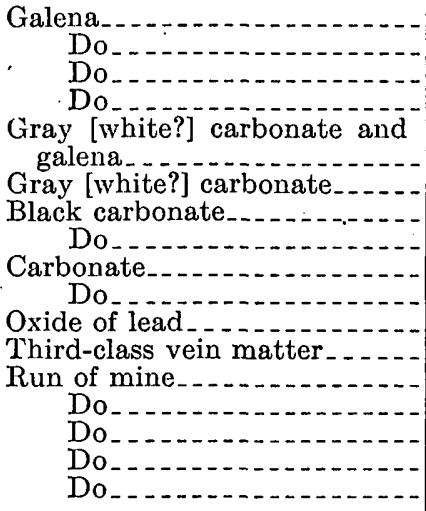 & $\begin{array}{r}75 \\
60 \\
68 \\
72 \\
75 \\
83 \\
(1) \quad \\
40 \\
58 \\
53 \\
60 \\
57 \\
55\end{array}$ & $\begin{array}{l}34.62 \\
30.37 \\
38.45 \\
36.57 \\
35.07 \\
31.49 \\
25.8 \\
16.96 \\
29.16 \\
27.32 \\
30.37 \\
33.41 \\
36.00\end{array}$ & 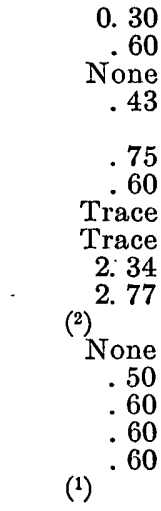 \\
\hline
\end{tabular}

1 Not determined.

Included in silver.

The old ore bodies gave out and the company ceased operations in December 1876, and since that time the mine has been worked by lessees. No great amount of ore was produced until 1905, when the Tyng brothers, then leasing, opened another large body, which replaced the limestone along a nearly due east fissure for a total distance of over 400 feet and was 10 to 40 feet wide. The increased production for the district from 1905 to 1908 was due to this deposit. The rock replaced was a gray dolomite (?), overlain and underlain by shaly limestone. Two other bodies, smaller and less regular, were found 100 feet north of the main body, one on each side of a porphyry dike, whose strike is about $\mathrm{N} .70^{\circ} \mathrm{E}$. The main ore body ended abruptly on the east, possibly against a fault, and a search has recently been made for its eastward continuation, but up to 1913 only relatively low-grade oxidized ore had been found. The ore was principally rusted "sand carbonate" containing residual boulders of galena and showing copper stains but assaying less than 2 percent copper. The average content of the ore shipped from the Tyng lease was 0.98 ounce of gold and 21.72 ounces of silver to the ton, 39.29 percent of lead, 4.90 percent of zinc, 20.17 percent of iron, 2.61 percent of sulfur, and 3.56 percent of insoluble matter. These figures show that the ore was mostly oxidized and contained very little quartz or barite gangue.

Shipments of low-grade ore from this body along the fault (?) east of the main body, in 1913, averaged about $\$ 6$ in gold and 11 ounces of silver to the ton, 18 percent of lead, 37 percent of iron, 2.5 percent of zinc, 2.3 percent of sulfur, and 2.7 percent of insoluble matter.

The prospecting has been mainly confined to the horizon of the known ore shoots. The Lady Annie tunnel cuts the limestone member of the Ophir shale but not at its intersection with the easterly fissure; this intersection, so far as the writer is aware, has not been prospected.

\section{WORKINGS IN MAJOR EVANS GULCH}

Major Evans Gulch, which empties into American Fork near the south end of the mapped area, has its full share of interesting geologic structure. The head of the gulch is characterized by thrust faults in Cam- 
brian shale and limestone, thought to be of the Alta zone (p. 51), with which some ore seems to be associated here as elsewhere. A large window or fenster has the gulch is carved in rocks of Cambrian to Devonian age, dipping southeastward and cut by several faults, of which some are normal and some reverse. Dikes of

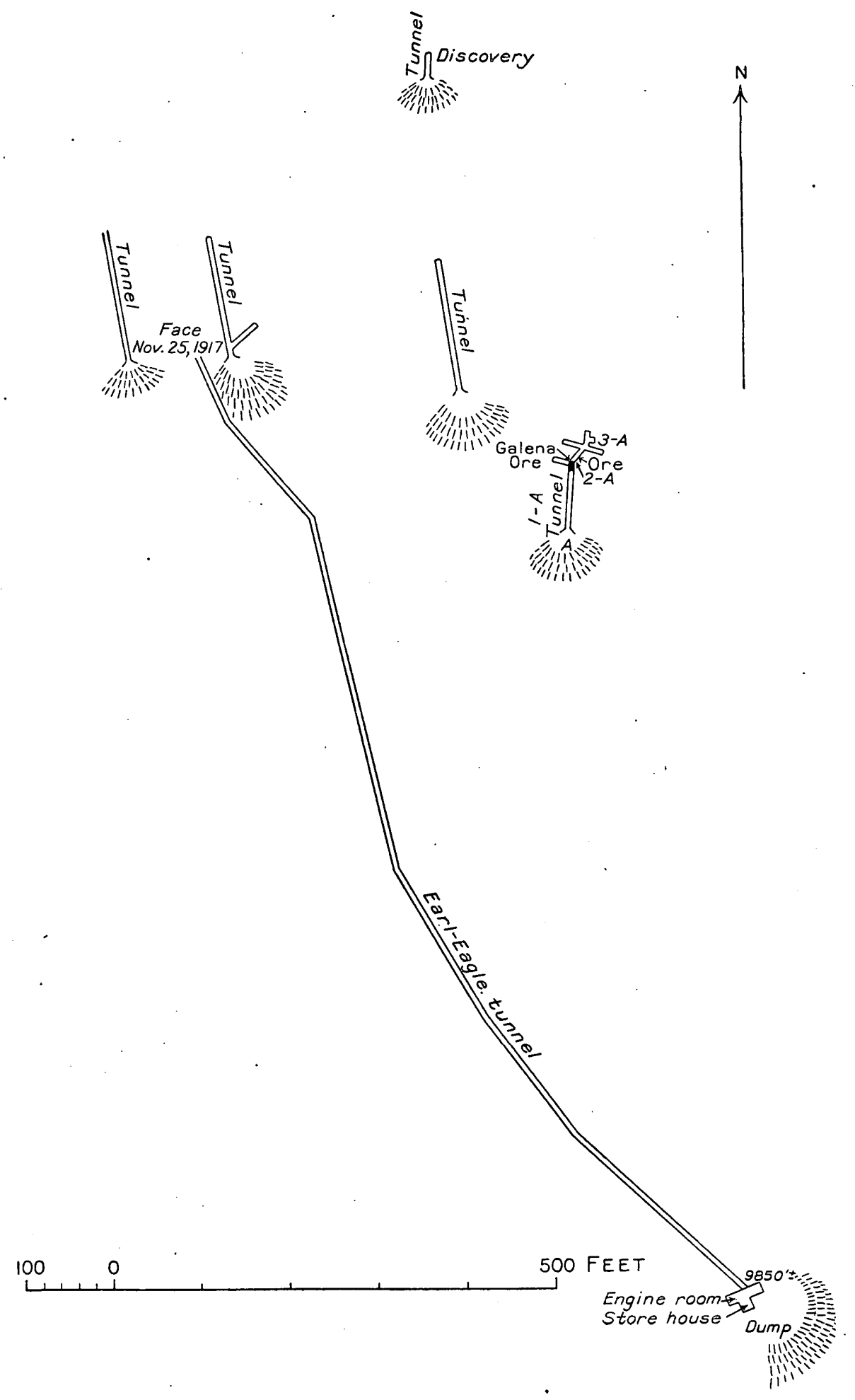

Figure 8.-Plan of Earl-Eagle tunnel.

been eroded through one of the thrust faults. The gulch also contains part of what may be a much younger anomalous thrust fault (p. 59), which brings the Humbug formation (upper Mississippian) over Cambrian rocks above the Ophir shale. The lower part of lamprophyre and of granodiorite and quartz monzonite porphyry are exposed at several places.

Most of the prospecting in the gulch has been done near its head, on a prominant outcrop of the Maxfield (Cambrian) limestone that is highly impregnated with 


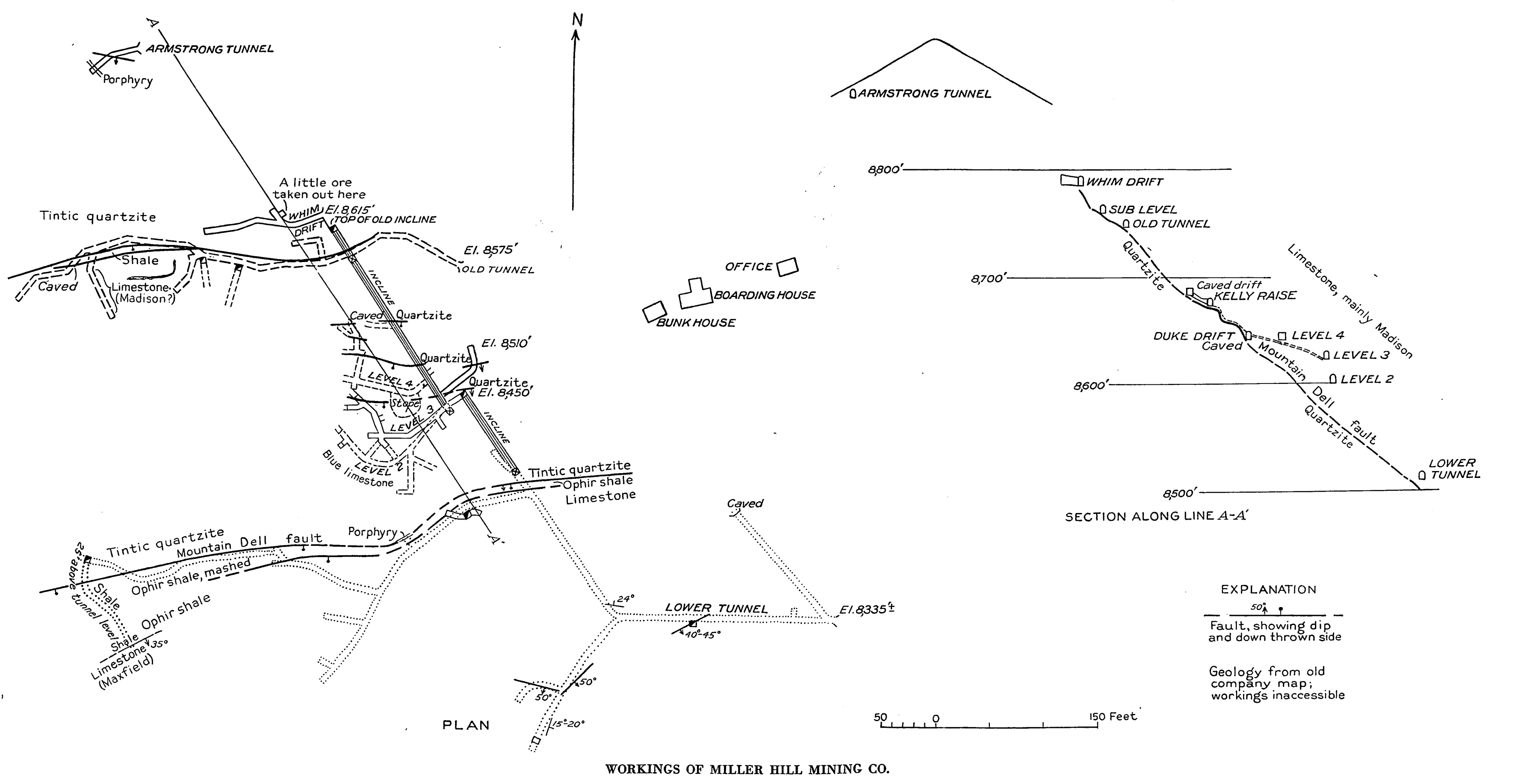


iron and contains some galena. Some large "boulders" of galena associated with this material are said to have been found, and others are said to occur in the drift farther down the canyon. Several tunnels have been driven to prospect the "iron zone" and it is reported that some ore has been found.

The most extensive development is the Earl-Eagle tunnel (fig. 8), which in 1919 had been driven about 2,000 feet to prospect the "iron zone" and the Ophir shale farther to the north at depth. No ore seems to have been devveloped in this tunnel.

There are many caved prospect holes in the middle part of the gulch, not known to have revealed any ore. Near the mouth is the Hobnail property, which has prospected a reverse fault of small throw, along the south side of which is a dike of monzonite porphyry. The lowest and longest tunnel is $\mathrm{Y}$-shaped in plan and consists mainly of a drift running eastward along the fault for about 200 feet, with a branch extending from near its middle point about 100 feet northeastward. In the end of the branch is a vertical sandstone dike, almost as hard as quartzite, which cuts across the bedding of Cambrian dolomite. No ore is known to have been found in these workings.

\section{HINES PROSPECTS}

Edward Hines did some prospecting in the Cambrian (Maxfield) limestone near the mouth of Mary Ellen Gulch on both sides of the canyon and he also prospected a deposit of "bog iron" that has apparently leached from the quartzite, with the purpose of locating the source of the iron which he presumed to be in sulfides in the quartzite.

\section{YANKEE}

HISTORY AND PRODUCTION

The only mine that has been worked recently in Mary Ellen Gulch has been known for some years as the Yankee, but the property represents a consolidation of the Live Yankee, Belorophan, and several other claims. In 1880 the Belorophan mine ${ }^{98}$ was opened by three tunnels over 600 feet long, and the Live Yankee, Mary Ellen, and West Extension claims had 1,600 feet of development (pl. 51). All these properties were operating and yielding some ore in 1919. A tunnel 800 feet long opened the Belorophan mine ${ }^{99}$ for which a small concentration mill was erected in 1918 . Some ore was treated which yielded lead concentrate. Lessees have operated the Live Yankee occasionally, and in 1919 it was operated with the Belorophan by the American Leasing Co. $\Lambda$ bout 750 tons of ore was produced from the Live Yanliee and Belorophan from 1911 to the end of 1919. The Live Yankee ore shipped in 1912 contained $\$ 17.64$ in gold and 31 ounces of silver to the ton and 36.4 percent of lead. The Mary Ellen property is developed by three

\footnotetext{
98 Director of Mint report for 1880 , p. 128, 1881.

oo This name is perhaps a corruption of Bellerophon, it is, however, consistently spelled as here printed, and pronounced "bell-orphan."
}

adits 700 feet in total length. The ore is partly sulfide and contains lead, silver, and gold.

From 1921 until about 1937 the Live Yankee and Belorophan group was developed by the American Smelting \& Refining Co. through what is known as the Yankee mine.

GEOLOGY

The sedimentary formations penetrated by the workings of the Yankee mine are the Tintic quartzite, the Ophir shale, and the Maxfield limestone. These rocks are cut by a thick east-west dike of granodiorite porphyry, known as the Yankee dike, and by a thinner dike, striking northeast, of a green much-decomposed lamprophyre. The former is near and about parallel to the Yankee fault, and the latter has a similar relation to the Belorophan fault.

The extreme complexity of the structure in the Yankee mine is shown to some extent by the geologic map of the main tunnel, or $501 \mathrm{drift}$, and of the Globe drift (pl. 51). The most conspicuous features of the structure are the Silver Fork, Yankee, and Belorophan faults.

The Silver Fork fault, which is one of the great faults of the district and has been traced throughout the length of the area from north to south, passes near the north working portal of the tunnel; the fault between quartzite and shale about 30 feet in from this portal is probably part of the Silver Fork zone, though it may not be the break on which the largest throw has occurred. A tunnel just south of the tram terminal extends westward a few hundred feet, and at its farthest accessible point, about 350 feet from the portal, further progress is blocked by the caving of smashed quartzite, presumably in the Silver Fork fault zone. These observations indicate that this fault here has a northeasterly strike, and seem to bear out the writer's impression that it is thrown, a little farther north, by an east-west fault that may be the Yankee. The Yankee fault is thought by the company geologists to be the earlier of the two, but apparently their relation to each other has not been directly observed. The throw of the Silver Fork fault at this place was estimated by F. D. Hansen, a geologist of the American Smelting \& Refining Co., as about 1,200 feet, but the relations at the divide to the north, where the fault cuts out all the Cambrian strata, would seem to indicate a much greater throw. This discrepancy can hardly be accounted for by the effect of the Yankee fault, whose downthrow is on the south and should therefore, if the Yankee is the older fault, increase the stratigraphic throw of the Silver Fork fault. In any case it hardly seems possible to do much more than estimate roughly the throw of the Silver Fork fault at this place.

The Yankee fault is crossed in two places by the Globe drift. It strikes a little south of east and is essentially vertical. Its downthrow is to the south, and on the main tunnel level it brings the Ophir shale-the upper shale member at the east and the lower shale mem- 
ber at the west-against the Tintic quartzite. Its.throw is estimated by Mr. Hansen to be about 450 feet.

The Belorophan fault, or fissure as it is usually called, strikes northeastward and dips northwest at angles that seem to vary considerably, the lowest dip noted being $44^{\circ}$ and the highest possibly $85^{\circ}$. This fault is normal, and its maximum throw must be at least 100 feet, for a the tunnel level the fault brings the upper shale member of the Ophir shale on the west against the lower shale member on the east. This fault apparently throws the Yankee fault, shifting its western segment southwestward.

Several other faults and fissures of northeasterly or northerly strike are crossed in the tunnel; all of them, so far as known, are normal. In the tunnel they separate different members of the Ophir shale, which is the country rock in the main tunnel from the face to within about 30 feet of the portal. To distinguish the lower from the upper shale is not always easy; the most reliable basis of distinction is the blocky character of the upper shale, as contrasted with the fissile character of the lower. Color is less reliable because the color of the lower shale is lighter here than in most of the area described in this report. The mapping of these shales in plate 51 agrees with that of the company's geologists except that the rock between two fissures 380 and 450 feet from the portal is tentatively mapped as the lower shale, whereas the company map here shows the upper shale.

A fault that is shown in many of the company's sections is the Footwall fault, said to be the one that crosses the tunnel 100 feet from the portal and dips $45^{\circ} \mathrm{SE}$.

The sections drawn by the company geologists nearly all show what is called the Mary Ellen fault, which apparently is a bedding thrust near the contact between the Ophir shale and the Maxfield limestone and does not cause any notable duplication of beds. This fault was not recognized in examining the tunnel level; at the only place where the contact was clearly seen-in the drift west of the Belorophan fault-the contact between these formations did not appear to be a fault. However, there seems to have been much mineralization, presumably along a zone of movement, at about this stratigraphic horizon.

The dips of the beds do not outline any large folds. The dips plotted on the map forming pl. 51 are hardly more than a random sample of those that were most persistent or most easily measured; much more contortion is shown by the elaborately detailed work of the company geologists, and the shale in the outer part of the tunnel is thrown into recumbent folds. On the whole the dips are low, and their prevailing direction southeasterly.

\section{ORE DEPOSITS}

The ore has been derived from three distinct types of deposits, each of which has made a considerable production. These are described below.

"Placer" ore.-Boulders and pebbles of galena, ranging in weight from a fraction of an ounce to hundreds of pounds, are found in the gulch west of the Yankee mine, most of them along its bed but some of them at considerable distances from it. They are confined to an area in the lower part of the gulch, apparently below the outcrop of the ore-bearing fissure. A considerable production has been made by sorting and washing these boulders and pebbles from this "placer."

Breccia ore.-On the upper levels there is a wide breccia zone along Live Yankee fault consisting largely of black shaly gouge and breccia. Within this zone are found large and small fragments of ore and a large amount of pyrite. The ore is chiefly valuable for its lead, silver, and gold, though it contains some copper. It is said that gold is most abundant in those parts of the deposit that contain chalcopyrite. The fault zone has been opened up in the gulch, and considerable ore has there been taken from it. The lower (Holden) tunnel was driven to develop this zone at greater depth, but although it passes beneath the breccia zone it shows no breccia. The Globe drift encountered a fault zone similar to that at the surface but without sulphides. In the "Iron tunnel," at a higher altitude, there are flat faults containing black shaly gouge similar to that of the east-west fault, and it seems probable that some nearly horizontal movement later than the Yankee fault-perhaps on the "footwall" fault-has shifted the beds above relatively to the south. The extension of the principal stopes along an east-west line south of the Yankee fault might thus be explained. Mineralization has occurred also along the base of the Maxfield limestone, probably by replacement in breccia along the Mary Ellen fault.

Fissure deposit.-Much ore was taken from the Belorophan fissure in the quartzite, where the vein had a width of 1 to 20 feet. The ore minerals-pyrite, galena, sphalerite, and tetrahedrite-were irregularly distributed through the fissure zone. Barite was the principal gangue mineral aside from unreplaced quartzite, being locally abundant. In some, at least, of the places where it is especially abundant it is associated with sphalerite. The ore is essentially a milling ore, though some shipping ore is sorted out. The Belorophan fissure also yielded ore in the rocks above the quartzite. In 1936 ore rich in zinc was being taken from the fissure in the Globe raise; the ore extended for a short distance laterally along the bedding of the Maxfield limestone near its base. 
It is not entirely clear whether more than one period of mineralization is represented. The ore from the breccias and from the fissure deposits differ considerably. The breccia ore, which is valuable mainly for gold and copper, is a pyrite, chalcopyrite ore; the ore associated with the Belorophan and other northeast fissures contains lead, zinc, and copper, the copper being mostly in tetrahedrite. Barite, though an abundant gangue mineral in the northeast fissure, is not so in the breccia ores. Mr. Hansen favors the view that the breccia ores are earlier and associated with the eastwest Yankee fault and that the earlier ore was brecciated by movement on the Yankee fault and on flat faults before the deposition of the ores associated with the northeast fissures.

\section{GLOBE}

The Globe group lies south of the Live Yankee. The Belorophan fissure and other fissures developed in the Yankee mine extend into the Globe, where the Belorophan fissure has been developed in the limestone and has yielded some ore. The workings, however, were not accessible at the time of visit. 



\section{INDEX}

\section{A}

Acknowledgments for aid

Actinolite, occurrence of

Alaskite porphyry, character and relations of -

Albion Basin, features of

Albion Basin landslide; fentures of

Albion mine, description of _._._._._. 129-130, pl. 45

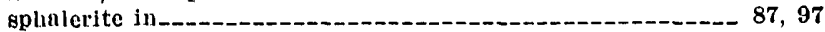

Albite, occurrence of, in lamprophyres.

Alice tunnel, features of

Allegan claim, ownership of -_._- 122

Alligator flssure, strike and dip of -

Alluvial deposits, character and occurrence of _._._._._._._. 50-51

Alta, features of geology near-_. 49, 51, 65-60

Alta Consolidated mine, description of -_..- 130-131, pl. 46 (in pocket) minerals of _._........ 89, 90, 97, 131

Alta-Gladstone mine, molybdenite in

Alta-Gladstoné vein, features of

Alta-Hecla clnims, ownership of ____

Alta overthrust, discovery of views of

Alta-Quincy tunnel, location of -

Alta stock, character and occurrence of geologic relntions of structure of -

Alta thrust zone, ore deposits associnted with relation of other overthrusts to stratigraphic relations and extent of

Alta tunnel, geologic relations in

Alta Tunnel \& Transportation Co., properties of pl: 37 (in pocket)

Alta United Mines Co. properties. See Albion mine; Smma mine; Sells claims; South Columbus tunnel; South Hecla mine.

Alteration, in dike rocks in ore deposits

Alturas clnim, ownership of _._. 105

American Consolidated Copper Co., claims of

American Fork, course of -

American Fork Canyon, geology of

American Fork district, mineralized fissures in mines and claims in mining in, history of production from smelter in

American group, production from_-_- 77

American Metal Mining Co., claims of _._._. 106, 107

American mine, features of

Amphiboles, occurrence of

Andalusite, occurrence of

Andradite, occurrence of -_._._. 88

Anglesite, occurrence of

Ankareh shale, character and occurrence of

Annie tunnel, geologle map of ore from

Anorthite, occurrence of Ant IKnolls, stratigraphic and structural relations near.- $26,27,28,29,59$ Antelope claims, description of

Antimonates, occurrence of

Antimony ores, oxldation of

Apatite, occurrence of.

Argenta, history of

Argentite, occurrence of

Augite, occurrence of

Aurich 88

88,106

88
$\mathbf{B}$

Page

Baby Mackee fissure, features of
Baker mine, features of

Baker mine, features of

Barite, occurrence of

Barry-Coxe mine, fissures in, strike of

Bay City tunnel, features of

Bay State mine, features of

Beaverite, occurrence of _._._._._._._. 89

Beeson, J. J., structure section by 124

Belorophan fault, features of relative age of

Belorophan mine, history of ore from

Bibliography

Big Cottonwood Canyon, alluvial deposits in general features of glacial deposits in rocks in Big Cottonwood Coalition, location of

Big Cottonwood district, mines and claims in _. 102-117, pl. 30 (in pocket) mining in, history of production from-_. smelters in

"Rig Cottonwood fault," use of name Big Cottonwood mine, rocks near..._. Big Cottonwood Monarch mine, features of Bindheimite, occurrence of Biotite, occurrence of 89

Bismite, occurrence of

Bismuth ores, occurrence of 128

Bismuthinite, occurrence of

Black Bess mine, ownership of

Block faults, occurrence of

"Blocky shale," use of name._._. 14

"Blue and White" limestone, use of name

Blue Rock claims, work on

Bluebird claim, location of

Bog mine, description of - 136 minerals of

Bone tunnel, ore in

Borates, occurrence of 89

Bornite, occurrence of

Borussia claim, features of 136

Bournonite, occurrence of

Brain fissure, features of 120

relation of Snow fault to

Brazer limestone, correlation of ........ 28

Brigham quartzite, correlation of $\begin{array}{rr}\text { Brighton, glacial deposits near } & 10 \\ \text { location of } & \end{array}$

Brooklyn fissure, features of

Brooklyn tunnel, location of

Brucite, occurrence of

Burgess fault, location of

Burgess tunnel, relations of _-__________-_ pl. 41 (in pocket)

Burling, L. D., fossils identified by

Burnswood tunnel, location of

C

Cabin claim; features of

Calamine, occurrence of

Caledonia claim, ownership of

Cambrian rocks, description of

fissure deposits in

Carbonate fault, features of 
Carbonate fissure, features of

Carbonate mine, description of minerals of

Carbonates, occurrence of

Carboniferous rocks, description of

Cardiff fissure, features of

Cardiff mine, description of

110, 111, pls. 23, $A, 24, B, D, 26, D, 27, A$

Cerargyrite, occurrence of Cerusite, occurrence of Cervantite, occurrence of

Chalcocite, occurrence of

Chert, character and occurrence of metamorphism of

Chlorite, occurrence of

Chrysocolla, occurrence of 89

Cincinnati claim, ownership of 122

City Rocks fissure, workings on

City Rocks mine, production from 131

Clarke tunnel, location of _._. 114

Clayton Peak stock, character and geologic relations of $41-42$, pls. $15, B, 16, A, 17, C$

Cleves tunnel, location of

Climate of the area

Cohen claim, ownership of

Collophanite, occurrence of

Columbus Consolidated mine, description of

Columbus overthrust, description of _._._._._._- 54, 57-58, pl. 7, $A$ $118-120$, pl. 40 (in pocket)

Columbus-Rexall mine, description of $117-118$, pls. $35,38,40$ (all in pocket) minerals of $46,87,88,96$, pls. $23, B, 26, B, 27, B$

Columbus tunnel, location of

Confidence mine, features of _._._.

Connor, Gen. P. E., discovery of silver by 73

Contact deposits, genesis of minerals in, source of$$
\text { types of }
$$

$92-93,99,100-101$

Contact metamorphism. See Contact deposits; Metamorphism in the area.

Continental-Alta Mining Co., property of Copper, native, occurrence of $81,82,83,84,86$

Copper deposits, alteration of

Copper fissure, character and relations of

Copper King group, geology of

Copper ores, oxidation and replacement in

Copper Prince tunnel, ore from 130

Cordierite, occurrence of

Cottonwood-Atlantis Mining Co. property, features of

Cottonwood Consolidated claims, features of _._._._. 111

Cottonwood Metals claims, features of _._._. 104

Covellite, occurrence of - 87

Craig tunnel, location of 108

D

Daily Union Vedette, quoted._. 72,73

Darlington Mining Co., property of

Davenport claim, features of

Davenport Fill, diorite porphyry from Silver Fork fault on

Days Fork, prospects on

Deep Creek district, relation of ore deposits in, to igneous rocks- $\quad 99$

Deer Creek, scheelite on

Defiance claim, ownership of _._._. 105

Deseret limestone, character and distribution of correlation of

Devils Castle, section of Maxfield limestone in view of

Devonian (?) rocks, description of relation of, to Mississippian strata_... 23 unconformity at base of

Deweylite, occurrence of

Diastrophism in the area, age of 51

Dickman claim, ownership of 122

Dikes, age of character and distribution of relation of, to stocks

Diopside, pccurrence of
Page character and distribution of norms of

Diorite porphyry, alteration of petrography of Director of the Mint; quoted. 105 Dolly Varden mine, features of Dolomite, character and occurrence of -- 15, 16, 88, pls. 11, $A, 12, B, 13, A$ metamorphism of _._._._._._. $41,92,100, \mathrm{pl} .21, C$ Drainage of the area.. Dry Fork Canyon, barite in 89 faults in Dutchman fault, features and relations of Dutchman mine, description of _-__-_- 137-138, pl. 49 (in pocket) Dwyer tunnel, features of

E

Earl-Eagle fault, features of -

Earl-Eagle tunnel, features of

142-143

Eclipse shaft, location of

Eilers, A., quoted...

Electric power in the area

Emma mine, geology of history of and production from minerals of _._._. $86,96,97,125$, pls. $25, A, B, 26, A, 42,43, A$ Emma overthrust, relations of _._._._._._._._. 58

Enargite, occurrence of _._._. 87

Epidote, occurrence of

Evarena fault, features of

Evergreen claims, features of

Excelsior mine. See Kennebec Consolidated Mining Co. claims.

\section{$\mathbf{F}$}

Faults, descriptions of

relation of ore deposits to

$51-53,54-71$

$90,91,95,98-99$

Fenster on Alta overthrust_._._. 57, 129, 141

Field work in the area-_

Fissures, age of geologic relations of
mineralization of See also names of fissures.

Flagstaff fault, features of

Flagstaff mine, geology of history of and production from minerals of section near.

Fuorapatite, occurrence of

Fluorescence of rocks and minerals_.___._._. 93

Folding in the area, general features of Footwall fault, features of Forsterite, occurrence of

Francis claim, location of _._. 114

Frederick tunnel, features of Fremont, Capt, J. C., exploration by
Future of the district.

Future of the district..............

Galena, occurrence of

Gạlena fault, features of

Gardner tunnel, location of 114

Garfield fissure, features of Garnet, occurrence of Geologic map and sections of the area...... pls. 3 and 4 (in pocket) Giles claims, features of _._._..... Gilluly, James, norms calculated by Gipsy Blair claims, features of 104 Girty; G. H., fossils identified by Glaciation in the area_... Glass, J. J., determinations by Globe claims, fentureș of Globe fault, features of 70 Golconda tunnel, location of Gold, occurrence of production of

Granodiorite, analyses of character and occurrence of norms of 
Graveyard Flat landslide, features of

Page Grizzly dike, location and character of Grizzly-Lavinin fissure zone, features of Grizzly overthrusts, features of Grizzly tunnel, geology in and near- $48-49,132$, pls. $21, C, 46$ (in pocket)

Grout IF IF, structure diagrams by

Grundy, Isanc, development of lead deposits by

"Guinea-hen" dolomite, fentures of

Gustavus Adolphus fissure, features of

Gypsum, occurrence of

H

Halolds, occurrence of

Hayes mine, production from chapters on history of mining and production in the

Hematite, occurrence of

Hinwatha claim, ownership of

Hiawntha fault, features of

Highland Chief mine, ownership of 115

Hines prospects, features of

Hobnail property, features of

Hoboken fissure, location of

Holston tunnel, location of:-

Honeycomb fault, features of

Honeycomb tunnel, length of

Hornblende, occurrence of

Howell mine, features of

Howland fault, features and extent of

Fowland tunnel, geology of

Fudson claim, ownership of

Humbur formation, age and correlation of character and structural relations of fossils in, list of inineralization in

Huntley, D. B., quoted_._._._._. 79-80, 106, 107, 115, 123, 137, 140

Hydrozincite, occurrence of

Eypersthene, occurrence of

Igneous rocks. See Intrusive rocks; Plutonic rocks.

Illinois fault, features of

Intrusive rocks, descriptions of _._. relution of, to ore deposits to overthrusting -

Iowa Copper mine, features of production from

Iron, oxilation and reduction of -

Iron 1310 som fault, features

\section{$\mathrm{J}$}

Jamesonite, occurrence of

Jefferson (?) dolomite, age and correlation of charncter and distribution of ore deposits in

sections of

Jurassic rocks, character and distribution of

\section{$\mathbf{K}$}

Kate Hayes fissure, character of

Kelsey, E. B., quoted.

Kenne Conclidated Mining 78

Kentucky-Utah property, description of ._.

\section{I}

Lake Solitude, rocks near._-___-___-_ 43-44, pls. 17, $C, 21, B$ Lamprophyres, character and distribution of Landslides in the area-r. 50

Lavinia mine, ownership of

lawrence, Joab, property of

Lead, early smelting of production of

Lend ores, oxidation of

Legget claim, workings on

Lexington tunnel, location of
Limestone, metamorphism of _._- 41, 92, 94-95, 100, "Limonite," occurrence of

Little Cottonwood Canyon, alluvial deposits in____-_._._. 51 faulting in general features of glacial deposits in
rocks in

Little Cottonwood district, mines and claims in pl. 30 (in pocket) mining in, history of production smelters in

Little Cottonwood stock, age of character and relations of ore deposits in, relation of erosion to veins in

Little Dolly tunnel, features of

Little Giant claim, ownership of

"Little lime," use of name.r. 13

Live Yankee mine. See Yankee mine.

Location of the area... 4

Logan syncline, relations of

Logger mine, features of 104

Long Trail shale member, correlation of 22

Loughlin, G. F., quoted_..._._._._._._. 135, 136, 137-138, 140-141

Lucky Dutchman claims, ownership of -

Ludwigite, formation and occurrence of

Lumbering in the area_____._._. 72

122

character and distribution of 24

fossils in

relation of, to Jefferson (?) dolomite

Magnesioludwigite, occurrence of

Magnetite, formation and occurrence of

Major Evans fault, features of

Major Evans Gulch, geologic features of workings in Malachite, occurrence of

Mannahansett tunnel, location of

Mansfleld, G. R., quoted__. 31

Mary Ellen fault, features of

Mary Ellen Gulch, faults near.. 70 glacial features of

Mary Ellen mine, features of

Massicot, occurrence of

Matilda claim, ownership of 130

Maxfleld limestone, age of 18 character and distribution of metamorphism of name of _..._ore deposits in sections of

Maxfield mine, features of workings of _-__- 31 (in pocket)

Metals, production of

Metamorphism in the areá.

$14,17,18,41,92-93,100-101$, pls. $15, A, 21, A$

Michigan-Utah mine, description of -_-_-_ 131-133, pl. 46 (in pocket) minerals of Microcline, occurrence of

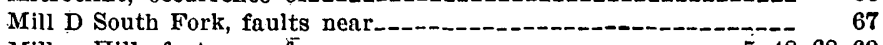

Miller Hill, features of geology near._. Miller Hill fault, features of Miller Hill Mining Co., properties of Miller Hill tunnel, features of Miller mine, description of . Miller Mining \& Smelting Co., property of --_ 139-141, pl. 50 (in pocket) Mineral Flat, glaciation of

Mineral Veins Coalition Mines Co. properties. See Columbus Consolidated mine; Columbus-Rexall mine; Flagstafi mine; Tom Moore tunnel; Wasatch drain tunnel.

Mineralization. See Ore deposits.

Minerals, occurrence of paragenesis of See also descriptions of individual mines. 
Page

Mines, production from

$80-86$

Mines and prospects, descriptions of

Mining, history of - 71-80, 85 locations, early regulations governing methods of -

Mississippian rocks, correlation of description of - 22-28, pl, 21, $B$

Molybdenite, occurrence of

Molybdenum ores, deposits of

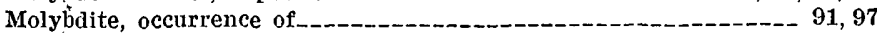

Montezuma claim, ownership of

Montezum fault, features and extent of relations of

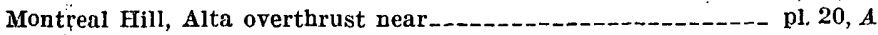
fossils from-_._. section on

Monżonite. See Quartz monzonite.

Monzonite porphyry, petrography o

(?) formation, age and correlation of character and distribution of

Mormons, early attitude toward mining---_-_-_-_-_-_---- 71

Mount Baldy, granodiorite porphyry from_-_-_-_-_-_-_ 42 stratigraphic and structural relations on

Mount Evergreen, diorite porphyry from

Mount Timpanogos, stratigraphic and structural relations in -... 5

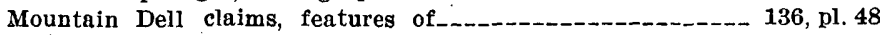

Mountain Dell fault, features and relations of -_-_._-_ 68-69, 135, 136 relative age of -

Moun tain Lake claims, features of $37,41,87,89,113-114$, pls. 22, $C, 28, A$

Mountain Lake mining district, organization and limits of -...-.- 72

Mule Hollow, section near--.-.--

Muscovite, occurrence of -

Native Copper claims, features of

New Sensation tunnel, ore in

North Star claim, history of

Nugget sandstone, age and character of

Ogden quartzite, use of name

$86,88,90,125, \mathrm{pls}, 25, A, B, 26, A, 42,43,45$

Old Emma ore shoot, character of

Olívine group, occurrence of

Ophir mine, features of

Ophir shale, age and correlation of character and distribution of ore deposits in

Oquirrb formation, correlation of

Ore, assays of milling of_____ mining of production of smelting of specimens of -_-_-_-_-_._- 22-29, 42-43 transportation of

Ore deposits, alteration of discovery of formations contajaining future development of genesis of - 97-101 geologic relations of in intrusive rocks. in sedimentary rocks_. minerals in, occurrence of _._._. $86-90$ paragenesis of

Orthoclase, occurrence of Overthrust faults, description of Oxford claim, prospecting on Oxides, occurrence of

Pacific fault. See Mountain Dell fault

Pacific fissure, age of features and relations of name of Pacific mine, description of _._._._._._._. 135-136, pl, 47 (in pocket) Paragenesis of ore minerals
Park City arch, relations of

Park City formation, age of collophanite in section of

Patsy Marley Hill, ore from_..._._._._._._._. 92-93, 132, 133

Pennsylvanian rocks, correlation of description of -...- 22-23, 28-31

Periclase, occurrence of

Permian rocks, occurrence of

Peruvian Consolidated Mining Co., property of

Peruvian Gulch, faults in and near.- 67-68 prospects in and near._. 128

Phosphates, occurrence of

Phosphoria formation, correlation of

Pioche shale, correlation of _._._. 14

"Pipe Raise" ore body, occurrence of

Pittsburg fault, features of

Pittsburg Lake, Tintic quartzite near.

Pittsburg mine, description of faults near._... 68 sections near._._.

Plagioclase feldspars, occurrence of

Plumbojarosite, occurrence of

Plutonic rocks, character and distribution of chemical composition of _._._. 40

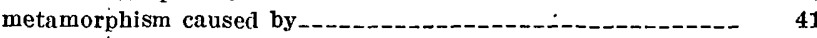
ore deposits in relation to

Porphyry. See Alaskite porphyry ; Diorite porphyry; Granodiorite porphyry; Monzonite porphyry.

Powellite, occurrence of -_.._- 90, 93

Power, electric, in the area._.

Pre-Cambrian rocks, character and distribution of fissure deposits associated with..... metamorphism in

Predipitation in the area..

Price claims, features of

Prince fissure, features of

Prince of Wales mine, description of _._._. 114-115, pl. 37 (in pocket)

Production of ore and metals_.__

Prospecting, suggestions for

Prospectors, early .

Provo area, Carboniferous rocks in

Psilomelane, occurrence of

Pyrite, occurrence of

Pyrolusite, occurrence of

Pyroxene group, occurrence of 88

$\mathbf{Q}$

88,95

uartz monzonite, analysis of

character and occurrence of norm of use of, in Mormon Temple_._. 38

Quaternary deposits, character and distribution of

Queen Bess mine, features of

Quincy tunnel, features of

$\mathbf{R}$

Railroads in the area

Raymond, R. W., quoted

Red Bell mine, production from

74-75

108-109 section near....._. 17

Reed \& Beinson Ridge, features of fossils from

Reed \& Benson thrust zone, geologic relations of

Reeds Peak claims, features of - 111

Regulator mine, ownership of

Relief claim, workings on

Relief in the area, effect of, on alteration of ores 96 features of

Rettich claims, features of _._._. 117

Revolution claim, ownership of

Rexall mine. See Columbus-Rexall mine.

Rexall prospect tunnel, Columbus overthrust near._-_._-_. $\quad 57$

Rhodochrosite, occurrence of _._._. 88

Roads in the area...

Rustler workings, geologic map of 


\section{s}

Sallor Jack claim, ownership of -

"Suilor Inck" fissure vein, locntion of

Salt Lake Tribune, quoted..._.

Sampson fault, features and relations of

Sumpson mine, faults near._._._._. 58, 67 section near._._._. 17

Snvage claim, ownership of._- 122

Scupolite, occurrence of -

Scheelite, occurrence of

Scott. Hill, fentures of

Scottish Chief mine, features of

Secret Lake fault, fentures and relations of _.__-___-_

Sedimentary rocks, formations of general sequence of metamorphism of ore deposits in

Sells claims, fentures of

Sericite, occurrence of

Serpentine, occurrence of

Settlements in the area.-_...-

Short, M. N., quoted

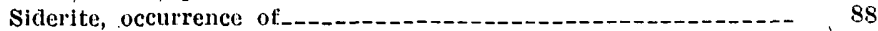

Silica, source of, in metamorphic minerals

Silicntes, occurrence of

Sills, possible occurrence of, on Big Cottonwood Creek___-____- 45

Silver, discovery of native, occurrence of
production of production of

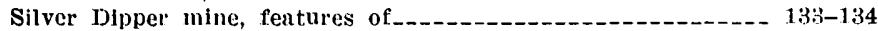
pre-Cambrian section near
r Fork fault, general features of

Silver Fork fault, general features of relutive age of

Silver King Coalition Mines Co., properties of

Silver King fissure, occurrence and features of

Silver Moon claims, features of

Silver Mountuin property, history of -_- 105

Silver ores, oxidation of

Skipper tunnel, ore deposits in

Smelting in the area, history of

Smithsonite, occurrence of:_._._._. 88 , pl, 22, $B$

Snake Creck, landslide near-

Snake Creek district, claims in

Snow fuult, fentures of.

Solitude tunnel, fentures of -----

South Columbus tunnel, features of _..._... 127, pl, 44 (in pocket)

South Fecla mine, geology of --_-_-_- 56, 125-126, pl. 44 (in pocket) history and production from ore deposits of

South Park dike, features of

South Park Mining \& Development Co., property of

South Star claim, ownership of

South Star fault. See Vallejo fault.

Sphalerite, analysis of.-

Spincl, occurrence of
Standard fnult, features and relations of

Stenmbont tunnel, features and workings of granodiorite from_..._. 40,41 , pl. 17, $B$ ores from.... pls. $25, C, D, 26, C, 28, B, 29, B$

Stocks, description of metamorphism caused by relution of to dikes to ore deposits... relative age of

Stolzite, occurrence of

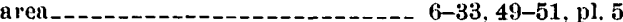
Structure of the area_-__-_-_-___-_._- 35, 36, 51-71, pls. 4, 19

Stuart fissure, diorite porphyry from

Sugarlonf Mountnin, view of _._._-

Sulfates, occurrence of _._._.

Sulfide ores, oxidation and concentration of metals in

Sulfides, deposition of occurrence of relations of -....... pls. $22, C, 24,25,26,27,28$

Sulfo salts, occurrence of

Sultana smelter, description of

Sunnyside tunnel, features of

Superior fault zone, feutures of relative age of.-.$462858-43-11$.
Page

9,19 $53,55,57$, pls. $7, A, 8, B$

Superior Peak, features of

Superior tunnel, features of

$\mathbf{T}$

Talus, occurrence of Tar Baby dike, features of Te:ir faults, occurrence of Te:lr faults, occurrence of
Tetrahedrite, occurrence of Texan fault, features of Texan Mining Co, property of 137 Thaynes formation, age of character and distribution of name of section of

Third Chance property, ore deposit in_-_-_-_-_- 91

Tiger Trail fault, features of

Tillite, age of character and distribution of relation of, to underlying rock ... 10

Tintic quartzite, character and correlation of deposition of stratigraphic relations of

Titanite, occurrence of

Titanosilicates, occurrence of _..._-___-_ 89

Tom Moore fault, features and relative age of Tom Moore tunnel, geology in 63. 65. 66. 121-122, pls. 11, B 41 (in pocket) Topography of the area____._._. Tourmàline, occurrence of .._._. Transportation in the area._. Treasure Consolidated claims, features of 137 Tremolite, occurrence of Triassic rocks, description of Tungstates, occurrence of Tungsten minerals, occurrence of _._._._._-_._-_._- 92-93, 97 Tungstenite, formation and occurrence of Twin Peaks, glaciation south of location and altitude of section east of talus north of

\section{U}

Uinta arch, features and structural relations of-_-_-- 52, 53, pl, 6, $A$ Uinta Range, general features of Unconformity, at base of Jefferson (?) dolomite at base of Tintic quartzite-. 11 Unity Mining Co., property of Utah Mines Coalition Co., property of V.

Vallejo claim, history of and production from__._._. Vallejo fault, features and extent of Variegated fault, features of
Vegetation in the area Vein materials, relation of, to jgneous rocks._- 99 Veins, minerals of occurrence of, in intrusive rocks. 91-92 Vesuvianite. occurrence of

"Vug lime," use of name_._. 20

\section{W}

Wandering Boy claim, ownership of $\begin{array}{llr}\text { War Eagle claim. } & 134 \\ \text { Waring. W. G., analyses by } & \end{array}$ Waring. W. G., analyses by
Wasatch drain tunnel, description of $-55-56,118-120$, pl. 39 (in pocket) Ophir shale from $\begin{array}{ll}\text { Wasatch limestone, use of name } & 14 \\ & \end{array}$ Wasatch Mines Co., property of Wasatch mining district, organization of -__________- 72 Wasatch Mountains, features of Water Fall mine, features of Water level, effect of, on alteration of ores. Watrous claims, features of Weber quartzite, character and occurrence of 
. Page

126

Wellington claim, ownership of

West Superior fault, features of _._.

West Toledo claims, location and features of

Whirlwind fault, features of

Whirlwind tunnel, faults near-

fegtures of

Wild Dutchman mine. See Dutchman mine.

Willow Creek, section at head of

Wulfenite, occurrence of

(1)

Wulfenite,

31
90
Yankee dike, features and relations of

Yankee fault, features of

Yankee mine, geology of history of and production from ore deposits in

$\mathbf{z}$

Zeolites, occurrence of

Zinc, occurrence of production of

Zircon, occurrence of _._. 89 